UCRL- -53934

DE89 016714

\title{
The Influence of Cooling Rate on the Microstructure of Stainless Steel Alloys
}

\author{
John Walter Elmer
}

(Ph.D. Thesis)

Manuscript date: September 1988 


\title{
The Influence Of Cooling Rate \\ On The Microstructure Of Stainless Steel Alloys
}

by

John Walter Elmer

B.SC. METALLIRGY, COLORADO SCHOOL. OF MIINES (19:9)

II.SC METALLLRGY. COLORADO SCHOOL OF MINES (1981)

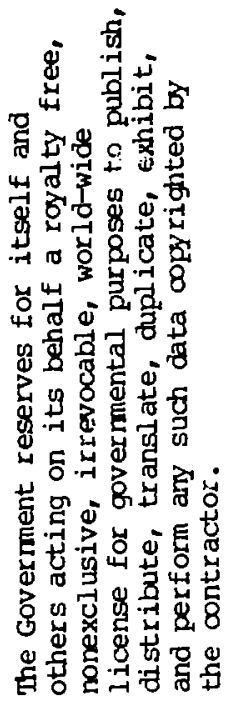

SL BMITTED TO THE DEPARTMENT OF

MATERIALS SCIENCE AND ENGINEERING IN PARTIAL

FLLFILLMENT OF THE REQUIREMIENTS FOR THE DEGREE OF

\author{
DOCTOR OF SCIENCE in METALLURGY \\ at the \\ MASSACHUSETTS INSTITUTE OF TECHNOLOGY
}

September 1988

(C) John Walter Elmer. 1988

The author hereby grants to MIT permission to reproduce and to distribute copics of this thesis document in whole or in part.

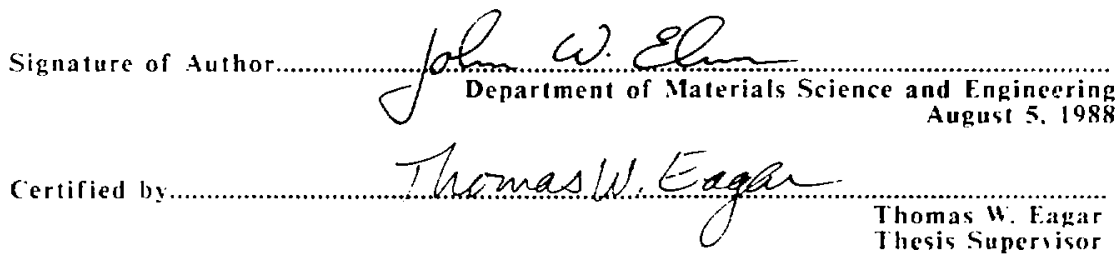

Certified and Accepted by 


\title{
The Influence Of Cooling Rate
}

\section{On The Microstructure Of Stainless Steel Alloys}

\author{
by \\ JOH. W. ELMER \\ Submitled to the Department of Materials Stence and Engincering \\ an tugust 5.1988 in partial tulfillment of the requirements \\ fur the Degree of Dostor of Seienee in Merallurg!
}

\section{ABSTRACT}

The emergence of high energs densits kelding. laser surface modificatiun and rapid solidificatun as commonly used metallurgical processing techniques has greatl. increased the range of cooling rates that ean be aceessed during the solidilication of netals and allo!s The microstruetures which develop during these rapid conling conditions ma te significantly different from those which develop during low cooling rate conditions as the result of aceess to new metastable phases with the additional hinctic limitations that accompany rapid solidification.

This investigation explores the influence of cooling rate on a serics of seven ternary allows which span the line of two-fold saturation in the Fe-Ni-Cr sistem. lligh specd clectron beam surface melting was used to resolidity thesc alloys at scan speeds up $105 \mathrm{~m} 5$. The resulting cooling rates were estimated from dendrite arm spacing measurements and were confirmed by heat flow modeling to sary from $7 \times 10^{\circ}$ ${ }^{\circ} \mathrm{C} S$ to $8 \times 10^{\circ}$ "C $\mathrm{s}$. The microstructures that deseloped from each solidification condition were camincd using optical metallography. clectron microprobe analisis, seanning electron microscopy and a vibrating sample magnetometer. These results were used to ereate diagrams to predict the primary mode of solidification, the ferrite content and the complex microstructural morphologies which develop as a function of intertace velocit? and composition.

Changes in the primary mode of solidification with increasing cooling rate were observed in alloys that lie close to the line of two-fold saturation. The thermodsnamies and kinetics of solidification were used to explain these changes bs shouing how cpitaxially grown metastable phases can dominate solidification at high cooling rates, "ithout the necessity of postulating the nuclcation of metastable phases within the melt. The influence of cooling ra:c on interface stabilits and solidification segregation was evaluated by calculating the solutal diffusional characteristics at the tip of columnar dendrites growing under steads state conditions. These salculations werc used to prediet the dendrite tip underoovling for cach solidification condition and the results were used to evaluate the influcnes of cooling ratc on the amount of second phase formation, the lerrite content, and the absence ol sicond phases at high cooling rates.

The solid state transformation of ferritc during the cooling of the resolidified $\mathrm{Fc}-\mathrm{Ni}-\mathrm{Cr}$ alloys was shoun to be analogous to the decomposition of austeniti in $\mathrm{Fc}-\mathrm{C}$ alloss. Parallicls were drawn between these two systemis whin allowed a wealth of analysis pertioned on the Fc-C system 10 be applied to the Fe-Ni-Cr system. The inlluence of rooiing rate on the nueleation and growth binetics ol austenite uas then used to cxplain the cenditions which are responsible lor the formation of grain boundary allotriomorphs. Widmanstatten platelets. Widmanstatten needles and massise a ustenite grains in the resolidified electron beam melts

Thesis Supervisur : Dr. Thomas 16 . Eagar. Professor of Materials Inguecring

Thesis Co-Superisor: Dr. Samuel M. Allen. Assoe. Trifesser ol Phostai Metallurg: 


\section{Table Of Contents}

Title Page

Abstract

List of :igure Captions

List of Table Captions

14

Acknowledgments

Chapter 1

Introduction And Background

1.1 Previous Inrestigations

1.1.1 Constitution and Microstructure of Stainless Stcel Alloys

1.1.2 The Elicet of Rapid Solidification on the Microstructure

1.2 Present Investigation

1.2.1 Objectises

1.2.2 Approach

\section{Chapter 2}

Materials and Experimental Procedures

2.1 Materials

2.1.1 Fabrication of the High Purity Alloys

2.1.2 Are Cast Butrons

2.1.3 Melt Spun Ribbons

2.2 Surface Melting and Resolidification

2.2.I Held Coupon Preparation

2.2.2 Elcctron Beam Surfacc Melting

2.3 Mlicrostructural Characterization

2.3.1 Optical Mctallography

2.3.2 Dendrite Arm Spacing Measurements

2.3.3 Ferrite Mcasurements

2.3.4 Electron Probe Microanalysis

2.3.5 X-ray Difleaction

2.5 Isothermal Studies of the Ferrite to Austenite Transformation

Chapter 3

Me'asuring the Forrite Content of Rapidly' Solidified Stainless Stent Allons

3.1 Review of Conventional Ferrite Measurement Techniques 
3.3 The Saturation Magnetization of Ferrite $\quad 60$

$\begin{array}{ll}3.3 .1 \text { Background } & 60\end{array}$

3.3.2 Fully Ferritic Specimens

3.3.3 Saturation Magnetization Results 66

3.4 Predicting the Composition of Residual Ferrite

3.5 Verification and Application of the IS:M Mathod 73

3.5.1 Ferrite Content of the Are Cast Alloys

3.5.2 Commercial Stainless Sicel Alloys

$\begin{array}{ll}3.6 \text { Conclusions } & 81\end{array}$

Chapter 4

The Cooling Rut' of Electron Beam Surface Melts

4.1 The Shape of Electron Beam Melts $\quad 83$

4.2 Dendrite Arm Spacing Calculations $\quad 83$

4.3 Analytic Solution to the Heat Flow Equation $\quad 89$

4.3.1 The Temperature Distribution Surrounding a Melt 89

4.3.2 Derisation of an Analy tic Expression for the Cooling Ratc 92

4.3.3 Estimating the Cooling Rate in the Liquid Pool

4.4 Finite Element Model $\quad 97$

4.4.1 Assumptions and Boundary Conditions

4.4.2 Temperature Gradient and Cooling Rate Calculations 99

$\begin{array}{ll}4.5 \text { Compariron of the Models and Summary } & 104\end{array}$

$\begin{array}{ll}4.6 \text { Conclusions } & 107\end{array}$

\section{Chapter 5}

The Influence Of Cooling Rate On

The Priman Mode Of Solidification And Microstructural Morphologn 108

5.1 The Primary Mode of Solidification 109

5.1.1 Results of the Solidification Experiments 109

5.1.2 Epitaxial Growth and Plane Front Solidification 121

5.2 Cellular/Dendritic Solidification and Competitive Growth 129

5.2.I Primary Austenite Solidilied Alioss 1.31

5.2.2 Primary Ferritc Solidificd Alloys

5.2.3 Alloys That Change Solidification Mode With Cooling Rate 1.34

5.3 Microstructural Features of Resolidified Stainless Steel Alloys 136

5.3.1 Characterizing the Ferrite and Austenite Morphologics 136

5.3.2 The Combined Elfects of Cooling Rate and Composition Itt

$\begin{array}{ll}5.4 \text { Conclusions } & 147\end{array}$ 


\section{Chapter 6}

The Influence Of Cooling Rats On

The Resilual Ferrite Content Of Stesinkess Sie't Allows

6.1 The Ferrite Content at Slon Cooling Rates 150

6.1.1 Full Diflusional Equilibrium

6.1.2 The Are Casi Butions 153

6.2 The Ferrite Content of Electron Beam Surface Melts 159

6.2.1 Primar? Austenitc Solidificd Alloss 1.2 and $3 \quad 100$

6.2.2 Allo! 4 102

6.2 .3 Alloy $5 \quad 164$

6.2.4 Full: Ferritic Solidified tlloys 6 and $?$

$\begin{array}{ll}6.3 \text { Summars and Conclusions } & 170\end{array}$

\section{Chapter 7}

The Influence of Cooling Ruse On

Solute' Rodistrilution Alid Seconkl Phase Fomation

7.1 Solidification Paths and Parameters in the Fe-Ni-Cr System 174

7.l.l Solidilication Paths 175

7.1.2 Pseudotinary Diagrams to Represent Soliditication Bchasior 178

7.2 Interface Stabilit! 184

7.2.1 Growth Rate and Temperature Gradient

7.2.2 Dendrite Tip Characteristies 191

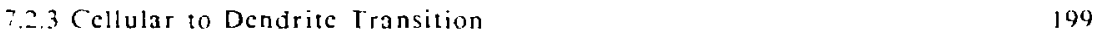

$\begin{array}{ll}7.3 \text { Solute Redistribution Mlodels } & 201\end{array}$

7.3.l The Schcil Approximation $\quad 202$

7.3.2 Back-diffusion and Undercooling 204

7.3.3 Ternary Alloy Systems 206

7.3.4 The Influence of Soliditication Velocity on the Partition Ratio 207

7.4 Calculations of Solute Redistribution in the Electron Beam Melts 208

7.4.I Solute Redistribution and Sccond Phasc Formation zos

7.4.2 Back-diffusion Ellects 212

7.4.3 Dendrite Tip Indercooling and Sccond Phase Formation 214

7.5 Summary and Conclusions 222

\section{Chapter 8}

The Inflarece Of Cooling Rate On

The Solid State Transformation Of Femite

8.1 Diffusion Controlled Growth 225

8.1.I A Iirst Order Approximation

8.1.2 Hinile Dillerence Approach 230 
8.2 The lassive Transformation

8.2 .1 Microstructural Charazicristios

232

8.2.2 Thermodinamies

int

8.2.3 Vusleation Kincrics

8.2.4 Growth kinctics

8.2.5 Massive Austcnitc Summary

8.3 The Decomposition of Single Phase Ferrite

8.3.1 Morphological Classification

8.3.2 The Lliect of Cooling Rate on Austenite Morpholog!

251

8.3.3 Vucleation and Growth $K$ inctios

32

8.t lsothermal Transformation Experiments

8.5 Summars and Conclusions

\section{Chapter 9}

Summan, Conctusions cand Future Hork

9.1 Summary

9.1.1 Experimental Resulis

9.1.2 Analysis and Modclling

Appendix A Derivation of the Cooling Rate Equation 


\section{List Of Figure Captions}

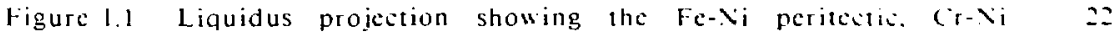
curectic and melting point minimum along the linc of two-fold saturation, alter Risilin et al. [1.32].

Figure 1.2 Thermodynamically calculated isothermal section at 1400.6 .

Tic lines arc indicated in the wo-phase ficlds. F-ferrite. A-austenite, L-liquid.

Figure 1.3 lsopleth through the Fe-Ni-Cr system at $59^{\circ}$. Fe. atter Risitin ct al. [1.32].

Figure 1.t The Fe-Ni-Cr line of two-foid saturation and Cr vi ratio bi 1.5 superimposed on the Schacfler diagram.

Figure 1.5 Shifting of the $0 \%$ and $100 \%$ ferrite boundaries of the Sihaefler diagram at high cooling rates. Pulsed laser welds at $1050 \mathrm{C}$. alter Katayama ct al. [1,43].

Figure 2.1 Compositions of the scien Fc-Ni-Cr alloys plotted on the 59 "." Fc isoplcthal scetion.

Figurc 2.2 Mclt pool width. length and depth as a lunction ol clcctron beari scan specd. All melts madc at lo0kV. $20 \mathrm{~mA}$. sharp locus.

Figure 2.3 X-Ray dilfraction results for a) single phạc ferrite b) single phase austenite and e) duplex stainless stecl alloys.

Figure i.l a) Schematic drawing of the vibrating sample magnetometer, alter Cullity [3.2l] and b) a typical M-H curve from a duples stainless stecl allos.

Figure 3.2 Slater-Pauling uries showing the saturation magnctisation lor arious binary alloy combinations. alter Cullit? [3.21].

Figure 3.3 Comparison between the ferrite solvus and the componstion of residual delta lerrite for alloys with dificrent nominal iron contents.

Figure 3.t The ferritetaustenitc two-phase licld in the Fe-Ni-corstem at $1300^{\circ} \mathrm{C}$.

Figure i.5 Saturation magnctization of the fulls lerritic melt spun $6^{-}$ ribhons as a function of $\mathrm{Cr}+\mathrm{Ni}$ contcnt.

Figure 3.6 Thermodsnamic calculations of the chromium centent an ferrite as a function of temperature and iron comtent al lac ferrite.

Figure 3.7 Thermodynamic calculations of the nichel content in lente as a lunction of temperature and iron cuncent of the fertate

I igure 3.8 Thermodynamie salculations of the cr vi ratio of ferate a a function of temperature and iron content of the lestite 


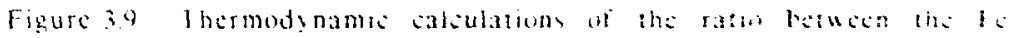
content of ferrite and the le content at dustenate a 3 function of cemperature and iron content whe tertate

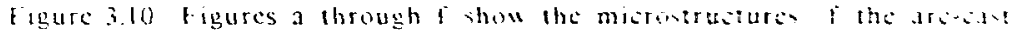

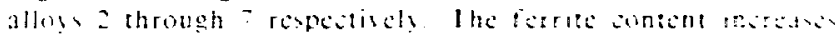

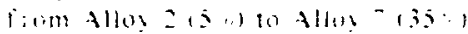

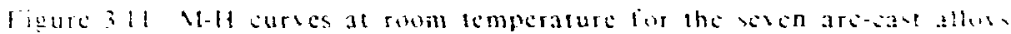

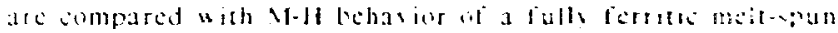
ribrin (F)

figure 3.12 Compatison of the ferruce meanurements make on the aro-at

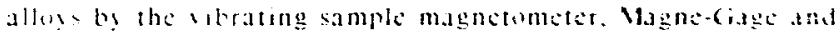
Quantiative Merallographe techniques

Figure +1 dariations in the dendrite arm spang frgures a and w sompare the sariation for a gisen set of welding parameter $1600 \mathrm{~mm}$ s) at the fuston boundary and at the tenter of the mell respectively. Figures $\&$ and d compare the larges dendrite spacings in the casting with the smallest spacings in the highest specd melt.

ligure t.2 promary and secondary dendrite arm spacing as a funcllon of clectron beam soan specd + onc standard deviation error bars are indicated.

ligure t.3 couling rate. based on dentrite arm spacing measurements. ploted rersus the electron beam sean sped.

Figure 4.4 Coordinate system used to represent the electron beam surliac melts.

Figure t.5 a) Dimensions of the base plate and binite clement mesh of an clcetron bean nelt used to calculate cooling rates and temperature gradicnts at the melt pool boundary.

figure to FFM calculations of a the cooling rate and $b$ the tomperature gradient in the $6.4 \mathrm{~mm} s$ cletron pean melt $x$-axis and $Y$-axis dimensions are in inches.

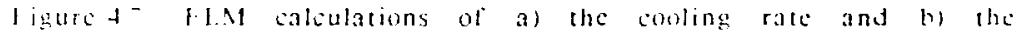
comperature gradicnt in the $25.4 \mathrm{~mm}$ s elcetron beam meth $X-a x$ is and $r-a x$ is dimensions are in inches.

ligure t.8 Sehematic eross section of a resolidificd rone indeating the locations where the analstic expression. Itll matel and dendrite arm spacing measurements apply

figure t.9 Comprison of the maximum conling ratc predicted $h$ the analstie cquation with the average cooling rate peollated dendrite arm spacing measuremenis for the o 1 - 13 mels 


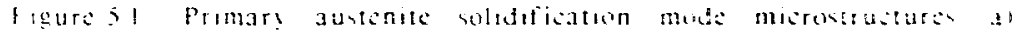
$11 ;$

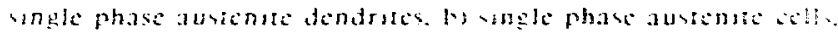
$\therefore$ interdendrita ferrite and d) interselfalar ferrite

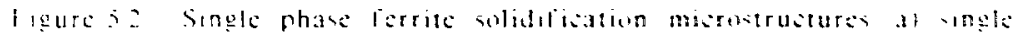

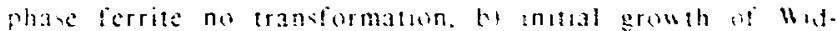

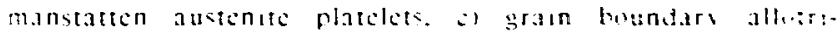

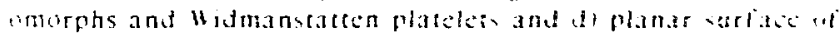
tite platelets

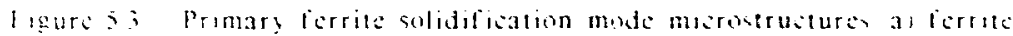
lasted at the eell cores in interedlutar austente mole. W

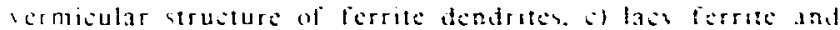
d) Wloch! austconite.

legre 5 t comparison of the microsiruetures formed by al promer awtenite with second-phase ferrate and bl primats ietrate wh second-phase austenite at equal lesels ol resulual ferilis

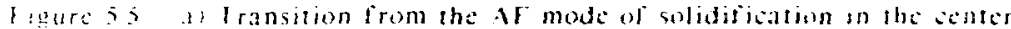
at mierograph to the FA mode at seldiblication an the the wit the miscograph. fllos 4. $6.3 \mathrm{~mm}$ s. Wh ine spaseng of ferriti platelets formed during the solid vete transtiemation at istritc. 1 llo? $5.100 \mathrm{~mm}$ s.

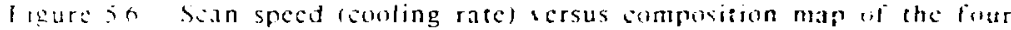
moles of solidification. Multiple data poines reter a ditier. ent modes obsersed within the same melt.

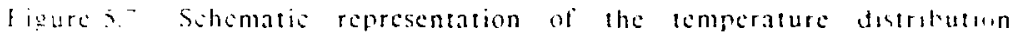
12 surrounding a melt-pool. Scotion B shews hat the tompera. ture gradient in the travel speed direstion in ecro at the mont uf maximum melt width.

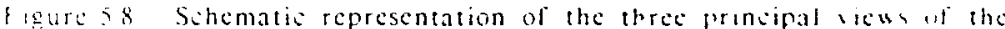
melt pool. Locations of the sarisus misostructural licatures are illustrated on the soss sectional wew and the origen of

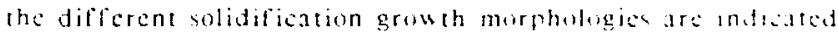
un the top and longitudinal icus.

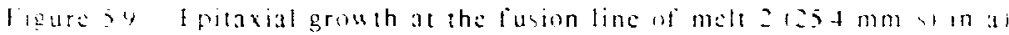

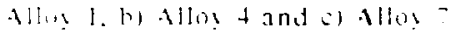

logurs 510 Protrusion of the higher melting point ferrite antu the molten zonc or a two-phase substrate when subicated ti a linear tomperature gradient at cemperatures sline to the meltung puint.

legure 511 Ihe single phase nature of high spesd reboldalled male at and $b$ " shou single phase austonite grouing from lless l and

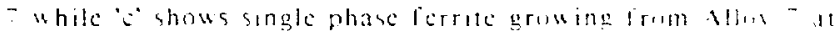
$=900 \mathrm{mms}$. 
I

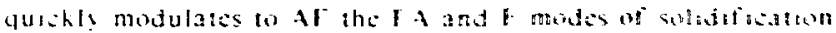
in the high $\mathrm{Cr}$ Ni ratio allows a shous tllas 5 where the

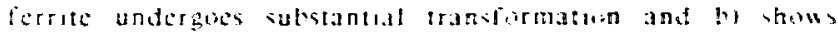

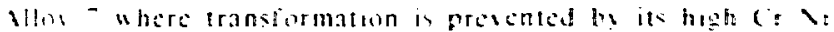
r.Ith

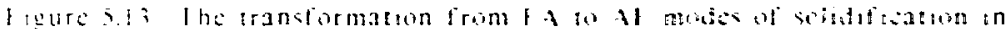

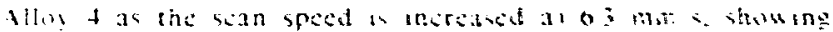

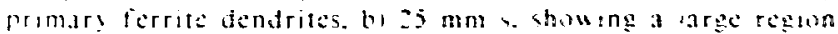

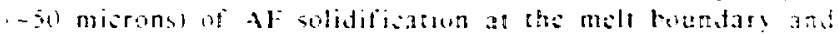

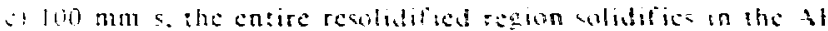
m...te.

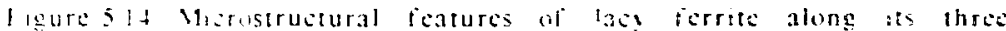
prinipal diretions. The primary dentite core and the revindar dendrice arms san clearls le distinguished

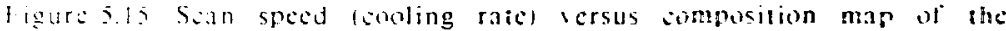
matostructural morphologics that result from solitilianion and solid state iransformation of stainlecs sfecl al is

ligual Ination of the seren Fe-Ni-Cr allons with respest to the ferrite solvus. austenite solsus and the line of two-luld aturation, afier $R$ isilin ct al, $\{1.3=\}$

figure oz luation of the seven Fe-vicer alloys on the Sihactiler di.ieram.

Figuren: Percent residual ferrite as a lunstion of $\mathrm{Cr}$ Ni ratio in are-uclds of unieal 304 upe stainlesa sicel allous.

Figure ot Residual ferrite on the scien are-cast alloss compared to the residual ferric predicted by the Sohactiler diagram for 59 "I"r Fe alloys. The solidification nodes. as deternined from the sast alloy's. are indicated.

Figure 6.5 The measured ferrite sontent of t and if solidilied alloss 1 . Z and 3 as a tunction of elcetron beam scan specd.

Figure 60 The estimated trend of ferrite conent in 1 and at solidified alloss as a lunction of soliditication rate. The amount of ferrite that solidifics and the residual ferrite. afier solid state transformation. are indieatcd.

Figure 6. ${ }^{-}$The measured ferrite content of thes 4 which thanges its mode of solidification from $F+t 0$ if 6 th as the swa specd is increased.

Figure 6.8 The estimated trend of lecrite sontent for the ta solidifisation mode as a function of solidificaton race The amount of ierrite that solidilies and the residual ferrite. alter solid state irancformation. arc indisaled. 
Figure 6.9 The measured ferrite content of Alloy 5 as a function of electron beam speed. Scan speeds where massive and Wid. manstatten austenits form in the fully ferritis solidificd regions are indicaicd.

Figure b.1, the estimated trend of ferrite content in Alloy 5 as a function wit sean speed. The amounts of ferrite that solidit? and the residual ferritc. alter solid state transformation. are indicatcd

Figure o 11 The meanted ferate contents of the full ferritis solidified tlloss 6 arid as a function of clectron bean scan specd.

Figure 6.1: The cstmated trend of ferritc content in lull! ferritio solidificd allous as a iunction of solidifiotion rate. The amoun of territe thet solidifies and the residual territe, alter solid statc iransformation, is indisated.

Figure 6.13 Summary of the estinated trends of the amount of ferrite that solidifics fer cach of the scien alloys, as a function of cooling rate.

Figure 6.14 Summary of the measured residual ferrite contents in the scien alloys as a function of clectron beam sean specd.

Figure 7.1 Thermod namically calculated isothermal scction through the Fe-Ni-Cr ternary system at $1413 \circ \mathrm{C}$ showing the oricntation of tic-lines in the two-phase regions at temperatures close to the solidification range of the seven alloys.

Figure 7.2 Solidification paths for Alloys 1 and 7 cstimated from the lincar cxtrapolation of the tic lines shown in Figure 7.1.

Figurc 7.3 Soliditication paths for Alloys 1 and 7 calculated by 178 solidification segregation modeling.

Figurc 7.4 Pscudobiary diagram along the solidification path of Allos 180 1, based on thermodynamic calculations. The solidification bchavior of primary austcnitc solidificd alloys is represcnted ior chromium contents te to $31.5 \mathrm{wt} \%$.

Figure 7.5 Pscudobinary diagram along the solidification path of Allo:

7, based oil Thermodynamic calculations. The soidification bchavior of primary ferritc solidificd alloys is represented for Ni contents up to 16.3 wt.\%.

Figure 7.6 The cstimated solidification paths and the intersection of 183 these paths with the line of two-fold saturation. for the scien Fc-Ni-Cr alloys.

Figure 7.7 Schematic representation of a surface melt showing the relationship between the travel specd. S, melt geometry and the interfacial velocity. $R$. 
Figure : 8 Average temperature gradicnt on the melt pool surlase. $:$ and

the estimated temnerature gradients in the liquid. : and solid. $:$ at the $L S$ intertace. FES temperature gradient calculations arc ploted for comparison.

Figure 79 Peelet number sersus interlace sclosits saleulations fior al 196 flloy ! and bl Alloy 7 .

Figure 7.10 Dendritc radius versus interface velocit! calculations for al Allor l and b) Allos?

Figure - 11 Dendrite tip temperature sersus ineriace velocity for al Alloy 1 and b) Allo!?

Figure 12 Temp-rature gradient versus interface sclocity comparing tho salculated and measured transitions for planar. cellular and dindritic growth conditions.

ligurc -1; Sthematic drawing showing the solute retistribution predicted bs the Sehcil equation.

Fisure - It The fraction ferrite that solidilies from the cutcetis liquid as a lunation of temperature along the line of two-fold saturation. bascd on thermodynamic calculations.

Fingre-15 Results of the Schcil calculations showing the reiatice amounts of primary and second phase ferritc and primary and scound phase ausienite that solidifies from each of the sesen allus.

Figure - 10 Schematic binary allo: phase diagram showing the shit in cutcetic composition with undcroonling below the cutectic temperature.

Figure - I : Results of the solidification segragation model shouing the relative amounts of ferrite and austenite that solidity for the sfow cooling rate cast condition. The solidification mode shanges from primary austenite to primary ierritc between Allo:s 3 and 4 .

yigure 7.18 Results of the solidification segregation model shouing the 219 relative amounts of icritc and austenitc that solidily at intermediatc cooling rates in E-beam melt No. 4 . Tho calculations were made for both primary phases in tllo! 4.

Figure 7 la Results of the solidification segregation model showing the relative amcunts of ferritc and austenitc that solidify at high cooling rates in electron beam melt No. 6. The primary mode of solidification changes from primars austenite o priniars ferritc betwecn tlloys 4 and 5

ligure 8.1 Illustration of a model to predict the nereentage of ferrits in the microstructure that transiorms inr a given characeristic diftusion distance. $L$. 
Figure 8.2 Color metallographic technique used to distinguish between the austenite which forms during solidification and the austenitc which forms during transformation of fcritc. a) shows ferite dendrites and b) shows ferrite cells, both from Alloy 4.

Figure 8.3 Comparison of a) single phase ferrite microstructure and b) massive austenite which transformed from single phase icrite in Alloy 5.

Figure 8.4 Electron microprobe scan across an untransformed Ferrite region. surrounded by massive austenite in Alloy 5 . The results indicate the composition invariance of the massive tralesformation.

Figure 8.5 Thermodynaically calculated vertical section through the Fc-Ni-Cr diagram along a path that represents partitioning in the F+A two-phase ficld. Equivalent compositions of the seven alloys are indicated and the $T_{0}$ line in the $F+A$ region was calculated at 1575 and $1650 \mathrm{~K}$.

Figure 8.6 Gibhs frec encrgy versus composition plots along the 58 wo Fe isopleth, a) at $1300^{\circ} \mathrm{C}$, b) at $1375^{\circ} \mathrm{C}$.

Figure 8.7 Gibbs frec energy versus composition plot along the 53 w.\% Fe isopleth showing the volume frec encrgy change for ferrite transtorming to austenite in Alloy 5 .

Figurc 8.8 The influenec of sean specd on the perecntage of the melt which undergoes the massive transformation in Alloy 5 . Massively transformed areas appear as white regions. the remainder of the melt transforms by Hidmanstatten austenite formation. a) $6.3 \mathrm{~mm}$ /s, b) $25 \mathrm{~mm}$ s, c) $100 \mathrm{~mm} / \mathrm{s}$ and d) 500 $\mathrm{mms}$.

Figure 8.9 a) Hidmanstatten austenite sideplates growing from grain .248 boundary allotriomorphs at intermediate cooling rates, b) Widmanstatten sideplates at low cooling rates and c) intragranular Widmanstatten plates in Alloy 7.

Figure 8.10 a) Primary Widmanstaten sideneedles growing from grain boundary allotriomorphs and b) intragranular Widmanstatten needles in the heat affected zone of Alloy 7.

Figure 8.11 Degencrate forms of Widmanstatten sideplates. a) faceting. b) and c) sympathetically nucleated sideplates and d) branching.

Figure 8.1: Comparison of the isothermal transformation kinctics of 256 Alloys 6 and Alloy 7 .

Figure 8.13 Johnson-Mehl-Avrami analysis of tinc transformatic n kincrics 258 of a) Alloy 6 and b) Alloy 7 . 


\section{List Of Tabie Captions}

Table l.l Estimated cooling-rate ranges for arious solidification processing tcchniques.

Table 2.1 Compositions of the seven alloys (wt. perent)

Table 2.2 Chemical composition at different processing stages (wt. '..

Table 2.3 Elcetron beam melt summary. All melts at $100 \mathrm{kV}$ and $20 \mathrm{~m}-\mathrm{l}$. to

Table 2.4 Averagc width. depth and length of the six single-pass urtace th melts in $\mathrm{mm}$.

Table 2.5 Arerage compositions (wt perent) of the ferrite and aurenite phases in the arc cast buttons.

Table 2.6 Summary of $X+r a y$ diffraction results

Table 2.7 Density measurements made on the base metal allo:s 1.- and on fully ferritic specimens of alloy 6 and 7 .

Table 3.1 Nomenclature used to describe the magnetic measurement.

Table 3.2 Compositions of the fully ferritic, melt spun, allo!s

65

Table 3.3 Spontancous magnetization of fully ferritic spccimens.

(1)

Table 3.4 QTM ferritc measurements

Table 3.5 VSM measurements of " and ferritc.

Table t.l Cooling rates calculated from primary and sccondary dendrite arm spacing measurements

Table 4.2 Nomenclature used in chapter 4

Table 4.3 $P_{t}$, and, for the six clectron beam melts.

Table 4.A Phısical properties for stainless stecl

Table 4.5 Maximum cooling ratc in the liquid at the $L$. $S$ interfacc.

Table 4.6 Welding parameters, physical dimensions and mesh propertics 100 for the two welds to be studied by FEM analysis.

Table 4.7 Comparison of the FEM and DAS estimations of the cooling 104

Table 5.1 Summary of the primary modes of solidilication for the seicn alloys at low, intermediate and high cooling rates

Table 5.2 Liquidus and solidus tempcratures for ferrite and austenite

Table 5.3 The ferrite content in the $1 \mathrm{~mm}$ decp electron-beam surlate treated zone and in the basc metal substratc. 
Table 5.4 Comparison of the terminology used to describe the different microstrustural morphologies in stainless steel alloys.

Table 5.5 Deseription of the ferrite and austenite phases.

Table 5.6 The solidification mode. solidification sequence and solid-statc iransiormation events responsible for the different miscostrueiures.

Table 6.1 Equilibrium ferritc contents at the solidus and at 1000. $\mathrm{C}$

Table 6.2 Predicted and measured ferritc contents of the are cast buttons

Table 7.1 Partition cocfficients and the slope of the liquidus lines for primary ferrite and primary austenite solidified alloss.

Table ?. Cominal. cutectic and maximum solid compositions (4t.

Table 7.3 Wold pool dimensions and average interiace velocits for eath of the six clectron beam surface melting conditions.

Table 7.4 Ascrage temperature gradicnts during solidification of the 6 clectron beam rielts.

Table 7,5 Propertics used to ealculate the dendrite tip characteristies.

Table 7.6 Nomenelature used to describe solute redistribution amount of icritc and austenite in the seren alloss

Table 7.8 The Bredy and Flemings back-diffusion parameter caliulated for allo:s 1 and 7 at each of the soliditication conditions

Table 7.9 Comparison of the solutal undcreooling calculated for the castine and two elcctron beam melts with the underiooling neccssary for single phase solidification.

Table 8.1 Volume diftusion in BCC Ferritc

Table 8.2 Volume dilfusion in FCC Austenitc

Table 8.3 Characteristic diffusion distance and dendrite arm spacings.

Table 8.t The amount of ferrite that transtorms as a function of conting rate.

Table 8.5 Perecntage of massile and Widmanstatten austenite that form in the fully ferritic solidilicd portions of the E-beam melts in Allo! 5.

Table 8.6 Results of the isothermal transformation experiments listing 4. Fration ferritc as a funtion of time.

Table 8.? Cocficicnts for the Johnson-Mehl-Arrami cquation 


\section{Acknowledgments}

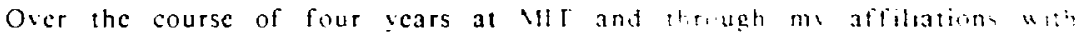
Laurence livermore National Laboratory, I hac becn atridused to man new lis: and have met many pcople that have helped to shape this work and is final firm

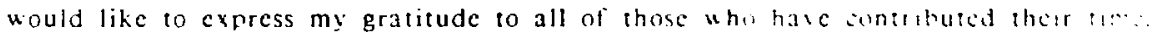
encouragement and support of my efforts.

I would like to first achnowledge the guidance and direstun gave to me :. Prolessor T. W. Eagar, thesis supervisor and liciend lie sac me the uppurtunit:

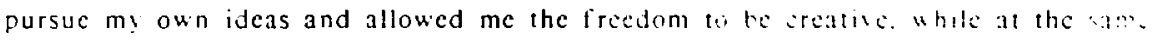
timc maintaining my rescarch on a productive path.

The invaluable contributions of my thesis committce members hase not unl: helped to direct my research but also to guide my professional adsancement. I am grateful to Prolessor S. M. Allen, who, as co-supervisor, guided me through the rigur of academic life at MIT and added valuable phase transformation expertice to m: work. I consider myself fortunate to have had the opportunity to work with Professor M. Cohen and Professor M. C. Flemings. As members of my thesis committce. they gave me insight into the theories of solid-state phasc transformations and solidification and provided many helpful suggestions to this thesis. Its through their acceptance of this work that gives me the greatest sense of accomplishnent. I would like to also express my thanks to Dr. Y. Shiohara who taught me solidilication theory and offered friendly assistance to my project, as if it were his own.

The congenial atmosphere provided by the Joining group in room 4-047 at M1T has helped to make these ycars a rewarding and memorable expericnce. We have becn thiough many good rimes and have seen many changes together. I am thankful to Dr. C. Sorensen for assisting with computer-related tasks in the laboratory and to Dr. $\mathbf{M}$. L. Lin for writing the FEM code that added so much to this work. Special recognition goes to Dr. M. A. Khan and the other members of the 4 W's for our "non-technical" discussions.

I am grateful for the assistance offered by the knowledgeable and skilled people at MlT and Lawrence Livermore National Laboratory. Firstly. I would like to express 
my thanks to the welding and joining group at LLNL, especially to D. M. Hoflman and $B$. L. Olsen for assisting with the electron beam surface melting. I would also like to thank Professor W. H. Gicdt for discussions about high encrgy densit! welding and heat flow, Dr. K. Mahin for initial discussions concerning a suitable thesis topic. H. Weiss for his encouragement and for his belief in my abilities and C. E. Witherell for his assistance with the alloy castings. In addition, I would like to acknowledge the skilled netallographic assistance offered by P. K. Ambalal, W. L. Beil and S. S. Digallonardo. Special thanks go to M. K. Kong for his generous contributions in generiting the 3-Dimensional FEM meshes and to S. Cowan for her friendly and timcly help in typing many of the chapters of this thesis.

Sccondly, I would like to thank the pecple at MIT who have kindly provided their time to this project. Dr. R. C. OHandley fel reviewing the portions of this thesis that deal with the magnetic behavior of matcrials. Dr. Y. Hara for introducing me to the VSM. H. M. Lec for showing me how to use the Thermocale programs, and the L'ROP ztudents: Michele Sequeira and Andre McFayden for help with laboratory experiments.

l Would like to sincerely thank Glenn. Karen and Sarah Campbell. and Tciichi and Sumiko Ando who have offered their house and home to me upon many occasions in the Boston area. I would also like to express my decpest gratitude to my parents and bother who have always supported my work with lieir love, encouragenent and their faith in my abilitics.

Finally the author, grateful for her affectica. understanding and help with many aspects ot the preparation of this document. would like to dedicatc this thesis 10 S. 1. Currs. 
To Sandra Lee Cam. 


\section{CHAPTER 1}

\section{Introduction And Background}

The integrity of stainless steel astings and welds is known to depend on the presence of delta ferrite in the microstruciure. Traditional studies [1.1-1.12] have shown that ferrite contents on the order of 5 volume to will reduce susecptibility to solidification cracking. improve hot workability. and lower the amount of non-merallic inclusions in the alloy. Masumoto [1.3] has shown that these effects predominate when ferrite is the first solid to form from the liquid. and Brooks [1.1:] has summarized the reasons for this behavior. Two bencfitial propertics of ferrite in stainless sicils are the higher solubility of sulfur and phosphorus in ferrite than in austenitc, and the irregular, erack-resistans, grain boundaries that form during nulti-phase scilidication. Therefore, primary lerrite solidification reduces the amount of low melting-point liquids. by dispersing $S$ and $P$. and inereases the crack propagation resistance of the microstructure.

Despite such desirable propertics, ferrite is not always beneficial to the mierostructure of stainless steel alloys. For example. in austenitic stainless stcels. during prolonged cxposurc to high temperatures. Ferrite san transform to sigma phase which is britile [1.13]. The severity of the embrittement depends on the degree of transtormation and the amount of ferrite in the microstructure. For this reason alone ferrite contents are of ten minimized, but there are esen further disadvantages. Ferrte san reduce the corrosion resistance. [1.14.1.15] and it can reduce the low-lemperature tracture toughness of austenitic stainless stecls [1.16-1.18].

The beneticial effeces of ferrite in sone applieations and the deleterious effects in whers requires a good understanding of the sonditions whith lead to the formation 11 ferrite in the micostructure. Numerous insestigations of the relationship betueen themisal sompusition and ferrite content hase been made and are summarized b! Otsun 11.19]. These studies hate led to the delelopment of methods and diagrams tu prodist ferrite sontent [1.20-1.24]. ferrite morpholog! [1.25.1.20j. and the prinar! solidilication mode $\{1.27 .1 .28\}$. Howerer, these results are onls valid lue cunsentional watlogs and welds which colidily at low cobling rates 
Advances in rapid solidification processing and the use of high energ: densits welding for an increasing number of applications have emphasized the importance al cooling rate in the crolution of stainless stecl mierostructures. Recent intestigations have concluded that the amount of ferritc and the primary mode of solidification san be significantly altered in pulsed laser beam welds, in clectron baam welds. and in atomized droplets. These microstructural modifications eannot be predicted using the conventional methods and there have only been a lew studies of the microstructure of stainless stecls solidificd at high cooling rates. This chapter begins with a resiew of the literaturc conecrning the enstitution of Fe-Ni-Cr alloys for low cooling rate and high cooling ratc processes which revealed man! arcas that required further investigation and helped to direct the rescarch elforts presented in this thesis.

\subsection{Previous Investigations}

\subsubsection{Constitution and Microstructure of Stainless Steel Alloys}

Austenitic stainless stcels of the AISI 300 scrics designation have two primary constituent phases: austenitc and ferritc. A third phasc. martensite. san be induced to form in these alloys by low temperature mechanical deformation However, the martensitic transtormation will not be studied here. since this investigation is only concerned with the phases which develop during solidification. The austerite phase has a facc-centcred cubic structurc and is paramagnctic. Ausicnitc can form during solidification, or during the solid-statc transformation of ferritc. Nickel, mangancsc. carbon, and nitrogen promote the fomation of austenite during solidilication. and the majority of the AISI 300 series stainless stcels contain austenite in cxcess of 80 vol\%.

The ferritic phase, delta ferritc, has a body-centered cubic structure and is ferromagnctic. Ferritc forms only during solidification and transforms to ausicnitc at lower temperatures. Frequently the transformation is incomplete. learing residual icritc in the microstructure. This residual ferritc can be present in several dilferent morphologies, depending on the chromium-to-nickel ratio of the alloy [1.25,1.26.1.29-1.31]. Chromium, silicon, molybdenum, and niohium pronute the 
formation of lerritc during solidification and proside it with stability at huser temperatures. The residual ferrite present in the microstructure is therciore a result of the ferrite which solidilies minus the amount that transtorms as the alloy cools.

The single most important lactor in the development of the mieroutrature at a

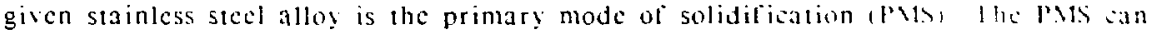
cither be austenite or lerrite and is primarily a function of compentlan. The pas defines the primars phase to solidity from the melt and it alu defincs the solidification morphology which determines the conditions for the vuluequent whd statc transformation. Chromium rich alloys tend to solidity as prman ferrite "hils nickel rich alloys tend to solidify as primary austenite. The compunitinal range fin cach mode can be predicted by the line of twolold saturation in the 1 - Vi-cr stylcm.

Figure 1.1 shows that the linc of cwo-fold saturation cxtends from the l s-ii peritcetic at 4.?" $\mathrm{Ni}$ to the $\mathrm{Cr}-\mathrm{Ni}$ cutcetic at $49^{\circ}, \mathrm{Ni}$ and has a melting point minimum at $49^{\prime \prime},\left[\mathrm{r}, 43^{\prime \prime} \% \mathrm{Vi}[1.32]\right.$. Solidification of compositions that lic on the line of two-fold saturation occurs by a peritcotic mechanism at high iron contents and bs an cutectic mechanism at low iron contents. The ternary composition where the peritectic bchavior changes to cutectic behavior has been reported by Sihurmann

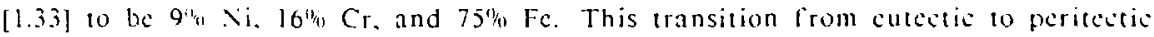
behavior lics slose to the composition of many of the $18-8$ stainless steci alloys. Thermodynamic calculations of the Fe-Ni-Cr system have been perlorned (sec Appendix () to determine the location of the tic lines in the tuo-phase ficlds. Figure 1.2 shows an isothermal section at $1400^{\circ} \mathrm{C}$ and indivates that the segregstion ratios let $\mathrm{Ni}$ and $\mathrm{Cr}$ in Fe vary considerably in the ferrifi-liquid, austenite-liquid and ferrite-austenitc phase ficlds. These resulis will be discussed in detail in the shaptsis to conic.

Vertical sections through the Fe-Ni-Cr ternary system can le determined h! cxperimental measurcments or by thesmodynamic eakulations. Ihese diagrams are uscful in describing the solidification and solid state transtormalion hehasior of stainless stecls. The experimentalls determined licuidus, solidus, and isothermal sections reported by Rivlin and Raynor [1.32] were used to constedet a vertical tection through the Ie-Ni-Cr sgstem at a constant iron content of of"n. Ligure la shows the

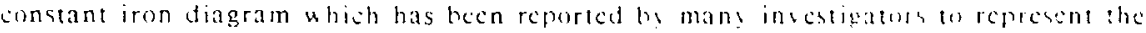


solidification hehavior of stainless stecls. B3 comparing the tie-lines presented in I ig. I. with a constant $\mathrm{Fc}$ isopleth, one secs that althugh the actical cection pesented in Fig. I.3 has an appearance simita to a hinary whase diagram. the tio-lines in the two-phase fickds do not necessarily lic in the plane of the lertical scotion this is particularly true for the the liquid-solid ficlds that determine the solidiliation segregation ratios. A more aceurate representation of the soliditieatiun hehavior van be determined by taking the vertical sections along a path that contains the tic-lines of interest. Chapter 7 presents the results of thermodynamic calculations which were used to determine the pseudobinary diagrams for primary ferrite and primar austanite solidilication. These modafied sertical scetions are useful in derermining the solidification paraneters and the segregation of solute during solidifiation.

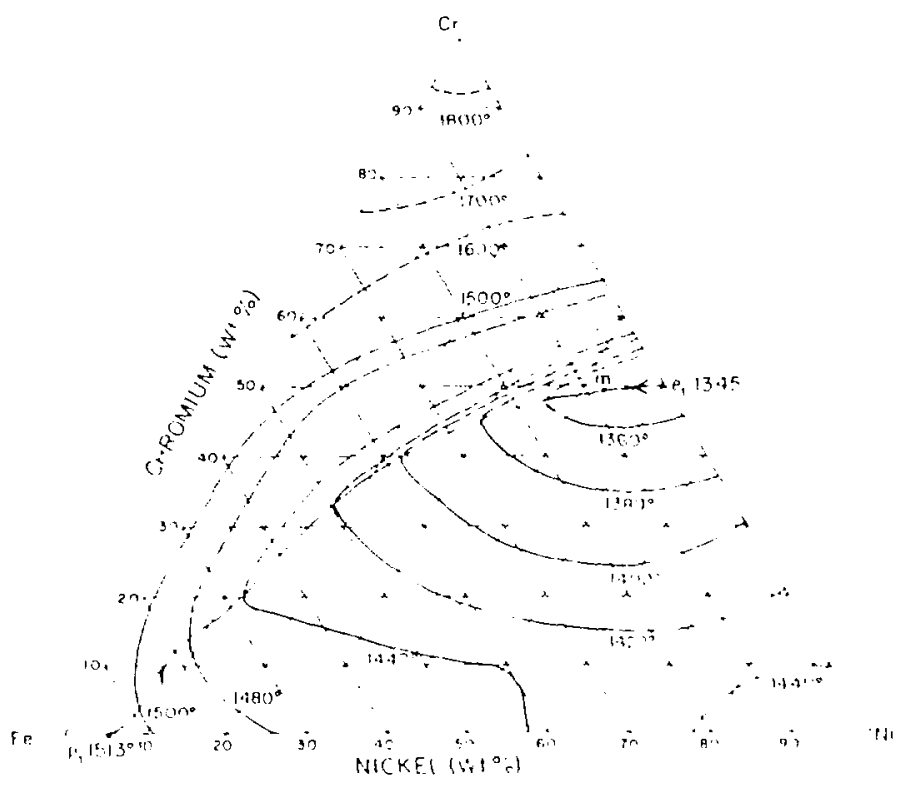

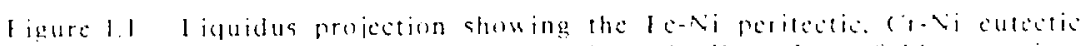

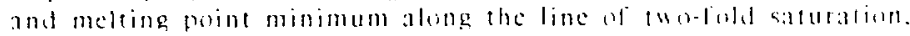
alter Risitin et al. 11.32\}. 


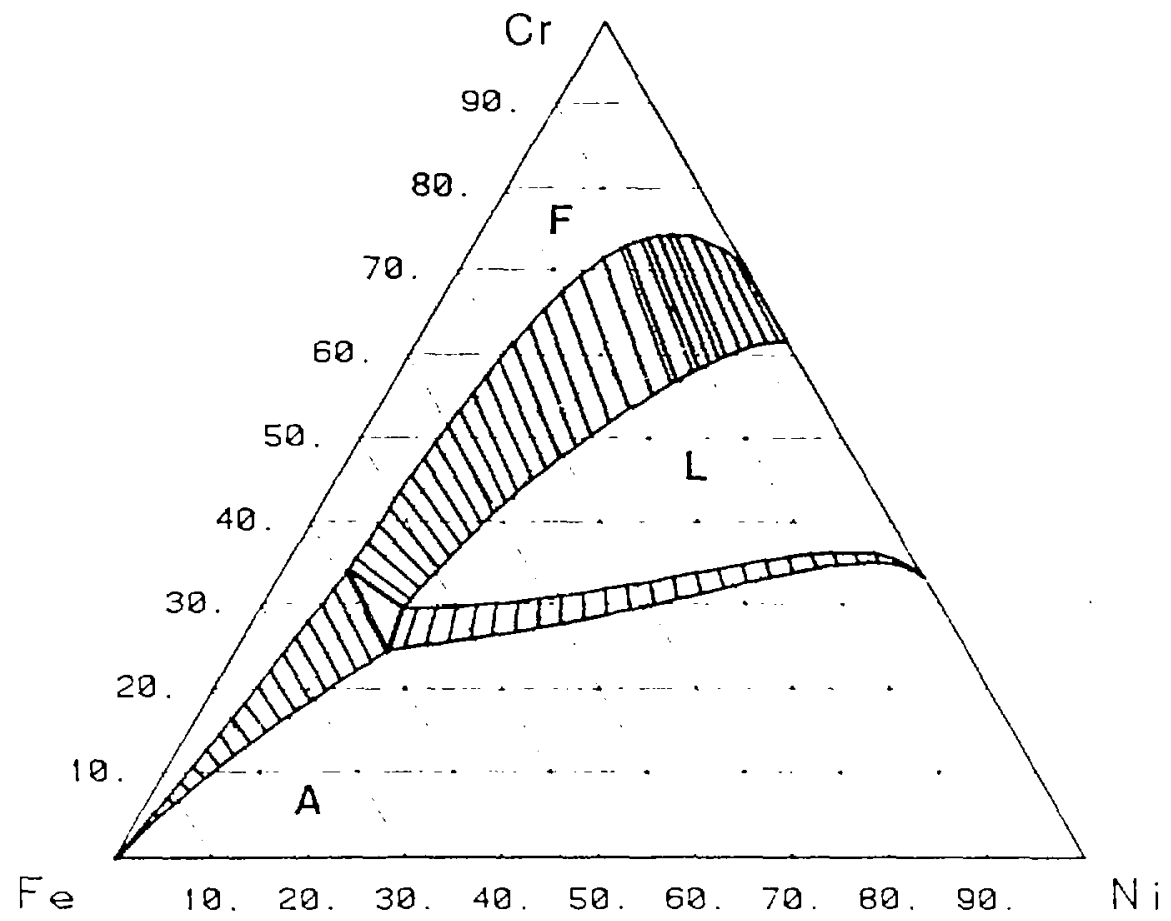

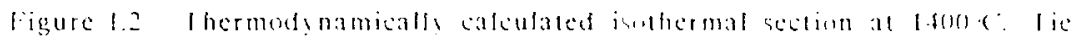
lines are indicaled in the two-phate lichls. 


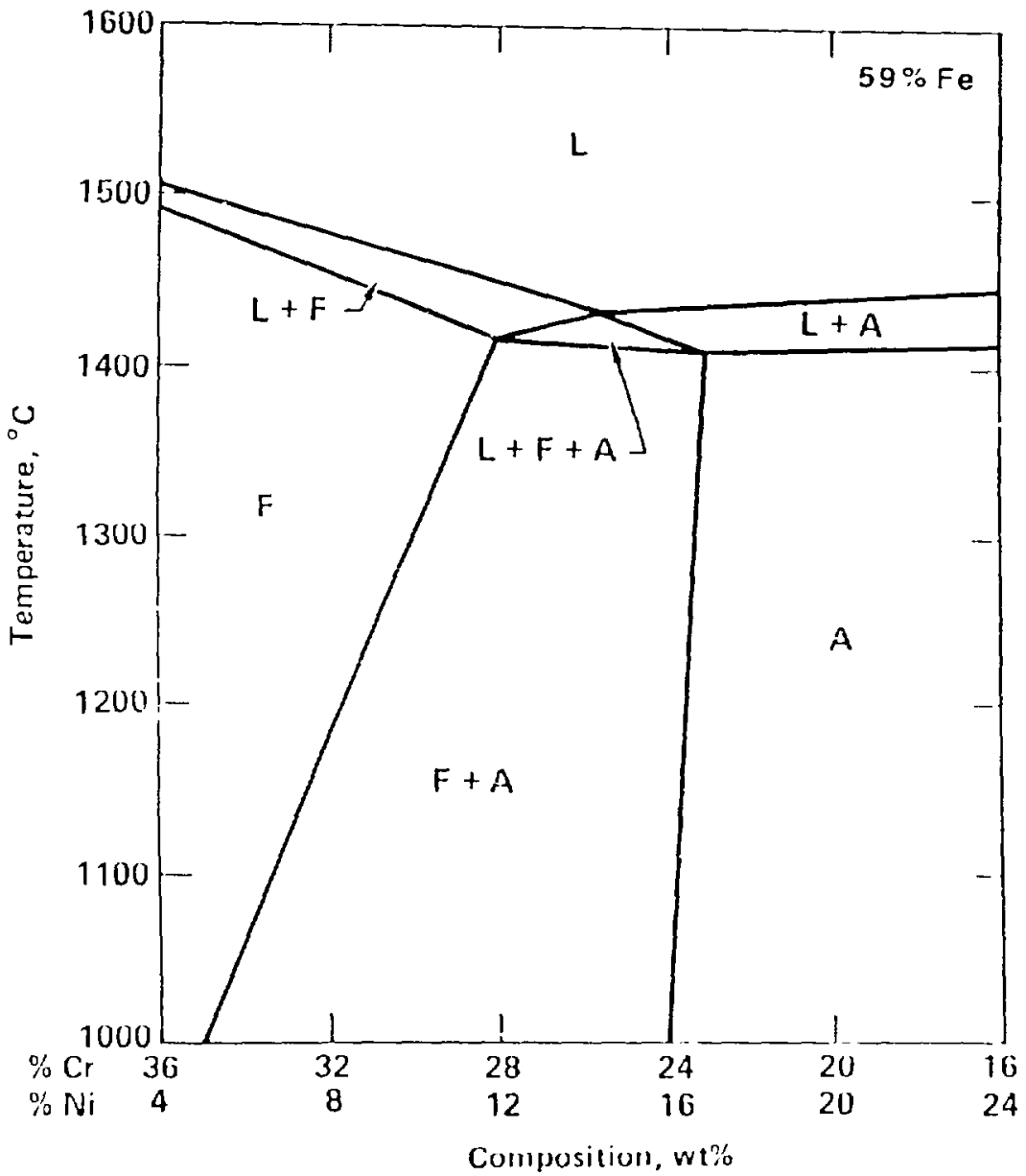

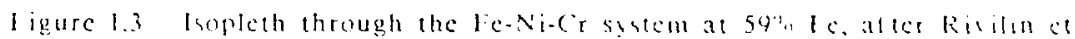
al. $|1.32|$ 
The line of two-fold saturation crosses the $60^{\circ}$ " Fe plane at a composition of $25.5^{\circ}$. $\mathrm{Cr}$ and $14.5^{\prime \prime} \mathrm{Ni}$, which is a $\mathrm{Cr} \mathrm{Ni}$ ratio of 1.76 . The maximum separation betueen the liquidus and solidus lines is about $50^{\circ} \mathrm{C}$. and the slope of the liquidus is steeper for primary ferrice solidification than for the solidification of primars austenite. Under equilibrium conditions. live modes of solidilication are possible depending on the composition of the alloy with respect to the line of wo-lold saturation:

F: Single-phase ferritic solidification. Ferrite solidilics as the prinary and only solid phasc. Austenite may nucleatc and grow from grain houndarics or interdendritic boundarics at subsolidus icmeraluses.

FA: Ferritio-austenitic solidification. Ferrite solidilies as the minary phase in a dendritic or cellular mode with second phase austenite forming at the eell walls. The second-phase austenite provides growth sites for the subsolidus austenite to ferrice transformation.

F: Eutcetis solidification. Ferritc and austenite both solidit? from the cutcelic liquid as conjugate solid phases This reation gencrally tatics place after some primary solid phase has formed. The spacing of the eutectic microstructure is smaller than the primary phase spacing which mates the eutectic ferrite particulariy susceptible to the solid state translormation.

AF: Austenitic-ferritic solidification. Austenite solidifies as the primar: phase in a dendritic or cellular mode with second-phasc fersite forming at the cell walls. The sccond-phase ferrite partially transforms to austenite at subsolidus temperatures.

A: Single-phase austenite solidification. Austenite solidilies in a dendritio ol cellular mode as the primary and only solid phase. segregation oceurs to the ecll walls but no ferrite is present in the microstructure.

Under the nonequilibirum conditions which oceur during solidification. the same modes of solidification cxist but some compositions ma! change mote with conling 


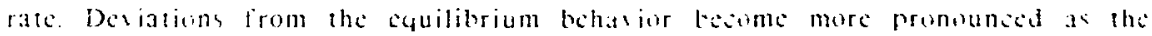
cooling rate is moteased and the cooling rate will be shown th have a vignoliant elfert an the soliditication mode.

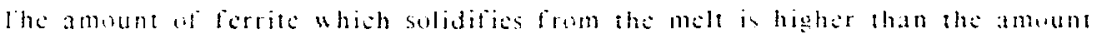
which is present at rom temperature beause fente transtiems to autenste as the

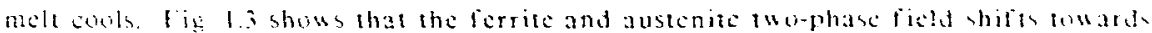

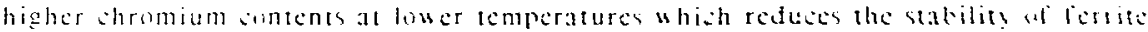

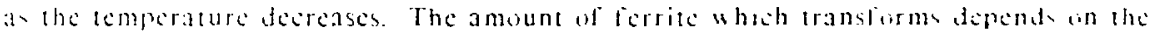
sompusition and the owling rate. Since isothermal sections through the fe-vi-gr

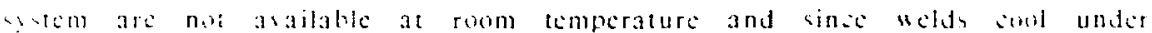
nom-equilitrium anditions. other means hase heen deschos for predisting the amunt al ferrite in stainless stecks

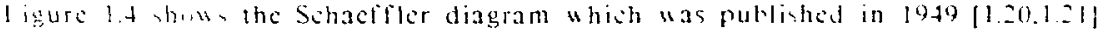

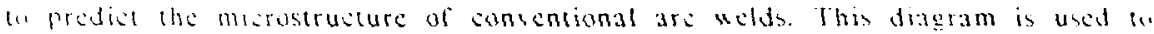
prodict the amount of lerrite in stainless sted welds baed on their nominat smpmition but des not incorporate cooling-rate effects. Ihe ohromium and nichel

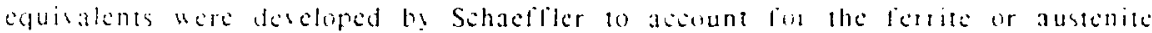

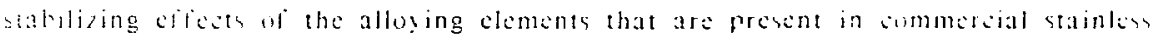

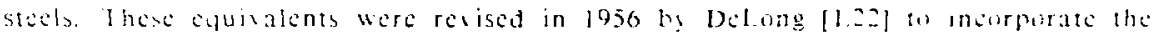
austonitizing elicets ol nitrogen. and are derined as fullows:

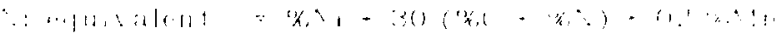

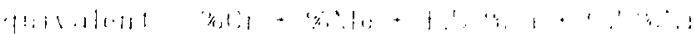

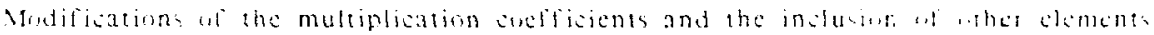

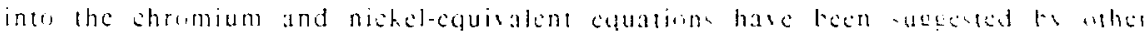

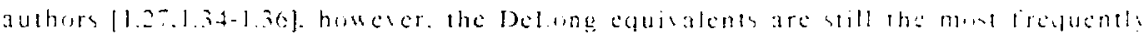
used cquations.

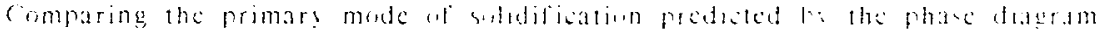

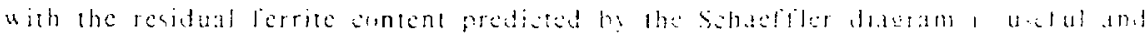

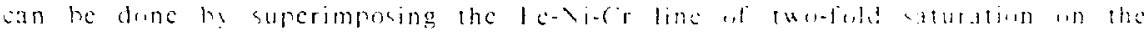


Sehather diagram. This line separates primary ferrice solidificatien fum mima! austenite solidification for cquilibrium conditons. Figure 1.4 shoms that it sabes

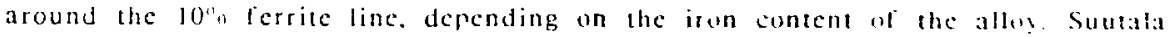
[1.27,1.28] has proposed that the primary soliditiation whase san bs predicted in welds by a Cr Ni ratio of about 1.5; allogs with a higher (1 Ni ratio than 1 s will solidif: as primar! ferrite. while those lower than 1.5 will solidity as prima! austenite. Sutaias $\mathrm{Cr} . \mathrm{Ni}=1.5$ line is also shown on Fig. 1.4 and indicalcs that it is elose to the line of two-fold saturation.

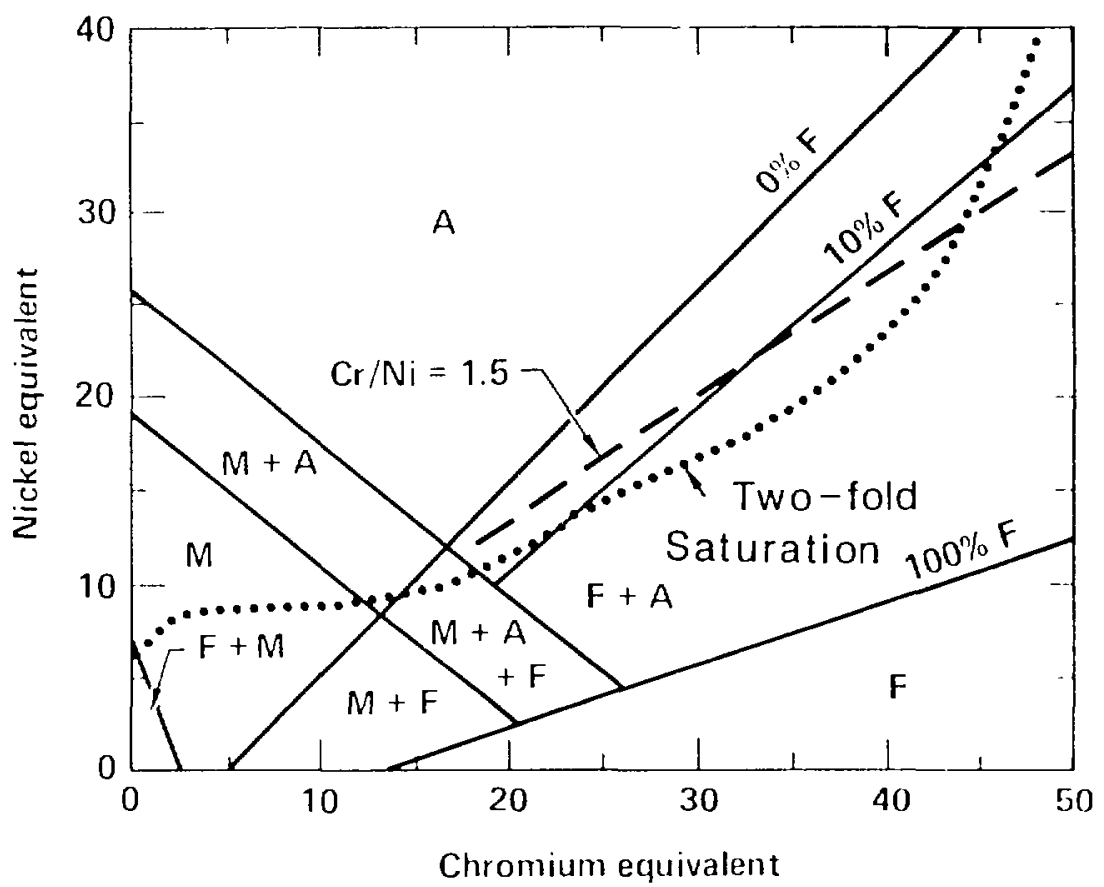

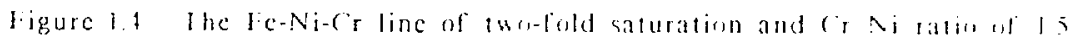
superimposed on the Schacliter diagram. 
Therefore. the primary mode of solidification and the amount of residual ferrite in stainless stecl alloys ean tic predicted reasonally well a low cooling rates. Howerer. at high cooling rates the impirically derived diagraris san not be used to predict ierrite contents. ierrite morpholog! or cven the primary node of solidilication. The relatiscly recent emergence of rapid soilidification processing and high energy density welding requires that a better understanding of the influenee of cooling rate be developed in order to predict the efreets of these processes on the mierostrusture ol stainless stecls.

\subsubsection{The Effect of Rapid Solidification on the Mlicrostruct ure}

The influche of cooling rate on the microstrueture of staintess stect alloys has lecen observat at low. medium and high cooling raies. However. the most dramatio cflocts osur at the high cooling rates produced by rapid solidilication processing and high-energy densil! welding. The inherent ariations in the cooling rate for different solidilication processes arc summarized in Table 1.1 and are shown to sover about 9 orders af magnitude.

Table 1.1: Estimated cooling-rate ranges for various

solidification processing techniques.

\begin{tabular}{|c|c|}
\hline Process & $\begin{array}{c}\text { Cooling Ratc } \\
(\mathrm{ks})\end{array}$ \\
\hline Directional solidification & $10^{-1}-10^{1}$ \\
\hline Casting & $10^{0}-10^{2}$ \\
\hline ArE welding & $10^{1} \cdot 10^{3}$ \\
\hline Elcctron beam welding & $10^{2}-104$ \\
\hline laser beam welding & $10^{2}-10^{6}$ \\
\hline Rapid solidilication processing & $10^{3}-107$ \\
\hline EB or $1 . B$ surface modilication & $10^{5}-107$ \\
\hline Single laser pulse & $10^{7} \cdot 10^{n}$ \\
\hline
\end{tabular}


At the lowest cooling rates $\left(10^{-1}\right.$ to $10^{10} \mathrm{C}$ s) which occur in directional solidification or an large ingots. only small shanges in the microstructure oceur with variations in the cooling ratc. Percira $[1.37]$ has shown that cooling-ratc sariations over the range of $2-40^{\circ} \mathrm{C}$ s will produce changes in the ferrite content: with insteasing cooling ratc, primary ferritc-solidificd compositions will increase in ferrite content from 13 to $16 \%$. Whilc primary austenitc-solidified compositions will decrease from 1.5 to $1.0 \%$. Fredrikkson $[1.38\}$ has also investigated the role of cooling rate on solidification mode and concludes that a cooling ratc incrcasc in the range of 10 " to $10^{3 \circ} \mathrm{C}$ favors the primary formation of ferritc.

Moderate cooling rates $\left(10^{1}\right.$ to $10^{3 \circ} \mathrm{C}$ s), which are produced in are welw., show only small changes in the microstructure as the cooling rate is intreascd. Suutala [1.28.1.39] has obsersed a gradual decrease in ferrite content as the weld travel specd is increased. and concludes that an increase in travel specd (which increases the cooling ratel. lavors the primary formation of austenite for dendritic soliditication. Delong [1.4] has also recognized the ability of the cooling rate to modify the microstructure of stainless stecl welds and castings. He states that he st input has an effect on the ferrite number, but that this effect is only a minor consideration.

The high cooling rates which can oceur in elcetron beam and laser beam welds significantly alter the microstructure. Vitck and David [1.40-1.42] have reported the changes in ficrite content associated with high cooling rates in a comparison of are-welded and laser beam welded AISI 308 stainless stecl. They reported a decrease in ierrite content from $10 \%$ to less than $1 \%$, with a change from GTAW llow cooling rate) to LBW (high cooling ratc) welding processes respectively. They belicse that this behavior occurs because of a change in primary solidification mode from ferritc to austenitc.

Katayma and Matsunawa [1.4.3] have also investigatcd the high cooling rate $110^{5}$ to $1060 \mathrm{C} / \mathrm{s}$ ) behavior of laser beam welded microstructures for about thirty different commercial AIS1 300 series and high purits stainless stecls. They conclude that the Schacfiler diagram requires modilications at high cooling rates. and thes reconmend a compression of the austenite-ferrite two-phase field as shown in Fig. 1.5. For high cooling rates their observations indicate that the ferrite content of lou-ferritc uclds is reduced while the ferrite content of high-ferrite uclds is increased. Kata! ama and 
Matsunawa attribute these two distina behasios to a change in pimb

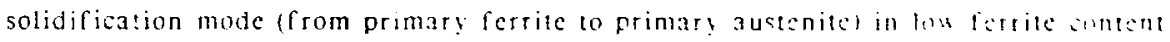
welds, and to a suppression of the solid-state transtormation of fertiti in hah $1: 2$ tate content uelds.

Changes in the solidification mode have also been obsered at hish winling tates which can be induced in electron beam welds. Lippold 11.44 ha eamined the solidification conditions fot a decp-penctration elcetron heam wela in intl aginlese stecl and has shown that for certain conditions a change in the primar coliditication mode occurs. Lippold concludes that welds which normalls solitili as primar ferrite can solidily as primary austenite in the decp penetrating purtion al the welit pool which has the highest cooling rate. These results support the ulderati... i refs. 1.40-1.43 for laser beam welded stainless stecl.

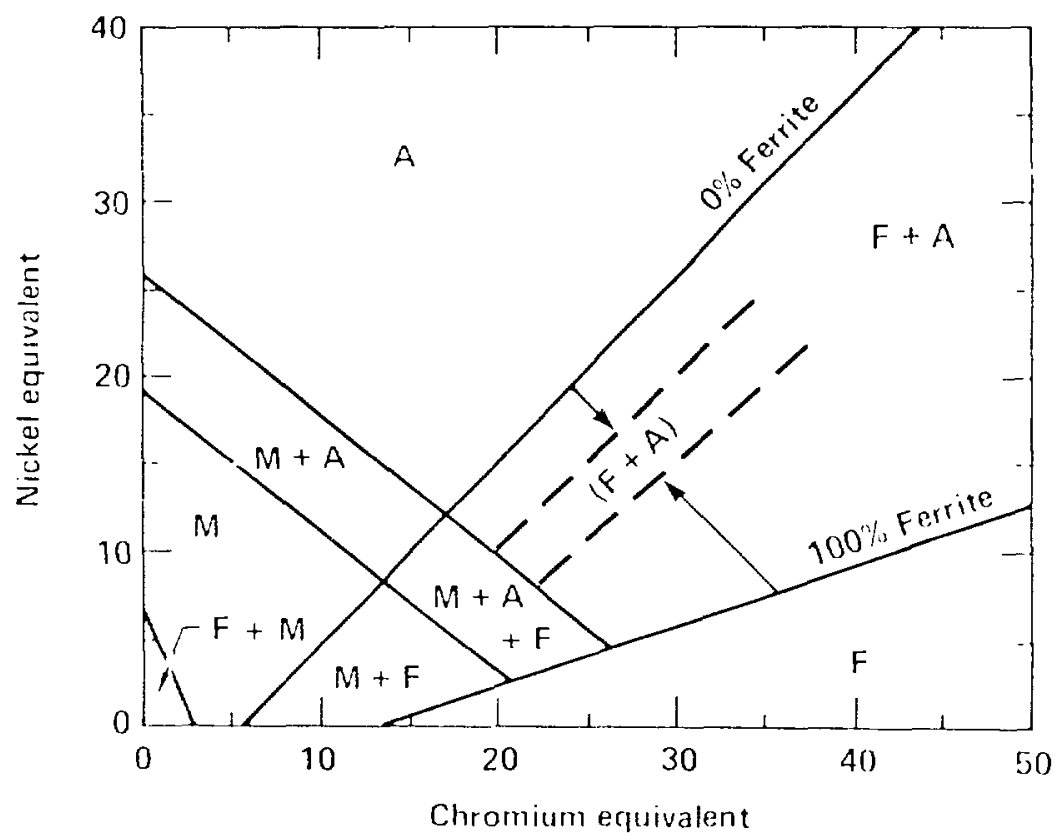

Figure 1.5 Shifting of the $0 \%$ and $100 \%$ ferrite houndaries of the Selace ilet diagram at high cooling rates. Pulsed laser welds at lon. aller Katayama et al, $\{1,4.3\}$. 
Changes in the primary solidification mode have been obseried for rapidly solidilicd stainless stecls. Kclly [1.45] has investigated microstructural and compositional iariations that occur in atomized droplets of AlSt 303 stainless stecl. droplets which normally solidit! with the formation of primary austenitc. Such droplets achicse cooling rates on the order of $10^{5 \circ} \mathrm{C} s$. Kelly's results show that. since the smallest droplets receive the largest thermal undercooling. ferrite preferentially nucleates in favor of austenitc. He provides thermodynamic data and a kinctic model. which confirm the change in solidification mode lor highl! undercoolcd Jroplets. This work shows a preference for primary ferrite at high sooling rates while referenecs $1.40-1.44$ show a preference for primary austenite at high cooling rates. The apparent inconsisteney is duc to the diflerence in the nucleation behavior betucen humogencously nucleated atomized droplets and heterogencously nucleated welds.

In summar. the cooling rate plays a significant role in the crolution of stainless stecl microstructure. Its influence can not be generatized and one must consider both the shemical composition and the solidification conditions of a given alloy. These wo factors combinc together in a complex way to influenec 1) the primary solidification mode. 2) the amount of solidification segregation and 3) the nucleation and growth hehavior of the ferrite to austenite solid-state transformation. These clicets alter the ferrite content and ferrite morphology. However, a systematic investigation of the relative importance of these three effects in determining the microstructure has not been performed.

\subsection{Present Investigation}

\subsubsection{Objectives}

The purpose of this investigation was to study the microstructures which develop in Fe-vi-Cr ternary alloys under rapid solidification conditions, with several objectives in mind. Firstly, the results of this study were to proside a basic understanding of the complex solidification and transformation behasinr which oceurs during the rapid resolidification of stainless stecl alloys. Explaining this 
behavior required solidification experiments to be performed on Fe-Ni-Cr ternar! alloys and confirmation with rapid solidification theory. This l! pe of analysis was used to predict the inflacnec of cooling rate on the microstructure of stainless steel alloys and the basic concepts developed here can also be applied to other alloy sistems that involve solidification and subscquent solid state transformation erents.

Secondly, the eyperimental results will be used to create diagrams that can he used to predict the primary mode of solidification, the ferrite content and the ferrite morphology of stainless stecls solidified over a large range of cmoling rates. These diagrams san also be used to decouple the separate contributions of solidilication mode. solidilication segregation and the solid state transformation if ferrite on the resulting microstructure. These diagrams have practical significance in that they can predict the microstructures of stainless stecl alloys which have been wat, welded or rapidly solidified at different cooling rates.

Thirdly, recent investigations $\{1.42,1.43$ ) of high encrg! density welds and rapidly solidificd melts have shown large differences between the microstrustures whish develop at high cooling rates and those which develop at low cooling rates. Ilowerer. the theories that have been postulated to describe these differenees has not yet heen substantiated by a thorough scientific study. In particular, one author [1.40.1.42] belicves that a change in the primary mode of solidilication occurs by nucleation of metastable austenitc in pulscd laser welds. A similar change in solidification mode is observed in clectron bcam surface melts, however, in the clectron beam melts the a mount of undercooling was shown to be $30^{\circ} \mathrm{C}$ or less. This undercooling is not large crough to explain the nucleation of metastable phases from within the melt and it Was shown that the change in solidification mode can he explained by the preferential growth kinctics of the austenite phase at the melt periphery. Therelare. another objective of this study was to erphasize the importanec of growth kinetics in rapidly solidificd surface melts and to illustrate that the PMS mas change at high cooling rates without necessity of postulating nucleation of metastable phases from the me!t. 


\subsubsection{Approach}

A serics of Fe-Ni-Cr tenar! alloys was made with systematio variations in composition. Silcn allo!s werc cast from high purity clements, all having 0.59 we Fe but with dificrent $\mathrm{Cr} \mathrm{Ni}$ ratios that ranged from 1.2 to 2.2. This ariation $\mathrm{ir}$ ( $\mathrm{rr} \mathrm{Ni}$ ratio is representative of the general behavior of a wide range of stainless steci alloys. High purity alloys were selected in favor of comnercial stainless stecls so that the composition could be controlled in order to eliminate the cficets of interstitial and other alloying element segregation.

Variations in the cooling rate werc produced by an elcctron beam surtace niclting technique. The power level of the electron beam was held constant for all of the melts but the travel speed was varied from $6 \mathrm{~mm} 5$ to $5000 \mathrm{~mm} \mathrm{~s}$. This resuited in different cooling rates in the surface melted regions that varied from $4.7 \times 10^{2}$ o $\mathrm{C}$ for the slowest travel speed to $7.5 \times 10^{6}{ }^{\circ} \mathrm{C}$ : for the highest travel specd. All of the metts were compared to the arc-cast buttons which cooled at a rate of $7 \circ \mathrm{C}$. Elcetron beam surface melting was selected because the power input to the substratc can easily be characterized and because it can produce controlled specd surface melts at high blocities. A more detailed deseription of the materials, solidification cxperiments and other experimental procedures is presented in Chapter?

Chapter 3 deseribes a ferrite measurement technique that can be used to measure the ferritc content of rapidly solidificd stainless stecl alloys. This method is new and was developed as part of this investigation because the ferrite content of the rapidit cooled specinens could not be measured by conventional techniques. This method utilizes a Vibrating Sample Magnetometer to measure the saturation magnetization of an unhnown specimen and by knowing the saturation magnetization ol ferrite. the bolume pereent ferrite can be calculated. Since the ferite content is related to the saturation magnetization of the specimen, this technique does not depend on the size. geometry or orientation of the specimen and can casily measure the ferrite content in the small volumes of material that are produced in rapid soliditication processes. lloweres. since the saturation magnetization of ferrite depends on the ferrite composition. a separate study was required to determine the composition of residual ferite lom the nominal alloy composition and to declop an empirical cquation tu, 
calculate th, saturation magnetization of icrritc from its composition. The results of this study allow the Vibrating Sample Magnctometer to be calibrated so that the ferrite concent of a wide range of stainless stecl alloss can be measured.

Chapter 4 summarizes the methods used to cstimate the cooling rate in the clectron beam melts. Since the electron beam melts were small and were mosing at high rates of speed. the temperature and cooling rates in these melts could not he measured by consentional techniques. Therefore. the cooling rates were estimated by 1) dendrite arm spacing measurements. 2) an analytic solution to the heat flow equation which was used to cstimatc the highest cooling rate in the surlace melts and i) a finite clement model which was used to calculate thermal gradients and cooling rates at the liquid solid interlace for a few selected conditions. The threc techniques agread well with each other and showed that the cooling rates varicd orer 5 orders of magnitude. From the cooling rate measurements and the interlace velocits. the avcrage temperature gradient was also calculated in cash melt. These temperature gradient calculations were confirmed using the FEM program and the results were used in later chapters to calculate interface stability and solute redistribution in the clectron beam melts.

Chapter 5 summarizes the cffects of cooling ratc on the primary mode of solidilication and the residual ferritc morphology for cach of the seren alloys. The results of this chapter are based on the optical metallographic cxamination of the clectron beam melis and are summarized in tho diagrams. One diagram presents lac primary mode ol solidification as a function of cooling rate and composition while the sciond diagram presents the microstruttural features which form from cash mode of solidification The first diagram describes the solidification bohavior of stainfess steel alloys while the sceond diagram describes the solid state transtormation hehas ior as the melt cools to room temperature. From these diagrams. the mude wit solidilication and the ferrite morphology can be determined for a wide range ul stainless steci alloys and for a wide range of solidilication conditions. In addition la the predictive diagrams. the surface melts were studied we determine the methol bs which the primars solidification mole declops. These obserations shou that icrate and austenite both grow epitaxialls from the melt periphers. Nisustutural examination of the high speed melts abs showed that changes in soldufication mude 
which oceur with increasing cooling rate are a result of the lavorable growth hineties of motastable austenitc rather than the nucleation of motastable austenite from within the melt pool.

Chapter o insestigates the influence of cooling rate on the fertite content of the stainless stecl allots. The results of this chapter show that the ferrite content changes signifiantl! with sooling rate and that the amount of residual ferrite in the miscostrueture depends on the primar! mode of soliditication, the Cr Ni ratio of the allos and the couling rate. Thesc observations confirm the carlier results [1.42-1.44] on laser beam and clectron beam welded stainless stcels at high cooling rates. In addition. these results show that the ferrite content decreases (or increases) in a continuous manner with cooling rate by studing infermediate cooling rates which had not been presiously investigated.

Chapter ? models solute redistribution and the amount of ferrite that forms furing solidification as a function of interface selocity in the clectron beam surface melts. This shapler is of central importance to this investigation in that it explains the results of the presious thapters, which are largely empirisal in nature, based on a quanlitatic model of the solidification behavior. As part of this studs. the soliditiation paths for each alloy were determined in the Fe-Ni-Cr system. These path. atong with thermodinamically calculated phase diagram information, were used to ercate psedobinary diagrams to represent the solidification behavior for each wit the alloss. From these diagrams, the solidification parameters werc deternincd and "sore used in the intertace stabilit! and solute redistribution calculations. Dendrite tip salculations ucre performed for constrancd columnar grouth behavior fur eash alle! and for each soliditication condition. These calculations were used to make predialuns of the cellular to dendritic transition and were used to caleulate the underouling at the dendrite tip. A solute redistribution model that incorporates lip underembing was then cmplosed to saleulate the amount of primars and secundars phases that solidily from the mell as a function of cooling rate and these resules werc used to explain the high sooling rac bohasor obserat in the actual clectron beam melis. 
Chapter 8 insestigates the solid state transiormation of lerrite that oceurs as the melt cools to roum temperature. Several transformation meshanisms werc observed in the aloss depending on the primary mode ol solidification and cooling rate. For alloys that solidily with both ferrite and austente present in the mierostructure. the transtormation takes place by the growth of primary or second phase austenite. This transformation is controlled by the diffusion of alloying clencents from the iseritc a ustenite interface and san be modeled to prodict the intluence of soling ratc on the cxtent of the transtormation. For allogs that solidify in the full! lerritio mode, nucleation of austenite is required before the transformation san proced. The composition-dependent stability of the ferrite and the cooling rate cath contribute to the nucleation and growth characteristies of the austenite to produce threc diflerent morphologies: Widmanstatten austenite platelets. Widmanstatten austenite necdics and massive austenite grains. This chapter discusses the composition and cooling rate regincs where cach morphology exists and explains the solid state translormation meshanisms by tahing into account the thermodynamic and kinctic iactors which are responsible for the nucleation and growth behavior. Furthermore, many paralleis can be drawn between the phase transformation behavior of the Fe-C system and the Fe-Ni-Cr system. The austenite morphologics which develop during the decomposition of delta ferrite in the Fe-Ni-Cr system are identical to many of the ferrite morphologies which develop during the decomposition of austenitc in the Fe-C system. The analog? betucen these two systems is presented as a useful starting point lor understanding the solid state transtormation of ferrite.

Chapter 9 integrates the cmpirical findings of chanters $t, 5$ and 6 with the thoorctical results of Chapters $i$ and 8 as a summary of the concepts which were descloped during this investigation. I hese concepts represent the general framewerk of the influeice that cooling rate has on the mierostructure ol staintess stecl allogs from the initial stages of solidification through the final stages of the solid state transformation. Because of the many-tacesed nature of the aspects insolved during the solidification of stainless steel alloss. there were sereral areas that were identified there additional researeh needs of he perlurmed. Ihese areas are alue summaries in chapter 9 along with a summars of the majur cunclusions of this inesis. 


\section{CHAPTER 2}

\section{Materials And Experimental Procedures}

\subsection{Materials}

\subsubsection{Fabrication of the High Purity Alloys}

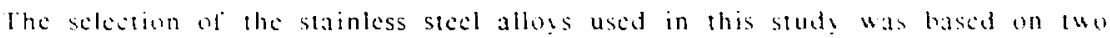
primars comslderations. The allogs had to be of high purit a faciliate

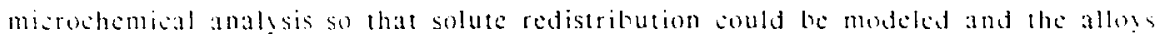
had to span a large composition range so that the cliests of hoth primary atustenite and primar! ferrite solidification could be insestigated.

Seren high purils Fe-Ni-Cr ternary alloss were produced that contained 5q"u fe but had dilierent $\mathrm{Cr}$. $\mathrm{i}$ ratios. which varied from 1.1 to 2.2. These sompositions span the line of tho-lold saturation as shown on the constant-iron sertisal scotion in lig. 2.1. Stainless stecl alloys containing $59^{4}$ iron were sclected in faror of the more common $70^{\prime \prime}$ iron alloss (AISI 304. 316) for two reasons: 1) The fower iron content is clearly separated from the peritestic to eutectio transition. thus insuring eurectio

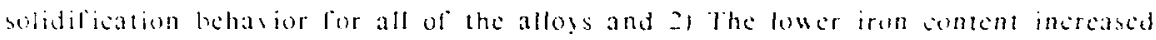

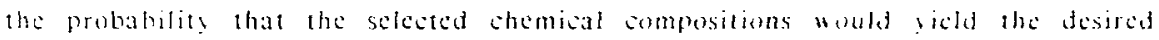
solidification mode since the threc-phase $L+l+1$ region spans a latger composition range at lower iron contints.

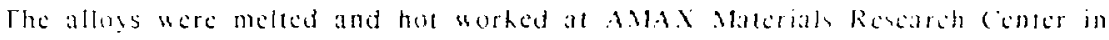

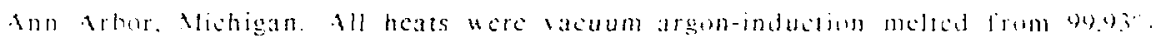

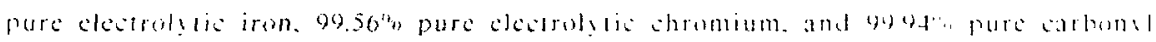

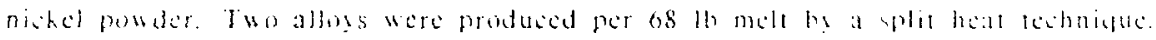

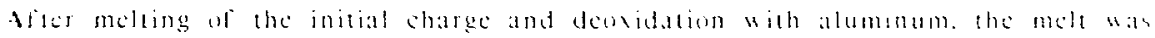

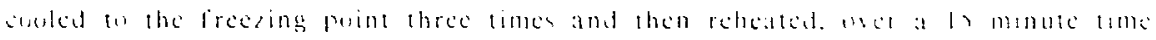

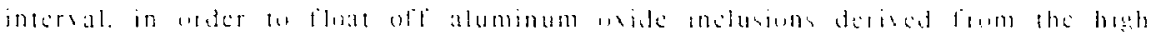

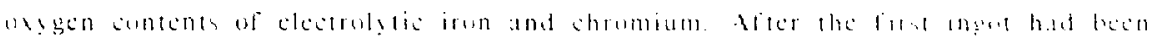

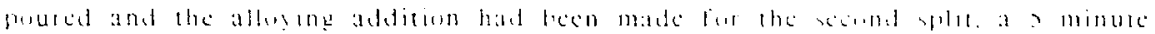




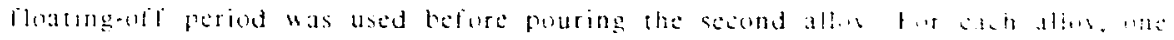

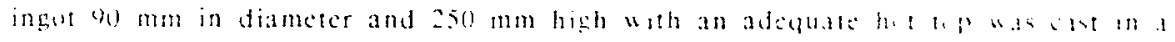

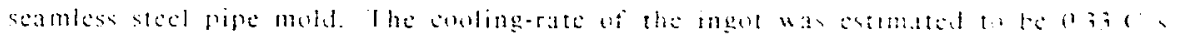
m measuring the tomperature on the ouside of the sted mold at a heltion 5 mom pelow thi hat-lop.

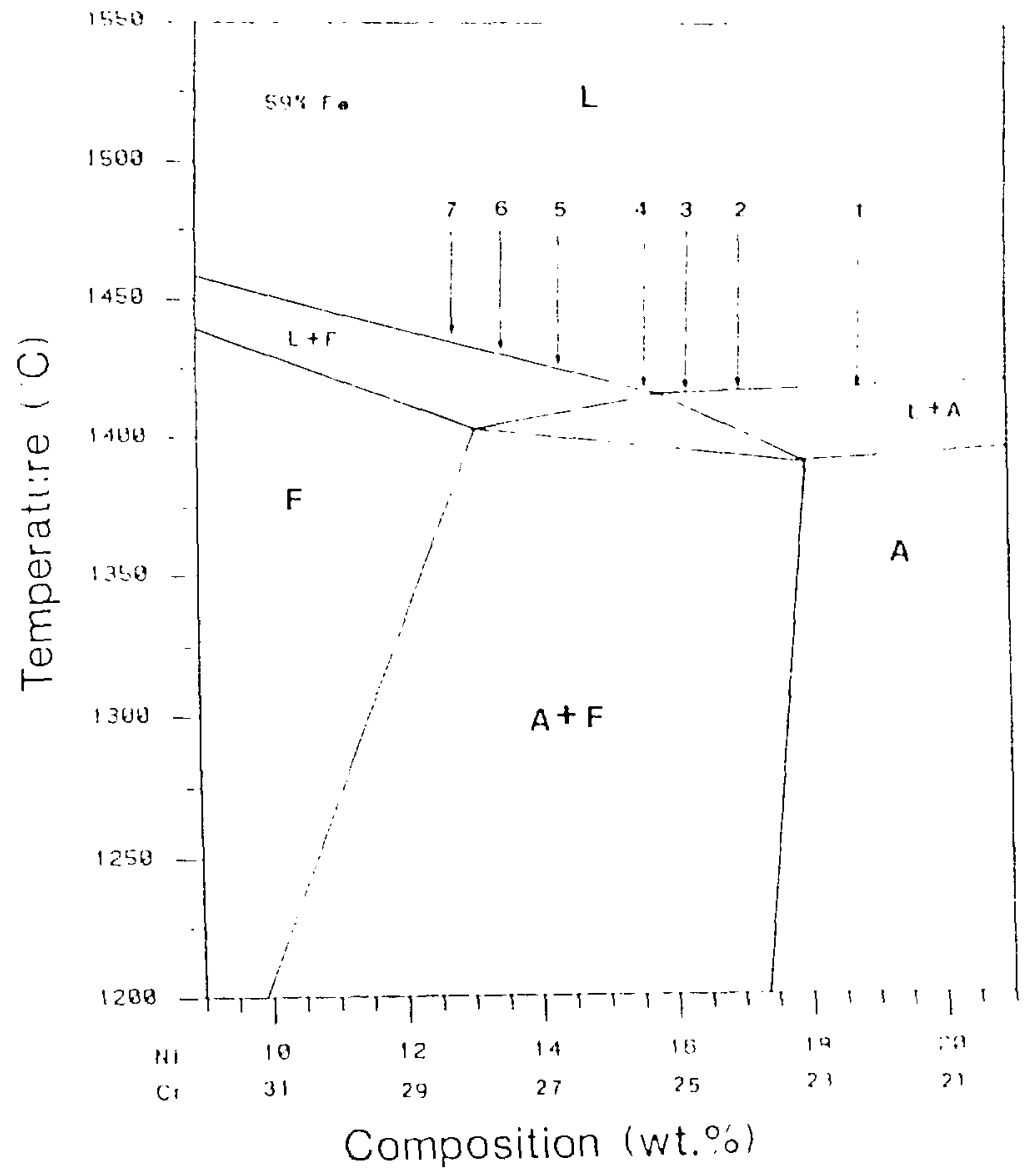

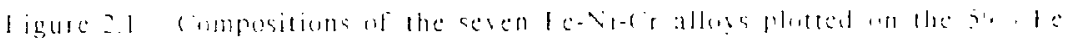
inflethal sevenom. 
Chemical analysis was performed by hilkl on a thill sast luteon whish was remosed from the hottom of the ingot. The concentrations of Mn. Si. Cr. Mi and P' were determined by wet chemical methods; sl was analyzed by eptial cmission spectroscopy; $\mathrm{C}$. $\mathrm{N}_{2}$. $\mathrm{O}_{2}$ and $\mathrm{S}$ were anajzed by gas fusion kehniques. 1 he results of the chemical analysis are shown in Table 2.1 and indicate that the allis are at least

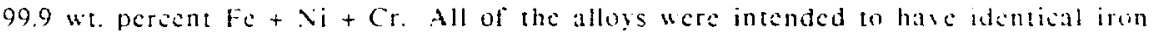
contents and the cheinical analys shows that the iron content varies by no more than 0.5 pereent from the mean value of 58.7 wt. peresnt.

Table 2.1 Compositions of the seren allogs (wt perent)

\begin{tabular}{|c|c|c|c|c|c|c|c|}
\hline Elcment & $!$ & $=$ & 3 & 4 & 5 & 6 & $?$ \\
\hline C'r & 22.36 & 24.25 & $=4.99$ & 25.52 & 20.43 & $\therefore 60$ & 28.05 \\
\hline $\mathrm{Si}$ & 0.0151 & 0.056 & 0.042 & 0.0 .32 & 0.048 & 0.042 & 0.044 \\
\hline Al & 0.022 & 0.029 & 0.02 & 0.031 & 0.027 & $0.0^{9}$ & 0.044 \\
\hline$N i$ & 19.32 & 17.32 & 16.49 & 15.77 & 14.29 & 13.06 & 12.66 \\
\hline $\mathrm{Mn}$ & 0.002 & 0.001 & 0.003 & 0.008 & 0.002 & 0.004 & 0.002 \\
\hline$\lambda$ & $0.00=8$ & 0.00 .32 & 0.0026 & 0.0028 & 0.0038 & $0.00=6$ & 0.0035 \\
\hline$c^{\prime}$ & 0.002 .3 & 0.0022 & 0.0019 & $0.00=6$ & 0.011 & 0.0019 & 0.00 .39 \\
\hline 0 & 0.00477 & 0.0053 & 0.0102 & 0.0034 & 0.0026 & 0.0075 & 0.0026 \\
\hline $\mathrm{S}$ & $0.00 ! 8$ & 0.0016 & 0.003 & 0.0022 & 0.0013 & 0.003 & 0.0012 \\
\hline $\mathrm{P}^{\mathrm{P}}$ & 0.001 & 0.001 & 0.001 & 0.002 & 0.001 & $0.00 !$ & 0.001 \\
\hline$(1 \mathrm{c})$ & 58.23 & 58.33 & 58.44 & 58.63 & 59.2 & 5804 & 59.19 \\
\hline $\mathrm{Ic}+\mathrm{Vi+Cr}$ & 99.91 & 99.9 & $99.3^{2}$ & 99.92 & 90.9 & $09.9=$ & 40.9 \\
\hline ( is eq. & 22.44 & 24.33 & 25.05 & 25.57 & 20.5 & $=-6.8$ & $28.1=$ \\
\hline $\mathrm{Nica}$ & 19.48 & 17.48 & 16.63 & 15.44 & 14.44 & 138 & $12 k s$ \\
\hline (c) $\mathrm{I} i \mathrm{Cu}_{4}$ & 1.15 & 1.39 & 1.51 & 1.60 & 184 & $: 01$ & $2: 8$ \\
\hline
\end{tabular}

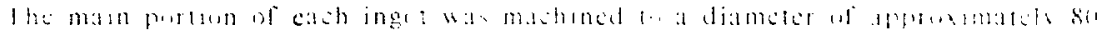

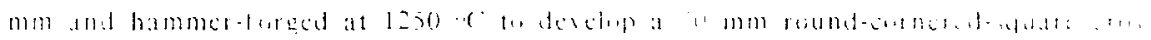

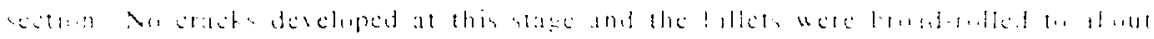

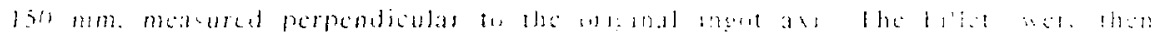


long-rolled parallet to the original ingot asis. 7 he redutions were to "per pass. and typicall! irom three to six passes ate made per reheat. depending on the wornabilits of the stcel. four of the alloss 11.2 .3 .43 were robled wo the desired 10 mm thich ness without staching. Slighto-scicre oraching. howeres. aceured in allats 5.6 and?

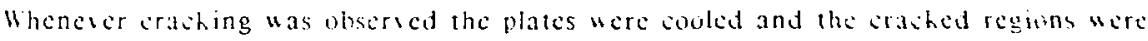
cut awa! betore resuming rolling. The tinat hot-rolled plates measured $150 \mathrm{~mm}$ wide. $10 \mathrm{~mm}$ thich and the lengths aried from approximatels $100 \mathrm{~mm}$ to $400 \mathrm{~mm}$.

\subsubsection{Are Cast Buttons}

The shucst cooling ratc condition was to be representod by the original sast ingot microstructure. however, the original ingot mierostructure was altered during high-temperature homogenization and hot working of the ingots. Iherelure. a new basting was made on cach allos to represent the slow coling-rati microstructure.

Approsimately $200 \mathrm{~g}$ of material was renoved from cach hutrolled plate and descaled by mathing of the surface lager. Part of his specimen was sulmitted for whemical analy bis and the remainder was recast in an are-melting lurnace which was backfilled with argon gas to approximately 0.5 atm. Lach allos was melted in a water-cooled copper hearth which produced a button $80 \mathrm{~mm} 10 \mathrm{ng}$. $40 \mathrm{~mm}$ wide and 20 mm thich.

Chemical analysis was performed on cach are cast button and on the original hot rolled plate to berify the cleanliness of the are casting process these results whah are shoun in Table 2.2 indicate that the $N$ i and Cr contents var b! lese than 0 s

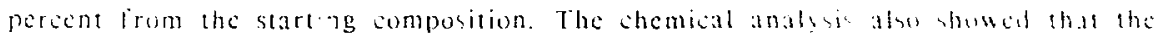

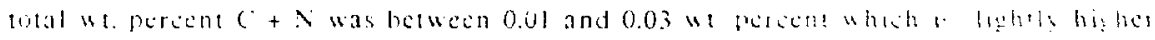

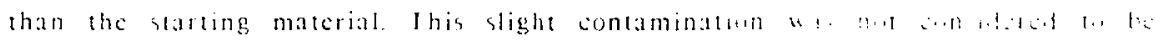
signilizant in this insestigation. 
Table a.2: Chemital composition at dillerent processing stages 1 II. "I)

\begin{tabular}{|c|c|c|c|c|}
\hline Allos & Flement & $\operatorname{lngot}$ & Plate & Button \\
\hline \multirow{3}{*}{1} & $\mathrm{Cr}$ & 22.36 & 22.35 & $=2.53$ \\
\hline & $\mathrm{Ni}$ & 19.32 & 18.73 & 18.56 \\
\hline & $\mathrm{Fc}$ & 58.23 & 58.7 & 58. \\
\hline \multirow{3}{*}{2} & $\mathrm{Cr}$ & 24.25 & 24.45 & $=4.48$ \\
\hline & $\therefore i$ & 17.32 & 17.2 & $1-.03$ \\
\hline & $\mathrm{Fe}$ & 58.33 & 58.1 & 58.1 \\
\hline \multirow{3}{*}{3} & $\mathrm{Cr}$ & 24.99 & 24.99 & 25.05 \\
\hline & $\mathrm{Ni}$ & 16.49 & 16.38 & 16.16 \\
\hline & $\mathrm{Fe}$ & 58.44 & 58.4 & 57.3 \\
\hline \multirow{3}{*}{+} & $\mathrm{Cr}$ & 25.52 & 25.56 & 25.5 \\
\hline & $\therefore i$ & 15.77 & 16.04 & 15.54 \\
\hline & rc & 58.63 & 57.9 & 58.7 \\
\hline \multirow{3}{*}{5} & $\mathrm{Cr}$ & 26.43 & 26.54 & 26.66 \\
\hline & $\because i$ & 14.29 & 14.87 & 14.67 \\
\hline & $\mathrm{Fc}$ & 59.2 & 58.4 & 58.4 \\
\hline \multirow{3}{*}{6} & $\mathrm{Cr}$ & 27.62 & 27.78 & $=-46$ \\
\hline & $\mathrm{Ni}$ & 13.66 & 13.73 & 1357 \\
\hline & $\mathrm{Fe}$ & 58.64 & 58.3 & 58 \\
\hline \multirow{3}{*}{ - } & $\mathrm{Cr}$ & 28.05 & 28.28 & 28,31 \\
\hline & $\therefore i$ & 12.66 & 13.26 & 13018 \\
\hline & $\mathrm{Fe}$ & 59.19 & 57.70 & $i x+$ \\
\hline
\end{tabular}

\subsubsection{Melt Spun Ribbons}

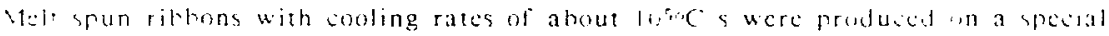

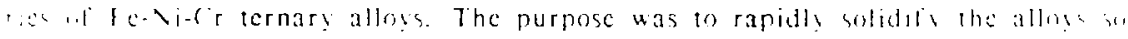

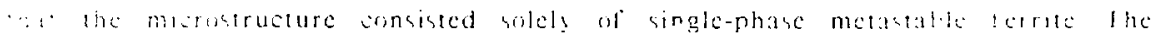

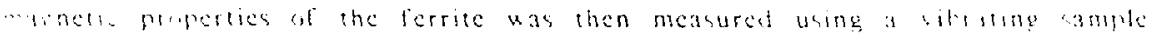


magneconcter and the results were used as the magnctio ealibration landarti for calculating the ferrite content of austenitic ferritic stainless stects. Ihe conpusition of these allous is ammarized in Chapter 3.

rhe alloys uere made ly a two-step procedure. First. a $25 \mathrm{~g}$ ingot was induction meltad and scomd. this ingor was remelted and melt spun into riblon the initial ingot was made from 99.9+ purity iron, nichel and shromium and meltca in a $15 \mathrm{~mm}$ quarte erucible. The chamber was first cuacuated to 30 .. Hg and hathlilled with a partial presure of argon gas. The charge was induction melted using a graphite

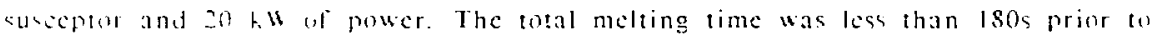
hutting oft the purer and allowing the ingot to sool.

The ingut was remosed irsm the lumace and because of the high oxgen content di the clestroly iron. an bude sealc had formed on its surface. The seale was

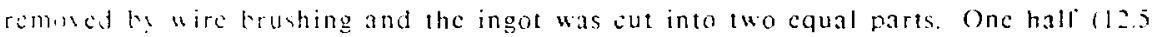
g) was used for melt spinning. the other for characterization of the cast structure.

The $12.5 \mathrm{~g}$ tharge was placed into a $16 \mathrm{~mm}$ diameter quartz crusible for me! upning in a cimmercial unit. manufastured by Marto Matcrials. The sucible was manulatured with a 25 ... diancter hole at its base to allow the molicn charge to fliw wath the water cooled copper chill. The chamber was pumped down to 30 .." Ig. racklibet with argon. and the induction melting was performed using a graphite beceptit and a hll pouer. The charge was allowed 10 melt and was healed for $180 \mathrm{~s}$ plus an aditional oos to superheat the liquid. The copper substrate was rewhing at 1500 rpm and the superheated liquid was allowed to flow onto it from a distance al ; mm atuc as surtace. The ribbons measured $1 \mathrm{~mm}$ wide and about 38.1 . thish and

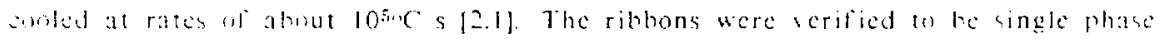

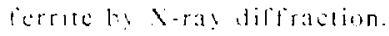

\subsection{Surface Melting and Resolidification}

\section{2.i Wedd Coupon Preparation}

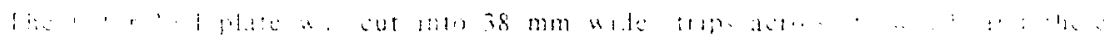

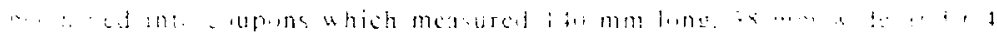


mm thick. The microstructure of these coupons resealed a bers litge promars dendrite arm spacing and a secondary dendrite arm spacing of atout 35 . Thin mierostructure was considered to be tow coarse for the high speed elestron beam surtace melts which penetrate less than $100 \ldots$. .

The microstructure of the coupon was relined bs melting the writic with acrlapping electron-beam passes down the length of the coupon. Ihis surlace homogenization technique consisted of approximatel! 15 passes at $100 \mathrm{hl}$. is ma and $25.4 \mathrm{~mm}$ s. A delocused beam was used and approsimately $150 \mathrm{~s}$ "as alluwed hetucen passes for conl down. The surtace of the plate was homogenized w a depth at ahrul $1.5 \mathrm{~mm}$ with a primary dendrite arm spacing of less than 10 . Fach soupon was hated to 500 ( lior 1800 and hot pressed in a 300 ton forge to remore the dibturtiun saused b! the surlace honugenization. The surlace of the plates uere lapped wan $s$ ... rms rinish in linal preparation for the clewron leam welds.

\subsubsection{Electron Beam Surface Melting}

It was desired to produce a series of melts on cach allog with increasing souling rates from about $100 \mathrm{C}$ s to about $10^{60 \mathrm{C}} \mathrm{s}$. The technique chosen was similar to that used $h$ Boctinger et al. 12.2] who kept the clectron beam power lesel constant and aricd the tratel specd. Preliminary melts on stainless stect allus shoucd that a : $\mathrm{kW}$ power lesel $(100 \mathrm{hV} .20 \mathrm{~ms})$ was sulieiche to produe melting at trabel speck as high as $5 \mathrm{~m}$ s. concequentls. this power lesel was used throughout the tuth.

Single pass. and overlappine multiple pass melts were mase acrose the is mm

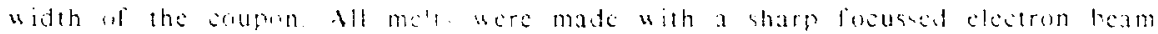

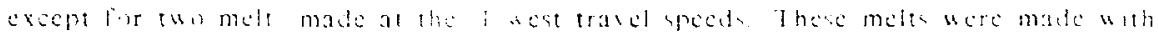

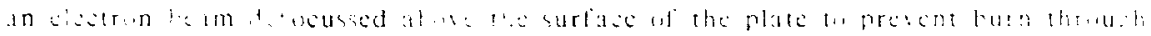

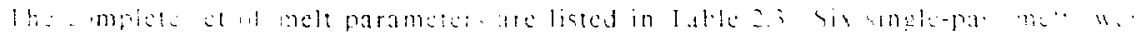

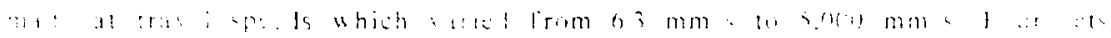

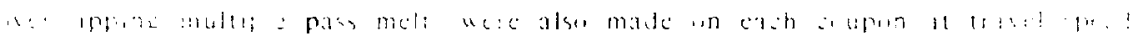

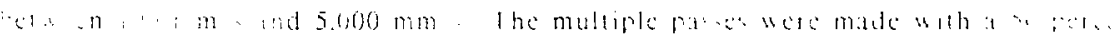


overlap and approximately 120s was allowed between each pass for cooling down. The number of passes was selected to produce a $6 \mathrm{~mm}$ wide strip and required between 9 and 20 passes at each travel speci seting.

The cross sectional shape of the surtace melts aricd considerably as the travel specd was incrased. Me!ts I and 2 had decp penctrations and were formed by a key-hole mode. Melt i was nearly semicircular in cross section and approximalely 1 mm decp. Melt $t$ had a double-humped appearance which was presumaly caused by the non-uniform clestron-beam force pushing the molten metal to the edge of the melt. Melts 5 and 6 had shallow and uniform penctrations of approximately $25 .$. and $5 \cdots$. respectively.

Table 2.4 summarizes the atcrage widh and depth of the surtace melts as measured from the metallographic cross sections. The average length of each melt was optically moasured on the surface of melts 1, 2. and 3 and metallographically measured on longitudinal scetions for melts 4 and 5 . Aclt 6 was 600 shallow to examine and its length was assumed to be cqual to the radius of the electron beam spot. Fig. 2.2 plots the melt dimensions versus travel speed and showe that the width approaches a limiting value at high specds. This limiting value corresponds to the size of the clectron-beam focal spot. At low specds. the longer time for heat diffusion widens the fusion zone beyond the focal spot size. The length is approximately sonstant for melts 1, 2, and 3. Howerce. the length of melts 4 , 5, and 6 decrease and appear to arproach the radius of the electron-beam spot. Melts 4. 5. and 6 are all characterized by depths which are shallow compared to their width and therefore solidification is controlled by heat flow through the depth rather than through the width of the iusion zonc. 

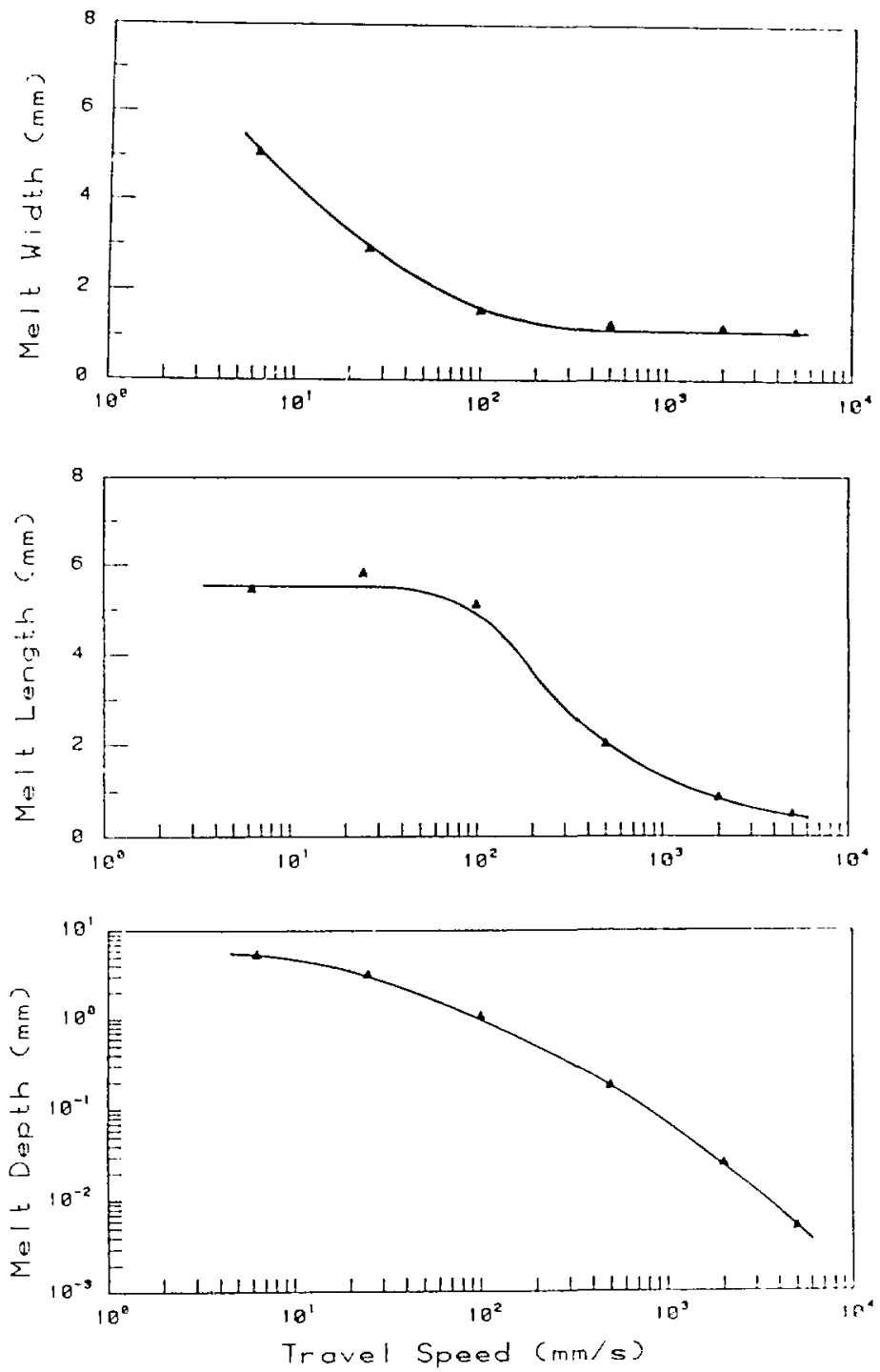

Figure 2.2 Melt pool width, length and depth as a function of clectron beam scan specd. All melts made at $100 \mathrm{k} \mathrm{V}, 20 \mathrm{~mA}$, sharp focus. 
Table 2.3: Flectron beam melt summary. All melts at $100 \mathrm{hl}$ and $20 \mathrm{~m} \cdot \mathrm{l}$.

\begin{tabular}{|c|c|c|c|}
\hline Scan lo. & $\begin{array}{c}\text { Travel Specd } \\
(\mathrm{mm} \mathrm{s})\end{array}$ & Vi) ol passes & $\begin{array}{c}1 \\
0\end{array}$ \\
\hline 1 & 6.3 & 1 & - \\
\hline 2 & 25 & 1 & - \\
\hline 3 & 100 & 1 & - \\
\hline 4 & 500 & 1 & - \\
\hline 5 & $=.000$ & 1 & - \\
\hline 6 & 5.000 & 1 & - \\
\hline 3 & 100 & 9 & $\therefore 1$ \\
\hline 4 & 500 & 10 & $\therefore:$ \\
\hline 5 & 2.000 & 12 & $\therefore$ \\
\hline $6^{\circ}$ & 5.000 & 20 & $\therefore 1$ \\
\hline
\end{tabular}

Table 2.4: Average width, depth and length of the six single-pass surtiace melts in $\mathrm{mm}$.

\begin{tabular}{|c|c|c|c|c|c|c|}
\hline melt & 1 & 2 & 3 & 4 & 5 & 0 \\
\hline depth & 5.33 & 3.10 & 1.07 & 0.178 & 0.025 & 0005 \\
\hline it lth & 5.08 & 2.89 & 1.55 & 1.24 & $1.1^{-}$ & 1.11 \\
\hline in: ih & 544 & 5.80 & 5.10 & 2.00 & 0.86 & 115 \\
\hline
\end{tabular}

\subsection{Microstructural Characterization}

\subsubsection{Optical Vetallography}

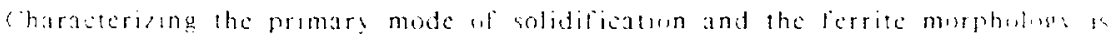

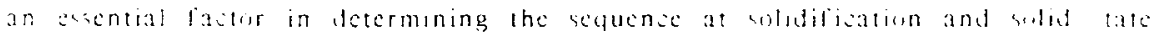


transformation cffects which contrihute to the linal microstructure. The letrite and austenitc are dissimilar in erystal structurc and in composition. therefore the ate casily distinguished b! optical metallographic techniques.

The metallographis spocimens were polished by conventional method and "ate ctiched by one of two techniques. The majorits of the specimens were electrolvidill, ctched in a saturated oxalic acid or 10 pereent sodium hydroxide solution. in applied potential ol approxinatels 1 solt was used at a current densits of abut 0.5 Amp em². These conditions preferentially dissolved the ferrite phase, giving the ferrite a dart appearance and leasing the austenite reflective and shins in the bright ficld microsione.

For a lew spezmens. a second and more discriminating color etshing teinnigue was used. Beraha's color eteh Vo. 1+12.3] $20 \mathrm{~g}$ ammonium billuoride, $0.5 \mathrm{~g}$ potassium metabisullite and $100 \mathrm{ml}$ distilled water was prepared fresh and the specinoc was immersed at roum lemperature for approximately 30 s until the specimen had a heatinted appearance. The specimen was removed from the ctehant and rinied in water lolfowed hy acetons. reagent grade methanol and immediatels bloun dr! with compressed air. When etihed properly, the lerrite has a white appearanec and the ctch can distinguish between the two types of austenite. The austenite that solidified from the melt has a golden-broun color and the austenite that iransiormed from the lecrite phase has a dark hrown color. This technique was aluable for determining the primary moke of solidilication and was most sucessful on the tou somling-rate melis of alloss 3 . A. and 5 which soliditied as primary ferrite and contained helucen 10 and 25 perient ferrile.

The results of the miscustructural characterization are summated in chapter where hoth the primary mode of solidifianion and ferrite morphulug uate derernined as a function al cuoling race.

\subsubsection{Dendrite $1 \mathrm{rm}$ Spacing Measurements}

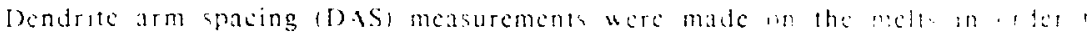

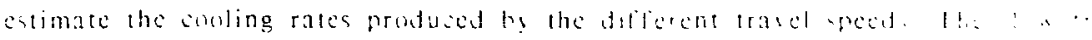

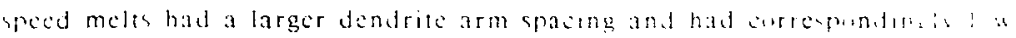


rates than the high specd melts. The castings and melts 1, 2, 3, and 4 soliditicd in a cellular or dendritic mode with a primary spacing larger than the $1 \ldots .$. These $s: l l$ sizes werc able to be measured by optical metallographic methods. Nelts 5 and 0 however, solidified at high cooling rates with a eell size smaller than 1 ... and required a scanning elcetron microscope to resolve the microstructure.

For the majority of the alloys. the low cooling rate microstructure consisted of primary dendrites with well defined secondary arms. However, as the eowling rate was increased, the microstructure refined in size and formed cells rather than denalrites. Since secondar! arms were not alwass present in the higher cooling rati melts $(i-b)$. sccondar! arm spacings could not be used to cstimate the cooling rati. Therelins. primary DAS measurements were made on the alloys cooled at lou rall and ecll ial measurements were made on the alloss cooled at high rates.

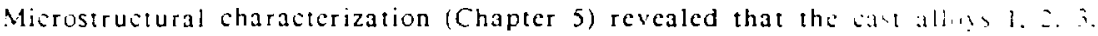
4, and 5 solidifjed in fully austentic or austenitic ferritic modes win wall define. dendrites or cells. The DAS measurements were correspondingly direst and call: made. Alloys 6 and $?$ however, solidified in a fully ferritic mule and the solidification substructure uas 'crased' during the solid-statc transtormatwn of the ferrite. Therciore. DAS measurements were only able to be made un allus I thrugh 5 .

The measurements were made by a line-intercept technique on the optical or SI: 1 micrographs. All measurements were made in the upper portion of the melt. at a location hall way between the fusion line and the melt centerline. The revults are listed in Table 4.1 as the average alue from the 5 alloys. " and standard dariations. 5 These data will be used to calculate the cooling rate in chapter $f$.

\section{$2.3^{3}+1+1$ ite Measurements}

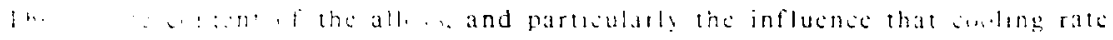

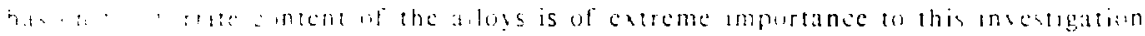

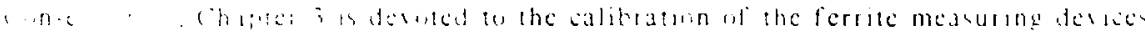

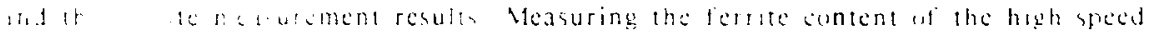


surlace melts required the development of a new technique, using a vibrating sample magnetometer (VSM). This approach is discussed in detail in Chapter 3 and only the sample preparation techniques will be discussed here.

Conventional lerrite measuring techniques (Magne-Gage, ferrite meter, quartitative metallography) could not be used to measure the ferrite content of the high cooling rate melts because of the small physical dimensions of the rapidy cooled melts. However, the VSM tecinnique could be used for small specimens which weighed as little as $10 \mathrm{mg}$. The specimens were increasingly difficult to extract as the cooling rate increased. The single-pass, slowest cooling rate melts 1 and 2 had deep enough penctrations and specimens were cut from the top enter of the melt measuring approximatels $6 \mathrm{~mm} \times 3 \mathrm{~mm} \times 1 \mathrm{~mm}$. However, single pass melts $3,4,5$ and 6 were too shallow for specimen removal. Therefore, multiple pass melts 3.4. 5 and 6 were made (sce section 2.2.2), which were wide cnough to produce suitable specimens.

The specimens from shallow penetration melts were prepared by a hand lapping tochniqus. A section of the plate was removed which contained a $6 \mathrm{~mm}$ wide by 10 mm long strip of the surlace melted material and this specimen was mounted to a 15 mm thick brass block using organic resin. The base metal was then ground away liom the surlace melted region using 240 grit paper. By successively measuring the thiskness of the block + resin + specimen between grinding steps, the thickncss of the speimen (melt + base metal) could accurately be measured. Grinding was completed when the specimen thickness was smaller than the depth of penetration of the mett. Specimens were easily prepared with 10 wn thickness or larger but the 5 wm thick melts from the $5 \mathrm{~m} 5$ travel specds were not sucessfully extracted without base metal Dontamination.

\subsubsection{Electron Probe Microanalysis}

The are sast buttons had a coarse microstructure which altowed the composition of the ferrite and austenite phases to be measured by electron probe microanalysis (E) Pla) The mieroprobe was focused in the enter of the ferrite or austenite dendriles and a quantitatice analysts was performed bo decrmine the Fe. Cr and Ni 
concentrations in cach phase. The microprobe was calibrated using purs fe. (r and vi standards. Ihe whage was held constant at $20 \mathrm{hV}$ and a l if ers stal was used lo analsecthe $\backslash-1$ a $! 5$.

Specimens were prepared for the misoprobe by comsmounal metallographic techniques and polished with an alumina slurry to a rimal $0.3 . \cdots$ Tinish. Thesc specimcns were ery light! clectrolytioally etched in saturated malie acid to outline the phase boundaries and then rinsed in water. followed b! acounc. reagent grade methanol and linally blown dry with compressed air.

The misoprobe was used to measure the atomie percent le. Vi and Cr in both the

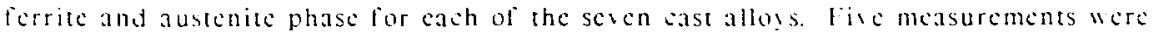
made in each phase and Table 2.5 gives the average composition in 61 pereent. These values "cre sonverted from atomic pereent using molecular weights of 55.9 (g mole) for $\mathrm{Fe}$. 58." (g mole) for Ni and 52.0 (g molet for Cr. Statisties pertermed on each set of 5 data points showed that the typical standard deviation was small and varied betucen 1 to Z pereent of the mean lalue lor Fe. and 1 to 8 pereent of the mean value for Cr and Ni. Tutal atomic pereents (Fe+NitCr) baried berween 99.0 and 101.0

It is interesting to nots that the composition of the lerrite and austenite phases in the castings focs not lary significantly botucen the seren alloss. Only allo!? appored we devate from the in ariant compositional trend. It is belicted that this is a result of inaceurate EPMA measurements because of the ser line spacing between the corrite and austenite "plates" in alloy 7. This fine spacing $(5 .$.$) is a result of the$ solid state transtormation of ferrite and is unique to allog. 7.

Atempts were made to use the lPMA technique to measure the emmosition of the ferrite and atstenite phase in the melts. Howerer, the miermatuctute of the melts were. lor the most part, wo closely spaced to give acourate measurements. Jhe liow

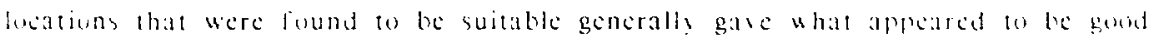

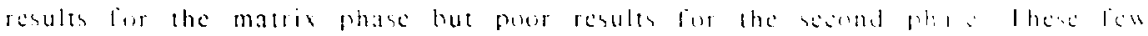

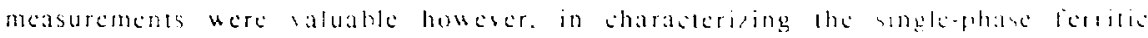

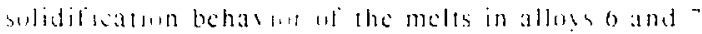


Table 2.5: Acrage compositions (wt. perest) ol the torrat and austonitc phases in the are sast buthoms

\begin{tabular}{|c|c|c|c|c|c|c|c|c|}
\hline \multirow[t]{2}{*}{ Casting } & \multicolumn{4}{|c|}{ Forrise } & \multicolumn{4}{|c|}{ Ausicnate } \\
\hline & $\mathrm{Cr}$ & $\mathrm{Ni}$ & $\mathrm{Fc}$ & Or $\mathrm{Ni}$ & $\mathrm{Cr}$ & $\mathrm{Ni}$ & $\mathrm{Fc}$ & $\Leftrightarrow \mathrm{F}$ \\
\hline 1 & - & - & - & - & - & - & - & - \\
\hline$z$ & 35.4 & 10.1 & 54.5 & 3.50 & 25.3 & 16.1 & 58.6 & $1 i^{-}$ \\
\hline 3 & 35.8 & 9.2 & 54.9 & 3.89 & $=4.9$ & 16.0 & 5). 1 & 1.20 \\
\hline 4 & 36.2 & 8.7 & 55.1 & 4.16 & 25.7 & 16.0 & $5-2$ & 155 \\
\hline 5 & $\$ 5.0$ & 9.3 & 55.7 & 3.70 & 25.9 & $10 .^{-}$ & $5-4$ & 1.55 \\
\hline 0 & 35.1 & 8.3 & 50.0 & 4.23 & 26.4 & 14.5 & 58. & 1.28 \\
\hline- & 3.9 .9 & 6.3 & 53.8 & 0.33 & 27.1 & 15.1 & 57.8 & $1 .-4$ \\
\hline
\end{tabular}

\subsubsection{X-ray Diffraction}

V-ra! diffaction experiments were performed to verit? that the melt spun mbions were tully ferrice. The single phase nature of the ribbons was of partioular interese sinee the ribbons were to be used as ferrite standards to calibrate the bitraing sample magnetometer.

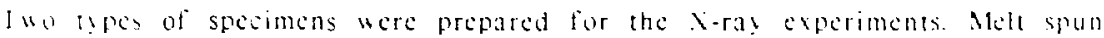
ribtum and powder specimens mate from the east alloss. the ribbons measured

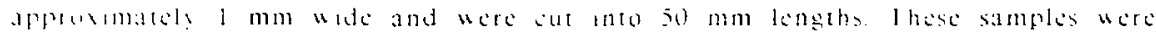

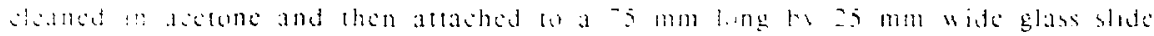

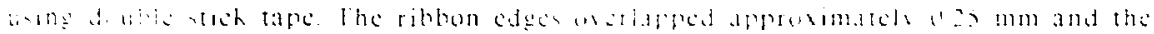
:ntac

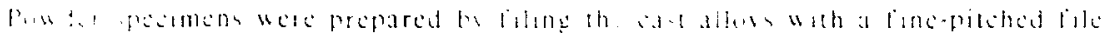

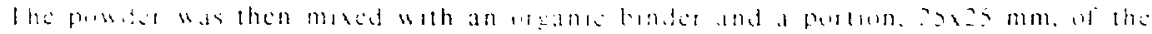

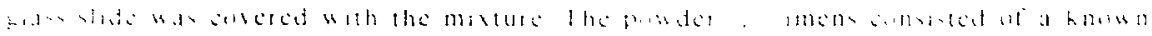

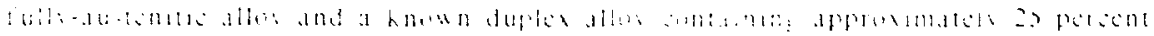
$\therefore 1: 11$ 
The X-ray difiractomeser was equipped with a chromium tube and cr a ratiation was used, having a wavelength of 2.291 A. The divergenes blit and recising slit angles were set at 3 deg. and 0.1 deg. respectively. The sean specd was set at 8 deg. min and the specimen was seanned becween $2 . "$ a rigles from 20 deg. w 100 deg.

For the above dittration conditions, the following plancs appear. BCC ferrite: (110), (200), (211): FCC austenite: (111), (200), (220). The lattice constant al fertite was taken to be $2.871+[2.4]$ and the 2 values for the fertite peahs were calculated iron this lattioc paranater to be 68.7. 105.8. and $155.6 \mathrm{deg}$. for the $(110)$. 1200$)$. and 1211 planes respectively. Table 2.6 compares the 2.1 alues whith wore calculated "ith those whish were experimentally determined. The calculated and cxperimentally determined salues agree to whin $0.3 \mathrm{deg}$. Which indicates that the peaks are properly indexed. The austenite peaks were similarly indexed and from lia experimentally determincd peahs. the lattiec parameter for austenite was determined to be 3.500.

Fig. 2.3 illustatcs th: diltractometer chart records for a fully ferritic a fully austenitic and a duplex alloy stainless sted specimen. With the peaks characterized. the melt spun ribbons wse shown to be fully ferritic and all of the ribbons had X-ras charts shatacteristic of the type shown in Fig. 2.3 a.

Tatle 2.6: Summary of X-ray diffraction results

\begin{tabular}{|c|c|c|c|c|c|}
\hline Phace & Plane & $h^{2}+k^{2}+1^{2}$ & $\begin{array}{c}d \\
(A)\end{array}$ & $\begin{array}{c}\% 0 \\
\text { salculated } \\
\text { (deg) }\end{array}$ & $\begin{array}{c}\because 0 \\
\text { cxperimental } \\
(\operatorname{deg})\end{array}$ \\
\hline \multirow{3}{*}{ トєети: } & 11101 & 2 & 2.050 & 68.7 & 68.9 \\
\hline & 12001 & 4 & 1.4 .26 & 105.8 & 106.1 \\
\hline & 12111 & 6 & $1.1=$ & 1550 & 1559 \\
\hline \multirow{3}{*}{ Andentte } & 11111 & 3 & $=(0,0)$ & $6: 5$ & $0^{-4} 4$ \\
\hline & 12001 & 4 & 1.85 & 48 & 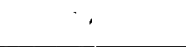 \\
\hline & $1220)$ & 8 & $1: 12$ & 1304 & $12 \cdot 8$ \\
\hline
\end{tabular}




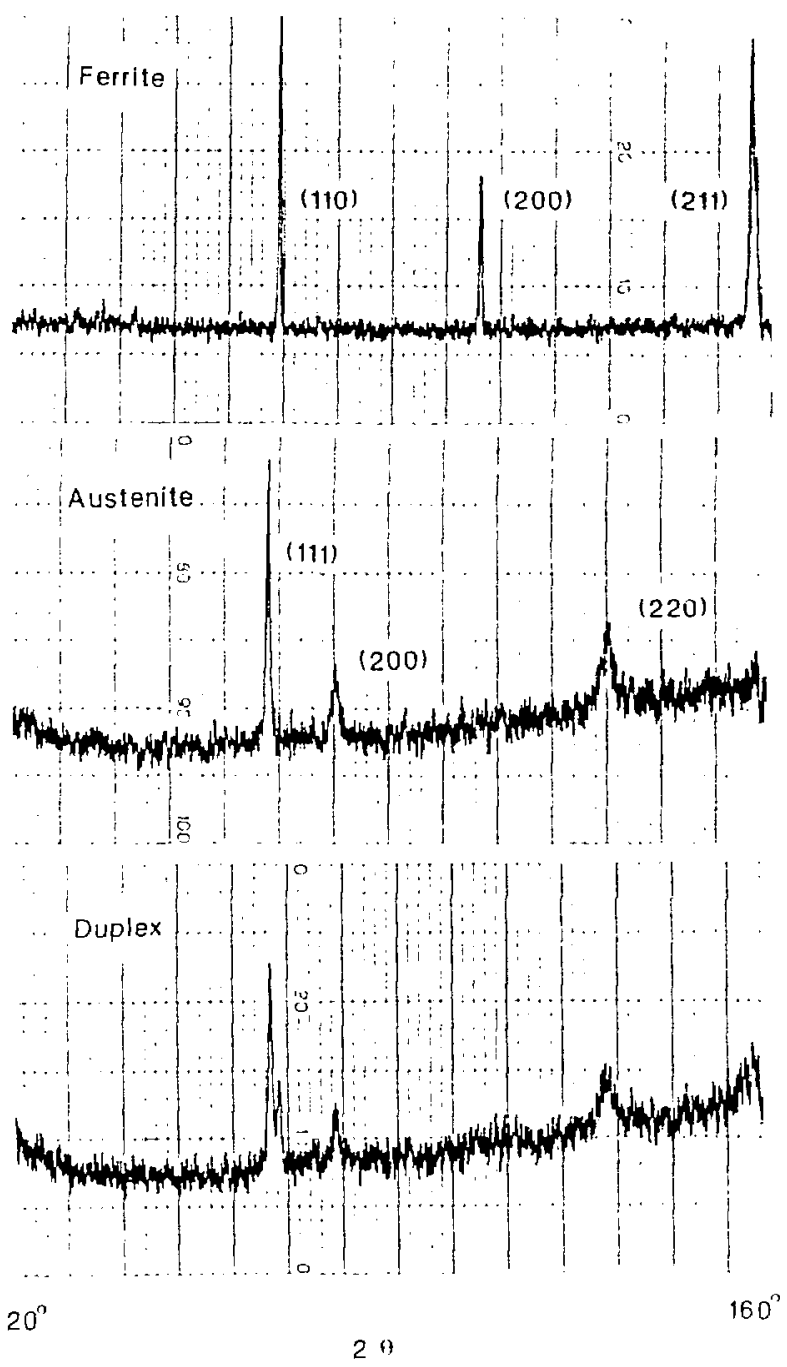

Figure 23 S-Ray difleraction results lor al single phase ferrite. W eingle phase austenite and c) duplex tainless atect alloys. 


\subsection{Density Measurements}

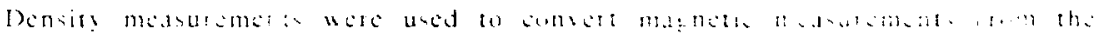

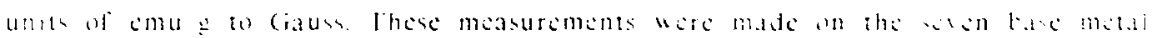

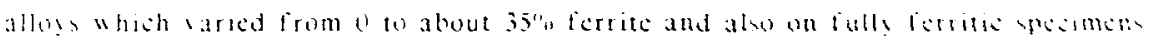

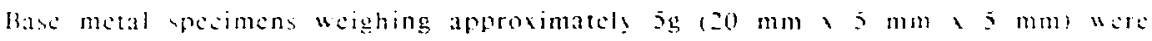

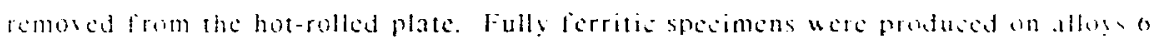

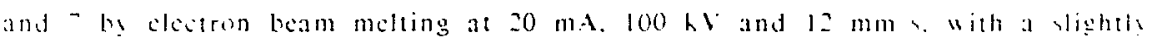
detocused bean. The lusion zones mosured approximatel? a mm dect and 1 . num

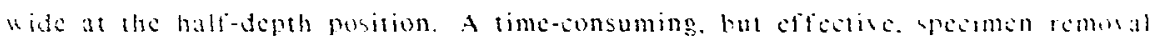

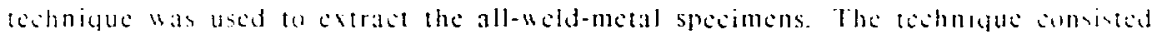

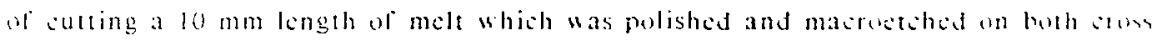
scetional cods and on one longitudinal side of the melt. The hongitudinal side "a

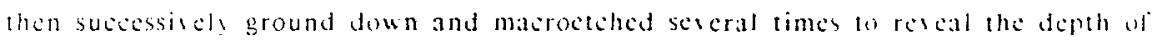
the mell. At this point. the specimen was sliced. paralled to the longitudinal scotion. un a diamond watering saw. This produced a thin walor of all-wold-matal foriti

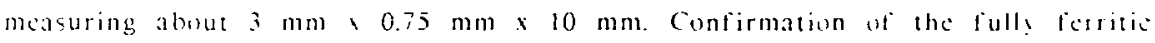
struture was made by obsering the six macroctiod surtices of the specimen.

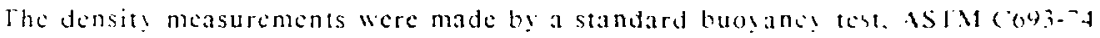
$[2.5]$ with folucne as the immersion Tluid. Densily alues of $0.80^{-} \mathrm{g}^{2} \mathrm{~m}^{3}$ and $0.0011: 3$ $g$ em. were uscd for toluene and air respectively. The densits of the specimen was sileulated from the equation:

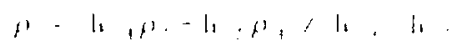

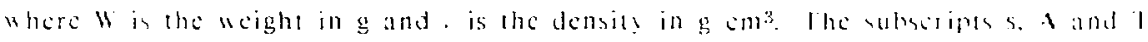

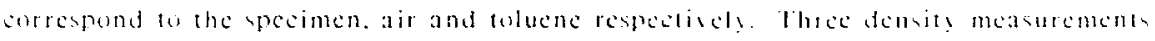
were made on cach specimen and. in acondance with the procedures. the

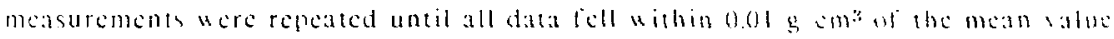

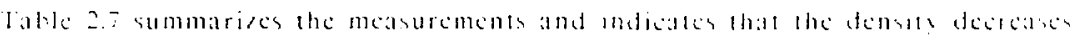

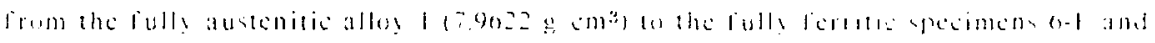

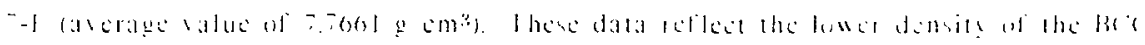

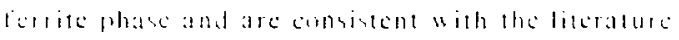




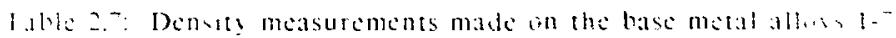
and on lully lerritic specimen so allog 6 and-

\begin{tabular}{|c|c|c|c|c|c|c|c|c|c|}
\hline , & 1 & 2 & $j$ & 4 & 5 & 6 & - & 0.1 & --1 \\
\hline$\left(g-\mathrm{sm}^{3}\right)$ & .9002 & 7.9419 & 7.9198 & 7.9018 & $7.86^{-1}$ & $7.8+34$ & -810 & $\because 50,5$ & -..it \\
\hline
\end{tabular}

\subsection{Isothermal Studies of the Ferrite to Austenite Phase Transformation}

The hinctiss of the ferrite to austenite phase transformatun uere studict w measuring the fraction of lerutc that translormed as a lunstion of time under isothermal conditions. The data were analyzed using the Juhnun-Mehl-hrami approach and attempts were made 10 conliom diffusion sucticient data in the Fe-vi-Cr sistem.

The isothermal heat treating was performed in a melten salt hath he iamersing the specimen lor the desired time. lollowed by a water quenth. The specimens were placed in a wire bashet made from thromel thermosouple wire and wo proted the specimen from the corrosive molen salts, each specimen was wrapped in 0 obs mm thich lye 304 stainless siect foil and double erimped shut on all ceder

The starting material was single phase lerrite of alloy 6 and allus i compusulum. The single phase ferrite specimens were prepared from the electron beam melted alloss using the same method at extraction that was mesented in seitun 4 Iach

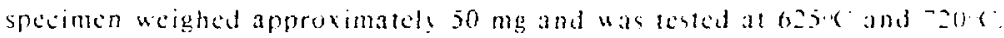

An initial magnctic moasurenent was made on the snceimen using the Isu ace

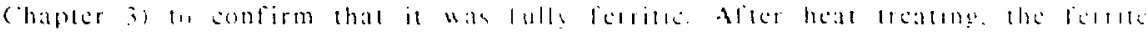

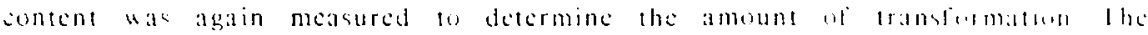

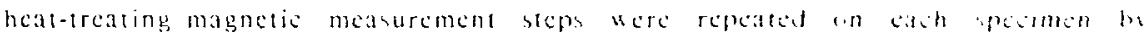

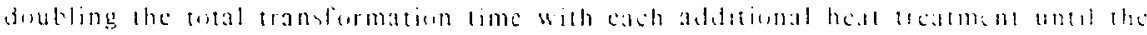

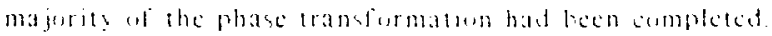




\section{CHAPTER 3}

\section{Measuring The Ferrite Content of Rapidly Solidifed Stainless Steel Alloys}

\subsection{Review of Conventional Ferrite Measurement Techniques}

Many techniques have been used to measure the delta ferrite content of stainlecs stee] welds. Constitution-diagrans. such as the Sehaclfer diagram [3.1,3.2] and the Delong diagram [3.3], rely stricty on composition to predict the ferritc content of the resulting weld microstructure. These diagrams only provide accurate correlations between ferrite content and composition for "typical" stainless steel allos compositions [3.4.3.5]. and for a narrow range of welding conditions that bave cooling rates which are similar to those of gas tungsten are welds [3.6.3.7]. Post-weld ferrite nueasurements are gencrally performed using magnetic instruments such as the Magne-Gage or ferrite meters 13.8. 3.9]. These instruments have been descloped to measure the amount of the ferromagnctic ferritc in a ciaplex stainless stecl altos and are reasonably succestul at measuring ferritc in arewelds and castings tor lypial austenitic stainless stcels containing about 70 perecnt iron. Howerer for allus whish destate lion this iron content, the composition-dependent magnetic propertics ol the Furite musi be taken into account $[3.10,3.11]$ and these corretions are not well establishod.

The concentional magnetic instruments hase an additional limitation which is aused by the unceraints of the magnetic field gencrated by the measuring probs. Ihese fictds are non-uniform within the volume of the material cesed and do not uniformly saturate the ferrite Conscquently. these instruments respond to the permeabilits which is not a matcrial property. As a result. these instruments are senstive to the orientation and shape of the ferritc as well as whe gcometry and whome of the specimen being tested. In order fo reliably noasure ferrite with these instruments. the specimen must be lagge enough to oblain the maximum magnetie

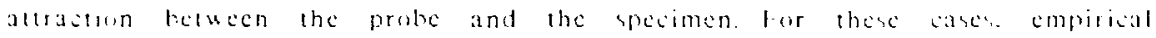

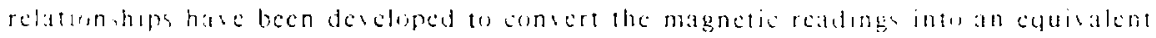


ferrite ontent Heneser. these masusenente are only alid if the specimen exect

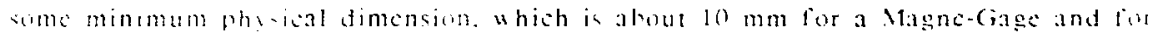
whe conconanal magnetic instruments [3.9!.

The limitation wn the spesimen size presents problems for high subling-rate wold and rapid! solidilicd allogs. The size of electron heam welds ma! he less than $1 \mathrm{~mm}$ wide, pulsed laser welds may be onl! $0.25 \mathrm{~mm}$ deep and rapidly solidificd alloys hase aen smaller physical dintensions. It is impossible to measure the ferrite content if these specimens with consentional magnetic instruments. Onl! quantuatue metallography (QTA) san le used to inspeet the rapidly solidified microstruatures. Howerer. QTM is not acturatc for measuring ferric in are welds and rapidls soliditicd allons lecause of the small size of the ferrite particles. Alls A4.2-86 [58] discusses the irreproducibility of quantatic metallography and conclusics that QTM is anl! aceurati bur measuring the ferrite content of sastings. Therefore. a new technique was in estigated which is not limited by a small specimen size and which an be used (1) measure the ferrite content in rapidly solidified stainless stecl alloss.

\subsection{The Vibrating Sample Magnetometer Method}

The bibrating sample magnetometer (VSM) measures the magnetis monent of a

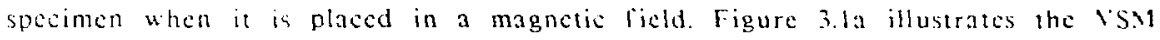
method which is based on the change in flux when the specinen is vibrated within a detection enil. The specimen is attached to the end of a rod which is fixed to a mechanical vibrator and the rod librates at about $80 \mathrm{hz}$ in a dirceition which is at right angles on an applice magnetic ficld. Also attached to the rod is a small permanent magnet which aets as a reforence specimen. Both the relerence specimen and the unknown specimen induce an cme in their respective coils and ahe diflerence hetween the two signals is proportional to the magnetis moment of the unhown specimen. Since the reference specimen and unknown specimen bibrate at the same amplitude and frequenes. the method is insensitice w vibration amplitude and irequency. The VSM is calibrated with a specimen of known saturation magnctization and when the $1 S M$ is properly aligned and ealibrated, 11 an decel changes in the magnetisation of less than $10^{-3} \mathrm{cmu}$. The high sensitibits of the lst is apparent 
since a single gram of ferrite in stainless sted allen has a saturation magnetization of about 100 emu. The nomenclature used to denter magnetis moasurements is summarized in Table 3.1.

Table 3.1: Comenchare used to descibe the magnctio neasurements

\begin{tabular}{|c|c|c|c|}
\hline S! mlnul & Description & L'nits & Valuc \\
\hline 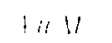 & saturation magnctization & Gauss & - \\
\hline$\therefore$ & $\begin{array}{l}\text { specitic (saturation) } \\
\text { magnetizasion of ferrite }\end{array}$ & emug & - \\
\hline 19 & $\begin{array}{c}\text { specific (saturation) magnetization } \\
\text { of the specimen }\end{array}$ & $\mathrm{cmug}$ & - \\
\hline ? & wcight lraction ferritc & - & - \\
\hline+1 & mass density of ferrite & $\mathrm{g} \mathrm{em}^{3}$ & $\neg .7$ \\
\hline$H$ & saturization moment per atom & Bohr Niagnetons & - \\
\hline$H$ & applicd magnctic ficld & $\mathrm{Oc}$ & - \\
\hline 11,11 & licld dependent magnetization & Gauss & - \\
\hline
\end{tabular}

The lsh measures the magnetization of a specimen. Or $M$. in response 10 I

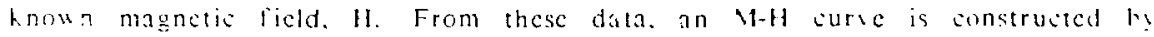
performing a series of measurements with increasing magnetio ficlds which were sarict from - io $\mathrm{kOc}$ to $+10 \mathrm{kOc}$ in this insestigation. At high li licks. the ferrite saturates and the saturation magnetization. $M_{5}$ of the specimen can be meastred. The

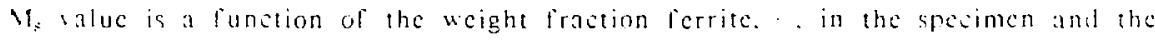
composition-dependent magnetic propertics of the ferrite:

$$
1: \|-1 \pi 0,1, n ; \quad|6,11 ; ;|
$$

whare the spectic saturation magnctization of the ferritc. . M measured in smug and, is the density of the ferrite in $\mathrm{g} \mathrm{em}^{3}$. Therebore. it and the denst! wi ferrite are bnown. Then the blume fraction ferrite is casil: calculated be a sinale. rum-temperature. M-H measurement. The densits of ferric was neabured lu be -...

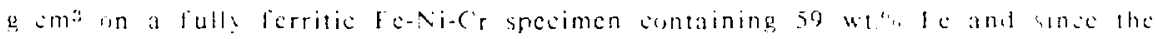

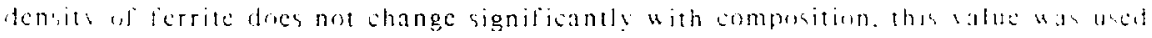


for all of the alloys in this study. However, is a strong linction of composition and methods to predict the saturation magnetization of ferrite from its compusition "ill be discussed in the following scctions.

In austenticterritio stainless stecl allogs. the ferrite phase has no significant cocrcitity and the M-H curve passes through the origin with no hystcresis. Jigure

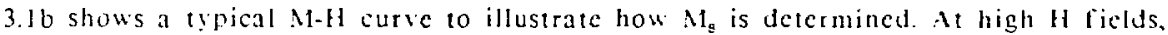
the ferrite saturates and the M-ll behaijor becomes lincar. Ihe spontancous magnetization is graphically detcrmined by cxtrapolating the high ficld susceptibility to zero applied field. The resulting value of $M A_{B}$ corresponds to the magnetization required to saturate the ferrite and is a material property. In this paper $\mathbf{M}_{\mathrm{g}}$ will be uscd to represent the saturation magnetization of ferritc.

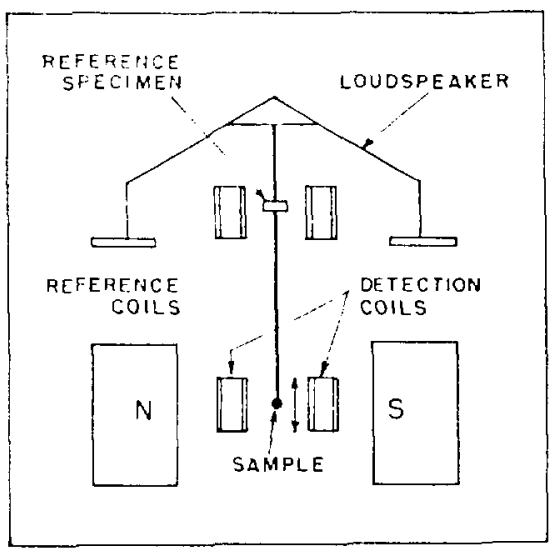

(a)

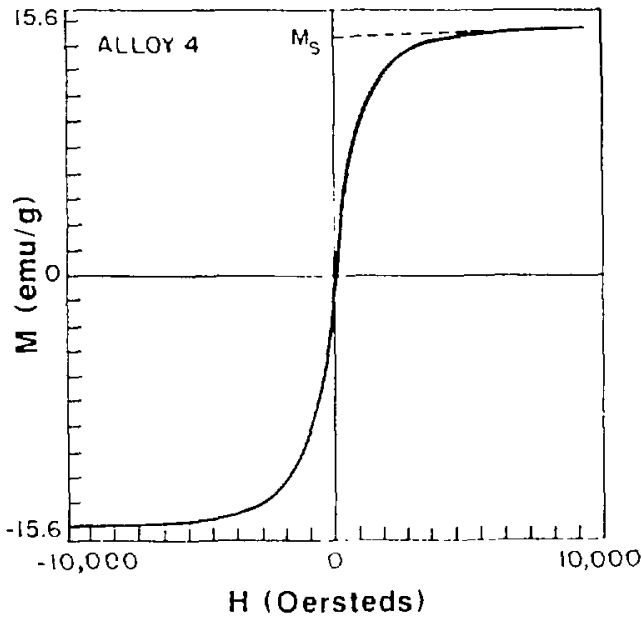

(b)

Jigure 3.1 a) Schematie drasing of the vibating sample magnetumeter. alter cullity [3.21] and b) a lypical M-H curse from a duplex stainless stecl allos. 
The saturation magnetization tests were periormed by calibrating 1 , SM with a pure nickel standard of known emu. Specimens from the welds were ${ }^{\prime}$ red as thin waters $(-0.5 \times 3 \times 3 \mathrm{~mm})$ weighing between 10 and $50 \mathrm{mg}$. Th. s mples were attached to a quartz holder using teflon tape and the M-H curves were zencrated in 200 Oc increments. Is values were decermined for cach sperimer and thesc measurements were converted into pereent ferrite using cquation 3.1.

\subsection{The Saturation Magnetization of Ferrite}

\subsubsection{Background}

The volume perecnt ferrite is easily calculated using cquation 3.1 if the saturation magnetization of lerrite is known. Howeser. 9 . is a function of composition and this presents two problems. First, in duplex alloy stainless stecls, the ferrite phase has a different composition than the nominal alloy composition. Therefore. the composition of the ferrite phase is not known a from. Measuring the composition by mierochemical analysis techniques is only practical for careful laboratory experiments while estimating the composition of ferrite is not a standard calculation. One objective of this insestigation was to develop a method to predict the lerrite composition as a function of nominal alloy composition, through the usc of thermodynamically calculated phase diagrams.

A sccond problem accurs because magnetic theory can only predict : from compositional data in certain single-phase binary-alloy solid-solutions. Onc method for estimating the saturation magnetization uses the Slatcr-Pauling curves which can predict the magnetic moment of an alloy as a lunction of composition [3.12]. This relationship assumes that the saturation magnctization of the alloy is related to the number. $n$, of $(3 d+4 s)$ clectrons per atom. according to the rigid band theory. For $n$ values greater than about 8.3 , there is good agreement with experiments and theory as long as the binary alloy consists of adjacent elements on the periodic table. For non-adjacent elements and for $n$ values less than about 8.3 , there is disagrement between simple rigid band theory and experiment.

Figure 3.2 shows the Slater-Pauling curves for a number of binary alloy systems. Additions of Cr. to Fe-Cr allogs lowers the saturation magnetization in proportion to 
the amount of $\mathrm{Cr}$ added while additions of $\mathrm{Ni}$ to Fe-Ni allors anitiall has hatle effect on the saturation magnetization. For nichel additions greater than appuaimately 15 atomic \%, the saturation magnetization decreases in proportion to the amount of $\mathrm{Ni}$ in the alloy. For the addition of nontransition clements such as Si, 11. and $\mathrm{Cu}$ to iron rich aloys, the rate of decrease in magnetization is mutills abutt the same for any element that is added. These clements correspond to typical allusing elements in commercial stainless stecl alloys and tend to reduce the magnetization as if the Fe atoms were being replaced by atoms of zero magnetic moment. This behavior can not be explained by rigid band theory.

For ternary alloys or higher alloy systems, theory is even less capate of explaining the saturation magnetization as a function of composition ()nc attcmpt at deriving an cquation to predict magnetization in the Fe-Ni-Cr formars system was developed by Curtis and Sherwin [3.13]. Their model is based on a "rule al mivtures" approach, which predicts the saturation magnetization as follows:

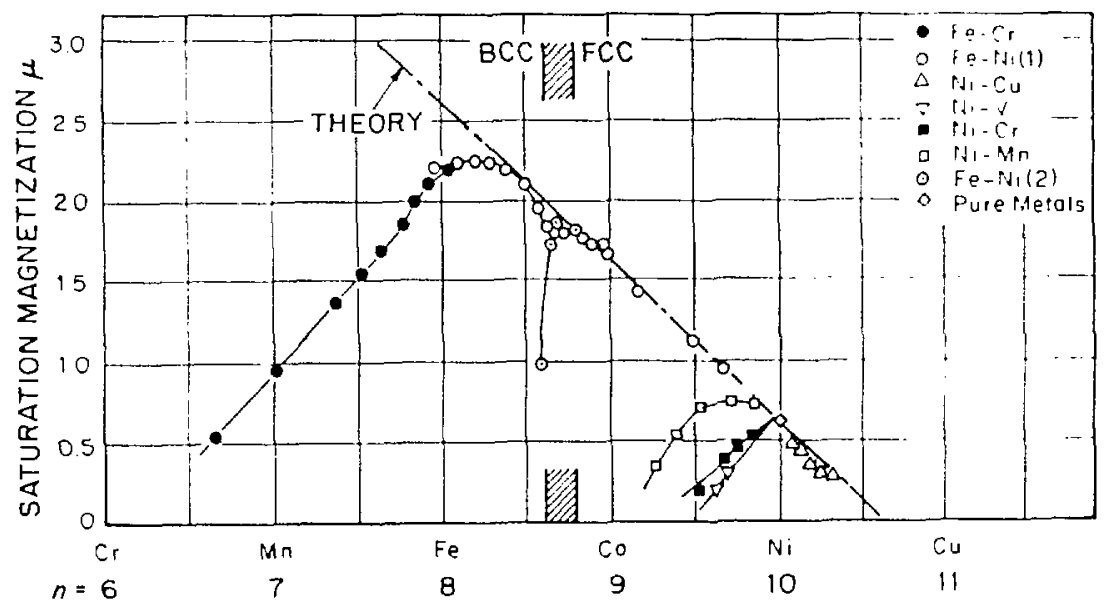

Figure 3.2 Slater-Paling curves showing the saturation magnelizalion lior various binary alloy combinations, alter Cullity [3.21]. 


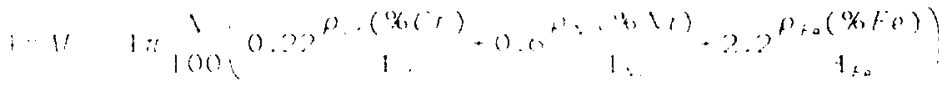

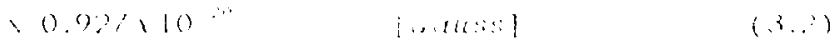

where A, refers to the atomic weight of element $i$ is trogadro's number and. is the density. This equation predicts a saturation magnetization for pure Fe of 21,910 Gauss and predicts a higher decrease in $\therefore$ for $\mathrm{Cr}$ than for $\mathrm{Ni}$ additions. Uniortunately, there is not good agrecment between this equation and experimental results. Thereforc. cmpirical relationships have becn derived to predict the saturation magnctization of lerritc as a function of composition.

The cmpirisal relationships betuecn composition and hate hecn derived by mcasuring fir a large number of alloys and measuring the ferrite content of these alloss by quantative netallography. The saturation magnetization can then he sliculated for cach alloy by the ratio of to the volume fraction ferrite and these Aata san he fit by regression analysis. Onc such relationship was derived by Merinos ct al. [3.10.3.11]:

$$
\begin{aligned}
& 17 u=.1 .000-271(\%(\%)-3330(\% 11)-280(\%, 1 n)-610(\% .51) \\
& .60(\%) 1 \%)-670(\% \%)-630(\% 11) \quad \text { 16011s: }
\end{aligned}
$$

This relationship between composition and saturation magnetization confirms the general trend predicted by the Slater-Pauling curves and shows that $\therefore$ is reduced by all of the lypical alloying elements in stainless stecl. The higher multiplication factors associates with the lower density elements suggest that this equation is written in terms of wt. $1 / 4$ although the units are not specifically stated in Merinov' paper.

The major alloying elements in standard 300 serics stainless stcels are $\mathrm{Cr}$ and $\mathrm{N}$.

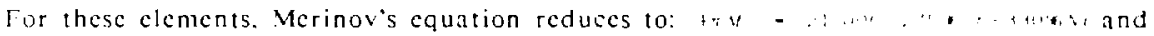
can be applied to Fe-Ni-Cr tcrnary alloys. The multiplying lactors for chromium and nickel are similar and suggest that the iron content of the ferritc is the principal factur in decrmining. in the ternary system, i.c. for a given fe content, i. onls changes a few pereent for large differenees in the Cr Ni ratio. 
1 comparion of equation 32 with equation 3.3 for a chromium and nishel

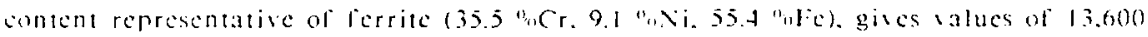
and 8.300 ciauss respectively for. This large diterence could not be reonsiled form the data provided by the incestigators and a scparate stuly was initiatcd le determine. as a lunction of chemical composition. The results of this study shous that the equation derised by Curtis and Sherwin is not accurate but that the equation deried by Merino satsfactorily represents the saturation magnetization of ferrite in stainlesss sted alloys.

\subsubsection{Fully Ferritic Specimens}

1 serics of $100^{\prime \prime}$ ferrite specimens of dilferent nominat iron contents were produced and the specific saturation magnetization of cach altog was measured by lac

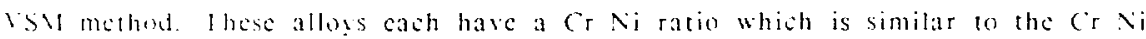

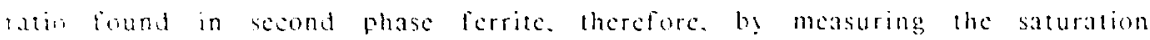

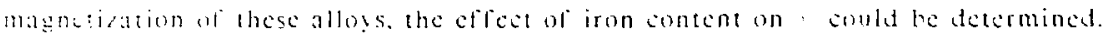

The composition of residual ferrite in arowelded stainless stects has lecn measured using fPMA and STEM lechniques [3.14-3.18] and the results of these tudis were used to plot the composition of ferrite on the Fe-Ni-cr ternary diagram a 1 ig 3 S This ligure shows that the cxperimentally determined composition of

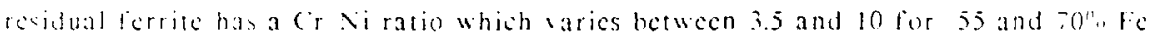

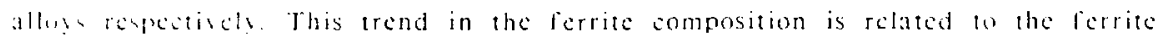
xilu at cicated temperatures.

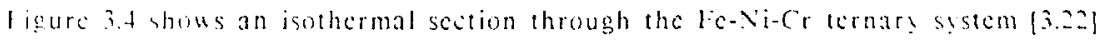

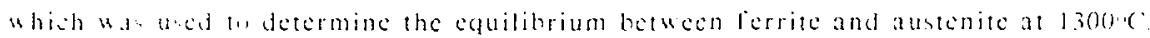
The ferrite whes is indiaged and prediets the equilibrium compesition of ferrite just belate the whtiliation comperature. There is a correlation between the actual compusitun af the residual delta ferrite presented in fig. 3.3 and the thermed nami-

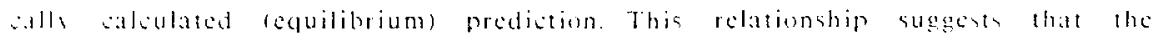

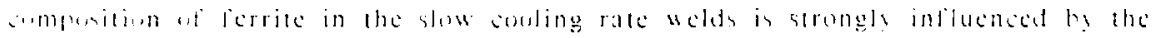

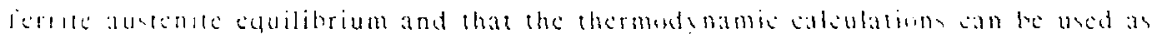

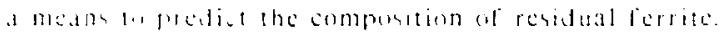




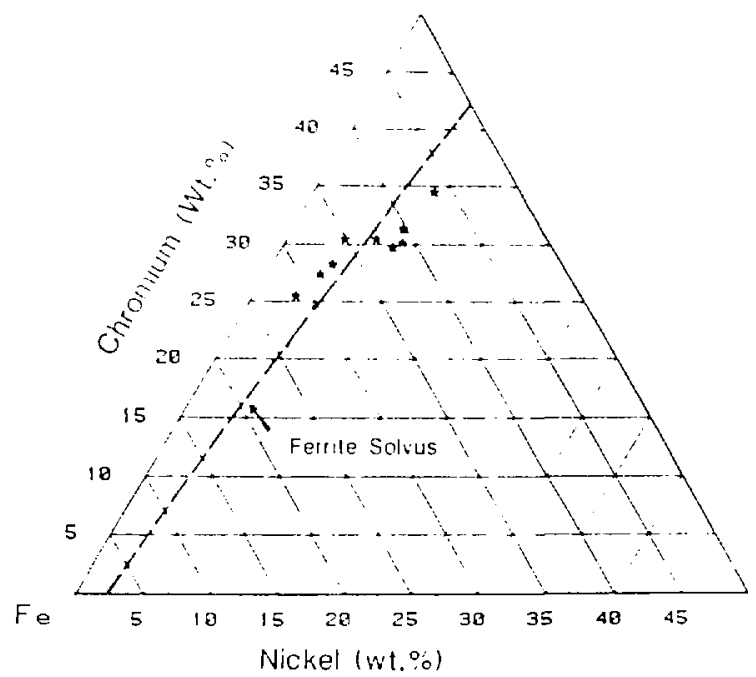

Figurs 3.3 Comparison between the ferrite solvus and the composition of residual delta ferrite for alloys with different nominal iron contents.

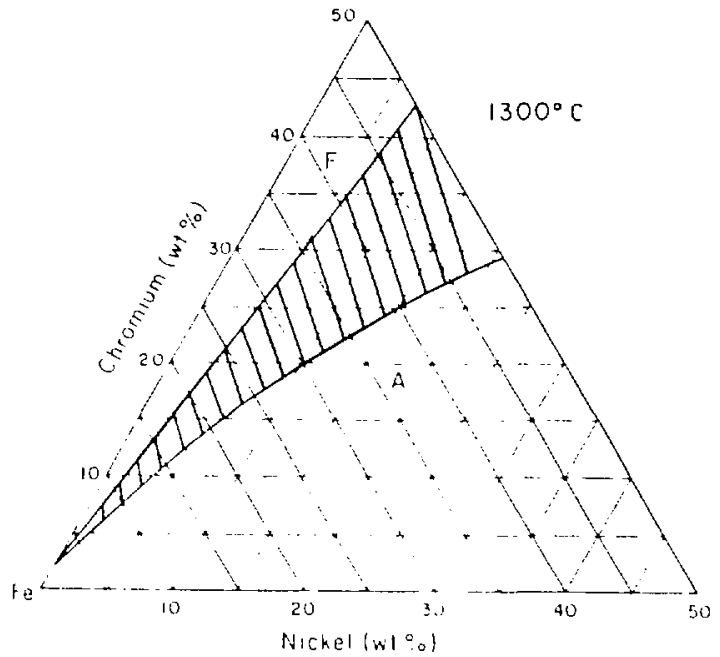

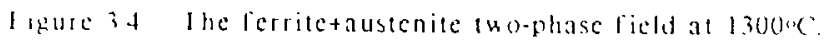


From these data, a series of alloys was prepared to meet the following sriteria: 11 since these alloys ware boing selected to ropresent residual ferrite. their compusition had to be close to that of residual ferrite in typical stainless stcels and 2) the allou, had to be rich cnough in chromium to allow them to solidify in the single phase ferrite mode. It was determined that alloss which nect the first criteria will also mect the second eriteria, but onls when the alloys are soliditicd at high rates. Therefore, to aroid the formation of austenite during the solidilication. the allogs ucre solidificd by a rapid solidification melt-spinning technique to suppress the solid state transtormation of lerrite. The resulting ribbons were shown to be single phase ferric b! X-ras diftrastion.

The composition of the alloys saried from 50 to 80 wth Fe and the Cr $\lambda i$ ratio ol cash alloy was maintaincd constant at t.0. A lig ingot of cach alloy was induction melted from high purity clements for the compositions specificd in Table 3.2 and then cach ingot was melt spun into ribbons to solidify the alloys in the lull! ferritio condition. Each ribbon measured about $2 \mathrm{~mm}$ wide and about 25 ."” thich which resulted in cooling rates of about $10^{4}$ to $10^{5}$ oC $s[3.19\}$.

Table 3.2: Compositions of the fully lerritic, melt spun, alloys

\begin{tabular}{|c|c|c|c|c|}
\hline Alloy & $\mathrm{Fc}$ & $\mathrm{Ni}$ & $\mathrm{Cr}$ & $\mathrm{Cr} \mathrm{Ni}$ \\
\hline $\mathrm{A}$ & 80.0 & 4.00 & 16.0 & 4 \\
\hline $\mathrm{B}$ & 75.0 & 5.00 & 20.0 & 4 \\
\hline $\mathrm{C}$ & 70.0 & 6.00 & 24.0 & 4 \\
\hline $\mathrm{D}$ & 65.0 & 7.00 & 28.0 & 4 \\
\hline $\mathrm{E}$ & 60.0 & 8.00 & 32.0 & 4 \\
\hline $\mathrm{I}$ & 55.0 & 9.00 & 30.0 & 4 \\
\hline$G$ & 50.0 & 10.0 & 40.0 & 4 \\
\hline
\end{tabular}




\subsubsection{Saturation Magnetization Results}

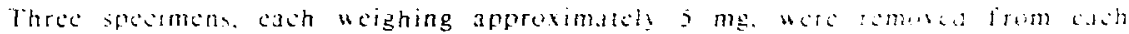
ribbon and the saturation magnetization was measured ung the ist. Ihese

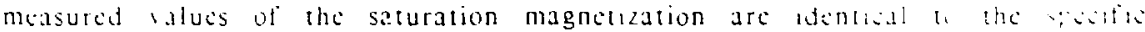

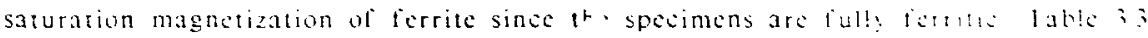

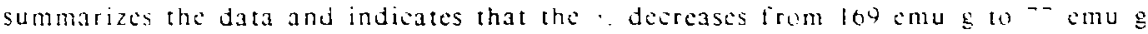
as the iron content of the alloy decreases from 80 wt "w 1050 w " respectively.

latic 3.3: Spontancous magnetization of fully ferrits specimens.

\begin{tabular}{|c|c|c|c|c|}
\hline fllos & Specimen & $\begin{array}{c}\text { Mat } 10 \mathrm{kOc} \\
(\mathrm{e} \text { mu g })\end{array}$ & $\begin{array}{c}\prime \prime \\
\left(c^{2} n u g\right)\end{array}$ & $\begin{array}{l}|n| W \\
\text { (Gauss) }\end{array}$ \\
\hline$t$ & $\begin{array}{c}1 \\
\vdots \\
3 \\
\text { Aig. }\end{array}$ & $\begin{array}{l}168 \\
171 \\
176 \\
172\end{array}$ & $\begin{array}{l}165 \\
108 \\
172 \\
169\end{array}$ & $\begin{array}{l}16.100 \\
16.400 \\
16.800 \\
16.500\end{array}$ \\
\hline B & $\begin{array}{c}1 \\
2 \\
3 \\
\text { Aig. }\end{array}$ & $\begin{array}{l}154 \\
158 \\
164 \\
159\end{array}$ & $\begin{array}{l}151 \\
155 \\
161 \\
156\end{array}$ & $\begin{array}{l}14.700 \\
15.100 \\
15.200 \\
15.200\end{array}$ \\
\hline$c^{\circ}$ & $\begin{array}{c}1 \\
2 \\
3 \\
\text { Aig. }\end{array}$ & $\begin{array}{l}141 \\
145 \\
147 \\
144\end{array}$ & $\begin{array}{l}138 \\
142 \\
144 \\
141\end{array}$ & $\begin{array}{l}13.300 \\
13.900 \\
14.100 \\
13.800\end{array}$ \\
\hline $\mathrm{D}$ & $\begin{array}{c}1 \\
\vdots \\
3 \\
\text { Aig. }\end{array}$ & $\begin{array}{l}119 \\
119 \\
124 \\
12 !\end{array}$ & $\begin{array}{l}117 \\
117 \\
122 \\
119\end{array}$ & $\begin{array}{l}11.400 \\
11.400 \\
11.900 \\
11.600\end{array}$ \\
\hline I: & $\begin{array}{c}1 \\
2 \\
3 \\
A \mathrm{~g} .\end{array}$ & $\begin{array}{l}106 \\
107 \\
110 \\
108\end{array}$ & $\begin{array}{l}104 \\
104 \\
108 \\
106\end{array}$ & $\begin{array}{l}10.200 \\
10.200 \\
10.500 \\
10.300\end{array}$ \\
\hline $\mathrm{F}$ & $\begin{array}{c}1 \\
\vdots \\
\vdots \\
A \mathrm{~g} .\end{array}$ & $\begin{array}{c}94 \\
98 \\
101 \\
98 \\
\end{array}$ & $\begin{array}{l}91 \\
95 \\
98 \\
95\end{array}$ & $\begin{array}{l}8.890 \\
9.280 \\
9.570 \\
9.280\end{array}$ \\
\hline Ci & $\begin{array}{c}1 \\
\vdots \\
\vdots \\
\text { Aig. }\end{array}$ & $\begin{array}{l}77 \\
80 \\
81 \\
79\end{array}$ & $\begin{array}{l}75 \\
78 \\
79 \\
77\end{array}$ & $\begin{array}{l}-320 \\
\because 020 \\
\therefore 10 \\
\therefore 520\end{array}$ \\
\hline
\end{tabular}


The composition of the melt spun alloys can be represented by the formula $\mathrm{Fe}_{(1-x)} \mathrm{Cr}_{(4 x / 5)} \mathrm{Ni}_{(x / 5)}$ where $x$ represents the sum of the $\mathrm{Ni}$ and $\mathrm{Cr}$. lsing this

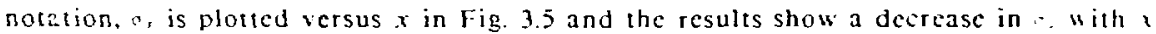
Linear regression analysis of the 21 data points gives the following relationstuip between $a$ and the we fraction of $\mathrm{Cr}+\mathrm{Ni}, \mathrm{x}$ :

$$
\sigma_{F}=-308(x)+231 \quad[6 m u / 9]
$$

Extrapolating this data to pure iron. i.e. $x=0$. shows that equation 3.4 mould predict the specific saturation magnctization of pure iron to be 231 cmu $g$. This value is higher than that reported for pure iron of $218 \mathrm{cmu} \mathrm{g}[3.20]$ and suggests that a slight nonlinearity may cxist between $\sigma$ and composition.

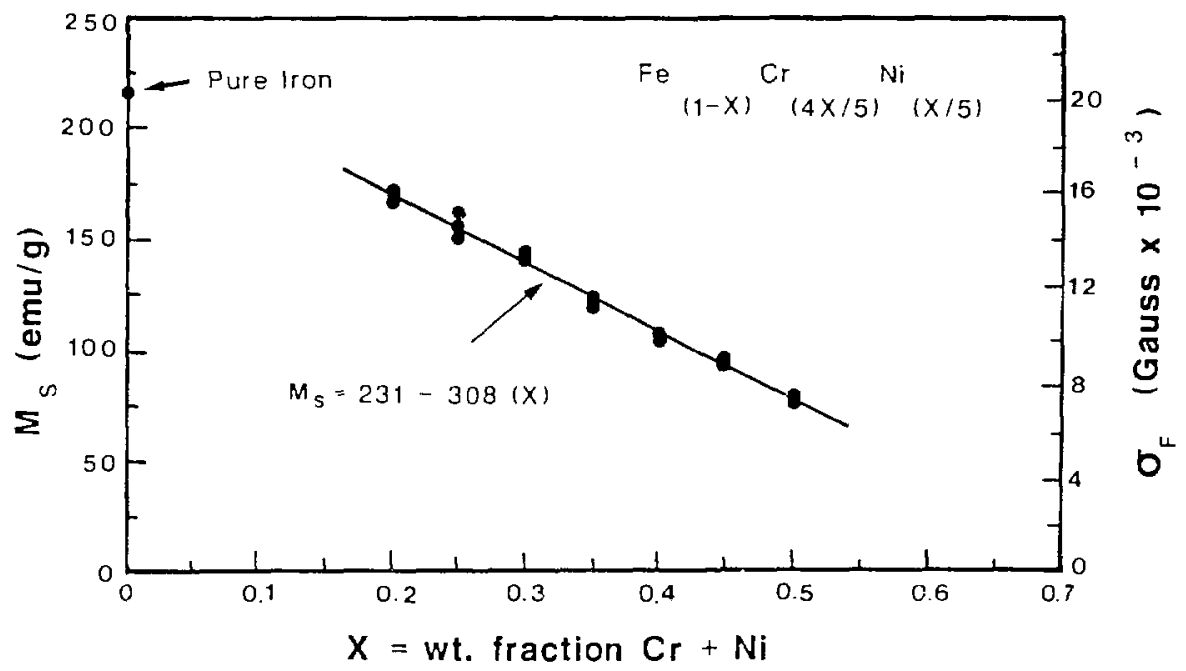

Figure 3.5 Saturation magnetization of the fully ferritic mele spun riblous as a function of $\mathrm{Cr}+\mathrm{Ni}$ conten: 
The specific saturation magnetization of ferritc. . Was soncered from the units of emu $g$ to Gauss using cquation 3.1 and... . . : The saturation magnetization in the units of Gauss for the seven allos are also reported in rable 3.3 and the abrage in walues for cach allos are plotted in Fig. $i 5$ as an alicrmatc t-axis. A regression analysis of the data shows the following relationship between $\therefore$ and the weight iraction Cr+Ni, $x$ :

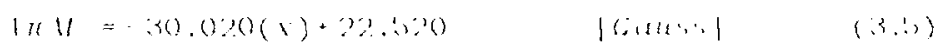

Extrapolating cquation 3.5 to $x=0$ shows the saturation magnetization of purc iron wo be 22.520 Gauss which is $4 "$ "higher than the measured alue of 21.580 Ciauss 13.20].

The results of this study are summarized in eq. 3.5 and ean be compared to Merinos results whish are summarized in eq. 3.3. For Fe-Ni-Cr alloss. with a Cr Ni ratio of 40. ce. 3.5 predicts a decrease in a. of 300.2 Gauss for cach perent fee that is replaced by $\mathrm{Cr}$ and $\mathrm{Ni}$. Merinos"s cquation predicts a decrease in ol 275 Gausi for cach pereent Cr and 330 Gauss fur cach pereent Ni. Thereforc. for a Cr Ni ratio ol 4.0. Merinos cquation would predict a decrease in 1286 Gauss for cach perecnt Fe that is replaced by $\mathrm{Cr}$ and $\mathrm{Ni}$ in this ratio. These two predictions are surprisingly similar when considering the differences in alloss studicd and the diflerences in cxperimontal tcohniques.

\subsection{Predicting the Composition of Residual Ferrite}

Using "Thermocalc" software [3.21], a scries of isothermal sections were created lhrough the Fe-Ni-Cr ternary system [3.22]. These diagrams were used we determine the cquilibrium compostion of ferritc as a function of temperature and the results of these caliulations are summarized in Figures 3.6 through 3.8 . These phots show the

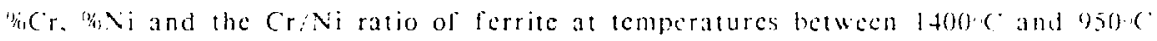
for $50.60,70$ and 80 wt." iron in the ferrite.

The chromium content of the ferritc increases and the nichel sintent of the lerrite decreasen as the temperature decreases $40950 \mathrm{C}$. This resulte in higher cr vi ratios at lower iemperatures. Figure 3.8 show that the cr $x i$ ratius al ferrib

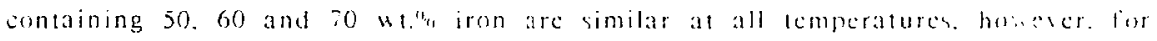

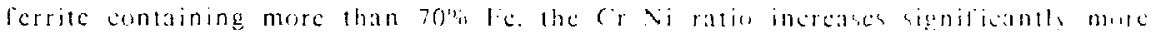
With decreasoin lomperature. 
Inlormation beyond what was provided in the prececding figures is revuaret in order to prediet the composition of ferrite from the nominal allus compoimon Isothermal sections, such as the one presented in Fig. 3.4. can be used to determinc the exact compostion of ferrite at a given temperature. However. mans such diagrams would be needed to represent a large range of temperatures. Since the most important parameter in determining $\sigma$ is the ion content of the ferrite. a method was descloped to estimate the iron content of fersite by summarizing the resuls uf man! isothermal sections into a single diagrant.

In stainless steel alloys, tic lincs in the ferritctaustenite wo-phase ficld show that the iron eontent ol the ferrite is lower than the iron contem af lhe numinal alloy. By taking the ratio of iron in the ferrite to iron in the austenite at the lie-line cndpoints. one can place an upper limit on the difference in the fe content of the ferrite and the fe content of the nominal alloys because all of the alloys that lic on a given line hase the same lerrite and austenite composition.

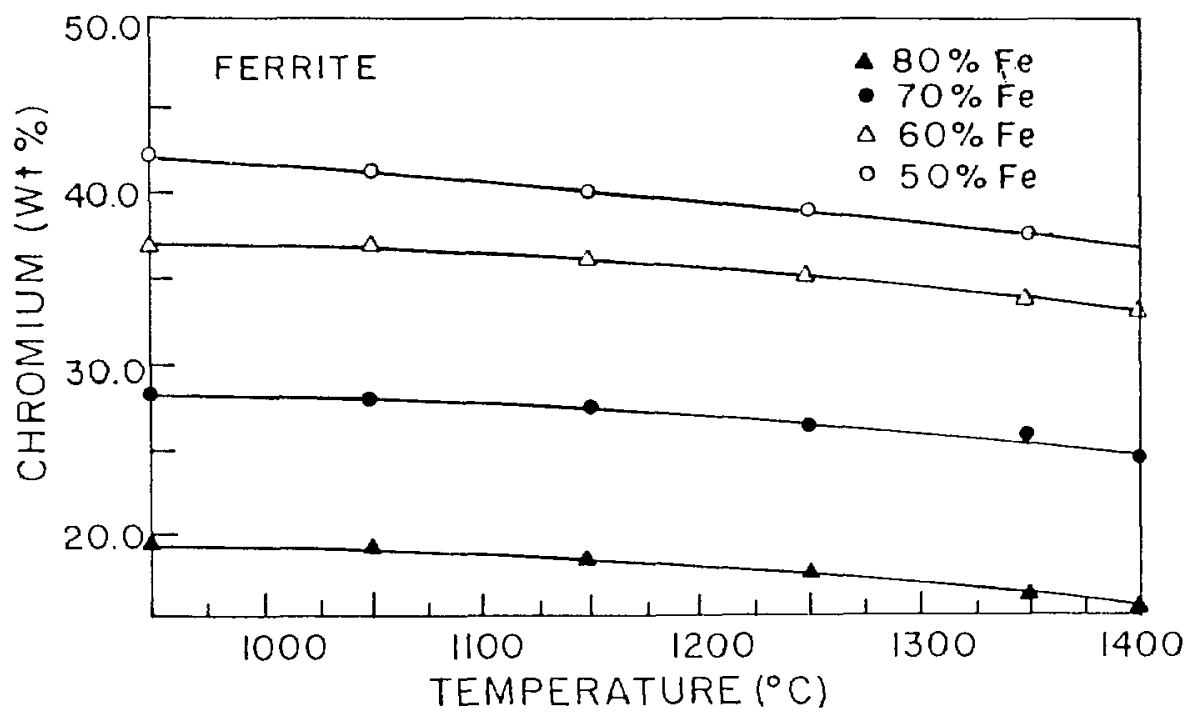

Vigure 3.6 Jhernodynamic calculations of the chromium content in ferrite as a lunction 1.1 temperature and iron content of the lerrite. 


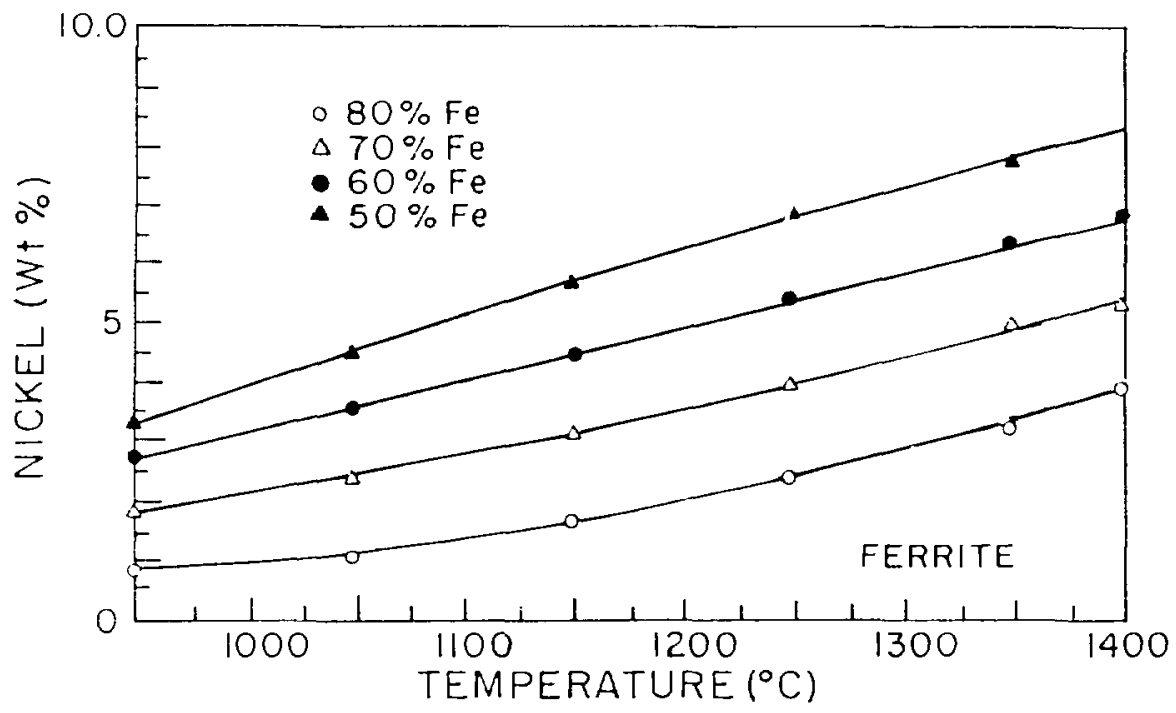

Figure 3.7 Thermodynamic caleulations of the nitkel content in fertite as a function of temperature and iron content of the ferritc.

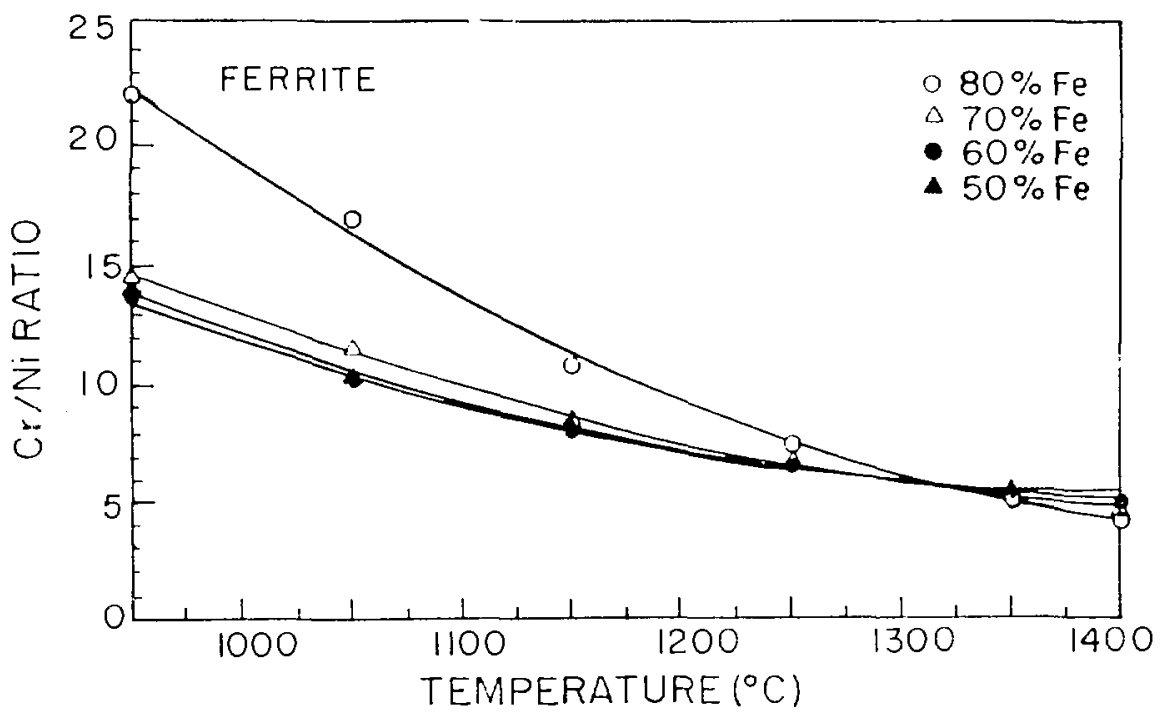

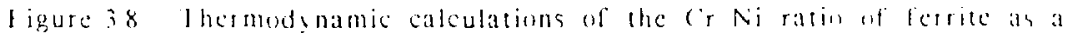
innetion of temperature and iron content of the fertic 
Figure 39 shows the ratio of the $F c$ in the lerrite to $F$ in the austenite fior lerrite containing 50. 60, 70 and 80 wt." Fe. This figure wa" deribat irom the tie-lines generated by thermodynamic cal:ulations and the results are plotted for comperatures between $14000 \mathrm{C}$ and $9500 \mathrm{C}$. To use this diagram, one must recall that: 1) a Fe ferrite Fe ausicnite ratio of 1.0 corresponds to the nominal allo! composition being identical to the ferrite composition. i.c. 1.0 corresponds to a fullt ferritic specimen with composition at the tie-line end point and 2 ) an allog that has the same composition as the austenite lic-line end point will have an Fe ferrite fe austenite ratio equal to that presented in Fig. 3.9. Therefore. 10 predit the iron somposition

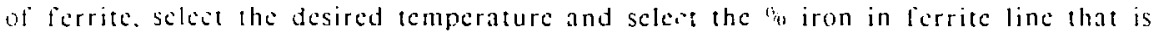
the same as the nominal Fe content of the alloy. This requires interpolation sinec only 50.60 . 0 and 80 " iron in ferrite trends are shown. The actual iron content of the ferrite lics between the Fe ferrite Fe austenite ratio of the nominal allos and and 1.0 .

At high temperatures (>1300 C) and for low allog stainless steels $\left(>70^{\prime \prime}\right.$ Fe $)$, the iron content of the ferrite is within $2 \%$ of the nominal allog compostion. At lower temperatures $\left(<1200^{\circ} \mathrm{C}\right)$. the range of possible Fe contents in the ferrite is larger. The tcmperatures at which the ferritc forms can be predicted by the clifestic quanch temperature [3.23]. This temperature corresponds to the temperature where cquilibrium can no longer be maintained during solidilication and is a lunction of the cooling ratc. The higher the cooling rate, the higher will be the cficetive quench temperature since less time is available for diflusion.

Comparing the cquilibrium forric composition at $1300^{\circ} \mathrm{C}$ with the neasured ferrite composition in the 59 wto are-ast buttons showed a good correlation. ie. the 1300 . temperature appears to be elose to the elfective quench temperature lur the are-cast condition. Helds, which cool at higher rates. Hill have esen higher cliceline quench emperatures and the ratio of the iron sontent of the ferrits la lhe iron coment of the austenite that forms under these onditions uill le enon eloser fo unit!. 


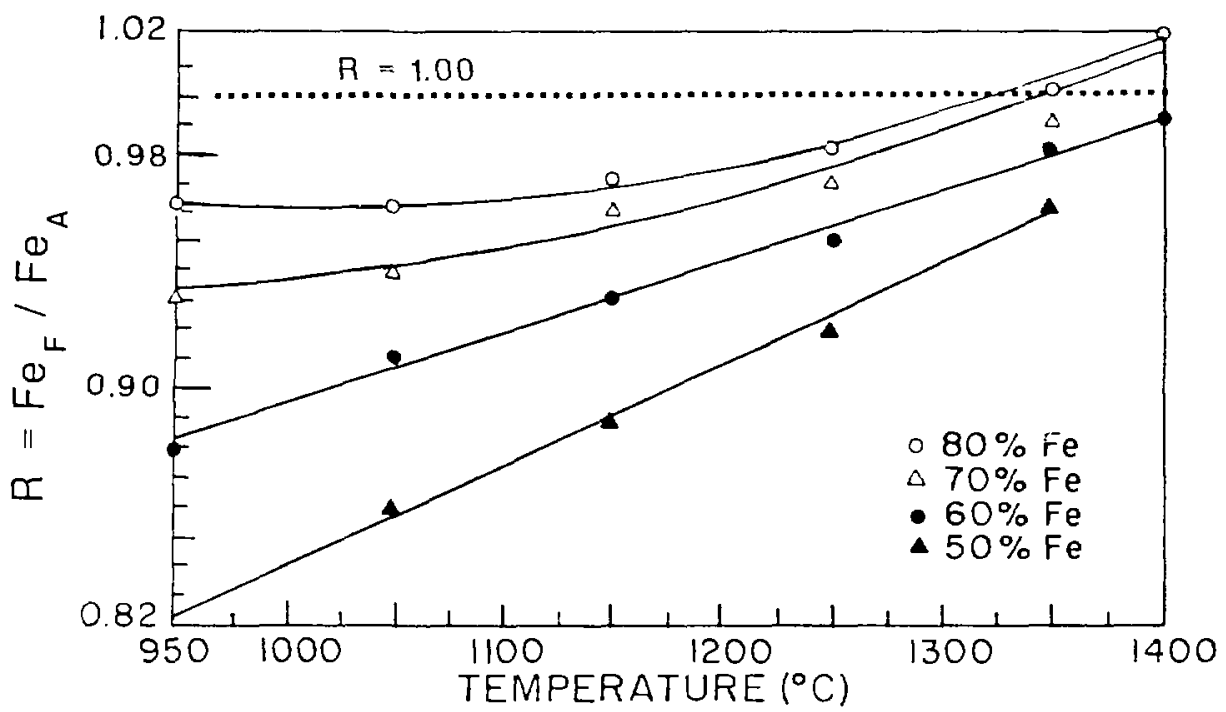

Figure 3.9 Thermodynamic calculations of the ratio hetuecn the fe content of ferrite and the $\mathrm{Fe}$ content of austenite as a function of temperature and iron content of the ferrite.

For stainless stecls containing $60 \%$ Fo or greater and having effectise guench temperatures of $13000^{\circ}$ or greater, the Fe content of the fertite can accurately he cstimated from the nominal alloy composition. Figure 39 shows that the range of possible iron contents in the ferrite is small at high temperatures. For example. ferrite that forms from a typical $70 w t \%$ Fe alloy at $1300 \times C$ has possible Fe contents that range from $68.8 \%(0.983 \times 70 \%)$ to $70.0 \%$. Thercforc, hy knowing the nominal allos composition and the effective quench temperature which can he taken to he lingne for castings and welds) the amount of iron in the ferrite can he predicted from I.ig. 39. This information can then be used to calculate the saturation magnetization of the ferrite using the relationship between "s and alomic "is ion in the fertiti which will he discussed in the following section. 


\subsection{Verification and Application of the VSMI Method}

\subsubsection{Ferrite Content of the Arc Cast Alloys}

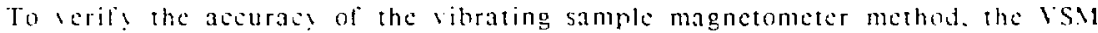
was empared with the Magne-Gage (MG) and quantitatice teterision microscop! (QTM). Eath cohnique was used to measure the ferrite content on a series of high-purity east alloys and the results were compared. The composition of the east alloys is shown in Table 2.2 and the microstructure of the alloss is shown in Fig. 3.10 . tllu I has no ferrite and the remaining alloys inerease in ferrite content from thoy

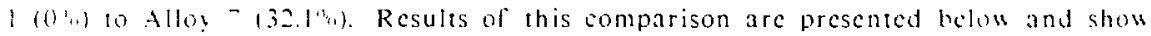
that the VSM is as accurate as the other ferrite determination methods. The saturation magnetization of ferrite ean also be used to consert the ferrite number. measured by the Vagne-ciage. directly into pereent ferrite for a wide range of stainless sted compusitions.

\section{Quantitatie betallographs}

The aat alloys were metallographicall! prepared for QTM analysis aceording to reterenec 3.19 using a $\mathrm{KOH}$ clectrolytic eteh. The ferrite which is present in the mierostructure is the dark etching phase and because of the relatively conse microstrueture of the castings. the QTM measurements were casily periormed. Six micrographs were analyzed from each alloy and the results are presented in Table 3.t. The number of micrographs analyzed, $n$, and the standard deviation. $s$. of the readings are indicated and the ferrite contents measured by this method are shown to ars from 0 to 37.2 "

Table 3.4: QTM ferrite measurements

\begin{tabular}{|c|c|c|c|}
\hline $\begin{array}{c}\text { Sast } \\
\text { Allos }\end{array}$ & $n$ & $s$ & $\begin{array}{c}\text { Ferrite } \\
\text { ("w) }\end{array}$ \\
\hline 1 & 0 & - & 0 \\
\hline 2 & 6 & 0.74 & 5.35 \\
\hline 3 & 6 & 2.7 & 11.0 \\
\hline 4 & 6 & 1.9 & 14.2 \\
\hline 5 & 6 & 2.1 & 22.8 \\
\hline 6 & 6 & 2.9 & 32.4 \\
\hline 7 & 6 & 5.1 & 37.2 \\
\hline
\end{tabular}




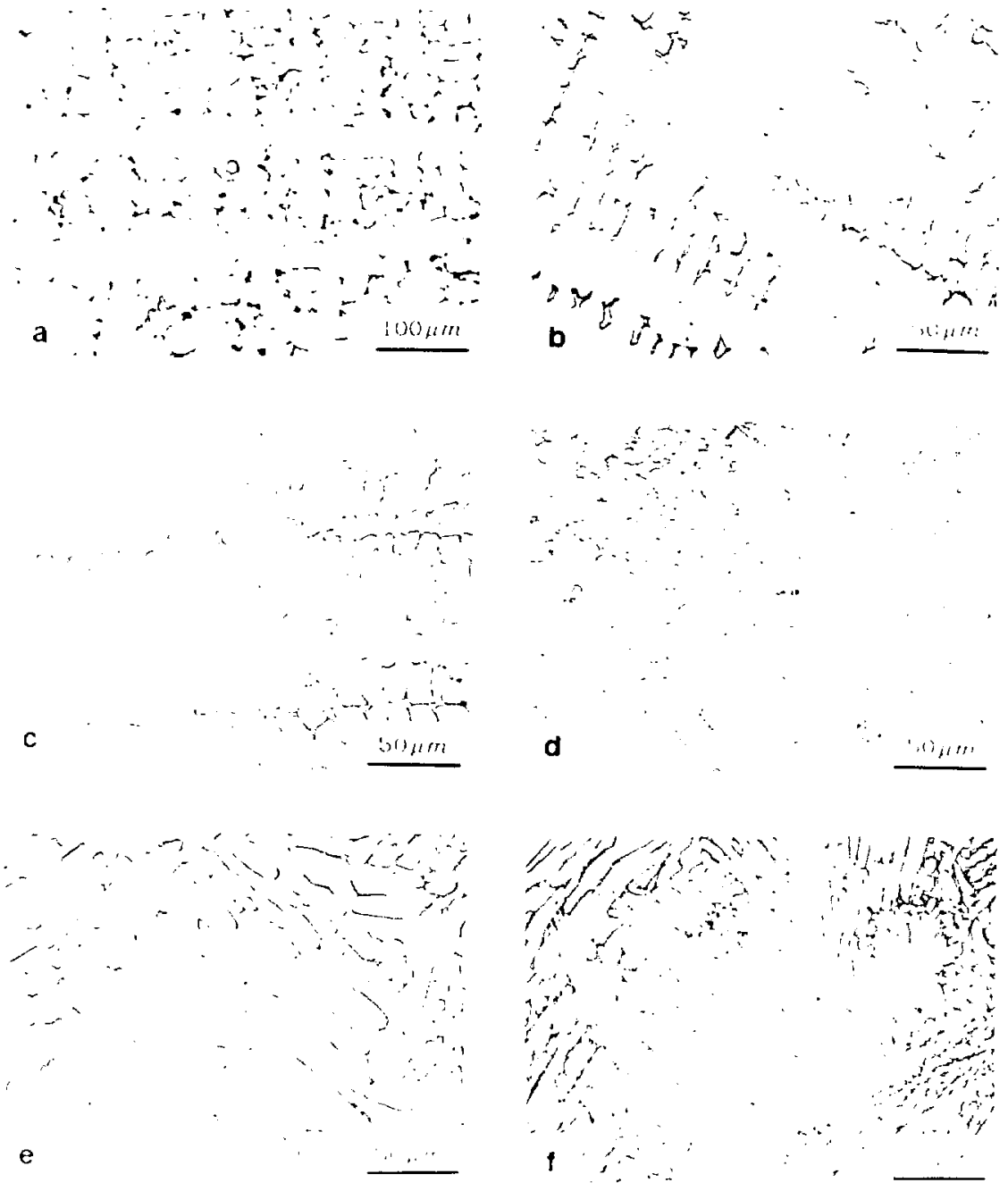

Figure 3.10 figures a through $f$ show the microstructures of the are-cast alloys 2 through 7 respectively. The ferrite content incrases from Allo! $215 \%$ to Alloy 7 (35\%). The primary mode of solidifiation changes from primary austenite to primary ferrite between alloys $3(b)$ and f(c respectisely. 


\section{Vibrating Sample Maguetometer}

The VSat measurcments were made on three samples from cath sast allow. Fach specimen weighed approximately $50 \mathrm{mg}$ and the rom temperature magnetic properties were measured to determine the saturation magnetization. Ihe M-H cures for the seicn alloss are summarized in Fig.3.11. As the Cr Ni ratio of the allo! is increased Crom allo! I 10 allos 7 , the spontancous ferrite magnetization varies from 0 to 30 emu g. The M-H hehasior indicates that all of the alloys saturate at an applied magnetie lield of about 4 kOe. The initial M-ll behasior of a lull fertitic spesimen. F. Which has a saturation magnetization of 101 emu g. is also shoun on this ligure lir comparison.

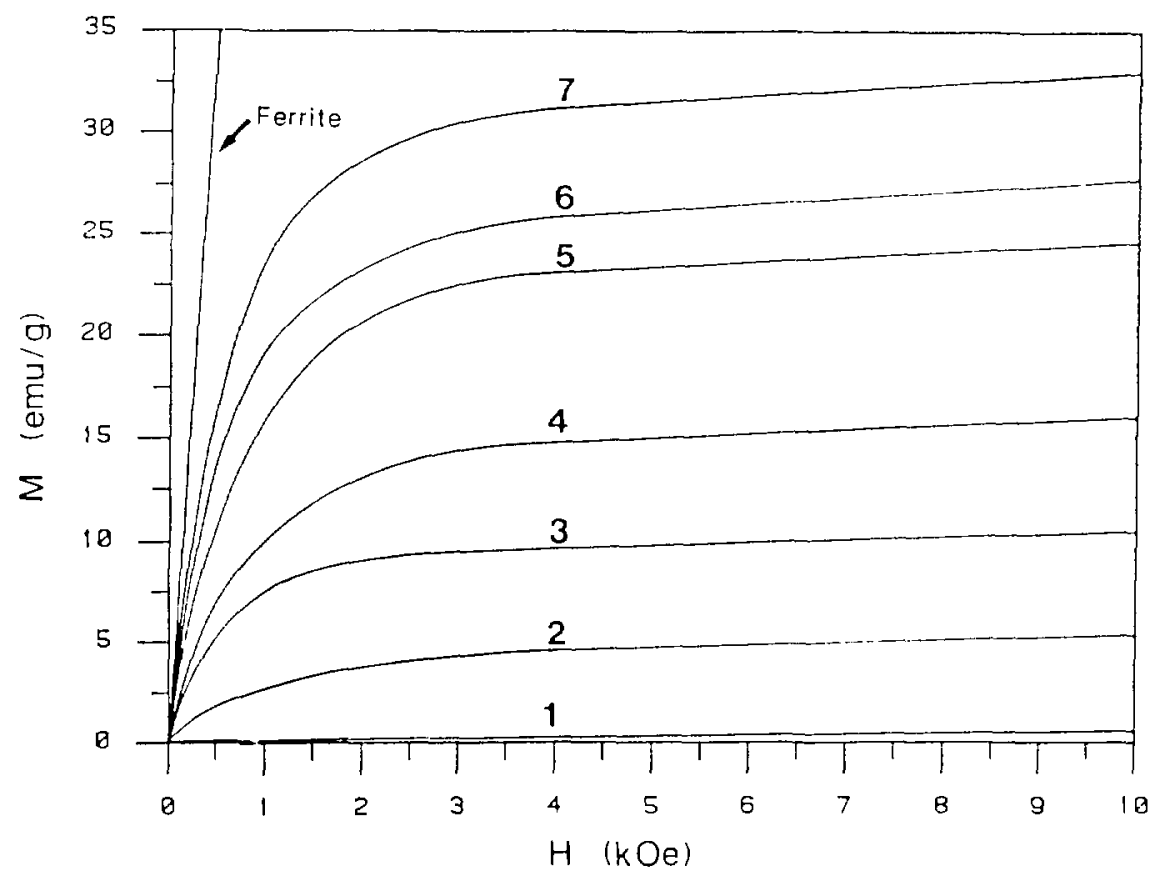

figure 3.11 M-ll cures at rom temperature bur the secen are-cast allus are

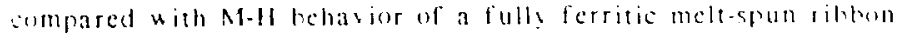


Table i.s summarizes the saturation magnetization results and reports the abrage of the threc neasurements for each alloy. The specitic saturation magnetization of ferrite in the castings was estimated from its composition so that the $\mathbf{M}_{8}$ data could be sonicred into pereent ferritc. To do this, the composition of the ferrite was measured in cach alloy by elcotron microprobe analysis. These results are shoun in rable 2.5 and indisate that the ferrite composition is similar for cach of the alloys. The arerage ferrite somposition is $35.5^{1 \%} \mathrm{Cr}$. $9.12^{1 \%} \mathrm{Ni}$ and $55.4^{11 \%}$ Fe. Therefore, the Cr Vi ratiu of the ferrite is significantly higher than the nominal alloy composition lut the $t c$ content of the ferritc is only slightly lower than the nominal alloy composition. l'sing the measured lerrite composition. the saturation magnetization was determined o be $93.6 \mathrm{cmu} g(9,125$ Gauss) as determined by equation 3.4 .

Table is shows the pereent ferrite in each of the alloys as calculated from the aluration magnetization of the eastings and the above value for a.. The ferrite contents are shown to range from 0 to 32.1 pereent and these values compare lisurably the quantitative metallographic measurements.

Table 3.5 : VSM measurements of ". and ferrite.

\begin{tabular}{|c|c|c|c|c|c|}
\hline $\begin{array}{l}\text { Cast } \\
-1110\}\end{array}$ & 1 & 0 & cmus & A $\cdot g$. & $\begin{array}{c}\text { Ferrite } \\
(\%)\end{array}$ \\
\hline 1 & 0.01 & 0.00 & 0.00 & 0 & 0 \\
\hline 2 & 4.77 & 4.02 & 4.13 & 4.31 & 4.6 \\
\hline 3 & 9.08 & 9.01 & 9.45 & 9.18 & 9.8 \\
\hline 4 & 15.0 & 14.6 & 147 & 14.8 & 15.8 \\
\hline 5 & 20.8 & 210 & 21.4 & 218 & 23.2 \\
\hline$h$ & 24.9 & 24.4 & 249 & 24.7 & 26.4 \\
\hline- & 302 & 28.7 & 312 & 30.0 & 321 \\
\hline
\end{tabular}




\section{Magne-Gage}

Magne-Gage measurements were also made to determine the ferrite number. IV. of the cast alloys. The ferrite number is defined by the fores at atractun 1.81 between the magnetic probe and the specimen. Higher ferrite number correspind to higher ferrite contents, however. since the saturation magnetization is a fundiun of Ferrite composition, the ferrite number does not uniquely define the anum it ferrite in the specimen. Therefore, correlations between FN and lerrite cuntent an only be made for alloys of similar composition unless the ferrite sumpuition $\therefore$ lin raken into account.

The elfeet of ferrite composition on the $F N$ is oftentimes newleted llumever. the saturation magnetization of ferrite can casily be accounted for when con a: at:

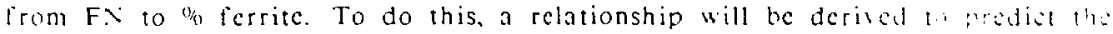

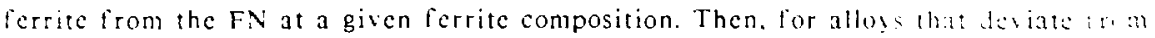
this composition. the saturation magnetization effects ean be used th molil lis equation.

Kotecki $\{3.25]$ measured the FN and the extended ferrite numlet. I.f $\backslash$, li, it serics of 15 ast alloys of CF8 and CF8M composition. The ferrite sontont of these alloys brict from 0.2 to $48.6^{1 / t}$ as determined from a point counting teshique. I linear regression analysis on these data shows that the EFN ean he related lo the Fereent ferrite as follows:

$$
\%, t=0.1(f F)+0.6 \%
$$

The iron content of each alloy was reported and has an average value of $66.8^{\prime \prime}$ with a standard deviation of 2.J\%. Therefore, since the composition of these allus are similar, the composition of the residual ferrite in each alloy san be assumed we the same. From Fig. 3.9, the iron content of the ferrite in the CF8M alloys will be 98 pereent of the iron content in the alloy based on an elfective quench temperature of 13000 l'sung this ratio, the saturation magnetization of the ferrite in these alloss was calculated using cquation 3.5 to be 12.200 (iauss based on a Cr+vi sontent of 100 4 
In order to convert lrom EFN to n// ferrite for alloys that have a diflerent nomigal composition, the EFN must be multiplied by the ratio of $\therefore$ in the CF8 alloys to. in the alloy being measured:

$$
n+1-0 .(1 \% 1)\left(\begin{array}{c}
1,200) \\
0 !
\end{array}+0.31\right.
$$

where. an be determind from cquation 3.5. For ferritc contents less than about 30 " ralloys 1-5). the FN ean be directly measured with a Magne-Gage and substituted for the EFX with no loss in accurasy. Howerer. Alloys 6 and 7 contain more than 30 "icrite and the Magne-Gage was calibrated to directly measure the EF.

The $F_{e}$ concent of the ferrite in the are-sast buttons is lower than the iron sntont in the CF8 alloys. Therefore, the saturation magnetization of ferrite in the arr-cast buttons is lower than that in CF8 alloys and was shown to he 9.125 Gauss. l sing this valuc ol, the ferrite number was converted to \% ferrite using equation $\therefore$ and the results are shown in Table 3.6 . These results show that the ferrite content measured by this method compares lavorably to the other wo techniques.

Table 3.0: Magne-Gage measurements and calsulated fertite contents.

\begin{tabular}{|c|c|c|c|c|c|c|}
\hline $\begin{array}{l}\text { Cast } \\
\text { lifor }\end{array}$ & 1 & $\begin{aligned} & W D \\
= & \end{aligned}$ & $\begin{array}{c}\text { Reading } \\
3\end{array}$ & Avg. & $F N$ & $\begin{array}{c}\text { Ferrite } \\
(\%)\end{array}$ \\
\hline 1 & 109 & 110 & 110 & 110 & 0 & 0 \\
\hline$=$ & 20 & 90 & 89 & 90 & 4.9 & 4.5 \\
\hline 3 & 70 & 76 & 73 & .75 & 8.3 & 8.0 \\
\hline 4 & 5 & 49 & 51 & 51 & 14.4 & 13.5 \\
\hline 5 & 14 & 13 & 17 & 1.3 & 23.6 & 21.8 \\
\hline $6^{\circ}$ & 63 & $6 ?$ & 69 & 66.3 & 29.7 & 27.4 \\
\hline$-\cdot$ & $=0$ & 28 & 24 & 20 & .39 .6 & 36.5 \\
\hline
\end{tabular}

- I vencasurements 


\section{Comparison of the Three slethods}

A summary of the results of the three measurement methods is platted in Fig. 3.1 ? as \% fertite versus $\mathrm{Cr} / \mathrm{Ni}$ ratio along the $59 \% \mathrm{Fe}$ isopleth. The ferrice content appears to increase linearly with increasing chromium content and there is a good correlation between the average ferrite trend and each of the three measurement terhniques. The deviation between the measurements is small at low ferite contents but increase= with increasing ferrite content. Each technique measures ferrite cuntents that lic above and below the average trend and it appcars as theugh the thrce measurement techniques are showing the same trend. Therefore, the differen s in ferrite contents between the techniques are most likely the result of the small population size used to calculate the statistics.

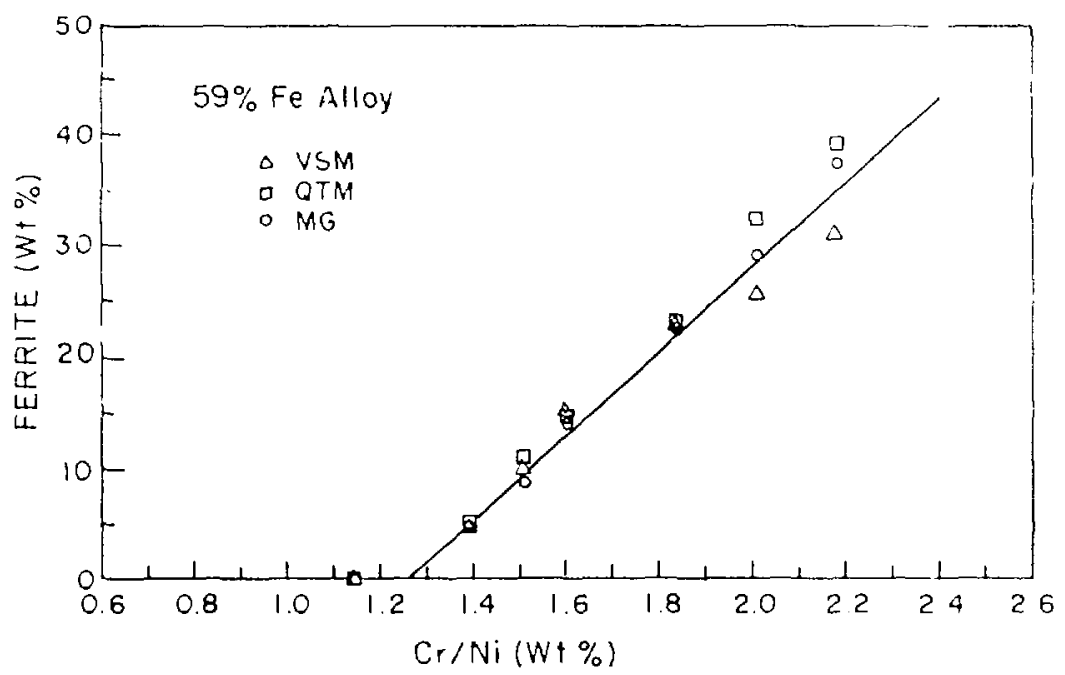

Figure 3.12 Comparison of the ferrite measurements made on the ate-ast alloys by the ribrating sample magnetometer. Magne-fiage and Quantitative Metallographic echniques. 


\section{3,5.2 Extending the VSM Method to Commercial SST Alloys}

Commercial stainless stecl alloys contain alloying elements other than Fe. Ni or Cr and the eflect of the additional elements must be taken into account when calsulating the saturation magnetization of ferrite. The most common additional clements are Min. Si. M10, No, N, C. S. and P. These elements are not ferromagnetic and do not contribute significant magnetie moment to the ferrite. Theretore, the iron content of the ferrice is still the nust impuitant factor in detcrmining..

Equation 3.5 san be rewritten to predict 0 . in terms of atomic "v Fe in the ferrite:

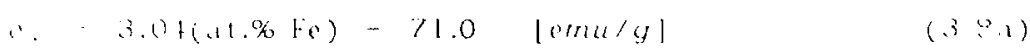

or.

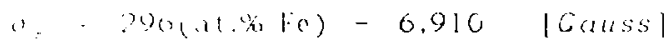

Assuming :hat the alloying clements segregate to the ferrite and the austenite in cumal amounts during soliditication, then the atomis $\% \mathrm{Fe}$ in the icrrite san be predicted from the atomic $v_{0} \mathrm{Fe}$ in the alloy using the methods in section 3.4 .

Finally, the weight iration icrtite can be ealculated using cquation 3.1 . Onl! a small percentage correction is required to convert from waight fraction ferrite to volume iraction ferrite besause the density of ferrite $\left(7.77 \mathrm{~g} \mathrm{~cm}^{3}\right)$ is close to the Jensity of austenite $\left(7.96 \mathrm{~g} \mathrm{em}^{3}\right)$, . 


\subsection{Conclusions}

1. The amount of ferrite in stainless stecl alloys can be defermincd by mcasuring the saturation magnctization of a small stainless stcel specincen with a vibrating sample magnetometer. This $m^{\prime}$ nique is not limited by sample size and can be used to measure the ferritc content of rapidy solidificd stainless steel alloys.

2. The saturation magnetization of fully ferritic spccimens was cxpcrimentally determined on a series of rapidy-solidificd Fe-Ni-Cr alloys which had compositions similar to that of residual ferrite in stainless steel alloys. The results of these measurements can be used to predict the saturation magnetization of residual ferrite from its composition.

3. Methods were presented to show how the composition of ferrite can be predicted from the nominal alloy composition using thermodynamic calculations. In particular, a range of possible iron contents in the ferite can be cstima: from the nominal alloy composition and the concept of the effective quench temperaturc. By knowing the iron content of the ferrite. its saturation magnctization can be used to calibratc the VSM to measure the forite content of a wide range of stainless steel alloys.

4. The results of the saturation magnetization stuci wa also be used as a hasis to calibratc the Magnc-Gage for non-standard stainless stcel alloys. By considering the saturation magnetization of residual lerrite, the ferrite number can be converted directly into $\% / \%$ ferrite for a wide range of nominal alloy compositions. 


\section{CHAPTER 4}

\section{The Cooling Rate Of Electron Beam Surface Melts}

Variations in cooling rate werc produced by controlling the travel specd of clestron-bean surlacc melts. Each melt was madc at a constant power level cf $2 \mathrm{~kW}$ and the travel specd ranged from 6.3 to $5000 \mathrm{~mm}$; s. The cooling ratc could not bc dircotls measured on the melts becausc they were too small to instrument with thermucouples or to monitor with optical tempcrature measurement devices. Therefore. the cooling rate was estimated, rather than measured, using the following tcehniques: I1 the dendrite arm spacing method, 2) an expression that was derised from Rosenthal's heat llow analysis for quasi-stationary conditions and 3) a numerical approach using the finite clement method to calculate the cooling rate and temperaturc gradient at the melt interface. The heat flow calculations confirm the dendrite arm spacing cstimations of the cooling rate and show that the alloys solitilied at rates between $7{ }^{\circ} \mathrm{C} / \mathrm{s}$ and $8 \times 10^{\circ \circ} \mathrm{C}$ : s.

The cooling rate is an casy concept to define in single phase materials as it is simpl! the change in temperature. $1 \%$, with respect to a chal. ${ }^{\circ}$ in time, 11 , at a given point. However, during the solidification of an alloy the physical meaning of the tern cooling rate is not as casily defined. The presence of at least two phases at the liquid-solid interlace having different physical propertics, the fact that the interlace is moving and releasing a latent heat of fusion, and the possibilitics of a non-planar solidification front all contribute to the complexity of the temperature-time relationship for a lixed point in space being overtaken by a liquid-solid interface.

In this chapter. two types of cooling rates will be discussed and will be assumed to be equivalent measures of the solidification rate. The first method predicts the coling rate by dendrite $3 \mathrm{rm}$ spacing measurements. This method represents an 'average' cooling rate liom the inception to completion of solidilication. Here, "1, is the change in temperature between the dendritc tip where soliditioation initiates and the dendrite 'base' where the Iast liquid solidifics. The change in time required to produce this change in tempcrature is the tine nescssary for the L:S interlace to move the distance corrcsponding to the length of protrusion of the dendrite in front 
of the interface and is consequently related to the interface velocity. The second method calculates the "instantancous" cooling rate at a given point. This method can be app'icd to the $L / S$ interface to ealculate the cooling rate at the solidification temperature but neglects the details of the interface by assuming plane-front rather than dendritic behavior. Herc, the temperaturc gradient, G, and the interface velocity, $R$, are sombined to represent the cooling rate during solidification. This method will be discussed in detail in the following sections.

In welds and surface melts, the travel speed. $S$, is held constant but the velocity of the $L, S$ interface varics from zcro to a maximum value of $S$ on the mele interiace. Variations in the temperature gradient are also present around the surface of the melt, therefore, neither the interlace velocity nor the temperature gradient can be uniqueiy specified by the welding parameters. Conscquently, the cooling rate. . . and the dendritc arm spacing, $i$, vary throughou the cross section of the weld. This chapter discusscs methods that cnable the cooling ratc to be calculated and also prescnts results to show the variations of $G, R, '$, and $x$ within a given weld.

\subsection{The Geometric Shape of Electron Beam Melts}

The geometric shape of the molten zone influences the depth of penetration, the width of the fusion zonc and the cooling rate in the melt. These fastors are of essential importance to welding and surface modification applications and a stud! was performed to determine the influence of electron beam paramerers on the melt pool shape. The results of this separate study are presented in Appendix $G$ and rere used to select the electron beam melting parameters used throughout this study. In addition, by using dimensionless quantatics to represent the weld pool shape, the resulis of this study can be used to predict the width. depth and length oi the resolidificd zone for a wide range of operating parameters.

\subsection{Dendrite Arm Spacing Calculations}

Two factors contributc to the dendrite arm spacing (DAS) [4.l]. Firsty, during solidification, the dendrites optimize their spacing to optimize both constitutional supcrcooling and interfacial suriace encrgy cffects. The frec cnergy associated with constitutional supcrcooling is minimized by a small DAS while that of the surfate 
cnergy intertace is minimized by a large DAS. Therciore, the actual spacing is a balance betuecn these lactors and cach lactor is inluenecd by the cooling rate. Sccondly. after the solidification spacing has becn cstablished. coarsening of the dendritc arms can occur as the melt cools. The driving force for coarsening is a reduction in the total surface cncrgy [4.2] and only the highest order arms are aflected. For example, sccondary arms, but not printary arms, will coarsen when secondary arms are present, while primary arms (or eclls) will coarsen when no secondary arms are presens.

Relationships between DAS and cooling rate (1) have been developed and show that a linear relationship exists between $\log$ DAS and $\log$, [4.1, 4.2]. These ralations have the following form:

$$
\lambda=a(r)^{-n}
$$

where a and $n$ are material-dependent constants and 1 represents the dendrite arm spacing. The cooling-rate cxponent, $\mathrm{n}$, is known to be close to 0.5 for primary dendrite arms and varics between 0.25 and 0.33 for secondary dendrite arms [4.1]. The lower value for secondary arms is a result of coarsening. If secondary arms are not present, the primary DAS may have an $n$ value close to 0.3 .

Microstructural cxamination of the clectron-bcam melts made in this insestigation showed that the DAS was not uniform within the melt. Cross-sectional views of the decp penctrating. slow speed melts $(1,2,3)$ showed that the spacing was typically small at the lusion line and increased towards the ecnter line. Along the ecnter line. there was a slight decrease in spacing at the top of the melt. Cross-sectional vicus ol the shallow penctrating, higher specd melts (4.5.6) showed that the DAS was small at the fuston linc and increased to a larger spacing within a few dendrite spacings of the boundary. The DAS then remained approximately constant to the top of the melt. Figure 4.1 a and $b$ compare the microstructure at the lusion line with that at the center for melt 3. to illustrate the range of dendrite arm spacings observed within the same mell.

The DAS measurements show that the cooling rate is not constant throughout the melt. The variation in DAS is approximatcly a bactor of three, which corresponds to a sariation in cooling rate of appro; matcly ten. 

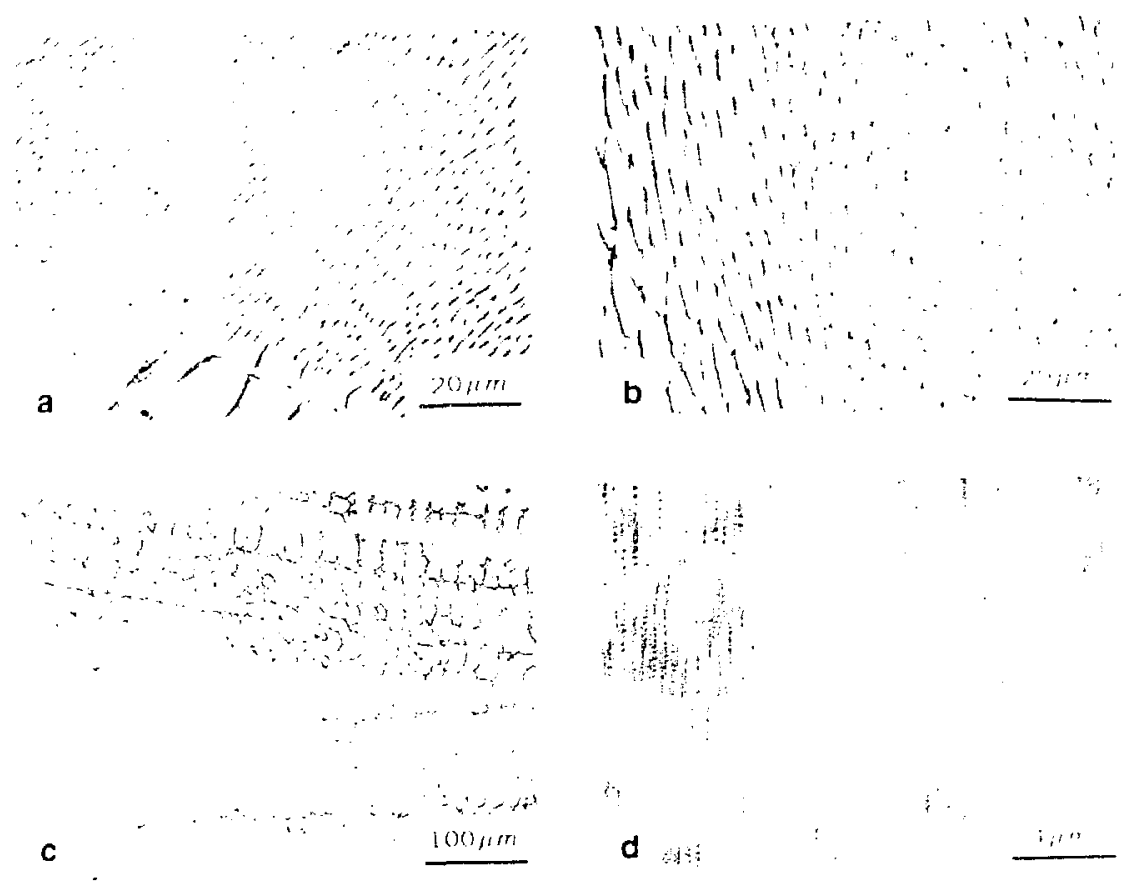

Figure 4.1 Variations in the dendrite arm spacing. Figures a and b compare the variation for a given set of surface melting parameters $(100 \mathrm{~mm} / \mathrm{s})$, at the fusion boundary and at the center of the melt respectively. Figures $c$ and $d$ compare the largest dendrite arm spacings in the casting with the smallest spacings in the highest speed melt. 
However, a large pereentage of the change in the DAS Oceurs close to tre fusion line and the majority of the melt solidities with a cooling rate variation of only a factor of tive or less.

The DAS measurements were made in a location which is representatic of the average behasior of the mele and where the specimens would later be curated fin Ferrite content measurements (sec section 2.3.2). The results of the dendrit arm spacing measurements are listed in Table t.l where a represent the primary dendrite arm spacing for melts 1.2 and the are cast butum. and ecll spacings for melts 3. 4, 5 and 6 . The scoondary dendrite arm spacing is represented by and was able tu be measured on the low specd melts that solidilied in a dendritio mode. These data shou that the primary DAS decreases lrom a value of 42 wit for the $a$ an to 0.43 . for the highest travel specd. These two microstructures are compared in fig. 4.1 . alld $d$.

A prot of $\log$ a 1 crsus $\log S$ is shown in Fig 4.2 for the six molts, where $S$ relers to the travel specd. The best-lit linear relationship between 1 and $S$ has a slope of -0.49 and indieates the relinement in DAS with increasing travel specd.

Table t.1: Cooling rates calculated from primary and secondary dendrite arm spacing measurements.

\begin{tabular}{|c|c|c|c|c|c|c|c|}
\hline$M 101 t$ & $\begin{array}{l}\text { Travel } \\
\text { Specd } \\
\text { (mim s) }\end{array}$ & 1 & $\begin{array}{l}\lambda_{1} \\
s \\
\ldots \cdots\end{array}$ & $\left(\begin{array}{c}1 \\
(K s)\end{array}\right.$ & $\begin{array}{c}1 \\
\ldots\end{array}$ & $\begin{array}{l}\lambda \\
s \\
\therefore\end{array}$ & $(k s)$ \\
\hline cast & - & 42 & 3.9 & -7.0 & 180 & 3.3 & -3.2 \\
\hline 1 & 6.3 & 10.5 & 1.5 & $-4.7 \times 10^{2}$ & 4.7 & 1.2 & $-3.9 \times 10^{2}$ \\
\hline 2 & 25 & 6.6 & 1.8 & $-1.9 \times 10^{3}$ & 3.0 & 0.54 & $-1.9 \times 10^{3}$ \\
\hline 3 & 100 & 3.2 & 0.9 & $-1.7 \times 104$ & - & - & - \\
\hline 4 & 500 & 1.1 & 0.4 & $-4.4 \times 10^{5}$ & - & - & . \\
\hline 5 & 2.000 & 0.73 & 0.05 & $-1.5 \times 10^{6}$ & - & - & - \\
\hline 6 & 5,000 & 0.43 & 0.07 & $-7.5 \times 10^{0}$ & - & - & . \\
\hline
\end{tabular}


Katayma et al. [4.5] experimentally determined values for the constant, a, and the cooling rate exponent, n, for type 310 stainless stecl. They give the lollowing relationship between dendrite arm spacing and cooling rate :

$$
\begin{aligned}
& \lambda_{1}=80(t)^{-03} \\
& \lambda_{2}=20(r)^{-020}
\end{aligned}
$$

These values were used to calculate the cooling rate based on equation 4.1 and should apply to the alloys used in this investigation for two reasons. Firstly, type 310 stainless stecl has a high alloy content and contains approximately 55 "t perecne iron Which is close to the 58 we percent iron of the alloys used in this study. Sccondly, the colling rate cxponent of 0.33 for the primary dendrite spacing suggests that the structure has possibly coarsened during solidifieation. Coarsening of the primary vructure might also be expected in this study since the higher cooling rate melts solidificd in a cellular manner with no secondary arms.

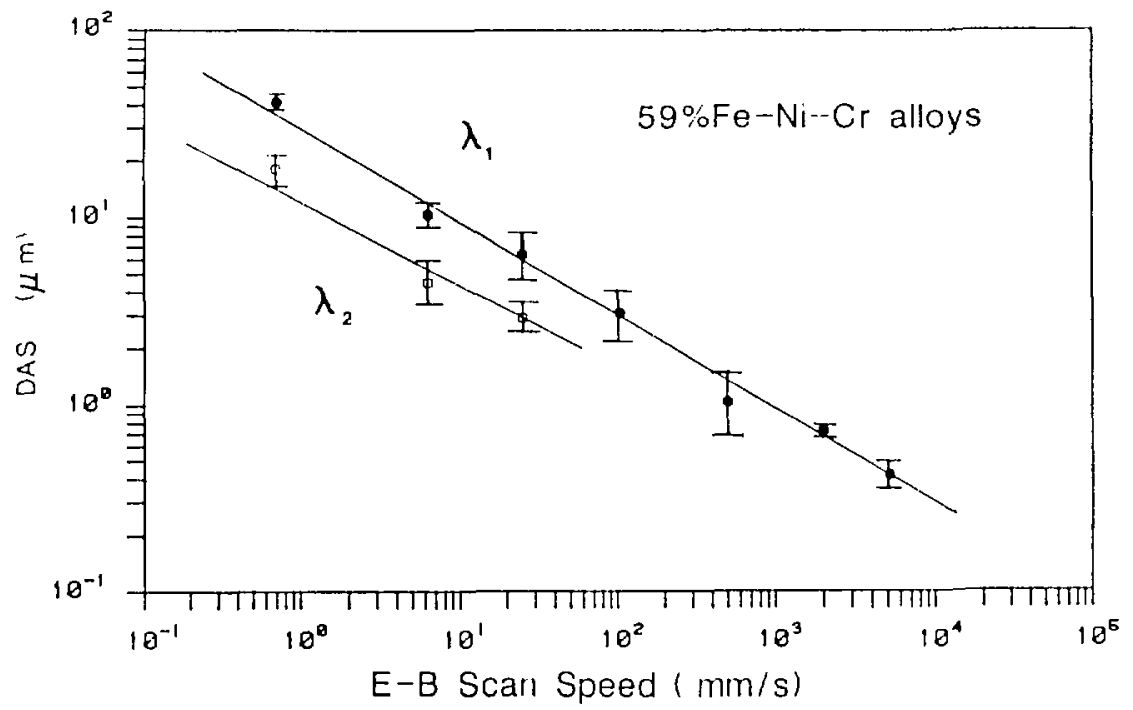

Figure 1.2 Primary and secondary dendrile arm spacing as a tunstion ol clectron beam scan speed $t /$ - one standard deviation crou bas are indicated. 
A plot ol the cooling rate versus travel speed is shown in $\mathrm{fig} 4.3$ for the clectron beam melts and the casting. Since the travel specd could not be comtrolled lur the casting, an cflective interface velocity of $0.7 \mathrm{~mm}, \mathrm{~s}$ was calculated using a DAS of 42 um and an cxtrapollation of Fig 4.2. The primary DAS results predict a couling rate

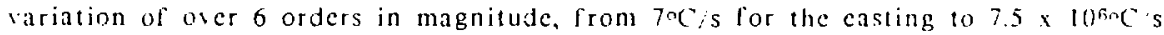
for the highest speed melt. The secondary DAS prediction of the cooling rate confirns these values for the low cooling rate melts.

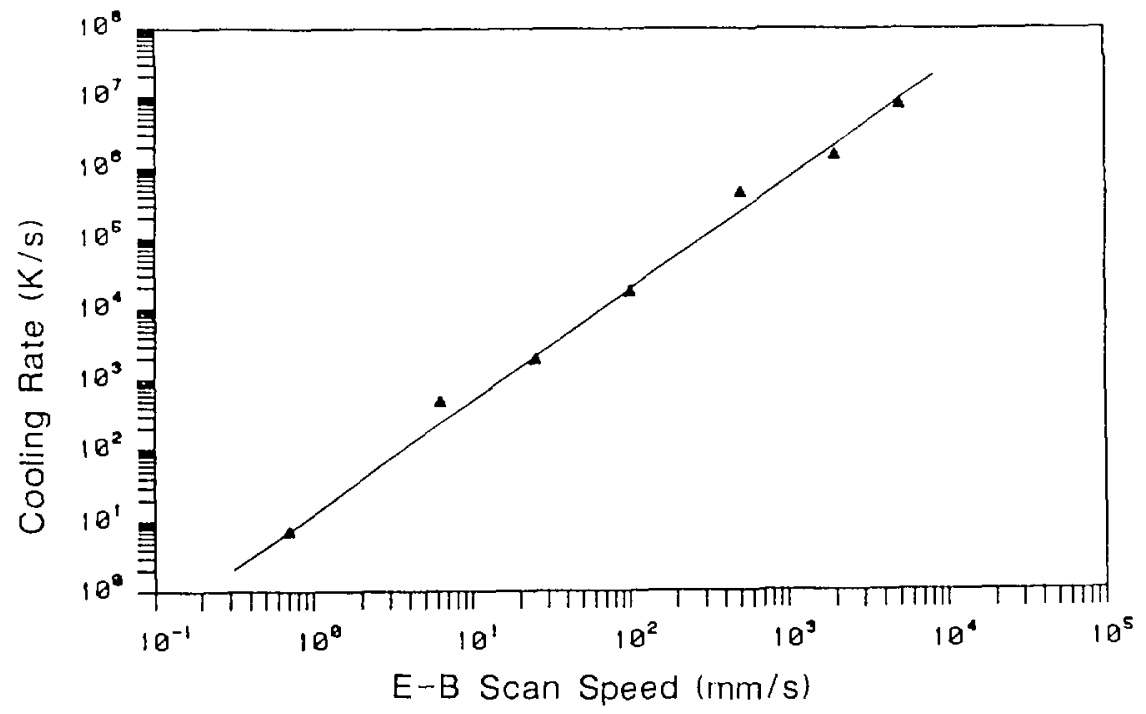

Figure 4.3 cooling rate, based on dendritc arm spacing measurements, plotted versus the electron beam scan specd. 


\subsection{Analytic Solution to the Heat Flow Equation}

\subsubsection{The Temperature Distribution Surrounding a ilet}

Inc theory of heat flow due to a mosing print source bas fiest examined and applied tu weles by Rosenthat in 1946 [4.6]. Since then. other investigators hase

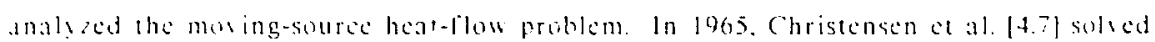
the protem ung dimensionless sarables which allowes a large spectrum of siluations and materials w he compared. In 1983. Fagar and Tsai [4.8) replaced the print ande asumption $1 \mathrm{jth}$ a distributed heat sourec and soled the problem ly a numerisal procidure. In this scotion. Rosenthal's approach will be used to calculate the comperature distribution in the solid plate sines it allows an analytic solution to De dewad fut the colling rate. Foperiments has shown that the isotherms in the 1.an melal whith surround the heat souree soon become constant in the mosing liame uf reterence 1 has condition is called quasi-stationars heat low and the mathematial formulation used hy Rosenthat incorporates this assumption. Sereral other

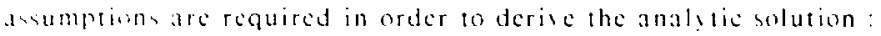

1 Ihe material propertics are independent al temperature and ato material is soncidered homogencous and isotropic.

2 Ihe heat souree strength is constant and is concentrated at a point.

i lhe travel speed is constant and there is no heat loss at the boundaries.

Ihe cyuations are formulated with the heat sours mosing at tratel apect $S$ in the postive a direstom as indicaled in Fig. 4.4. The heat low equation is writen for 4uastationam conditions in three dimensions with the sourec at the origin and by replating the $x$ coordinate with $:=x-10$ aceount for the mosing sourec:

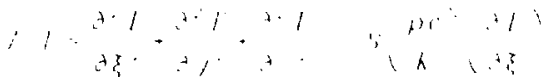

Ihe nomenclature used in this chapter is summarized in lahte 42 .

The solution to this diflerential cquation assumes that the base plate is semi-inlinite and that the heat flow is three dimensional. These conditions most accuratels approximate the high travel specd surlace-melts because of their shallow depth of penctration. 
The boundars conditon for this assumption hesomes $\because$ "aprobabes as a

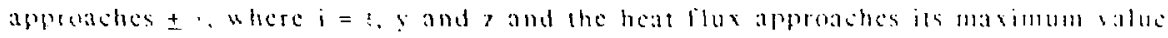

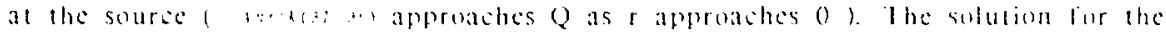
comperature distrihution in the solid then becomes $|+.0|$ :

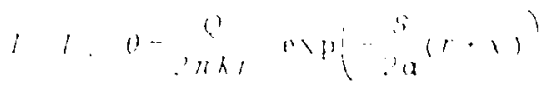

"here : has fecn replated $b_{3}$ a in the cxponential term and thus the temperature distritulion is assumed to be mate in the mosing liame of reference for an obsemer stuated at the urgin. The form of equation t.3 predists a shewed temperatuse destribution which has an infinite comperature at the source origin. lhe isotherms are compened ahead al the heat souree and expanded hehind the heat sourse and thes distributun is related the material properties as well as the heat sourec

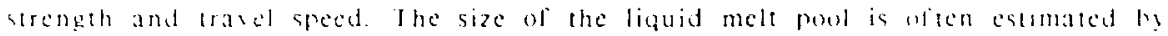

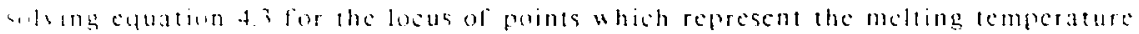

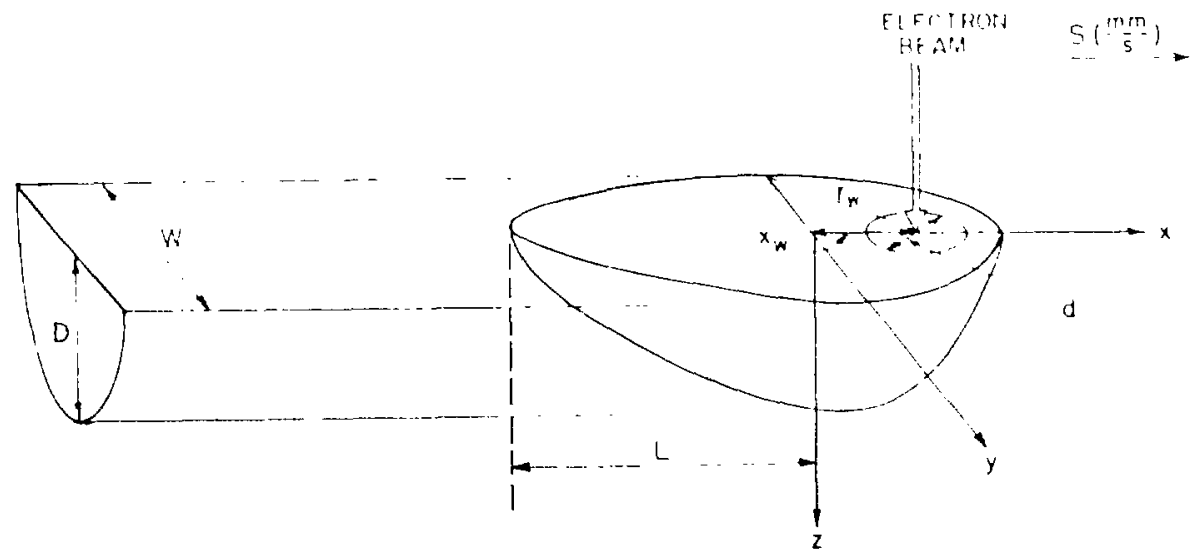

Figure it coordinate system used to represent the electron heam surface melts. 
of the allon. This approach predicts a melt pool which is semi-circular in shane with the depth being equal to one hall the width. In real melts, this "ideal" shape is alered by convection of the liquid in the melt pool.

Table 4.2: Nomenslature used in chapter 4

\begin{tabular}{|c|c|c|}
\hline Symtol & Description & MKS units \\
\hline $\mathrm{T} . \mathrm{T}_{1, \ldots} \mathrm{T}_{1}$ & temperature, ambiert, liquidus & $k$ \\
\hline$=(T-T .)$. & temperature rise & $k$ \\
\hline$n=\left(I_{1,-} I\right)$ & temperature rise & $k$ \\
\hline . & cooling rate & $k s$ \\
\hline t. $\quad !$ & time, tinc increment & s \\
\hline 1 & dendritc arm spating & $m m$ \\
\hline $1, n$ & DAS constants & - \\
\hline$d$ & clectron beam diameicr & $\mathrm{mm}$ \\
\hline 1 & velocity of the L $S$ intertace & - \\
\hline$r$ & radial coordinatc & $m m$ \\
\hline 3.2 & orthogonal coordinates & $\mathrm{mm}$ \\
\hline$x_{n} r_{n}$ & coordinates on melt isotherm & $m m$ \\
\hline$x_{*}$ & valuc of $x$ at max melt width & $m m$ \\
\hline$\tau^{*}$ & alue of $r$ at max. melt width & $\mathrm{mm}$ \\
\hline$=1-11$ & x-coordinate transtormation & mum \\
\hline 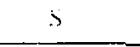 & Selocity of the heat sour e & $\mathrm{mm} s$ \\
\hline$\because$ & unit vestor normal wo weld rool & $\cdot$ \\
\hline 1 & unit vector in the $x$ directio, & - \\
\hline ; & density & $\mathrm{hg} \mathrm{m}^{3}$ \\
\hline$\therefore$ & heat capacit! & $\mathbf{J} k \mathrm{~g}-\mathrm{k}$ \\
\hline$k$ & thermal conductivity & $M m-k$ \\
\hline h & cliective thermal conductisity & W $m-k$ \\
\hline ir & thermal diffusivit! & $m^{2 i s}$ \\
\hline$Q$ & rate of heat input & $J s$ \\
\hline
\end{tabular}




\subsubsection{Derivation of an Analytic Expression for the Cooling Rate}

Fquation t.3 represents the instantaneous temperature distribution in the plate with the soure at the origin. At the next instant in time, the temperature at each point in the plate thanges because the soure has moved an amount 1 . This change in comperature sauses a cooling or a heating eflect at cach point in the plate. For a given material and heat sourec strength, the sooling rate is therefore dependent on how rapidl! the soures moves atross the surtace of the plate. In trpendix an analtic expresion is derisd which represents the cooling rate at an! point in the plate. This expression is described in the following paragraphs and is used wo

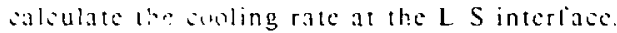

The colling rate at an! point in the base metal is defined as the shange in tempsature wh respes to time and is dimensionally equisalent to the produst of a temperature gradient and a velocity. For the heat sourse moning in the positise $x$ diretion at a sustant specd. S. the cooling rase at a given point heomes:

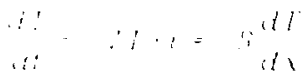

Iherefore, the woling rate san be calculated as the product of the temperature gradent in the $x$ direstion and the tratci speed.

Starting with the equation which represents the temperature distritution in the platc. ca. t3. an cxpression for the cooling rate san be dericed which is alid at an! point in the base plate:

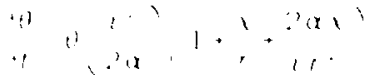

where. is delined as the local temperature rise and represents the velacits at the I $S$ intertace However, to mahe correlations with the dendrite arm spacing measurements, only the cooling rate at the liquid solid intertace is of interest. The temperation at the interlaee is Jefined by the liquidus temperature of the allon. TL. and at this location, $" r$ and $x$ are replaced $h y$ "m. $r_{m}$ and $x_{m}$ respecildely. The expression for the cooling rate in the solid at the liguid solid intertace is therelore:

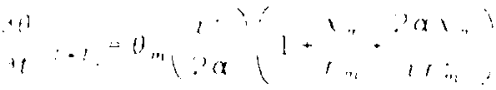




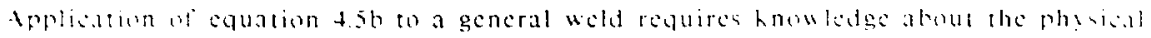

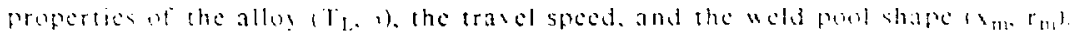

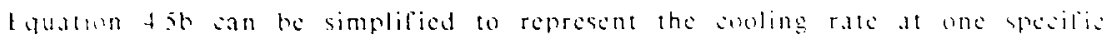

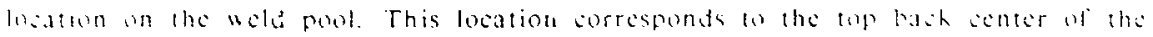

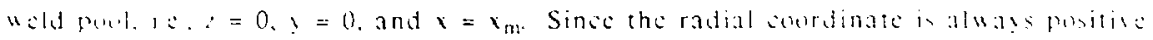

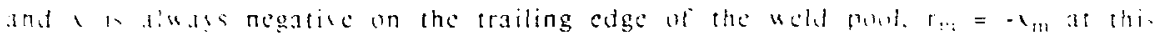

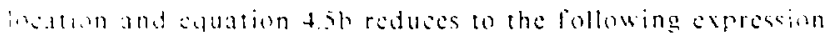

\section{$\because 1$}

1

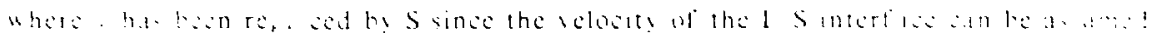

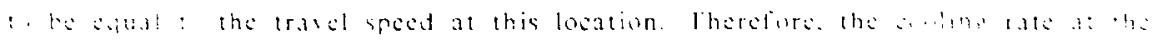

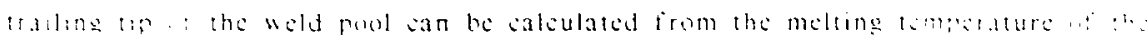

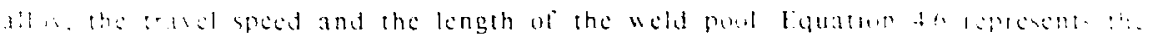

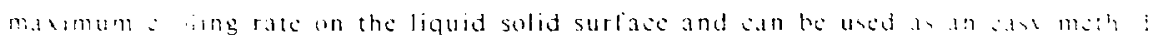

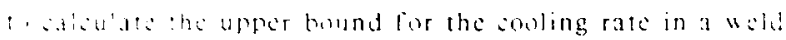

\section{$4.3^{2} .^{2}$ lintimating the cooling Rate in the I.iquid Pool}

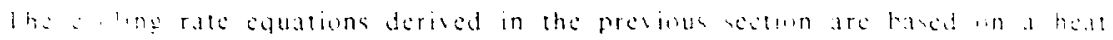

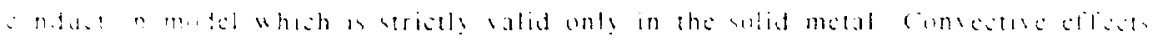

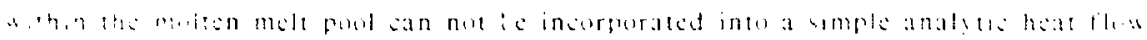

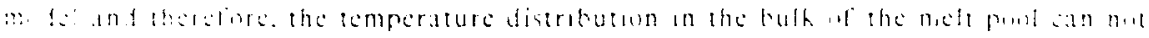

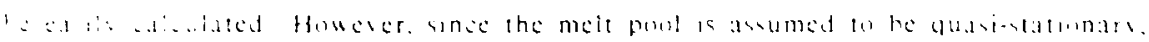

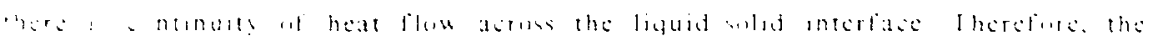

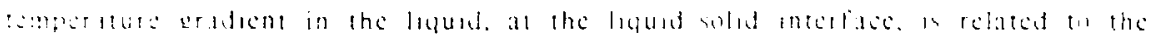

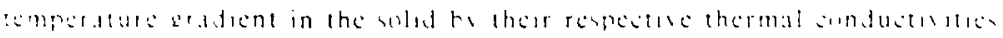

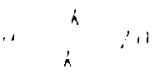

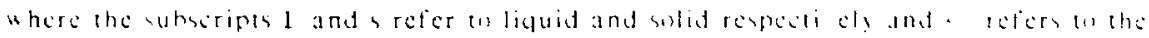

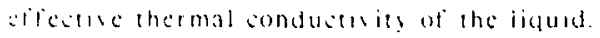




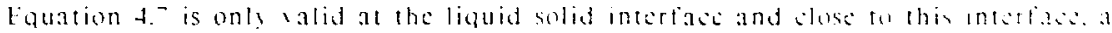

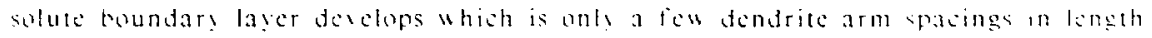

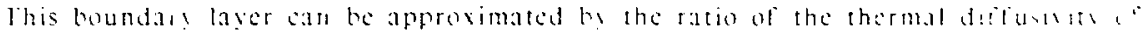

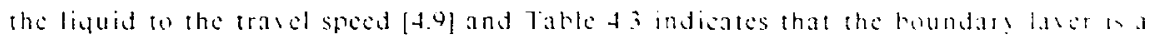

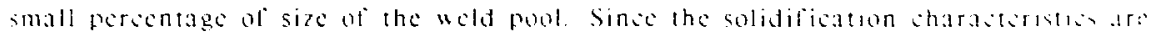

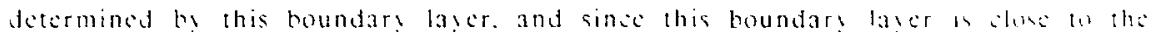

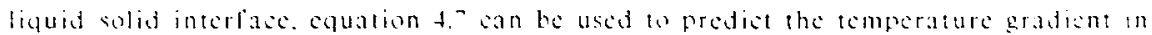

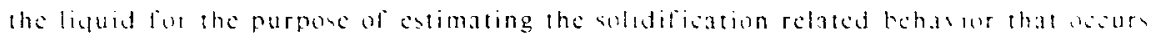

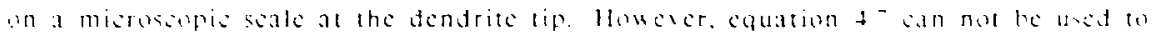

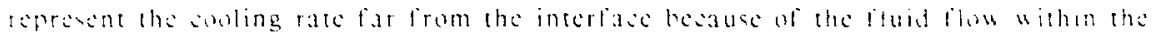
$u=i j$

lablet; $r_{t}$ and for the velectron beam melts

\begin{tabular}{|c|c|c|c|c|c|c|}
\hline$M: !$ & $\begin{array}{l}\text { Iracl } \\
\text { Specd } \\
\text { mans } 1 \text { l }\end{array}$ & $\begin{array}{l}\text { - Pluid } \\
\text { Pclusit! } \\
\text { lmm sl }\end{array}$ & $\begin{array}{c}1 \\
1 \mathrm{~mm})\end{array}$ & $\mathrm{P}_{\mathrm{t}}$ & $\begin{array}{c}\therefore \\
140\end{array}$ & ; \\
\hline $\begin{array}{l}1 \mathrm{HOF} \\
\text { rint }\end{array}$ & $\begin{array}{l}0.3 \\
0.3\end{array}$ & $\begin{array}{l}1.500 \\
375\end{array}$ & $\begin{array}{l}20 \\
05\end{array}$ & $\begin{array}{c}1 .: 00 \\
80\end{array}$ & $\begin{array}{l}1.500 \\
1.500\end{array}$ & $\begin{array}{l}: 5 \\
15\end{array}$ \\
\hline $\begin{aligned}= & (1, p) \\
& \ldots \ldots+1\end{aligned}$ & $\begin{array}{l}25 \\
25\end{array}$ & $\begin{array}{l}-50 \\
388\end{array}$ & $\begin{array}{l}0-5 \\
0 \leq 5\end{array}$ & $\begin{array}{l}\therefore 30 \\
4\end{array}$ & $\begin{array}{l}4(11) \\
4(1)\end{array}$ & $\begin{array}{l}=11 \\
111\end{array}$ \\
\hline : & 100 & 450 & 00 & $10=$ & 1 (1) & 10 \\
\hline 4 & 500 & 150 & 02 & 12 & 20 & $11:$ \\
\hline 5 & 2.000 & 23 & $0.0 ;$ & 0 & 5 & 05 \\
\hline 0 & 5.000 & 0 & $0 \cap 08$ & 0.024 & $=$ & (1) \\
\hline
\end{tabular}

$\mathrm{P}_{\mathrm{l}}=1 \mathrm{u}$ :L $\mathrm{i}=2.2\left(\mathrm{~mm} \mathrm{~m}^{2} \mathrm{~s}\right)$

$=D_{\mathrm{L}} \vee \cdot D_{\mathrm{L}}=1 \times 10^{-3}\left(\mathrm{~mm}^{2} \mathrm{~s}\right)$ 
The eflective thermal condustisit! of the liquad depends an the rates fi th:

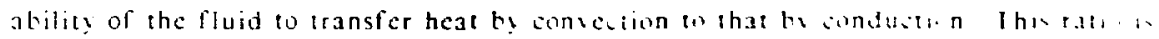
delined by the dimensionless thermal Peclet number. $P$,

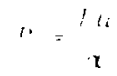

where $u$ is the fluid elocits. L is the distance from the sold intertas. and, 1 it: thermal diffusilts. For small Peclet numbers. Ennduction will r: mire impursint

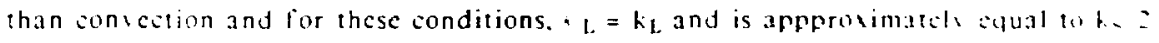
[4.10]. For large Petel numbers, contcetion will te more important than andust a and, $L$ will increase with $P_{t}$. Measurcments of * for high Pselst number ar:

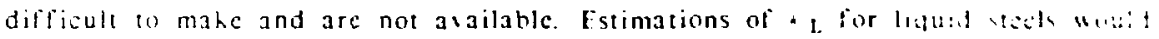

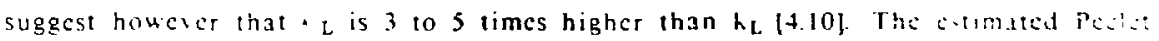
number. liquid diftusion boundary layer thichness and effectice thermal : ndu:tu: : of the liquid are shown in Table 4.3 for the six travel spees wed in th: insestigation.

Fsimations of the fluid velocity were made by assuming Marangane druen flis

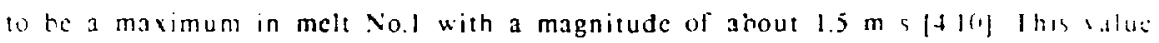
was assumed to decreasc in proportion to $\mathrm{L}$ as the travel specd increased and $P_{1}$ "a calculated from the estimated fluid velocity. Pt was then used to estimate the effective thermal conduetivity in the liquid.

Combining equations 4.5 and 4.7 gives an cxpression for the cooling rate in the liquid at the melt isotherm:

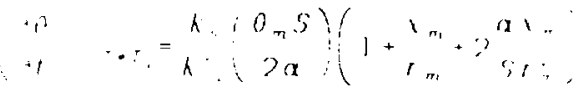

For the highest cooling rate portion of the liquid. at the top tach enter of the melt pool $x=x_{m} .:=0$. and $z=0$, cquation 1.9 simplifics to the follouing:

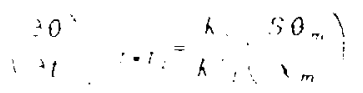

The physical properties for typical austentic stanless stects are listed in Talle 4.4 and indicate that the ratio of thermal conductivies between the colat and the liquid is a factor of 2 . The average length of the meles $\left(x_{m}\right)$ was measured isee 
sectoon 2.2.21 and is listed in Iate 4.4 . With the alose balues. and arumang the anbient temperature to be $250 \mathrm{C}$. the mavimum cooling rate in the molt wa :aleulated using equation 4.10. The results of these cakulations are summarized in

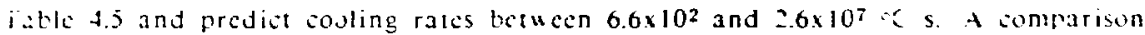
of thesc data with the DAS predictions is presented in scction 4.4.

Table 4.4: Phisical propertics for stainless steel

\begin{tabular}{|c|c|}
\hline $\begin{array}{l}\text { Vtatcrial } \\
\text { Propers! }\end{array}$ & Value \\
\hline$h_{s}$ & $18(11 \mathrm{~m}-\mathrm{k})$ \\
\hline 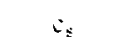 & $500(\mathrm{~J} \mathrm{~kg}-\mathrm{k})$ \\
\hline 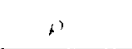 & $7,900(\mathrm{~kg} \mathrm{~m} 3)$ \\
\hline is & $4.6 \times 10-6\left(\mathrm{~m}^{2} \mathrm{~s}\right)$ \\
\hline$h_{I}$ & $-1 \geq k_{s}$ \\
\hline$\dot{L}_{L}$ & $-\therefore$ \\
\hline$\therefore$ & $\rho_{s}$ \\
\hline ir & $1 / 2 a_{3}$ \\
\hline $\mathrm{I}_{\mathrm{L}}$ & $1+40^{\circ} \mathrm{C}$ \\
\hline
\end{tabular}

Table +5: Marimum cooling rate in the liquid at the $L$ 'S intertace.

\begin{tabular}{|c|c|c|}
\hline$H c / t$ & $S$ & $\begin{array}{l}\max \\
(\mathrm{K} s)\end{array}$ \\
\hline 1 & 6.3 & $-6.6 \times 10^{2}$ \\
\hline 2 & 25 & $-3.1 \times 10^{3}$ \\
\hline 3 & 100 & $-2.8 \times 10^{4}$ \\
\hline 4 & 500 & $-7.1 \times 10^{5}$ \\
\hline 5 & 2.000 & $-7.1 \times 10^{5}$ \\
\hline 0 & 5.000 & $-2.6 \times 10^{7}$ \\
\hline
\end{tabular}




\subsection{Finite Element Model}

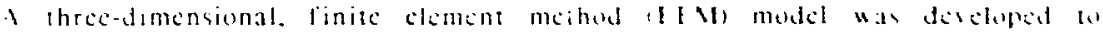
alculate the temperature distribution in the solsd surrounding the molten and Ints data was then wed to saliualec the evoling rate in the mele at the ligutd suld intertace. The fro model utilizes the three-dimensanal shape of the nele pow a a

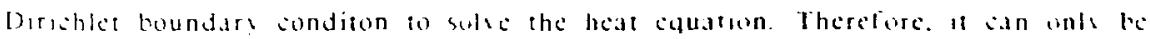

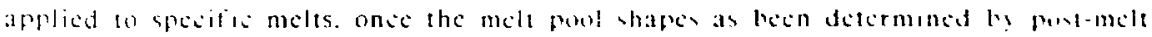
metallographic andysis. Results from this model were used to conturm the ambng

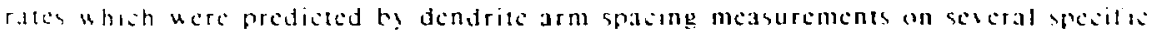
nite. The FEM program also gate informaton about the temperature gradient at the loputa soldd intertace as uell as showing the distribution of corleng rates and Iemperature gradients around the surface of the I S interlace.

\section{4.t.1 Assumptions and Boundary Conditions}

The model is lormulated by assuming quasi-btationar? "clding conditions whith imply that the weld pool shape does not bary with time. The base nuctal plate is assumed large compared to the weld. Which is a realistic assumption for the high tratel upees welds. This assumplion allows the problem to be solved bi treating the plate ciges to he insulated and at a constant (ambient) temperature. Radiation heat loss from the lep surlace of the plate is assumed to be small and the material properies. Table 4.4 , are assumed to be independent of temperature. Ihe problem therefore becomes one of he t conduction. whese the heat from the sourec is distributed into anc solid base mel.. plate through the iriegularls shaped lacuid solid

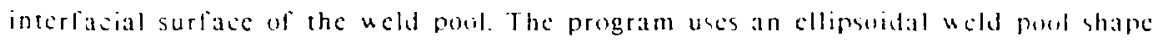
assumption which is reasonahte for shallow nenctrating schls but an rat be wed w represent decp penetrating uelds because of their heshoie appearanec.

The FEM program requires a threedimensional mesh to represent the hase metal

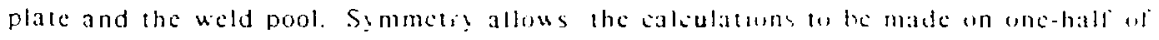
the plate uhich simpities the calculations. Figure 4.5 a show the damensions af the base plate. the location of the weld pow and the cusudinate sobem which "as used 
for the coliculathons. I tyute a

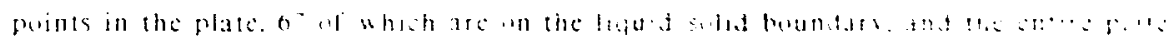
Entains 08 (4) ictahedral ciancuts

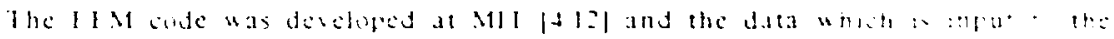

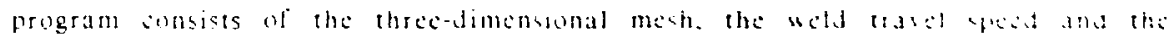

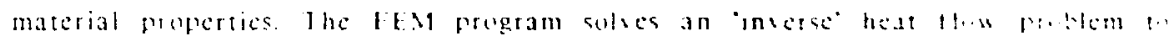

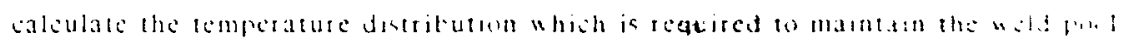
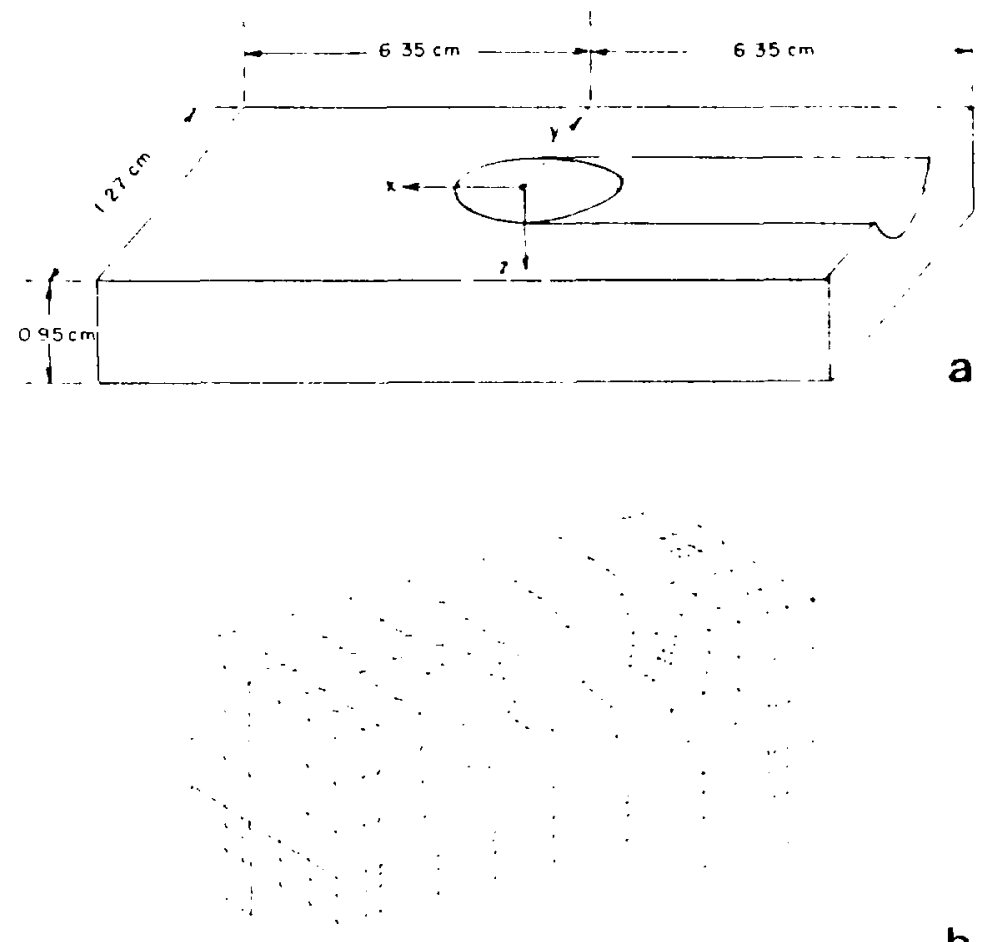

b

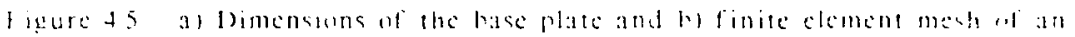

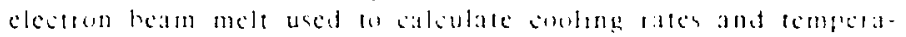
ture gradients at the melt porl boundar? 
boundar! at its liquidus temperature From this temperature destrbution. the program saliubles the temperature gradient in the solid. . In a diretion which is normal to the liquid solid interlace for eath nodal point on the weld boundars. Iho produc of this temperature gradicnt and the sclecits at the weld boundary gives the cooling rate at the boundar! in the solid:

$$
1+1 \cdot 1=i+1(1,1)
$$

where the unit vector is normal to the liquid solid interface and the unit vertor is in the positive $x$ dircstion The sooling rate in the liquid san be caliulated by the ratio of the thermal conductisitics as diseussed in the prececting scction :

$$
1=-\frac{h}{h} \quad \therefore \quad(1 \cdot n)
$$

The output from the prostram consists of the lemperature gradient and the cooling rate at cach of the nodal points on the weld isotherm. The typical mesh contained betuecn 30 and 40 points on the solidifying portion of the seld pool.

\subsubsection{Temperature Gradient and Cooling Rate Calculations}

The intent of the FEM program was to calculate the cooling rate of the clectron beam melts examined in this study. However, the non-uniform eross sectional shapes of the lou specd melts and the highls clongated shapes of the high spect melts did not allow the six electron beam melts to be easily modeled. Therefore. Iwo additional melts werc made on 304 stainless stecl to determinc the distribution and magnitude of the cooling rates and tempcrature gradicuts for thpical clectron beam melts. Table 4.6 lists the clectron beam parameters that were selectet to moduce cllipsoidal shaped melt-pools that could be modeled. The dimensiuns at the weld pools. as decermined by metallographic analssis are also reported in this Iahle. Ihece data and the physical property data from Table 4.3 were ifinut to the 11.1 program to calculate the temperature gradient in the solid. Ts. the cosine betucen the nurmal to the melt pool and the trasel specd direction. $X$. and the sociling rate in the ligutd. s. at each boundary nodal point on the solidilying hall of the melt fool. The results of the calculations are listed in Tables B.I and B.2 in Appendix H lor tinc couling rate and tempcrature gradicnt at the liquid sulid interface. 
Table to: Hetding parameters, phesical domensiuns and mesh propertos

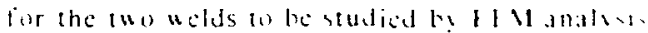

\begin{tabular}{|c|c|c|}
\hline Paramcise & 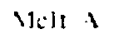 & $11: 41$ \\
\hline specd $1 \mathrm{~mm}$ il & 6.4 & 254 \\
\hline surrent $(m-1)$ & 30 & 30 \\
\hline whtage (ht) & 100 & 1010 \\
\hline length (mm) & 1.29 & 152 \\
\hline depth $1 \mathrm{~nm}$ & 1.19 & 0.58 \\
\hline wath (mm) & 2.39 & $1.1^{-}$ \\
\hline
\end{tabular}

\section{Cooling Rater}

Tigure tha and tha shew 'topographical projesions of the couling rate in the liquid at the liquid solid intertate on to the $x=0$ eross-section of each molt. Ihe colling rate in the liquid was cakulated from the couling rate in the solid using cyuation t.l1 while the data outside the melt pool was ignored constant couling rate conlours are ploted through the data and it is elear that the cowling rate increases firom 0 un the melt periphery to a maximum at the cop enter al the melt. The comburs represent the general cllipsoidal shape of the melt and anc an sec that there are no suditon shanges in the cooling ratc throughout the cross section. An orthograptic representation of the cobling rate in threc dimensions is atso shom in Appendia $B$ and is an cliestis moans of illusarating the distribution cil culing rates around the melt peol interface. The influcnec of trasel specel on the cunling rafe can be determoned by compuring the melis made at $6.4 \mathrm{~mm}$ s and $25.4 \mathrm{~mm}$ s. Ihis

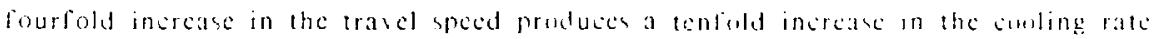
and reduces the size of the molten zone by a lacker of ahout ous.

To show that the cooling rate approahes ero on the mele periphert. the lustation wi the melt periphers nust be mathematioally determined and then indered imtu

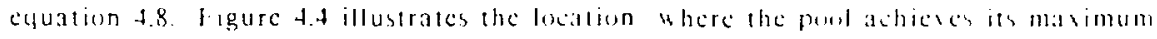




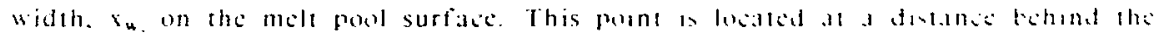

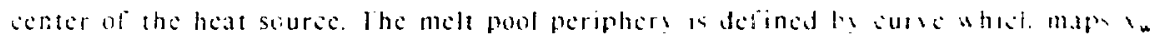

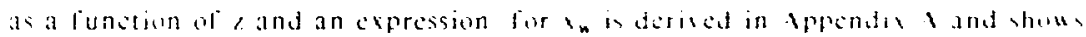

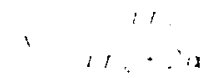

"here $r_{n}$ is felincd as the radius at the masimum widto:

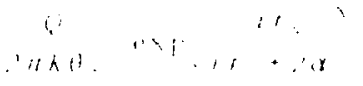

In order w deternine su cquation 4.14 must be soled for $r_{n}$ le a trall and error

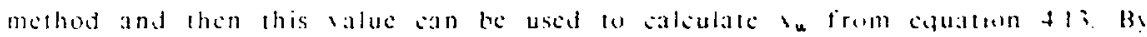

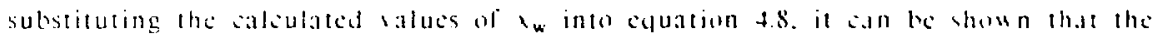
smoling rate approsthes zero on the melt periphery.

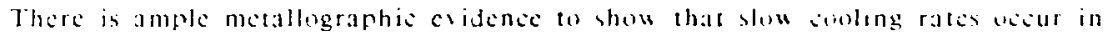
the region slies to the melt periphery. Figure fila shows the merontructure af a

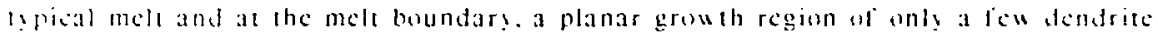
arm spocings wide exists: eclls ar dendrites form throughout the remander at the

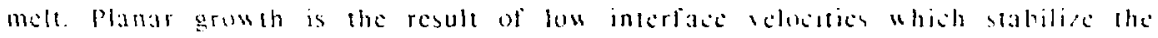
liquis: solud incoliace and onsequenth are assosiated wh lou sobling rates.

\section{Temperature Girallients}

lemperature gradiont salculations are also listed in lables B.l and 4 : an the

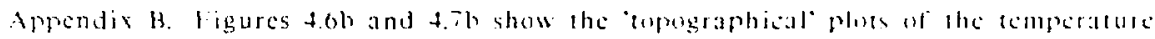

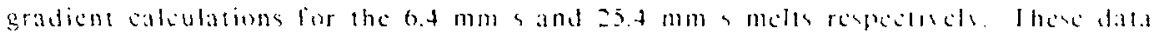

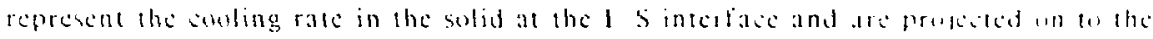

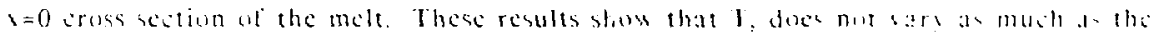

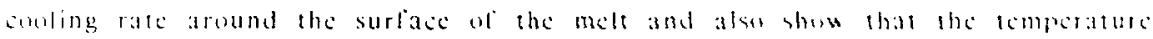

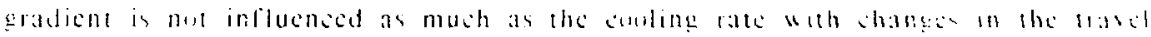

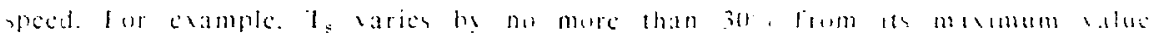

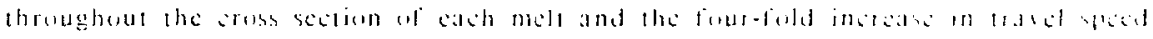

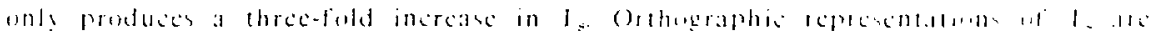

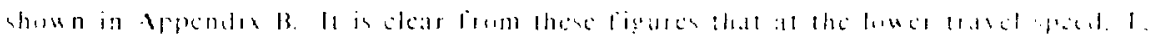




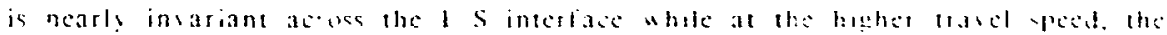

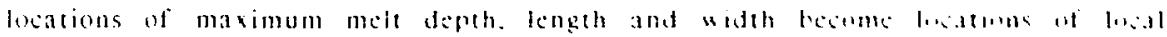
maximums in -1 s.

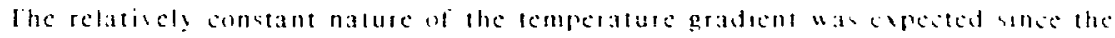

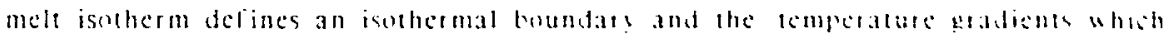

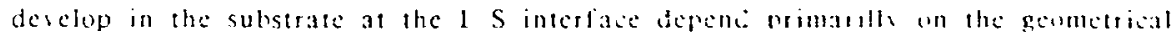
shape of the meli. I äathons of smalt radius olf aurature allow for more divergense of heat flow and are assobated with higher temperature gradicnts but sille the shape

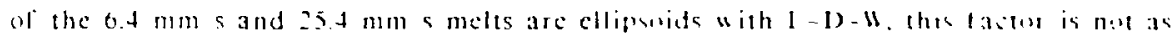
pronounced as it might be in decp penctuating sectron feam welds that hase a

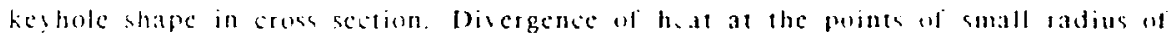

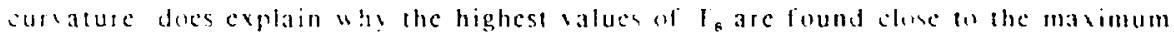
melt depth. width and length locations. At these points, the :adius of curbature is

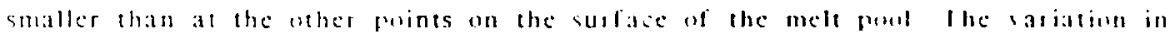
temperature grabient was shoun to be mose exteme for the higher spect melt which an he caplained by the smaller shape of the highe epeed melt. Ieading lo smoller ratif of survature.

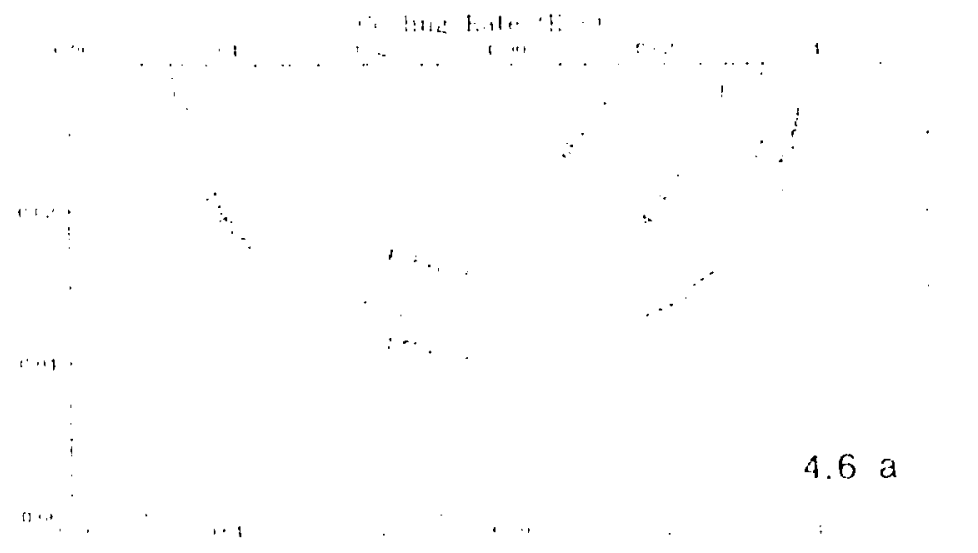

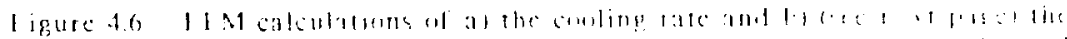

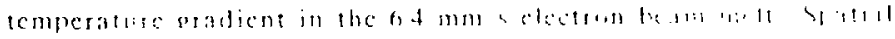
enordinater are in mines 

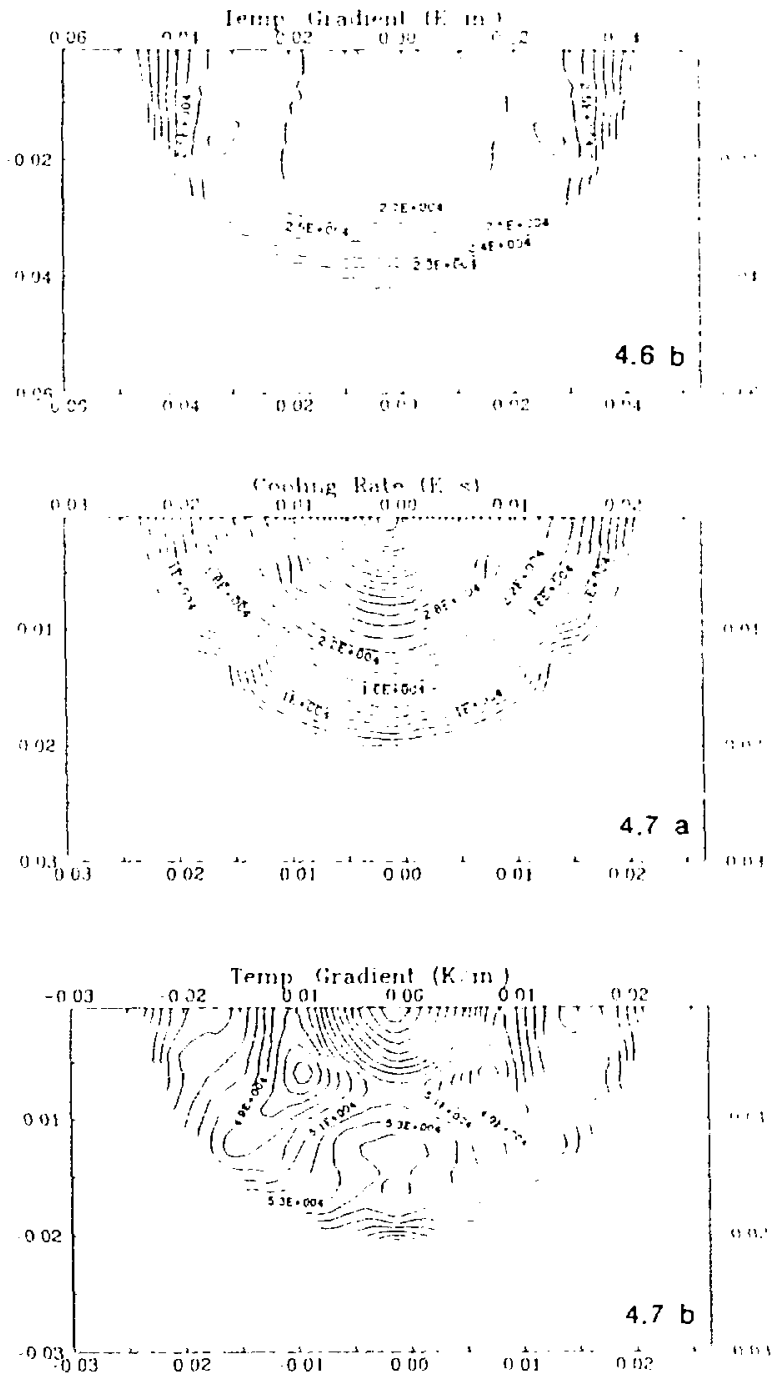

Figure 4.7 FEM calculations of a) the coolirg rate and b) the temperaturc gradient in the $25.4 \mathrm{~mm} / \mathrm{s}$ electron beam melt. Spatial coordinates are in inches. 


\subsection{Comparison of the Mlodels and Summary}

The major furpose of the heat flow modeling was lo prowde cudente wupport the use of dendrice arm spacing measurements to cstimate the sulting rate wi the the

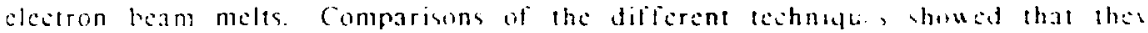

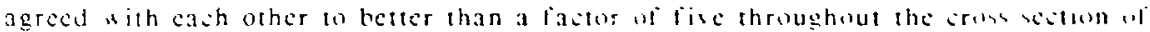

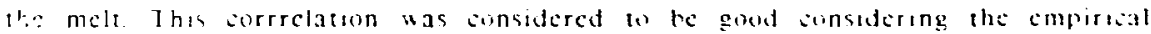
nature of the Dets. catimatios ard the sarous approumation that were made in the heat flus minds.

Figure 48 indicates 5 nodal points along the ecnter line of the $254 \mathrm{~mm}$ melt on

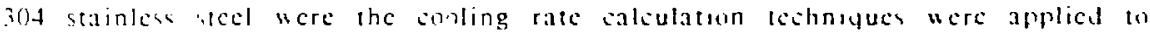
direstls sompare the threc methols. The result listed in Table 4 - show that the I t model and I tS estinations of the couling rate agrec reasonabls well with cash other throughout the melt. howerer. the Frst program appears to gae higher soling rates in genctal.

1a:le $4^{-}$: Comparison of the FEll and DAS cstimations wi the cooling rate in the liquid at the fise moints indisated in Fig. 4.7.

\begin{tabular}{|c|c|c|c|c|c|}
\hline \multirow{2}{*}{ Point } & \multirow{2}{*}{$\begin{array}{c}7 \\
(\mathrm{~mm})\end{array}$} & \multirow{2}{*}{$\begin{array}{c}\mathrm{T}_{\mathrm{s}} \\
(\mathrm{K} \mathrm{mm})\end{array}$} & \multicolumn{3}{|c|}{$1 \quad(k, \cdots)$} \\
\hline & & & FI:II & $D A S$ & Analytic \\
\hline 1 & 0 & $24 \times 10^{3}$ & $-6.1 \times 10^{4}$ & $=2.4 \times 10^{4}$ & $-4.0 \times 10^{4}$ \\
\hline 2 & -1.2 & $=1 \times 10^{3}$ & $-4.1 \times 10^{4}$ & $-1.2 \times 10^{4}$ & - \\
\hline 3 & -3.5 & $1.9 \times 10^{3}$ & $-3.2 \times 104$ & $=2.5 \times 10^{4}$ & - \\
\hline 4 & -4.3 & $2.1 \times 10^{3}$ & $\therefore .4 \times 10^{4}$ & $-5.8 \times 10^{4}$ & - \\
\hline 5 & -5.8 & $24 \times 10^{3}$ & 0 & 0 & 0 \\
\hline
\end{tabular}

This disparity is most likely a result of the melt poul heang modeled by an "ellipsoidal" shape which ts picall! oscrestimates the solidificaton front velust!. and conscquently nercstimates the cooling rate at the cop central portion of the melt pord The analate cxpression presented in cquation 4.9 was alo applicd to this melt. Since this approach predicts the maximum conling raic in the melt. it should poside an upper bound for the other estimations. Table $4^{-}$shows that the anatucexpression 


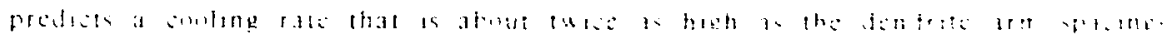

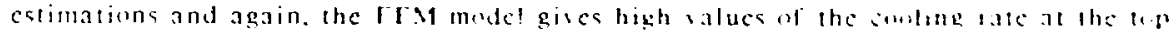
ecnter of the melt for the reasons stated abose.

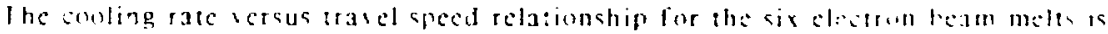

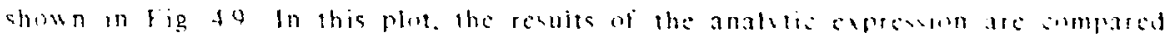
with the tesults from the dendrite arm spacing measurements the analvie

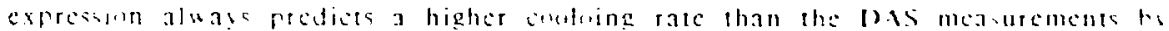

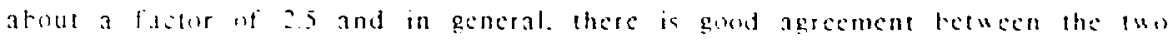
technigues

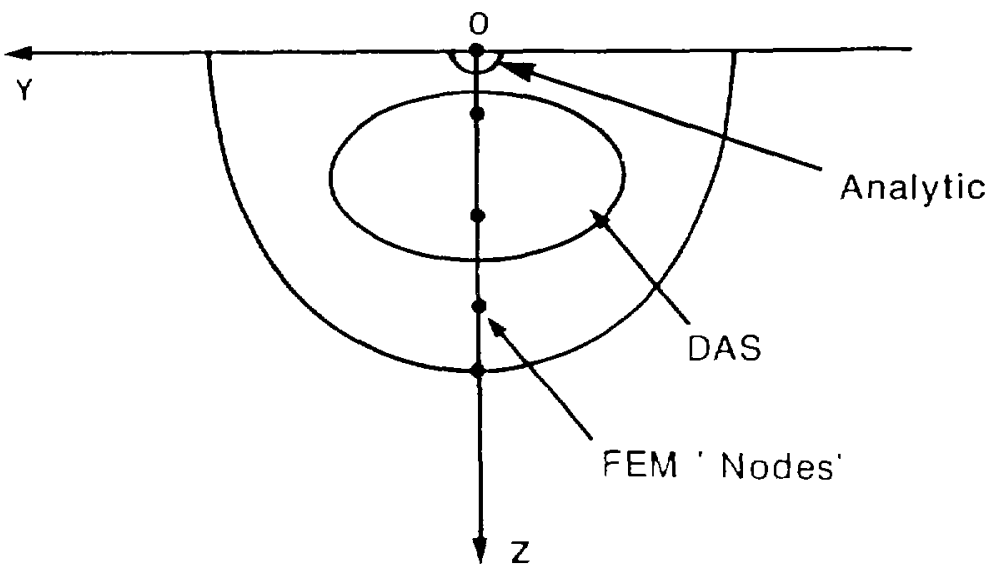

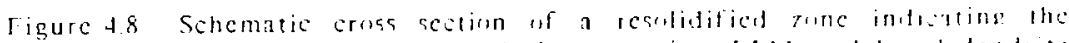

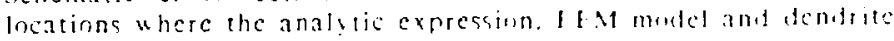
arm spacing measurements aptls. 


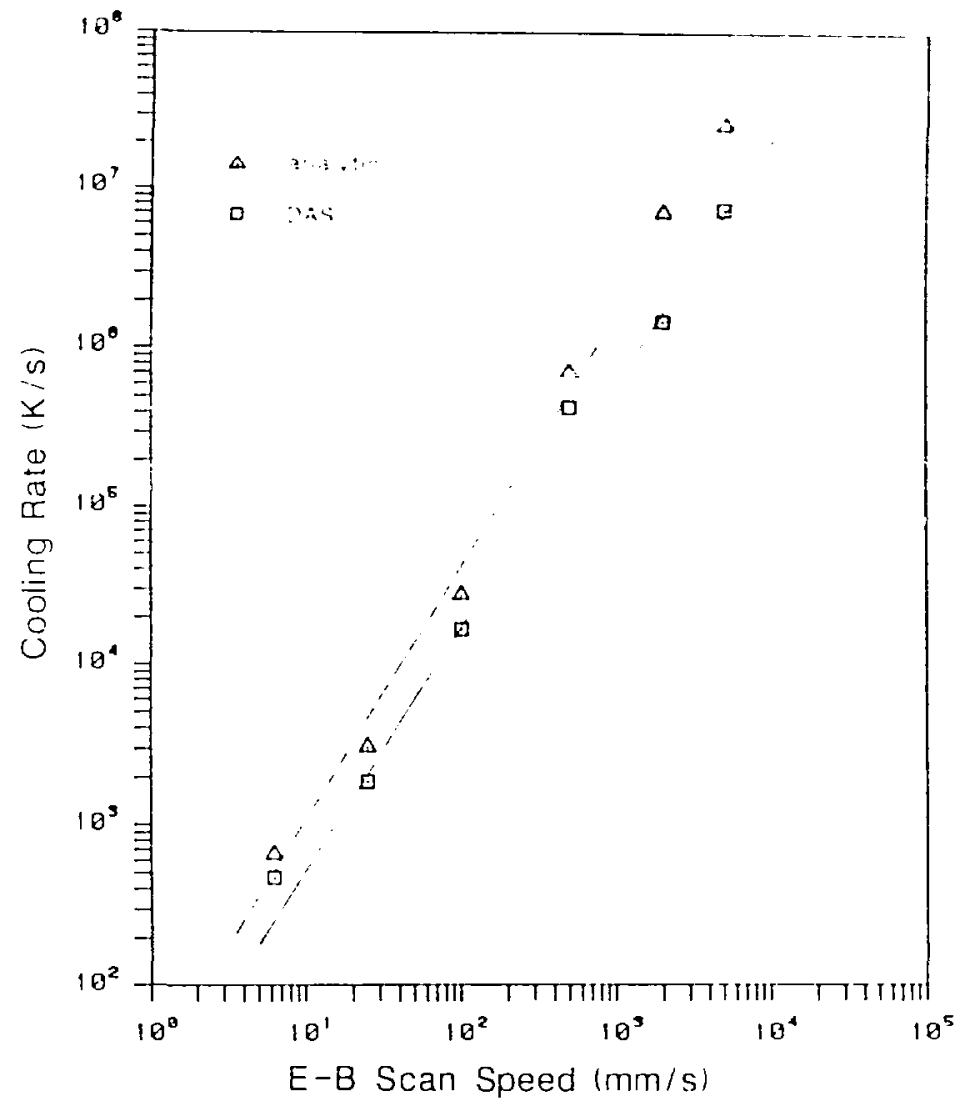

Jigure 49 comparison o! the maximum couling rate piedisted by the analytic equation with the average comeling rate pedseted ha dendrite arm epacing measurements lin the of 1 . $\mathrm{B}$ melts 


\subsection{Conclusions}

1. Dendrite arm spacing stimations of the socling rate shris that the ar: east hution colidilicd at $C$ s and that the stx clestron-teds molt solidifict at rates whish bried betucen $4-102-C$ and $-5 \times 10^{\circ} c^{\circ}$ These measurements are supported by the imeling rate saliulations

2. An anal:tio cupression. eq 4.5b. was derised for resicsent the sinting rat: in the sold at an! fwation on the surtase of the welt This cxpresion san re simplificd to represent the maximum soling rate in the weld ied.

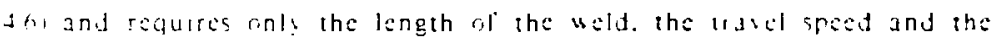
melting icmperature of the allog to be knoun. Similar expressong are derised sed t9 and ca +10 to estimate the soling rate in the liquad at the L 5 initian

$\therefore$ The DAS meaurements and the FEsl Ealeulations show that there is $a$ varation in woling rate within a gisen ucid. The majuit: wi the ariation wesurs close to the melt periphery and the remainder w the weld ants ustain a fastor of about risc.

4. Heat flou zaliulations showed that the high zst cooling rate rizurs at the top senter of the weld pool while the louest cooling rate ozurs at the melt periphery. On the melt perinhers, the cooling rate is zero but rapids: increases uithin a feu dendrite arm spazings of the houndars. SMatlorgraphis obseriations of the microstrusture conftrm these salaulatim:

5. The FEM saliulations shoued that the temperature gradient aried onls atout $30 \%$ around the surface of the melt These alsulaturns also shrued

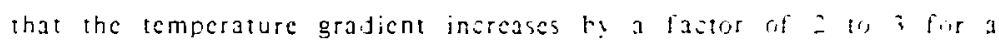
rouriold increase in travel speed. 


\title{
CHAPTER 5
}

\section{The Influence Of Cooling Rate On The Primary Mode of Solidification And Microstructural Morphology}

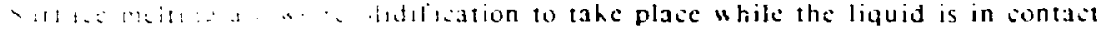

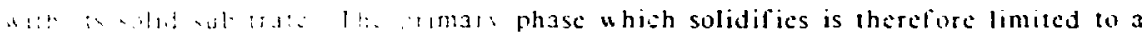

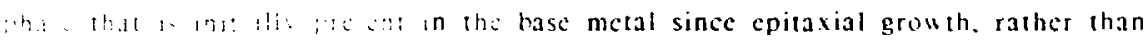

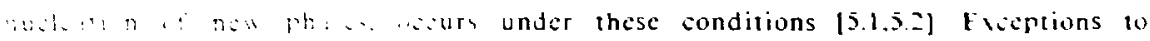

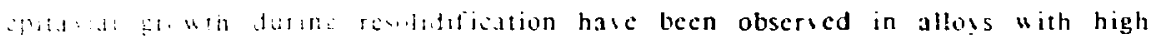

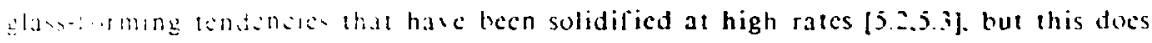
not appoar to be the ease in the Fe-Ni-Cr ternary system.
\end{abstract}

The first section of this chapter insestigates the influence of cooling rate and composition on the primary solidification mode (PSM) through mitrostructural abservations of the clectron beam melts. In duplex staintess stecls. since buth austenite and ferrite are present in the microstructure, cither phase can grow epiturialiy from the substratc. Theretore. the primary solidilieation mode is not governed bs nucleation but instcad. b! the growth kinciis of the two phases. At the m:lt periphery. the tho phases initially compcte. houcuer, onc phase duminates to become the primar: solid phase and its growth hincties depend on the nommal allus composition and the cooling rate.

The second section of this chapter investigates the microstructural morphologics that desclop from cach PSM. The morpholog: of the residual ferrite is largels a result of the ferrite of austenite solid-state transtormation. Howerer. the PSil cstalvishes the microstructure prior to the transiormation and plays an cqualls important role in descloping the resulting microstructure. The principal tactors responsible for the ferrite to austenite transformation are () the as ailabilits of sites for nucleation and growih of austenite which are determined by the solidification conditions. 2) the thermodynamii stability of the ferrite which is determined by its composition and 31 the fime-temperature relationship for the ferrite to austenite phase transformation which is determined by the conling rate of the melt. This chapter investigates cach w thesc factors. qualitatively, through the microstructural examination of the F-B melts. 


\subsection{The Primary Mode of Solidification}

Cbscrvations of the solidification behavior of stainless steck indicatc that austente forms as the primary phase at low Cr Ni ratios and ferrite forms as the primary phase at high $\mathrm{Cr} \mathrm{Ni}$ ratios. At low cooling rates $1<10^{3+2}$ sl. the transition in solidification behavior occurs at a $\mathrm{Cr} N$ ratio of approximately 1.5154 .553 . and the morphology of the primary phase is typically dendritic with well defined sccondars arms. However, at high cooling rates ( $>1040 \mathrm{C}$; $)$, the transition in the primar! solidification mode occurs at higher CriNi ratios. Sigoss uth $\mathrm{Cr} \mathrm{Ni}$ ratiox approaching 2.0 have becn obscricd to suidify entircly as auste: tic in laser leam welds [5.6.5.7], and they solidify in a cellular rather than a dendrits mode. (lihet investigators have observed a change in the solidilication mode linm pramary lerrti to frimary austenite with increasing cooling rate in welds [5.6-5. 3 . "cll $1 \mathrm{~h}$ : inverse behatior, in which the solidification mode thanges from primur austenut: at low cooling rates to primary ferritc at high cooling rates has not ran whersed in uelds but has becn obsersed in rapidly solidificd powders uhtih tinieve lubs thermal underoonlings [5.10].

In this study. the scven Fc-Ni-Cr ternary allogs were suriase melted and resolidificd at cooling rates betwecn 7 and $7.5 \times 10^{6 \circ} \mathrm{C}$ s. The microstrutures of these alloys were studicd using optical and elcetron-optical techniques $n$ ith specti attentiun being given to tha growth of phases from the melt periphers and is compctitis growth within the surface melt. These metrlographic observations ucre used to deselop a cooling ratc versus composition map showing the diticrent reguns of solidification behavior and this diagram can be used to predict the PSM for a uide range of conling raics and nominal alloy compositions.

\subsubsection{Results of the Solidification Experiments}

\subsubsection{Characterizing the Primary Mode of Solidification}

The primary mode of solidification was determincd by optical cramination of metallographic specimens. The polishing and ctching techniques are presented in Chapter 2 and this section describes the microstructural features whict are associated 
with the primary modes of solidification: (A) single phase austenite. (AF) primary austenite with second phase ferrite. (E) cutectic lerrite and cuicelis austenitc. (FA) primary ferrite with second phase austenite and (F) single phase ferrite.

Single phase austenite and single phase ferrite solidification nodes are easils characterized and distinguished from eash ofher. Single phase austenite solidifisation is shown in Fig. 5.1 a and $b$. This mode is dendritic at low cooling ates and scllular at high cooling ratcs. At both low and high cooling rates. compositional iariations saused by microsegregation at the cell boundaries outlines the usually six-sided austenite cells by ctching darker than the interior of the cells. Figure 5.lb shows that the austenite cell houndarics typically etch as darkly as the grain boundarics and the overall appcarance of the microstructure is a regular array of cells appearing as a mesh. Perpendicular to the axis of the eells. the boundaries appear as hexagonal shapes. When sicued at an angle to their axes, the hexagonal shapes become elongated and. in the limit, the cells appear as long parallel laths.

Single phase ferrite solidification is casily detected at high cooling rates when no solid state translormation to austenite has occurred. This microstructure is showt in Fig. 5.2a and illustrates that the ferrite grain boundaries outline the mierostructure. The solidilication substructure is difficult to ctch and. in gencral, is ecllular at high cooling rates and aguciy cellular-dendritic at low cooling rates. The cellular-dendritis microstructure is interrupted by what appears to be sub-grain boundarics throughout the grains. The origin of these non-reguiar shaped boundaries has not becn investigated. At intermediate and low cooling rates, the ferrite undergoes a partial solid state transformation to austenite and is casily characterized by the presence of Widmanstatten austenite which nucleates and grows from the grain boundaries. Figures 5.2 b. c, and d show the microstructures formed by fully ferritic solidification. rollowed by differing amounts of solid statc transformation

The primary austenite with sccond phase ferrite (AF) and primary ferrite with sccond phase austente (FA) modes are casily characterized when the alloy solidifies with a large volume fraction of the primary phase. However, distinguishing between these modes ean be difficult when the amount of the sccond phase is high. The dificulty arises because the primary ferrite dendrites can partially iransform to austenitc as the weld cools, leaving a vermicular microstructure. This microstructure 
is easily confused with the sec ond-phase ferrite that forms during primary austenite solidification and both microstructures have a similar appearance to the cutcotic microstructurc. These modes of solidification can often be discriminated by careful metallographic cxamination to determine if the ferric is present at the cell walls or at the cell cores. Otherwise, the microchemical gradicnts across the ferrite dendrites must be detcrmined by clectron microprobc analysis or by scanning transmission clcctror microscopy [5.11].

A primary austenitc solidified alloy with a small amount of second phase ferritc is shown in Fig. 5.1c at low cooling ratcs and $5.1 d$ at high cooling rates. The microstructure is very much like that of single phase austenite cxcept that ferrite particles are present at the cell boundary triple points and cell walls. Some solid state transformation has occurred, leaving isolated spheres of ferrite at the ecll or dendrite walls.

Figure 5.3 show's the microstructurc of alloys that have solidificd with a large fraction of ferrite and only a small fraction of second phasc austenitc. The ferrite has gone through a significant amount of solit statc transformation from growth of austenite at the dendrite walls. These microstrustures will be discussed later and are casily characterized as being formed from the FA solidification mode.

Figure j.4a and $5.4 \mathrm{~b}$ compare $\mathrm{AF}$ and $\mathrm{FA}$ solidification modes when large amounts of the second phase are present. It is obvious that the ferrite is restricted to the cell walls in the AF mode, Fig. 5.4a, but it is more difficult to characterize the ferrite at the cell cores in the FA mode. The cell walls are more difficult to locate in the FA mode, Fig. $5.4 \mathrm{~b}$, which is of ten a sign of primary ferrite solidification because the ferrite preferentially etches and the cell walls. which are located in the austenite. do not etch. A consequence of the less prominent cell walls is that the FA microstructure has a morc random appearance than the AF solidification mode. particularly at low magnifications.

Alloys that solidify with a volume fraction of the second phasc $c^{\circ}$.yse to $50^{2} / \mathrm{m}$, can exhibit AF, FA and E modes of solidification. Under these conditions, it is possible for the primary mode to change within a given melt. An cxample of this transition is shown in Fig. 5.5a. The alloy is solidifying in an AF mode on the left hand side of the micrograph and in an FA mode on the right hand side of the micrograph. The 
transition takes place approximately at the center of the micrograph. where ferrite at the cell wall becomes ferrite at the cell cores. Similar transitions can be made to and from cutectic solidification and oftentimes it is difficult, if not impossible, to distinguish betucen thesc microstructures.

Figure 5.5 b shows the appearance of the cutectic microstructure formed in Alloy 4 which is a result of simultaneous growth of ferrite and austenite from the liquid. This microstructure forms most readily in alloys with compositions near the line of tuo-fold saturation but may also be present in small amounts in primary phasc austenite or ferrite solidificd alloys. The relative amounts of ferrite and austenite that form during cutcetic solidificaion will later be shown to be about $40 \%$ and $60 \%$ respectively: This condition should lead to a lamellar microstructurc, hovever, $a$ lamellar-type microstructure is not frequently observed. There are two possible reasons for this behavior. A first possibility is that the lamellar microstructure forms during solidification but due to the solic state transformation of ferrite. the final microstructure has becn significantly alter.d. A second possibility is that solidification leads to a divorecd cutcctic or a rod-typc cutcctic microstructurc. . divorced cutectic secms reasonable. particularly at moderately high cooling rates where the secondary dendritic arm spacing is small and prevents the formation of lamellar cutectic. This microstructure would be similar to the intercellular ferrite and interecllular austenite morphologics that solidify with a high volume fraction of the sciond phasc.

The results of the microstructural cxamination of the alloys used in this investigation showed that the PSM can be determined through optical metallographic examination. For the most part, the PSM is casily characterized for alloy compositions that solidify with a large volume fraction of the primary phase. However, alloys that have compositions elose to the line of two-fold saturation can be difficelt to characterize and may be combinations of intercellular ferrite, interecllular austenite or the cutcetic modes of solidification. 


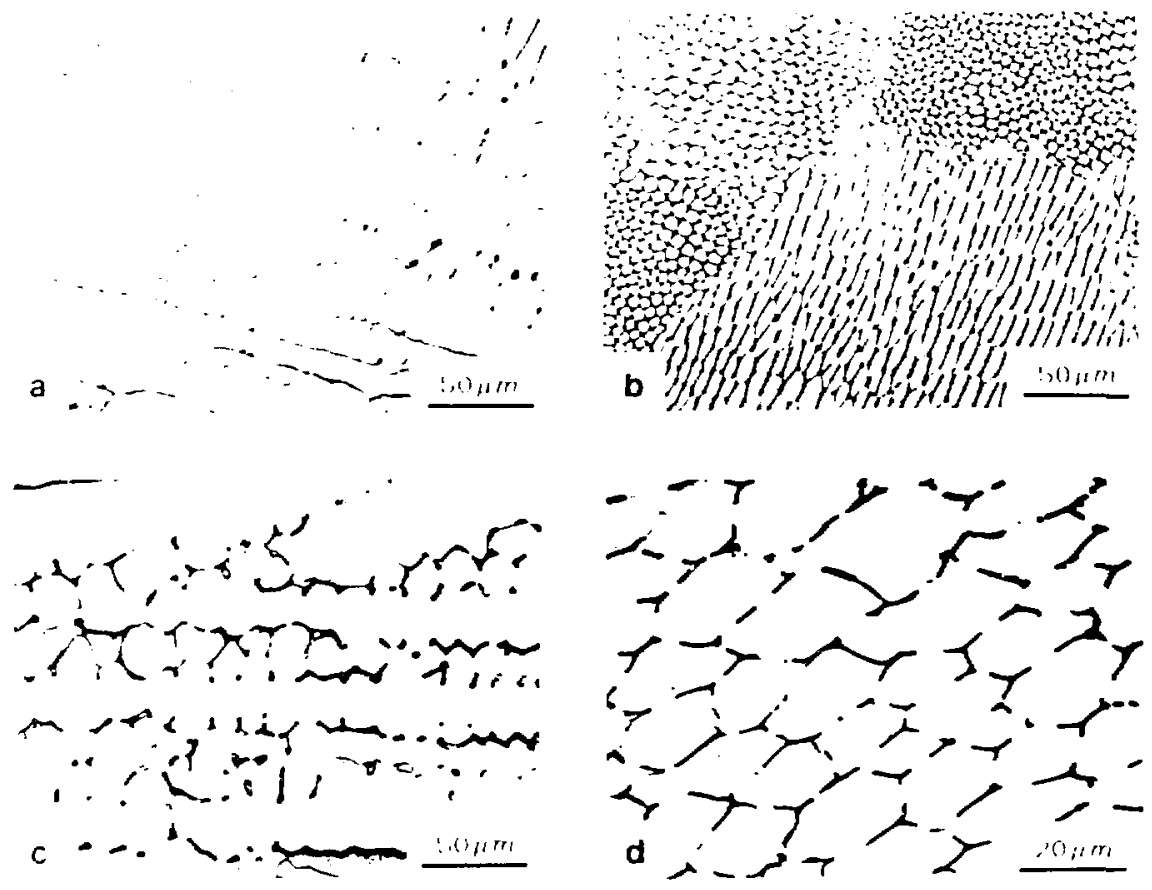

Figure 5.1 Primary austenite solidification mode microstructures. a) Single phase austenite dendrites, b) single phase austenite cells, c) interdendritic ferrite and d) intercellular ferrite. 

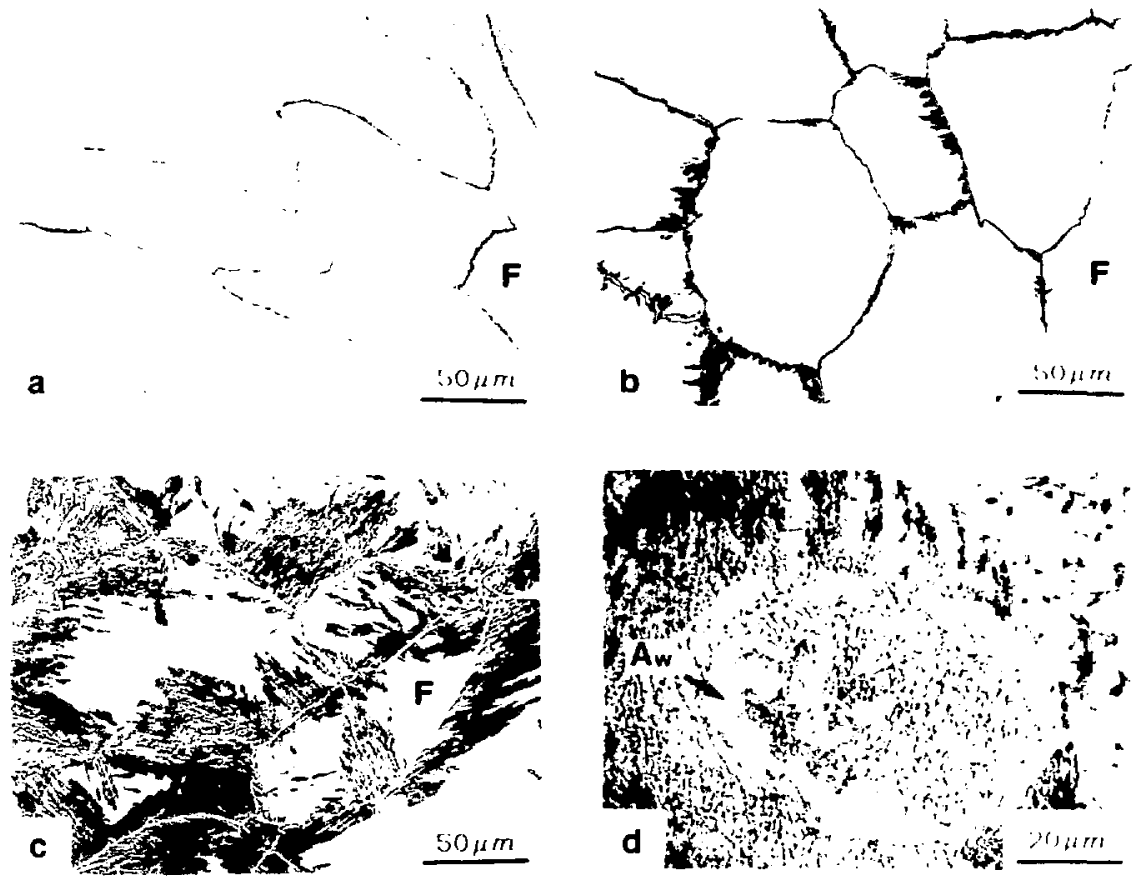

Figure 5.2 Single phase ferrite solidification microstructures. a) Single phase ferrite with no solid-state transformation, b) initial growth of Widmanstatten austenite platelets, c) grain boundary allotriomorpns and Widmanstatten platelets and d) the planar surface of the Viridmanstatten platelets. 

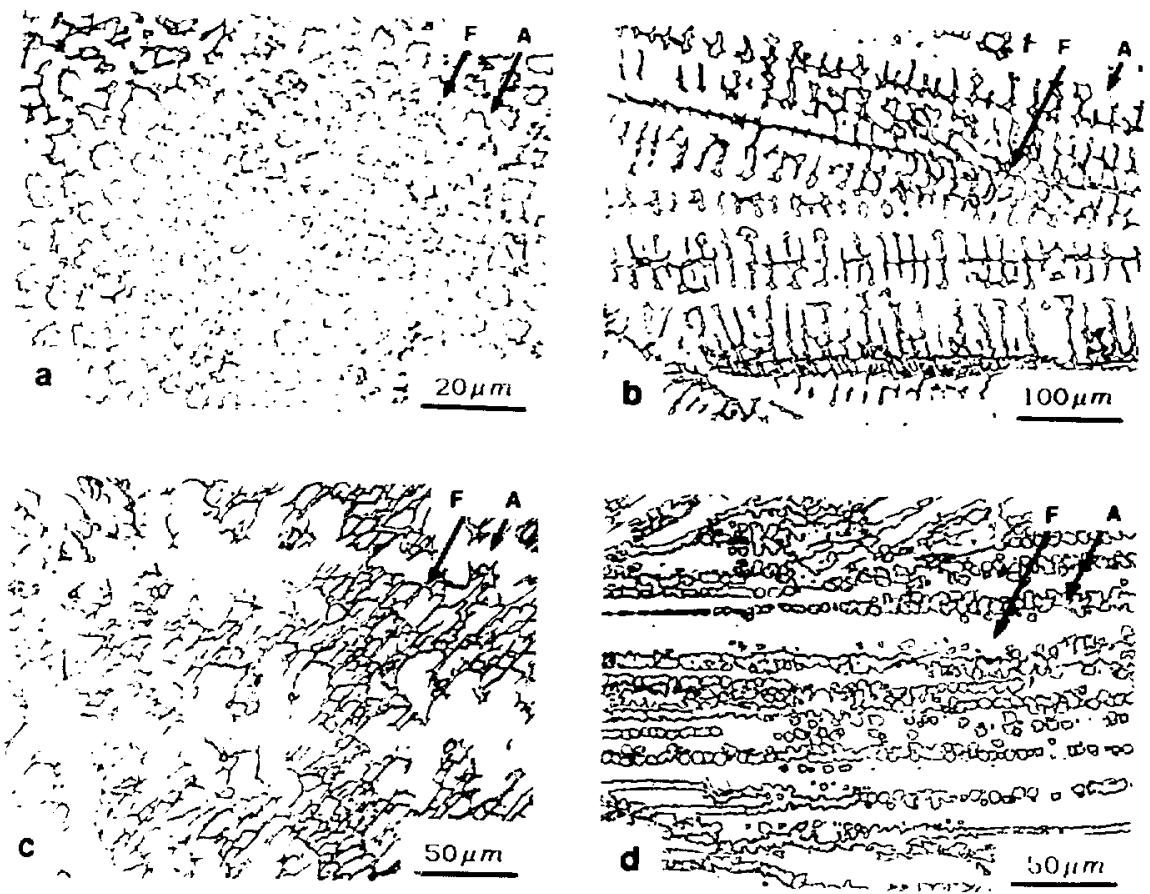

Figure 5.3 Primary ferrite solidification mode microstructures. a) Ferrite located at the cell cores in the intercellular austenite solidification mode, b) vermicular microstructure of ferrite dendrites, c) lacy ferrite and d) blocky austenife. 

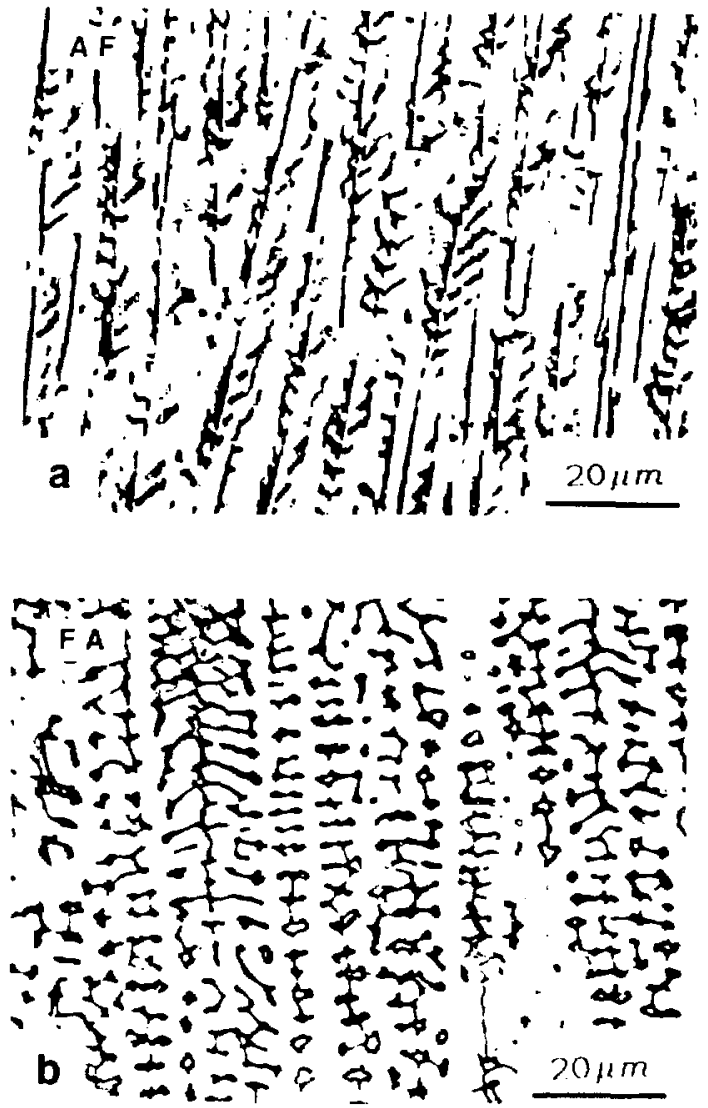

Figure 5.4 Comparison of the microstructures formed by a) primary austenite with second-phase ferrite and b) primary ferrite with second-phase austenite, at equal levels of residual ferrite. 

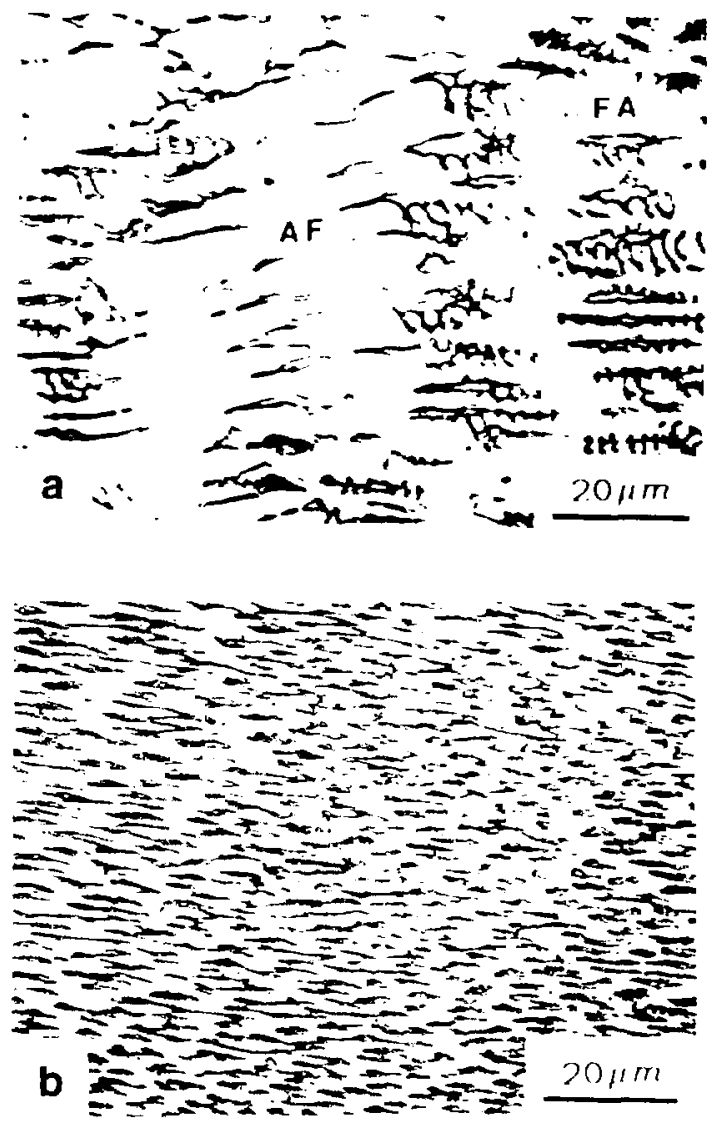

Figure 5.5 a) Transition from the AF mode of solidification in the center of micrograph to the FA mode of solidification on the rhs of the micrograph. Alloy $4,6.3 \mathrm{~mm} / \mathrm{s}$. b) Fine spacing of ferrite platelets formed during the solid state transformation of ferrite. Alloy $5,100 \mathrm{~mm} / \mathrm{s}$. 


\subsubsection{Mapping the PSM as a Function of Cooling Rale and Composition}

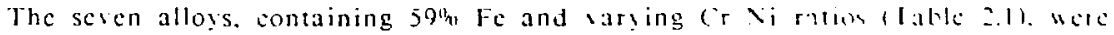

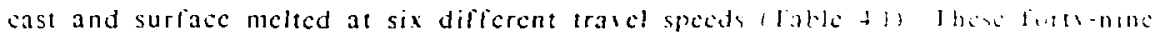

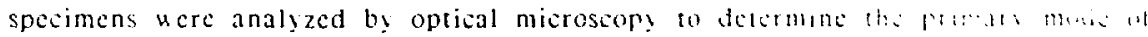
solidification. Some of the surface melts shoucd mate than in nus wi solidification because of inherent sariations in the couling rate witho a guen melt For these cases, the predominant mode was denoted bs the ane whoth w. repunible for more than 50"w of the microstructure.

Table 5.1 summarizes the general behavior of the sen allen thin 1 . : and : solidify in primar! austenitic modes for all cooling rates while dllos 5.6 and : solidily in primary ferrite modes for all cooting rates. Allos 4 changes its mode of solidification from predominantly primary ferrite at low cooling rates to cntirels primary austenitc at high cooling rates.

Figurc 5.6 plots rour PSM regions as a lunction of cooling rate and composition. Since the cutcetic mode was difficult to characterize and can be present with the FA and $\mathrm{AF}$ modes of solidification, it was not given a unique distinction on this diagram. The scan specd is plotted on the ordinate and the composition is plotted on the abscissa but both axes required minor corrections prior to plotting. Firstly. cach at

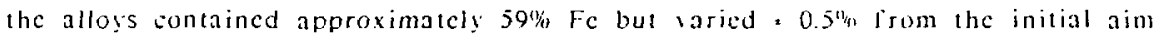
composition. Thereforc. to plot the alloys on a common composition plane in the Fe-Ni-Cr ss stem, a small adjustment was made to the Fe content to bring them to the $59^{1 \%}$ Fe isopleth while at the same time maintaining their measured ('v Ni ratio. Sceondly. the scan spceds were controlled for all the clectron-bam surfice melts hut not lor the casting. Therefore. an cquivalent sean specd of $0.7 \mathrm{~mm} s$ was estimated for the castings based on the primary dendrite arm spaing of the castings. The conling rates lor cach solidifiation condition. as cstimated bs deftefice arm spacings. are presented as an alternate ordinate seale. 


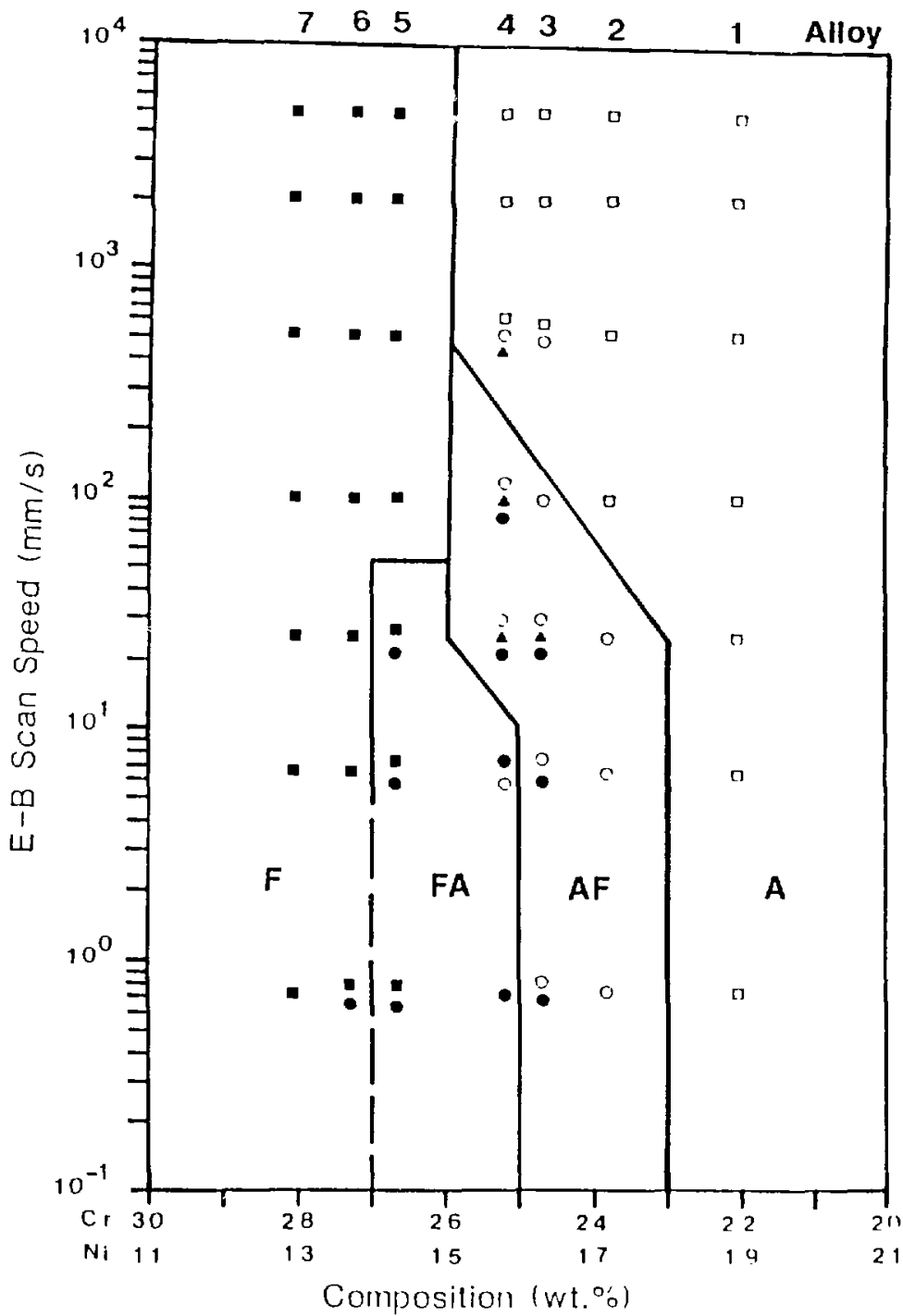

Figure 5.6 Scan specd (cooling rate) icrsus composition map of the four modes of solidification. Multiple data points tefer to different modes observed within the same melt: the upper-most and lower-most symbols correspond to the highest and lowest couling: rate portions of the respectice melse. The solid sequares and circles represent the $F$ and $F A$ modes. the open equares and circles represent the $A$ and $A l$ modes and the triangles represent the cutectic. 
Table 5.1: Summar! of the primar! modes of solidifisation for the seten alloys at low. interntediatc and high cooling rates

\begin{tabular}{|c|c|c|c|}
\hline \multirow{2}{*}{ Hlloy } & \multicolumn{2}{|c|}{$\begin{array}{c}\text { Cooling Rate } \\
\text { intermediate }\end{array}$} & high \\
\hline 1 & A & +1 & $A$ \\
\hline 2 & AF & AF & A \\
\hline 3 & AF FA & AF E & A \\
\hline 4 & FA AF & AF E FA & F \\
\hline 5 & FAF & F & F \\
\hline 6 & FA F & F & F \\
\hline
\end{tabular}

The points plotted on Fig. 5.6 are coded stch that oren squares and open eirsles correspend to single phase austenite (A) and ausicniticterritio (AF) solidilication respesticls "hile solid squares and solid circlas correspond to single phase ferrite if and ferrisistasto ritio (FA) solidification respestids. The cuteris (E) is represented in: a sulid triangic. For the surface melts that showed more than onc mode ol spliditiation. two or nore symbols are stached on top of each other. The symbol on the top of the stach represents the mode whish forms in the higher cooling rate purtions of the melt. i.e. close to the nelt periphers. While the symbol on the bottom represents the mode which forms at the loucr cooling rate portions of the melt. i.c.. whards the ecnter of the resolidificd zonc.

The different regions of solidification behasior are indicated in 1 ig. 5.6 and the results show the clicet that cocling rate has on the microstrusture. There are two impirtant puints to be noted on this diagram. Yirstly at lou saan specds $1<100 \mathrm{~mm}$ sl four modes of solidification are present while at high scan spects $(>500 \mathrm{~mm}$ s) onls tho modes of soliditicatior are present. single phase austenitc and single phase lerrite. Sccondly. Alloy 4 changes its mode of solidification from primary ferrite to primary ausicnitc as the scan specd is increased and it appeas 10 do so in a gradual wa!. As the scan speed is increased. Allos 4 thanges from the It mote lo mined 
FA AF $E$ modes with the amount of cutestic and primars ferrite solidified areas decreasing as the scan specd is increased. With further incrases in specd. tlla! 4 solidirics in the single-phase austenitio mode.

fllos 3 also shows signs of ambialen soliditisation hehasiur in the low cooling ratc portions of the lou tra:cl specd melts. In tllos 3 . at 6.3 and $25 \mathrm{~mm}$ s. the tf mode forms at the melt boundary and the FA mode forms towarts the ecater of the resolidificd zone. It is not clear as to which side of the line of two-lold saturation A'oy 3 belongs but is is obrious that it is vers near the line of two-fold saturation. Since a majorits of the microstructure solidifies in the AF mode. Allo! i us denoted as a primar: austonitc soliditying alloy.

The change in primar! solidification mode and the climination of the $F A$ and $A F$ modes at high scan specds can be cxplained by the inllucnec that scan specd fooling rate) has on solidilication segregation. In order to deseribe hou the PSM develops and is influenced by the sean specd. it is necessar! to lirst caminc how the solidiliation mode originates from the melt periphery and hou this structure grows into the melt.

\subsubsection{Epitaxial Growth and Plane Front Solidification}

\subsubsection{Epitaxial Growth from the Melt Interface}

Surtace melting and resoliditication on a metal substrate with an elcoron-bcam mosing at a constant velocity establishes a liquid-sotid interface which can be assumed to be quasi-stationary in the moving frame of reference. The shape of the liquid-solid interlace depends on the processing variables and in threc dimensions tends to be hemispherical at slow scan speeds and tcar-drop shaped at high specds. Figure 5.7 illustrates a simplified icmperature distribution along the centerine of a surface melt. As the heat source approaches, the metal ahead of the $1 . S$ interface is being heatcd to its melting and the metal behind the $L$ S interiace is being cooled. After incipient melting at the weld centerline. the liquid-solid region expands to iss maximum width and then contracts back towards the ecnterlinc as the heat sourec

passes and at the widest point of the liquid adrancement, defined as the melt periphery, the heat flow is balaneed. In front of this point the meral is being heated 
and behind this point the metal is reing conled. At this point, the allos is at its liquidus temperature and there is no driting forec for solidiliontion.

In threc dimensions. the shape of the melt peripher is a twa dimcensunal surtiace which can casily be idcatified in a metallographic cross cection. ligurc $5 \mathrm{~s}$ illustrates the threc principal vicus of the L. S region to illustrate how the grains derctop from the melt periphery. A plane-front solidicication zone cutends for a short distance from the base metal grains. This zonc quichl! hecomes unstable and breaks down into cells within a short distance from the interface. I he instalilits of the planar front develops into perturbations that lead to celluiar solidilication as the interface advanecs. At high cooling rates, the cellular zone ean extend through the entire melt. houever. at lower cooling rates which are typical of castings and ar: uelds.

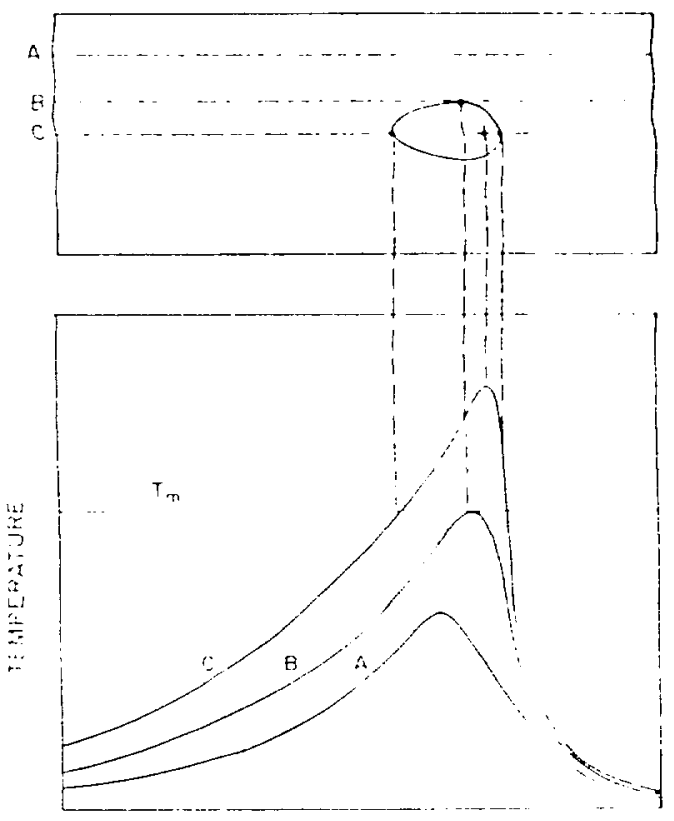

Figure 5.7 Schematic representation of the temperature dist,ibution surrounding a melt-pool. Section $B$ shows that the temperature gradient in the travel speed dircction is zero at the puint of maximum melt width. 
the cells are replaced by dendrites. During the final stages of solidifisation. the dendrites are replaced by an equiaxed zone at the tur center of the melt if the solidification conditions $(G$ and $R$ ) permit.

The nelt periphery is an important feature because from it grou all of the crystals that are present in the resolidificd region. It is along this nelt neripher! that the primary solidification mode first develops and one of two nossititics for the inception of the PSM cxist: I) epitaxial growth from the substrate or 2) nucleation of phases not initially present in the substrate. Examination of the forts-tuo surface melts produced in this investigation shoued that epitasial growth appears to be present in all cases but railed to show the presence of an amorphous phase or nucleation of metastable phases, eren at surface scan specis as high as $5 \mathrm{~m}$.
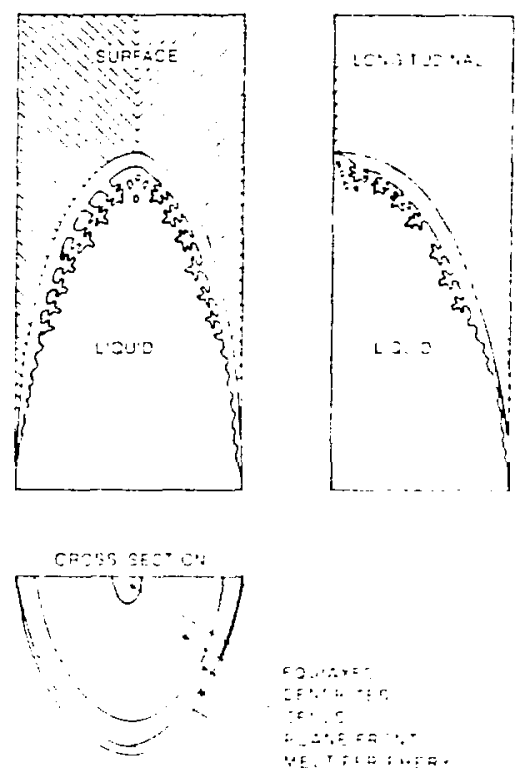

Figure 5.8 Schematic representation of the three prinsipal siens of the melt pool. Locations of the varous microstructural foatures are illustrated on the cross sectional iew and the origin of the different solidification growth morphologics are indicated on the top and longitudinal vicus. 
In general, nucleation of new phases at the melt periphery is the execption rather than the rulc. It requires a combination of both high solidification velocitics, io achicve sufficicnt undercooling. and a composition which is susceptible to metastable phasc formation [5.1-5.3]. Epitaxial grewth from the substratc oceurs in the majority of surface melting processes [5.1]. In the Fe-Ni-Cr ternary system only two solids erystallize from the melt. ferrite and austenite. To the author's knowledge. the conditions necessary to produce an amorphous phase in this alloy system have not becn cxperimentally achicved during surface melting. Studies of atomized droplets of a commercial stainless stecl alloy $[5.10]$ also failed to show the presence of an amorphous phase in highly undercooled droplets. Nuslcarion of metastable phases at the melt periphery has also not been observed to the author's knowledge. Epitaxial grouth is the leading candidate for the initiation of cystallization.

The sesen base metal substrates varied in composition such that Alloy 1 was full? austenitis and Alloys 2 through ? increased in ferritc content from approximatcly 5 to 35 volume perecnt respectively. Therefore. in all but onc alloy, hoth phases were present in the substrate to allow for cpitaxi.l growth. The planc-liont solidification zonc which surrounds cach melt is visible in optical metallographic cross sections. This zonc indicates that epitaxial growth has occurred and the thickness of this zone depends on the processing variables. Its $w$ idth is only a few cell spacings before it becomes unstable and breaks down into cellular solidification. If crystals grow epitaxially from the melt periphery, then austenitc will grow from austenite and ferrite will grow from fercite. This appeared to be the hehavior under all melt conditions. however. some cases were difficult to distinguish because of the solid state transformation of ferrite which made the growth of ferrite into the resolidified region difficult to characterize.

\section{\$1.2.2 Epitaxial Growth at Low Cooling Rates}

At low cooling rates the effects of epitaxial growth are casily observed. Figure 5.9 compares the behavior near the root of weld $2(25 \mathrm{~mm} 5)$ for Alloys 1,4 and 7. Single phase austenite in the melt zone is shown growing from an austenite basc-metal grain in Fig. 5.9a. 

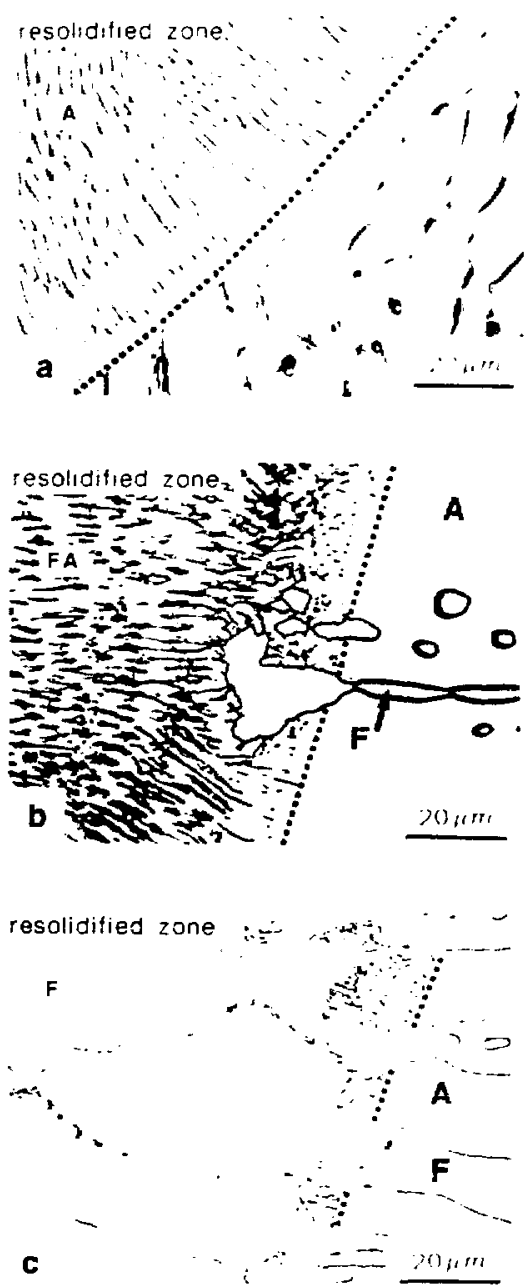

Figure 5.9 Epitaxial growth at the fusion line of melt $2(25.4 \mathrm{~mm} / \mathrm{s})$ in a) Alloy 1 , b) Alloy 4 and $c$ ) Alloy 7 . $F$ and $A$ refer to the ferrite and austenite phases respectively while $B$ and $B$ refer to the resolidified and base metal regions respectively. 
The growth is cpitaxial and a planc-front solidification zonc cxtends for about 2 microns prior to breaking down into cellular solidification with microsegregation to the Ecil bouncarics. Figure $5.9 \mathrm{~b}$ illustrates the typical behavior of an alloy which solidifics in an FA mode with a significant amount of sccond phasc austenitc. Examination of the interface region shows that the melt periphery extends farther into the austenite than the ferrite. This behavior was observed in all melts and can be explained by the higher melting point of the ferritc.

Table 5.2 compares the liquidus temperatures and solidus temperatures for ferrite and austenite. The average composition of ferrite $(34.4 \mathrm{Cr}, 9.2 \mathrm{Ni}, 56.1 \mathrm{Fe}$ and austenite $124.5 \mathrm{Cr}, 17.0 \mathrm{Ni}$. $58.9 \mathrm{Fe}$ was taken from microprobe measurements of the arc sast button. sec Table 2.5 and these sompositions were used to cstimate the liquidus and solidus temperatures of icritc and austenite [5.12]. The results show that $F_{S}<A_{S}<A_{L}<F_{L}$ where $A$ and $F$ refers to austenite and ferrite and the subscripts $S$ and $L$ refer to the solidus and liquidus temperatures respectively.

Table 5.2: Liquidus and solidus temperatures for ferrite and austenitc

\begin{tabular}{|c|c|c|}
\hline Phase & $\begin{array}{c}\text { Liquidus } \\
(\circ \mathrm{C})\end{array}$ & $\begin{array}{c}\text { Solidus } \\
\left({ }^{\circ} \mathrm{C}\right)\end{array}$ \\
\hline Ferritc & 1485 & 1398 \\
\hline Austenitc & 1418 & 1402 \\
\hline
\end{tabular}

Figure 5.10 sllustrates the bchavior of a wo-phasc substrate at the melt periphery when subjected to a linear temperature gradicnt. G. The ferritc from the substrate protrudes into the melt for a distance grcater than or equal to $\left(F_{L}-A_{L}\right): G$. In the actual substrate. the ferrite and austenite phases have composition gradients caused b) noncquilibrium solidification leaving less solute in the dendritc corc. Taking this into account, and using the above relatic ralues for the liquidus and solidus temperatures indicates that the ierrite should protrude into the melt and that the austenite ferrite interfaces should melt back farther than the cores. This is exacty what is observed in the surface melts. 
Returning to Fig. 5.9b, the cpitaxial growth from austenite is aprarent with its associated plane front zone. However, the plane front solidification zone cutending from the ferrite does not show clearly in the micrographs. It is belicsed that grouth from the ferrite is epitaxial with an associated plane front but that this region has been obscured by the subsequent solid state transformation of ferrite to astenite. Evidence for transformation is present in many of the ferrite particles $w$ hich hase a continuous ferrite nctwork extending inlo the melt. Other cridence is present from the faceted surface of the ferrite/austenite interface which suggests that a significant amount of transformation has occurred. Figure 5.96 also shous large ferrite particle extending into the melt and has a network of ferrite fingers extending further into the melt. These lingers cventually lead to a primary ferrite solidified microstructure that has undergone a significant amount of solid state transformation

it higher $\mathrm{Cr} \mathrm{Ni}$ ratios. the pereentage of ferrite in the substrate and the perentage of lerrite which solidifies from the melt, increases. Ihis larger bolume

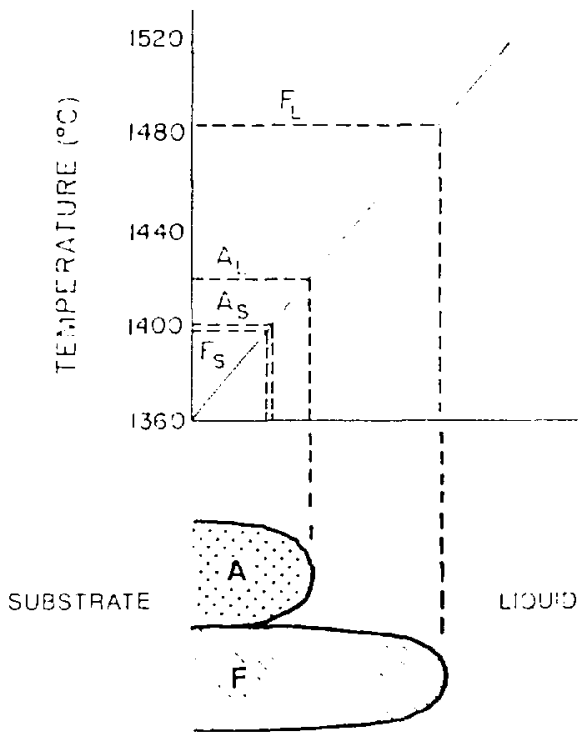

ligure s.lo Protrusion of the higher melting point ferrite into the molten zone of a iwo-phase substratc when subjected to a linear temperature gradient at temperatures close to the melting point. 
fraction of more stable ferrite makes epitaxial growth from the ferrite casicr to observe. Figure $5.9 \mathrm{c}$ shows the interface region from Allos 7 where the substrate contains approximately 30 percent ferrite. Epitaxial growth from both phases is apparcnt. The austenitc planc front breaks down into a cellular mode which leads into single phase icrrite solidification. The ferrite phase is continuous from the substrate to the resolidified region but the melt periphery is difficult to observe.

\subsubsection{Epitaxial Growth at High Cooling Rates}

At high cooling rates the width of the plane front zone is reduced. This makes resolution of the microstructural icatures at the interface more difficult. A carcful analysis of the intertace region would require transmission electron microscopy, howcrer, sample preparation on such small melts with the additional requirement of analyzing the intertaze region is difficult and precluded such analysis from this investigation. Instead, optical metallographic obscrvations were used and were found to be sufficient to support the epitaxial growth theory. However. these observations were not able to definitively prove epitaxial growth at high cooling rates.

Figurc 5.11 compares the behavior of Alloys 1,4 and 7 solidified at $2000 \mathrm{~mm} / \mathrm{s}$. At the high cooling rates, the alloys solidiry in a single phase austenitic mode (Alloys 1-4) or in a single phasc ferritic mode (Alloys 5-7). Figurc 5.1]a shows the growth of single-phase austenite cells in the melt from single phase austenite cells in the substratc. Obscriation of the interface region show's a plane front zonc extending from the austenite grains in the substrate. The planc front zone quickly reverts to cellular solidilication with microsegregation to the cell boundarics.

Figure $5.11 \mathrm{~b}$ iliustrates the behavior of single phasc austenite growing from the two-phase substrate in Alloy 4 . A thin plane front surrounds the melt periphery and breaks down into a highly refined ccllular network within the remelted zonc. The cell axcs are nearly perpendicular to the substrate and the microstructure of the remelted zonc is similar to that which occurs in the fully austenitic Alloy I. The ferrite in the substratc melts back close to the periphery and extending from the ferrite is a dark etching phase. This phase is also ferrite and typically finds its wat to the cell walls in the resclidified zone. Close to the melt periphers are blocks of ferrite which only appear in Allo: 4 at the high cooling rates and look to be a continuation of the 
ferrite dendrites from the substratc. The origin of these blocks is thought to be caused by incomplete mixing slose to the melt periphery. Because the mixing is incomplete, regions of high $\mathrm{Cr} \mathrm{Ni}$ ratios extend from the ferrite dendrites in the substrate into the melt zone. These regions then have enough chemical driving force to change the PSM from single phase austenite to single phase ferrite. The ferritic solidification quickly vanishes because of convective mixing in the bulk of the melt zonc.

Figure $5.11 \mathrm{c}$ illustrates the high cooling ratc behavior ol Alloys 5,6 and 7 . The resolidificd region is single phase ferrite and the soliditication substructurc is apparent. Single phase ferritc grows cpitaxially from ferrite in the substratc and carcful cxamination of the austenite blocks in the substrate show that they hase melted back and that austenite appears to have grown cpitaxially lrom them. The plane front austenite zone is small and it directly changes to single phase ferritic solidification close to the melt periphery. The resulting microstructure is fully Ferritic with no solid statc transformation to austenitc.

In suminary, analysis of the meit periphery shows that cpitaxial growth occurs from the substrate at low and at high cooling rates. Since the substrate is a two phase material, both ferrite and austenite grow from the interface. Onc of the two phases crentually dominates the PSM throughout the resolidilicd region and this dominant mode is a function of composition and cooling rate. The next section discusses how the primary mode devclops from the two phase cpitaxial growth at the melt periphery.

\subsection{Cellular/Dendritic Solidification and Competitive Growth}

The prifcipal factor in determining the PSM is the composition. High Cr. Ni ratio alloys solidify as primary ferritc whilc low Cr. Ni ratio alloys solidify as primary austenite. However, for compositions which are close to the line of two fold saturation, the PSM was shown to change with increasing cooling rate. The reason for this bchavior is related to the growth kinctics which allow epitaxial metastable austenitc to grow throughout the resolidificd melt at high cooling rates. 

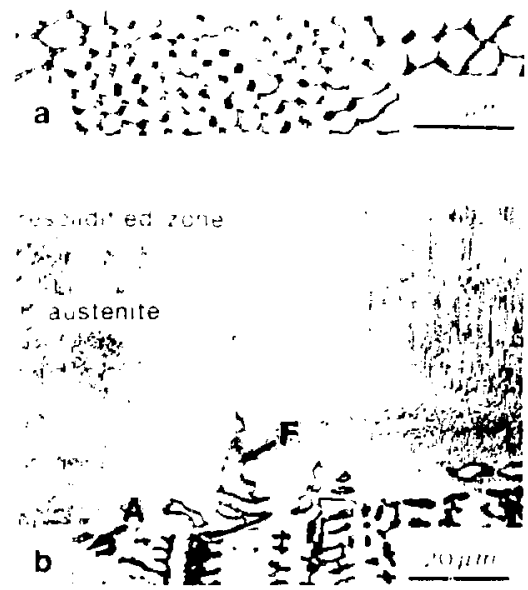

resolidified zone

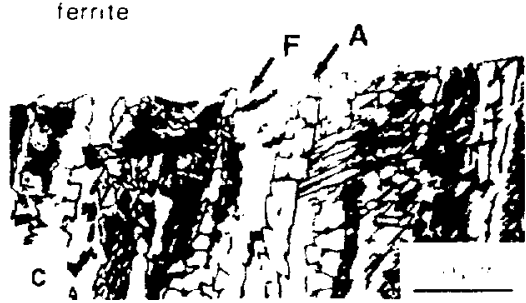

Figure 5.11 The single phase nature of high speed solidified melts. Microstructures 'a' and ' $b$ ' show single phase austenite growing from Alloys 1 and 7 while ' $c$ ' shows single phase ferrite growing from Alloy 7 at $2000 \mathrm{~mm} / \mathrm{s}$. 


\subsubsection{Primary Austenite Solidified Ailoys}

Alloys 1.2 and 3 solidify in a primary austenitio mode (A or $A F$ ) at low and at high cooling rates. Table 5.3 shows that the base metal substratc from flloy 1 cuntains no ferritc and the base metal substrate from Alloss 2 and 3 contains les than 6 pereent ferrite. This leads to a plane front austenite zone which surrounds the cntire melt zone in Alloy I and the ast majority $(>99 \%)$ of the melt in flloys 2 and 3. Therefore, epitaxial growth of austenite dominates the microstructure at the melt periphery and where ferrite is present in t.e substrate at the periphers. it rapids forms second phase ferrite at the ecll boundarics.

Table 5.3: The ferrite content in the $1 \mathrm{~mm}$ decp clectron-beam surface treated zonc and in the base metal substrate.

\begin{tabular}{|c|c|c|c|c|c|c|c|c|}
\hline & \multirow[b]{2}{*}{ Condition } & \multicolumn{7}{|c|}{ Alloy } \\
\hline & & 1 & 2 & 3 & 4 & 5 & 6 & 7 \\
\hline \multirow{2}{*}{$\begin{array}{c}\text { Ferritc } \\
(0 / 2))\end{array}$} & $\begin{array}{l}\text { base } \\
\text { metal }\end{array}$ & 0 & 1.6 & 5.9 & 9.6 & 22.4 & 26.7 & 36.3 \\
\hline & $\begin{array}{l}\text { surface } \\
\text { treated }\end{array}$ & 0 & 0.7 & 3.4 & 12.0 & 23.4 & 49.4 & 86.9 \\
\hline
\end{tabular}

In the casc of single phase austenitc (Alloy l) and AF solidilication (Alloys 2 and 3). chromium segregates to the cell boundaries. However, because of the low initial Cr: Ni ratios of these Alloys, the amount of chromium which segregates to the boundarics is not sufficient to change the mode of solidification from primar: austenite to primary ferrite. Therelore. cven at low cooling rates, where segregation of ferrite stabilizing chromium 10 the cell boundaries is high. the mode of solidification is primary austenite throughout the entire resolidified zone. 


\subsubsection{Primary Ferrite Solidified Alloys}

Alloys 5. 6 and 7 solidify in a printary ferrite mode (F or FA) at low and at high cooling rates. The $\mathrm{Cr} \mathrm{Ni}$ ratios of these alloys is much higher than that of dlloys 1 and 2 which leads to two signilicant diflerenes. Firstly. Table 5.3 shows that the ferrite content of the substrate is much higher and this reduces the anount of epitaxial austenite that forms at the melt periphery. Secondls. the liquid metal is surished in shromium to the point where a large perentage $\left(>80^{\prime \prime}\right)$ of the microstructure solidirics as ferrite. Epitixial growth of ferrite and austenite is cident in Allogs 5.6 and 7 and becomes increasingly casicr to observe as the amount of ferrite in the substratc increases.

Fig. 5.12a shows that the planc fron austenitc zonc in Alloy 5 breaks doun into prinary austenitc solidificd cells within a feu microns of the interlace at slow scan specds. The primar! austenitc cellular region cxtends for only an additional icw mierons belore it transiorms into primary ferritc (F or FA) solidilied eclls, howerer, the solidilication mode is difficult to determine because of the substantial amount of solid state transiormation. The ferrite cells then grow into columnar dendrites and finally equiaxed denorites. At higher speeds, the plane front austenite and ecllular austenitc regions are compressed into a region of about I mitron or less. The remainder ol the weld solidifics in an FA or F cellular mode.

The $\mathrm{Cr}$ Ni ratio of Alloys 6 and 7 is high cnough so that both alloss solidify in the single phase ferritic mode. Furthermore, because of the high $\mathrm{Cr} \mathrm{Ni}$ ratio of the allo;s, less of the ferritc transforms as the alloy cools. Figure 5.l2b shows the developnent of the microstructure from the melt periphery in Allo! ?. The cpitaxial growth of a ustenite breaks down into eclls and then single phase ferrite within a lew microns of the interlace. The epitaxial growth of ferrite leads diredly into the single phase ferrite solidified strueture which continues to grow throughout the remainder of the resolidilicd region. Ausicnite appears to be present as wesisional grain

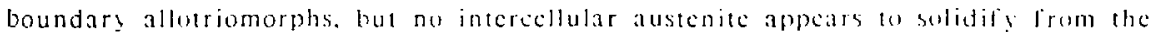
niclt. 

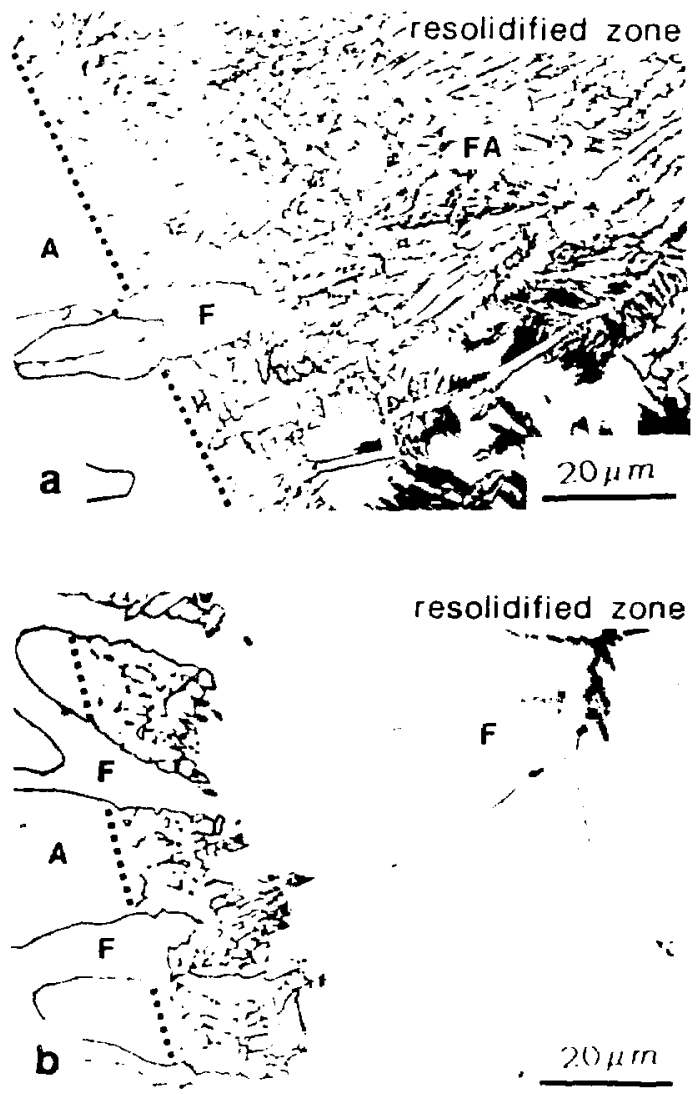

Figure 5.12 Epitaxial growth of austenite from the base metal substrate quickly modulates to the $A F, F A$ and $F$ modes of solidification in the high $\mathrm{Cr} / \mathrm{Ni}$ ratio alloys. a) shows Alloy 5 in which the ferrite undergoes substantial transformation and b) shows Alloy 7 where the transformation is prevented by the high $\mathrm{Cr} / \mathrm{Ni}$ ratio of the alloy. 


\subsubsection{Alloys That Change Their Mode of Solidification With Cooling Rate}

Alloys 1. Z and 3 solidit? as primary austenite while thlis 5,6 and ${ }^{2}$ solidily as primas ferrite lor al: the cooting rate condituns. This lechator indieates that the line of two-fold saturation lies somewhere betucen tlloys 3 and 5 and as indieated in Fig. 5.6. Allos t thanges its mode of solidifieation. At low rates. Allus + solitilices as primary icritc (FA) and at high rates it solidilies as primar! aublenite (Al or $t$. Anals sis of the microstructure shows that Allos + lies on the promars icrile side of the line of tho fold saturation, and that primary austenite liums at high cowling rates in this allos due to the lasorable growth hinctics of the austenite from the medt Feripher!

Figure 5.1.3a shows that the resolidified rone of lller + consists mosts af primar: ferrec dendriles at low soan spects although the magrit! at the melt periphery is austenite. This behavior is caused hy a change an solidification modes

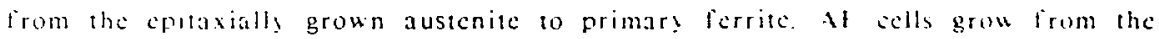
cpitasial austenite and transtorm to FA cells within a les marons of the melt periphery a: $6.3 \mathrm{~mm} . \mathrm{s}$. These FA colls then grow info columnar and linally equialded ferrite dendrites which coarsen in spacing towards the ecoter of the eross section. Figure 5.13 indicates that the epitaxial growth of austenite leads to a much larger

(.).) zone of AF eclls at $25 \mathrm{~mm}$. S. These AF cells transform into the culcetic or intercellular ferrite phase which continues throughout the remainder of the resolidilied $7.0 \mathrm{nc}$. At $100 \mathrm{~mm}$ s and faster the cntire resolidified zone is compused ol AF eclls or cutcetic as indicated in Fig 5.1 is and the amaune of interellular ferrite decreases with increasing travel specd.

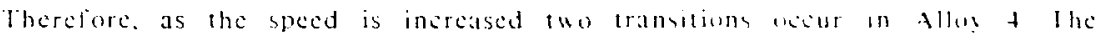
dendritic mode is replaced by eclls or the eutectic phase and the ameunt of primary

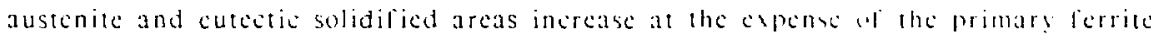
solidified regions. This transition is gradual and is related lo the reducto amount of time a ailathe for segregation as the couling rate is increased thbough the alloys sulidify as a large volume fraction ferrite. onls a small anuont of ferrite (elo"nl is present in the substrate besause of the solid state tandiomation af ferrite. Since the

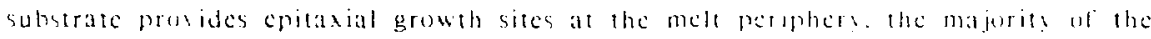

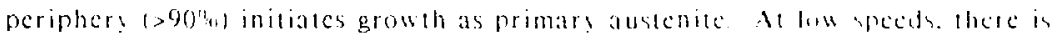



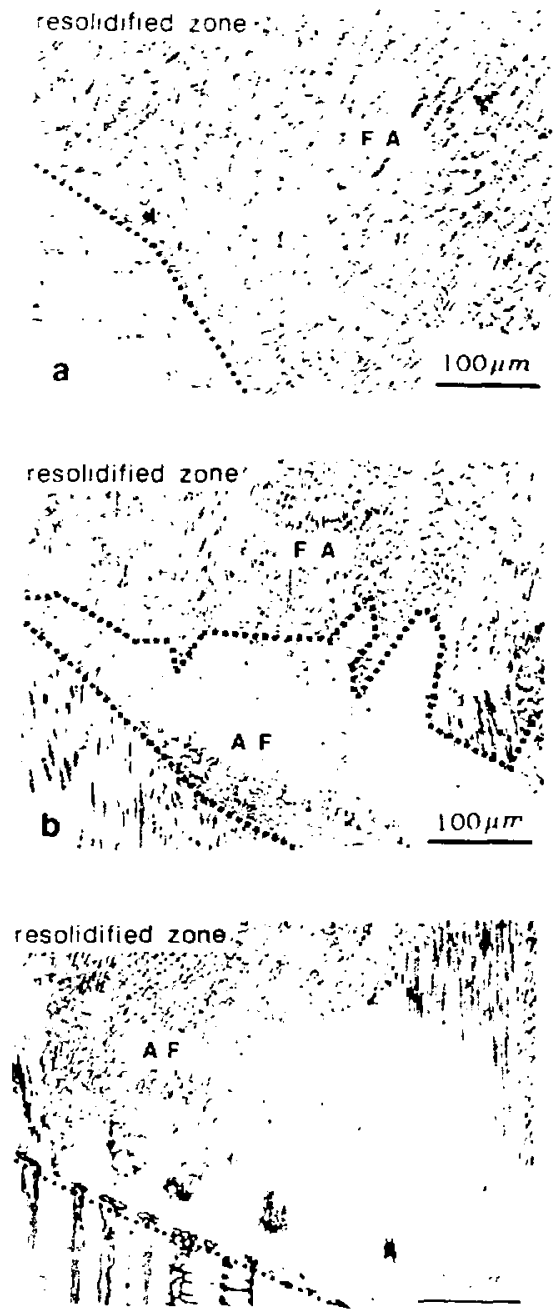

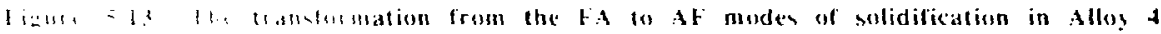
1. the wan yeed is increayed: a) $6.3 \mathrm{~mm}$, showing primary ferrite den-

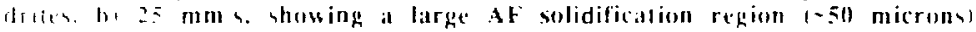

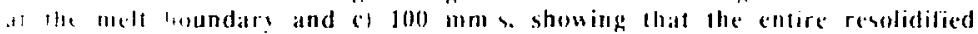

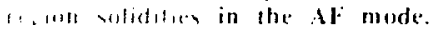


cnough time for solidification segregation to alter the cpitaxislly grown austenite to a primary ferritc mode. This fact is aideneed by the formation of ferrite dendrites which imply a largc amount of scgrcgation. Howcicr. at high specds. therc is less time for segregation. as cridened by the lack of dendrites and the presenec of austenite cells. Lnder these conditions, the epitaxial grown primary austenite zone does not change its solidification mode to the thermodynamisally preferred primars ferritc phase.

\subsection{Microstructural Features of Resolidified Stainless Steel Alloys}

ith section describes the origin of the complex microstruetures whish develop in solidilicd stainless sicel alloys. These mierostruetures form as a result of five different solidification modes and are further modilied by the solid state transtormation of licritc.

The mode of solicitiention has a large influcnec on the ferrite morphology by prosiding nuelcation sites for austenitc. Optical metallographic examination of the resolidifict zoncs shoucd that cleven distinct morphologics cxist and these morphologies can be thought of as subgroups of the primary modes of solidification. The microstructures which develop during the solidification of stainless stecls have becn investigated 15.11.5.12-5.18], however, the terminology used to deseribe the microstructures saries someuhat between authors. Table 5.4 summarizes the names given to the ferrite and austenite morphologics in this studt and compares the terminology used by several other investigators.

\subsubsection{Characterizing the Ferrite and Austenite .Morphologies}

\subsubsection{Ferrite Morphologies in $A$ and AF Solidified Alloys}

Second phase ferrite lurms in promars ausenite solidilied allows and is present at the cell or dendrite walls the amount of ferrite which forms durng al. solidifiation is small and is surbunded h: ausenite Iherefore durang the ferrite

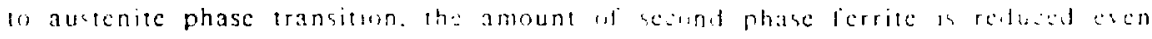
further as it transforms to austents 
Table 5.4: Comparison of the cerminolog! uscd to deseribe the different misrostrustural morphologies in stainless steel alloss.

\begin{tabular}{|c|c|c|c|c|c|c|}
\hline \multirow[t]{2}{*}{ Mode } & \multicolumn{6}{|c|}{ Reference } \\
\hline & This Study & $\begin{array}{c}\text { Katayama } \\
\text { ctal. }\end{array}$ & Dasid & $\begin{array}{l}\text { Lippold } \\
\text { et al. }\end{array}$ & $\begin{array}{c}\text { Brooks } \\
\text { ctal. }\end{array}$ & $\begin{array}{c}\text { Suctala } \\
\text { ct al. }\end{array}$ \\
\hline A & $\begin{array}{l}\text { dendritic A } \\
\text { Eollular A }\end{array}$ & iully $A$ & fully $A$ & - & austenitc & lull: $A$ \\
\hline \multirow[t]{2}{*}{$A F$} & $\begin{array}{c}\text { inter- } \\
\text { dendritic } F\end{array}$ & - & - & - & - & $\begin{array}{c}\text { inter- } \\
\text { dendritic } p\end{array}$ \\
\hline & $\begin{array}{l}\text { inter } \\
\text { sollubat } F\end{array}$ & $\begin{array}{l}\text { inter- } \\
\text { ccllular } F\end{array}$ & $\begin{array}{l}\text { inter- } \\
\text { sellular } F\end{array}$ & $\begin{array}{l}\text { inter- } \\
\text { sellular } F\end{array}$ & - & - \\
\hline E & cutectis & cutestic F & - & - & cutestis & - \\
\hline \multirow{4}{*}{$F A$} & $\begin{array}{l}\text { inter- } \\
\text { ecllular } 4\end{array}$ & - & - & - & - & - \\
\hline & icrmicular $F$ & $\begin{array}{c}\text { vermicular } \\
F\end{array}$ & $\begin{array}{c}\text { vermicular } \\
F\end{array}$ & $\begin{array}{c}\text { vermicular } \\
F\end{array}$ & shclctal $F$ & $\begin{array}{c}\text { vermicular } \\
F\end{array}$ \\
\hline & lacy $F$ & lacy $F$ & lacy $F$ & acicular $A$ & - & lath F \\
\hline & blocks a & - & - & - & - & - \\
\hline \multirow{4}{*}{$F$} & $\begin{array}{l}\text { Widman- } \\
\text { statten A }\end{array}$ & $\begin{array}{l}\text { Widman- } \\
\text { statten A }\end{array}$ & acicular F & $\begin{array}{l}\text { Widman. } \\
\text { statten } A\end{array}$ & $\begin{array}{l}\text { Widman. } \\
\text { staten A }\end{array}$ & $\operatorname{lath} t$ \\
\hline & massive A & - & $\cdot$ & $\cdot$ & $\cdot$ & $\cdot$ \\
\hline & acicular A & acicular $A$ & - & - & - & - \\
\hline & $\begin{array}{l}\text { dendritic } F \\
\text { ecllular } F\end{array}$ & fully $\mathrm{F}$ & lully $F$ & - & - & - \\
\hline
\end{tabular}

Because of the high austenite ferrits interfasial areas and mall alumes fil ferrale

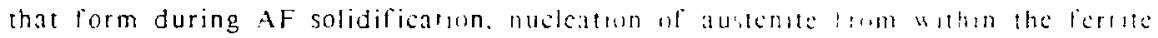
does not occur in these alloys.

The microstructures that forn from the at or it modes are casilt characterias In the single phase austenite solidifiation nusde. there is no ferrite present l'nuter these conditions, primary austenite dendrites form at low gooling rates fig s la and 
primary austenite cells, Fig. 5.th, form at high cooling rates. Mlicrosegregation of chromium to the ecll walls results in the obseriod etohing differenes but is not sulficiently high enough in concentration to form second phase ferrite.

In the AF solidification mode, segregation of chromium to the ecll and dendrite walls is sufficient to form sceond phase ferrite. Interdendrits ferrite. Fig. 5.le. forms a low cooling rates when the primary phase is austenite dendrites. Interecllular ferritc. Fig. 5.ld, forms at high cooling rates when the primary phase is austenite sclls.

\subsubsection{The Eutectic Mlicrostructure}

The cutcetic microstructure forms from the simultancous solidilication of austenite and ierritc. Its mitrostructure was discussed in section 5.1.1.2 and is shoun in Fig 5.8h. Since this mierostructure is similar in appearanec and icnds to form with interecllular ferrite and interecllular austenitc. its presenec is often diflieult to detect. In this study. the term cutcctic will be given to those microstruetures which are difficult to judge and might in lact be intercellular ferritc or intercellutar austenitc with a high volume fraction sceond phase.

\subsubsection{Ferrite Morphologies Which Develop From FA Solidified Alloys}

The ferrite morphologics which develop from the fa solidiliation mude are more complex than those which develop from the $t$ or AF mulce the crimplevity arises from the substantial amount of solid state ferrite transliomation that ociurs as the melt cools. The ferrite which forms during sthilication al duplex stanlew "ects is thermodinamically stable at elevated temperature. huserer. als the

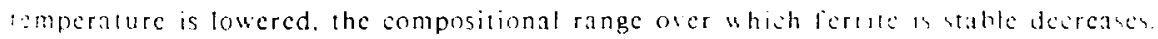
iustente beomes the more stable phase at lower temperature and the decrease an comperature provides a driving forec for the solid state tantomation sil ferrite

This translormation san begin by the growth of cxisting prinary or secund phaxe a dutenite. If no austenite is present in the microbtructure, as wuth he the alse fin 
single phase ferrite solidilication. then austenite can nucleate and grow from the ferrite. The preferted hecerogeneous nucleation sites for austenitc are arcas of low $\mathrm{Cr} \mathrm{Ni}$ ratios such as grain boundaries or cell walls.

In order to describe the microstructures which develop. a distinction must be made betwecn the austenite and ferrite which form during solidification and that which forms during the solid state transformation of ferrite. The terminology used to describe the various microstructural features is summarized in Table 5.5 .

Table 5.5 : Description of the ferrite and austenite phases.

\begin{tabular}{|c|c|}
\hline Sỵmol & Description \\
\hline$F_{R}$ & Residual ferrite in the microstructure at room temperature. \\
\hline$F_{P}$ & Primary ferrite which solidifics from the F or FA modes. \\
\hline $\mathrm{F}_{\mathrm{E}}$ & Second phase (cutectic) ferrite which solidifics from the AF mode. \\
\hline$A_{P}$ & Primary austenite which solidifies from the A or AF modes. \\
\hline$A_{E}$ & Second phase (eutectic) austenite which solidifies from the FA mode. \\
\hline$A_{T}$ & $\begin{array}{l}\text { Austenite which forms during the solid state transformation of ferite } \\
\text { by diffusion controlled growth of austenitc from F'A boundarics. }\end{array}$ \\
\hline$A_{\mathrm{N}}$ & Austenite which nucleates within primary ferrite dendrites. \\
\hline$A_{M}$ & $\begin{array}{l}\text { Austenite which forms during the solid etate transformation of ferrite } \\
\text { by a massise phase transformation within a ferrite matrix. }\end{array}$ \\
\hline$\lambda w$ & $\begin{array}{l}\text { Widmanstatten austenite "platclets" which nucleate and grow ing the } \\
\text { grain bowndarics in single phase ferrite solidificd alloys. }\end{array}$ \\
\hline$A_{A}$ & 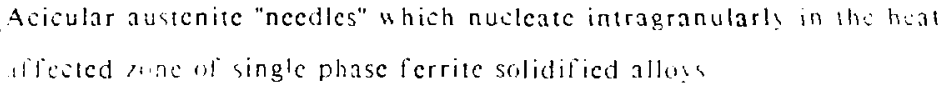 \\
\hline & 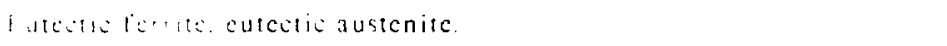 \\
\hline
\end{tabular}


There are four basic morphologics whith develop from the FA mode of solidification. Intercellular austenitc, vermicular ferritc. lacy ferrite and blocky austcnitc. The vermicular and lacy ferritc morphologics have becn recognized by other authors while the intercellutar ferrite and blocky austenite morphologies have not becn given unique distinction in the past.

Figurc 5.3a shows the apper-ance of intercellular austenitc which can oceur under two conditions. At moderately high cooling rates the microstructure consists of primary ferritc cells growing approximately parallel to the heat flow dircction. The solidification mode is FA and cach cell is surrounded by second phasc austenite. This microstructure has an appearance of a semiregular array of ferrite corcs with austanitc at the cell walls. During the solid statc transformation of ferritc. the ferritc which is locatcd at the cell cores partially transforms to austenite. The final microstructurc is an array of ferritc corcs which halc angular cdges becausc of the solid state transformation. The oricntation relationship between ferrite and austenitc is known to be of a Kurdjumor-Sachs 1ype [5.19] and leads to the angular edges at the transiormation interface. The resulting microstructure show's ferrite cores surrounded by a laycr ol transformed austenitc. AT, and an outer layer of sceond phase austenitc. $A_{E}$. A sccond set of conditions that producc this type of microstructurc are those wherc cquiaxed ferritc cclls form in the centcr of melts which werc cooled at low rates. Herc the ccllular mode is produced by nucleation of ferrite cells in the cquiaxed zone but the microstructures are quite similar.

Figure 5.3b shows the typical appearance of vermicular ferrite. This morphology forme at low cooling rates and is the result of columnar dendritic ferrite soliditiation followed by a substantial amount of solid statc transformation. The ferriti dendrites bate uell fefinct scondars arms with second phase austenite present at the secumary ans fumary dendrite arm walls. During the solid state tranuformation. the acond phase austenite. AE grows inte the ferrite denurites

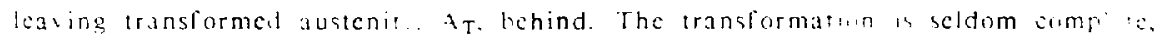
and lewses the residual ic.... Aendrite core in the microstructure

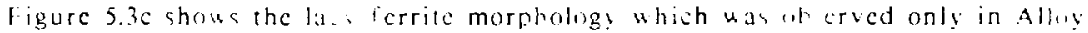
5. This microstructure forms from frimary ferric dentrites which occur at low cooling rates and higher $C r$ Vitios than vermicular ferrite these alloys solidify: 
with a very high volume fraction ferritc and some of the morphological icatures are the same as dendritic ferrite. The second phasc austenite. $A_{E}$. is present between the secondary arms and provides heterogencous nucleation sites for the ferrite transformation. This austenite grow's into the secondary ferrite arms and into the dendrite core leaving a roughened outline of the original ferrite dendrite. Howerer. becausc of the large volume fraction ferrite. the transformation does not appear to he completed by the growth of sccondary austenite into the ferrite dendrite alonc. Austenitc may possibly nucleate within the dendrite corc which would help to crplain its microstructural appearance shown in Fig. 5.14. Intradendritic austenitc. Ax. appears to nucleatc at many sites within the dendrite and its growth is sontrolled hy the diffusion of ferrite stabilizing clements ahead of austenite ferite interface. When adjacent austenite regions approach each other, the transformation stops and leaves a wall of ferrite between the two advancinf fronts. The microstructural appcarance of lacy ferrite in its threc principal directions is shown in Fig.5.14. The top of the cube shows dendrites with their axes normal to the plane of the mctallographic cross section while the sides of the cubc show the dendrites with their axes parallel to the plane of liac section. However, in order to definitely prose the cxistence of intradendritically nucleated austenite, additional cxperimental work would have to be performed.

Figure 5.3d shows the microstructural features of blocky austenite. Austenitc blocks outline the columnar dendrite boundarics and were only observed in Alloy 6 at low cooling rates. This alloy solidified with a volume fraction ferritc which is close to $100 \%$ and the origin of the austenite blocks is most likely to be that of heterogeneously nucleated grain boundary allotriomorphs. Since the ferrite has a higher CriNi ratio, it is more stable than the ferrite of the previous tuo cascs. This stability prevents intradendritic nucleation of austenitc and only growth of the allotriomorphs occurs and is restrieted to the grain boundary vicinity for certain cooling rates. Therefore, the microstructure consists of a high volume fraction ferrite with blocks of austenitc, AT, oriented along the columnar grains This austenite grows as the ferrite transforms, however. because of the higher stability of the ferritc, less transformation occurs. 


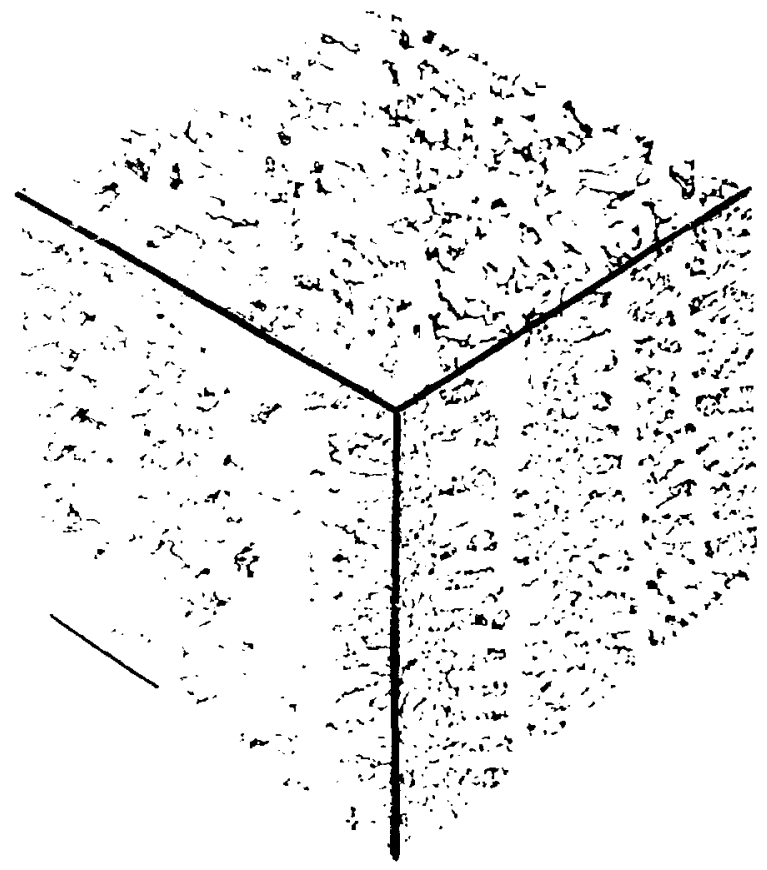

Figure 5.14 Microstructural features of lacy ferrite along its three principal directions. The primary dendrite core and the secondary dendrite arms can clearly be distinguishèd. 
Occasionally, austenite blocks are located between the dendrites. indicating that possibly some second phase austenite may hase been present at the secondary dendrite arm locations to proside a location for heterngencous nucleation ol austenite.

\subsubsection{Single Phase Ferrite Solidified Alloys}

Fig.5.2a shows the appearance of the single phase ferrite grains uhith form from the fully ferritic solidification mode in high Cr Ni ratio alloys. Ferrite cells grou at high rates and ferrite dendritcs grow at low rates. The sclt houndarics do not cteh as prominently as the grain boundaries which makes the ferrite grains the must prominent features in the microstructure. The microstructure renains fully ferrilit as the alloy cools if the nucleation of austenite can be surpressed. This can $k$ accomplished by rapidly cooling the alloy through the transtormation temperature range. This occurred in the melts that solidificd at $1040 \mathrm{C}$ s or iaster.

At lower conling rates, there is sufficient time to nucleate and grow austenite as the ferrite cools. The grain boundaries, which may have some second phase austenile. provide heterogeneous nucleation sites for Widmanstatten austenite. Figure 5.2h shows this microstructure before significant growth has occurred and indicates that thin adjacent platelets of austenite nucleate at the grain boundaries and grow into the ferrite matrix. Fig.5.2c shows the Widmanstatten microstructure at low sooling ratc. when the austenitc platelets have grown entircly across the ferrite graln. Thu microstructure has been ealled acicular ferritc by other authors, however. sines the mechanism is the same, both morphologies will be referred to as Widmanstatten austenite. Figure 5.2d shows that the plate-like appearance af the Widmantaiten $\therefore$ atenite which can be observed when the plane of the plateles lies nearla patillet wh the polished surface.

The formation of massive austenite was only observed in Allit 5 and wrls at hugh curling rates. This alloy solidifies in the fully ferritic mode frow to tranufurmation and this micostructure undergoes a massive transformation o austenite al subsoldus temperatures. The morphology of massive austenite has been studed in standess stecl 3 lisys $[520]$ and is the result of undercooling the ferrite belou the austente ficrite I temperature and will be discussed in detail in Chapter 8. 
Intragranular austenite needles werc observed in the heat aftected zonc of the high Cr Ni ratio alloys. Examples of this microstructure are shoun in Chapter 8 and indicatc that this microstructurc presumably forms during the reheating of single phase ferrite which ean oceur in the heat aflected zone of a weld. The nucleation characteristics of acieular necdles are discussed in detail in Chapter 8.

\subsubsection{The Combined Effects of Cooling Rate and Composition}

The microstructures which develop during rapid resolidification acre first shown to be related to the primary solidification mode and second. to compositional and cooling ratc batiations within a gisen PSM. Table 5.6 summarizes the solidification and solid state transformation sequences that lead to the different morphologies. These morphologies were described in the previous section and all were observed during surlace melting and resoliditication execpt for acicular austenitc, which was obscried only in the heat aflected zone.

The relationship between the various morphologies can be plotted on a scan-specd versus conposition Jiagram in the same way as the four PSM regions were plotted. Figure 5.15 shous the map of the morphologies and since the morphologics are "subsets" of the PSM, cach PSM region is divided into several different areas which represent the predominant morphology.

Variations in the cooling rate cxist within cach resolidilicd zonc. Therelore, a mixture of morphologies mas be present for a given set of clectron beam paranicicrs. The higher cooled regions of the nelt which have small dendrite arm spacings tend to be located close to the nelt periphery and at the root of ucep penctrating welds. Ihese regions tend to have morphologieal characteristics which do not represent the butk of the solidilied metal but do have characteristics which are more lihe the alloys solidilicd at the next higher trasel sped. These aspects were taken into acooent in draling 1 i! 5.15 . 

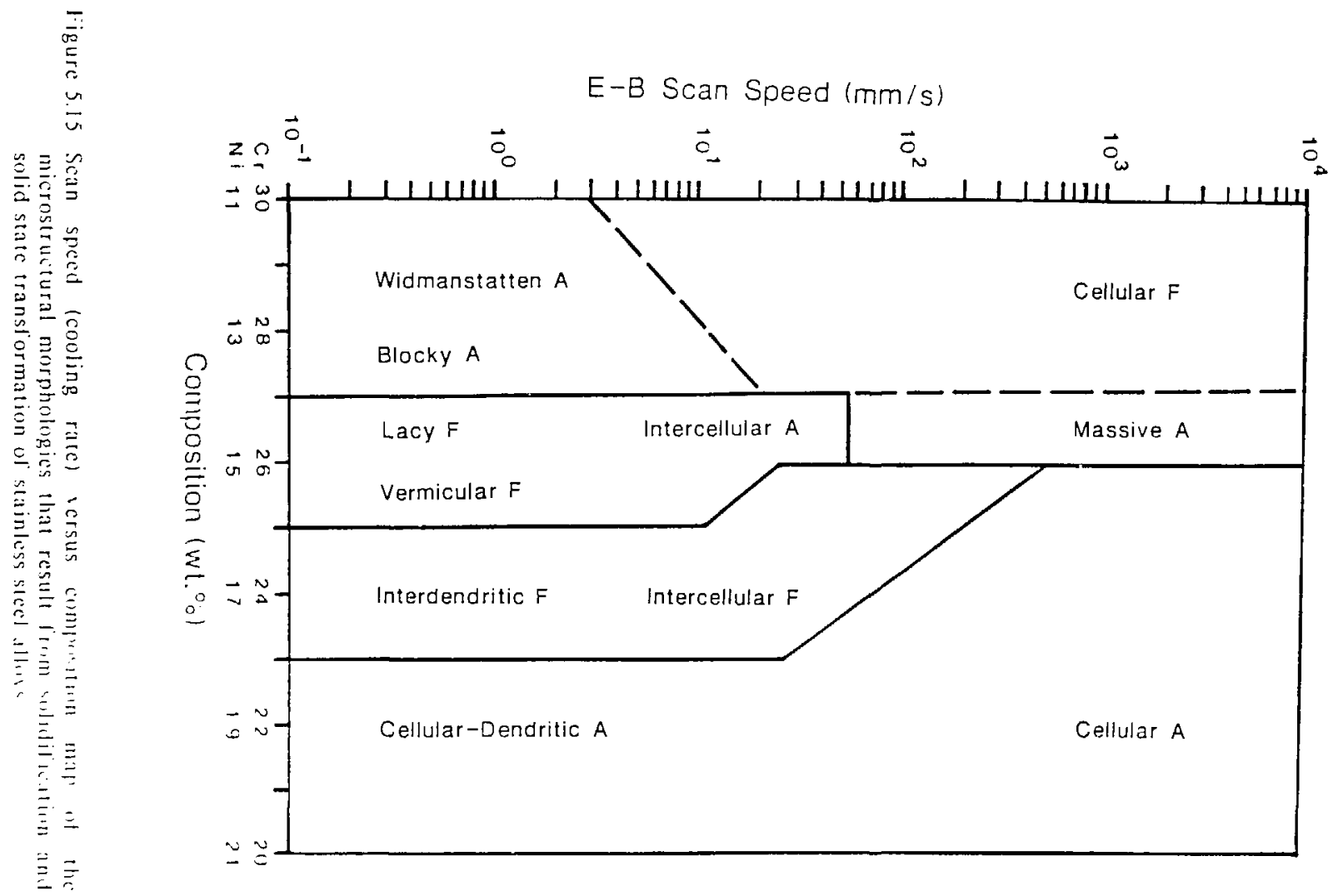
Table 5.6: The solidilication mode, solidification scquence and solid-stalc translormation events responsible for the different microstructures.

\begin{tabular}{|c|c|c|c|}
\hline Mode & $\begin{array}{l}\text { Soliditication } \\
\text { Sequence }\end{array}$ & $\begin{array}{c}\text { Solid State } \\
\text { Transformation }\end{array}$ & Morphology \\
\hline$A$ & $L \rightarrow\left(L+A_{P}\right) \rightarrow A$ & None & $\begin{array}{l}\text { Dendritic A } \\
\text { Cellular A }\end{array}$ \\
\hline$A F$ & $\begin{array}{c}L \rightarrow\left(L+A_{P}\right) \rightarrow \\
\left(L+A_{P}+F_{E}\right) \rightarrow\left(A_{P}+F_{E}\right)\end{array}$ & $\mathrm{F}_{\mathrm{E}} \rightarrow \mathrm{A}_{\mathrm{T}}$ & $\begin{array}{l}\text { Interdendritic F } \\
\text { Interecllular } F\end{array}$ \\
\hline$E$ & $\begin{aligned} \text { L. } & \left(L+F_{E}+A_{E}\right) \rightarrow \\
& \left(F_{E}+A_{E}\right)\end{aligned}$ & $\mathrm{FE}_{\mathrm{E}} \rightarrow \mathrm{A}_{\mathrm{T}}$ & Eutectic \\
\hline \multirow[t]{2}{*}{ FA } & \multirow[t]{2}{*}{$\begin{array}{c}L-\left(L+F_{P}\right) \rightarrow \\
\left(L+F_{P}+A_{E}\right)-\left(F_{P}+A_{E}\right)\end{array}$} & $\mathrm{F}_{\mathbf{P}} \rightarrow \mathbf{A}_{\mathrm{T}}$ & $\begin{array}{l}\text { Intercellular A } \\
\text { Vermicular F } \\
\text { Blocky A }\end{array}$ \\
\hline & & $F_{P} \rightarrow A_{T}, A_{N}$ & Lacy $F$ \\
\hline \multirow{4}{*}{$\mathrm{F}$} & \multirow{4}{*}{ L. $\rightarrow\left(L+F_{P}\right) \rightarrow F_{P}$} & $F_{P} \rightarrow A_{W}$ & Widmanstatten $\mathrm{A}$ \\
\hline & & $F_{P} \rightarrow A_{M}$ & Massive A \\
\hline & & $\mathrm{F}_{\mathrm{P}} \rightarrow \mathrm{A}_{\mathrm{A}}$ & Acicular A \\
\hline & & Nonc & $\begin{array}{l}\text { Dendritic F } \\
\text { Ccllular F }\end{array}$ \\
\hline
\end{tabular}

The results presented in this diagram represent the combined effects of two lactors. Firstly. the composition axis represents the thermodynamic stability of the Perrite phase. As the Cr. Ni ratio is increased, a higher volume fraction of ferrite solidilies from the melt and the lerrite that forms becomes more resistant to the solid state phase transtormation. Secondly, the sean specd (cooling rate) axis represents the hinetic response of the system. As the speed is increased, there is an increased resistance to change. That is, the amount of solidilication segregation decreases and the amount of ferrite that transforms to austenite decreases. In the limit. partitionless solidilieation would oceur. however. these conditions were not observed in this sids. A more thorough analysis of the microteructures which were obsered in the resulidificd electron beam melts is presented in chapter 8 which includes

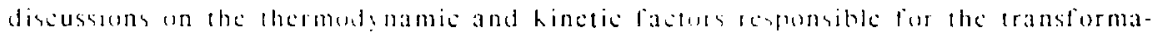
tum meshanioms 


\subsection{Conclusions}

In summary, live modes of solidification and eleven morphologies were obsersed during the resolidification of the seren allos. These microstructural sharacteristics are belicicd to be a completc "sct" of the possible solidification and solid statc transformation events that occur in typical stainless stecl alloys and can be related to the alloy composition, the cooling rate and the extent of the solid state transformation ol ierrite.

The results of this study were used to ercale diagrams which san be used to predict the primary solidification mode and the austcnitc and ferrite morphologics, based on shemical composition and cooling rate. Figure 5.6 shows the relationship between the primary mode of solidification and the cooling rate for the scren alloys which eross the line of tho-fold saturation while Fig. 5.15 shows the microstructural morphologies which develop from these solidilication conditions.

Carciul metallographic cxamination of the suriace melts showed that licrite and austenitc grow cpitaxially from the basc metal substratc. Epitaxial growth fron the resolidification of a two-phase substrate requires that the two phases compete to hecome the primary solid phase to solidily in the remelted zonc. At low cooling rates. the thermodynamic factors take preference and the PSM is dictated by the more thermodynamically stable phase which can be predicted by the line of two-fold saturation. However, at high cooling rates, the growth kinctics of the metastable phase ma! supersede the formation of the equilibrium primary phasc. This situation was ohsericd in Alloy 4 which solidifies in the FA mode at low rates and in the AF mode at higher rates and in the fully austenitic mode at the highest rates.

Onc of the objectives of this incostigation was to determine if the thange in solidilication modes with cooling rate was caused by the nucleation of metastable phase from within the melt. Although one cannut rule out the possibilit? of metastable phase rucleation from within the molen zome at high cooling rates, it does secm unlikely that this nucleation cient would weor hesiuse of the lash of

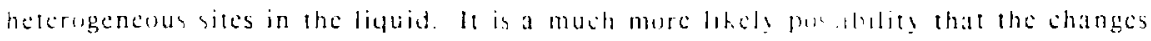

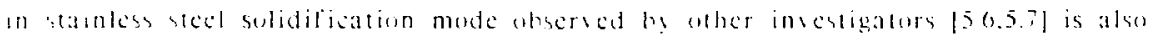


the result of the epitaxialty grown metastable austome descloping into the romars

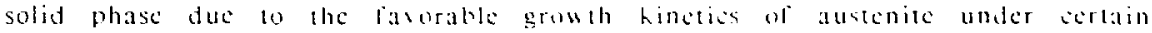
solidification eonditions.

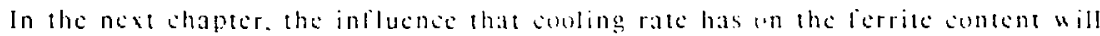

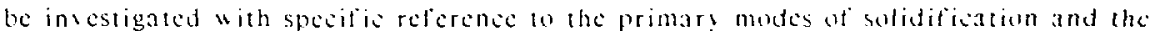
microstructural morphologies presemted in ligures 5.6 and 5.15. 


\section{CIIAPTER 6}

\section{The Influence Of Cooling Rate On The Residual Ferrite Content Of Stainless Steel Alloys}

Residual ferrite is present in the microstruerurc of duplex stainless stect allos in volume fractions as high as 50 perecnt. Cicn at low solume fractions, Ferritc can influence the integrity of stainless stecl alloss and mans investigators have trice to develop relationships between the allos composition and the lerrite content of stainless stcel astings and welds. At slow cooling ratcs. the printipal tactor which controls the amount of ferrite is the composition, howeter. rapis solidification proecssing has been shoun to dranaticalls alter the amoune of ferrite in the microstructure. L'nder these conditions. the conling rate becomes as important as the composition in detcrmining the resulting icritc content. These clifects are not well understood and an important aspect of this investigation was to declop a relationship betucen cooling ratc and the residual ferritc content in stainless stecls.

This chapter examines the results of the cooling rate experiments which were performed on the series of seven Fe-Ni-Cr ternary alloss that span the line of wo-jold saturation along the $59 \%$ Fc isopleth. Cooling rate a a rations werc produced by clectron-beam surlace meiting the allogs at rates between $4.5810^{2}$ " $\left(\mathrm{s}\right.$ and $7.5 \times 10^{4}$ oC $s$. The results show that the coo!ing rate has a signilicant cllect on the licrite content but that its influence is not casily gencralized. The solidilication mode. cooling rate and con position were shown to be cquall! important. and interretated. factors in the determination of the ferrite content.

For primary austenite solidified alloys, the ferritc content uas shown to decrease with increasing cooling ratc. While for primary ferritc solidilicd allogs the lerrits content was shown to increase with incrasing cooling ralte. These clfects arc sor

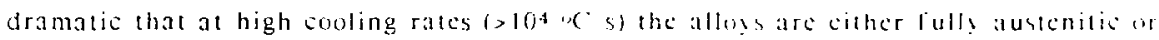
lully lerritic depending on their primars mode of solidifiealion. I the reasus lor this

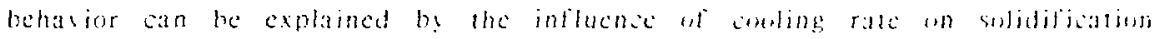
segregation. Chapter ?and solid state translormatiun. (hapter 8 


\subsection{The Ferrite Content at Slow Cooling Rates}

The amount of renduat icrite present in stainlen stect allogs is equal to the amount of ferrite which forms during soldtitiation minus the amount of forritc Whith transtorms as the melt cools to room temperature. Both the solidification and solid state transformation clilects are intluenced by cobling rate and arc difficult 10 isolate from each other. At slow cooling rates. the largest amount of ferrite transforms as the melt cools and this section camines the ferrice content of slom soling rate nelts by first cstimating the amount of ferrite whish would be present if equilibrium conditions could be achicicd. Then. thesc results are sompated with the icrite content of the slow-cooling-rate are-cast buttons.

\subsubsection{Full Diffusional Equilibrium}

Full dilfusional cquilibrium means that there is cnough rime during the solidifiation process so that composition gradicnts are eliminated in both the liquid and solid phases. Lnder these conditions, the amount of lerrite whish solidifics from the mett. the sollidification path. and the composition of the liquid and solid phases san be defermined irom the equilibrium phase diagram

The liquidus and solidus projections are shown on a portion of the Fe-Ni-Cr system in lig.6.la. These data are taken lrom experimentat measuremenis [6.1] and the compositions of the seren alloys examincd in this insestigation are pluthed on this figure. The location of these alloys with respest to the liquidus and solidus lines shows that Alloy 1 will solidify in the fully austenitic mode. Alloys 2 and 3 in the AF mode. Alloys 4,5 and 6 in the FA mode and Allos 7 in the fulls lerritic mode. There is goed agrement with the primary modes of solidilication predicted by fig $6.2 a$ and those csamined in Chapter 5 for the stow cooling rate are cast buttons. houeser. the line of two-jold satumtion predieted by thermolynamis calculations deviates at higher chromium contents.

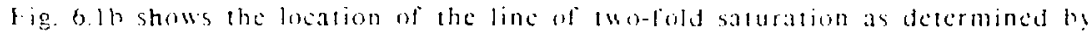

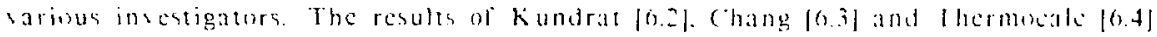

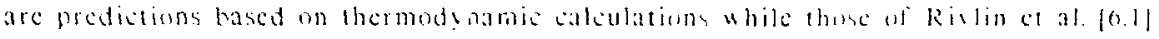

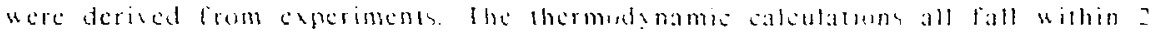

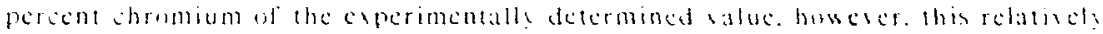




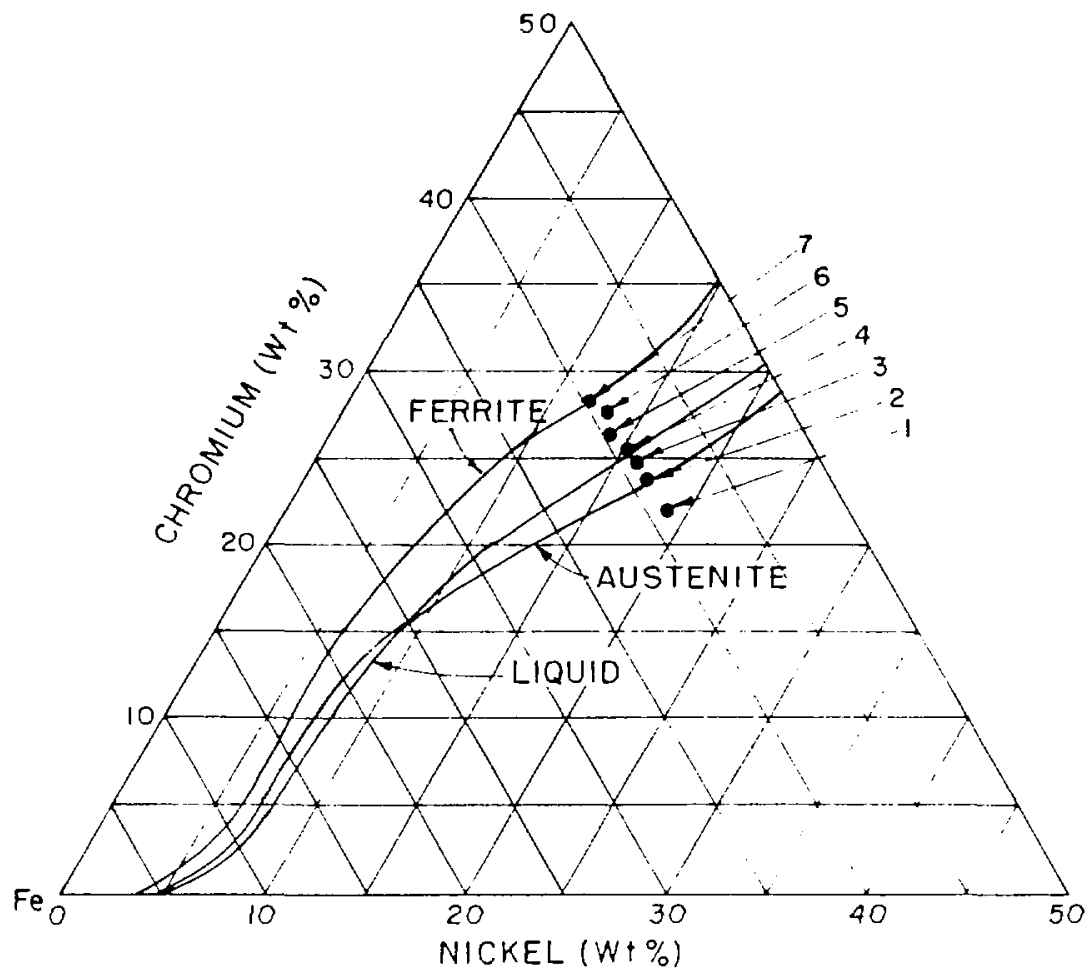

Figure 61 Location of the seven Fe-Nidr allos with respect to the fertite solvus, austenite solvus and the line of tuo-fold saturation. after Rivilin et at, [1 32]. 
mall $\therefore$ : fersuse in the losation of the line of twolold saturation can be misleading when tring to predict the PSM. Throughout this investigation, the experimentall! determined liquidus and solidus lines by Rillin and Ra! nor will be assumed to be the "true" alues since they match the experimentat results of this incetigation. Howerer. when comparisons are made between thermodynanit preditions and cxperimenial measurements, a shift in the alloy compositions needs to be made so that the two methods agrec on the location of the linc of two-fold saturation.

For cquilibrium solidification conditions. Fig. 6.1 indicatcs that flloy 1 cools through the $L+A$ wo-phase licld and dircelly into the single phase austenite ficld with no ferrite in the microstructurc. Alloss 2 and 3 cool through the L.+A two-phase ficld and then into the $L+A+F$ threc phase ficld where second-phase ferrite forms in the microstructure. Alloys 4, 5 and 6 cool through the L+F two-phase ficld and then through the $L+A+F$ threc phase ficld where sceond-phase austenite forms. Finally. flloy : cools through the L+F wo-phase ficld and directly into the single-phase ferrite ficld with no austenite in the microstructure.

From this figure, the amount of ferrite that forms in the alloys can be estimated by applying the lever rule to the tie lines in the $F+A$ two phase ficld which are nearly parallel to the constant Fe section at these temperatures. Table 6.l shows the amount of ferrite which will solidif from each alloy under cquilibrium conditions. These caleulations were predicted from Fig. 6.la and indicate that the ferric content at the solidus temperature varies from $0 \%$ in Alloy 1 to $100 \%$ in Alloy 7.

The phase diagram ean also be used to estimate the amount of ferrite which iransforms in austenitc under cquilibrium conditions. Ai clesated temperatures. the lic-lines in the F+A region are nearly parallel to the $59^{\prime \prime \prime}$ Fe isopleth and the isopleth san be used to estimate the ferrite contene. Table 6.1 shows the cquilibrium residuat ferrite content of the alloys at $1000^{\circ} \mathrm{C}$. At this lemperature, all of the ferrite has transformed to austenitc in Alloy 2 and $60^{\prime}$, has transiormed in Allo! 7 . B! extrapolating the ferritc and austenite solvus lincs to lower temperatures onc can sec that the sccond phase ferrite in Alloys 2 and 3 should completely transtorm and that a majorits of the primary ferrite contained in Alloys $4-7$ should transform by the ume the allos cools to room temperature under cquilititum condilions. Howeser, in actual melts. Kinctic limitations prevent the transiormation at low tenuneratures and some residual ferrite remains in the microstructure. 
Table 6.1 rquilibrum ferrite contents at the solidus and at 1000 -

\begin{tabular}{|c|c|c|}
\hline+110 & $\begin{array}{c}\text { "to Ferritc } \\
\text { that solidifics }\end{array}$ & $\begin{array}{c}\text { "n Residual Forrite } \\
\text { at } 10000 \mathrm{C}\end{array}$ \\
\hline 1 & 0 & 0 \\
\hline 2 & 20 & 0 \\
\hline 3 & 35 & 8 \\
\hline 4 & 55 & 14 \\
\hline 5 & 70 & 24 \\
\hline 6 & 92 & 31 \\
\hline 7 & 100 & 40 \\
\hline
\end{tabular}

\subsubsection{The Arc Cast Buttons}

The are cast buttons represent the slowest cooling rates cxamined and were used as a standard with which to compare the high cooling ratc microstructures. Ir Chapter 4 it was shown that the primary and secondary dendrite arm spacings of the are castings were 42 and 18 ,"m respectively and that this spacing corresponds to a cooling rate of about ? ${ }^{\circ} \mathrm{C}$. $\mathrm{s}$. Arc welds typicaly solidify with cooling rates between 10 and $10002 \mathrm{C}$ s. therefore. the cooling rate in the arc cast buttons can be considered to be similar but on the slow cooling rate side of are welding.

The Schaffler diagram was used to predict the ferritc content ol the are cast buttons. The alloy compositions are plotted in Fig. 6.2. Alloy $I$ is in the lully austenitic region and Alloys $2-7$ are in the duplex. Ferrite-austenite. region. The ferrite contents estimated from the Sehacfler diagram are shown in Table 6-? and range from $03 \%$ for Alloy 1 to $32 \%$ for Alloy 7.

A sccond. and less conventional, method was uscd to crinatc the amount of residual ferritc. Based on several investigations [6.5.6.6.6.7]. where the ferritc content of a large number of commercial stainless stecl (AISI 304, 308, 309. 316) are-uclds was measured. Fig. 6.3 can be used to prediet the territe content for different Cr vi ratio alloys. 
Taple 6.2 Fredicted and measured ferrite contents of the arc cast buttons

\begin{tabular}{|c|c|c|c|c|c|c|}
\hline \multirow[t]{2}{*}{ Alloy } & \multicolumn{2}{|c|}{$\begin{array}{r}\text { Predictive Methods } \\
(\%)\end{array}$} & \multicolumn{3}{|c|}{$\underset{(1 / 0)}{\text { Micasured }}$} & \multirow{2}{*}{$\begin{array}{l}\text { A } \\
\text { (") }\end{array}$} \\
\hline & Schaeffler & $\mathrm{Cr}, \mathrm{Ni}$ & $M G$ & VSM & QTM & \\
\hline 1 & 0 & 0 & 0 & 0 & 0 & 0 \\
\hline 2 & 5 & 7 & 5.4 & 4.6 & 5.4 & 5.5 \\
\hline 3 & 7.5 & $1 \mathrm{i.5}$ & 8.7 & 9.8 & 11.0 & 9.7 \\
\hline 4 & 12 & 14.8 & 14.6 & 15.8 & 14.2 & 14.3 \\
\hline 5 & 16 & 23.5 & 23.6 & 23.2 & 22.8 & 21.8 \\
\hline 6 & 27 & 29.7 & 27.4 & 26.4 & 32.4 & 28.6 \\
\hline 7 & 32 & 35.9 & 36.5 & 32.1 & 39.2 & 35.1 \\
\hline
\end{tabular}

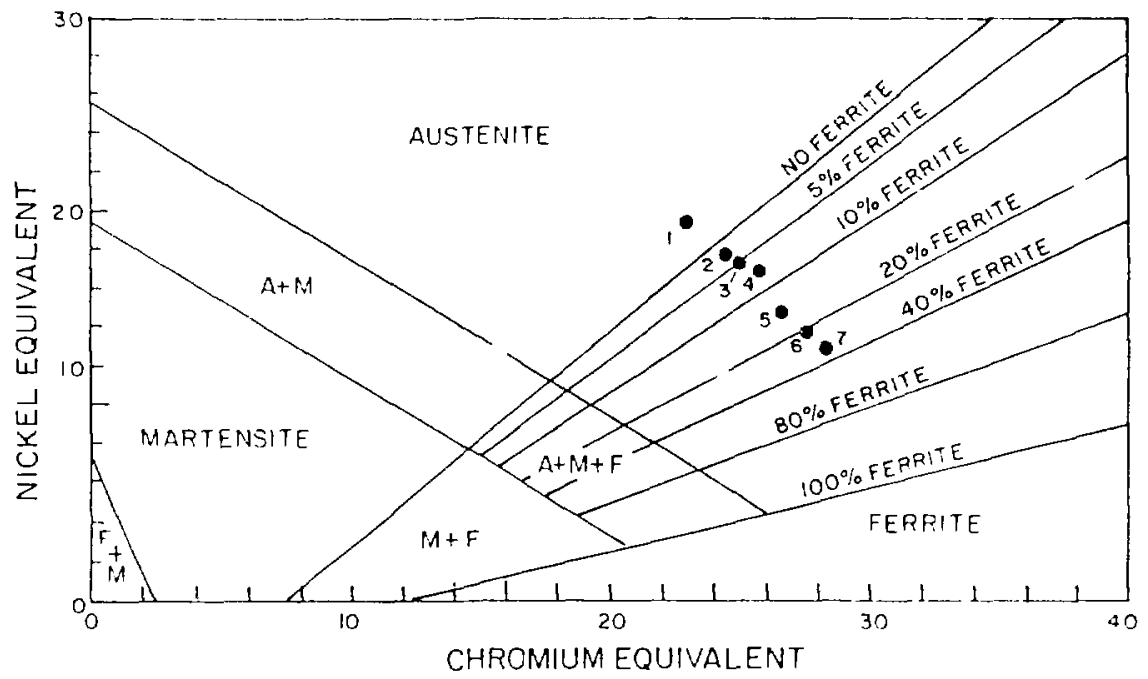

rigure 6.2 Location of the seven Fe-Ni-Cr alloys on the Schaefflet diagram 
For Cr Ni ratios below 1.20 the ferrite content is zero while for Cr $\mathrm{Ni}$ ratios beqween 1.20 and 2.0. a regression analysis shows the following relationsisip betuecn Cr Vi ratio and ferrite content:

$$
4.1=36.6(0 / 1)-13.8
$$

The ferrite is estimated in weight pereent and the $\mathrm{Cr}$ and $\mathrm{Ni}$ cquivalents suggested by Delong (cq. 1.1 and 1.2) shculd be uscd. Table 6.2 show's that this approach also predicts ferrite contents of the east alloys should ary from 0 to above 30 pereent.

The fertite content of the castings was measured using several techniques. Since the eastings had a thickness greater than $10 \mathrm{~mm}$, the ferrite number could be measured using the Magne-Gage. Since the castings had a coarse microstructure, the ferrite could be directy measured using quantitative metallography. These Magne-Gage readings were converted to perecnt ferrite using the proscdure that was discussed in Chapter i. L'sing the cxtended ferritc measurement method [3.4] the ferrite content was determined and the results are shown in Table 6.2. These

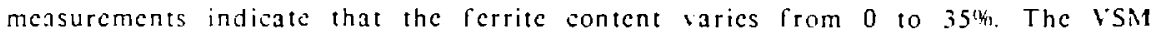
technique was used as the sccond measurement method and is also described in Chapter 3. The results of these measurements are also presented in Table 6.2 and indicate that the fertite contents vary from 0 to 32.1 pereent. Finally, quantitative metallographic measurements were used to confirm the ferrite content of the scien alloys.

Figure 6.4 compares the measured ferritc content (VSM) with the predicted ferrite content (Schacfller) along the $59 \mathrm{wt}$. " Fe composition axis of the Fe-Ni-Cr ternary system. The Sihacfiler prediction shows that the ferrite content varics from $0 \%$ at 23.3 wt." $\mathrm{Cr}$ to $100 \%$ at $34 \mathrm{wt} . \% \mathrm{Cr}$ and predicts a linear increase in ferrite content for the compositions studied that varies from 23.3 to 26.5 wt. $1 \% \mathrm{Cr}$. The predicted amount of ferritc deviatcs sharply from this lincar relationship to higher ferrite contents at chromium levels greater 26.5 wt. "). The measured ferritc contents are close to the predicted values and follow an interesting trend. For shromium contents above $26.5 \%$. i.c. in the nonlinear Schacfler region, the measured valucs are lower than the predicted values. For chromium contents below 26.5\%, i.c. in the lincar Sehacflicr region, the measured values are higher than the predicted values. 


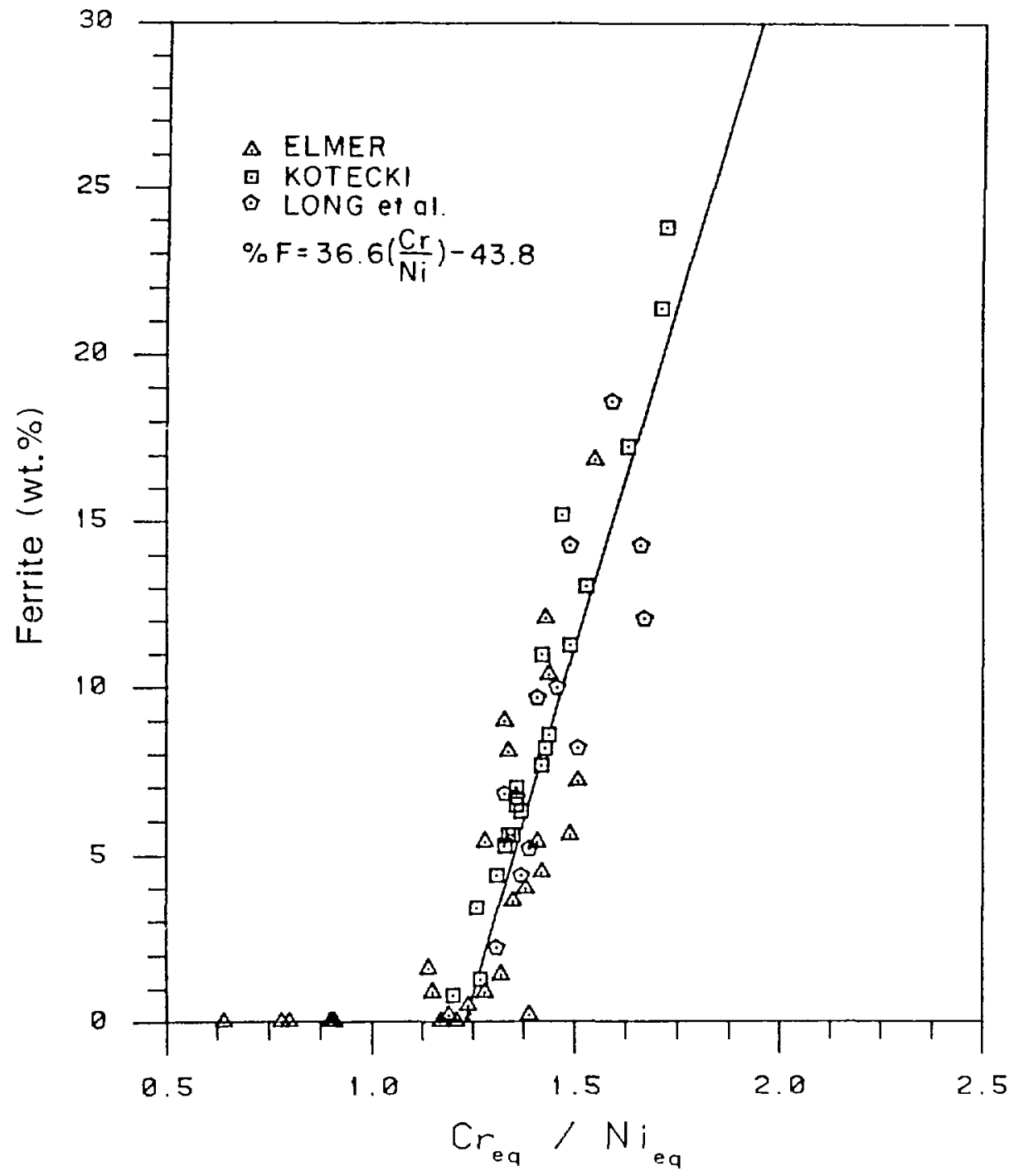

Figure 6.3 Percent residual ferrite as a function of $\mathrm{Cr} / \mathrm{Ni}$ ratio in are-welds of typical 304 type stainless steel alloys. 


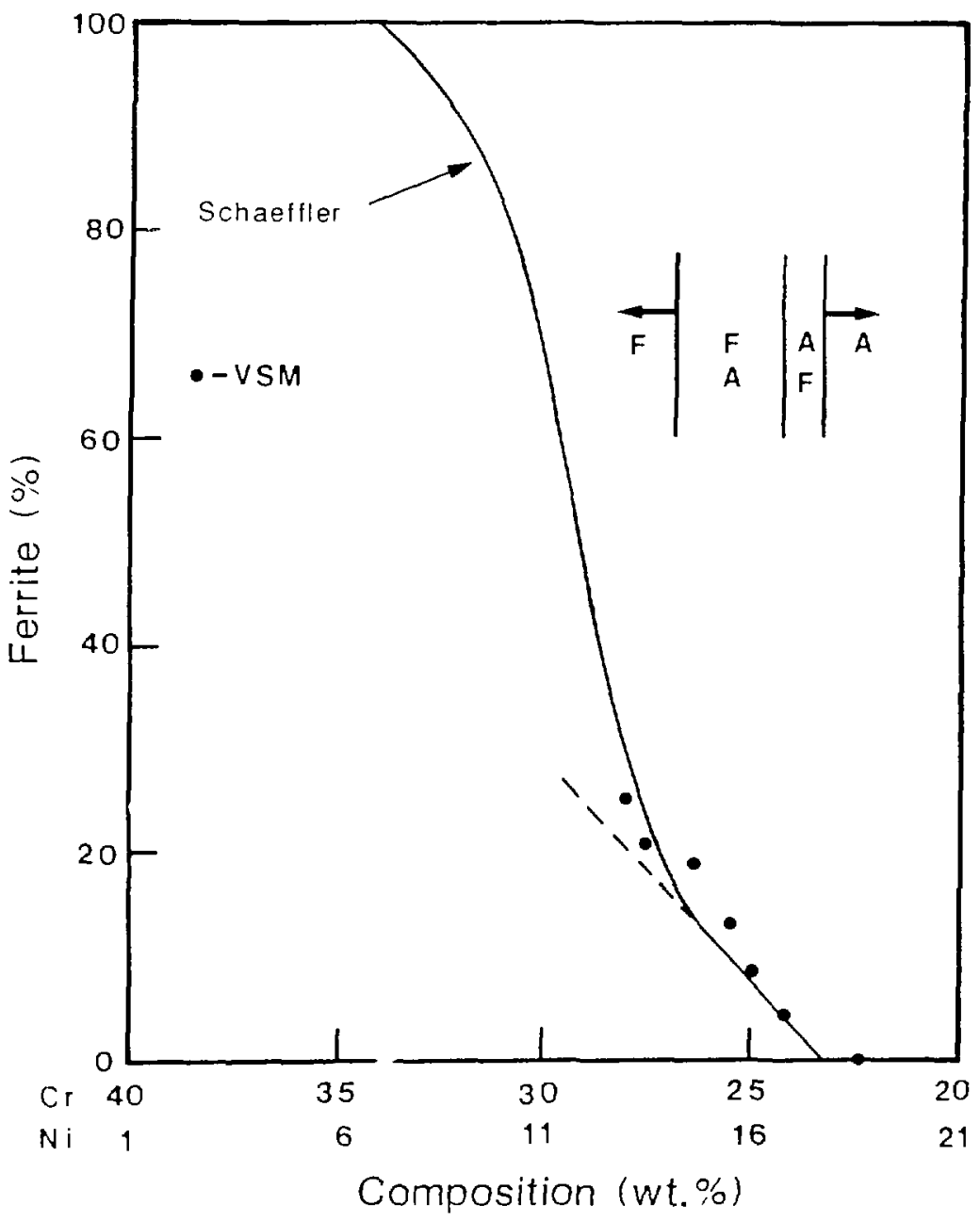

Figure 6.4 Residual ferrite on the seven are-casi alloys compared to the residual ferrite predicted by the Schacfler diagram for 59 with Fe alloys. The solidification modes, as determined from the cast alloys, are indicated. 
The differenes between the measured and predicted values can he explaincd b! the fact that the cast alloys cool at a slower ratc than what the Sihacitler predictions are based on. It was shown in Chapter 5 that below 27 we. "ohromium. the sast alloys containing $59 \%$ Fe solidiry in a duflex ferrite-austenite modes while aboue 27 wl. "1h chromium. the alloys solidify in the fulls ferritic mode. This shange in solidification modes at $27 \%$ Cr ean be used to cxplain the deviation in lincarity ol the Sehaclifler prediction and also can be used to explain the differenec in predieted and measured values above and bclow $27 \% \mathrm{Cr}$.

The deviation of the Schacffer prediction from its initial. low Cr. linsar behavior is associated with the change in solidification modes from the fto the f mode. In the FA mode, increases in chromium content increase the amount uf ferrite that solidifics from the melt. Therefore, there is a gencral increase in the ferrite content with increasing chromium. When the chromium lesel is increased ti the point where the solidification becomes rully rerritic, shere is no lurther interase in the amount of ferrite that forms during solidification with increasing chromium and the resulting ferrite content is solely dependent upon the amount of ferrite to austenite transformation that occurs. This transformation requires nucleation of Widmanstatten austenite at the ferrite grain boundarics. Since the grain boundary area is much less than the interdendritic area where austenite is present in the FA mode. less transformation occurs in the fully ferritic mode.

The difference between the measured ferrite content of the castings and the predicted values from the Schacffler diagram can be cxplained by transformation kinctics. The ferrite content of alloys which solidify in the fully ferritic mode are very sensitive to cooling rates. A slower cooling rate allows more time for austenite to nucleate and grow from the fully ferritic microstructure. Therefore, slower cooling rates always result in lower residual ferritc contents. Since the castings 00 ! at a slower rate than the Schacffer predictions. a lower ferrite content is cxpceted in the castings.

In the FA mode however, the situation is more complicated because two phases solidify from the melt. A slower cooling ratc allows for more segregation. creates a large dendrite arm spacing and allows more time for the ferrite to austenite transformation. These fators have mixed effects on the residual ferrite content. In the FA mode, more segregation means less ferrite, however, the ferrite that forms will 
have a higher $\mathrm{Cr} \mathrm{Ni}$ ratio and will be more resistant to tranjiormation. A larger dendrite arm spacing has less austenite ferrite interfacial area which provides less area for austenite growth during the transtormation, however, the slower cooling rate allows for morc transformation and helps to balance this factor. Therefore, the situation is complicated and the cficet af a slower cooling rate is difficult to predict in the FA mode. The experimental results show that the castings have nore ferrite than the Schaefler diagram estimates and indicates that the larger dendrite arm spacing and higher stability of the ferrite outueigh the lower initial amount of ferrite and the greater time for the ferrite to transtorm at lower cooling rates.

\subsection{The Ferrite Content of Electron Beam Surface Melts}

Electron beam surface melts wese perlormed on each of the alloys to produec cooling rates that varied from $4.7 \times 10^{20} \mathrm{C}$ s $57.5 \times 10^{60} \mathrm{C} / \mathrm{s}$. The ferritc content was shoun to shange significantly with cooling rate. These changes can be described by the inlluence of cooling rate on the mode of solidification, the amount of solidilication segregation and the extent of the solid state transformation of ferrite.

The fertite content of each alloy was measured by the vibrating sample magnetometer method which is described in Chapter 3 and the results of the ferrite measuremenis are presented in Table 6.3 for cach of the seven alloys and each of the soliditication conditions. Threc readings were made on cach cast alloy and onc reading was made on each clectron-bcam melt. At the highest travel specd, $5 \mathrm{~m} / \mathrm{s}$, the samples were tou small to be extracted without substrate conamination. Nevertheless, the results showed the ferrite content of these melts 10 be elose to $100 \%$ ferrite for the primar: ferrite solidified alloys and close to $0 \%$ lerrite for the primary austenite solidilied alloys.

Two types of diagrams represcnting the icritc content as a function of cooling rate are shown in this chapter. The actual measured ferritc content is plotted versus scan specd on figures $6.5,6.7,69,6.11$ and 6.14 . The second type of diagran is schematic in nature and represent the estimated amount of ferrite for particular idealized solidification modes. Figures 6.6, 6.8, 6.10, 0.12 and 6.1.3 are plotied as approximate ferrite content versus approximate cooling rate where the cooling ratc seale of these ligures is similar to that of the actual ferrite content versus sian speed 
ligures. B! selecting the scales of ferrite content and cooling rate to be the same for the actual and schematic drauings. ligures 6.5 through 6.13 ean be dircetly compared to observe shanges in the ferrite content with couling ratc.

\subsubsection{Primary Austenite Solidified Alloys 1, 2 and 3}

The behavior of alloys which solidily in the $A$ or AF modes will be deseribed by cxamining the behavior of alloys 1. 2, and 3. Alloy 1 solidifics in a fully austenitic mode at all cooling rates and contains no ferrite. Alloys 2 and 3 both solidily in an austenitic-ferritic mode at low cooling rates and in a luliy austenitic mode at high cooling rates. Therefore, the ferrite content of these alloys decreases as the cooling rate increases. The results presented here show that the amount of sccond phase ferrite decreases with increasing scan specd. This behavior can be cxplained by undercooling at the dendrite tip. Chapter 7 will present calculations which show that the dendrite tip undercooling increases with increasing scan speed and that the amount of second phase which forms decreases accordingly.

Figure 6.5 shows the measured ferritc content versus scan specd relationship for alloys 1,2 and 3 . Alloy 1 is fully austenitic at all specds and its ferrite content is zero regardless of the cooling ratc. Alloys 2 and 3 both have ferrite contents in the are cast condition $(0.7 \mathrm{~mm} / \mathrm{s}$ cquivalent spced) which arc close to the Schaclfler prediction and both have a gradual decreasc in ferritc content as the scan spccd is increased. Alloy 2 reaches zero perecnt ferrite at a sean specd of about $100 \mathrm{~mm} / \mathrm{s}$ while Alloy 3 reaches zero perent ferrite at slightly higher specds. The lact that Alloy 3 has more ferrite and requires higher scan spects to reach zero perecnt ferrite than Alloy ? is a result of its higher $\mathrm{Cr}$, Ni ratio.

The cooling rate influenees the ferrite content in two ways. Firstly, it influenecs the amount of ferrite which solidifics from the nelt. Sarral and aboschian [6.9] have shown that the amount of scond phase that forms rcaches a maximum valuc at intermediate cooling rates. At high rates. dendrite tip undercooling increases the pereentage of primary phase and reduecs the amount of second phase that forms. 


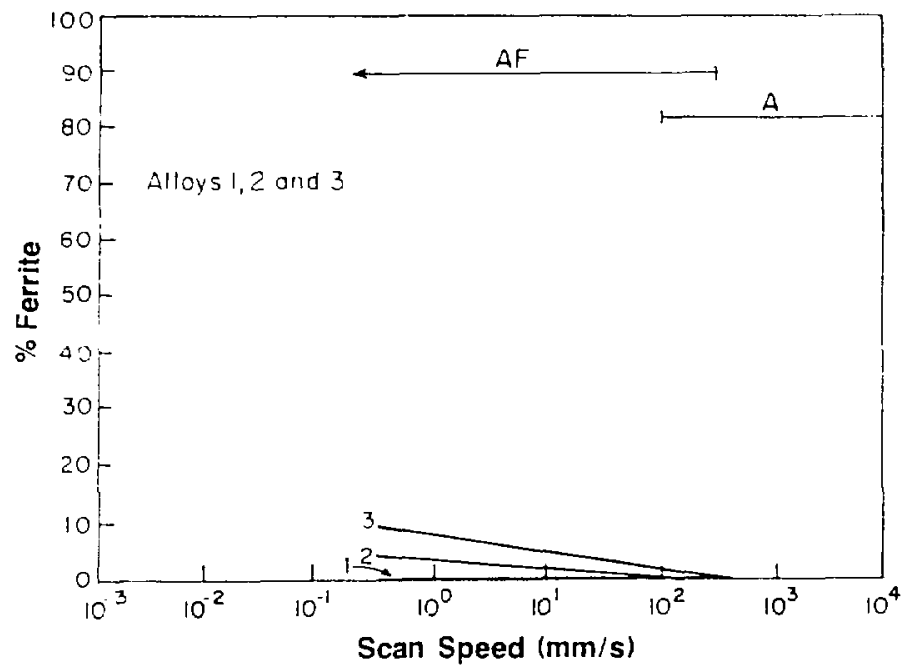

Figure 6.5 The measured ferrite content of $A$ and AF solidified alloys 1,2 and 3 as a function of electron beam scan speed.

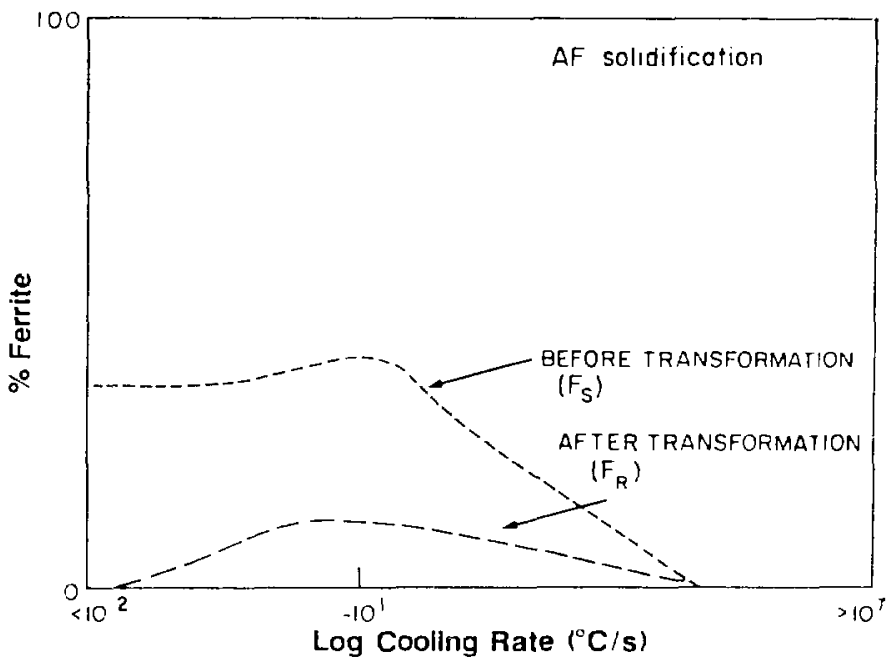

I igure 6.6 The estimated trend of ferrite content in $A$ and $A F$ solidilied alloys as a function of solitification rate. The amount of ferrite that solidifies and the residual ferrite, after solid state transformation, arc indieated. 


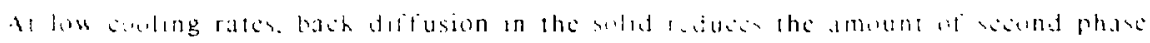

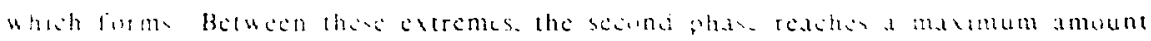

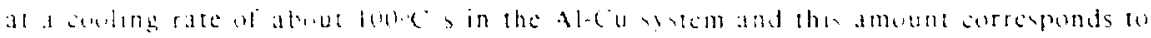

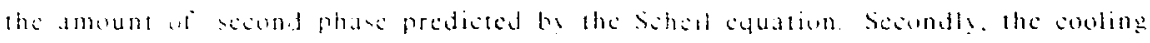
rate influences the amount if ferrite which transforms to austenile. ti high rates there is mo cime for cransliomation to oceur while al low rabes the matimum amount of ferrite transiorms and the ferrite content appreathes it equilibrium alue.

These two factors are sifematically shown in Fig. 6.6. At low couting rates, a high perecntage ol ferrite transtorms to austenite while at high cooling rates. the pesentage that transforms approaches zero. Therelore, a maxmum in the amount of residual lerrite also oceus at an intermediate cooling rate for primary austenite solidified alloss. Comparing the actual amount of residual ferrite in Alloss 2 and 3 (Fig. 0.5) with Fig. 6.6 shows that the tests performed in this stud! all oceur at the high cooling rale side of Fig. 6.4 since a peak in the actual ferrite content was not obsersed. This las is contirmed by a small alue $(1<0.1)$ ut the Brody-ticmings bach diflusion parameter in the are cast buttons and even smaller values for the clectron-boam melts.

\subsubsection{Alloy 4}

Alloy + bchares uniquel because it solidifies in a primary ferritio mode (FA) al low cooling rates and in a primary austenitio mode ( $A F$ or $A$ ) at high cooling rates. This change in soliditication behavior has a significant clices on the ferrite content. Figure 6.7 shows the actual ferrite content of Alloy $t$ as a function of the clectron beam sean speed. The ferrite content was measured by the vitrating sample magnetomecer and the results are compared to the amount predicted by the Sithafler diagram.

As the scan specd increases from $0.710100 \mathrm{~mm}$ s. The ferrate level increases from It 1018 percent. In this region. the mode of solidification is $1 \mathrm{~A}$ and the incrase in ferrite content is eased by the increase $i_{n}$ the amount of primas fersite that

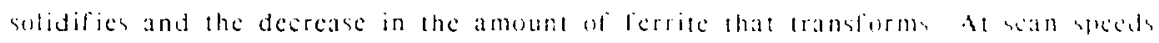

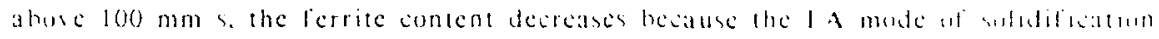
a beng replaced by the Af or 1 mode of whildiation and linalls 


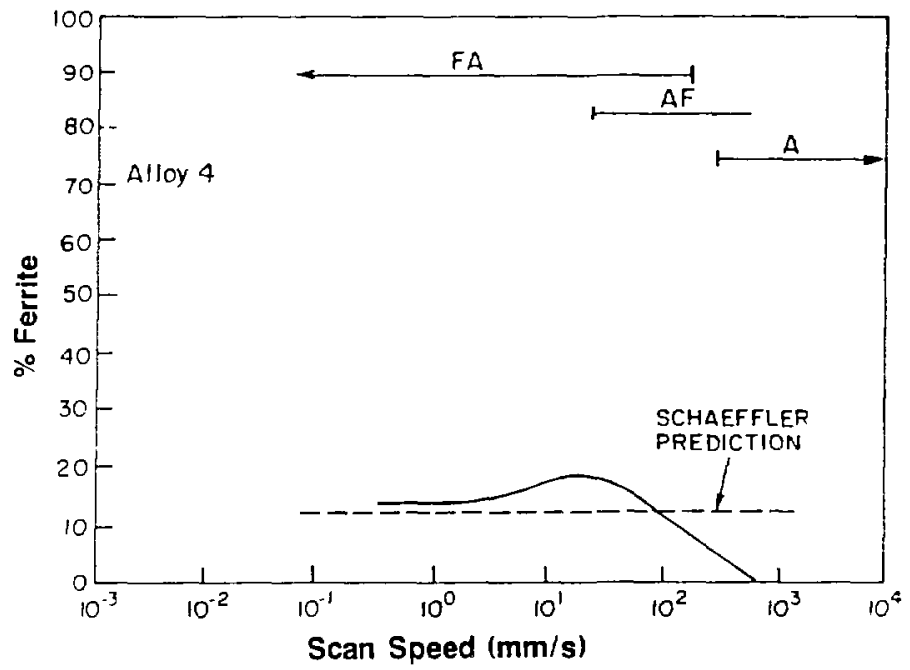

Figure 6.7 The measured ferrite content of Alloy 4 which changes its mode of solidification from FA to AF to $A$ as the sean speed is increased.

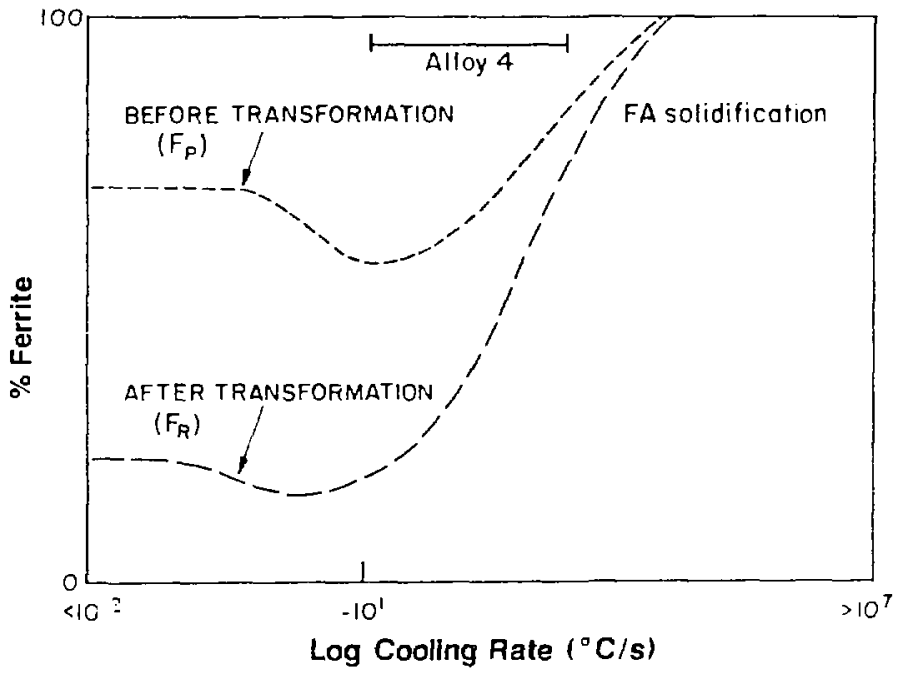

Figure 6.8 The estimated trend of ferrite content for the FA solidification mode as a function of solidification rate. The amount of ferrite that solidifies and the residual fertite, after solid state transformation, are indicated. 
the full! austentic mode of soliditication. The thange in soliditioation modes with sean specid was discussed in Chapter 5 and is shoun in Fig. 5.11.

The separate coneributions of soliditication and solid-state transtormation are schematically shown in Fig. 6.8 for primars lerrite solidilied alloss. This ligure ilfustrates both the amount of ferrite that solidifies liom the melt and the amount of ferrite that transtorms as a function of cooling rate. The ferrite content versus cooling rate behasior passes through a minimum for primary lerrite solidificd alloys rather than a maximum as it did for primary austenitc solidificd alloys and the minimum occurs at an intermediate cooling rate when the highest olume fraction of second phase austenite solidifies. The range of cooling rates wer whish alloy 4 solidifics in the FA mode is indicated on this diagram and vecurs where the amount of lerrite is shown to intrease with cooling rate.

di scan speeds greater than $100 \mathrm{~mm}$ s, the residual ferrite content of Alloy 4 decreases and reaches zero pereent at speeds abouc $500 \mathrm{~mm}$ s. The decrease in lerrite comicnt can not be cxplained by primary ferritc solidification. Examination of the microstructure showed primary austcnitc (AF and A) solidificd regions in the high specd melis. At $100 \mathrm{~mm}$ s, approximatcly $20 \%$ of the microstructure solidilied in the AI: mode but at $2000 \mathrm{~mm} / \mathrm{s}, 90 \%$ of the microstructure solidilicd in the A or AF modes. This change in solidification mode explains the decrease in ferrite content alter the initial increase in ferrite with increasing cooling ratc. The microstructure of Alloy 4 at low and at high scan specds was discussed in Chapter 5 and is shown in Fig. 5.12 .

\subsubsection{Alloy 5}

Allos 5 solidilies in a fully ferritic modo or in an FA mode at fow cooling rates and follows a similar paltern as Allog 4 up to $100 \mathrm{~mm}$. S. However, at higher travel specds. Alloy 5 solidifics only in the full ferritic mode and the low cooling rate portions of the melt undergocs a transformation to Widmanstatten austenite whilc the high cooing rate portions of the melt undergo a transformation to massive austenite. Therelore, the amount of lerrite which solidilies from the nelt in tllog 5 is quate diflerent from that in Allos 4, blet. because of the massise transtormation of lerrite. the residual ferrile content in Allus 5 also decteases at high cowling rates 
The measured ferrite content of Allos 5 is plotted versus scan spect in 1 ig. 69 The solidilication mode is primary ferrite. FA. at sean specds befow $100 \mathrm{~mm}$ s. The lerrite content increases with cooling rate just as in the FA solidilication mode region of Alloy 4. At scan specds greater than $100 \mathrm{~mm}$ s. The solidification mode begins to convert to the fully icrritic mode. At $100 \mathrm{~mm} \mathrm{~s}$ approximatcly $30^{\prime \prime}$ of the melt solidifics in the $F$ mode and these regions are concentratcd sose to the melt periphery. At scan specds of $500 \mathrm{~mm}$ s and higher. $100^{\prime \prime}$ of the melt solidifics in the fully ferritic mode. This transition was discused in Chapter 5 and the microstrustures of the melts are siown in Fig. 5.10.

The massice transtormation only occurs in alloys which solidity in the lulls lerritic mode. If sciond phase austenite is present. FA mode. the austenite provides hetcrogencous nuslcation sites which begin to transform beforc the allos has reached sufficient undercooling to nucleate the massive austenite grains. Alloy 5 becomes fully ierritic at cooling rates of $10^{5}{ }^{\circ} \mathrm{C}$ or greater but the actual ferritc content of Alloy 5 does not show a sharp drop in ferritc content with travel specd. This oceurs because the surface melts do not cool at a uniform rate and allows a perecntage of the melt to transform as massive austenite and the remainder of the nelt to transtorm as Hidmanstaticn austenitc. The percentage of the microstructurc that iransforms into massive austenitc grains increases with cooling rate and ercates a smooth transition betwecn the FA and F modes. This bchavior is responsible for the maximum in the ferritc versus cooling rate curve.

At sean rates greater than $2000 \mathrm{~mm}$ s the ferrite content begins 10 increase. Examination of the microstructure shows that these mel:s also solidify in a fully ferrita mode and that this ferritc also undergocs a massive translormation, howcver. some of the original ferrite is lelt behind in the microstructure becausc only a portion of the ferritc transiorms to austenitc. This behavior will be discussed in more detail in Chapter 8 and is a result of incomplete mising in the high specd surface melts which lease regions of high Cr Ni ratio ferrice that are resistant to the massive translormation.

Figure 6.10 schemationlly shows the behasior of Allos 5 which solidilies as primary ferrice and then undergoss a massice transfermation of ferrite in the lull? ferritic solidified regions. The amoum of ferrite that solidilies liom the mett is the

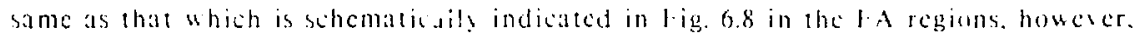




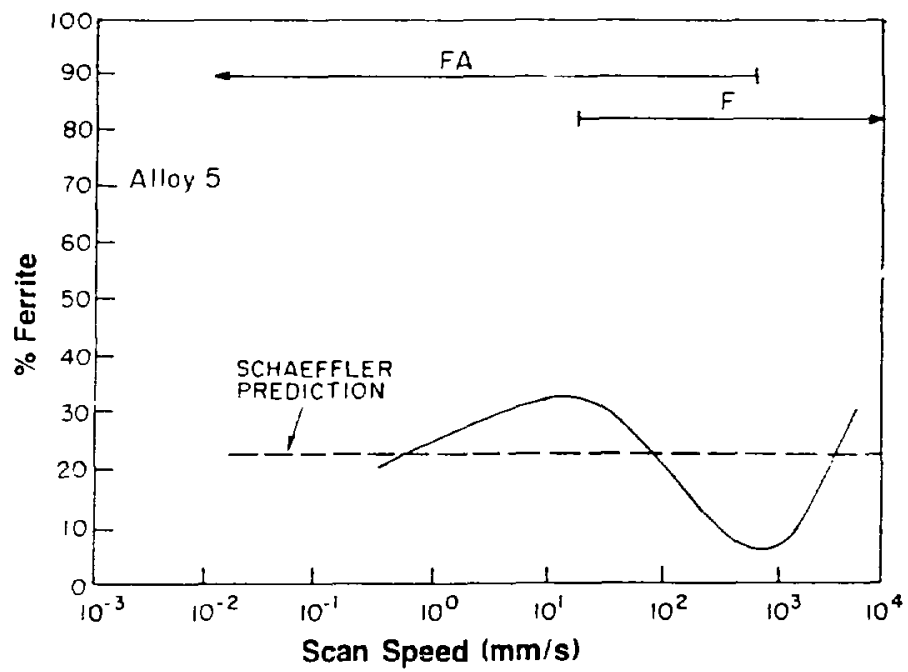

Figure 6.9 The measured ferrite content of Alloy 5 as a function of elcctron beam speed. Scan speeds where massive and Widmanstatten austenite form in the fully ferritic solidified regions are indicated.

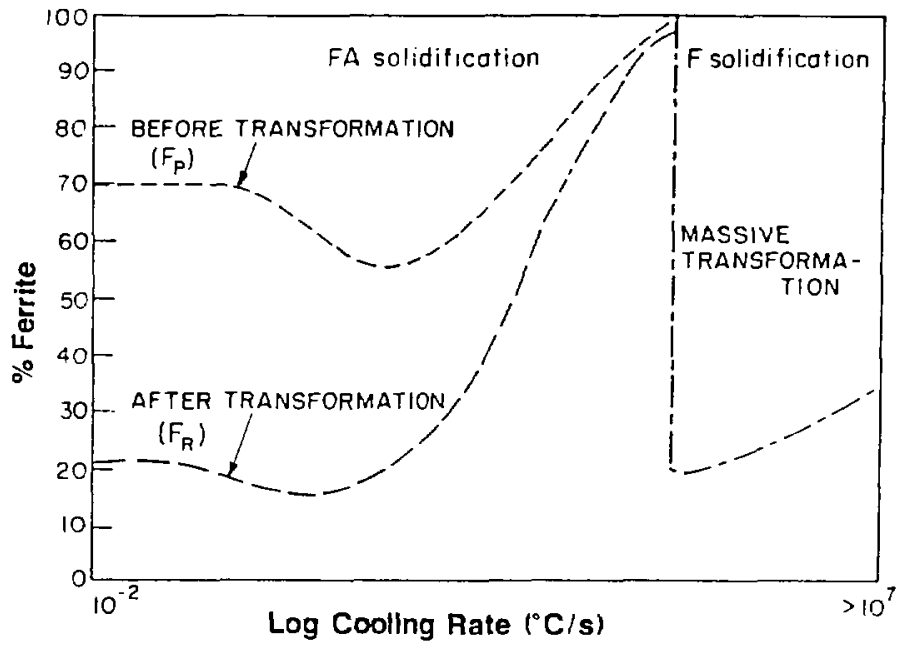

Figure 6.10 The estimated trend of ferrite content in Alloy 5 as a function of scan speed. The amounts of ferrite that solidify and the residual ferrite, after solid state transformation, are indicated. 
because of the change in the solid state transtormation meshanism at high conling

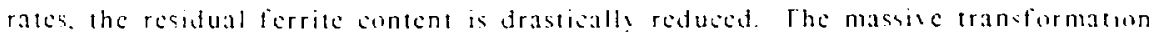

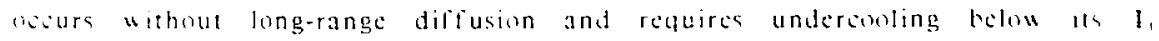

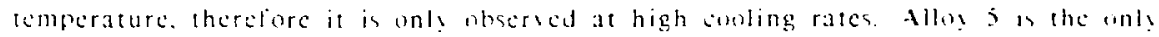

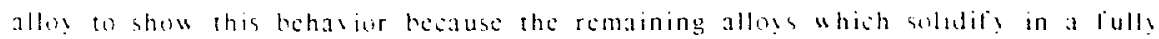
ferrtic mote hase higher Cr Vi ratios and hase ferrite compositions which are stable encugh w present the massic transformation.

\subsubsection{Fully Ferritic Solidified Alloys 6 and 7}

thes: - solidilies in the fulls ferritio mode at all of the rean spocds in in this stud! and slloy 6 solidilics in the fully ferritis mode at son specds greater than $25 \mathrm{~mm}$ s. Inder these conditions, changes in the ferrite content with cooling rate are directs related to the extent of the ferrite to austenite solid state phase transtormation

The ferrite onntent versus scan specd relationship is shown for slluss 6 and 7 in 12. 0.11. This diagram indicates that the residual ferrite content increases lrom its are ast value of about 30\% to 100\% at a scan specd of $6 \mathrm{~mm} s$ in Alloy 7 and 25 $\mathrm{mms}$ in Allos 6. The ferritc contents are compared with the Sehacfler predicted values and show that in the cast condition $(0.7 \mathrm{~mm} / \mathrm{s}$ cquivalent sean spced the ferrite contents are slightly lower than predicted by the Schacfler diagram. This fact has alread! been discussed and is caused by the difference in cooling rates betwecn the castings and are welds. The influcnec of cooling ratc on the microstructure of fully ferritic solidificd allo:s is the best understond of the sascs slusted hecause the amount of ferrite that solidilics from the molt is knoun in be lojow and the average lerrite composition is the same as the nominal allos crimposition

The schematic solidification and solid-state transformation hehatur of these

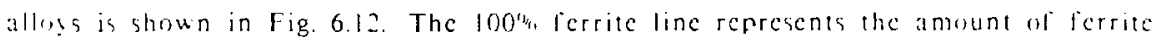
that solidifies from the melt and the residual ferrite is related to the anmunt of time fir the solid state transformation to oceur. at shos conling rates. more time is alliued for the transtormation and a lower ferrite content results 


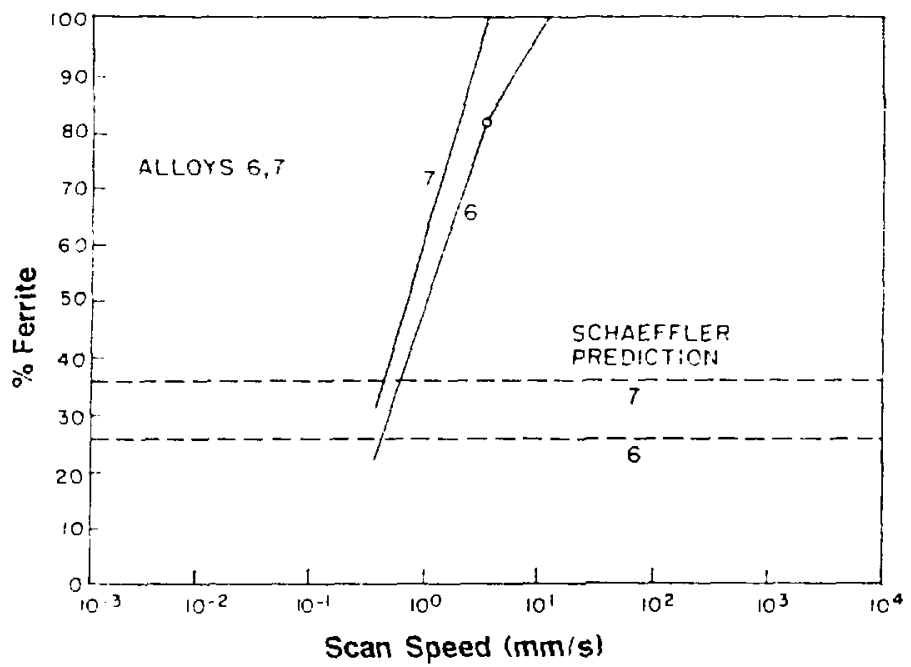

Figure 6.11 The measured ferrite contents of the fully ferritic solidified Alioys 6 and 7 as a function of electron beam scan speed.

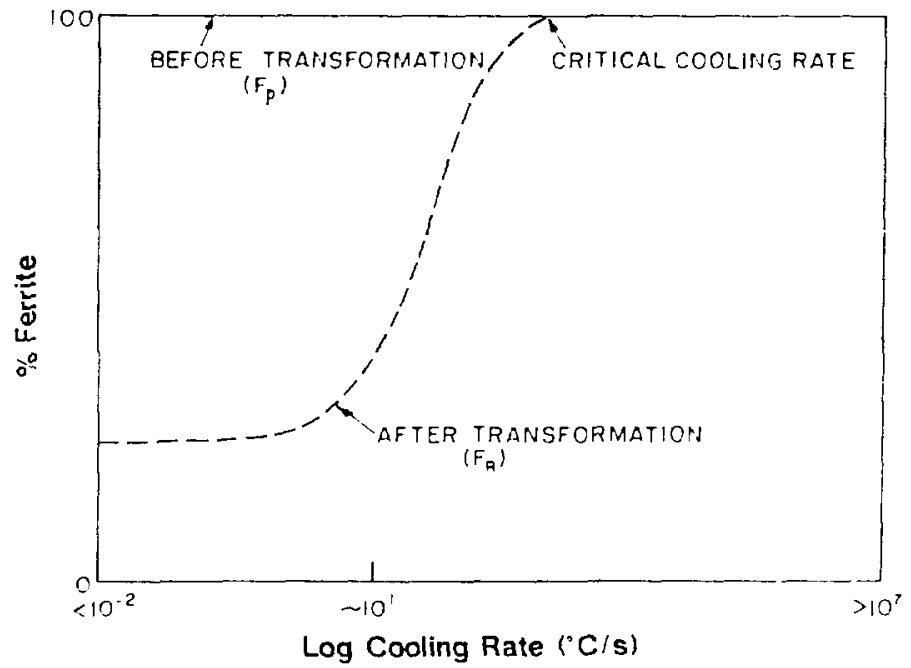

Figure 6.1 2 The estimated trend of ferrite content in fully ferritic solidified alloys as a function of solidification rate. Ihe amount of ferrite that solidifics and the residual ferrite, after solid state transformation, is indicated. 
Therefore. the ferrite content increases with couling rate to the point where no Iransformation decurs and the mierostrueture remains lulls ferritis. The crithal sooling rate "hore transtormation is suppressed is a function of somposition and this sitical cooling ratc decreases with increasing $\mathrm{Cr}$. Vi ratio of the allon

\subsection{Summary and Conclusions}

For allos which solidity in the AF mode. the residual ferrite ountent was shoun to deciease with increasing cooling rate. This behasior is casils coplatined by the decrese in the amount of ferrite that solidifies from the melt as the sooling rate is inserased and a quantitatis analysis of solidifiention segregation will be presented in Chapter - 10 describe this behavior. Figure 0.13 shows that the ferrite content of tllo!s 1. 2. and $i$ which solidity in the AF mole. approaches zero as the scan specd is increased. The measured residual ferrite content of Allos 1 . 2. and 3 is shown in figure 6.14 to confirm this hehavior. The sean rate required to produce lull! austenitic behavior increases with increasing $\mathrm{Cr} \mathrm{Ni}$ ratio of the alloy due to the higher amounts of chromium and nickel 'solute' that are assosiatcd with higher $\mathrm{Cr} \mathrm{Ni}$ ratio alloss. Allos 4 solidilics in the AF mode at scan specds greater than $100 \mathrm{~mm}$. therefore. its ferrite content also approaches zero at the high specds.

Allo: 4. at scan specds less than about $100 \mathrm{~mm}$. and Alloy 5 . at scan specds less than ahout $10 \mathrm{~mm}$ s. solidif! in the FA mode and the amount of ferrite that forms during solidification increases with increasing cooling rate. The approximate amount of ferrite that solidilies from the melt in these alloys is indicated in Figure 6.13. The equilibrim lerrite content is represented at low cooling rates and this figure shows that a smaller amount of second phase ferrite forms at intermediate cooling rates. Houever. this trend is revered at higher cooling rates which leads to a minimum in the ferrite cooling-rate curve. Veither Alloy 4 nor Alloy 5 solidity in the Fa modes at high sonling rates and their solidification behavior beones fully austenitio or iulls ferritic respectivels.

The effect of cooling rate on the solid statc transformation hehasius in the $f$ solidificd alloss is sush that less of the ferrite transiorms as the cooling rate increases. This fact is discussed in chapter 8 by considering hoth the reduction in 
dendrite arm snacing and the reduction in characteristic diffucion distance as the conling rate is increased. Therefore, the residual ferrite of $\Gamma$ a solidificd alloys, shown in Figure 6.14, is reduced more at low cooling rates and this tends in remose the minimum in the residual ferrite versus cooling rate behavior of these afloys.

Alehough Alloy 4 and Alloy 5 solidify with different primary modes of solidification at high cooling rates, their ferrite versus conling rate behavior is similar. This anparent anomaly was related to the formation of massive ausicnite in Alloy 5 at high conling rates which rapidly transforms the ferritc to austenite hecause of its high interface velocity. These aspects will be discussed in more detail in Chapter 8 and since the massive transformation leaves some residual ferrite in the microstructure. Alloy 5 does not approach zero ferrite at high cooling rates.

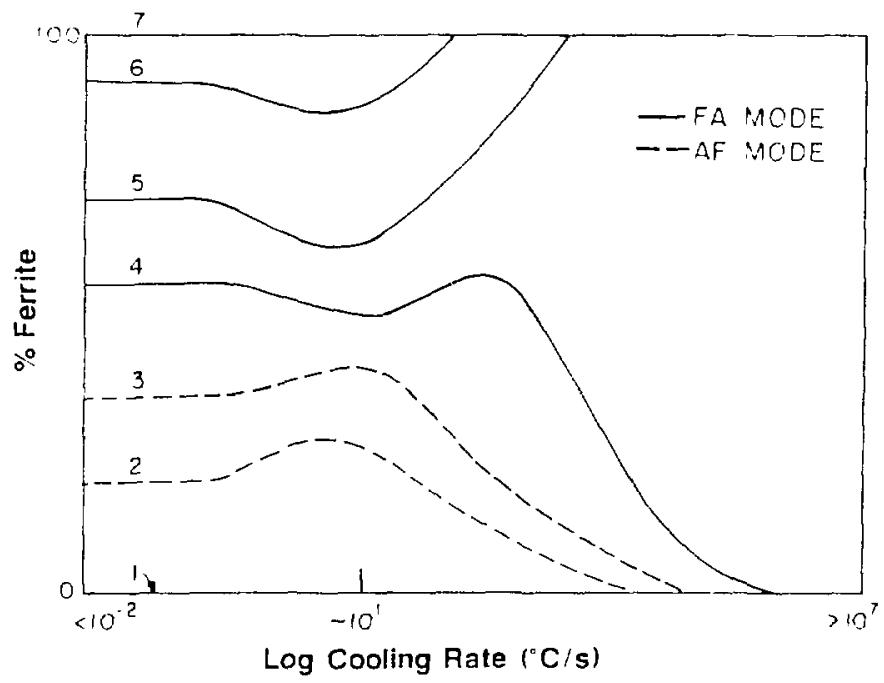

Iigure 6 1 Summary of the catimated irends of the amount of fertite that solidifies for each of the sesen alloys, as a function of eouling at 
Alloys 6 and 7 solidif! in the fully ferritio mode for all of the ennditions studied During cooling. the ferrite transforms by the nucleation and grouth of Widmanstatten platelets. Therefore, the residual ferrite coneent of these allos increases with increasing cooling rate due to the reduced amount of time for grow th of austenite $A$ critical cooling rate was obscred. Where no transformation ocsurs in these alloys This cooling rate is higher for the lower Cr Ni ratio alloys due to the reduced thermodynamic stability of ferrite of the lower $\mathrm{Cr} \mathrm{Ni}$ compositions.

Based on the measured ferrite contents of the clectron beam melts and the metallographic observations of the microstructure. the following conclusions can be made relating the effects of cooling rate to the ferrite content of stainless stecl allo!s

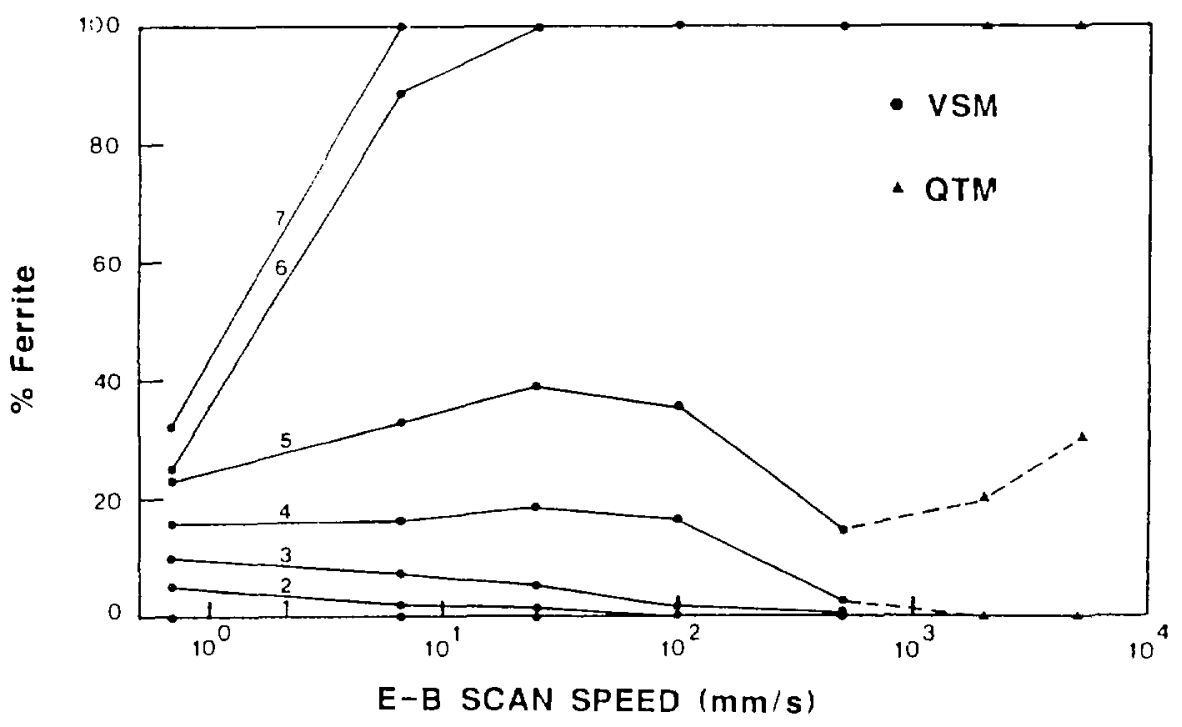

figure 6 1.4 Summary of the measured residual ferrite contents in the seven alloss as a function of electron beam scan specd. 


\section{Conclusions}

1. The composition and the primary mode of solidilication decterminc how the cooling rate will influenec the amount of ferrite that solidifies from the melt.

2. At high cooling rates the alloys solidify in either the fully ferritic or full: austenitic modes with no second phase in the microstructure.

i. At low cooling rates, the residual ferrite content increases for $F$ and $F t$ solidificd alloys but decreases for AF solidified alloys. This hehavior can he cxplained by the combined effects of the decreasing amuunt of solute segregation and the decreasing amount of ferrite irantiomation with increasing cooling ratc.

4 Based on conc.usions 2 and 3 , one would expect the ferrite content in the alliph to either increase towards the fully ferritic condition or descase amwardi the full! ausicnitic condition as the cooling rate increases. Howerer. the resilual ferrite sontent of Alloys 4 and 5 goes through a maximum at intermediate cooling rates. This behavior was cxplained by 1) the change in solidification mode of Alloy 4 from FA to AF with increasing cooling ratc and 21 the formation of massive austenite in Alloy 5 at high cooling rates. 


\section{CHAPTER 7}

\section{The Influence Of Cooling Rate On Solute Redistribution And Second Phase Formation}

The preceding chapters investigated the cffects that cooling rate and oumposition have on the firrite contem and morphology of resolidified stainless stecl alloss. For the most part. the results were enpirical and were based on the observations of the clectron beam auriace melts. This chapter takes a more fundamental aproach. by studing the clies of colling rate on the factors which are responsible lor soliditication segregation

Mistogegregation ean be modeled sufficiently well to predict the influence of cooling rate on solute redistribution in binary alloy systems [7.1]. The factors which inlluence mierosegregation include the physical properies of the alloy, the solidilication parameters and the kinctic response of the system. all of which are known or an be estimated in nany binary alloy systems. In ternary alloy systems, such as the re-vi-Cr. the redistribution of solute during solidilication is mush more difficult to model and to verify besausc of the lack of information about the behavior of ternars alloys.

The difficultics associated with predisting misrosegregation in cornary alloy systems are related to the lack of information about the solidilication parameters. For cxample. the ternary component gives the system an additional degrec ol licedom Which leares the solidilication path unspesilicd, therefore, it must be determined experimentally or cstimated by solidilication modeling. Methods in predict the solidification paths in the Fe-vi-Cr system will be presented in the first section of this shapter and unce the solidification path has becn cstablished. the remaining paramers whith influcnec solidificaion can be determined from the caullibrium phase diagram.

Predisting the amount of microgegregation imolves other difficultics as acll. Interface instablitics leading to ecllular or dendrite growth necd to be laken into aciount and the solute redistration models are hased on assumptions which have to 
be carefully justified. These factors were studied in the Fe-Ni-cr ternary system and the results were used to salculate solute redistribution as a luncion of interlatio velocity for the clectron-bcam surface-melted alloys. The solute redistribution calculations incorporate undercooling at the dendrite tip using a constrained dendritic growth model and the results were used to predict the amount of primary and second phase ferrite that solidifics in each alloy as a function of clectron heam saan specd.

The solidificaton segregation model predicts the amount of ferrite that firms during solidification but does not incorporate the eflects at the solid state transformation that occurs in the low sooling rate melts. Therelore. the calculated fertite contents represent an upper bound for the residual ferrite comrent and this upper bound provides a useful starting point for understanding microntructures whish derclop in resolidified stainless steel alloys. In addition. the dendrite tip calculations san be used to predict the solidificaton conditions that lead to the undercouling necessary for the growth of metastable phases by comparing the underowing at the dendrite tip with the thermodynamically calculated equilibrium and metastable phase diagrams.

\subsection{Solidification Paths and Parameters in the Fe-Ni-Cr System}

During the solidification of binary alloys, the composirion of the solid and liquid phases are given by the solidus and liquidus lines respectively. Therefore. the solidification path and tic lincs are known by virtue of the fact that the Gibbs phase rulc allows zero degrees of frecdom for two phases in cquilibrium at constant icmperature and pressure.

If a third component is added to the system. two phases will be in cquilibrium at constant temperature and pressure but onc degrec of frectom still cxists. Ihis compositional degrec of frecdom extends the liquidus and solidus lincs into surfaces. The tic lines which join the liquidus and solidus surfaces arc not fixed in ans given temperature-composition plane and arc not known a prme. Therefore, withui knowledge of the tic line locations. the path that the solid and liquid compositions follow during solidification is also not known. 
Fortunately, thermosynamic ealublation of phase cquilibria in cernary allos systems has been refined to the point where tie lines can be predicted in mans: systems. These types of salculations will be briefly summarized in this section and results will be presented "hich show the location of tie lines and solistication paths for the alloys studicd in this investigation. From these solidification paths. pscudubinary diagrams will be determined to represent the solidification behasior of cach allos and the solidification parameters ean be decermined from ahese diagrams.

\subsubsection{Solidification Paths}

lowthermal sections "ere calublat in the Fo-Ni-Cr system using the Thermovals soltudre package. Detaits of the computations and plots of the isothermal scotions are summarized in Appendix C. The results of the calculations give information regardi.2g phase cquilibia. insluding tic lines in all of the two-phase regions. for tomperatures ranging from $1023 k$ is : se melting point of chromium.

From a soliditication standpoint the most important isothermal sections are those which are slose to the liquidu: tomperature. Figure 7.1 shows the $14120 \mathrm{C}$ isotherm and illustrates tie tie line locations for primary austenite and primary lerrite solidification. The Fe-Ni-Cr system has a small tempeature difference between the :iguidus and solidus and the oricntation of the tic lines docs not shange significantl! from the beginning to the end of soliditication. Thereforc, ihese tic lines can be used w approximatc the solidifisation path because segregation will be in the general tic line "direction" until the remaining liquid reashes the line of twotold saturation. At this temperature, the liquid eomposition follows the line of two-fold saturation while three phases (liquid. austenite and lerrite) cocxist until solidification is completed al

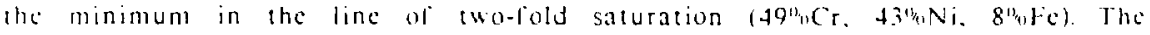
solidfication paths for allog I (primars austenitc) and allos T (primary ferrite) are

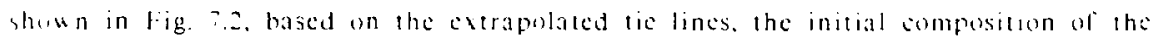
allus and the line of ixo-lisld suturation [1.32].

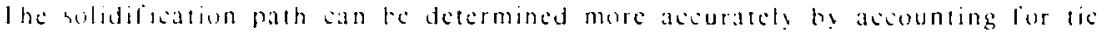

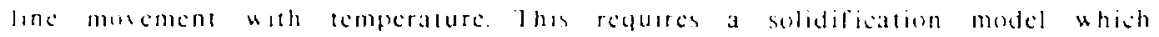

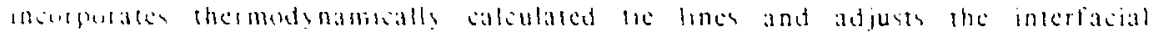


compositions as a function of solidification icmpcrature. One iuch model was developed by Kundrat [7.2, 7.3] and utilizes the Scheil approximation to represent solute redistribution. Kundrat's model was used to calculate solidification paths for alloys 1 and 7 in the Fe-Ni-Cr ternary system [7.4] and these paths are shown in Fig. 7.3. Also plotted in this figure are the tic lines piedicted by Thermocale to show that the two methods of predicting the solidification paths give similar results. The closeness of these estimations is related to the natrow separation between liquidus and solidus temperatures and the fact that the tie-lines generated by Kundrats model are nearly identical to those generated by Thermovale.

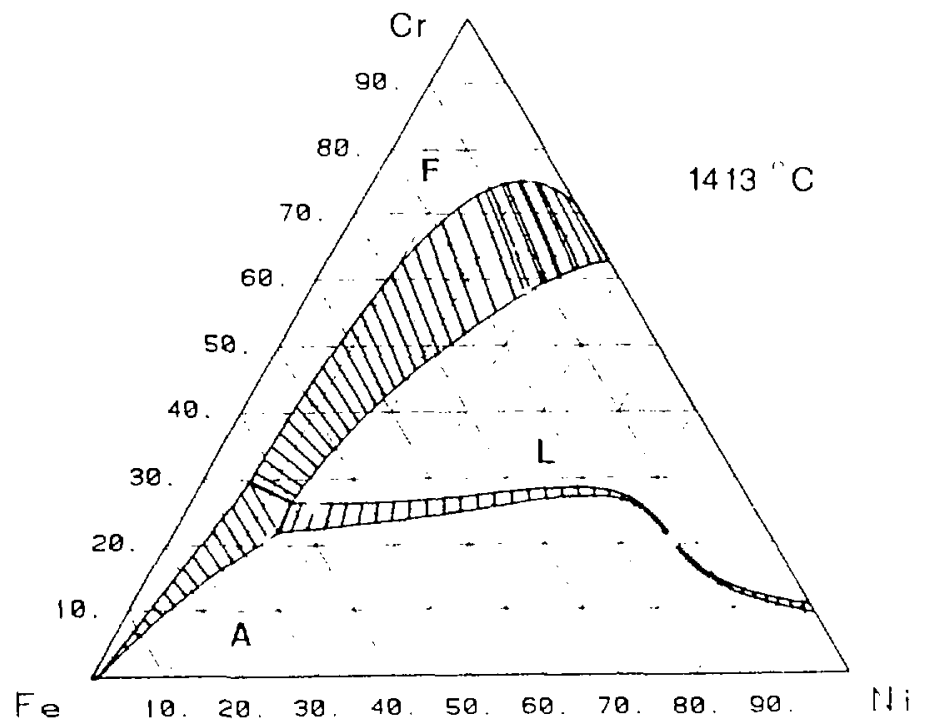

Higure 7.1 lhernodynamically calculated isothermal section through the

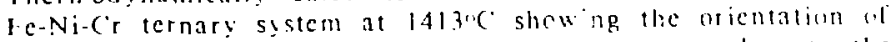
tie-lines in the two-phase regions at temperatures close in the solidificatior range of the seven alloys. 
Figure 7.2 shows that the solidification paths do not curve significantly from the initial solidification composition to the composition where the liquid reaches the line of two-fold saturation. Therefore, the solidification paths can be approximated by straight lines which is fortunate because it allows the ternary alloys to be treated in a manner similar to that of binary alloys. The pseudobinary diagram, which represents the solidification behavior along these paths, can be determined by plotting the temperature-composition vertical plane containing these paths.

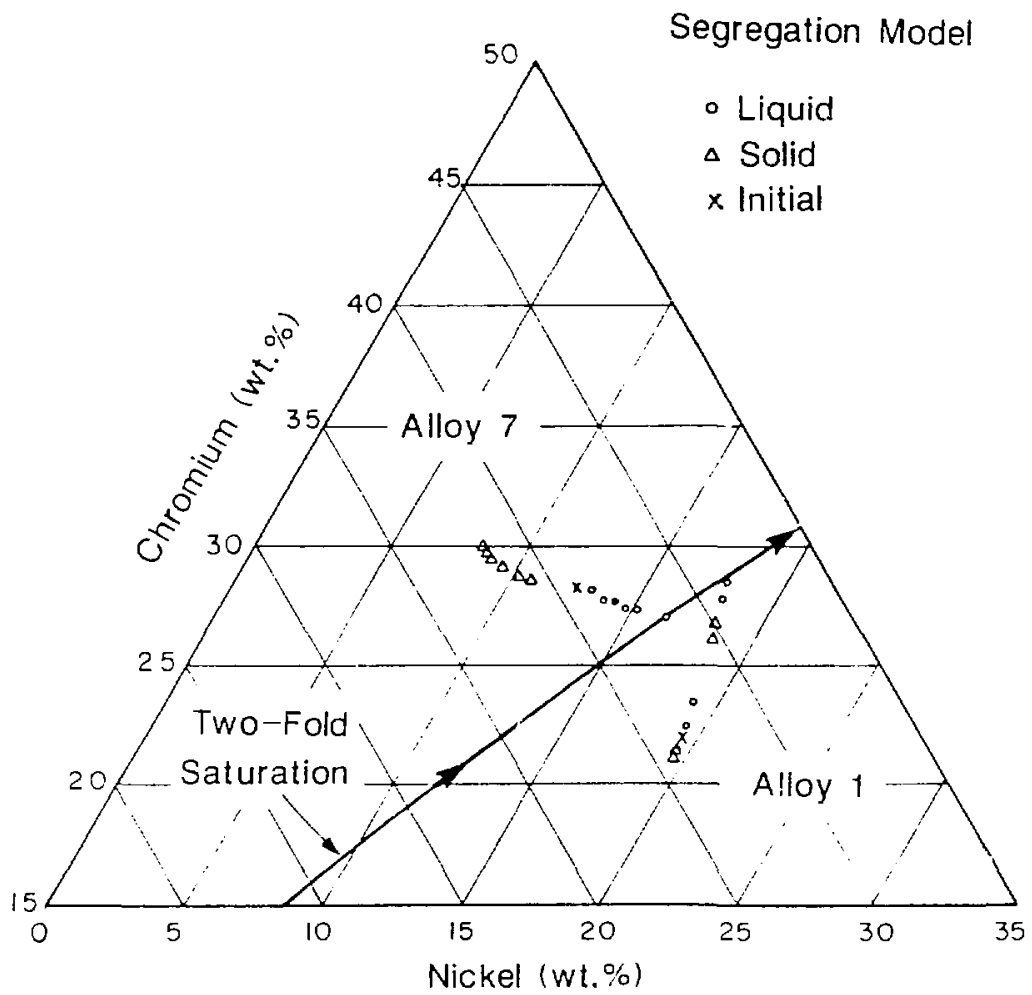

Figure 7.2 Solidification paths ror Alloys 1 and 7 estimated from the linear extrapolation of the tic lines shown in Figure 7.1 . 


\subsubsection{Pseudobinary Diagrams to Represent Solidilication Behas ior}

Pscudobinary diagrams were decermined for prinary austenite and primars ferrite solidification behavior using the thermodynamically calculated isothermal phase diagrams and the solidification paths presented in Fig. ?.3. These diagrams are shown in Figures 7.4 and 7.5 and represent the solidification bchavior for primary ferrite and primary austenite solidificd alloys that contain 59 wt. Fe. Constant Fe vertical sections have been ased in the past to estimate the solidification behavior of stainless stecl alloys by many investigators. However. these diagrams do not accurately

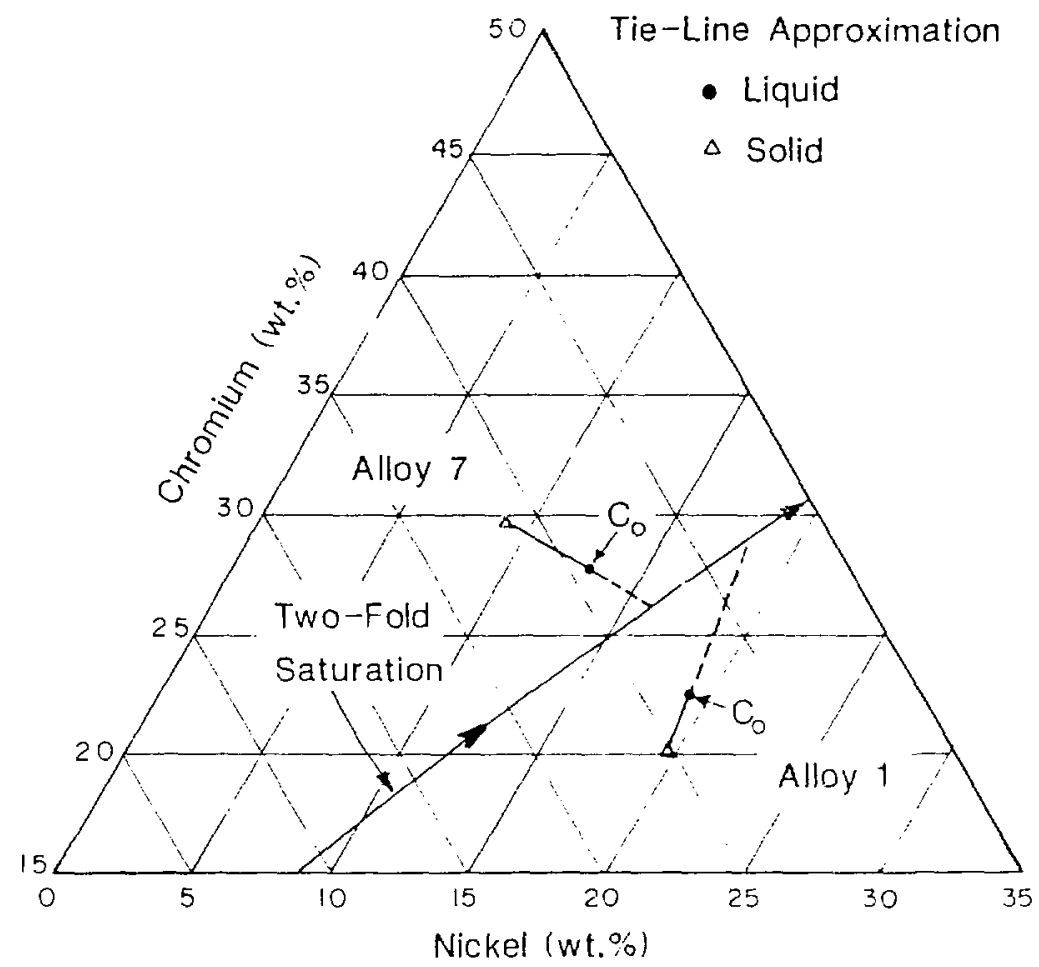

Figure 7.3 Solidification paths for Alloys 1 and 7 calculated by solidification segregation modeling. 
represent the soljdifieation segregation since the tic lines in the $1+5$ phase fields do rot lic in the constant Fc plane. B! choosing the vertical sections presented in Figures 7.4 and 7.5 to lic atong the solidilioation path, the tic-lines also lic in these planes. Thercfore. the diagrams presented in Figures 7.4 and 7.5 aceurately represent the solidification behasior of primary ferrite and primars austenite solidilication conditions. These nes diagrams are ignilicant improsenents or the constant Fo vertical sections used in the past.

Partition ratios, $k$, and the slope of the liquidus surlace. mi. . an be determincel for $C r$ and lor li partitioning from the pscudobinars diagrams using the following cquations [?.5]:

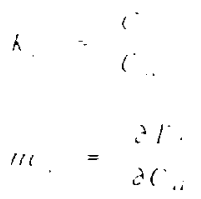

where l. reters to liquid. the subseript $i$ denotes $\mathrm{Cr}$ or $\mathrm{Ni}$ and the substript idenotes the austenite or ferrite phases. The other nomenclature which are used in this chapter are summarized in Table 7.0. Figure 7.4 san be used to calculate h and $m_{1}$ for Alloy 1 (primary austenite) where the subseript j denotes the austenite phase while Figure 7.5 can be used to calculate $k$ and $\mathrm{m}_{\mathrm{L}}$ for alloy 7 primary ferrite) where the subserim j now denotes the lerrite phase.

Since the liguidus and solidus lines along the solidification paths are nearly lincar with composition. $k$ and $\mathrm{m}_{\mathrm{L}}$ can be treated as constant throughout the solidificalion prosess and their numerical values are summarized in Table 7.1 . Sinco the inilial compositions of the primary austenitc solidilicd alloys $(1,2,3)$ are similat it san be assumed that $k$ and $m_{L}$ will not be significantls different lor allogs 1.2 and 3 . Likewise. the compositions of the primary ferrite solidilied alloys (4.5.6.7) are similat and should have similar solidification segregation behasior. Therefore. the values of $k$ and $m_{L}$ calculated for allos 1 can be used to represent the behasior of alloss z and 3 while $k$ and $\mathrm{m}_{\mathrm{l}}$, salsulated for alles 7 ean be used to represent the behas of of alloss 4.5 and 6 . 


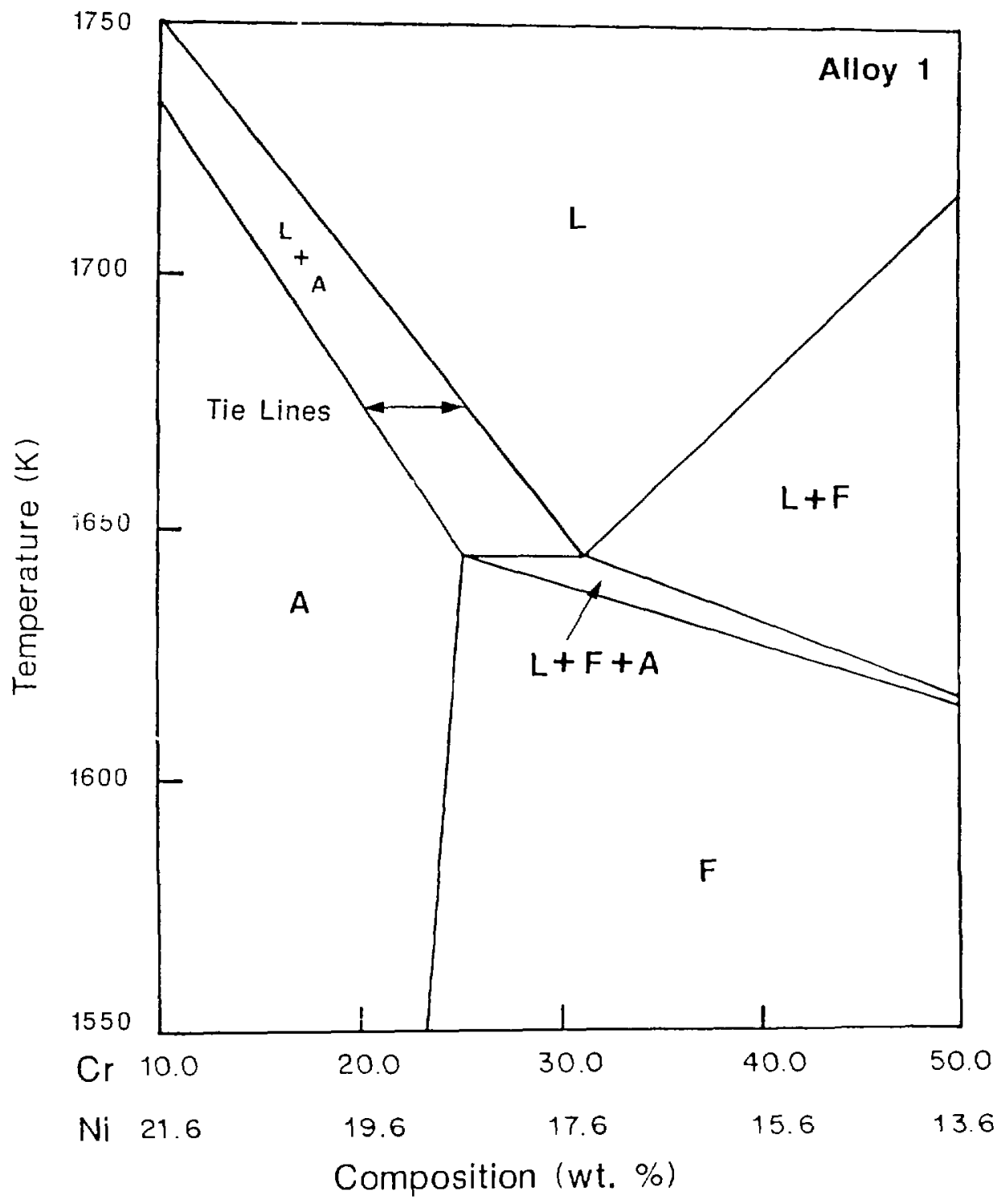

Figure 7.4 Pscudobinary diagram along the solidification path of Alloy l, based on thermodynamic calculations. The solidilication behatior of primary austenite solidifici alloys is represented for chromium contents up to 31.5 wt?. 


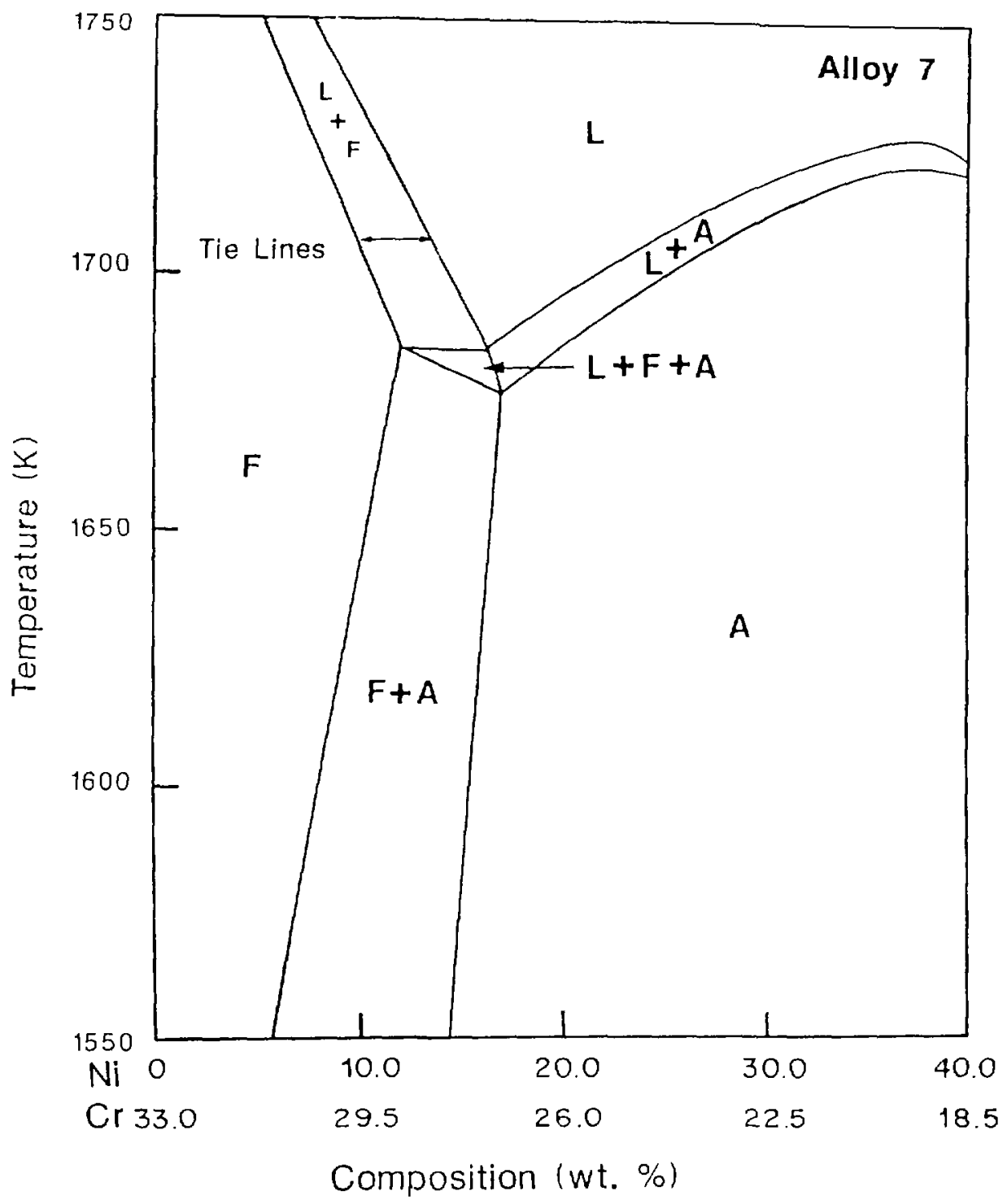

Figure 7.5 Pscudobinary diagram along the solidification path of Alloy 7 , based on Thermodynamic calculations. The solidification behavior of primary ferrite solidified alloys is represented for $\mathrm{Ni}$ contents up to 16.3 wt.\%. 
Table ? 1 Partition cocticients and the slope of the liquidus lines for primary ferrite and primars austenite solidificd alloss.

\begin{tabular}{|c|c|c|}
\hline Primary Phase & Quantit! & Valuc \\
\hline \multirow{4}{*}{ Ferrite } & $\mathrm{n}_{3} \mathrm{~F}_{\mathrm{L}-\mathrm{Cr}}$ & $13.14 \mathrm{C} " \mathrm{nCr}$ \\
\hline & ${ }_{n} F_{L} \cdot N$ & $-7.410 \mathrm{C} " 1 \mathrm{Ni}$ \\
\hline & $\mathrm{h}_{\mathrm{Cr}}$ & 1.10 \\
\hline & $\mathrm{b}^{\mathrm{F}} \mathrm{N}_{3}$ & 0.74 \\
\hline \multirow{4}{*}{ Austenite } & $\mathrm{m}^{\mathrm{A}} \mathrm{L}, \mathrm{Cr}$ & $-5.6) \cdot \mathrm{Cr}$ \\
\hline & $\mathrm{n}^{\mathrm{A}} \mathrm{L}, \mathrm{Ni}$ & $12.4 \mathrm{C} " \mathrm{nCr}$ \\
\hline & $\mathrm{HACr}$ & 0.80 \\
\hline & $\mathrm{h}^{\mathrm{A}} \mathrm{Ni}$ & $1.0 j$ \\
\hline
\end{tabular}

Another estential solidification parameter is the composition that corresponds to the line of wo-foid saturation of the liquid with respect to ferrite and austenite, $C_{E}$. When the liguid somposition reaches this point then a second solid phase begins to cosolidity with the primary phasc. Since $C_{E}$ is the intcrscction of the solidilication path and the linc of two-fold saturation. cach alloy has a diticrent $C_{E}$ composition. Assuming the solidilication path 'dircetion for alloys 2 and 3 are parallel to alloy 1 and that the solidilication path dircation for alloys 4.5 and 6 are parallel to allus 7 . $C_{E}$ an be determined for cach alloy. Figure 7.0 show's the solidilication paths for the seren alloys and their intersection with the line of two-fold returation. Compositions al Ce for eaci of the scren alloys arc listed in Table 7.2 .

In summary, the 'lincar' soliditiation paths which where dacrmined in section 7.l.1 allowed pseudobinary diagrams to be decominci fur primary astenite and primary ferrite solidification. These diagrams were used to predict values of $k$ and $m_{L}$ for $\mathrm{Cr}$ and $\mathrm{Ni}$ partitioning for primary austeniti and primary ferritc solidilication behasior. The composition of the liquid where the second phase lirst l:yins to develop during solidification was also decemince for cach allog by the cersection of the solidification path with the line of cmo-pold saturation. These solidification parameters will be uscal in lollowing secions of quantily solute redistribution during solidification. 
Table 7.2: Nominal, cutectic and maximum solid compositions iwt."ial.

\begin{tabular}{|c|c|c|c|c|c|c|c|}
\hline \multirow[b]{2}{*}{ Alloy } & \multirow{2}{*}{$\begin{array}{l}\text { Primar: } \\
\text { Phase }\end{array}$} & \multicolumn{2}{|c|}{$C_{0}$} & \multicolumn{2}{|c|}{$\mathrm{C}_{\mathrm{E}}$} & \multicolumn{2}{|c|}{$C s, M$} \\
\hline & & $\mathrm{Cr}$ & $\mathrm{Ni}$ & $\mathrm{Cr}$ & $\mathrm{Ni}$ & $\mathrm{Cr}$ & $\mathrm{Ni}$ \\
\hline 1 & \multirow{3}{*}{ Austenite } & 22.0 & 19.0 & 31.0 & 18.0 & 25.0 & 18.5 \\
\hline 2 & & 23.7 & 17.3 & 28.0 & 17.0 & 24.0 & 17.1 \\
\hline 3 & & 24.6 & 16.4 & 26.2 & 16.1 & 22.0 & 16.6 \\
\hline 4 & \multirow{4}{*}{ Ferrite } & 25.4 & 15.6 & 25.5 & 15.9 & 26.8 & 11.8 \\
\hline 5 & & 26.6 & 14.4 & 26.0 & 16.0 & 27.5 & 12.0 \\
\hline 6 & & 27.4 & 13.6 & 26.5 & 16.1 & 28.0 & $: 2.1$ \\
\hline : & & 27.8 & 12.8 & 27.0 & 16.3 & 28.5 & 12.2 \\
\hline
\end{tabular}

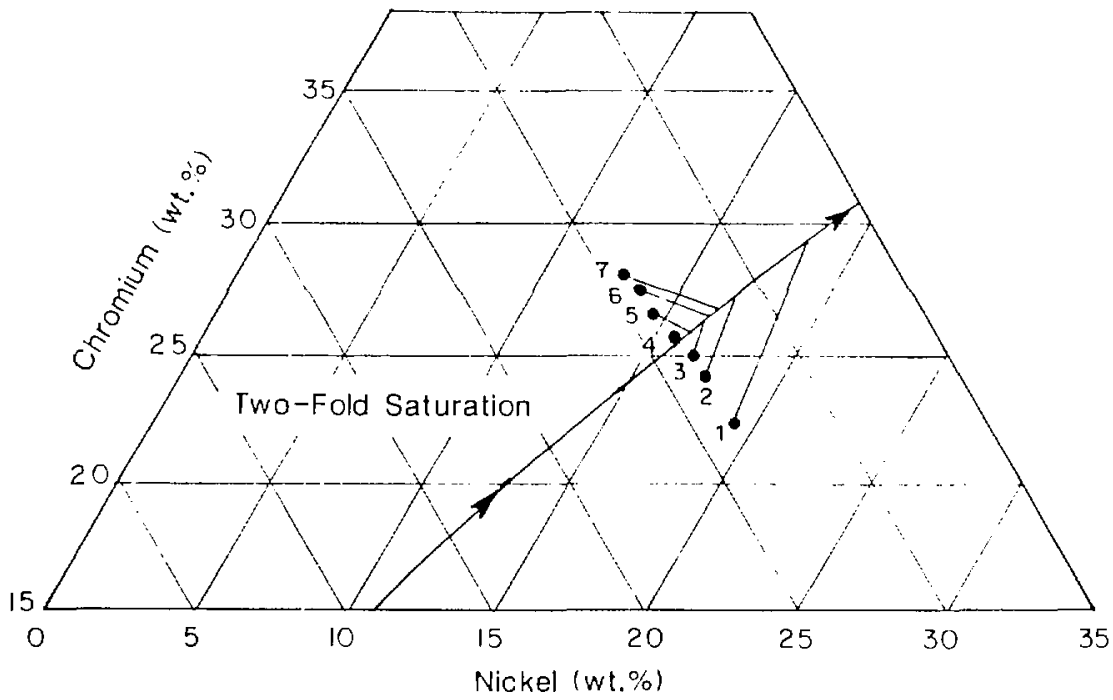

Figure 7.6 The estimated solidification paths and the intersection of these paths with the line of two-fold saturation, for the seven Fe-Ni-Cr alloys. 


\subsection{Interface Stability}

During plane front solidification, the liquid solid interface is assumed to be a smooth planc tratcling in a dircetion normal to its surlace. A solutc-rich boundary laser builds up ahead of the interlace and this contiguration is stable at low growtir rates, R, and high temperature gradients, G. Howeser, typical castings, welds and surtace melts solidily by a cellular or dendritic mode rather than by a plane front. Constitutional supercooling. causcd by ahe solute-rich boundary layer, is responsible for instabititics in the plane-tront that lead to collular dendritie growith. Since this theory is well dereloped it will only be brielly discussed here.

The conditions newcssary to cause instabilitics in the planc front are related to $G$, $R$ and the alloy propertics $k, C_{0}, m_{L}$, and $D$ by the following equaion [7.5]:

$$
\therefore / K=\frac{-m,(2)(1-h)}{k i)_{i}}
$$

Where $D$ relers to the dilfusivity and the subseript $L$ refers to the liquid. If the above incquality is satisficd, solidification will take place via a plane-front. If the incquality is not satisficd. the interface is unstable but cquation 7.3 only indicates that instability is present and does not relate any further information about the details of thi L. Sinterlace.

In 1963. Mfullins and Sckcrka [7.6] provided a rigorous solution to the dynamics of the $L S$ interlace in a constitutionally supercoolcd liquid. They analyzed the conditions under which a small sinusoidal perturbation will grow or shrink by taking into account solute and thermal riclds. L/S surface energy a, and tinctics of the interface. Their results incorporate the solidification parameters and alloy propertics and reliac the stability critcria presented in cquation 7.3 .

Mullins and Sekerka predict a transition from plane front to the cellular mode as the growth rate is increased. They also predict a rescrse transition from celluiar to planc front at high $(>1.0 \mathrm{~m} / \mathrm{s})$ growth rates. This reversion to planc frons solidification is termed absolute stability and is caused by the reduction in dendritc arm epacing at high rates. The small dendrite arm spacing, and associated small dendrite tip radius, give the interface a high surlace area. This factor increases the surface energy of the interface which opposes the driving forec produced by 
constitutional superooling. Therefore, a lower limit is placed on the dendrite arm (ecll) spacing when these rwo elfeets are equal and below this limit, the interlace becomes planar.

The aboue mentioned stabilit: eritcria have hes introduced to illustrate the three incerchated solidilicarion parameters which are important to the stability of the intertace: the grouth rate $R$. the temperature gradizn ; and the dendrite tip radius $r_{t}$. Jhe extent to which these bators are hnown depends on the soliditication process. Fir cample, during the surface resclidifiention experiments performed in this study. $R$ an he estimated from the imposed scan velocity of the electron beam. however. C; and $r$, must be saludated liom first principles.

In the lublowing section. methods for estimating $R$ and for calculating $G$ will be applied to the difierent solidification conditions used in this study. From these data. $r_{t}$ will be alieulated and used to predict undercooling at the dendrite tip.

\subsubsection{Growth Rate and Temperature Gradient}

The gromith rate is detined as the local rate of advance of the liquid solid interlace. For surface resolidificd melts. the quasi-stcady-statc heat flow assumptions uere discussed in Chapter 4. These assumptions allow the $L$ S interiace shape to be treated as constant. therefore, the growth rate can be cstimated from the trasel specd. S, and the ueld pool shape.

For a given quasistationary surface melt, growtt rates vary from zero to a maximum baluc which can not cxeced the travel specd of the source. Variations in growth rates around the melt pool surlace were shown in Chapter 4 to be related to shanges in the solidifieation direction with respect to the dircetion of the heat source. Although the growth rate varics from 0 to a maximum of $S$, the majority of the $L$ interface moves at some intermediate grouth rate. This "average" growth rate of a given weld can be approximated from the geometry of the molten zonc and aan be determined by metallographic cxamination of the resolidificd zonc.

At slow travel speeds, the width of the fusion zone is smaller than its depth and the growth direction is predominantly across the width of the weld. For these conditions, the surface topography of the resolidificd melt can be used to cstimate the 
growth rate. The , angle "hish represents the trating edge of the molt poul and is whersed on the surlace of resoldiditied molts is illustrated in Jig. 7.7 lhe angle of

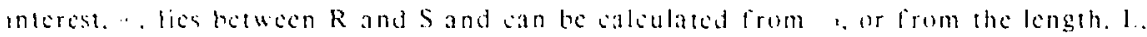
and the width. W. Wh the following geometric equation:

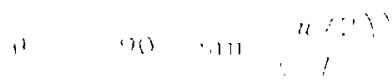

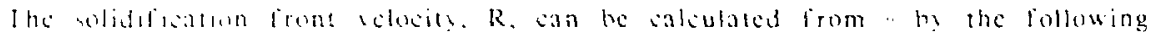

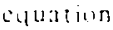

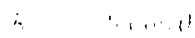

$(\therefore$,

"here - represent the atcrage solidilication rate of the melt.

A high iracl apects the depth heomes smaller than the with and the grouth

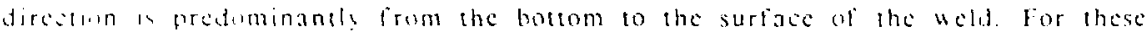

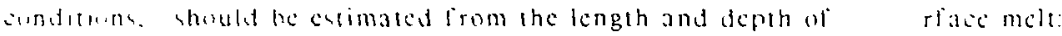

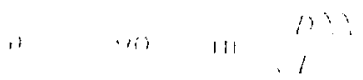

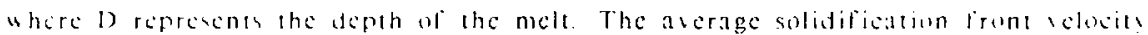
an then he saliulated for these sonditions using eqn. 7.5 .

The aserage length. Width and depth of the surface melts perlormed in this

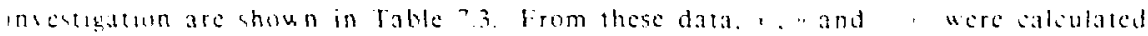

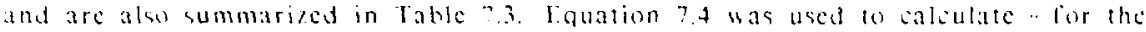
lum sreed meles 1. a and 3 while cquation 7.6 was used to saleulate for the high

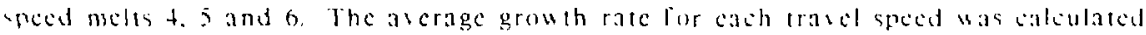
lim sond "using cquation 7.5 . 


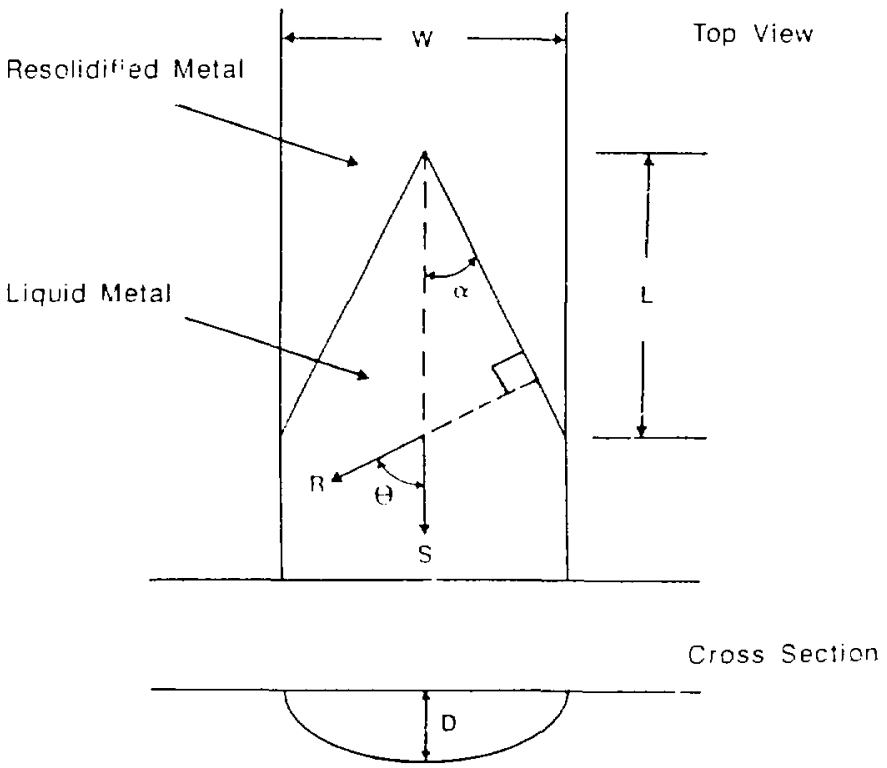

Figure - Schematic representation of a surface melt shouing the relationship between the travel speed, $S$, melt geometry and the interfacial velocity, R.

I able 2.3 Held pool dimensions and average interface velocity for each of the six clectron beam surface melting conditions.

\begin{tabular}{|c|c|c|c|c|c|c|c|}
\hline Mclt & $\begin{array}{c}\mathrm{S} \\
(\mathrm{mm} \mathrm{s})\end{array}$ & $\begin{array}{c}W, 2 \\
(\mathrm{~mm})\end{array}$ & $\begin{array}{c}\mathrm{L} \\
(\mathrm{mm})\end{array}$ & $\begin{array}{c}\mathrm{D} \\
(\mathrm{mm})\end{array}$ & $\begin{array}{c}0 \\
(\mathrm{dcg})\end{array}$ & $\begin{array}{c}\text { cos } 0 \\
(\mathrm{~mm} \cdot \mathrm{s})\end{array}$ \\
\hline 1 & 6.3 & 2.5 & 5.4 & 5.3 & 31 & 0.86 & 5.4 \\
\hline 2 & 25 & 1.5 & 5.8 & 3.1 & 76 & 0.26 & 6.5 \\
\hline 3 & 100 & 0.8 & 5.1 & 1.1 & 81 & 0.16 & 16 \\
\hline 4 & 500 & 0.63 & 2.0 & 0.20 & 84.3 & 0.10 & 50 \\
\hline 5 & 2,000 & 0.60 & 0.80 & 0.040 & 89.62 & 0.08 & 100 \\
\hline 6 & 5,000 & 0.50 & 0.55 & 0.008 & 89.92 & 0.02 & 175 \\
\hline
\end{tabular}


The average calculated growth rates were shown to vary from 5.4 10 $175 \mathrm{~mm}$ s lor variations in travcl specd from 6.3 to $5000 \mathrm{~mm}: \mathrm{s}$ respectivels. The $5000 \mathrm{~mm}$ s melt was too shallow to metallographically cxamine for its melt pool length. Thereforc, its length was initially assumed to be equal to the radius of the clectron beam spot Table 2.4 gives this radius as $0.55 \mathrm{~mm}$ and using this value, an average interiace velocity of $100 \mathrm{~mm}$ s was calculated. However, this value of $R$ is questionable sines there was no apparent increase in velocity as the travel speed wa inereased irmm 2000 to $5000 \mathrm{~mm} \mathrm{~s}$. Therefore, the average interface velocits fur the $5000 \mathrm{~mm}$ speed melt was estimated by extrapollating the $S$ versus R behaviur wi the filv 5 melts. This gave the average interface velocity of $175 \mathrm{~mm} 5$ whish w reportid in Table .3

lt is apparent tha, at the high travel specds, the shallow natus: i the sulli: melt reduses the growth rate substantially. This last has sometime land ignored by other investigators who have used ejther the travel speed or the islest cstimlted

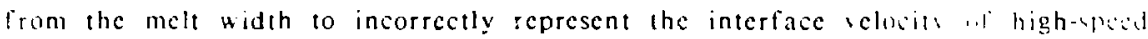
directed-energy resolidified melts. The maximum interface velocit! high speed elcctron beam melts in this study was only $175 \mathrm{~mm} 5$ which is not hugh cnough to produce the conditions necessary for partitionless solidification

Equation 44 was used to determine the average temperature gradicnt surrounding the clectron heam melts produced in this investigation. As discussed in Chapter 4 , this equation relates $R, G$ and ite cooling rate. Assuming the temperature gradient is in the direction of heat flow. $G$ is normal to the $L$ 'S interlace and $R$ can tic assumed to be in this same direction. Thereforc, the average cooling rates which were estimated fy the dendrite arm spacing measurements in Chapter 4 and $k$ which was ealculated above from the melt pout geometry were used to determine the average remperature gradient on the L, S interface:

$$
C=\stackrel{r}{R}
$$

l'sing this relationship. s was calculated for each surface meli and thesc values are summarized in Table 7.4 . 
Table ? A Acrage temperature gradicnts during solidification of the 6 clcctron bean meles.

\begin{tabular}{|c|c|c|c|c|c|c|}
\hline Mclt & $\left(12 C^{\circ} s\right)$ & $\begin{array}{c}R \\
(\mathrm{~m}+\mathrm{m} s)\end{array}$ & $\begin{array}{c}C \\
(\alpha \mathrm{C})\end{array}$ & $k_{1} / k^{\prime}$, & $G:$ & $G$ \\
\hline 1 & $4.7 \times 10^{2}$ & 5.4 & $8.7 \times 10^{1}$ & 0.4 & $6.1 \times 10^{1}$ & $1.5 \times 10^{2}$ \\
\hline$=$ & $1.9 \times 10^{3}$ & 6.0 & $3.3 \times 10^{2}$ & 0.5 & $2.5 \times 10^{2}$ & $4.9 \times 10^{2}$ \\
\hline ; & $1.7 \times 10^{4}$ & 16 & $1.3 \times 10^{3}$ & $0 . j$ & $9.8 \times 10^{2}$ & $2.0 \times 10^{3}$ \\
\hline 4 & $4.4 \times 10^{5}$ & 50 & $8.0 \times 10^{3}$ & 1 & $8.0 \times 10^{3}$ & $8.0 \times 10^{3}$ \\
\hline 5 & $1.5 \times 10^{6}$ & $1: 0$ & $2.0 \times 10^{4}$ & 2 & $3.0 \times 10^{4}$ & $1.5 \times 10^{4}$ \\
\hline 0 & $? .5 \times 10^{6}$ & 175 & $4.6 \times 10^{4}$ & 2 & $6.9 \times 10^{5}$ & $3.5 \times 10^{4}$ \\
\hline
\end{tabular}

The as arage temperature gradicnt varies from $8.7 \times 10^{1}$ to $4.6 \times 10^{\circ} \circ \mathrm{Cm}$ as the travel apeed is increascd lrom 6.3 to $5000 \mathrm{~mm}$ s. Thesc valucs arc plotted in Fig. 7.8. : an alsu be defined as the conductivity-ucighted thermal gradient [7.7]:

$$
\because-k i, k
$$

and using the relationship between $G_{s}$ and $G_{L}\left(G_{S}=\left(k_{L} k_{S}\right) G_{L}\right)$, the arerage temperature gradiont in the solid. $:$, and liquid. $\therefore$. can be calculatcd. Values for : and: are reported in Table 7.4 and arc ploted in Fig. 7.8. At low trasel specds the Peolet number is large and $:$ is less than: hea use convection in the melt is important. At high travel specds, the Peelet number is smalt and convection hecomes less important. resersing the relationship between $:$ and $i$.

The a erage temperature gradient in the solid was also calculated by the finite clement method for tho travel specds. These calcuations are summarized in Chapter 4 and are plotted in Fig. 7.8. There is good corrclation between the calculated temperature gradicnes and the estimated icmperature gradicnts. The calculated values of : are within a factor of two and have the same apparent slope is the cstimated values of : based on the weld pool geometry and DAS calculations. 


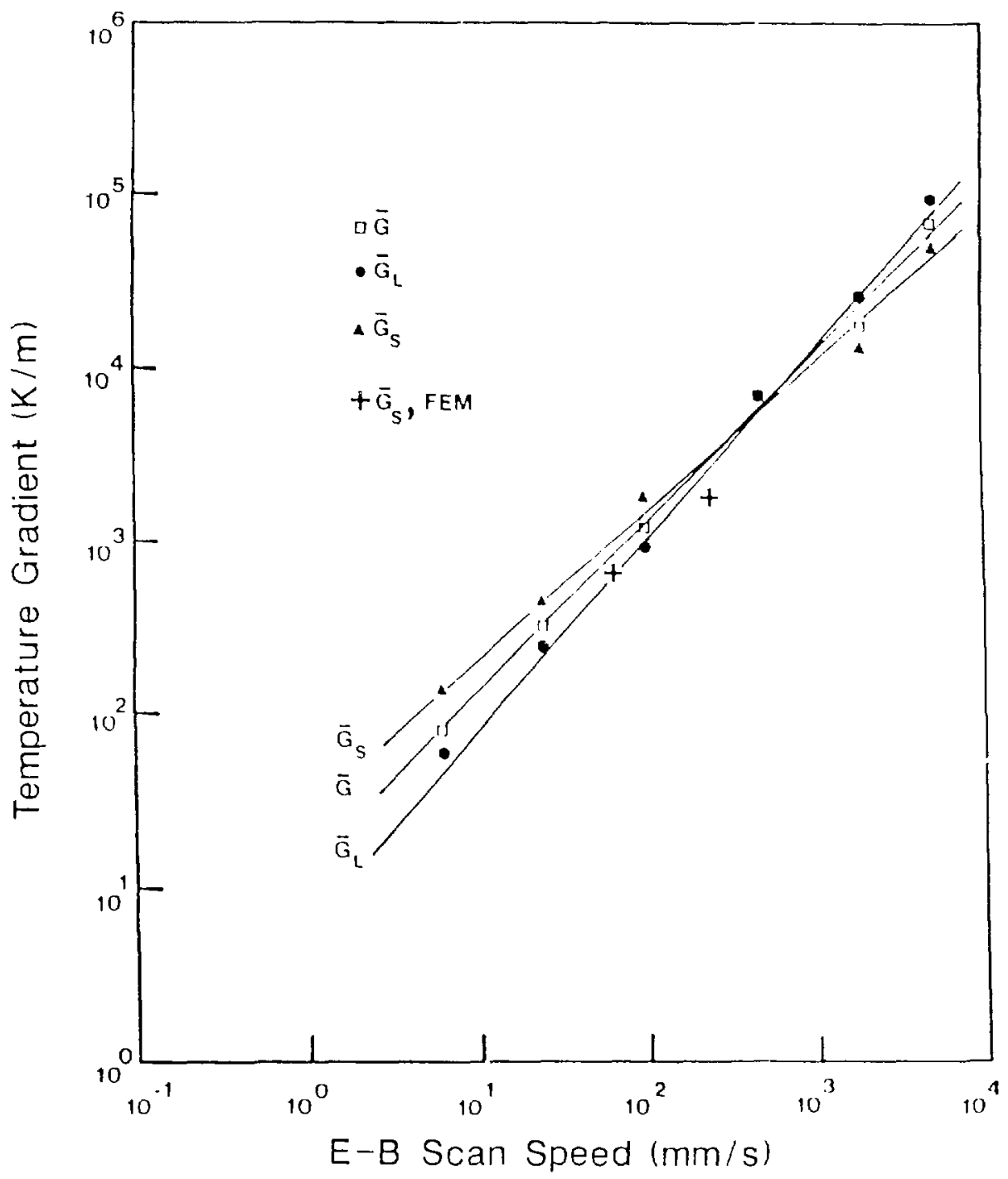

Figure 7.8 Average temperature gradicnt on the melt pool surface, 6 , and the estimated temperature gradienes in the liquid, $\bar{c}$. and solid, $\cdots$ at the $L / S$ interface. FEM temperiture gradient calculations are plotted for comparison. 


\subsubsection{Dendrite Tip Characteristics}

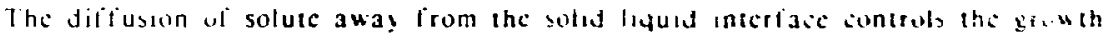

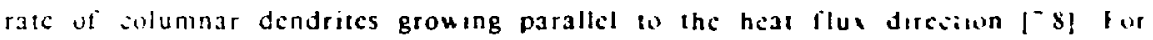
solute difiusion-sontrolled growih, necdle-like itstals an grous aighci rat than a planar interiace because the redistributun of solute is morc cliticnt around 3 iap with a small radius of Eurature. The rejected solute ereates a boundars laver. . around the tip arit the diffusion of solute is controlled by the solute gradients Ereated in the liquid. Therefore. the grouth rate and morphulogical iharacteristis af the dendrites are dependent on the behasior at the dendete tip.

The driving forec for diffusion of solute at the dendritc lip is represented s, the supersaturition.

$$
\therefore-k=\frac{c i-c a}{i}+i(1-k)
$$

Since a relationstip cxists betucen the temperature and the composition of the liquid. also represents the related undercooling. ". uhich drises the solidification process:

$$
11=m a_{n}-c_{i}=m c_{n}\left(1-\frac{1}{1-1)(1-1)}\right)
$$

The shape of the dendrite tip is closely represented by a paraboloid of ratulion $[78]$ and for this geometric shape. the mathematical solutins to the diffusion problem was derived b! Wanstor 17.9]. This relationship cauates.. to $r_{t}$ and $R$ ia the solutal Peclet number. $P_{c}$. and the lvanstov function $1\left(P_{e}\right)$

$$
1 .=1 r^{\prime}
$$

where

$$
r=\operatorname{Rr}
$$

and

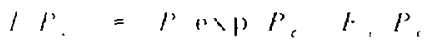

Here. $E_{1}$ is the exponential integral function and $;$ is the interdiffusion cocfficient in the liquid. For numerisal caleulations $E_{l}\left(P_{c}\right)$ and II $\left.P_{c}\right)$ san he approximatcd from the following cquations $[7.8]$ : 
for $0<r<1$

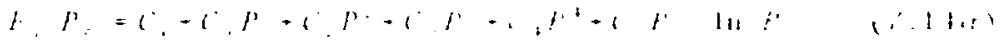

where.

$$
\begin{array}{ll}
c_{0}=-0.577216 & c_{1}=0.999992 \\
c_{2}=-0.249911 & c_{3}=0.055200 \\
c_{1}=-0.009760 & c_{5}=0.0010^{-9}
\end{array}
$$

ior $1=P<\infty$

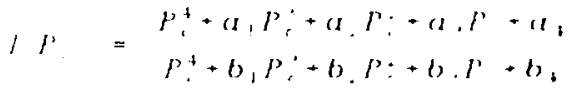

where,

$$
\begin{array}{ll}
a_{1}=8.573329 & b_{1}=9.573322 \\
a_{2}=18.059017 & b_{2}=25.632956 \\
a_{3}=8.634761 & b_{3}=21.099653 \\
a_{4}=0.267774 & b_{4}=3.958497
\end{array}
$$

Equation $7.11, n=l\left(P_{e}\right)$. docs no! spccify a unique functional derendence betucen the tip radius and the interface velocity, thereforc, another cquation is required. This adfitional cquation comes from the stability eritcrion and relates the tip radius to the surtace energy and the temperature gradient. According to Trivedi [?.10]. a relationship can be derived to describe growth at the limit of morphological stability. The marginal stability theory is based on a dendritc tip having a small radius would increase its radius duc to the growth of perturbations close to the tip. Houcrer. a dendritc tip with large radius would decrease its curıture duc to instabilitics Conscquently. growth occurs at an intermediate tip radius uhich is represented by the following cquation:

$$
r i=m+i
$$


uhere: is the Gibbs-Thompson parametcr (ratio of surface encrg! to melting entropy). $G_{c}$ is the concentration gradient in the liquid and $G$ is the temperature gradient in the liquid at the $L . S$ interface. $G_{c}$ is given by Lipton et al $\left.\right|^{-}$. ?] to be

$$
G=\frac{-2 P_{1}(\because(1-h)}{r_{1}}
$$

Therefore, by combining cquations $7.9,7.11,7.12,7.15$ and 7.16 the follouing relationship can be derived which relates $R, r_{2}$ and $G$ :

$$
R \cdot-\left(\begin{array}{c}
D r i m(1-h) C . \\
n+l r,(1-h)-1
\end{array}\right) R+\left(\begin{array}{c}
D^{2} P^{2} C \\
n^{2} r
\end{array}\right)=0
$$

This equation is identical to that described by Esaka and Kurz [7.1i] as the parabolic model II. Solving equation 7.17 explicitly for $r_{8}$ is an impossible task since the product $R_{r_{t}}$ is incorporated in $P_{c}$. Therefore, the equation is solved by choosing spcific values for $P_{c}$ and $G$ and calculating $R$ from equation 7.17. Knowing $R$ and $P_{c}$. the tip radius can be calcualted from the definition of the Peclet number. cquation 7.12. For surface melting. $R$ is considered the independent variable and yet it must be calculated from a sclected value of $P_{c}$. Therefore to calctiate $r_{t}$ for $a$ specilic $R$ and $G$ combination requires an iterative scheme to guess the Peclet number which corresponds to the desired velocity. Altcrnatcly, a plot of $r_{t}$ is. $R$ can be generated by sclecting a range of Peclet numbers and calculating the relationship between thesc variables.

Once the dendrite tip radius is known. the undercooling ereated by the solutal boundary layer, 17 , can be calculated from equation 7.10 and undercooling caused by the radius of curvature, 11 , can be calculated from the Gibbs-Thompson relationship:

$$
H_{1}=r_{1}-I_{t}=\frac{2 \%}{t_{1}}
$$

$\because$ describes the depression of the cquilibrium melting point of solid $u$ ith inlinitc radius of curvature, $T_{L}$, with the actual temperature at the tip. $T_{t}$. 


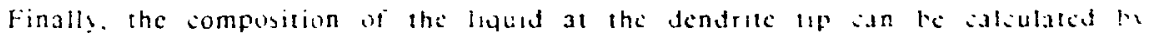
contining cquations -9 and -11 .

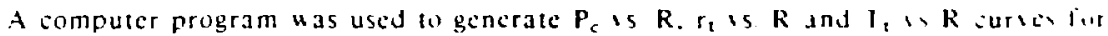

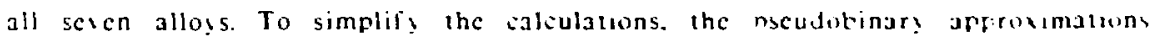
deseribed in scetion 7.1 here used and only partitioning of the duminant segregitung clement uas considered. ic. Si for primars ferrite alloss and (ir for promar? ausicnite alloys. The ph!sical propert! values for the alloys are inted in Takle - 5 and the calculations ucre periormed for a serics of temperature gradicnts that ranged from $10^{5}\left(\mathrm{k} \mathrm{m} /\right.$ to $10^{9}(\mathrm{~K} \mathrm{~m})$.

Table 7.5 Propertics used to saleulate the dendrite tip characteristics.

\begin{tabular}{|c|c|c|c|}
\hline Property & Lnits & Allos 1 & Allo: 7 \\
\hline$m_{L . N_{1}}$ & $\left(k \quad n_{1}\right)$ & - & -7.4 \\
\hline $\mathrm{m}_{\mathrm{L}, \mathrm{C}_{\mathrm{r}}}$ & $\left(k k^{\prime}(1)\right)$ & -5.6 & - \\
\hline$k \mathbf{N i}_{1}$ & - & -1.0 & 0.74 \\
\hline$k_{C_{r}}$ & - & 0.8 & -1.0 \\
\hline b. $\therefore$ & $\left(m^{2} s\right)$ & - & $46^{-} \times 10^{-4}$ \\
\hline$I_{2}$, & $\left(m^{2} s\right)$ & $3.0 \times 10^{-5}$ & - \\
\hline 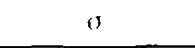 & (J $\left.\mathrm{m}^{2}\right)$ & 0.403 & $0=69$ \\
\hline $15 ;$ & (J $\left.\mathrm{m}^{3} \mathrm{~K}\right)$ & $1.21 \times 10^{6}$ & $9.37 \times 10^{5}$ \\
\hline 1 & $(m k)$ & $3.33 \times 10^{-7}$ & $=86 \times 10^{-7}$ \\
\hline$\rho$ & $\left(\mathrm{kg} \mathrm{m} \mathrm{m}^{3}\right)$ & 8.000 &. .750 \\
\hline 1 & $\left(\mathrm{~m}^{3}\right.$ mole $)$ & $6.98 \times 10^{-6}$ & $221 \times 10^{\circ}$ \\
\hline $\mathrm{T}_{\mathbf{L}}$ & $(K)$ & $16+1.0$ & 1709.4 \\
\hline $11=1_{i}-1$ & $(K)$ & 450 & $24+$ \\
\hline$D^{\prime} \backsim$ & $\left(m^{2} s\right)$ & $1.14 \times 10.12$ & - \\
\hline$D:$ & $\left(m^{2} s\right)$ & - & $1.40 \times 101-1=$ \\
\hline
\end{tabular}




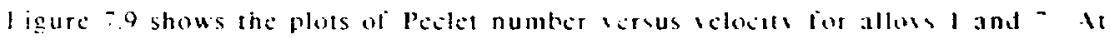

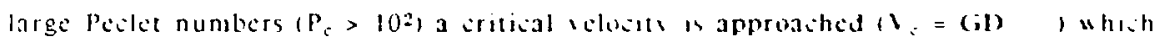
corresponds to the limut of constitutional superiouling. As $R$ M mereared. P. drom rapidls to a minimum value which is strongle dependent on the lemperature gradient is $R$ is increased further. $P_{c}$ continues to increase put becomes independent ol the

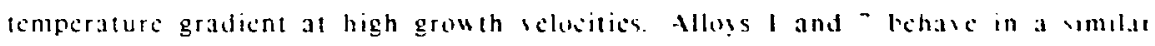
manner and there is little diflerence between the $P_{c}$ icrsus $R$ surses for lhe two alloys. The hehavior of the remaining alloss talls betwecn these awd sutremes.

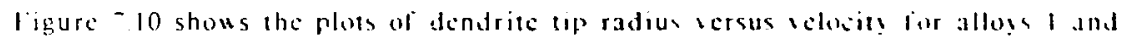
- Large tip rasii are fuund at low velositics th the aclocits is increased. the radiu, drops sharpl! and is strongly dependent on the lompcrature gradicnt Ihis regime correspond to the planar tre=f to icllular transition. At higher acloitics the lip radius fecomes independent ol temperature gradient. Here. solidilication tahes place in 3 dendritic mode until the lip radius is reduced to the point uhere capillarit! cflects beome dominant and the structure recers to ecllular and linally planar at the limit af absolute stabilits. The tip rafius versus velosity behasior at all af the alligs are yuac simitar.

I igure - II shous the plots of dendrite lip temperature. I, Iersus iclocil! fior allus 1 and - The anount of underooling . . . san be determincd from thex plis Iy subtrating the equilibrium temperature. Im. I'om the tip temperature it high growth rates. the underoobling increanes with incroasing velocit! and is independent of the temperature gradient. This behasior is assestated with the

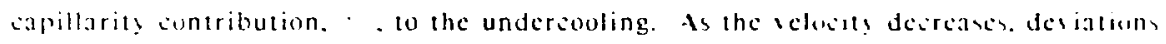

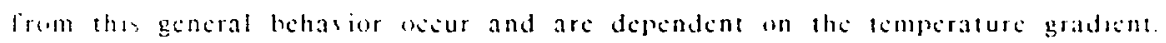

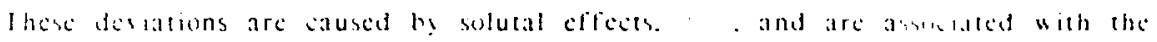
transition from dendritic to planar solidification as the grom th rate approdiche ils

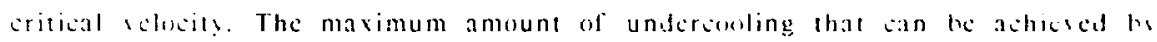
solutal clicess is equal to. and the loues limit of the top temperature at fas celcitics is the cquilibrium solidus temperature. Hoss I through again helase in a similar manner. The remaining allogs sere shoun la hase similat tharacterives and the resules of the calsulations are summaried in Aprendive 

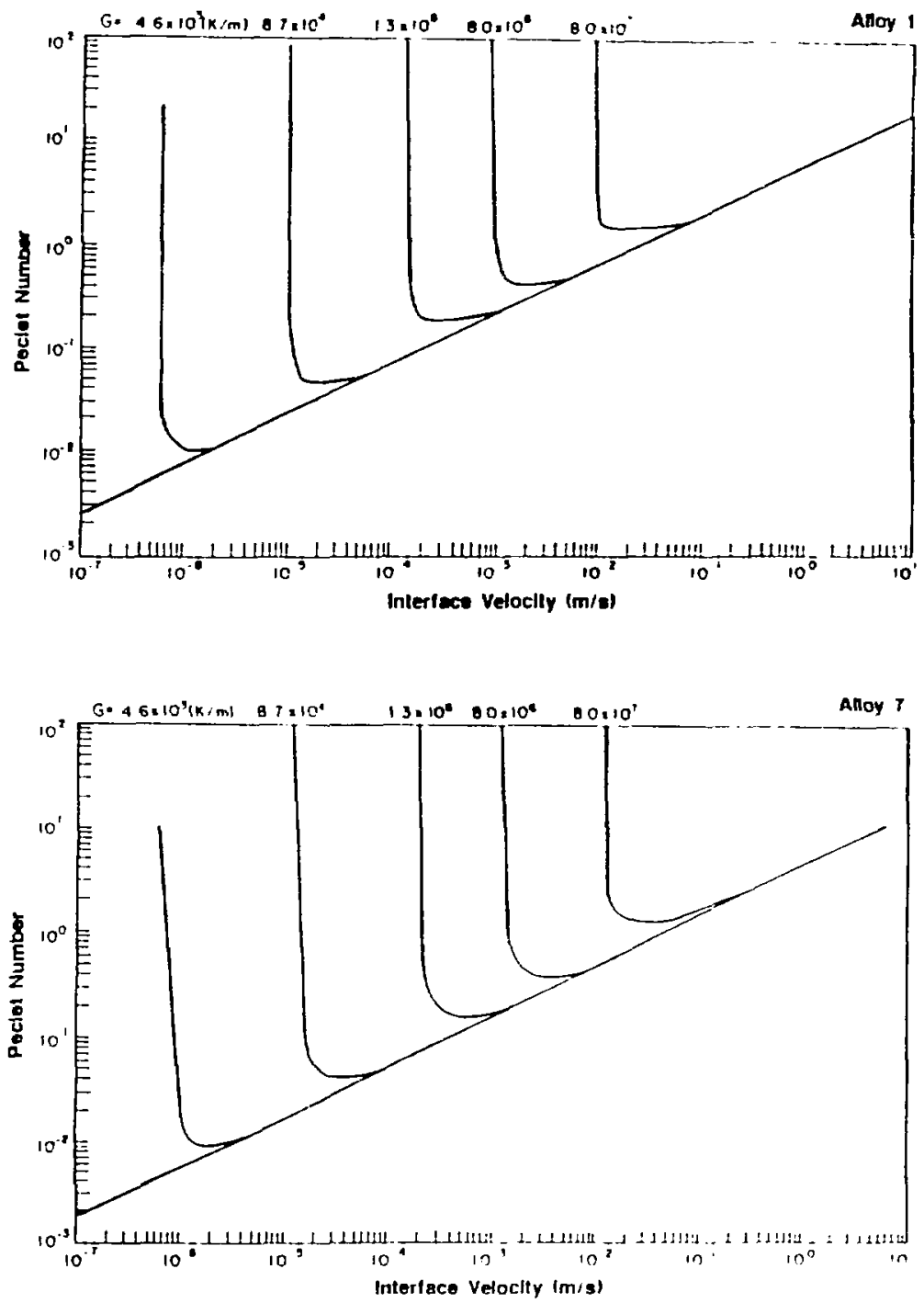

Figure 7.9 Peclet number versus interface velocity calculations for al Alloy 1 and b) Alloy 7 . 

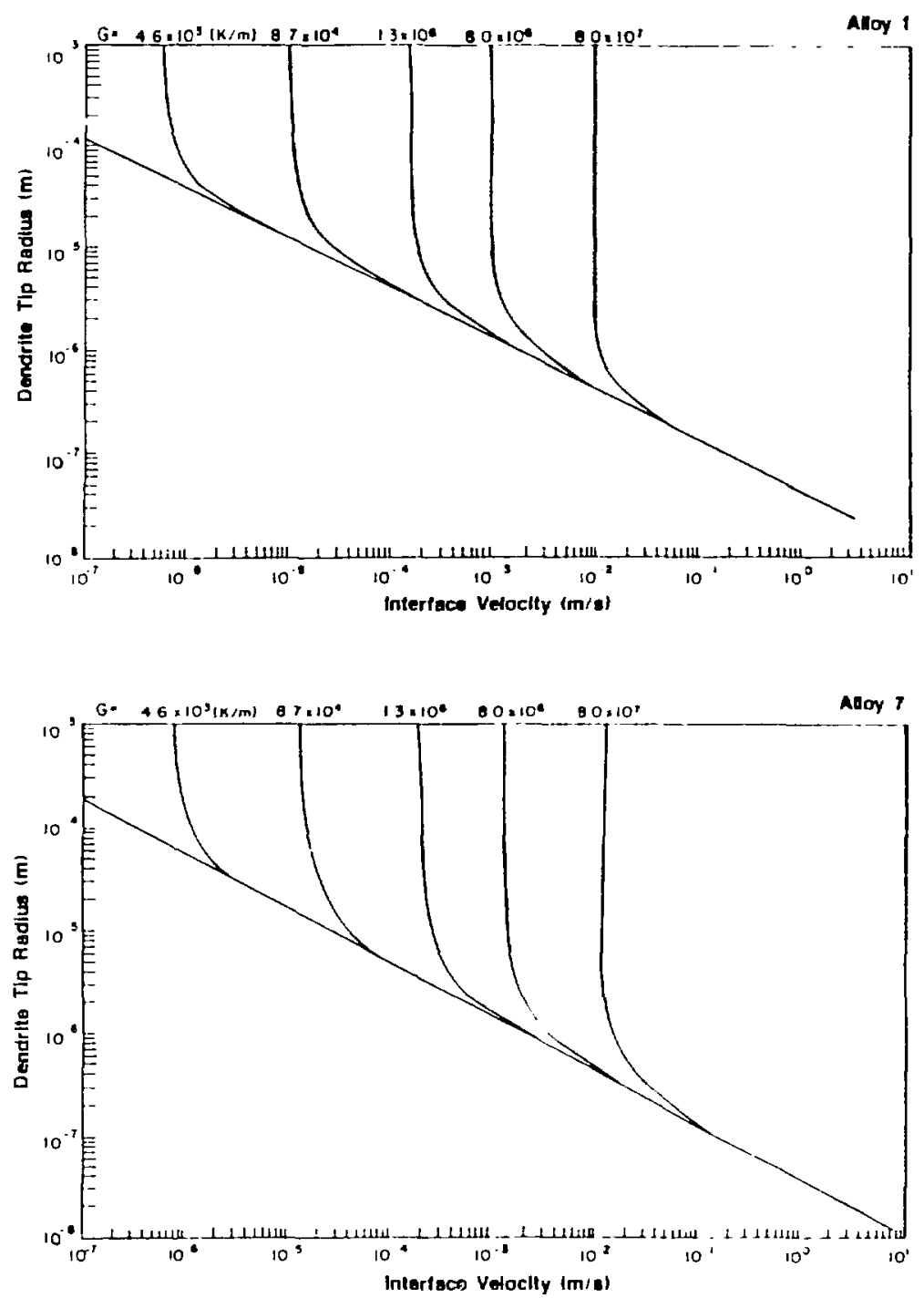

Figure 7.10 Dendrite radius versus interface belocity calculations for a) Allos 1 and b) Alloy 7 . 

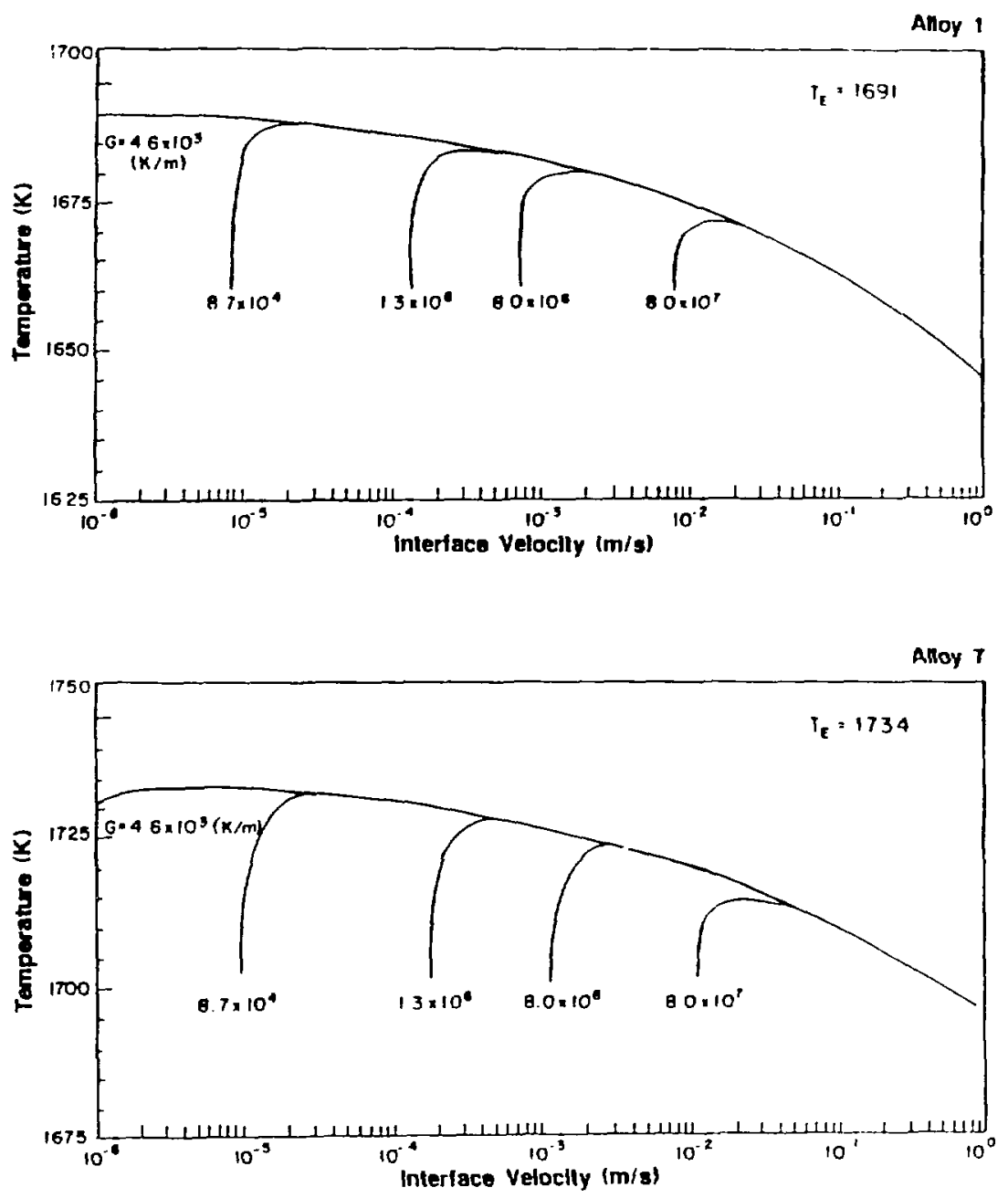

Figure 7.11 Dendrite tip temperature versus interface velocity for a) Alloy 1 and b) Alloy 7. 


\subsubsection{Cellular to Dendritic Transition}

The stabilit! of the liqu d-solid intertace was shoun whe relates to be : mount of underooling in the solute boundar! lager and the growth hinclies wi wortic

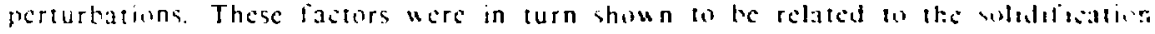
parameter (i and R. Fquation - Is a he used to desitite the sindituon under whith a planc front will preak down into cells based or constitutional superoboling theors and the alloy properties listed in Tabe -5 were used fo show that the Erital 6

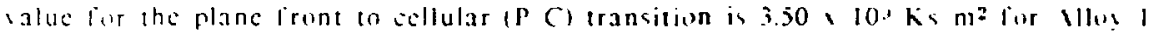

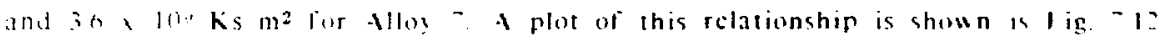
whete $G R$ salues higher than this reiationship will result in plane iront solidilication whic $6 \mathrm{R}$ ialues lower than thas relationship will be unstable

(i R balucs whith sorrespond to an unstable interiace san solidit? as alls or

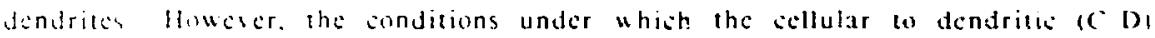
trancition tahes plaze are not as casily detined as the planar to sellutar iransition.

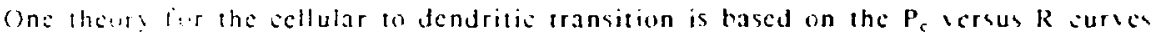
"hith were saliulated from the denrite tip charateristics.

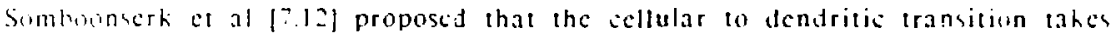

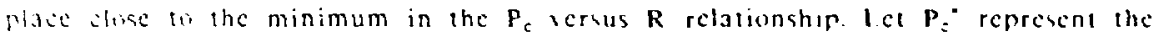
Peilet numler at the minimum in the curve. ses $f i_{3}, 9$. and let $R^{-}$icpresent the velacts at this point. $P_{c}^{*}$ and thus $R^{*}$ arc iuntions of the temperature gradient. therelies, a plot of $R^{*}$ iersus $G$ will scparate the enditions fir cellular and dendriti

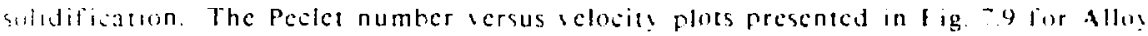
l and - uere both shoun to hase similar stitial salues and are ploted as a single line in Fig. T.12. For icmperature gradients belou this ince dendrotic soliditiation hehatur would be cxpected by this theory.

A comparison can be made hetueen the ecllubr to dendritie transitun predieted

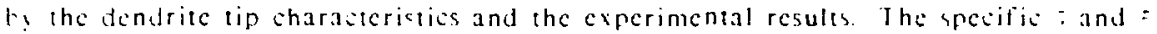
alues for cach of the six surface melting condition are listed in rable 7 and are also ploted in Figure -.12. The mopholugical characteristes of cath mele was discussed in Chapter 5 and dendrites with well defined secundars arms were onl: obsersed in the tuo lowest growth-rate melts. The remaining four. higher growih-rate. melts were composed entirels of elts thereforc. the tuo lou specd 
melts which solidified in a dendritic manner should lie reluw the (1) wansiurn line while the remaining melts should lic ahose the $C D$ line but befow the $F$ (ransition line. The experimental results show that all of the melts lic below the P ( Iransition as they should, however. the C D transition is not eorrectly predicted by the minimam in the Peclet number versus velocity curve theos.

The experimental data points which are plotted in riguse 7.12 are coled. The solid circles represent the melts that contained dendrites with well defined secondary arms and he open circles are entirely composed of fincly spaced cells.

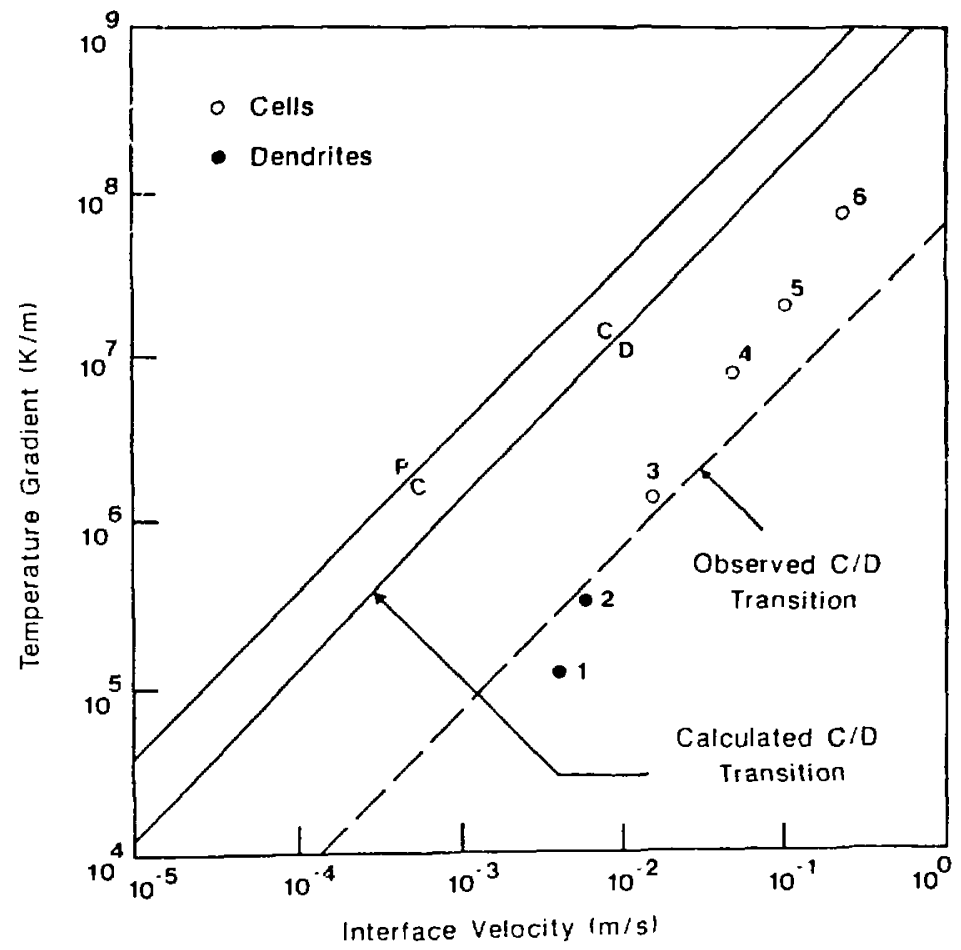

Figure 7.12 Temperalure gradicnt versus interface velocits comparing the calculated and measured eransitions for planar, cellular and dendritic growth conditions. 


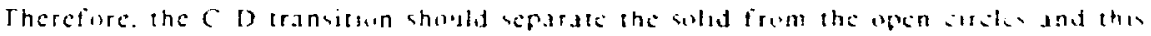

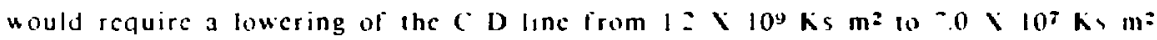
which is a factor of about $1^{-}$Several possible cxplanaturns for this disiceranis crist.

First. although the $C D$ transition is hnown to tahe plase slose to the minimum in the Pcelce number versus growth rate curse. it most ihely osous at higher velostics Miyata et al [?.13 hase evidence for this but their data only appears to actount for a lactor of $j$ or so and does not in itself explain the factor of $I$. Second. the $59 \mathrm{w}$ percent iron alloys studied in this insestigation contain a large persentage of solute. The dendrite tip characteristics were calculated based on assumptions that are more likely to be ialid for less concentrated solutions. Third, concentration independent diffusivitics werc assumed and the cffest of ternary alloy additions on diffusivit! was not taken into account when ealculating the dendrite wo sharacteristies. These cffects might change the calculated Peclet number Icrsus growth rate characteristics. Finall!, the fine cells that appear in the microstructure ma! possibly have solidified as dendrites which have coarsened during solidification. It is not possible to determine which of thesc effects has contributed to the differences beiucen obscriation and theory without further insestigation.

In summary. the growth ratc and velocitics werc calculaicd for cash of the surlace melting conditions. These miasurer.ers:s were used to calculate the dendrite tip characteristics and onc of these characteristics. the minimum in the Pcelet number versus velocity curve. was uscd to predict the cellular to dendritic transition. This transition was compared to the cxperimental data and was shown to be off bs a constant multiplying factor of about 17. This difference can be rationalized by the asumptions used to calculatc the dendrite tip characteristics and uncertainty in the C D transition thcory itscle.

\subsection{Solute Redistribution Models}

Solutc redistribution occurs during the cellutar or dendritc solidification of all alloys. The amount of solute which segregates is related to the solidilication parametcrs. $G, R$ and $r_{t}$. Solute redistribution sa. influcnce the amount, composition 


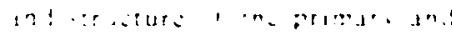

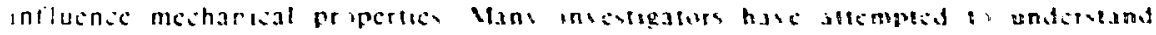

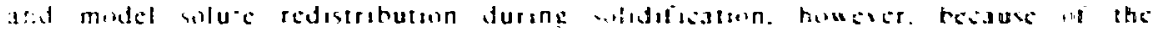

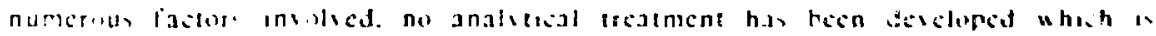

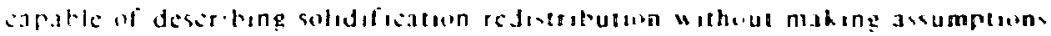

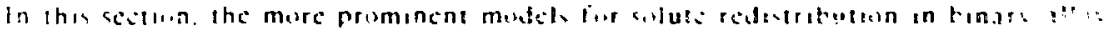

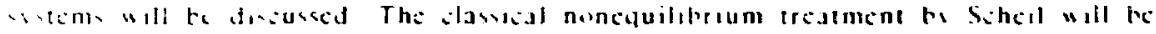

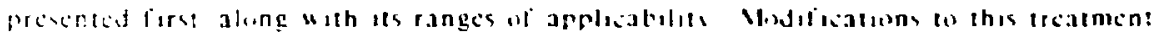

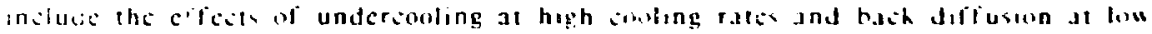

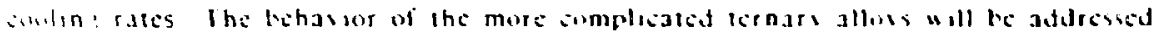

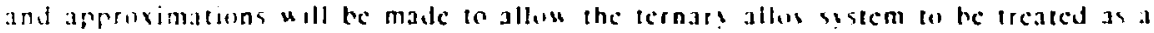

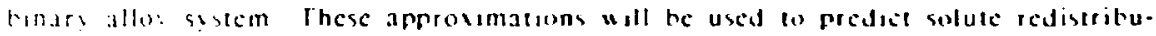

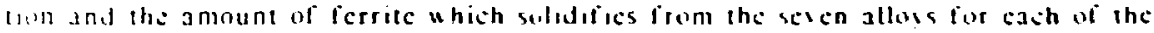
aldilization condrouns studicd in thas incestigaton

\subsubsection{The Scheil Approximation}

Chemisal potential differences whish exst between the solid and liqual phases frovde the drising forec for solute redistritudion during soliditioztion. In an ticmpl to minimize shemical potential gradents. the clements preferentiall! ditiuse

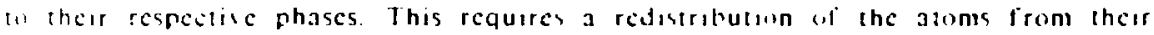
randirm solution in tne liquid state During the rediutratuon. incentration graticnts are established in the liquid and solad nhases restuse of hantio linuations

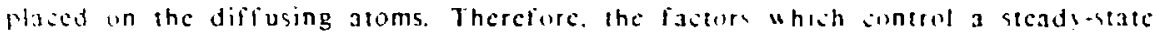

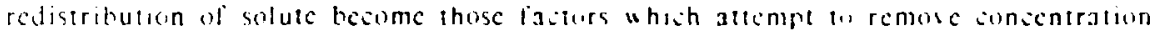
gradients from the sistem

For the special casc of equilibrium soludilizaton. ansentration gradicnts are cleminated and the solid and liquid phases hase uniturm compositum. Inder these

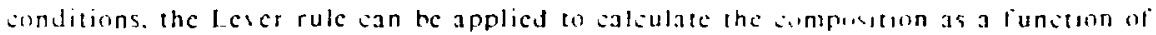
cemperature or irastion soliditicd. For lincas figudus and soidus lines these cquations are: 
Tahic 7.6 summarizes the nomenslature used to represent the solidifieation related sariables.

During most solidification prosesses. the sonentration gradients san not te climinated and nonequilitrium conditions cvist for these eascs. assumptinns are made to simplify the problem. The elassisal noncquiltbium treatment assumes perfect diffusion in the liquid phase and no diliusion in the solid phase These assumptions proulde fur a mavimum amount of solute to be stored in the remaining liquid. Whish represents an upper limit on the amount of second phase whish an form during soliditiatun. This treatment as often refered to as the Suherl approaith and represents the interlasial sumpisitson en terms of temperature or fraction soidilicd:

The differential liom ol cquation - 21 a ean casily he derised b? a mass balanac and is oticn usciul:

The Sihell equation san re used to predist the somposition and relatise amounts of the primar! and secondar! phases. Houcser. this method an onls he apolied t", s!stems in whith the difluswities of the allowing clements are similar and for intermediate cooling rates $[-1]$. At slow sooling rates $[-1$. - 151 or for sustems with last diffuing clements such as anterstitials [ $\left.{ }^{-} 14\right]$ ba:h diffusion into the sold phase limits the applicatilits of the Scheil equation. At high cooling rates. dendrite tin

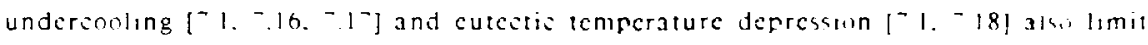

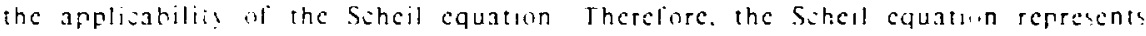

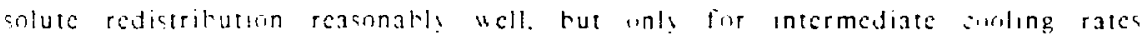
Indifications are required for the high and lou croling rate regimes 
Table 7.6 Nomenclature used to deseribe solute redistribution

\begin{tabular}{|c|l|}
\hline Variables & \multicolumn{1}{|c|}{ Description } \\
\hline C. $T$ & composition. temperature \\
\hline $\mathbf{k}$ & equilibrium partition ratio \\
\hline $\mathrm{f}_{\mathbf{s}}$ & Praction solid \\
\hline $\mathrm{D}$ & volume diffusion coefficient \\
\hline$\theta_{s}$ & local solidification time \\
\hline$a \cdot \alpha^{\cdot}$ & coefficient for back-diffusion \\
\hline$\Omega$ & solutal supersaturation \\
\hline$\Gamma$ & Gibbs-Thompson parameter \\
\hline
\end{tabular}

\begin{tabular}{|l|l|}
\hline Subscripts & \multicolumn{1}{|c|}{ Description } \\
\hline S & solid, solidus \\
\hline $\mathrm{L}$ & liquid, liquidus \\
\hline 0 & nominal \\
\hline
\end{tabular}

\begin{tabular}{|c|c|}
\hline Superscripts & Description \\
\hline & interface \\
\hline E,M,C & eutectic, maximum, solutal \\
\hline$r, t$ & radius of curvature, dendrite tip \\
\hline
\end{tabular}

\subsubsection{Back-diffusion and Undercooling}

Brody and Flomings [3.15] modified the Scheil equation to account for the back-difrusion which occurs at low cooling rates. In their model, they assume perfect diffusion in the liquid and account for volume diffusion in the solid for two types of dendrite shapes: lincar and parabolic plates. In practice, cells and dendrites tend to be shaped close to a parabloid and this approximation is more accuratc. For this casc. the composition of the solid at the interface was shown to be [7.15]:

$$
C_{s}^{*}=k C^{0} 1-(1-2 a k) f_{s}^{(k-1)(1-20 k))}
$$




$$
\alpha=\frac{1 / 2,0,}{1}
$$

Clne and nure $[-|+|$ show that these cquations remain approximatcly valid. prisidine the : usiun houndary layer in the solid is small (small a) compared to the

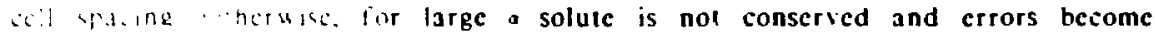
aibar... $[\because$, ind hur/ $[-.14)$ modificd cquation 7.24 to ensure that the model approatices the Sithel cquation as, approaches zero and that the model approaches the los: rule : , aproashes infinity. Their modification to a for a parabolic Acotrit: hapo

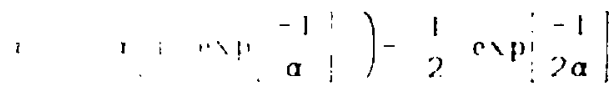

Although this equation is not bascd on a physical model at intermediate values of a [7.1]. it remains to be a uscful relationship for deseribing solute diffusion at low to intermediate cooling races.

At high cooling rates. back-diffusion is eliminated but other deviations from the Schcil equation occur. The lever law and Scheil models both assume that the temperature at the dendrite tip is the equilibrium liquides temperature. However. because of incomplete diffusion of solute in the liquid and becausc of radius of sursalure clfects. the dendrite tip temperature is depressed. These conditions cause a reduction in the amount of second phase which forms and can be described by the overall undercooling which is present at the dendrite tip.

During surface melting. the heat is extracted by the substrate and no thermal undercooling cxists ahead of the dendrite. Thereforc, the only contributions to the overall undercooling are the constitutional effects caused by solute buildup at the tip. .17 , radius of curvature effects $1 \%$, and the attachment kinetics of the atoms at the interface 11 . The interface kinetic term is known to be small for nonfaceted matcrials and can be ignored [7.8]. This leaves two terms to represent the oscrall underrcooling $x$ :

$$
H=1 \%+1 \%
$$


Bolh $\because$ and $\because$ depend on the radius of the acndrite lip. These quantities were calculated and the results ucre used to calculate solidification segregation and $\mathbf{w}$ ill be discussed in following scctions.

\subsubsection{Ternary Alloy Systems}

The principles for solutc redistribution in ternary alloy systems arc the same as those in binary alloy systcms. Howescr. the additional degree of frecdom in icrnar! alloy systems not only complicates the computations bu: also results in additional problems saused by a lack of phase diagram information regarding lic lincs and solidification paths. L'nless simplifying assumptions are made, solutions to the soluic redistribution cquations requirc a numerical approach since the partition cocflicicnt is a tunction of tempcraturc. Although the tic-lines, which definc the partition sucficicnt. are not gencrally knoun in ternary systems. computer-ealeulated phase-diagram information can be used to generate the necessary data. In this section, the hasic solute redistribution cquations for ternary alloy systems will be discussed and simplifications will be presented for the case where the solidification path allows the icrnary system to be represented by a pscudobinary diagram.

Interface stability and solute redistribution can each be mathematically described by models of varying complexity in binary alloy systems. This ternary alloy representation of the basic models has becn madc. For cxample, the threc-component analog to the Multins and Sckerka interfacc-stability analysis and the threc-somponent analog to the Scheil cquation have becn insestigated but are not widely uscd because of a lack in phase diagram and physical property data. However, to the author's hnowledge, the more descriptive dendrite-tip radius calculations have not been appicd to ternary alloy systems.

The threc component analog to the Scheil cquation can be deri ed iram a mass balance of the two segregating species. Initially. the primary phase begins lo solidify from the melt and assuming no diffusion in the solid and perfect diffusion in the iiquid, the differential form of the Seheil equation (7.22) san be written uith respect (1) each component. 


$$
\begin{aligned}
& \text { df }=-f \text {. } \\
& \text { di: }=C_{1}, 1-k_{0} \text {, } \\
& \begin{array}{c}
d f:=c \\
d C: s
\end{array}=C_{I E} \mid-k_{1 E}
\end{aligned}
$$
$(\therefore \cdots)$

Where $C_{L A}$ and $C_{L B}$ refer to the liquid composition of elements $A$ and $B$ respectivels while $h_{2}$, and $h_{2}$, refer to the partition ratios between the liquid and primar! phase.. lur elements $A$ and $B$ respectively. Therefore. by knowing the tie line locations as a Punction of temperature $C_{L A}, C_{L B}, k_{A}$ and $k_{B}$ can be determined and cquations $: 2-$ an be solicd to predict the composition of the solid phase.

At sume point during the solidification process, the liquid will be sulficiently enriched in solute to reach the line of two-fold saturation. At this temperature a second phase starts to form and an additional term must be added to the solute redistribution equations:

$$
\begin{aligned}
& d t=\frac{-f_{2}}{d C_{A} 1-h_{a}}-\left(\begin{array}{c}
h_{A}-h_{a}+ \\
1-h_{B}
\end{array}\right) d f_{A}
\end{aligned}
$$

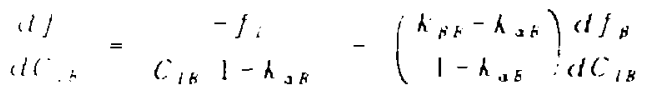

where ..' refer to the weight fraction of second phase a and 8 respectively while ${ }^{2}$ and. refer to the partition ratio between the liquid and phase for components 4 and $B$ respectivley. If $\mathrm{dC}_{\mathrm{L}}$ is taken to be the independent variable and the segregation ratios are defined by the phase diagram then there are two unknown quantities : $\therefore$ and $f_{L}$. Therefore. equations $7.28 \mathrm{a}$ and $7.28 \mathrm{~b}$ are both required to solve for the change in raction liquid with a change in liquid composition along the line of two-fold saturation.

\subsubsection{The Influence of Solidification Velocity on the Partition Ratio}

The ealculations presented so far hase utilized the equilibrium phase diagram to decermine the relationship between the solid and liquid composition. This relation. ship is delined b! the tic-lines in the two-phase liquid and solid ficlds and is called the equilibrium partition ratio. $h$. At high interfiacial selocities. the local cquilibrium 
assumption used to represent partitionaing at the liquid solid interiace has been shown to be invalid [7.20, 7.21]. Models of the interface kinctics have becn descloped to represent the deviations from equilibrium and indicate that $k$ increases with increasing $R$ from its cquilibrium valuc at low rates to unity at high rates.

One model for solute redistribution during rapid solidification was developed by Aziz [7.22] and predicts equilibrium partitioning from $R \ll D_{L}$ a and complete solute trapping $(k=1)$ for $R>D_{L}$ a wherc $a$ is the interatomic spacing. For the alloys studied in this investigation. $D_{L / a}$ is approximately $7.5 \mathrm{~m} / \mathrm{s}$.

Table 7.3 lists the average interiace velocity for cach imposed travel specd. Although the travel speed, S, reaches velocitics close to that of $7.5 \mathrm{~m} \cdot \mathrm{s}$, the maximum interface velocity, $R$, is only $0.175 \mathrm{~m}$ /s at its highest value because of the geometry of the shallow surface melts. Therforc, assuming $0.175 \mathrm{~m} / \mathrm{s}$ is significantly less than 7.5 $\mathrm{m} / \mathrm{s}$, the partition ratio can be assumed to be close to its cquilibrium value for all of the tratel specds investigated in this stur,.

\subsection{Calculations of Solute Redistribution in the Electron Beam Melts}

\subsection{Solute Redistribution and Second Phase Formation}

The Scheil cquation can be used to predict solute redistribution and the amount of second phase that forms during solidification. This model relies on some basic assumptions which limit its uscfullncss to a narrow cooling rate change. However, the results provided by the Scheil equaticn are an important point of reference because they predict the maximum amount of sccond phase which san form during any solidification process. The assumptions and details of the Scheil cquation have alrcady been discussed and in this section they will be used to provide first-order solution to the amount of ferrite which solidifies from the melt for each of the seven alloys.

Figurc 7.13 shows the solute distribution predicted by the Scheil cquation (7.20a) for a hypothetical binary alloy cutcetic system with $k<1$. The composition of the first solid to form is $\mathrm{kC}_{0}$ and since solute is rejected in the liquid, the composition of the solid incresses with fraction solidified. When $f_{S}=f_{S}^{*}$. the composition of the liquid is 
enriched in solute to the eutectic composition and at this point the composition of the solid is $C_{S M}$ and the composition of the liquid is $C_{E}$. The remaining liquid solidifies at this eutectic composition.

The amount of primary phase a that solidifies is represented by the fraction $r_{s}{ }^{*}$ while the amount of second phase, $\beta$, that solidifies is represented by $\left(1-r_{s}^{*}\right) x$, where

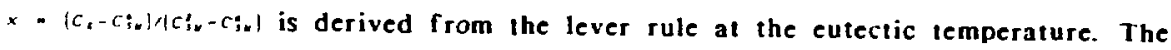
total amount of a phase is therefore the amount of primary a plus the amount of a that solidifies as eutectic $\left(1-f_{s}\right)(1-x)$.

\section{Scheil Prediction}

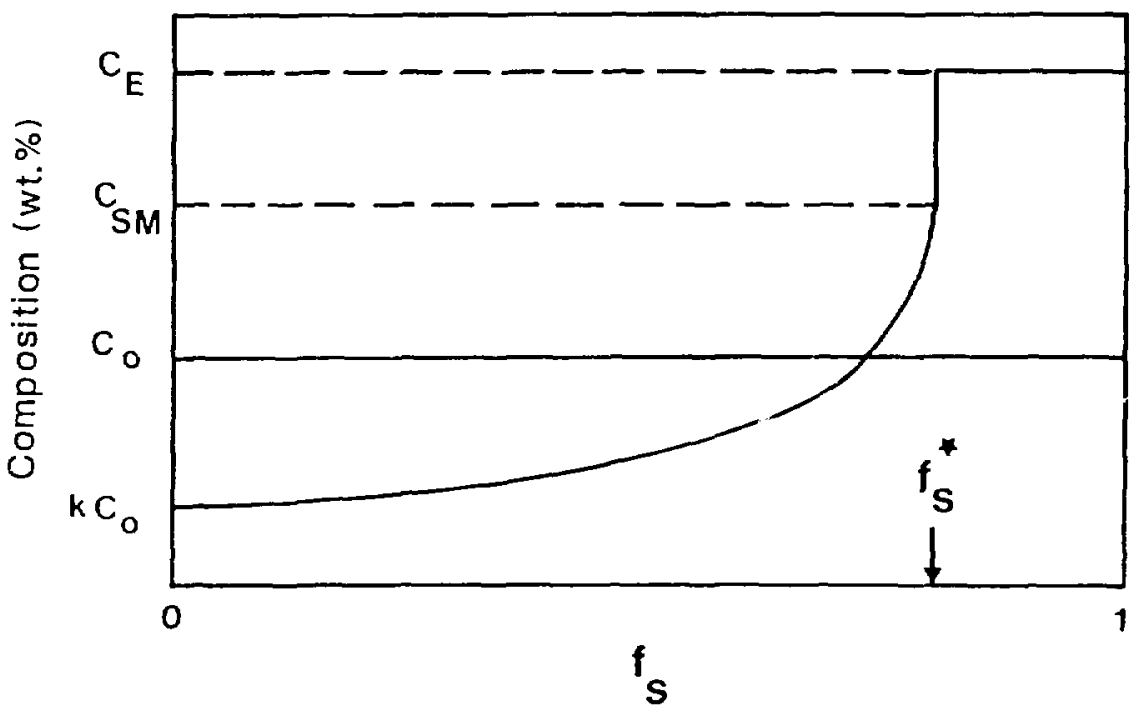

Figure 7.13 Schematic drawing showing the solute redistribution predicted by the Scheil equation. 
A similar approach can be applicd to the pscudobinary diagrams. Following the method described by cquations 2.27 . segregation of $\mathrm{Cr}$ and $\mathrm{Ni}$ ian be independentl? predicted using figures -.4 and 7.5 . The amount of the primary phase san therctore be preditted by nutung is when the eutectic composition is reached. The amount of $\because \ldots$ f. 1. - : In the thermodinamically calculated isothermal sections.

Ih: Sihsil cquation san le uscd to predict fs for cither Cr or Ni partitioning and in .... Woth cements would give the same nunerical value for is*. Howerer. in protia. the approxmations made in derising the pseudobinars diagrans result in

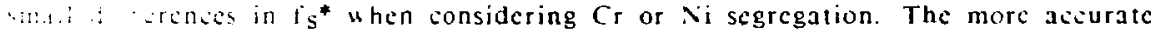
whe it is* is alsolated by the element that partitions the greatest extent during solidilication sine this clement averages out the uncertainties in the phase diagram. The solidilication paths presented in Fig. 7.6 show that $N i$ segregates 10 a greater extent than $\mathrm{Cr}$ during primary icritc solidification and $\mathrm{Cr}$ segregates to a greater cxlcnt than Ni during primary austenitc solidification. Thereforc, the Sehcil cquation uas solucd by considering nickel scgregation during primary ferrite solidilication $\therefore$ * + - + and chromium segregation during primars austcnitc solidilication A. - o. $\quad 1:-1 \%$.

L'sing the above partition ratios and the $C_{0}$ and $C_{E}$ compositions listed in Table 7.2. the Sehcil equation was used to calculate the amount of primary (P), secondary (S) and total (T) amounts of phases that form during solidification of the seven alloys. Thesc values are listed in Table 7.7 and show that the amount of primary phasc decrises as the nominal composition ncars the line of two-fold saturation. which is located betwecn alloys 3 and 4 . The amount of cutctic is similarly presented. From this cutectic, the second phase forms and additional amounts of the initial phase will also form, but of the cutcetic and not the primary composition. 
Table 7.7 The Schcil approximation of the primars. Scoondars. and tural amount of ferritc and austenite in the seren allus:

\begin{tabular}{|c|c|c|c|c|c|c|}
\hline Allos & $F_{P}$ & $F_{S}$ & $V_{T}$ & $A_{3}$ & ts & $A_{r}$ \\
\hline 1 & 0 & 7.2 & 7.2 & 8? & 10.8 & $9=8$ \\
\hline 2 & 0 & 18 & 18 & 55 & 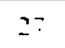 & $s:$ \\
\hline 3 & 0 & 30 & 30 & 26 & 41 & 70 \\
\hline 4 & 7 & 37 & 4t & 0 & 56 & 50 \\
\hline 5 & 33 & 27 & 60 & 0 & 40 & 40 \\
\hline 6 & 47 & 21 & 68 & 0 & $\therefore$ & 江 \\
\hline 7 & 60 & 16 & 70 & 0 & $=4$ & $=4$ \\
\hline
\end{tabular}

The amount of sccond phase that forms is a fraction of the amount wi cutcitic liquid. This traction can be cstimated b! the lever rule and the isothermal section at the cutcetic icmperature. Comparison of the line of tuo-lold saturation with the tie-triangles from the isothermal sectons shows the pereentage of the liquid that solidilies as ferrite and the percentage that solidilies as austenite. Figure 7. It shous the amount of ferrite that forms from the cutcetic liquid as a function af comperature, lor liquid compositions ranging from 59 "nl $11+50$ "C) 10 the minimum in the linc of two-fold saturation (1310"C). l'sing an acragc saluc of this ratio. 25"it licrite, the anount of sceond phase that forms during the solidifization of cutcotic-composition liquid was calculated and is listed in Iable: :

A histogram of these results is shown in Fig.7.15, indjating the relative amounts of primary and second phase austenitc and primar: and seound phase forrite that solidits from the seicn alloss. The amount of primary ierrit. and the total ferrite content increases from alloy 1 to alloy 7 as the amount of primars and cecondar! austenite decrease. The maximum ferrite conent predicted in allos 7 is a pereent with a majorit! $\left(60^{\prime \prime}, 1\right.$ being the primary phase. In subecguent sestiom of this chapter. a model will be utilized to prediet segregation during dondritic soliditiation and the results of this model will be compared with the result wi the sibul approximation which are summaried in tig. : 15 


\subsubsection{Back-diffusion Efrects}

The Brody and Flemings model was presented in section 7.3 .2 to describe the effects of back-diffusion on solute redistribution. This model was shown to be useful at low cooling rates where diffusion in the solid is significant but is an unneccssary modification at high cooling rates where the characteristic diffusion distance is small.

Therefore, there is a cooling rate that separates the low from the high rate behavior. This cooling rate can be estimated from the Brody and Flentings parameter a. For a values greater than unity, back-diffusion is important because the characteristic diffusion distance is on the order of the dendritc arm spacing. For a values much less than unity back-diffusion can be neglected.

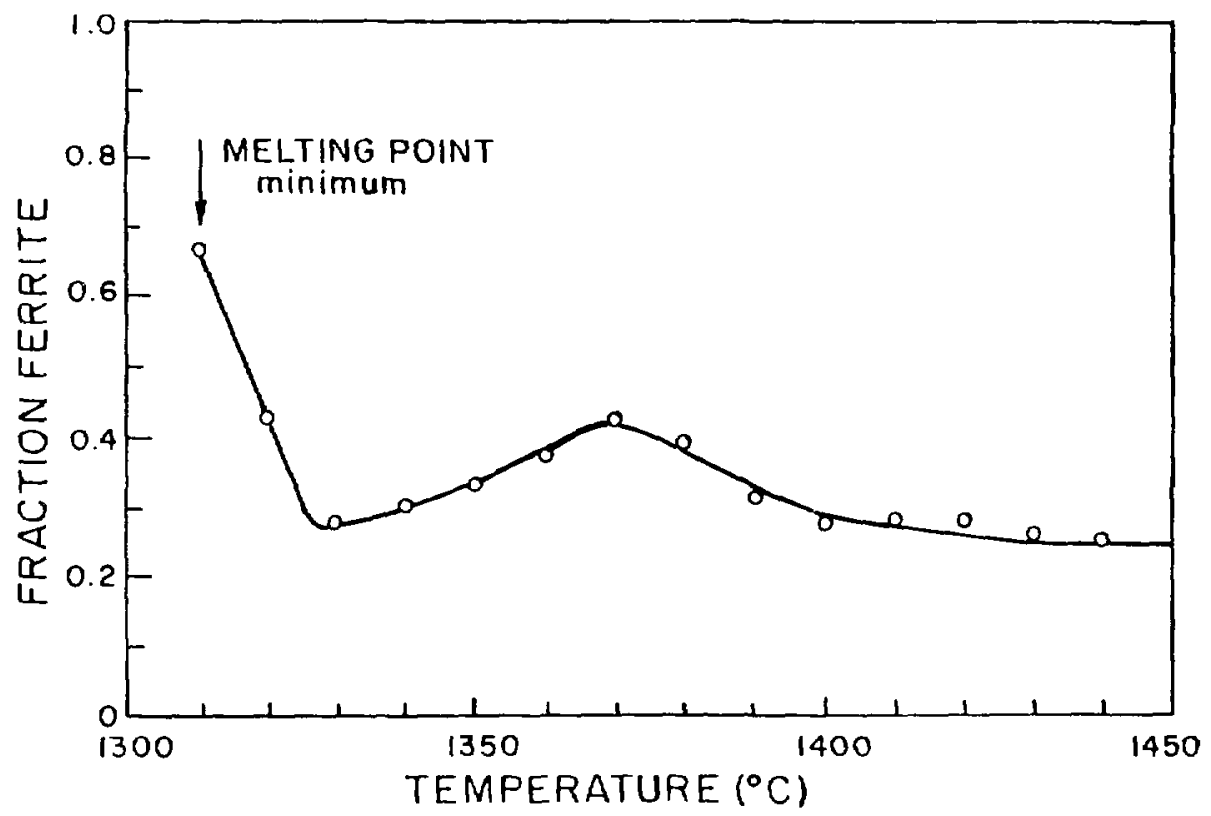

Figure 7.14 The fraction ferrite that solidifies from the eutectic liquid as a function of temperature along the line of two-fold saturation, based on thermodynamic calculations. 


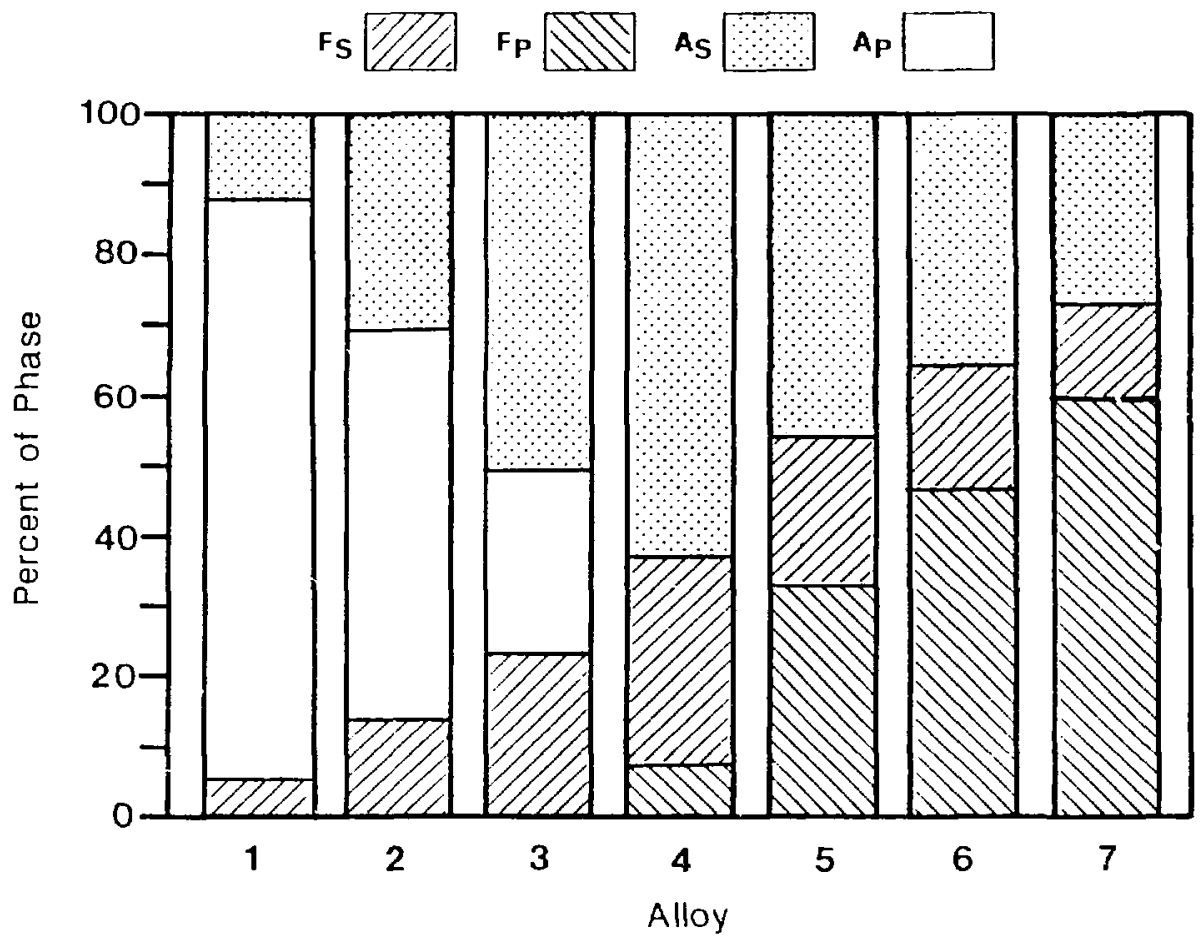

Figurc 7.15 Results of the Scheil calculations showing the relative amounts of primary and second phase ferrite and primary and sccond phase austenite that solidifies from each of the seven alloys. 
Values of for the casting and cath of the six elction beam melts are presinted in Table 7.8 for primary auslenile and primary ferrac solidiliation conditions. These alculations ware mate using the scoondar? dentritc arm spacings of be casting. melt 1 and melt Z and ecll soacing measurements for meles t-o.

Table 7.8 The Brod and Flemings bach-dittusion parameler Ealiculated for alloss 1 and 7 at each of the soliditieation conditions:

\begin{tabular}{|c|c|c|c|c|c|c|}
\hline Melt & $(k s)$ & $\begin{array}{l}0 . \\
\text { (s) }\end{array}$ & $\begin{array}{c}\lambda \\
(1 / n)\end{array}$ & $\begin{array}{c}\lambda \\
(\mu / n)\end{array}$ & Nllo! : & $\begin{array}{c}a \\
\text { tlloy } 1\end{array}$ \\
\hline Cast & 7.0 & 5.7 & - & 18.0 & $7.4 \times 10^{-2}$ & $8.4 \times 10^{-2}$ \\
\hline 1 & $4.7 \times 10^{2}$ & $4.7 \times 10^{-2}$ & - & 4.7 & $8.8 \times 10^{-3}$ & $1.2 \times 10^{-2}$ \\
\hline$=$ & $1.9 \times 10^{3}$ & $9.6 \times 10^{-3}$ & - & 3.0 & $4.4 \times 10^{-3}$ & $6.0 \times 10^{-3}$ \\
\hline 3 & $1.7 \times 10^{4}$ & $1.3 \times 10^{-3}$ & 3.2 & - & $5.3 \times 10^{-4}$ & $1.9 \times 10^{-3}$ \\
\hline 4 & $4.4 \times 10^{5}$ & $4.1 \times 10^{-5}$ & 1.1 & - & $1.4 \times 10^{-4}$ & $1.9 \times 10^{-4}$ \\
\hline 5 & $1.5 \times 10^{6}$ & 1. $2 \times 10^{-5}$ & 0.73 & - & $9.4 \times 10^{-5}$ & $1.2 \times 10^{-4}$ \\
\hline 6 & $7.5 \times 100$ & $2.4 \times 10-6$ & 0.43 & - & $5.3 \times 10-5$ & $7.2 \times 10^{-5}$ \\
\hline
\end{tabular}

The highest a value ocours in the slow cooling ale asting and is less than 0.1 . The lowest a aluc occurs in the highest sooling rate weld and is less than 10-4. 1 herclore. since all the solidification conditions hate. Ialues which are significantl! less than unity. it was concluded that the effects of bach-dillusion on solidificatiun scgregation could be neglected in this study.

\subsubsection{Dendrite Tip Lndercooling and Second Phase Formation}

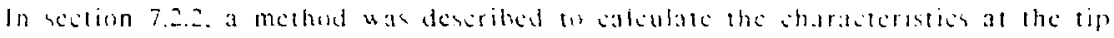

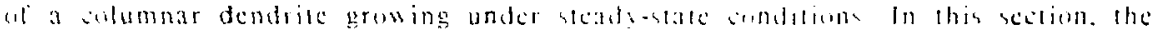

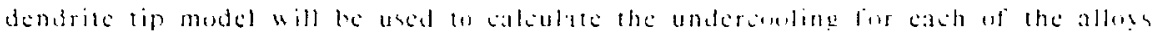


and for each ol the solidilication conditions studied. I rom these data. the amoute at solute segregation will be predicted and these results will he sumpred with the Sibet approvimation.

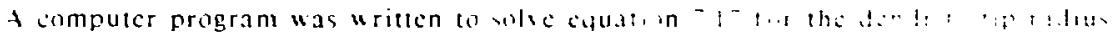

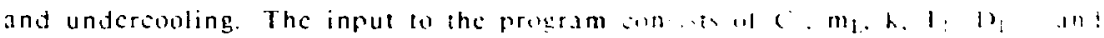

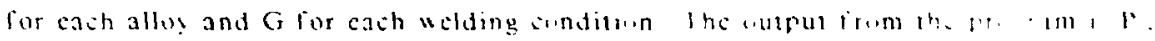

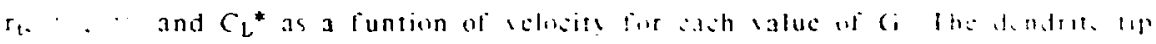

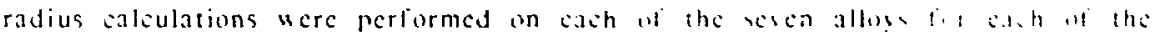

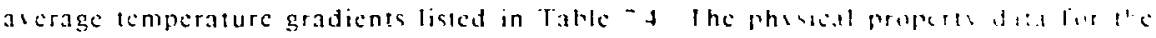

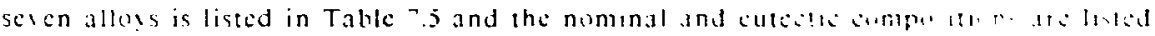
in Table - .

The ascage intertace velocity for cath meleing condition is also listed in lable it. Ihese data were used to determine, $r_{t} .$. . and $C_{L}^{*}$ for cach of the solidilieation conditions from the computer geacrated solutions to equation 7.1 ? These data are summarized in Appendix D For each allos. the total undereobling increases "ith increasing interface velocity from salues al about $10^{\circ} \mathrm{C}$ ia the casting (1) alues of about $30^{\circ} \mathrm{C}$ in the highest specd clectron beam melt.

Sarreal es al [7.l] presented a model for predicting the amouni of soluts segregation that occurs for undercoled dendritio growth sonditions. In this riodel. if is assumid that the undercooling is dissipated at the dendritio tif lis lorming a certain iraction of the primary phase solid. Is". Corresponding to the leser rule at the underecoled temperature The remaining liquid $\left(1-f^{\prime \prime}\right)$ ! then asumed to solidili is the Seheil approximation. Solute wonsersation eyuation applical the dendrite lip under these conditions ficld the following cquatwos:

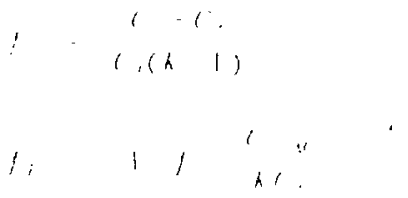

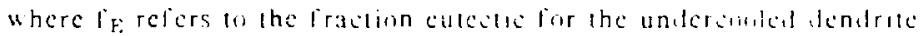


A modification to thesf equations is required it the undercooling brings the tip temperature below the "cutectic" temperature. For this sase. '. Is salculaied by cquation 7.29. is still accuratc. assuming the metastable crlensions of the liquatus and solidus are lincar. However, the cutcetic somposition and the maximum solid solubility increase to higher solute lesels $w$ ith increasing undercooling. These parameters in turn. influence the perecntage of liquid which solidifies as the primar! solid phase and CSM must be corrected to account for this difference. Assuming linear behavior for the metastable extensions. Fig. 7.16 illustrates the adjustments that should be made to Csm by the addition of the quantit!. Io account for the underooling below the cutcetio temperaturs $\because$ :

$$
r v=r v+\frac{1 r_{t}}{m_{i}}
$$

Therefore, cquation 7.30 and 7.31 can be used to represent the fraction of the liquid that solidifies as cutectic for the following conditions:

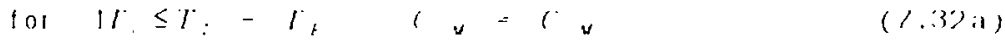

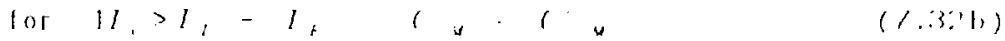

Lsing the above cquations and the dendrite tip undercooling calculations. the amount of primary austenite and primary ferrite that forms during solidification was calculated for each solidification condition. Once the amount of primary phase is known the remaining liquid solidifics at the cutcctic composition but the percentage of the cutectic liquid that solidifics as ferrite must still be calcilated. Figurc 7.14 is a plot of the percentage of the cutcetic liquid that solidifics as ferrite as a function of temperaturc along the line of two-fold saturation. From this figurc, the average fraction of the liquid that forms second-phase ferrite uas determined to be 0.32 and this bluc was used for all of the calculations. 


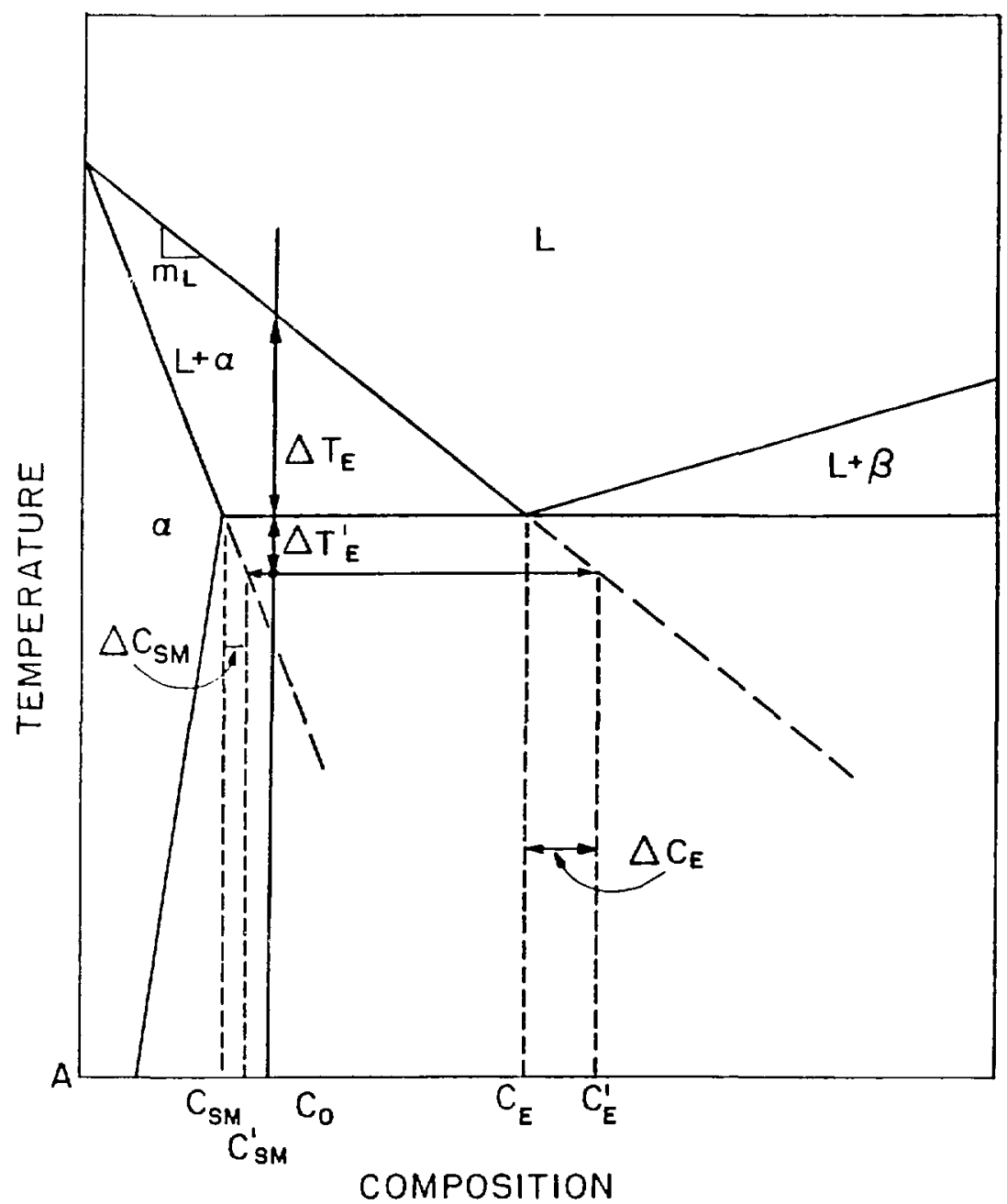

Figure 7.16 Schematic binary alloy phase diagram showing the shift in cutcctic composition with undercooling below the culcctic temperature. 
The results showing the amount of each phase that solidities irom the melt are tabulated in Apondix $D$ for each of the sesen alloss and fin eath of the solidilization conditions. Also induded in these tables are the resulte wf the Sitheil analysis and the equilierium solidification predistinns for comparican Since tllu f was oberted to solidify in the FA mode at low rates and in the Migug at high cooling rates. the solidification segregation calculations uere performed for hoth modes of solidification in this alloy.

The solidification segregation calculations. which incorporate dendrite tip underenoling effects. are ploted in the histograms presented in figures -1 ? 78 . and 7.19. I heve figures shou the influence of composition, at a given solling rate, on the amount il ferrite and austenite that solitifics in cach allos. Figure - 1 - rensecents the slnwest conling rate tcastl condition. Figure? 18 represents an intermediate cooling rate condition (FB melt 2) and I igure: 19 represents the hiphest conding rate condition if $H$ melt 6 )

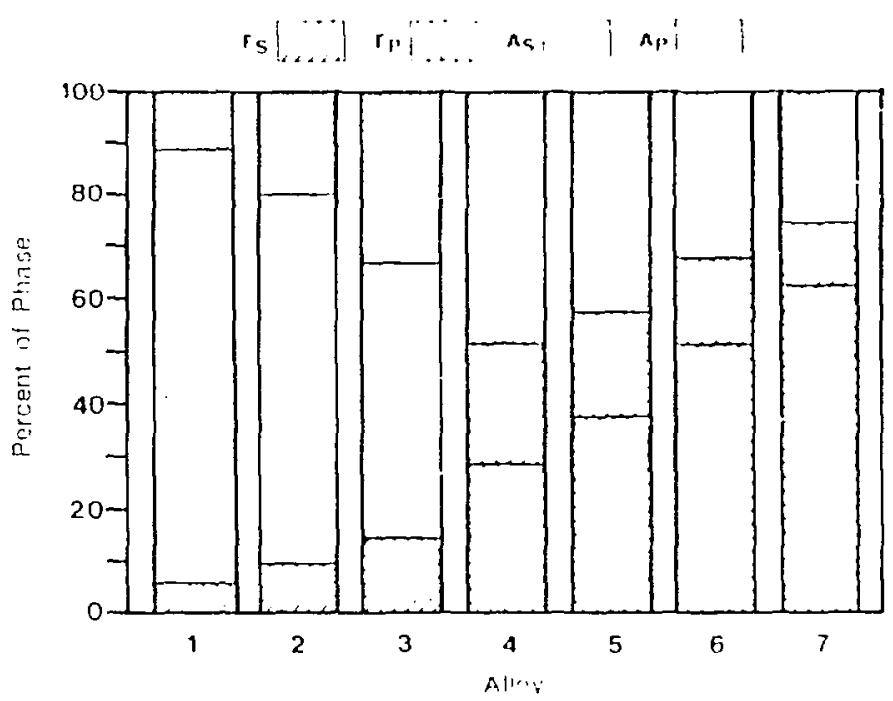

Figure 7.17 Results of the solidification segregation madel shou ing the relative amounes of ferrice and austenite that solidits tar the slow cooling rate cast condition the solidificatiun mode changes from primary austenite 10 srimars ferrite tetuen Alloss 3 and 4 . 


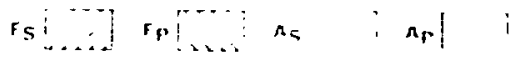

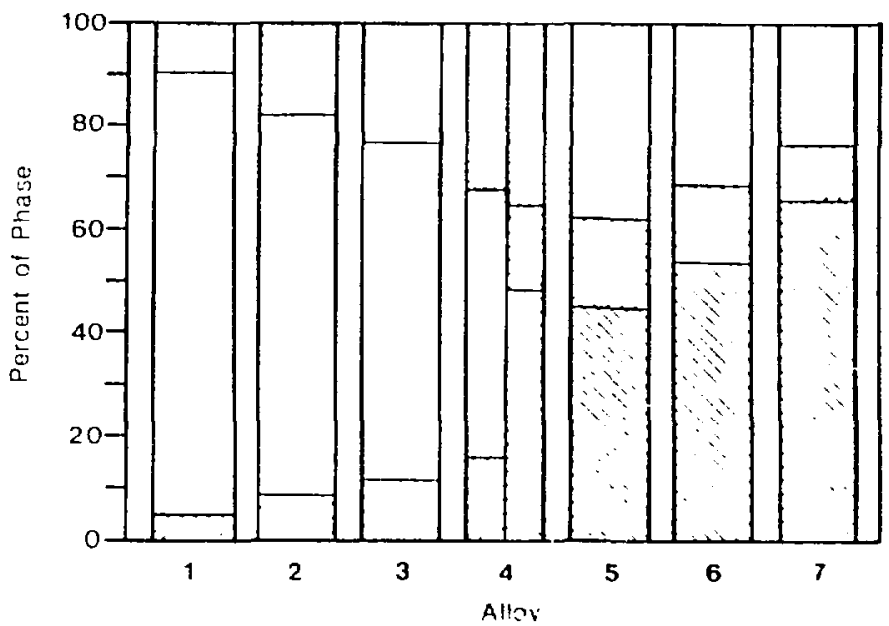

Figure 7.18 Resules of the solidification segregution model showing the relative amounts of ferrite and austenite that solidify at intermediate cooling rates in electron heam melt No. 4. The calculations were performed for both primary phases in Alloy 4 .

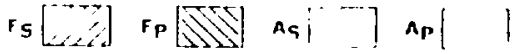

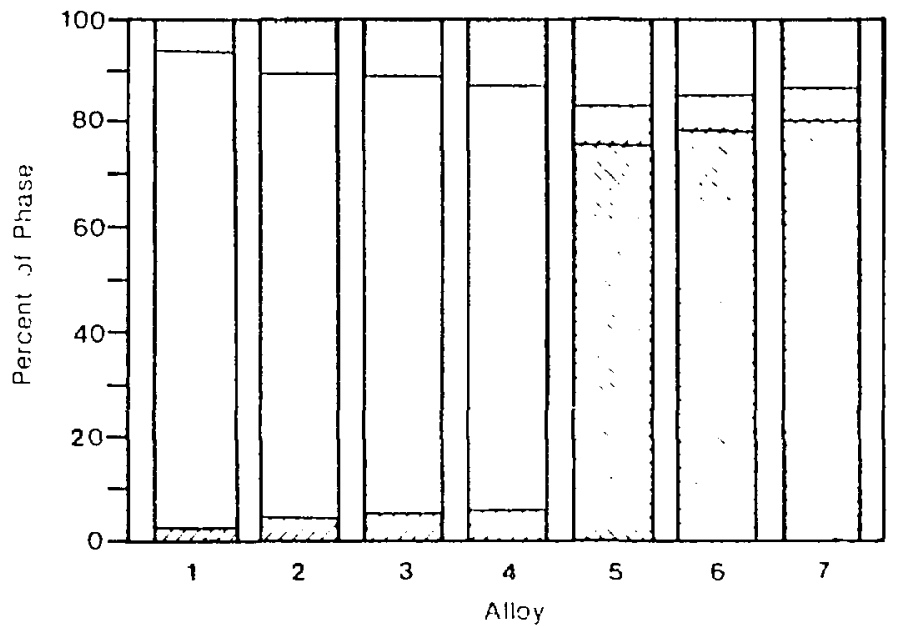

Figure 7.19 Results of the solidification segregation model showing the relative amounts of ferrite and austenite that solidify at high cooling rates in electron beam melt No. 6. The primary mode of solidification changes from primary austenite to primar? ferrite between Alloys 4 and 5 
of the seven solidification conditions, the casting shows the highest amount of second phase formation. As expected, the segregation calculations for the casting are similar to the results predicted by the Sche!! equation whith uere presented in Figure 7.15. In the casting. the calculations indicate that for the primar! austinitc solidificd alloys 1.2 and 3, the amount of primary phase austenite decreases and the amount of second phase ferrite increase with increasing Cr Ni ratio. This reculis in a mavimum sccond phase ferrite content of about $15 \%$ in alloy 3 as comparcd lo about 2514 predicted by the Scheil equation. For the primary ferrite solidificd allous 4, 5.6 and 7. the amount of primary phase ferrite increases with $\mathrm{Cr} \mathrm{Ni}$ ratio at the expense of second phase austenite. The total ferrite content of these alloys inereases from 51"n in Alloy 4 to $74 \%$ in Alloy 7 as compared with the range of $37 \%$ th the Schcil approach.

The major difference between the Scheil approximation ond the castings is in the reduction in the amount of second phases that form. These differences lecone most apparcnt when comparing Alloys 3 and 4 which have similar compositions but have different primary modes of solidification. Where the Scheil equation predicts a small increase in the total ferrite content between Alloys 3 and $4\left(13^{n} 0\right)$. the segregation calculations for the casting show a larger increasc (36\%). This discontinuity (the difference in total ferrite content between the primary austenite and primary ferrite solidified alloys) increases as the coolng rate increases and is responsible for the alloys solidifsing in either the fully fertic mode or fully austenitic mode at high cooling rates.

The solidification segregation calculations for EB inelt 2 at $25 \mathrm{~mm} / \mathrm{s}$ and EB melt 6 at $5.000 \mathrm{~mm}$ s are represented by Figures 7.18 and 7.19 respectively. The influence of cooling ratc on the phasc which forms can be secn by comparing the results for the casting $\left(70^{\circ} \mathrm{C} \cdot \mathrm{s}\right)$, a $25 \mathrm{~mm} / \mathrm{s} \mathrm{mclt}\left(1.9 \times 10^{3 \circ} \mathrm{C}\right.$ 's) and the $5 \mathrm{~mm} \mathrm{~s} \mathrm{mclt}\left(7.5 \times 10^{6 \circ} \mathrm{C}\right.$ 's $)$. The amounts of primary phase increasc and the amounts of secondary phase decrease which creates the discontinuity in total ferrite content betucen the primary ferrite and primary austenite solidified alloys. At the highest cooling rate, this discontinuity was calculated to be $77 \%$ between Alloys 4 and 5 . Howerer. the clectron beam resolidification experiments show Alloy 4 to be fully austcnitic and Alloy 5 to be fully ferritic at this specd. i.e., the discontinuity in ferrite content is actually $100 \%$.

The difference between the calculations and experimental obscrvations at high 
cooling rates is most likely caused by the approximations that werc made in deriving the pscudobinary diagrams or in the approximations made in estimating the intertace velocity for the high scan specd melts. The fact that no second phase formation is observed in the high speed melts suggests that these alloys are being undercooled to a temperature where single phase solidification can occur, i.c.. below the solidus tcmperature and into the siable (or metastable) single phase region. The necessary undercooling to bring the alloy into the single phase region can be defined as $T_{\mathbf{L}}-T_{S}$ and is a function of alloy composition. Table 7.9 summarizcs $T_{L}-T_{S}$ for cach of the alloys and compares these values to the undercoolings calculated for the casting. EB melt 2 and EB melt 6 . In the highest spced melt. where single phasc solidification behavior was obscrved, the undercoolings that were calculated fall 10 to $15^{\circ} \mathrm{C}$ above the calculated solidus temperature. Therefore, it is apparent that either the Ealculated solidus tcmpcratures are too low or the amount of undercooling calculated at the dendrite lip is too low. However, since approximations were made in deriving the pscudobinary diagrams and since approximations were made in the dendrite tip calculations, cither onc might be in crror and additional analysis would necd to be performed to specify the solidification conditions more preciscly.

Table 7.9: Comparison of the solutal undercooling with the undcreooling necessary to reach the solidus tempcrature.

\begin{tabular}{|c|c|c|c|c|}
\hline \multirow[t]{2}{*}{ Alloy } & \multirow[t]{2}{*}{$\begin{array}{c}\mathrm{T}_{\mathrm{L}}-\mathrm{T}_{\mathrm{S}} \\
\left({ }^{\circ} \mathrm{C}\right)\end{array}$} & \multicolumn{3}{|c|}{$\pi$} \\
\hline & & $\begin{array}{l}\text { Cast } \\
(\circ C)\end{array}$ & $\begin{array}{l}\text { E-B } 2 \\
\left({ }^{\circ} \mathrm{C}\right)\end{array}$ & $\begin{array}{c}E-B \quad 6 \\
(\circ C)\end{array}$ \\
\hline 1 & 31.3 & 7.3 & 12.4 & 22.2 \\
\hline 2 & 34.0 & 7.6 & 12.8 & 23.8 \\
\hline 3 & 35.0 & 7.8 & 13.5 & 24.6 \\
\hline $4-A$ & 35.7 & 8.0 & 13.9 & 25.0 \\
\hline $4+F$ & 41.0 & 6.8 & 12.9 & 25.5 \\
\hline 5 & 37.1 & 6.8 & 12.0 & 23.0 \\
\hline 6 & 35.6 & 6.5 & 11.5 & 22.8 \\
\hline 7 & 33.0 & 6.2 & 11.0 & 21.9 \\
\hline
\end{tabular}




\subsection{Summary and Conclusions}

Solidification paths were calculated for primary ferrite and primary austenitc solidification conditions. These paths vere uscd to detcrmine pscusubinary diagrams through the Fe-Ni-Cr system to allow the solidification behatior of the ternar! allus to be treated like binary alloys. These diagrams are shown in Figures - + and -5 and represent significant improvements over the constant Fe sections that have been ured in the past to illustrate the solidification behavior of stainless stecl allous

Average temperature gradients and average interface velocities were salculated for each of the solidification conditions used in this investigation. These parameters were then used to calculate the dendrite tip radius. and dendrite tip underasoling for cach alloy and cach solidification condition using a constraincd tindrite growth $\bmod c$. The results of these calculations showed that the solutal underiouling iaries from about $5^{\circ} \mathrm{C}$ :o about $30^{\circ} \mathrm{C}$ as the cooling rate is increased from the sasting ( 7 . $\mathrm{C}$, to the highest speed clectron beam melt $\left(7.5 \times 10^{60} \mathrm{C}\right.$ 's).

Based on the minimum in the Peclet number versus interface selusits curses. predictions were made for the cellular to dendritic transition as a runction of grouth rate and temperature gradient. These calculations were compared uith the misrostructures from each melt to show that the calculations appeared to be alf by a constant multiplying factor. The difference in calculated and experimental behasior was rationalized by the uncertainties in the cellular to dendritic transition theors and in the uncertainties used in developing the assumptions for calculating the dendrite tip characteristics.

Solutal undercooling at the dendrite tip results in an increase in the amount of primary phase and a reduction in the amount of secondary phase that solidifies from the melt. This factor was taken into account to predict the relative amounts of primary and secondary phases which solidify for cach of the solidification conditions.

The results of the solutc redistribution calculations clearly show the influenec that cooling rate has on the microstructure. At low cooling rates, therc is a continuous increase in the total ferrite content with $\mathrm{Cr} N \mathrm{Ni}$ ratio of the alloy. The calculations at slow cooling rates are confirmed by the Scheil predictions and by the general trend in ferrite content measured on the arc cast buttons. As the cooling rate 
is increased. the calculations indicate a discontinuits in the total ferrite content which develops between the primary ferrite and primary austenire soliditying alloss. The saleulations show that this discontinuity reashes $77^{\text {th }}$ betwecn Alloys 4 and 5 in the highest speed melt. i.c.. these results indieatc that Allos 5 should solidil, with 770 more ferrite than Alloy 4 in EB melt 6.

The ealculated discontinuity in ferritc content helps to explain the single phase nature of the high specd electron beam melts. At high specds, the reduction in the amount of the second phase that forms is so severe that the alloys solidify in the lully austenitic or lulls ferritic mode depending on their PSM. Although the alculations do not predict pure single phase behavior. thes do show the trend which explains the experimental observations. The difference between the calculations and the cxperiments is a result of the approximations made in deriting the pscudobinary diagrams and made in the dendrite tip ealculations. 


\section{CHAPTER 8}

\section{The Influence Of Cooling Rate On The Solid State Transformation Of Ferrite}

Metallographic anolysis or the clectron beam melis was presented in Chapter 5 to illus:rate the complex microstructures which develop during the resolidification of stainless steels. Thesc observations indicate that the ferrite which forms during the FA or AF modes of solidification transforms by the diffusion controlled growth (DCG) of prexisting austenite at the ferrite/austenite interface. However, for alloys that solidify in the fully ferritic mode, nucleation of austenite from the ferrite matrix must precede its growth. For these eases, the transformation of ferrite was shown to occur by: 1) the growth of massive austenite, which was limited to alloy 5 and was on!y observed at high cooling rates, and 2) the growth of Widmanstatten austenite platelets or needles from grain boundary allotriomorphs.

Qualitative analysis of the conditions responsible for the different transformation mechanisms was used to develop the microstructural map of the microstructures shown in Fig. 5.15. This figure shows the cooling-rate and compositions ranges where cach transformation mechanism was observed. In this chapter, the cmpirical observations which were formulated in the previous chapters are studicd through the quantitative application of nucleation and growth kinetic analysis applicd to the transformation of ferrite in the resolidified melts.

The growth kinetics of ferrite are discussed in two models. The first model is a first order approximation to the diffusion equation, applied to the continuous cooling characteristics of the electron beam surface melts. This model correlates well with the experimental observations and was uscful in describing the amount of transformation that occurs as a function of cooling rate for DCG conditions. A more careful analysis of the diffusion problem requires a numerical model to incorporate the complexitics of ternary alloy diffusion and the moving boundary nature of the transformation. A mathematical formulation of this problem was developed 
specifically for the Fe-Ni-Cr system. When coupled with the thermodynamis cquilibrium at the ferrite austenite interlace. this approach san be used to predist the rate and cxtent of the transformation as a iunction of cooling rate.

The microstrustures thich desclop durng cooling of iulls ferritio solidilicd Fe-Ni-Cr alloys were shown to be analogous to the microstructures which develop during the dccomposition of austenitc in the Fe-C systen. This analog! proted whe usclul in understanding the kinetics of the ferrite transiormation by prosiding the wealth of analysis which has been performed on the Fe-C sistem to to applicd to the Fe-Ni-Cr system. Experimental studies of the ferrite to a ustenite transturmation were also condueted on fully ferritic specimens to determine the transformation rate at different remperatures. These results ucre analyzed by the Johnson-lichl and tiram approach to determine the transformation kincties. and to estimate the inlluence ol cooling ratc on the amount of transformation.

\subsection{Diffusion Controlled Growth}

\subsubsection{A First Order Approximation}

The solid state transtormation of ferritc ocsurs as the allos is coolcd through the $F+A$ two phase ficld. Oricntation of the tic-lines in the Fe-Ni-Cr system sho:s that the partitioning of $\mathrm{Ni}$ and $\mathrm{Cr}$ occurs along constant $\mathrm{Fe}$ isopleths at temperatures near the solidus. As the alloy cools, the ferrite which forms during solidilication begins to transform by the diffusion of $\mathrm{Cr}$ to the ferritc and $\mathrm{Ni}$ to the austenitc. The rate at which this transformation taties place is governed by the rate at which the slowest moving element can diffuse from the austenite ferrite interiace.

Diflusion cocfficients have becn measured lor Fe. Cr and $\mathrm{Vi}$ in ferritc and austenite [8.1-8.8] and the results are summarized in Table 8.1 and 8.2 . These results suggest that the diffusion occurs at a slouer rate in austenite than in ferrite and that. in general, Ni diffuses at a slower rate than $\mathrm{Cr}$. Therefore. estimations of the transformation rate can be made assuming. : controls the reaction

The reported rates for diffusion of $\rightarrow i$ in austenite show that the actisation 
energs lends to decrease as the alloy eontent of the stainless steel increases. has a measured actiation energs. $Q$. of about os heal mole and a precaponential somstant. Do of about $5 \times 10^{-5} \mathrm{~m}=\mathrm{s}$ :

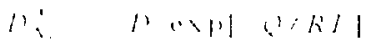

where $R$ is the gas sonstant and $T$ is the comperature in kelsin. Ihas roults in a diliusinil! ol about $9 \times 10^{-14} \mathrm{~m}^{2}$ s al $1.350^{\circ} \mathrm{c}$.

I able 8.1: Volume diflusion in $B C^{\circ}$ Perate

\begin{tabular}{|c|c|c|c|c|}
\hline rement & Allo! & $\begin{array}{c}Q \\
\text { (heial mule) }\end{array}$ & $\begin{array}{c}D_{1} \\
\left.(m)^{2} \times-1\right)\end{array}$ & Rel. \\
\hline Ic & - & - & - & - \\
\hline \multirow{5}{*}{$v i$} & Pure lc & 62.7 & $9.7 \times 10^{-4}$ & 8.1 \\
\hline & Pure Fe & 50.0 & $1.3 \times 10^{-4}$ & 8.2 \\
\hline & $1 \mathrm{c}-2.0 \mathrm{Cr}$ & 6.3 .4 & $1.2 \times 10^{-5}$ & 8.3 \\
\hline & $10-100 r$ & 05.6 & $3.6 \times 10^{-5}$ & 8.3 \\
\hline & $1 \mathrm{c}-20 \mathrm{Cr}$ & 53.0 & $7.0 \times 10^{-7}$ & 8.3 \\
\hline \multirow[t]{2}{*}{$C r$} & Plice Fe & 57.3 & $2.4 \times 10^{-4}$ & 8.4 \\
\hline & $F c-25 C r-5 \mathrm{Ni}$ & 50.7 & $0.0 \times 10.6$ & 8.5 .8 .8 \\
\hline
\end{tabular}

Table 8.2: Volume dittusion in FC ${ }^{\circ}$ tustenite

\begin{tabular}{|c|c|c|c|c|}
\hline Ilement & Allo3 & $\begin{array}{c}Q \\
\text { Iheal molel }\end{array}$ & $\begin{array}{c}\text { D.. } \\
\left(m=\sqrt{ } s^{-1}\right)\end{array}$ & Rcl. \\
\hline Ic & $1 \mathrm{c}-17(\mathrm{r}-12 \mathrm{Ni}$ & 66.8 & $3.6 \times 10^{-5}$ & 8.6 \\
\hline \multirow{4}{*}{$>i$} & Pure lic & 0.0 & $7^{-} \times 10^{-5}$ & 8.2 \\
\hline & Je-9Ni & 66.4 & $50 \times 10-5$ & $8:$ \\
\hline & $1 \cdot c-10 x i$ & 65.4 & $4.1 \times 10.5$ & 8.3 \\
\hline & $\mathrm{Fc}-17 \mathrm{Cr}-12 \mathrm{Ni}$ & 001.1 & $9.0 \times 10.7$ & $8=$ \\
\hline \multirow{3}{*}{$\mathrm{Cr}$} & Purelic & 6013 & $0.3 \times 10^{-0}$ & 84 \\
\hline & $1 c-1 T c r-12 x i$ & $0: 1$ & $1.3 、 10-5$ & 8.6 \\
\hline & $f c-17(r-12 N i-314)$ & 58.1 & $0.3 \times 101$ & 8.5 .88 \\
\hline
\end{tabular}


A first order approximation of the amount of transformation that occurs during cooling in the resolidification melts can be cstimated from the ahore diflusitit? of nickel in austenite and the characteristic dirfusion distanec. $\mathrm{L}$ :

$$
1-2(1) 11)^{1 \cdots}
$$

Where " represents the transformation time and is inversely related to the cooling ratc. . and the tcmperature rangc over which transiormation is occurring. 1 :

$$
I=1 /
$$

Since cquation 8.2 is nonlincar, a numerical approach is required to calculate the amount of diftusion that oceurs as the alloy cools to room temperature. By selccting

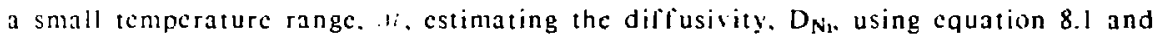
cstimating the transformation time. H. Over this tempcraturc rangc using cquation 8.3. the produst $i$. " can be determined. The characteristic diffusion distance, L. can then be calculated from the summation of $b$. lt by the following cquation:

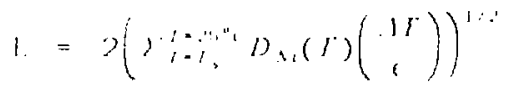

The diffusitity of nickel in austenitc was assumed to be the rate limiting fastor and the continuous cooling characteristics of the E-B process were taken into account in calculating the diffusion distance by using cquation 8.4 with a temperature increment of ${ }^{\circ} \mathrm{C}$. The results of these calculations arc summarized in Table 8.1 for cach of the cooling rates studicd in this investigation. The largest degrec of transiormation was observed in the casting which required $197 \mathrm{~s}$ to reach room temperature while the least amount of transformation was observed in the highest specd clectron bcam nelt which required only $1.9 \times 10.4 \mathrm{~s}$ to reach room temperaturc. This diflerence in cooling rates reduced the characteristic diffusion distance from 2.9 wm for the casting to $2.8 \times 10^{-3}$ w.m for the highest specd melt.

During cooling. the perecntage of ferrite that transforms is related to the sharacteristic diffusion distance and the thickness of the ferrits parieles. Both $L$ and the dendritc arm spacing. ". decrease with increasing cooling rate. However, since the characteristic diflusion distance is proportional to $\mathrm{W}$ and since the dendrite arm spacing is proportional to about $t$. L. decreases faster than * with increasing cooling 
rate. Therefore, as the cooling rate is increased. Iess perentage of the ferrite in the microstructure transforms, i.c., the solidification microstructure becomes "quenched in" at high cooling ratcs. This fast bccomes obrious by comparing the ratio of $L$ to which is shown in Table 8.3 to decrease from $10.0^{\%} \%$ in the sasting $100.7^{40}$ in the highest specd E-B melt.

Table 8.3: Characteristis diffusion distance and dendrite arm spacings.

\begin{tabular}{|c|c|c|c|c|c|c|}
\hline Mclt & $\begin{array}{l}\text { Cooling Ratc } \\
\qquad(0 \mathrm{Cs})\end{array}$ & $\begin{array}{c}\text { Time to } \\
\text { Reach RT } \\
\text { (s) }\end{array}$ & $\begin{array}{l}\text { Diffusion } \\
\text { Distance. L } \\
(11 \mathrm{~m})\end{array}$ & $\begin{array}{c}\lambda \\
(1+n)\end{array}$ & $\begin{array}{c}\lambda . \\
(\mu m)\end{array}$ & $1 / \lambda$ \\
\hline Cast & 7 & 197 & 2.9 & - & 18 & $1.6 \times 10^{-1}$ \\
\hline 1 & $4.7 \times 10^{2}$ & 2.9 & 0.35 & - & 4.7 & $7.5 \times 10^{-2}$ \\
\hline 2 & $1.9 \times 10^{3}$ & $7.3 \times 10^{-1}$ & 0.17 & - & 3.0 & $5.7 \times 10^{-2}$ \\
\hline 3 & $1.7 \times 10^{4}$ & $8.2 \times 10^{-2}$ & $5.8 \times 10^{-2}$ & 3.2 & - & $1.8 \times 10^{-2}$ \\
\hline 4 & $4.4 \times 10^{5}$ & $3.2 \times 10^{-3}$ & $1.1 \times 10^{-2}$ & 1.1 & - & $1.0 \times 10^{-2}$ \\
\hline 5 & $1.5 \times 10^{6}$ & $9.2 \times 10^{-4}$ & $6.1 \times 10^{-3}$ & 0.7 & - & $8.7 \times 10^{-3}$ \\
\hline 6 & $7.5 \times 10^{6}$ & $1.9 \times 10^{-4}$ & $2.8 \times 10^{-3}$ & 0.4 & - & $7.0 \times 10^{-3}$ \\
\hline
\end{tabular}

The percentage of the misrostruture that transtorms san be calculated lor cach cooling rate. Figure 8.1 illustrates a simple model that can be used lo predict the amount of transformation. The sccondary dendrite arms are assumed to be cqually spaced right circular cylinders and the distance between the ferrite particles is equal to the scondary arm spacing. To account for scoond phase austenite between the ferrite dendrites, the diameter of the initial ferrite "eylinder" belure transtormation was metallographically measured on several specimens to be ahoul 23 of this spating. Taking this factor into account. the pereentage of ferrite that translornicd san be approximated by the ratio of arcas beforc and alter transiormation: 
\% Transformed $=\left(\begin{array}{c}r^{2}-(r-1)^{2} \\ t^{2}\end{array}\right) \times 100$

where $r$ refers to the radius of the ferrite dendrite $(26$ DAS), and $L$ is the characteristic diffusion distance reported in Table 8.3

Table 8.4 summarizes the ferrite transformation calculations and the results show that $73.3 \%$ of the ferrite that solidifics in the castings will transform while only $4.0 \%$ of the ferrite that solidifies in the highest speed electron beam melt will transform. Therefore, the residual ferrite content of ptimary ferrite solidificd alloys should increase as the cooling rate increases. This behavior was observed in the actual electron-beam melts. For example Alloy 7 which solidifies in the fully ferritic mode has a measured ferrite content of 32 percent in the cast condition which indicales that $68 \%$ of the microstructure has transformed. This measured value compares favorably to the predicted value of $73.3 \%$.

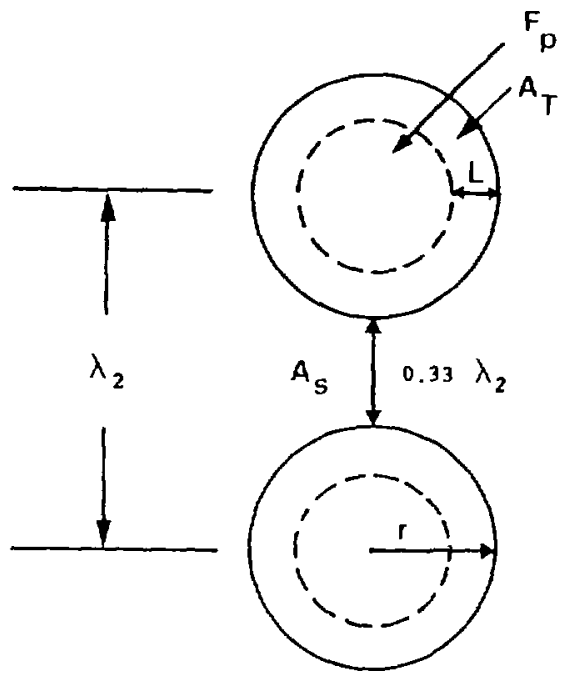

Figure 8.1 Illustration of a model to predict the percentage of ferrite in the microstructure that transforms for a given characteristic diffusion distance, $L$. 


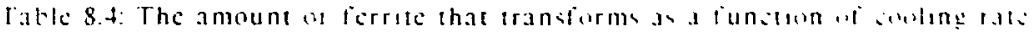

\begin{tabular}{|c|c|c|c|c|}
\hline Melt & $\begin{array}{c}1 \\
\therefore A_{1} \cdots\end{array}$ & $\begin{array}{c}\mathrm{r} \\
\ldots \\
\ldots\end{array}$ & $\begin{array}{c}1 \\
\ldots \\
\ldots\end{array}$ & $\begin{array}{c}\text { "randermed } \\
\text { trand }\end{array}$ \\
\hline Cast & 18 & 0.0 & 24 & -33 \\
\hline 1 & 4. & 1.5 & 0.5 & $41=$ \\
\hline 2 & 30 & 10 & $0.1^{-}$ & $\therefore 1$ \\
\hline$\vdots$ & $\therefore 2$ & 11 & $5 s+10=$ & $10 .:$ \\
\hline 4 & 1.1 & 0.2 & 11,102 & 8.0 \\
\hline 5 & $0^{-}$ & 0.24 & $0.1 \times 10-3$ & $\therefore 0$ \\
\hline 0 & 0.4 & 0.14 & $28 \times 10 .-3$ & +0 \\
\hline
\end{tabular}

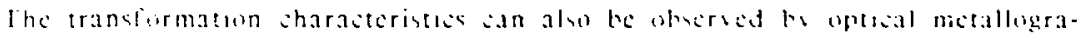

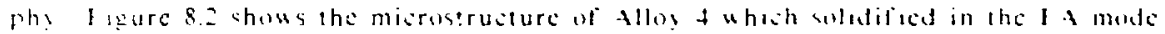

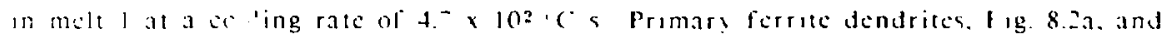
equased ferrite cells, Fig. 8.20. sere present in the misustructure. This specimen Was etohed with a color metallographic eshnique that reveals 11 primary ferrite whitel. Zl austenite that transiormed from lecrite and cosclops the primary ferrite are rark grey, and is second phase austenite that soliditied from the melt llaght gres? The width of the transtormet regiens aries from about $0.5 \ldots$ to $1.0 \ldots$ which

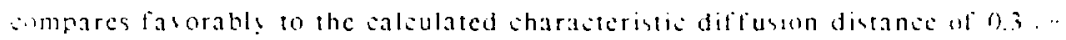

\section{\$.1.2 Finite Difference Approach}

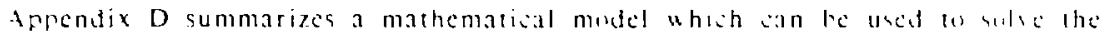

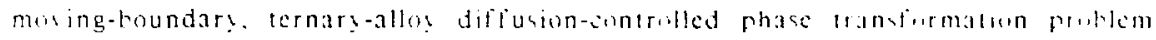

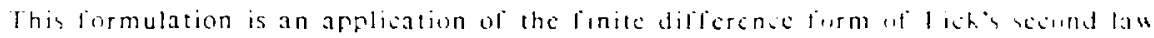

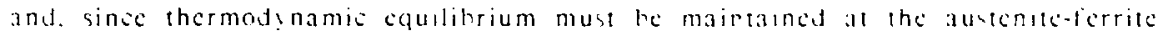

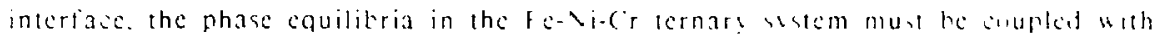

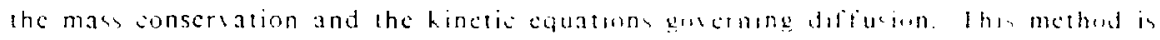
sultivicnt to develop a sompuler progiam to prodet the trandiumatun rate and the

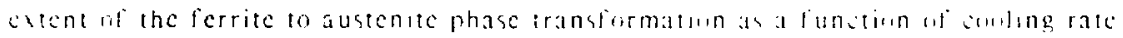



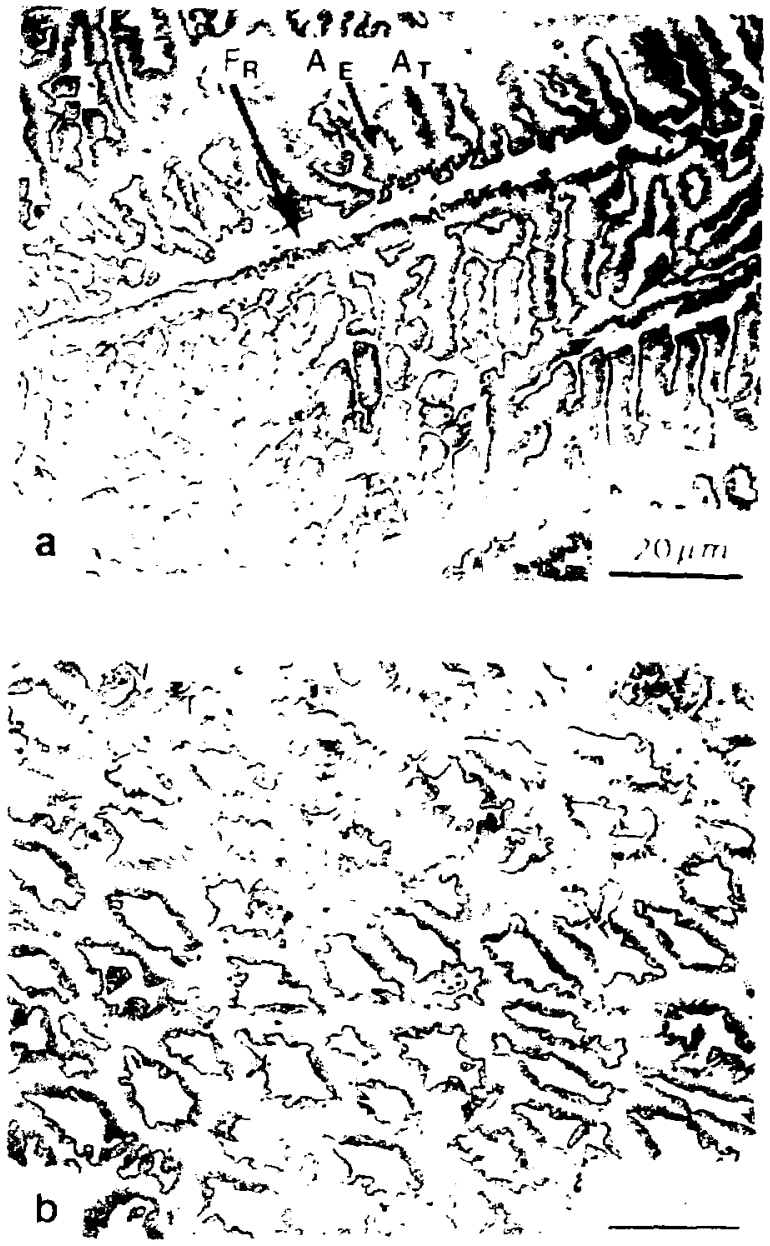

Figure $X .2$ (a'.r metallographic technique uned to dintinguish hetusen the austenite which forms during wlidification and the austenitc shich farms during irancormation of ferrite. a) bous ferrite dendrites and b) anos ferrite iella. both frome Nllos 4 . 


\subsection{The Massive Transformation}

Massive phasc transformations shange netastable phases 6 squilibrium phases or other metastable phases by a difiusional process that involics a rapid noncoopcrative transfer of atoms across a high-encrg! intertace. Thesc transformations arc thermally activated and cxhibit nucleation and grouth sharacteristics but require only short range diffusion of a fes atomic jumps to change onc erstal structure to another. The cooling rates nesessary for the massice transformation must be sulficiently rapid to suppress the formation of product phases that involic long range dilfusion. The resulting massive transformation docs not insolsc any change in the ovcrall somposition. This composition invariance is a important characleristic of the massive transformation and can be uscd to aid in its identification. Characleristic patches of the massisely farmed phase appear as blochs in the microstructure and chhibit ledge features. planar facets and twinning in some allos systems. The large driving force for the transformation allows the produst phasc lo eross grain boundarics and other obstacles.

The massive transformation was obscred in Alloy 5 at high cooling rates but was not obscried in any of the other alloys. cren though they had similar compositions. One of the objectives of this chapter is to cxplain. through thermodynamic and kinctic arguments, the conditions for which the massive translormation occurs in the Fe-Ni-Cr system and use these results to show why the massive transiormation was only obscricd in Allo! 5.

\subsubsection{Vicrostructural Characteristics}

I: has … lne rates. Nllos 5 solidifies in the fully ferritic mode and upon ise. Iran l., i. I hin biume fraction austenitc by the growth of new

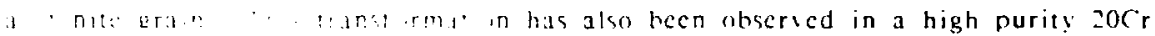

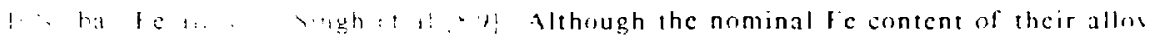

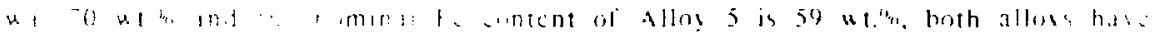

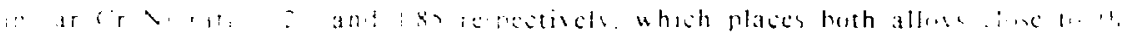

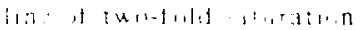


Figure 8.3 compares the mizrostructure of massivels formed austenite in tllos 5 with single phase ferrite in fllat 7 . The single phase ferrite mierosiructure is shown in Fig. 8.3 and indicates that the ferritc grain boundarics etch prominently and a cellular solidification "substrusture" can be observed. This specimen is hnown to he full: ferritic because of its high saluc of saturation magnctization $\left(10^{-} \mathrm{cmu} g\right.$ ).

The microstructure of Allos 5, prior tu the transformation, is single phase ferrice and should he similar in appearance to Fig. 8.3.a. Howeder, alier the Iransiormation. the microstructurc is predominandy single-phase austenitc grains and the grain boundarics tend to be aligned perpendicular to the soliditication direstion with a jaged appearanse. Tuinning is obserscd within the austenite grains and the specimen in hnown to hase a high solume fraction austenitc duc to its low saturation magnctization (I8 $\mathrm{cmu}$ g). The microstructure also shows that some ferrite is present at the austenite grain boundaries as a result of the incomplete transtormation to austenite. Ihis ferritc is responsible lor what magnetic moment the spcimen has: il the tranulormation to austcnitc had becn complete. the saluration magnetisation of the specimen would be zero.

To prote that the microstructures obscred in tllu! 5 are indecd formed by the massise transtormation, the composition insariance across the ferrite and austenite patches was determined by elcetron microprobe analysis. Figurc 8.4 a shous the microstructure at the root of melt 3. This melt was moving at $100 \mathrm{~mm}$ s. has a solidilication ecll spacing of $3.2 \ldots m$ and cooled at a rate of about $20000 \mathrm{C}$ s

Two microhardncss indentions were placed on the specinen and hetween these two indentions is an astenite icritc interiace. The microprobe was used to measure the Fc. Vi and Cr compositions at 2... intersals with a I, "Focal spot size figure 8 th shows the results of these measurements and indistev that the areage composition of the austenite phase is identisal tu that at the teste phase and that

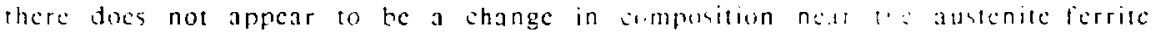

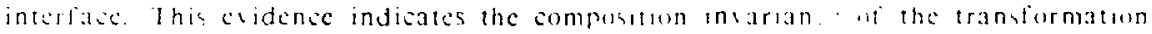

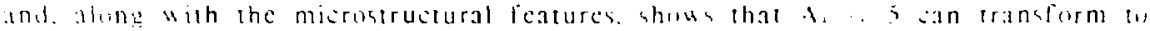

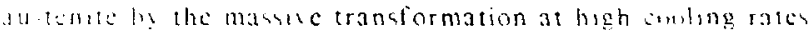




\subsubsection{Thermodynamics}

It is known that the massize transformation ean begin in the F+A two phase region at a temperature. To. where the Gibbs trec energs of the ferrite and austenite of the same compositions arc equal. Houcler, cxperimental evidence cxists to show that the eflective start temperacure for the tranciormation requires additional undercooling so that the nucleation temperature is closer to the austenite soli us [8.10]. Thercforc. the alloys which are susceptible to the rassive transformation tend to be losated close to the line of two-fold saturation to minimize the amount of undercoling required to bring the alloy slose to the austenite solvus.

Figure 8.5 plots the composition of the seven alloys on a vertical section through the Fe-Ni-Cr ternary phase diagram. This vertical section was taken along a composition path that represents the partitioning of $\mathrm{Ni}$ and $\mathrm{Cr}$ at temperatures just below the solidus temperature of these alloys. i.c.. the $1400^{\circ} \mathrm{C}$ tic lines in the F+A IWo-phase ficld lics in the plane of Fig. 8.5 and was determined from the isothermal scitions presented in Appendix C. As mentioned in Chapter 7. there is a difference in the fostion of the line of two-fold saturation calculated by Thermocale and the cuperimental observations. Since the relative location of the alloys with respect to the line of two-fold saturation is important, this difference was taken into accuent by shiting the position of the seven alloys by subtracting $2.8^{2 \mathrm{~h}} \mathrm{Ni}$ from cach composition hetise plowing them on the diagram. With this adjustment. the thermodynamic saliulations can be correlated directly with the ceperimental obscruations.

The location of the $T_{0}$ linc can be descrmined from the Githe fiec encrg! weris somposition plots in the Fe-Ai-Cr system. These calculations ucre also perfurm: 1

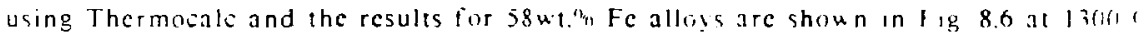
and $1350 \mathrm{C}$. The $T_{0}$ composition is defined where the fice energy of the ferritc and austenite of the same compositions are equal. These tun pointe that acre calculated from Fig. 8.6 can be used to estimate the $T_{a}$ line in the ferrite + autente tuo phace ricid.

The $T_{y}$ lane is indicated in Fig. 8.5 and is located approkimalely miduas betueen the ferrite and austenite solvus lines. This rigure indeates that $T_{n}$ rapull: decreases in temperature with small changes in composition. 

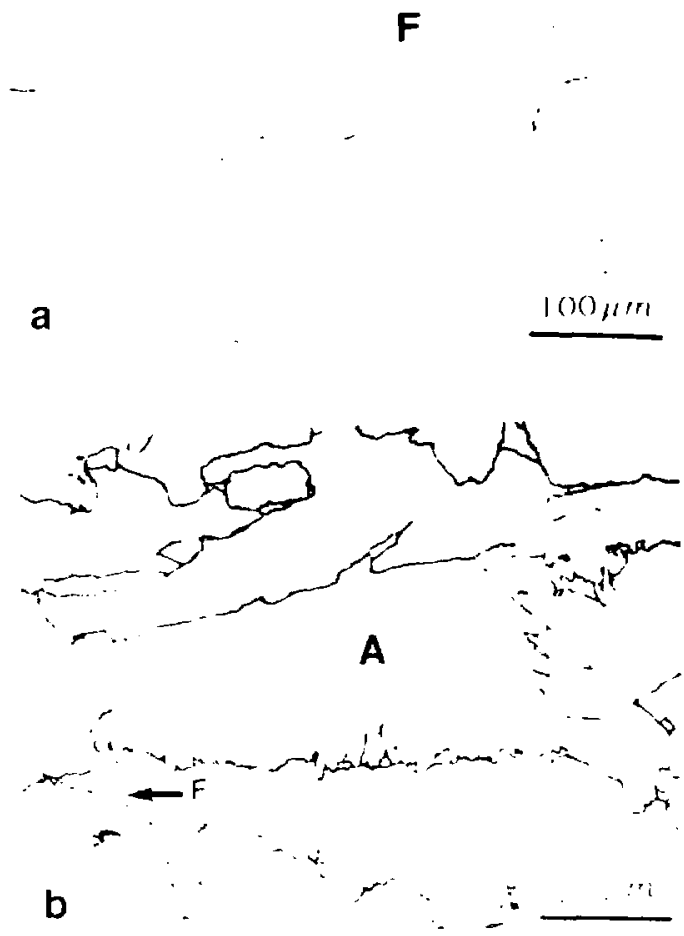

Figure 8.3 Comparison of at the single phase ferrite micrastructure and b) massive austenite which transformec foom single phase ferrite in Alloy 5 . 

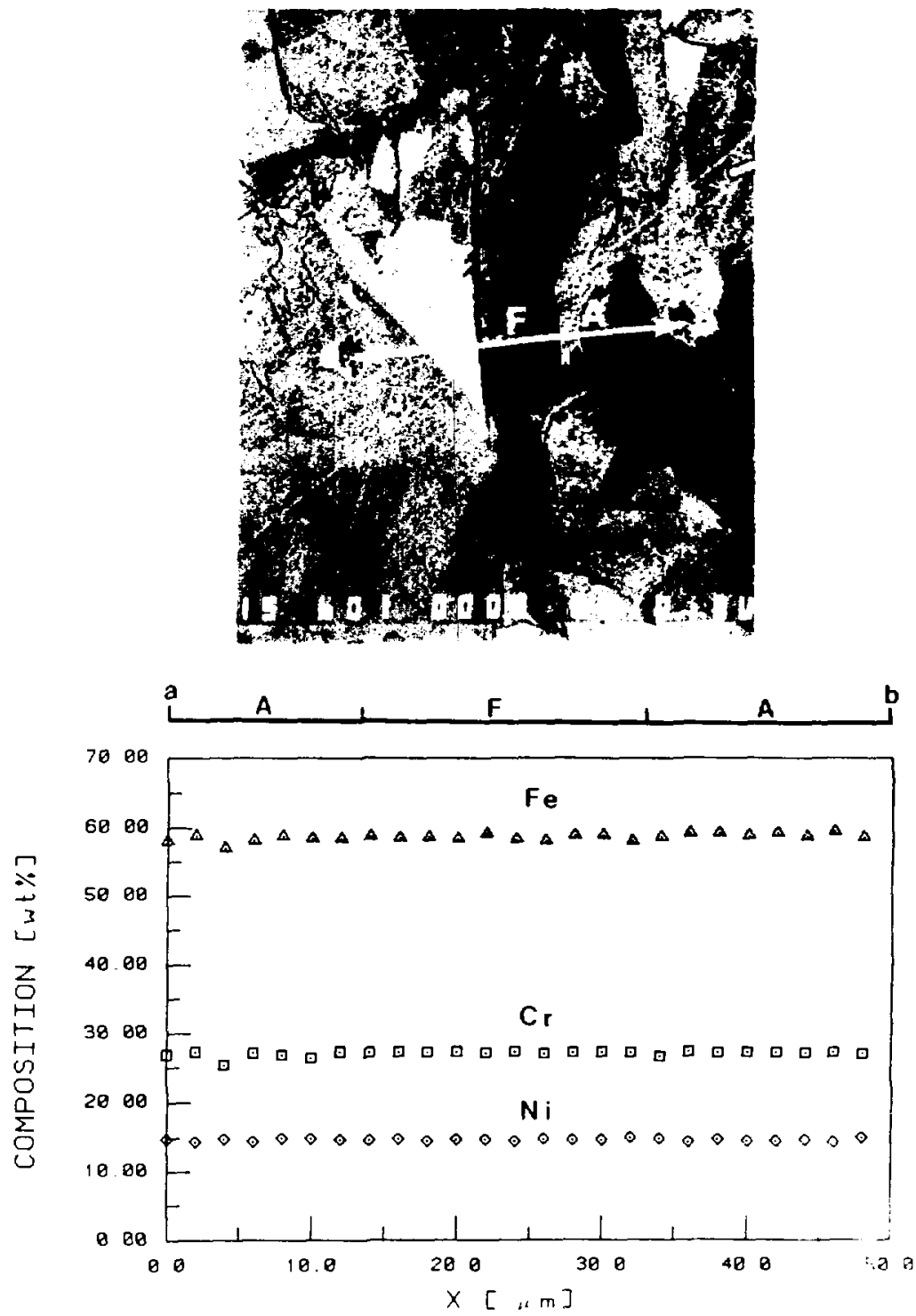

Figure 8.4 Electron microprobe scan across an untransformed ferrite region, surrounded by massive austenite in Alloy 5 . The results indicate the composition invariance of the massive transformation. F refers to the ferrite phase and $A$ refers to the austenite phast. 


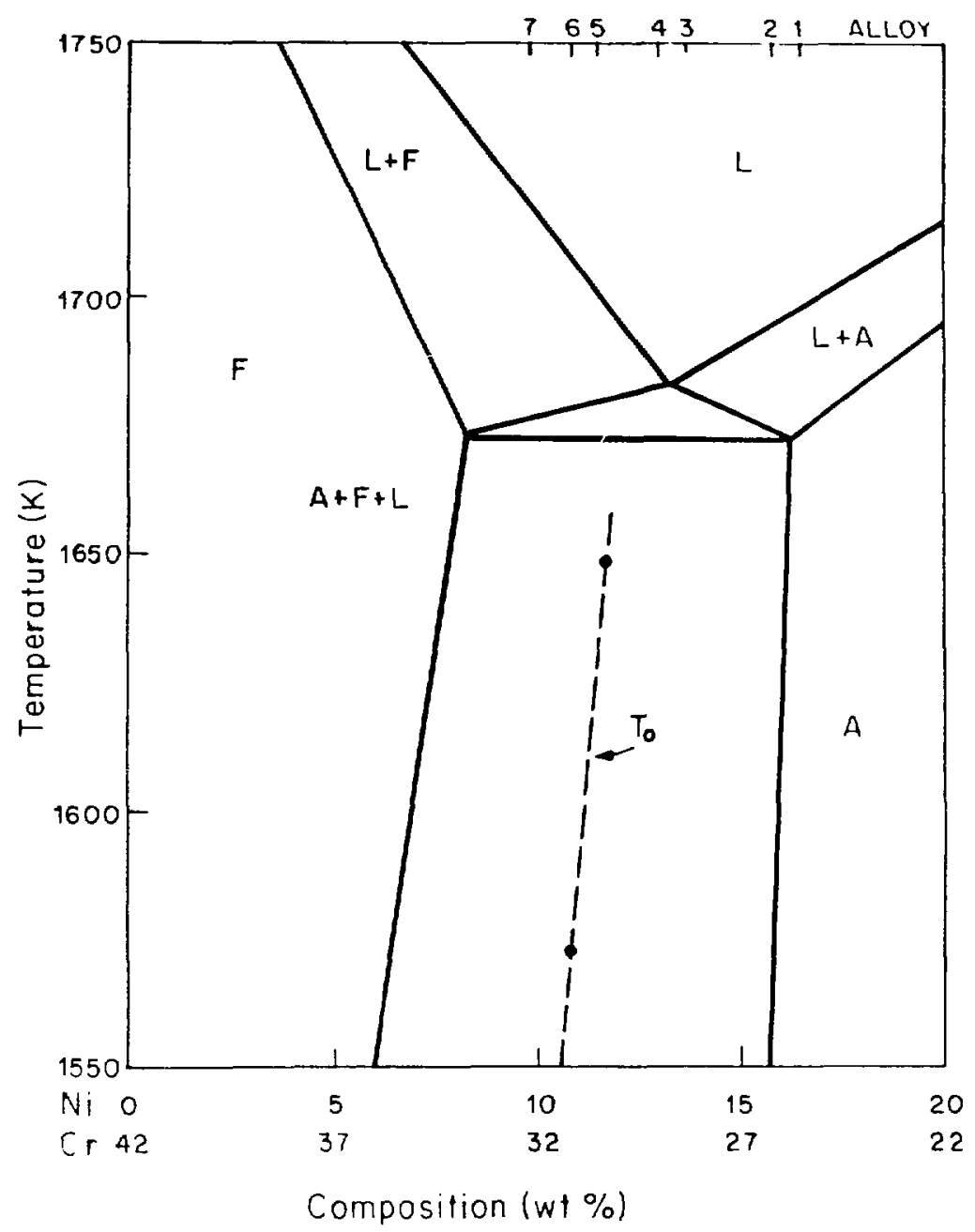

Figure 85 Thermodingizally calculated vettical acotion through the Fe-vi-C r liagram along a path that represents partitioning in the $F+A$ two-phase ficld. I.quivalent compositions of the seven allos are indicald and the $T_{0}$ line in the $\mathrm{F}+\mathrm{A}$ regirn was calculated at 1575 and $1550 \mathrm{~K}$. 

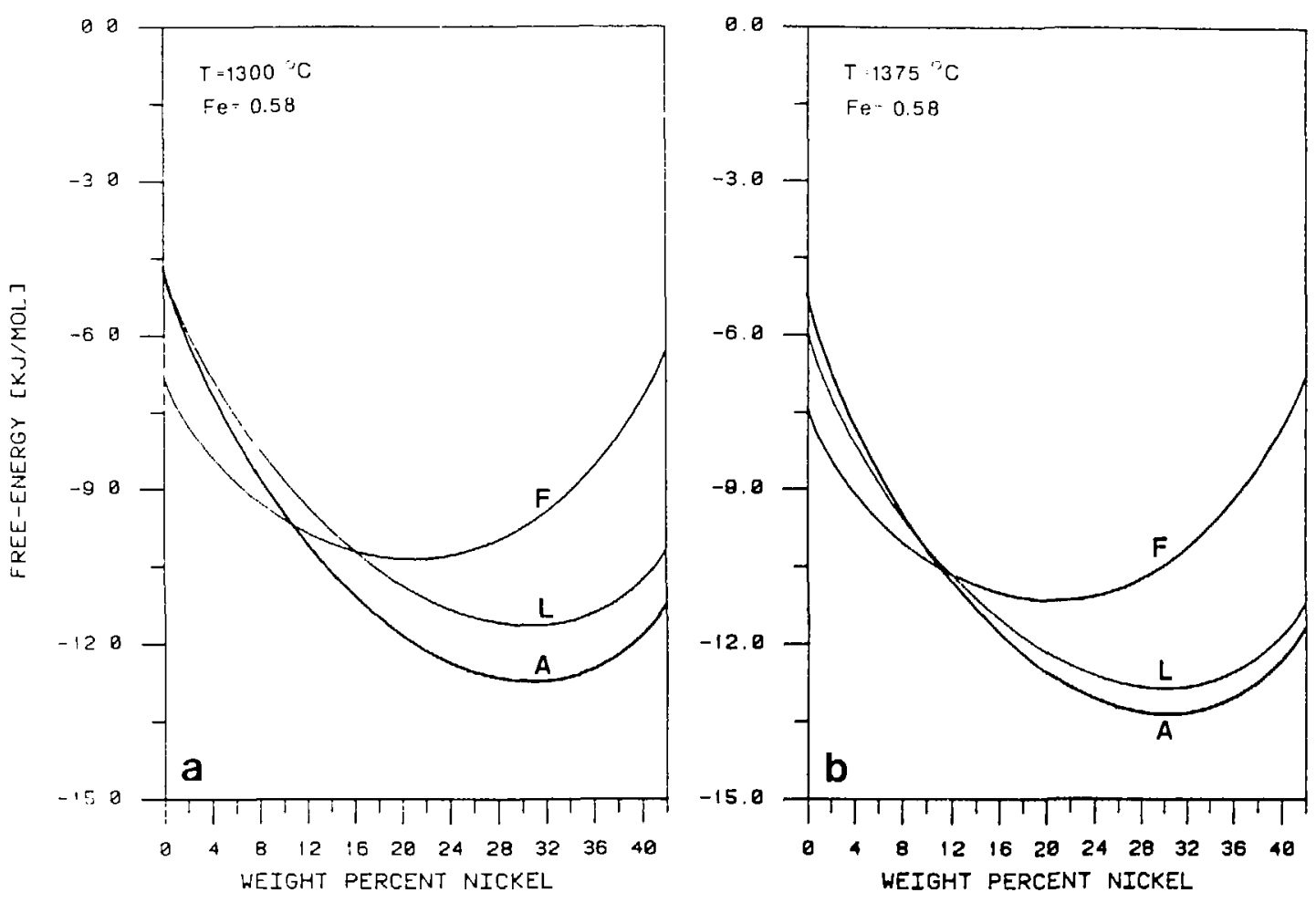

Figure 8.0 Gibbs free cnergy versus composition plots along the 58 wt\% Fe isopleth. a) at $1300^{\circ} \mathrm{C}$, b) at $1375^{\circ} \mathrm{C}$. 
For example, a $1 \%$ change in nickel content. drops the $\mathrm{T}_{0}$ tempcrature $85^{\circ} \mathrm{C}$. therctorc. Alloys 5, 6 and 7 which solidify in the fully ferritic mode at high cooling rates have significantly different $T_{0}$ temperatures even though their compositions are similar. Defining, $T_{B}$ to be undercooling required to bring the alloy from its solidus temperature to the $T_{0}$ temperalure,,$T$, will be an indication of how much undercooling is necessary for the massive transformation to become feasible.

$\therefore \mathrm{T}_{\mathrm{s}}$ was determined to be $31^{\circ} \mathrm{C}, 101^{\circ} \mathrm{C}$ and $186^{\circ} \mathrm{C}$ for Alloys 5,6 and 7 respectively. Additional undercooling would be required to bring thesc alloys closer to the austenite solvus temperature where the massive transformation is most likely to occur. However, the trend in undercooling, required to nucleatc massive austenite. will be the samc: Alloy 5 will require the lcast undercooling and Alloys 6 and 7 will require significantly morc undercooling to bring about the massive transformation.

\subsubsection{Nucleation Kinetics}

The rate at which the alloy cools through the austenite + ferritc two phase ficld is largely responsible for the amount of undercooling prior to the nucleation of austenite. At slow cooling rates, nucleation of Widmanstatten platclets occurs belore the temperature reaches $T_{0}$, i.c., there is insufficicnt undercooling at slow cooling rates for the massive transformation to occur becausc it is superseded by the formation of Widmanstatten austenitc. At higher cooling rates, nucleation of Widmanstaten austenite can be prevented because of the reduced time arailable for Hidmanstatten austenite nucleation. Under these conditions, the temperature drops to larger undercoolings before the austenitc nucleates. The massive transformation of Alloy 5 was observed in the high cooling-rate portion of melt 2 and in all of the higher cooling rate melts. This places the necessary cooling ratc lor the massice transtormation at about $2 \times 10^{3} \mathrm{~K} / \mathrm{s}$ and greater for the $26.4 \mathrm{Cr} .14 \mathrm{~K} \mathrm{Ni}$ allu.

The nucleation kinctics [8.11] and growth kinctios [8.12] of the massive translormation have recently becn revicwed. A relationship between the cooling rate and the undercooling tor nucleation can be derived from the classical approath. Ihe resulting expression relates the undercooling belou t'. ... . to the tooling ratle as follow's:

$$
1 r_{n}=r_{a} \cdot r_{H}=\left(\begin{array}{l}
1 \\
6
\end{array}\right)^{1 \cdots}
$$


where 5 is the cooling rate $C$ is a material-dependent and embryo-geometry-dependent constant [8,11] and $T_{M}$ is the nucleation temperature for massive austenite. Therefore. larger undercoolings precede the transformation at higher cooling rates.

In order to explai, why Alloy 5 undergoes the massive Iransformation while Alloys 6 and 7 do not, the effect of composition on the nucleation kinetics of austenitc must be examined. From the classical nucleation theory, applied to nucleation at grain boundaries during isothermal transformation [8.13], one can derive the following relationship for the nucleation rate, $J$ ":

$$
\left.J^{\prime}=Z \beta^{\circ}\left(\operatorname{sexp} \mid \begin{array}{c}
-I G^{\circ} \\
h T^{\circ}
\end{array}\right] \exp \mid \begin{array}{c}
-\tau \\
1
\end{array}\right]
$$

wherc $Z$ is the Zeldovich noncquilibrium factor relating the percentage of atoms which attach to the number of attempts, $s^{*}$ is the rate at which individual atoms attempt to attach to the critical nucleus, $N$ is the number of atomic sites per unit volume, $\mathrm{G}^{*}$ is the free energy for the formation of a critical nucleus, $t$ is the incubation time, $t$ is the isothermal hold time and $k T$ has its usual meaning.

The most important factor in equation 8.7 is the free energy of formation of the critical nucleus which is related to the volume frec encrgy change. $G_{v}$ and the strain cnergy : $G_{B}$ as follows:

$$
1 G^{\circ}=\frac{16 \pi \sigma_{b y}^{3} A}{31.1 G_{t}+.1 G_{s} 1^{2}}
$$

Wherc $k$ is a factor related to the geometry of the embryo and $o_{*}$. is the interfacial encrgy between the ferrite and austenite phases. Alloys 5, 6 ana 7 differ only slightly in composition, thereforc, only $\omega_{i}-c_{i}-c_{\text {: }}$ changes significantly between thesc alloys.

The free energy versus composition curve for $59 \mathscr{T}_{1} \mathrm{Fc}$ alloys at $1250^{\circ} \mathrm{C}$ is shown in Fig. 8.7. In addition to predicting the $T_{0}$ temperature, these curves can be used to estimate the difference in frec energy for the ferrite :o austenite transformation as a function of composition. At $12500^{\circ} \mathrm{C}$ Alloy 5 is $1190^{\circ} \mathrm{C}$ belou its $\mathrm{T}_{0}$ temperature and $1 G_{\mathrm{v}}=-150 \mathrm{~J} / \mathrm{mole}$, Alloy 6 is $49{ }^{\circ} \mathrm{C}$ below its $T_{0}$ temperature and $1 G_{v}=-20 \mathrm{~J} / \mathrm{mole}$. Finally. Alloy 7 is $36^{\circ} \mathrm{C}$ above its $T_{0}$ temperaturc and therefore has no driving force for the massive transformation. 
The results of the electron beam melting experiments contirm these calculations. At low cooling rates the massive transiormation was superseded by the formation of Widmanstatten austenite. At higher cooling rates, nucleation of 1 idmanstaticn austenite platelets was suppressed and the massive transformation was observed in alloy 5 which has the largest $\lrcorner G_{v}$ for the nucleation at any given amount of

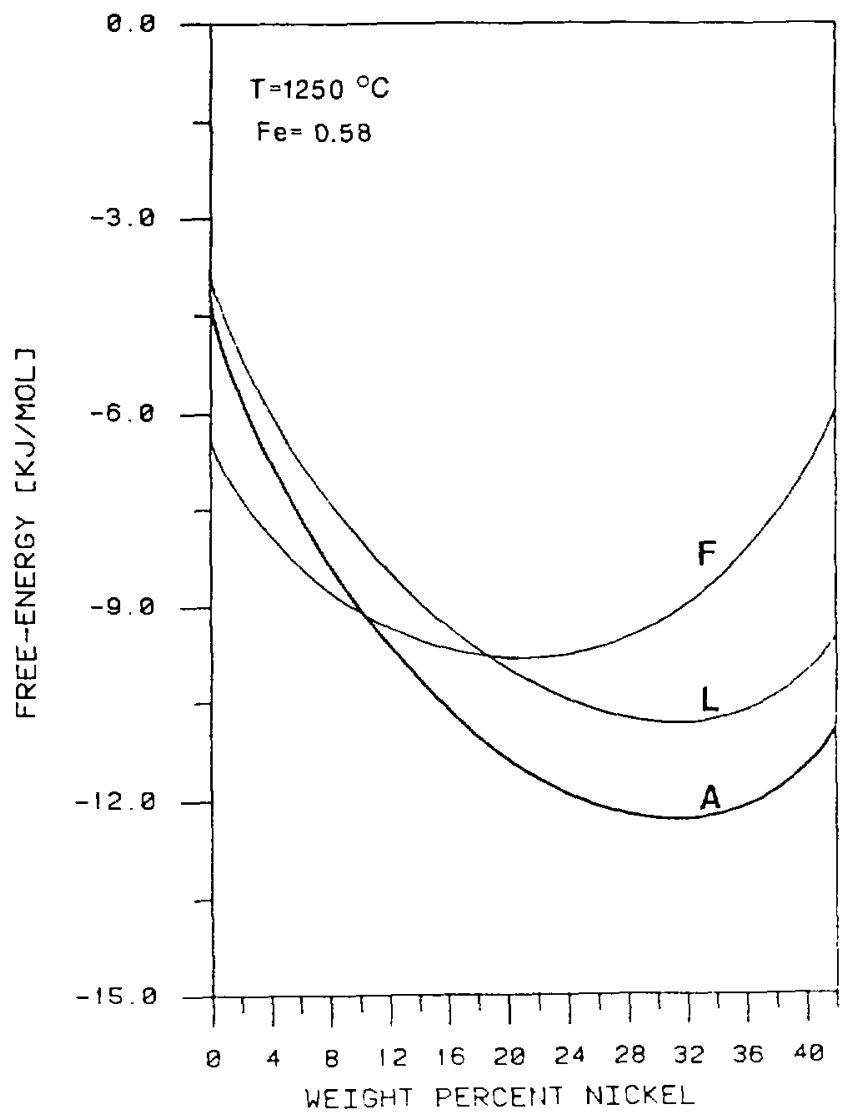

Figure 8.7 Cibbs free energy versus composition plat along the 58 w $t$ "I 1 isopleth showing the volume frec cnergb change los ferrite transforming to austenite in Allos 5 
undercooling. Howeser. Alloys 6 and ? apparently did not have sulficicnt drising forec for the nueleation of massise austenite and remained fulls ferritic under all at the high cooling rate conditions.

\subsubsection{Growth Kinetics}

The massive transiormation has becn observed 10 gron at vers rapid rates in many allo! s!stems 18.12]. The high growth rates are the result of 1) the high thermodynamic driting forec for the translormation which is nearly proportional to the degrec of underooling below $\mathrm{T}_{0}[8.12]$ and 2 ) the nature of atomis iranstic across the incrace which in olves a noncouperatic rearrangement of atoms involsing onl? a lew atomic jumps to change the erstal structure |8.121. Because of the high gromth rates, sharacterization of the interlace seloily. $R$, is difficult, howerer, the measurements that have been made show that $R$ is on the order of 1 to $10 \mathrm{~mm}$ in the Ag.t1 system [8.12].

The relationship between undercooling and inicrlace velocity has becn studicd by Perepezho 18.12] and the results show that the lichatior at lou undereoolings and high underoolings are diflerent. At low undercoolings $1 \because<10^{\circ} \mathrm{C}$ in the Ag-Al system) the results were interpreted by a step growth model. For the case of step formation limiting the reaction rate, the fullowing cxpression was descloped:

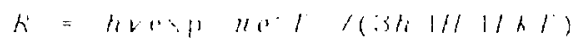

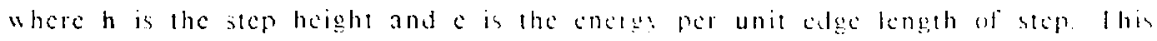

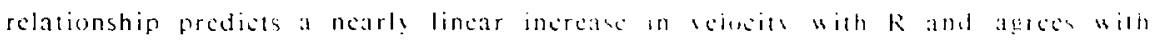

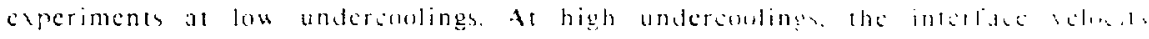

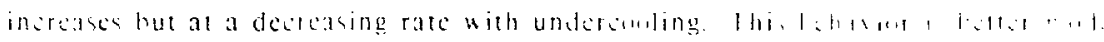

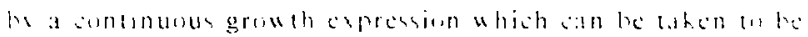

$$
\text { f } \quad 1: \%
$$

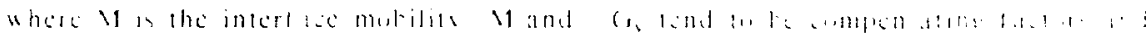

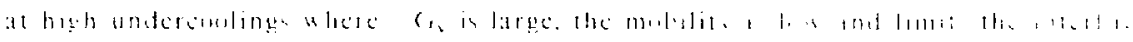

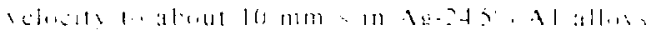




\subsubsection{Massive Austenite Summary}

The rerrite content of Alloy 5 san be used as a measure of the degree to which the massive transformation has occurred in each of the elcetron beam melts. In Chapter 6, ferrite measurements were presented to indicate the total amount of ferrite present in each melt. The results arc resummarized in Table 8.5. In this Table, $A_{w}$ and $A_{m}$ refer to the pereentage of the fully ferritic solidificd arcas that transformed to Widnanstatten and massive austenite respectively, while $F_{u}$ refers to the amount of untransiormed single-phase ferrite. The microstructures of these melts are show in Fig. 8.8 to illustrate the regions of massitc austenite (light areas) and the regions of Widmanstatten austenite (dark areas)

Table 8.5 Perecntage of massite and Widmanstatten austenite that forms in the fully ferritic solidificd portions of the clectron beam melts in Alloy 5.

\begin{tabular}{|c|c|c|c|c|}
\hline \multirow{2}{*}{ mclt } & \multicolumn{2}{|c|}{$\begin{array}{c}\text { \% Phasc } \\
A_{\mathrm{m}}\end{array}$} & \multicolumn{1}{c|}{$\mathrm{F}_{\mathrm{u}}$} \\
\hline 1 & $4.7 \times 10^{2}$ & 0 & 100 & 0 \\
\hline 2 & $1.9 \times 10^{3}$ & 10 & 85 & 5 \\
\hline 3 & $1.7 \times 10^{4}$ & 30 & 65 & 5 \\
\hline 4 & $4.4 \times 10^{5}$ & 85 & 0 & 15 \\
\hline 5 & $1.5 \times 10^{6}$ & 75 & 0 & 25 \\
\hline 6 & $7.5 \times 10^{7}$ & 70 & 0 & 30 \\
\hline
\end{tabular}

\subsection{The Decomposition of Single Phase Ferrite}

Scction 8.1 discussed the transtormation of ferritc by the diftusion controllct growth of precexisting austenite which forms during the AF and $F A$ modes of solidilisation. Because the austenite was prescnt prior to the solid state transiormation. nucleation was not required and the morpholog? of the resulting microstructure was suntrolled by the solidification conditions. 

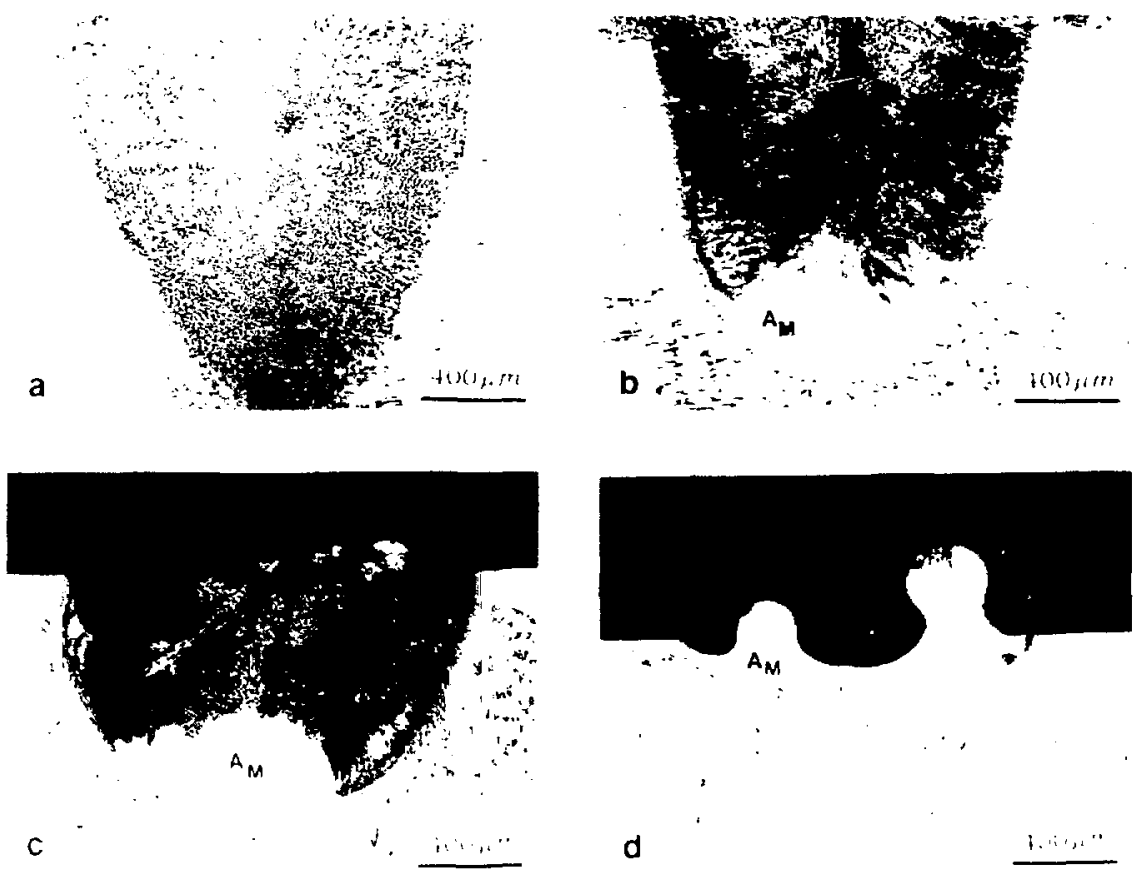

Figure 8.8 The influence of scan speed on the percentage of the mell which undergoes the massive transformation in Alloy 5. Massively transformed areas appear as white regions, while the remainder of the melt transforms by Widmanstatten austenite formation. a) $6.3 \mathrm{~mm} / \mathrm{s}$, b) $25 \mathrm{~mm} / \mathrm{s}$, c) $100 \mathrm{~mm} / \mathrm{s}$ and d/ 500 mmis. 


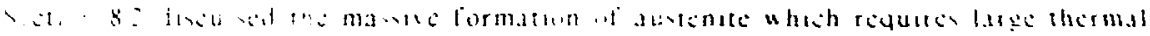

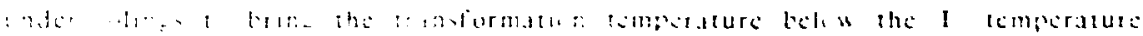

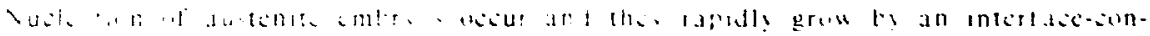

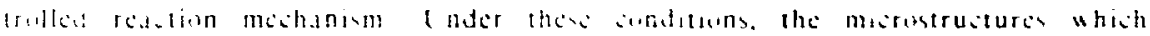

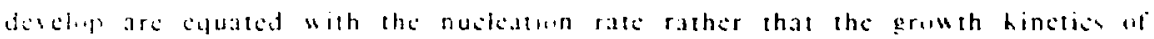

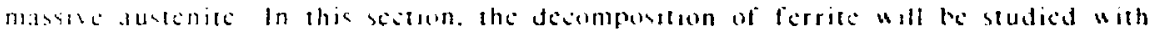
relerenic to morphologics that require nusleataon of austente firm a fulls ferratis matris but where the micostructure is controlled w diftusional grow $1 \mathrm{~h}$ meshanisms

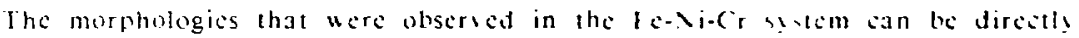
equated with morphologics which declop in the fece system cirain boundary allutrionorphs. Widmanstation sideplates. sidenectlos and degenerate forms of the Widmanstatien morpholugies uere all obsersed in the clectron beam welds of the high Cr $x$ ratio allo!s. The analug! between the Fe-Ni-Cr and Fe-C system appears to he iery good and allows the wealth of intormation about the Fe-C ssstem to be applical to the less-studied Fe-Ni-Cr sistem.

In this seston, the morphological features at the ferrite decomposition will be presented through the examination of the clectron beam melts. Besause of the large number of morphological features that wars obseried. detailed modeling of the nucleation and growth kinctios of cash satiation is not possible. Howerer. gencral guidelines will be established to show how the diflusion controlled processes can be modeled for a simpic sideplate geonetrs.

lsothermal transformation cxperiments werc a!so conducted on fulls ierritic specimens to monitor the transtormation hincties af the ferrite decompusition. The results of these coperiments were analized bi the Johnson-llchl-durami aproash whish allows the ellects of nualeation and grouth to be sompined into a single aqualion.

\subsubsection{Morphological Classification}

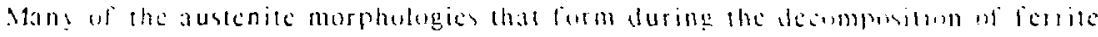

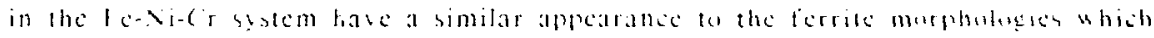

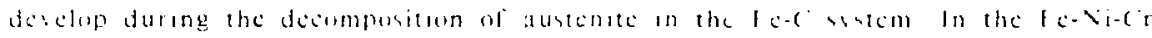

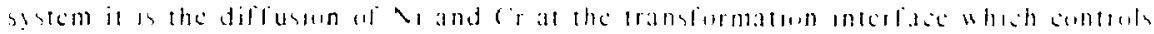




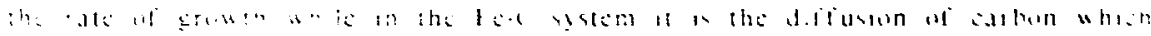

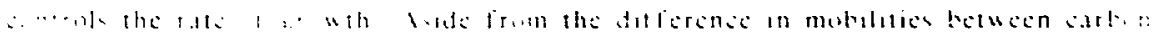

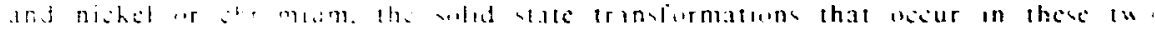

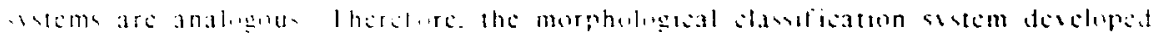

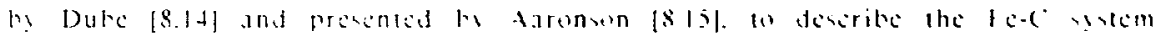
morpholugies. an le used turepresent the I

\section{Grain Boundars Allotriomorphs}

Grain boundar! allotriomorphs are ersstals of the produst phasc which nucleate at grain boundaries and grou preferentially along the boundars. The allotriomorphs tend to hase smooth shapes and provide hetcrogencous nuclaaton sites for the other grouth morphologics. Figurc 8.9 shous t?pical austenitc grain toundary allotriimorph, which form in the Fe-Ni-Cralloss. Ihe allotromorphe are cer! common and are present at nearly all of the grain boundarics in the alloss that hase undergone transformation and proside sitcs for Hidmanstatten austenitc growih

\section{Midmanstatten Plates}

Hidmanstatten sideplates are plate-shaped erystals that grou from the vicinit! of grain boundaries into the interior of the grain and can he categorized as hasing cither primary or sccondary sharacteristics. Primary sideplates grow dircotly from the gran boundar! and scondary sideplates declop from cristals of another morpholog! of the same phasc. Sccondary sidepiates werc by far the most commonly: obsersed morphology in the Fe-Ni-Cr alloys and primar! sideplates are not abundant. Figure 8.9 shows the sideplate morpholog: under high and tow cooling rate conditions. At high cooling rates (8.9a) the sideplates do not have time to grow across the grain and they appear as fincly spaced laths growing along crsstallographically defined dircetions. At low conling rates $(8.96)$. Widmanstatten sideplates grow across the cntire grain and also coarsen as the melt cools to room temperature.

Widmanstatten plates may also nucleatc and grou from the interior of grains. This intragranular morpholog! tends to be present in the Fe-Ni-cir allogs which conl at low rates. Figure 8.90 shows the intragranular sideplate morphologs. Mixed in with this microstrueture are small intragratar hlochs of austenite which are referred to as idiomorphs. Indiridual plates nucleate and grow aleng atstallegraphi- 
ally delined direstuns as do the other platelet iariants. These plates ma! prowde nucleation sites for ocher plates and when combined with the sideplates growing from the grain boundaries. they provide an cflectice means for transtorming a lage bolume fraction of the microstructure.

\section{Widmanstatten Veedles}

Widmanstatten necdles. Which are sometimes referred to as acicular necdles, are necdlc-shaped erystals which also can be catcgorized as having primary and secondary characteristies. Primary sidenecdles are again the less dominant variation in the Fc-Ni-Cr alloys studicd. Figurc 8.10 a shous the morphologs of the austenite sidencedles which grow "radially" from the grain boundaries and allotriomorphs. The nucleation irequency is casily observed since cach necdlc has a distinct appearance and does not tend to degenerate to other morphologies.

Intragranular needles were also obsersed and are a common feature of the microstructure. These needles nucleate within the grain and grow along well defined crystallographic directions as weli. Figurc 8.10 b shows this morphology and indicates that intragranular necdles provide nucleation sites for other necdles.

All of the Widmanstatten necdles observed in this investigation were located in the heat affected zone of a previous melt. Therefore, the needle morphology is the product of a high-tcmperaturc "heat treatment" rather ihan the direct product of the resolidification cxpcriments. This bchavior can be explained in terms of nucleation behavior and will be discussed in later section of this chapter

\section{Degenerate Midmanitatten Sideplates}

Variations of the austenite sideplate morpholog: ma! occur when the plates A) form "facets" on their faces. B) branch to form neu plates or (C) "s!mpatheticall! " nucleate ncw plates with new habit plancs. Each of thesc ariation was observed in the Fe-Ni-Cr alloys studicd in this investigation. The 'A morpholog: was the most commonly obscried degencration of the sideplates. Figures 8.11 a and 8 IIb show this microstructure in Alloys 6 and 7 respectivel!. In this microstructure. the light colored phase is austenite and the dark colored phase is ferrite. Man! facets have descloped on the austenite plates and give a random appearance to the microstrueture 

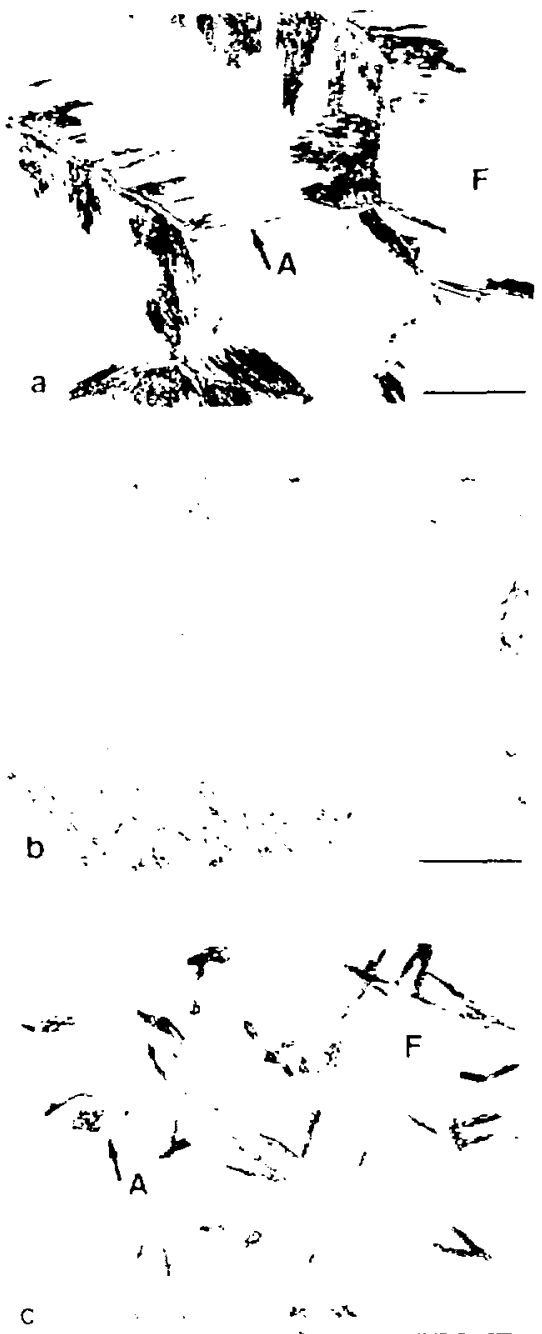

Figure 8.9 a) Widmanstatten austenite sideplates growing from grain boundary allotriomorphs at intermediate cooling rates, b) Widmanstatten sideplates at lon cooling rates and c) intragranular Widmanstatten plates in Alloy 7. 

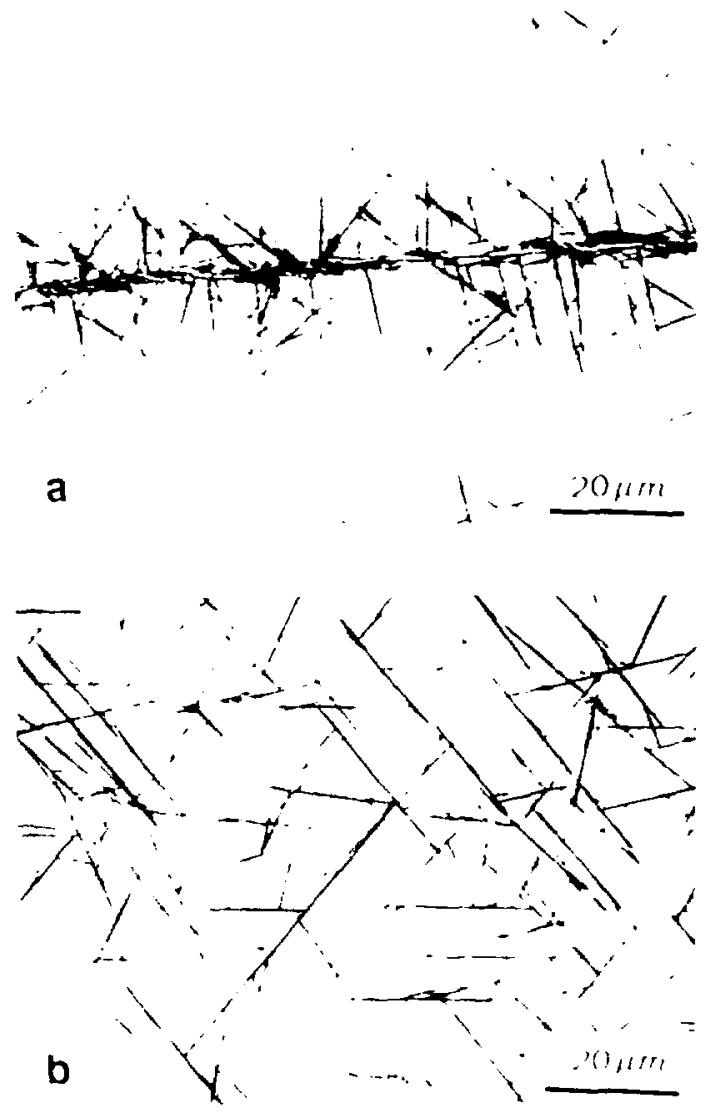

Figure 8.10 a) Primary Widmanstatten side-needles growing from grain boundary alloiriomorphs in Alloy 7 and b) intragranular Widmanstatten needles in the heal affected zone of Alloy 7. 

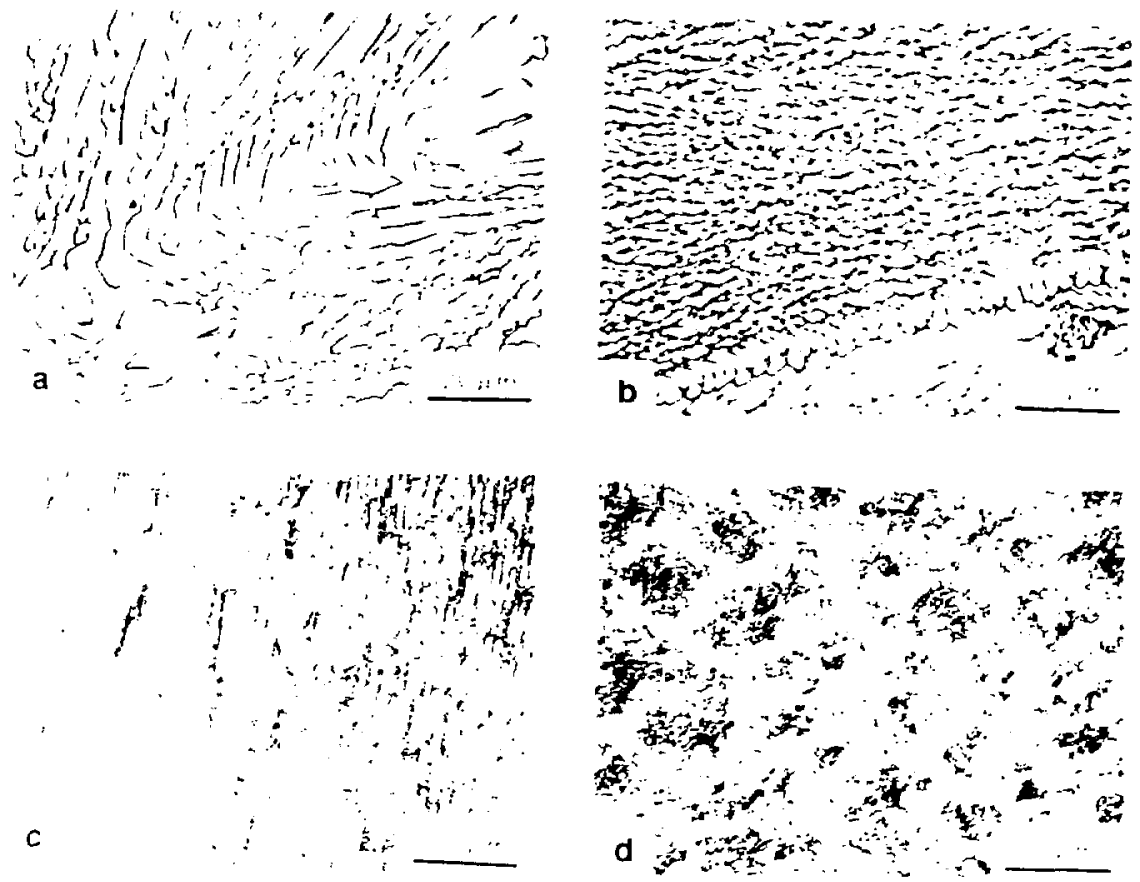

Figure 8.11 Degenerate forms of Widmanstatten sideplates. a) indicates faceting of the austenite plates; b) and c) show sympathetically nucleated austenite sideplates, and d) indicates branching of the austenite plates. 
The ' $B$ ' morphology was less frequently observed and is shown in Fig. 8.1ld. In this microstructurc, new austenite plates branch and grow with the same habit plane as the original plate. This gives the microstructure a ladder-like lattice structure.

The ' $\mathrm{C}$ ' morphology of new austenite plates or needles nucleating as the result of the growth of other plates or necdles. Examples of this microstructure are shoun in Figure $8.9 \mathrm{c}$ and $8.10 \mathrm{~b}$ for intragranular plates and needles respecticly. The ${ }^{\circ} \mathrm{C}$ morphology may also combinc with ' $A$ ' morpholog: to ercate the complex microstructures shown in Fig. 8.11c. The micrograph was taken from alloy 5 and occurs in the slower cooling rate portions of melt 3 .

\subsubsection{The Effect of Cooling Rate on Austenite Morphology}

The degree of supersaturation and the primary ferrite grain size are the two most important factors controlling the austenite morphology. Both of thesc factors are influenced by the cooling rate since the grain size and the transformation tempcrature both decrease with increasing cooling rate.

The effect that grain size has on the austenite morpholog! is to provide nucleation sites for grain boundary allotriomorphs and Widmanstatten sideplates or sideneedles. Therefore, as the grain size decreases, the larger grain boundary area results in a microstructure that has a larger percentage of the transformation originating from grain boundarics and a lesser percentage of intragranular morphologics.

The degree of supersaturation (the amount of undercooling) increases with increasing cooling rate and provides the driving force for the transformation. Small supersaturations only provide small driving fores. Therefore, the austenite requires heterogeneous sites such as grain boundaries or allotriomorphs to provide nucleation sitcs. The resulting microstructures consist of grain boundary allotriomorphs and Widmanstatten sideplates and sidenecdles. Large supersaturations provide large driving forces and the austenite may nucleatc at matrix or lattice defects within the interior of grains. The resulting microstructures at high supersaturations are typically a combination of grain-boundary nucleated and intragranular morphologics. 


\subsubsection{Nucleation and Growth Kinetics}

\section{Grain Boundary Allotriomorphs}

Nuclcation of grain boundary allotriomorphs. intragranular platcs and intragranular necdles leads to the majority of the mierostructures observed in this study. Of thesc ihrec. nucleation of grain boundary allotriomorphs is important since the sideplates that are responsible for the majority of the transformation. grow from the allotriomorphs. Aaronson [8.15] developed an equation to represent the nucleation rate. $N_{s}$. for hemispherical shaped embryos heterogencously nucleated against a planar grain boundary in the Fc-C systcm. Again, using the analogy between the Fc-Ni-Cr system where diffusion is controlled by the diffusion of $\mathrm{Ni}$ in austenite instead of carbon in the Fe-C system, Aaronson's cquation becomes:

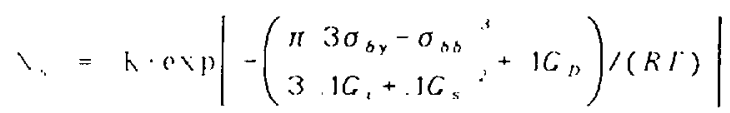

Where $\mathrm{K}$ is a composition dependent constant, $\%$. and $\sigma$. a are interfacial cnergies for ferritc-austenitc and ferritc-ferrite interfaces respctively. $G_{D}$ is the activation cnergy for the diffusion of $\mathrm{Ni}$ in austenite and the remaining terms have been previously defined.

The most important factor from the standpoint of nucleation kinctics is .1 $G_{v}$ bccausc it varics considerably with transformation temperaturc. As transformation tempcraturc decreases, $1 G_{v}$ becomes more negative and $N_{g}$ increases accordingly. Therefore, with larger undercoolings, produced by rapid cooling rate conditions, the nucleation rate increases. However, as the cooling rate increases. less time is available for the nucleation events. Thereforc, as cxperiments will show, the total number of nuclei that form and grow to a perceptible level per unit volume decreascs with increasing cooling rate past some critical valuc. This critical cooling ratc was shown to be about $2000 \mathrm{C} / \mathrm{s}$. Above this value the nucleation of austenite allotriomorphs can be suppressed and the microstructures remain fully ferritic.

Growth of the allotriomorphs is also controlled by diffusion and, once again, the diffusion of nickel in austenite is assumed to be the ratc concrolling step. The rate at which the allotriomorphs thicken can be shown to be proportional to (Dt) 2 :

$$
1=a(D l)^{1 \%}
$$


For planar and spherical geometries [8.15] where the constant $f$ is related the degree of supersaturation and the diffusion geometry. As presuusly disurid. the transformation time, diffusivity and diffusion distance decreases wath increang cooling rate which results in less transformation at high cooling rates.

\section{Orientation Relationship}

Widmanstatten plates and neciles grow with a crystallographic orientation relationship with the parcnt phasc. In plain carbon stcels and in Fe-Vi-cralloys this relationship is known to follow the Kurdjumov-Sachs specifications:

$$
\begin{aligned}
& (111),(110)_{a} \\
& 1110)_{v}(111)_{a}
\end{aligned}
$$

Where the subscript $r$ refers to the FCC austenite and the subseript relers the BCC ferritc.

\section{Widmanstatten Plates}

The spacing between adjacent Widmanstatten sideplates is related the nucleation frequency of the plates along the grain boundary allotriomorph interlace. Therefore. a model to describe the sideplate spacing would necd to explain how the initially planar austcritc allotriomorph interface becomes unstable and forms a scrics of relatively cven spaced platelets growing towards the interior of the grain. Tounsend and Kirkaldy [8.18] applied the Mullins and Scrkcrka [8.19] interfacc stability analysis to analyze the spacing of Widmanstatten sideplates in Fc-C alloys. Their analysis shows a good corrclation between theoretical and experimental results. The details of these calculations will not be presented here, hovever, one result of their analysis indicates that the perturbation frequency increases parabolically with increasing transformation tempcraturc:

$$
\lambda_{m} \propto T^{:}
$$

Therefore, the spacing of the sideplates should also increasc $u$ ith increasing transformation temperature. 
Mateingetural cramination was performed on the electron beam resolidified alliss th determine hos the cooling rate influenes the sideplate spacing. In the cast condition. Alloy 6 showed a spacing of $1 / \mathrm{mm}$ whoreas in the clectron beam melts of flloy 6. the spacing was $1 \mathrm{~mm}$ or less. The smaller spacing of the higher cooling rate melis is consistent with the theory proposed by Townsend and Kirkaldy since the higher eowling rates would provide higher undercoolings prior to the nucleation of the sideplates.

The platelet spacing of the castings is significantly smaller for Alloy 7 (2 nm) than for 1110 ) $6(11 \mathrm{~mm})$. This difterence in spacing cannot be to rationalized from simple transtormation temperature arguments. Although Allog 7 should hase a lower transformation temperature because of its higher $\mathrm{Cr} \mathrm{Ni}$ ratio composition. this dificense alone does not explain the order of magnitude difference in spaing for the alloys cooled at the same rate. Thereforc. The elfect of composition on the thermuts namic drising force for the allotriomorph interfase instability must also Plas a significant rolc. This factor entcrs into cquation 8.14 through the proportionalit! constant and is cxplained in more detail by Tounsend and Kirkaldy.

The growth hinetics of the Widmanstatten platelets were also studied by Tounsend and Kirkaldy for Fe-C alloys. Following the method dercloped by Zener $[8.20]$ the! derived an expression for the growth rate. R. of a platelet having constant radius of Lursature. $r$ :

$$
\left.h=\begin{array}{l}
D\left(C_{11}-C_{1}\right. \\
+1
\end{array}\right)
$$

l'sing the analog! between the Fe-Ni-Cr system diflusitity of $\mathrm{Ni}$ in austenite, $\mathrm{C}^{\circ} \mathrm{iF}$ is the cquilibrit lerritc at infinite radius of cursature at the $A F$ concentrations of clement $i$ in ferrite and austeni curiature cqual to r. the Fe-C system. D is the cincentration of element $\mathrm{i}$ in wriace and $C_{1 F}, C_{1 A}$ are the : espectinely at the radius of 


\subsection{Isothermal Transformation Experiments}

The transiormation kinctics of the decomposition of lerrite werc studicd under isothermal conditions. Section 2.5 summarized the experimental procedure in which small specimens $(-50 \mathrm{mg})$ were heat treated in a salt bath for various times. at $6.25^{\circ} \mathrm{C}$ and $720^{\circ} \mathrm{C}$. The ferrite content of each specimen was measured before and after each heat treatment using the vibrating sample magnetometer. This tcehnique allowed accurate ferrite measurements to be made so that the percent ferrite that had transformed could be determined as function of time under the isothermal tempcraturc conditions. Thesc cxpcriments were conducted on Alloys 6 and 7 to craluate the effects of ferrite composition as well as tempcraturc on the transiormation kinetics.

The cxperimental test matrix was formulated so that the amount of tinc that cach specimen was transformed corresponded to a doubling of the previous total transformation time. At $720^{\circ} \mathrm{C}$. the transformation rate was rapid and the initial time increment was taken to be $15 \mathrm{~s}$, whereas at $625^{\circ} \mathrm{C}$. the transtormation rate was slower and the initial time increment was taken to be 120 s. The experiments were continued to a total transformation time that corresponded to near cquilibriun conditions at .heir respective transformation temperature.

Table 8.5 summarizes the results of these experiments and reports the perecnt ferrite after each isothermal heat treatment. Figure 8.12 plots the results of Alloys 6 and 7 as fraction transformed (1-fraction ferrite) versus log time at a transformation temperature of $625^{\circ} \mathrm{C}$. For all cases, Alloy 6. which has a lower $\mathrm{Cr} / \mathrm{Ni}$ ratio than Alloy 7. transforms at higher rates than Alloy 7. The transformation curves have the classic sigmoidal shape which is characteristic of nucleation and growth kinctics. At short times, the transformation rate is slow due to the incubation time required to form austenite nuclei. During later stages, the transformation rate again reduces because of impingement cffects. The maximum transformation rate occurs at intermediatc times where the reaction is approximatcly half-way to completion. Figure 8.12 also shows similar results for Alloys 6 and 7 at a transformation temperature of $720^{\circ} \mathrm{C}$. At the higher tcmperature, the curves have the same gencral shape, however, the transformation rates are much higher and there is a larger cfiect of composition on the transformation rate at $720^{\circ} \mathrm{C}$ than at $625^{\circ} \mathrm{C}$. 


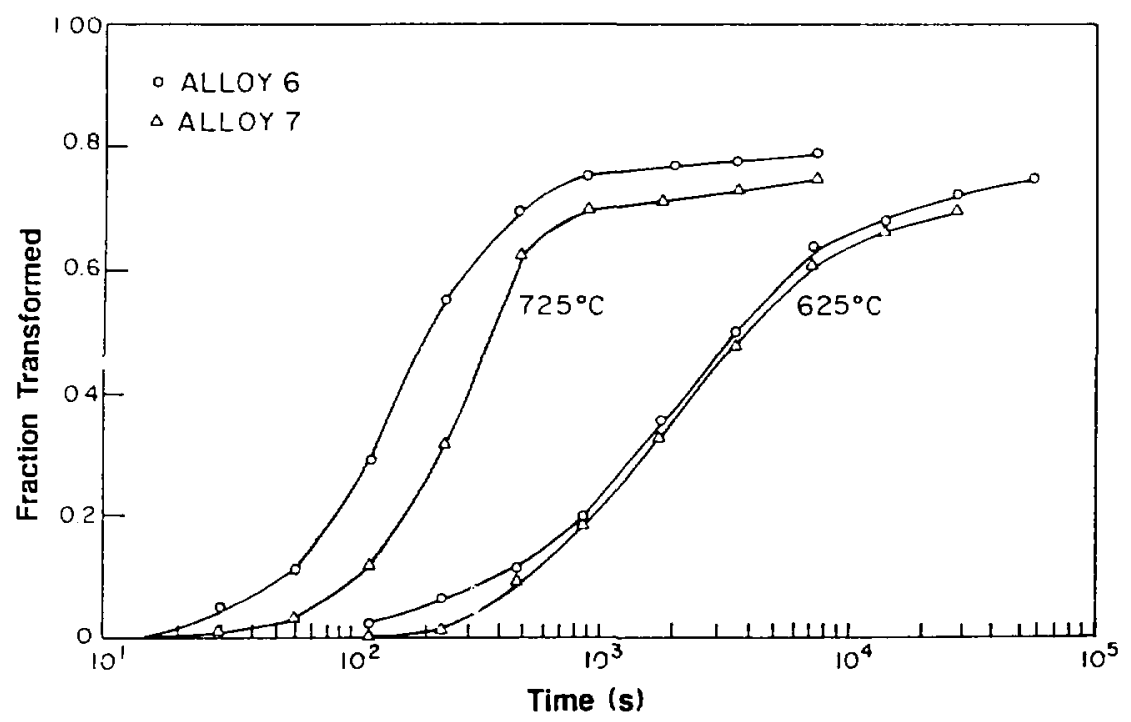

Figure 8.12 Comparison of the isothermal transformation kinetics of Alloys 6 and Alloy 7. 
The carly studies of the hinctics of nuclcation and grouth phase transformations Werc conducted by Johnsen and Mehl [8.16]. these studics led to the development of the relationship betuecn the iration transtormed. $I$. and the isothermal transtionation time, $t$ :

$$
f=1 \quad \text { in is }
$$

For continuous sooling transformation hinctiss. Christian [8.13] reports that the time cxponent. $n$. is related to the presipitate morphology and the behatior of the nucleation ratc $w$ ith transtormation time $B$ is a material dependent constant. These sariables ean be determined from a linearization of equation 8.14 bs tahing reneated logarithms to give the following equation:

$$
|0 ! 1| 1 n ! 1-f)|=| 04 B+n \mid 041
$$

From a plot of $\ln (1-f)$ icrsus $t$ on a Log-Log scilc. $n$ can be detcrmincd from the slope of the linc and $B$ from the intercept at $t=\mid s$.

Figurc 8.13 a and $8.13 \mathrm{~b}$ shows this relationship for Alloss 6 and 7 respectivaly. For cach alloy, the relationship is approximatcly lincar at short and intermediate transformation times but impingement effects at long translormation times reduce the slope dramatically. The initial slope provides the time exponent. For both alloss, the lower transformation temperature is associated with a lower slope. The measured values for $B$ and $n$ are reported in Table 8.6 and correspond to the cocflicients lor equation 8.16. At $50^{\%} \%$ transformation and $625{ }^{\circ} \mathrm{C}$, the values of $\mathrm{n}$ are 0.94 and 1.30 for Alloys 6 and 7 respectively, while at $720^{\circ} \mathrm{C}$, the values of $n$ are 1.40 and 1.74 for Alloys 6 and 7 respectively.

lt was once beliesed that from the salue of $n$, ont could determine the morpholog: of the precipitate. Although the morpholog! of the precipitats can influenec the rate of transformation, other lactors are also incorporated into the rate exponent. Data in the literature secms to indicate that $n=32$ for ditlusion controlled growth of plates. Spheroids or needles as long as the particles were all present at time zero and had negligibl! smal] initial dimensions [8.13]. Iherelore. variations in the obsersed values of $n$ are the result of non-zero finite initial particle size or non-dilfusion controlled grouth nucchanisms. 

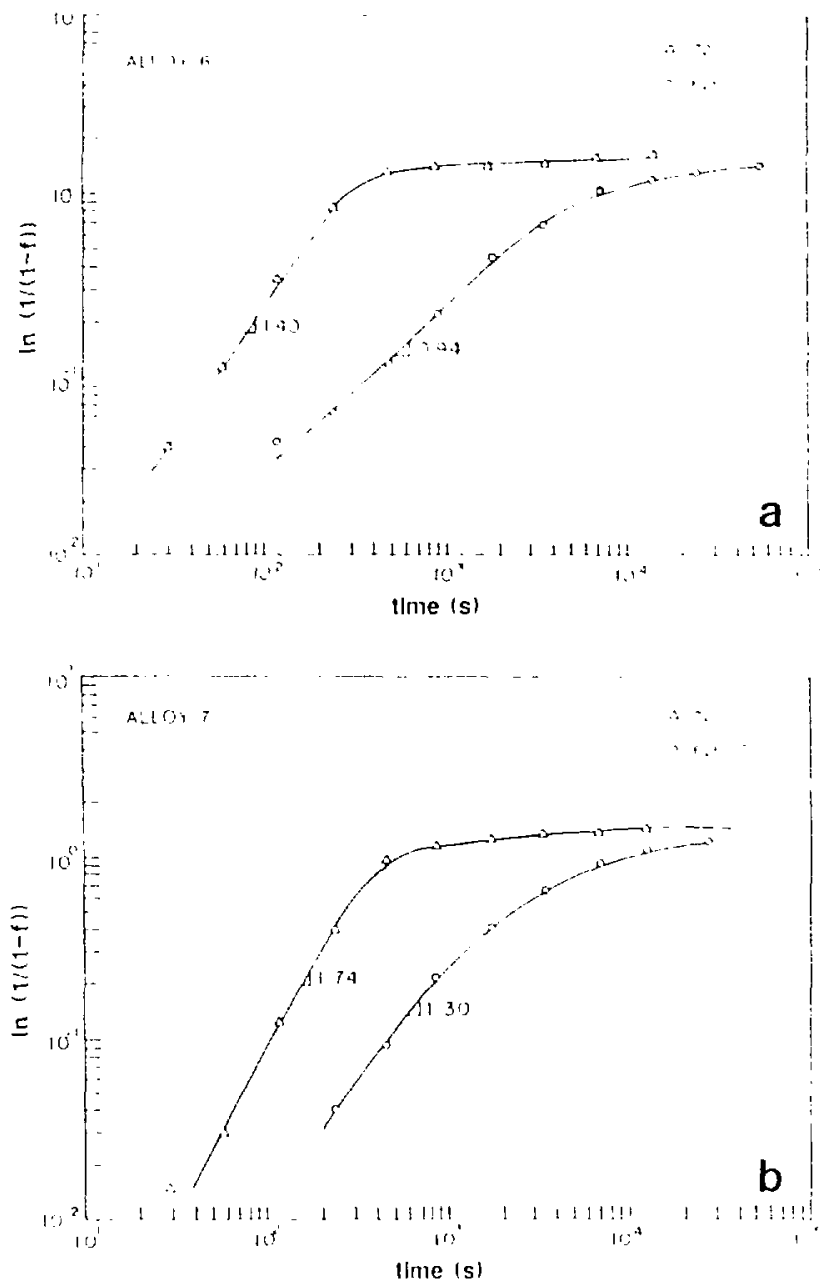

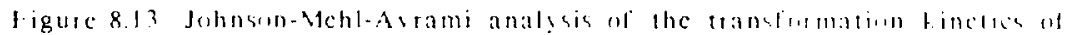
a) Allus $h$ and bi Allor ? 
The signaficance of differences in the measured values of $\mathrm{n}$. is diliticule to cualuate, houcver. a fen observations can be made. Firstls. n was obserbed to irs from vacs slightls less than +4 to salues of about 7 . This range is centered about $n=32$ and suggests that diffusion limited growth is controlling the transtionation. Sccondly. for each alloy. $n$ is approximately 0.4 lower at 6ajoc than at $720^{\circ} \mathrm{C}$. Obscrations of the microstructure indieates that there is a difference in particle morpholog! at these tho temperatures. Optical metallography :lcarl! indicates that Widmanstatten necdles form at $625^{\circ} \mathrm{C}$ uhereas llidmanstatten platelets form at $7300 \mathrm{C}$ lor both flloss 6 and? Il the difference in particle shape is not responsible for these differences in the value of $n$. then other factors. such as the inllucnec of temperature on nueleation rate must be responsible. Further studies would be required to craluate the signiliosnec of the difference in ratc coponents at the two comperatures.

Table 8.6 Results of the isothermal transtormation crperiments listing wt. fraction ferrite as a function of time.

\begin{tabular}{|c|c|c|c|c|}
\hline \multirow{2}{*}{$\begin{array}{l}\text { time } \\
(5)\end{array}$} & \multicolumn{2}{|c|}{ Alloy 6} & \multicolumn{2}{|c|}{ Alloy 7} \\
\hline & $6.25^{\circ} \mathrm{C}$ & $7200 \mathrm{C}$ & $625^{\circ} \mathrm{C}$ & $7200 \mathrm{C}$ \\
\hline 0 & 1.00 & 1.00 & 1.00 & 1.00 \\
\hline $1.5 \times 10^{1}$ & - & 1.00 & - & 1.00 \\
\hline $3.0 \times 101$ & - & 0.96 & - & 0.99 \\
\hline $6.0 \times 10^{1}$ & - & 0.89 & - & 0.97 \\
\hline $1.2 \times 10^{2}$ & 0.98 & .071 & 1.0 & 0.88 \\
\hline $2.4 \times 10^{2}$ & 0.94 & 0.42 & 0.96 & 0.68 \\
\hline $4.8 \times 10^{2}$ & 0.89 & 0.27 & 0.91 & 0.38 \\
\hline $9.0 \times 10^{2}$ & 0.80 & 0.25 & $0.8 \mathrm{I}$ & 0.30 \\
\hline $1.8 \times 10^{3}$ & 0.64 & 0.24 & 0.67 & 0.29 \\
\hline $3.6 \times 10^{3}$ & 0.50 & 0.23 & 0.52 & 0.27 \\
\hline $7.2 \times 10^{3}$ & 0.38 & 0.21 & 0.39 & 0.25 \\
\hline $1.44 \times 10^{4}$ & 0.32 & 0.20 & 0.34 & 0.24 \\
\hline $2.88 \times 10^{4}$ & 0.28 & - & 0.30 & - \\
\hline $5.76 \times 10^{4}$ & 0.25 & - & - & - \\
\hline
\end{tabular}


Tabic 8.7 Coctlicients for the Johnson-Mchl-Airami cquation.

\begin{tabular}{|c|c|c|c|}
\hline \multirow{2}{*}{ Allos } & $\begin{array}{c}\text { Temperature } \\
10 \mathrm{C})\end{array}$ & $\mathrm{n}$ & $\mathrm{B}$ \\
\hline 6 & 625 & 0.94 & $3.8 \times 10^{-4}$ \\
\hline & 720 & 1.40 & $4.0 \times 10^{-4}$ \\
\hline 7 & 625 & 1.30 & $3.0 \times 10^{-5}$ \\
\hline & 720 & 1.74 & $3.0 \times 10^{-5}$ \\
\hline
\end{tabular}

B: comparing the transiormation rate at the two temperatures. an cstimatc of the activation energ! for the transiormation can be made. Assuming the iransformation is thermally actisaled, gisen a time, t, required to translorm a cestain volume frastion ferrite. the temperature dependenec of the transformation rate becomes:

$$
1=10^{-6,3 !}
$$

where $Q_{T}$ represents the combincd activation energics of nucleation. QN. and growth QG. By taking the ratio of cquation 8.18 at the two tempcratures and simplif ing. the cxpression. QT becomes:

$$
Q=-R\left(\begin{array}{c}
r_{1} * r_{2} \\
r_{1}-r_{1}
\end{array}\right) \ln \left(\begin{array}{l}
t_{1} \\
t_{1}
\end{array}\right)
$$

Where $t_{1}$ and $t_{2}$ represent the times required for $50^{\prime \prime} \%$ transformation at tempcratures $T_{1}$ and $T_{2}$ respectively.

Applying equation 8.19 to the results presented in Figures 8.12 gires the activation cnergy for the transformation of Alioy 6 to be $53.6 \mathrm{Kcal}$ mole and Alloy 7 to be $44.2 \mathrm{Kcal}$ mole. Comparing these values to the activation encrgy for difiusion, shown in Tables 8.1 and 8.2. shows that the apparent activation cnergy for the transformation is 10 to $20 \mathrm{Kcal}$ molc less than the anticipated activation encrgy lor diffusion of nickel in austenite. This behatior might be caused b! a non-zero nucleation rate throughout the transformation cxperiments, combined with an additional dependence of the nucleation rate on the temperature. Ihis cifes would result in a higher volume fraction translormed than that assecialced $u$ ith the diflusional growth of a lixed number ol nuclei presens al time $\mathbb{E}$ A secund 


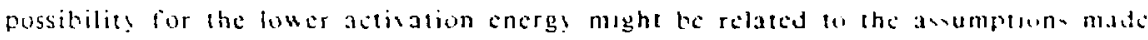
about the mechanism for grouth. If the transformation tahes place by an interias controlled grouth mechanism rather than the assumed diftusion controlled frouth mechanism the analysis of the results uould hase to be alicted igntionnts Additional esperiments would have 10 be performed in arder to separate out the reasons responsitile for ahe actisation energs of the ranstormation

\subsection{Summary and Conclusions}

The mierostructures which were obsered in the Fe-Ni-Cr alloss tere shoun to depend on the primar! mode of solidilication, the specilic allot composition and the cooling rate. Man! of the microstru...dral morphologies $u$ ere related to the solid-state transformations that ociur as the resolidified alls: cools to room temperature.

for alloys which solidify in the AF or FA modes, the transtormation ociurs by the dilliusion controlled grawth of austenite. The restiting microstructures consist of isolated ferrite particles, ocmicular ferrite or lacs ferrite, depending on the initial ferrite content and the cooling rate. The transiormation rate for the diftusion controlled growth of austenite was modeled using the diflusion of $\mathrm{Ni}$ in austeniti as the rate limiting factor. A simple. firsi-order. model allowed the transiormation rate to be calculated for cach of the solidification conditions that were studicd in this investigation. The results of thesc calculations shoucd that a decrasing percentage of the microstructure transforms as the cooling rate increases. despitc the fast that the "seale" of the microstructure also decreases with increasing cooling rale. This simpic model correlated ucll with cxperimental obserations and provided a ubiul approximation to determine the inluence of cooling rate on the amount of terrete that transforms be diflusion controlled grouth.

A scoond. and more aceurate. model of the difiusion controlled transtiomalion of ierrite was also decloped. This mostel utilizes the linite difference larm at lishs scoond las to calculate the rate of interface mosement as the ferrite iranstorm to austenite. Howeser. duc to the complexity of applying this approsich to a ternar! allos system. the application of this model to the transtormation characteristics of ferrife will be postponed to luture work. 


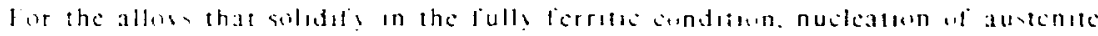

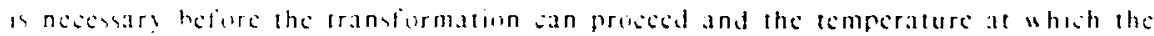

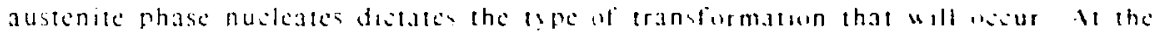

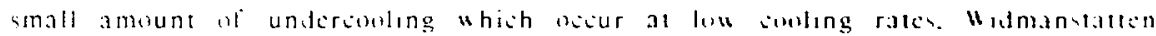

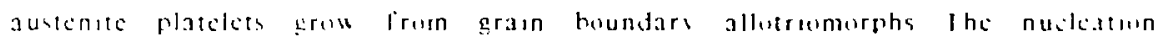

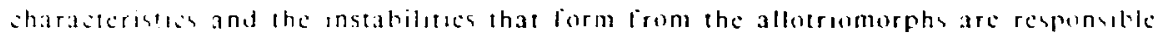
fir the spasing at the widmansatson platelets Onic the spaing has been

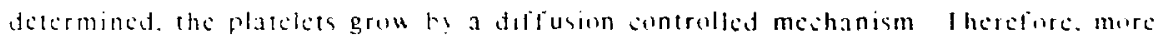
trantiormatmo werurs at low Eoling rates.

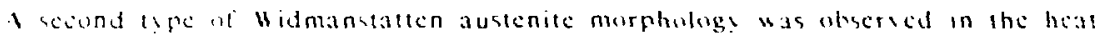
alfected sone at the resolditicd melts. This morphologs consisted at austenute neciles and thengh colhermal uansformation experiments. was shoun :a caur at latger underimiling than the matelets.

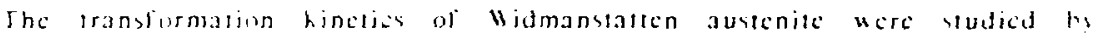
imothermal experiments to measure the frastion of the ferrite that iranslurms as a luneton of tome at tho diferent icmperatures. These canerimental measurements were interpreted by a Johnson-lkhl-Aurami analysis to quantity the transtormatum rate and the clicess of temperature uere used to cstimate the actisation energs fur

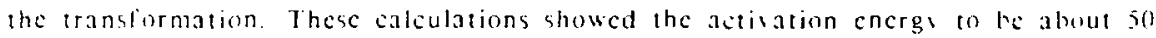
Kal mole which correlates with the actiation encrg! for a diflusiun sontrulled transtormation with a temperature dependent and non-zero nusleation rate. Ihe Johnson-Vehl-Arami and actisation energy calculations an he used to predat the rate and cutent of the phase transtormation as a lunction of time and temprature.

The massive transformation of ferrite to austenite was only obsersed in dles 5 This transformation occurs at high cooling rates and through the we wi thermodynamicall! calculated (ibbs fice energs versus compositun surses. the

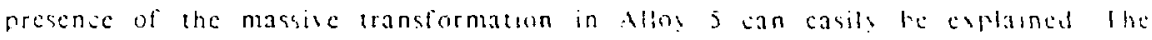

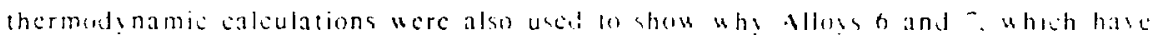
higher Cr vi ratio than Allos 5 do not undergo the massise transturmatun fur the cooling rates insestigated in this study 


\section{CHAPTER 9}

\section{Summary, Conclusions and Future Work}

lhe influence of smbing rate on the mierostructure af sainless ated allow has

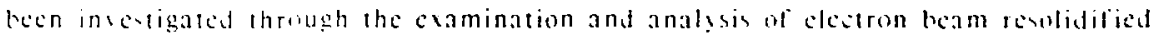

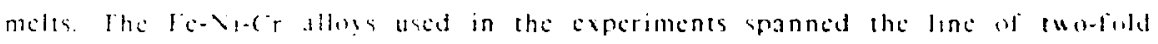

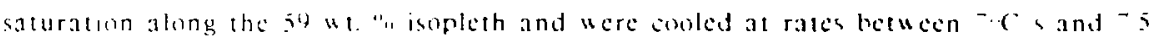

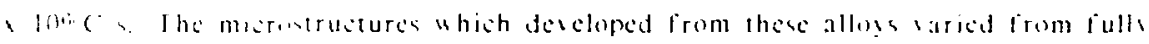

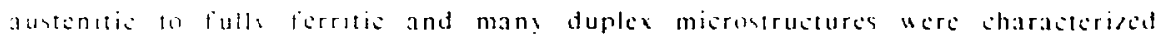
betucen these twa cutrentes.

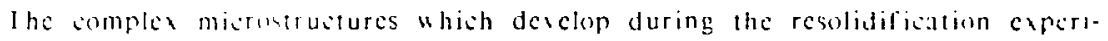
ments were camined and analszed to separate the clicets of combing rate on solute redistrihution dureng solidification from the cficets of cooling rate on the suld statc transformatun of territe. This required a combination of cxperimental results. thermolynamic analsis and hinetic analysis of the fillerent allos and billerent

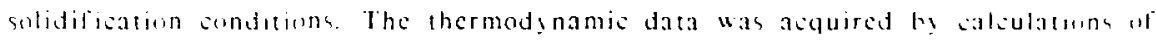

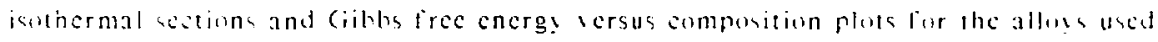
in this suts. The hincties of the solidifistion hehasior ucre studicd by analying the growth charaterintics of columnar dendrites. These results were used to model solute redistrihutum and to calculate the perecntage of primars and secundary phases

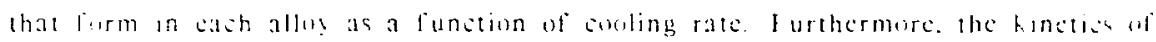

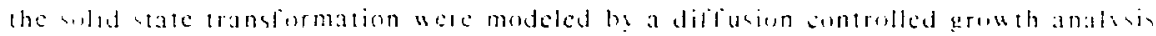
and everimentall! serificd through isothermal transtiomation studies.

This shaper summarizes the resuls of this insestegation and is meant la be an

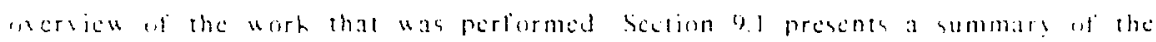

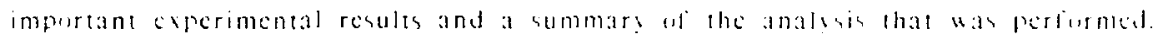

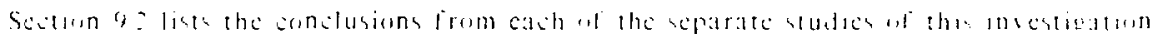

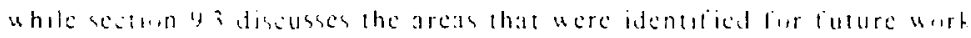




\subsection{Summary}

\subsubsection{Experimental Results}

The experimental results which shou the influence af colling rate on the misrostrusture of stainless stecl alloss are summarized in a number of key figures and tables in Chamers 5.6 and 8 . Figurc 5.6 shows the influcnce of clestron beam scan specd cooling ratel on the primary mode of solidification for each of the seren lic-Vi-cer alloss. Al how cooling rates. iour modes of solidification are prescnt while at high cooling rates only the lully ferritic and fully austenitic modes are prescnt. The regions where each PSM exists are indicated and this figure also shows that the solidifiction mode of tllo! + changes fron primar! ferrite to primary austenite as the cooling rate intreases.

The microstructural morphologies which develop as the resulidificd melts cool to room temperature ate summarized in Figure 5.15. This ligure indicates the cooling ratc-composition range where cach morphology was obscrucd and shows that the PSM is an important factor in the dcsclopment of the microstructural morpholngics. At bow conling rates. the widest range of microstructures appears. Cellular-dendrite single-phase austenile, interdendritic ferrite, sermicular ferrite, lacy ferrite. blocky ausicritc and Widmanstatten austenite form at Jow cooling ratcs as the $\mathrm{Cr}$ Ni ratio of :he alloy insteases. At intermediate cooling rates. dendritcs are replaced by cells ano the most commonly observed microstructures arc the cellular and interecllular forms of ferrite and austenite. If a cutcetic phase forms. its presence is difficult 10 characterize and is most likely a divorecd cutectic having a microstructure sintar to 1. tercelluar lerrite or interecllular austenitc. As high cooling rates. single phase lerrite or single phase austenitc are responsible for the majority of the mierostructures obscricd. Onc cxecption is the presence of massice austenitc which was onl! obsersed in Alloy 5 at high cooling rates.

A comparison of the morphological features obsersed in this study with those observed by other investigators is presented in Tabie 5.4 . This table allous a comparison to be made between the terminologs used by the diflerent insestigators w describe the same morphological icatures. Table 5.6 summarizes the solidification and solid state translormation cocnts which lead up to the declopment of cash af the 
morphologics.

One of the methods used to deseribe the influence of sooling rate on the microstructure was to measure the residual ferritc content for eath of the solidification conditions. The results of thesc measurements are presented in $\Gamma$ igure $6.1+$ and show l) the ferrite content of flloys 1.2 and 3 decreasc with increasing cooling ratc. 2) the ferritc content of Alloys 4 and 5 go through a maximum "ith increasing cooling ratc and 3) the ferritc content of Alloys 6 and 7 increase with increasing cooling ratc. These results werc interpreted by the influence of coling ratc on the primary mode of solidilication. solute redistribution and the solid state transformation of ierritc. Howcier. in order to decouple these effects, solidifisation modelling was required to decermine the amount of ferrite that solidificd from cach melt, prior to the solid state transtormation.

The transformation of ferrite was studicd under isothermal conditions by measuring the amount of ferrite that transformed as a function of time and icmperature. The results of thesc cxperiments are shown in Figure 8.12 as lraction translormed wersus log time and in Figurc 8.13 as analyzed by the Johnson-Mchl-Airami approach.

\subsubsection{Analysis and Modelling}

Quantitative analysis of the cxperimental results was performed in Chapters 4, 7 and 8. Chapter 4 investigated the influence of clectron beam scan specd on the acrage interface velocity. temperacure gradients and cooling rates at the $L S$ interface in the resolidificd melts. Cooling rates were measured by threc techniques: 11 dendrite arm spacing. 2) a modification to Rosenthal's heat flow analysis. and 31 a finite clement method. The heat flow models confirm the dendrite arm spacing measurements. The linite element method was also used to calculate the distribution of tempstaturc gradients and cooling rates on the L. S interface of the clectron beam melts. These results indicate that the icmpcraturc gradicnt is relatively sonstant on the melt pool surlace but that the cooling rate arics significantly from zcro on the melt periphery to a maximum at the top ecnter of the melt.

The experimental obsersations revealed several areas that required cither quantitative analysis or modelling to develop a better understanding of the eftects of cooling rate on the microstructure. These arcas are 1 the change in PSM af $A 110$ ! 4 
from primary ferrite to primary austenite with increasing cooling ratc. Z) the single phasc nature of the high speed melts, 3) the behavior of ferritc content with eooling rate, 4) the presence of the massive transformation in Alloy 5. and 5) the nucleation and growth kinctics of the ferrite to austenite phase transformation.

The change in the primary mode of solidification in Alloy 4 was shown to be related to the dominant growth kinctics of the austenite phase at high cooling ratcs. Although ferrite is the thermodynamically preferred primary phase in this allos. the difference in Gibbs frec encrgy between primary phase austenite and primary phase ferrite is small because its composition is close to the line of two-fold saturation. Epitaxial growth of austenite at the melt periphery allows the initial PSM to be dominated by austenite because approximately $90 \%$ of the base metal substrate at the melt periphery is austenite. At low cooling rates, the AF solidification mode which initially grows from the periphery quickly reverts to the FA mode besausc solidification segregation allows the thermodynamically preferred ferrite phasc to form as the primary phase. However, at high cooling rates, there is insulficient time for the AF mode to revert to the FA mode and the alloy solidifics entirely in the primary (metastable) austenitc condition.

The bchavior of the ferrite content with cooling rate and the single phase nature of the high speed clectron beam melts can be explained by the influcnce of cooling rate on solute redistribution. This analysis is presented in Chapter 7 where the effect of dendrite tip undercooling on solute redistribution was calculated. These calculations were performed on each alloy and for each of the solidification conditions to determine the undercooling caused by the iadius of curvature effects and the undercooling caused by solutal effects. The solutal undercooling is responsible for changes in the solute redistribution. This effect was shown to produce dendrite tip undercoolings as high as $30^{\circ} \mathrm{C}$ in the highest specd electron beam melt.

The results of the dendrite tip undercooling calculations were incorporated into a solidification model to predict changes in the amount of primary phase that forms with changes in the solidification conditions. These calculations show that the amount of primary phase increases as the cooling rate increases and in the limit, the alloys would solidify either as $100 \%$ ferrite or $100 \%$ austenite depending on their primary mode of solidification. However, the calculations fell short of predicting fully austenitic or fully faritic behavior because of the approximations made in 
deriving the pscudobinary diagrams and the approximations made in estimating the solidification front velocity for the high scan specd melts.

The solid statc transformation of ferrite was studied by decloping a simple. first-order model to predict the amount of transformation that occurs during the coniinuous cooling of the resolidificd melts. This model assumed that the transformation was controlled by the diffusion of nickel in austenitc. Thesc results confirmed the experimental observations and showed that the characteristic diffusion distance decreases more rapidly than the dendritc arm spacing with increasing cooling rate. This effect illustrates why the total amount of transformution decreases with increasing coolıng ratc and indicates the conditions necessary to "quench in" the microstrueture.

The massitc transformation obscricd in Alloy 5 was studicd from thermodynamic and hinctic standfonints. Thermodvnamic calculations were performed using "Thermoeale" to determine the Gitbs free energy versus temperature plots for Alloys 5. 6, and 7. These diagrams allowed estimations of the driving force for the transformation and showed that Alloy 5 had the most probable composition for the masive iransformation from single phase ferrite to austenite.

\subsection{Conclusions}

\section{Ferrite Content Measurements}

1. The amount of ferrite in stainless stecl alloys can be detcrmined by measuring the saturation magnctization of a small stainless stecl specimen with a vibrating sample magnctometcr. This tcchnique is not limited by sample sizc and can be used to measure the ferrite content of rapidly solidified stainless steel alloys.

2. The saturation magnetization of fully ferritic spccimens was cxpcrimentally dectermined on a serics of rapidly-solidified $\mathrm{Fe}-\mathrm{Ni}-\mathrm{Cr}$ alloys which had compositions similar to that of residual ferrite in stainless stcel alloys. The results of these measurements can he used to predict the saturation magnetization of residual ferrite from its composition. 
3. Methods were presented to show how the composition of residual ferrite can be predicted from the nominal alloy composition using thermodynamic calculatiuns. In particular, a range of possible iron contents in the ferritc can be cstimated from the nominal alloy composition and the concept of the effective quench temperaturc. By knowing the iron content of the ferrite, its saturation magnetization can be used to calibrate the VSM to measure the ferrite content of a wide range of stainless steel ailoys.

4. The results of the saturation magnetization study can be used as a basis to calibrate the Magne-Gage for non-standard stainless stecl alloys. By considering the saturation magnetization of residual ferrite, the ferrite number san be converted direstly into 1/4 ferrite for a wide range of nominal alloy sompositions.

\section{Cooling Rates and Temperature Gradients}

5. Dendritc arm spacing estimations of the cooling rate show that the are cast button solidilicd at $7{ }^{\circ} \mathrm{C}$ 's and that the six electron-bcam mclts solidificd at ratcs which varied between $4.7 \times 10^{20} \mathrm{C}$ s and $7.5 \times 10^{6 \circ} \mathrm{C} s$. These mcasurements are supported by other cooling rate calculations.

6. An analytic cxpression was derived, based on Rosenthal's heat llow analy'sis. to represent the cooling rate in the solid at any location on the surlace of the weld. This expression can be simplified to represent the maximum cooling rate in the weld hnowing only the length of the weld. the travel specd and the melting temperature of the alloy. Similar cxpressions werc derined to cstimate the cooling rate in the liquid at the $L_{i} S$ interiace.

i. Dendritc arm spacing measurcments and finitc clement calculations show that there is a briation in cooling rate within a given weld. The majority of the ariat.on occurs close to the melt periphery and the remainder of the weld cools within a lactor of about firc in cooling rate.

8. Heat low Ealculations shoued that the highest cooling rate wicurs at the lop center of the weld poot while the louest cooling rate ociurs at the melt 
periphery. On the melt periphers. the cooling rate is zero but rapidl increases within a lea dendrite arm spacings of the butndars. Metallographic obscrvations of the micrustructure confirm thesc calculations.

9. The FEM calculations showed that the temperature gradients baried onl: about

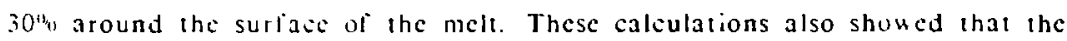
tomperature gradicnt increases by a factor of 2103 for a fourfold increase in tratel speed

\section{The Primary Solidification Mlode and Ferrite Morphology}

10. Fise modes of solidification and eleven morphologies were obserued during the resolidification of the seren alloys. These microstructural characteristics are belicicd to be a complete "sct" of the possible solidification and solid statc transformation events that occur furing the resolidification of typical stainless stccl allo!s. These microstructures were related to the alloy composition. the cooling rate and the cxtent of the solid statc transformation of ferrite.

11. Elation beam soan specd (cooling rate) versus composition diagrams " descloped to predict the primary solidification mode and the morphologics of resolidificd stainless stecl alloys. Figure 5.6 shows the relationship between the primary mode of solidilication and the cooling rate for the seven alloys while Figure 5.15 shows the microstructural morpologies which develop from these solidilication conditions.

$1:$ Epitaxial growth was observed from all of the two-phasc substrates studied in this investigation. Therefore, two phases initially compete to become the primary solid phase. At low cooling rates, the thermodynamic iactors tahe prelerence and the PSM is dictated by the more thermodynamically stable phase. Howcler, at high cooling rates, the growth kincics of the metastable phase ma! supersede the formation of the equilibrium primary phase. This situation was observed in Allos 4 which solidilics in the FA mode at lou rates and in the $A F$ mode at higher rates and in the fully austenitic mode at the highest riach 
13. Nucleation of metastable phases from within the resolidificd zone was not observed in this study. Thercforc. changes in solidification mode with couling rate werc determined to be the result of the expitaxially grown metastable austenite developing into the primary solid phase due to the favorable growth kinctics of austenite under ecrtain solidification conditions.

\section{The Residual Ferrite Content}

14. The composition and the primary mode of solidilication determine how the cooling rate will influence the amount of ferrite that solidifics from the melt.

15. At low cooling rates, the residual ferrite content increases for $F$ and $F A$ solidilicd alloss but decreases for AF solidified alloys. This behavior can be cxplained by the combined effects of the decreasing amount of solute scgregation and the decreasing amount of ferrite transformation with increasing cooling ratc.

16. At high cooling rates the alloys solidify in either the fully ferritic or fully austenitic modes with no second phase in the microstructure.

17. Based on conclusions 15 and 16 , onc would expect the frritc content of the alloys to cither monotonically increase ior FA solidificd alloys or monotonically decreasc for AF solidificd alloys as the cooling rate increases. However, the residual ferrite content of Alloys 4 and 5 was shown to go through a maximum at intermediate cooling rates. This behavior was cxplaincd by l) the change in solidification mode of Alloy 4 from FA to AF with increasing cooling ratc and 2) the formation of massive austenite in Alloy 5 at high cooling ratcs.

\section{Solute Redistribution}

18. A series of isothermal sections through the Fe-Ni-Cr ternary diagram were created through thermodsnamic calculations. These sections shou tic-lines in cach of the two-phase fields that can be used to predict solidilication segregation. 
19. Pseudobinary diagrams were created for primary austenite and primary ferrite solidification conditions. These diagrams are shown in Figures 7.4 and 7.5 and represent signilicant improvements over the constant Fe sections that have been used in the past to illustrate the solidification behavior of stainless steel alloys.

20. Average temperature gradients and average interface velocities were calculated for each of the solidification conditions used in this investigation. These parameters were then used to calculate the dendrite tip radius, and dendrite tip undercooling for each alloy and each solidification condition us ag a constrained deadrite growth model. The results of these calculations showed that the solutal undercooling varies from about $5 \circ \mathrm{C}$ to about $30^{\circ} \mathrm{C}$ as the cooling rate is increased from the casting $(7 \circ \mathrm{C} / \mathrm{s})$ to the highest speed electron beam melt $\left(7.5 \times 10^{60} \mathrm{C} / \mathrm{s}\right)$.

21. Based on the minimum in the Peclet number versus interface velocisy curves, predictions were made for the cellular to dendritic transition as a function of growth rate and temperature gradient. These calculations were compared with the microstructures from each melt to show that the calculations appeared to be of by a constant multiplying factor. The difference in calculated and cxpcrimental behavior was rationalized by the uncertainties in the cellular to dendritic transition theory and in the uncertaintics used in developing the assumptions for calculating the dendrite tip characteristics.

22. Solutal undercooling at the dendrite tip results in an increase in the amount of primary phase and a reduction in the amount of secondary phase that solidifies from the melt. This factor was taken into account to predict the relative amounts of primary and secondary phases which solidify for each of the solidification conditions. The results clearly show the influence that cooling rate has on the microstructure. At low cooling rates, there is a continuous increase in the lotal ferrite content with $\mathrm{Cr} / \mathrm{Ni}$ ratio of the alloy. These calculations ate confirmed by the Scheil predictions and by linc general trend in ferric content measured on the arc cast buttons. At high cooling rates, the calculations indicate a discontinuity in the total ferrite content which develops hetwecn the primary ferrite and primary astenite solidifying alloys. 
23. The ealculated discontinuity in ferrite content explains the single phase nature of the high speed electron beam melts. At high specds. the reduction in the amount of the sccond phase that forms is so sever that the allos solidity in the lully a ustenitic or fully ferritio mode defending on their PSM.

\section{The Solid State Transformation of Ferrite}

27. Many of the microstructural morpholugies that were obsersed in the resolidified neits uere related to the solid state iranstormation of ferrite. This transformation occurs by a nuclation and grow th mechanism and was shown w be analogous to the transformations that ocsur during the decomposition of austenite in Fir alloss.

25. Iho microstructures whith were observed in the Fe-Ni-C allogs uere shou $n$ depend on the primary mode of solidification. the specific alloy composition and the cooling rate. For alloys which solidity in the AF or FA modes. the transformation vecurs by the diffusion controlled growth at austenitc. The resulting microstructures consist of isolated ferrite particles. ismicular ferritc or lacy lerrite, depending on the initial lerritc content and the cooting rate.

20. The transformation rate for the diliusion controlled growth of austenitc was modeled using the diffusion of nickel in austenite as the rate limiting lactor. A simple. Pirst-order. model siloued the translormatun ste to he calculated for cach of the solidilication conditions that were studied in this intestigation. The results of these silculations showed that a decreasing percentage of the mierotructuse transforms as the cooling rate inereases. despite the fact that the "scale" of the microstructure also decreases with imereasing couling rate.

27. A second, and more aceurate. model of the diffusion controlled transtormation of lerrite was also develoned. This model utilizes the finde difference form al Fichs scoond law in calculate the rate of incriace mosement as the lerrate

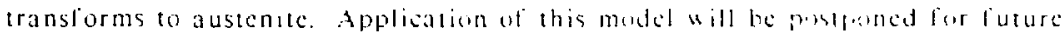
work. 
28. For the allogs that solidil! in the fulls ferrthe condition. nusleatur ul austenite is nescssar! forore the transtormation can prosed and th: temperature at which the austenite phase nusisates dictates the ipe ut transformation that will oceur. At the small undercoolings. Which oceur at lou cooling ratcs. Widmanstatton austonita platclets grou from grain roundar: allotromorphs. The nutleation tharacteries and the insabilitic that form

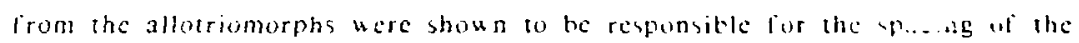
Widmanstaten plackets.

29. A second lype of Widmanstallen austenite morphelog? "as observed in the heat affected zone ut the resolidificd melts. Thas morpholugs consised of auscenite necdles rather than plates. Through isothermal transformation everaments the necdic mospholog! was shown to oceur at larger undercoofings than the platclets.

30. The iranoformation hineties of Widmanstatien austenite were studicd b! isothermal experiments to measure the fraction of the ferritc that iransiorms as 3 lunotun of time at tho dificrent timperatures. These coperimental measurements werc interpreted by a Johnson-Mchl-Airami anal!sis to quantil! the transtionmolion rate. The results of the salculations are consistent with diflusion sontrobled growih mechanisms and san be used to prodit the calent of the transtormation as a funtion of time aid temperaturc.

31. The actisation energs for the ferrite to austenite transformatise a a aleulated from the isuhermal cxperiments to be about $50 \mathrm{Kanl}$ mole. This alue is lewer than the acwation cnergy for difiusion of nichel in austenitc hut is consistent with a ditiusion controlicd provth model and a nen-ecro nuclesidun rare.

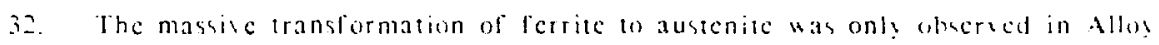
5. This transformation becurs at high cooling rates and through the unc ul

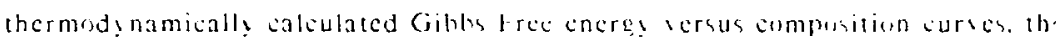
presenec of the massise transfurmation in sllos 5 can casily he caplatiled. th:

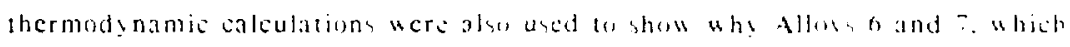
have higher ( $\mathrm{r}$ ij ratio than dllos 5. do not undergen the massis. iranslurmatiun for the coroling ates insestigated in this stud?. 


\subsection{Future Work}

During the course of this investigation, a number of areas were identified that required further analysis or additional computations. This final scetion discusses these areas of possible future research which would help to develop a better understanding of the inlluence ol cooling rate on the microstructure of stainless steel alloss.

First, soliditication of the stainless stecl alloys and the solid statc transformation of lerrite requires a redistribution of solute. These clects were modelcd by assuming local cquilibrium at the transiormation interface and by calculating the partitioning of clements to their respective phases. In the process of performing thesc cakulations. many assumptions were made that hase not yet been fully verilied. One method of verification would be to measure the microchemical composition gradients that are present across the ferrite and austenite cells.

At high cooling rates, the solidification microstructure is "quenched in" and the composition gradicnts would relatc information about the solidification bchavior of the alloys. At low cooling rates, the solid state transformation of ferrite "crases" the soliditication microstructure and establishes composition gradicnts representative of the ierrite-austenite equilibrium. Therefore, compositional rasurements at low cooling rates would relate information about the solid-state transformation of ferrite and could be uscd to verif $\because$ the diffusion controlled growth calculations.

Because much of the important composition information is located close to the austenite ferrite interface, an analytical technique that has high spatial resolution would be required. Low voltage scanning elcctron microscopy with a rocal spot sizc of 500 to 1000 angstroms is available and might give enough resolution for the low cooling ratc melts but scanning transmission clectron microscopy would be required to inspect the high cooling rate melts duc to the smait cell spacings of the mitrostructurc

Second, in order to periorm the solute redistribution calculations, the characteristics at the dendrite tip werc modeled. In the past, these calculations have only becn performed for binary alloy systems. Therefore, in this study, the Fe-Ni-Cr ternary system was approximated by the appropriate pscudobinary diagrams to represent the solidification bchavior. The approximations madc in deriving the pscudobinary 
diagrams could hase becn eliminated if the dendrite tip characteristics were modeled directly in the ternary sıstem.

Although thesc calculations have not been performed in the past, it would be possible by using a numcrical approach which incorporates the isothermal sections generated by Thermocalc. From these isothermal scetions, the solidification parameters cculd be detcrmined as a function of liquid composition and temperature and by choosing small cnough temperature increments, the dendrite tip characteristics could be modeled in a similar manner as presented in Chapter 7.

Third, a finite difference model was developed to solve for the moving-boundary diffusion-controlled-growth transformation of ferrite. Tnis model was not applied to the alioys irvestigated in this thesis due to time constraints, however. since the formulation of the problem has been completed, a computer program could be developed that utilizes this approach. Onec the program has been developed. the results could be applicd to the different alloys and different solidification conditions to detcrminc the cxtent of the transformation as a function of cooling rate. This model wouli also be able to calculate the composition gradicnts that form during the solid state transformation and these results could be compared to the microchemical composition gradient measurements for verification of the model. 


\section{REFERENCES}

\section{CHAPTER 1}

$1.1 \mathrm{~J}$. C. Borland and R. $\therefore$. Younger. "Some Aspects of Craching in tustenitis: Stecls," British Welding Journal 711). 22-60 11960 .

1.2 F. C. Hull. "Lificet of Delta Ferrite on the Hot Cracting of stainlesa Stcet." Wcloing Journal t6(9). Rescarch Suppl.. 399-s to 109-5 1196-7.

1.3 1. Masumoto. K. Tamahi. and M. Kutsuna. "Hot Cracking of Austenitic Stainless Stcel Weld Mctal." Trans. JWS 41111$), 1306-1341119^{-2}$.

1.t W. T. Del..... "Ferrite in Austenitic Stainless Stecl Weld Metal." Welding Journal 5.37 1. Rescarch Suppl.. 273-5 10 286-5 (1974).

1.5 Y. Arata. F. Matsuda, and S. Katasama. "Solidifieation Crach Susceptitilit! in Weld Metals of fully Austenitic Stainless Sicel (Report 1)." Trans. JWRI 5(2). $35.51\left(19^{7} 6\right)$.

10 Y. Arata. F. Matsuda, and S. Katayama. "Soliditication Crack Susceptibilit! in ald Metak of Full? dustenitic Stainless Stecl (Repolt ll). Trans. JWRI G(1). $105-116\left(19^{-?}: 1\right.$.

1.T J. A. Brooks and F. J. Lambert, "The Eflects of Phosphorous. Sulfur, and Ferrite Content on Held Cracking of Type 309 Stainless Stccl." Wclding Juturnal 5751. Rescarch.. 139-s to 143-s (1978).

1.8 K. Kujanpaa. $\therefore$ Suutala. T. Takalo, and T. Moisio. "Correbatun Berusen Solidilication Cracting and Microstructure in Austenitic and Austentiv-ferrite Stainless Stcel Welds." Weld. Res. Intl. 9(2). 55-70 (1979).

1.9 C. D. Lundin. (·P. D. Chou, and C. J. Sullisan. "Hot Cracking Resistancic al" Austonitic Stainless Sicel Weldments." Welding Juurnal 59181. Rescareh Suppl.. 226-5 $10232-5(1980)$.

1.10 J. C. Lippold. and W. F. Sarage. "Solidification of Austenitic Stainless Stecl Weddments. Part 3 - The Effect of Solidification Behasior on Hot Craching Susceptibility." Helding Journal 61(12). Researeh Suppl. 338-E tu 336-9 (1982).

1.11 J. C. Lippold. "Weld Cracking Nechanisms in Austenitic Siainless Stcels." in Trends in Welding Researeh in the L'nited States (Ameriean Soctets for Vetals. Ohiol. 209-242(1982).

1.12 J. A. Brooks. A. W. Thompson, and J. C. Williams, "A Fundamental Study ol the Bencficial Eflect of Delta Ferritc in Reducing Wel. Cracking." Welding Journal 63(3). Rescarch Suppl, 71-s to 83-s (1984). 
I.13 M. O. Malone. "Sigma and $885 \circ$ F Embrittlement of Chromium-Nichel Stainless Stccl Weld Mctals." Helding Journal 46(6). Rescarch Suppl. 241-s to z5i-5 (1967).

1.14 J. Honescombe and T. G. Gooch. "Effect of Mangancse on Cracking and Corrosion Bchavior of Fully Austenitic Stainless-Stcel Held-Mctals." Metal Const. \& Brit. Weld. J., $456-460$ (1972).

1.15 R. Viswanathan. J. I. Nurminen. and R. G. Aspden. "Stress Corrosion Behasior of Stainless Stecl Vields in High Temperature Water Containing Chloride," Wclding Journa! 58(4), Research Suppl., 118-s to 126-s (1979).

1.16 T. A. Whipple. H. I. MeHenry, and D. T. Read. "Fracture Behavior of Fcritc-Frec Stainless Stcel Welds in Liquid Helium." Welding Journal 60(4). Research Suppl., 72-s to 78-s (1981).

1.17 D. T. Read. H. I. MeHenry, P. A. Stcinmeyer, and R. D. Thomas, Jr., "Metallurgical Factos Affecting the Toughness of $316 \mathrm{~L}$ SMA Heldments at Cryogenic Temperatures," Welding Journal 59(4). Rescarch Suppl.. 104-s to $11.3-5(1980)$.

1.18 C. E. Witherell, "Welding Stainless Stecls for Structures Operating at Liquid Helium Tempcratures," Welding Journal 59(11). Research Suppl.. 325-s 10 342-s $(1980)$.

1.19 D. L. Olson. "Prediction of Austenitic Weld Metal Microstructures and Propertics," Welding Journal 65(10), Research Suppl., 281-s to 29l-s (1985).

1.20 A. L. Schaefler. "Constitution Diagram for Stainless Stecl Weld Metal," Metals Progress 56, 680 and $680 \mathrm{~B}$ (1949).

1.21 A. L. Schacfler, "Selection of Austenitic Electrodes for Welding Dissimilar Metals," The Welding Journal 20(10), Rescarch Suppl., 601-s to 620-s (1947).

1.22 W. T. DeLnng. G. Ostrom, and E. Szumachowski, "Mcasurement and Calculation of Ferrite in Stainless Steel Weld Metal," Welding Journal 35(11), Research Suppl., 526-5 to 533-5 (1956).

1.23 C. J. Long and W. T. DeLong, "The Ferrite Content of Austenitic Stainless Stecl Weld Metal." Welding Journal 52(7), Research Suppl., 281 -s 10 297-s (1973).

1.24 F. C. Hull, "Dclta Ferrite and Martensite Formation in Stainless Stecls," Welding Journal 52(5), Rescarch Suppl., 193-s to 203-5 (1973).

1.25 T. Takalo. N. Suutala, and T. Moisio, "Influenec of Ferrite Content on Its Morphology in Somc Austcnitic Weld Mctals," Mctallurgical Transactions 7(A). $1591-1592(1976)$.

1.26 N. Suutala, T. Takalo, and T. Moisio, "The Relatiunship Between Solidification and Microstructure in Austenitic and Austenitic-Ferrite Stainless Stecl Welds," Metallurgical Transactions 10(A), 512-514 (1979). 
1.2- \. Suutala and $\mathrm{r}$. Moisio. "l se of Chromium and Vichel Fquivalents in combidering Solidifisation Phonomena in Austenitio Staintos Stects." in Solidilication lechnotogs in the Foundry and can llouse the retals Socicts. lindun. 198011. pl. i10-314.

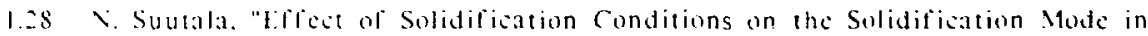

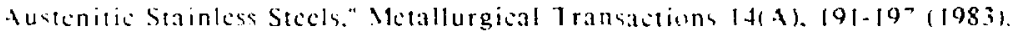

1.29 (;. 11. Gooduin, $\therefore$. C. Colc. and G. M. Slaughicr. "A Studs of Ferrite Morpholig! in dustonitic Stainless Stect Heldments." Weld. fournal 5l(9). Resciach Suppl. t.5-s 10 ti9-s (1972).

$1.30 \$ 4$ D. Diul. "Ferrite Morphology and Variations in Ferrite Content in Autenitic Stainless Stcel Helds. "Helding Journal o0t t). Rescarch Sunpl. 6i-s to $-1-9119811$.

1.31 J. A Brouks. "Solidifization and Solid State Transiomations of Austenitis Stamless Stecl Welds." in Trends in Welding Researeh in The l'nited States. S. 1. David. Ed. 1 ASM. Mctals Park. Ohio. 19821. pp. 331-33.

1.32 V. Ci. Rilin and G. V. Rasnor. "Critical Evaluation of Constitution of Chromium-lron-Vichel Sistcm," International Mctals Resicu. Reuicu No. 248. Vi). $1.21-38119801$.

1.j. E. Schurmann and J. Brauchmann. "Investigation of the Meling Equilibria in the Iron Corner of the Ternary System lron-Chromium-Nichel." Areh. fisenhutionuesen 48(1). 3-7 (1977).

1.it E. R. Szumachowsti and D. J. Kotecki. "Eflect of Mangancse on Stainless Stecl Neld letal ferrite." Nelding Journat 63(5), Research Suppl.. 156-5 to lol-s

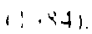

1.35 O. Hammar and l'. Sicnsson. "Intlucnce of Stecl Composition on Segregation and Microstructure During Solidification of Austenitic Stainless Stcel," in Solidification and Casting of Mctals (The Mctals Socicts. London. 1079), pp. $401-410$.

1.36 C. X. Mecoman. T. A. Sicuart, R. P. Recd and F. B. Lakc. "Mangancese and Vitrogen in Stainless Stecl SMA Welds for Cryogenie Service." Heleding Journal. (6013). 8+-5 4 92-s. (1987).

1.3- O J. Percira and J. Beceh. "Factors Inllucncing the Delta Ferrite Cuntent of (a" Juscnitic Stainless Siccls." in Solidilication Technology in The Foundr) and it House (The Metals Socicty. London, 1980). np. 315-321.

1.38 11. Fredriktson. "Solidification Sequenec in 18-8 Stainiess Stecl. Investigated by Directional Solidification." Metallurgical Transactions 3(11). 35-51 (1976).

1.39 ․ Sutala, "Solidilication Studies on Austenitic stainless Stecl. ACTA

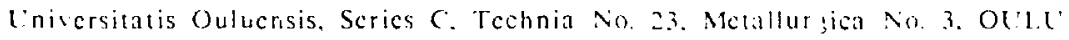
$(198:)$. 
1.40 J. M. Vitch. A. Dasgupta. and S. A. David. Mlicrostructural Modilication at" fustenitic Stainless Steel by Rapid Solidilication." Metallurgical Transactions 14(1). $1833-18+1(1983)$.

1.41 J. M. Vitck and S. A. David, "Microstructural Analysis of Austenitic Stainless Stecl Laser Wids." in Trends in Welding Researsh in the l'nitcd States (American Society for Metals. Ohio, 1982), pp. 243-258.

1.4. S. A. Darid. J. M. Vitek and R. W. Reed." Effect ol hapid Cooling Or Stainless Stcel Weld Microstructure and Jts Implieations on The Schaclfler Diagram." Widjing Journal. 66(10), 289-5 to 300-s. (1987).

1.7. S. Katasama and A. Matsunawa. "Solidification Microstructure of Laser Welded Stainless Stcils," Proc. ICALFO. P. 60. (1984).

1.4t J. C. Lippold. "Centerline Cracking in Decp Penctration Electron Beam Welds in T!pe : $(14$ L Stainless Stccl." Nelding Journal 64(5). Rescarch Suppl. 127-s to $136-5(1985)$

145 F. T. Kelly. M. Cohen. and J. B. Vander Sandc. "Rapid Solidification of A Droplet-Processed Stainless Stcel," Metallurgical Transactions 15(A),819-833 $(1984)$.

\section{Chapter $\underline{2}$}

2.1 E. M. Gutierrez and J. Szckely. "A Mathematical Model of the Planar Flow Mclt Spinning Process." Mctallurgical Transactions 17(B). 695-703 (1986).

2.2 H. J. Bocttinger, D. Shechtman. R. J. Schacfer, and F. S. Biancanicllo, "The Efrect of Rapid Solidification on the Microstructure of Ag-Cu Alloys," Mctallurgical Transactions I5(A), 55-66 (1984).

23 E. Berah and B. Shpiglcr, Color Mctallography, ASM. Mctals Park. Ohio. p.32. (1977).

24 S. Ohara, S. Komura and T. Takeda, "Magnetic Propertics ol Pscudo-Iron Fe $\left(\mathrm{Cr}_{0.5} \mathrm{Ni}_{0.5}\right)_{\mathrm{x}}$ Tcrnary Alloys." J. Phỵs. Socicty Japan. 34(6). (1973).

2.5 "Standard Test Method for Density of Glass by Buo:ancy". ASTM STP C693-74, ASTM. Philadelphia, (1974).

\section{Chapter $\underline{3}$}

31 sec reference 1.20

3.2 sec reicrence 1.21

$3.3 \quad$ secereference 1.22 
3.4 C. N. MeCowen. et al. 'Lpdating the Delong Diagram, paper presented at the 68 th Alls Convention. Chitago, $\left(198^{\circ}\right)$.

3.5 C. N. MeCouan et al.,"FX" Predicive Diagram for Stainless Stecl Welds," Paner presented at the 69th AWS consention. New Orleans (1988).

3.5 sec reference 1.32

3.7 sec reference 1.42

3.8 American Welding Socict!. "Recommended Procedures for Calibrating Magnctic Instruments...". AWS. A 4.2. (1974).

3.9 E. Stalmasck. "Measurement of Ferrite Content in Austenitic Stainless Stecl..." WRC Bulietin 318. September (1986).

3.10 P. E. Merinos et al., "A Scthod for the Quantative Determination of the Ferrite Content of Welded Joints in Crvi Stcels." Welding Production, 2.43), p. 49. (1977).

3.11 P. Merinov, S. Entin. B. Beketor and A. Runov. "The Magnetic Testing of the Ferrite Content of Austenitic Stainless Steel Weld Metal," NDI Int, 11(1), p 9. (19:8).

3.12 S. Chikazuni. Physics of Magnetism. New York, J. Wiley, 1967.

:13 G. C. Curtis and J. Sherwin. Magnetic Method for the Estimation of Ferrite in Stainless Steei Welds," Brittish JAP. 12(7), p. 344. (1961).

3.14 J. A. Brooks, J. C. Williams, and A. W. Thompson, "Microstructural Origin of Skelctal Ferrite Morphology of Austenitic Stainless Stecl Welds," Metallurgical Transactions 14(A). 1271-1281(1983).

3.15 F. T. Kelly, M. Cohen, and J. B. Vander Sande, "Rapid Solidification of a Droplet-Processed Stainless Stecl," Metallurgical Transactions 15(A), 819-83.3 $(1984)$.

3.16 S. A. David, G. M. Goodwin and D. N. Braski, "Solidification Bchavior of Austenitic Stainless Stcel Filler Metals." Welding Journal 58(11). (1979).

3.17 J. C. Lippold and H. F. Savage. "Solidifisation of Austenitic Stainless Stccl Weldments: Part I - A Proposed Mechanism," Welding Journal 58(12), 1979.

3.18 M. J. Cicslak. A. M. Rittcr and W. F. Savagc. "Solidification Cracking and Analyical Electron Microscopy of Austenitic Stainless Stecls," Widing Journal $6 !(1)$. (198:).

3.19 sec reference 2.1

321 B. D. Cullity, Introduction To Magnetic Materials. Addison-Weslcy. Reading, Massachusctts, 197 ?.

3.21 B. Sundman, B. Jansson and J.O. Andersson." The THERMO-CALC Datahank Systcm," CALPHAD, S(2), pp 153-190, (1985). 
3.22 J. W. Elmer, "Thermodynamically Calculated Isothermal Sections of the $\overrightarrow{r e-N i-C r}$ Ternary System for Temperatures Above In:3 K." II.NI.. UCID-20838, (1987).

3.23 J. M. Vitek and S. A. David,"The Concept of an Effective Quench Temperature and its use in Studying Elevated-Temperature Microstructures." Met Trans. 16A, pp1521-1523, August (1985).

3.24 sec reference 2.4

3.25 D. J. Kokecki, "Extension of the WRC Ferrite Number Sistem," Weliting Journal, 61(11), (1982).

\section{Chapter 4}

4.1 M. C. Flcmings. Solidification Processing (McGraw-Hill Booh Cimmany. New York. NY. (1974).

4.2 T. Z. Kattamis., J. C. Coughlin, and M. C. Flemings, "Influence of Coarsening on Dendrite Arm Spacing of Aluminum-Copper Alloys," Trancactions AlM1E. 239. 1504-1511(1967).

4.3 M. C. Flemings, D. R. Poirier, R. V. Barone, and H. D. Brody, "Microsegregation in Iron-Base Alloys," J. Iron Steel Inst. 208, 371-381 (1970).

4.4 T. F. Bower, H. D. Brody, and M. C. Flemings, "Mcasurements of Solute Redistribution in Dendritic Solidilication." Transactions AIME 236. 624-654 (1966).

4.5 Sec Reference 1.32 .

4.6 D. Rosenthal. "The Theory of Moving Sources of Heat and Its Application to Metal Treatments," Transactions AIME 43(11), 849-866 (1966).

4.7 N. Christensen, V. Davies, and K. Gjermundsen, "The Distribution of Temperatures in Arc Welding," Brittish Welding Journal 12(2), 54-75 (1965).

4.8 T. W. Eagar and N. S. Tsai, "Temperaturc Ficlds Produced by Traveling Distributed Heat Soruces," Welding Journal 62(12), 346s-355s, (1983).

4.9 sec reference 4.1 , Chapter 2

4.10 J Szckelcy, private communications, November, 1987.

4.11 Mr. M. Kong, Lawrence Livermore National Laboratory, 1986.

4.12 Dr. M. Lin, Massachusctts Institute of Technology, 1986.

\section{Chapter 5}

5.I A. Munitz, "Epitaxy and Surface Melting of Aluminum Alloys by High Powered Directed Energy," Metallurgical Transactions B 11(B), 563-573 (1980). 
5.2 R. J. Wallace and E. N. Kaufmann. "Nueleation and Growth in Suriace-Melicd Crystalline and Amorphous Fe40Ni40PI4B6 Alloys." J. Mater. Res. I(1). (1986).

5.3 H. W. Bergmann and B. L. Mordike. "Production and Properties of Amerphous Layers on Metal Substrates by Laser and Elcctron Bcam Melting." Rapidly Solidifics Amorphous and Crystallinc Alloys. Proc. Symp. of Materials Research Society, B. H. Kear. B. C. Giessen and M. Cohen (eds.), Vorth-Holland Amsterdam. $497-503$ (1982).

5.4 sec reference 1.2?

5.5 see reference 1.28

5.0 sec reference 1.4?

5.7 sec reference 1.43

5.8 sec reference 1.40

5.9 sec reference 1.44

5.10 sec refierence 1.45

S.11 see reterence 1.31

5.12 sec reference 3.22

5.13 J. C. Lippold and H. F. Savagc. "Solidification of Austenitic St i Stecl Weldments: Part 2 - The Effect of Alloy Composition on Ferrite, .ology." Wiclding Journal 2 , 48-s to 58-s, (1980).

5.14 N. Suutala. T. T. J and T. Moisio. "Single Phase Ferritic Solidification Mode in Austenitie-Ferritic Stainless Stecl Welds." Metallurgical Transactions $10(8), 1183-1190$. (1979).

5.15 S. Katayama and A. Matsunawa, "Solidification Behavior and Microstructural Characteristics of Pulsed and Continuous Laser Welded Stainless Stecl," to be published. (1988).

5.16 sec reference 1.25

5.17 sce reference 1.26

5.18 sec reference 1.30

5.19 E. L. Brown, T. A. Whipple and G. Krauss, "Metallography of Duplex Stainless Stecl Castings," Duplex Stainless Stcels edited by R. A. Lula, ASM, Metals Park, OH, p. 665 (1983).

5.20 J. Singh, G. R. Purdy and G. C. Weatherly, "Microstructural and Micramechan. ical Aspects of the Solid-State Decomposition of Delta Ferritc in Austenitic Stainless Stccls," Mctallurgical Tansactions 16A(8), 1363-1369 (1985). 


\section{Chapter 6}

0.1 sec reference 1.32

6.2 D. Nindrat, prisate communications, Notember, $198^{-}$.

6.3 Y Chuang and $Y$. A. Chang,"A Thermodynamic Analysis and Calculation of the Fe-Ni-Cr Phase Diagram, Metallurgical Transadions 4. i84151. -3.- 45. $\left(198^{-1}\right.$.

6.4 secterencici.22

65 sic relerenic $1: 3$

$06 \mathrm{~J}$ b. Elmet. I) L. Olson and D. K. Mallock. "The Thermal Expaming

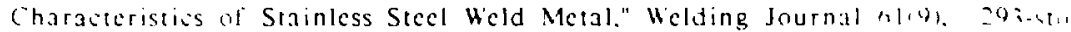
in) $-9,119821$

6" D J kutechl. "Welding Parameter Effects on Open-Are Stante- Steel Weld Metal Ferritc." Nelding Journal $57(4)$, 109-s to $11^{-}$-s. $119^{-} 81$.

$6.8 \sec$ reference 3.28

69 J A Sarteal and G. J. Abbascian. "The Fifect of Solidiliallun Rate in

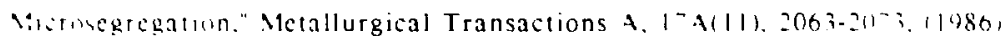

\section{Chapter 7}

- I sec relerense 6.9

? D M kundrat. "Thermodynamic Model of the Solidification Process of Allous. Par1 I," (ALPHAD, 11(4). 349-354, (1987).

3 D 11 Kundrat. "Thermodynamic Model of the Solidification Froess of Alloys. Part 11," CALPHAD. 1144), 355-360, (1987).

- 4 D.M. Kundrat. Priste communication and collaboration, September, (1987).

- 5 sec relernac 4.1

- W.H. Mullins and R. F. Sckerka, "Morphalogical Stahility of a Particlc Crou ing h) Diflusion or Heat Flow." J. Applied Physics, 34(2), pp. 32:-329, (1963).

7.7 J. Lipton, M.E. Glieksman and W. Kurz, "Dendrite Growti into Cnderenoled Allos Melts," Material Science and Eng. 65, pp. 57-63, (1984).

7.8 W. Kurz and D.J. Fisher, Fundamentals of Solidification. Trans Yec. Publications, Switzcrland. (1986).

7.9 G. P. [vanstor: Dohl Akad. Nauk SSSR vol.58. p. 567. (1947).

710 W. Kurz and D.J. Fisher, "Dendrite Growth at the limit of Stahility" Tip Radius and Spacing, "Acta Mct., 69), pp. 362-366, (1984). 
-.I: K. Soumboonsuh, J.T. Mason and R.Trivedi,"Interdendritio Spaing Part I Experimeental Studies," Mlet. Trans, 15A(6). pp 967-975, (1984)

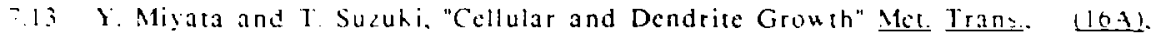
pp $1799-1814 .(1985)$.

- 14 T.K. Clyne and 1 . Kurz. "Solute Redistribution During Solidiliation with Rapid Solid State Dillusion," 1ㅡㄴ Trans A, 12A(6), pp. 965-71. 119811.

- is H.D. Brody and M.C. Flemings. "Solute Redistribution in Denuritio Soldification." Trans. Al111. =30(5). pp. 015-24, (1966).

".lo M.H. Burden and J.D. Hunt. "Cellular and Dendritic Grouth I." J. Cristal Grosth. 22. pr. $90-109 ; 1974)$

- $1^{-M}$ M. Burden and 3.D. Hunt. "Cellular and Dendritio Grouth II." I Cristal Grosih. I2, pp. 1(19-10,119-4).

- 18 K.A. Jachson and J.D. Hunt. "Lamellar and Rod Eutectic Growih," Irans. A1ME. ?3018). PP. $1129-42.11900)$.

- I4 Y. Hu. TJ Picone, Y, Shiohara and M.C. Flemings, "Dendritie Growlh al Linderooled viskel-tin Part I." Mct. Trans. A. 18A(5). pp. 915-24. 11987).

-.u J.C. Baher and J.W. Cahn. "Thermodynamics of Soidification." Am. Sus: Lier Metals. Mctals Park Oh. pp $23-58.11970)$

- I W.J. Boctlinger. S.R. Coricll and R.F. Sckerka, "Mcchanisms ol Miciasegregation-frec Solidification." Mfatcrials Sci. and Eng. (65). pp. 27-30.119841.

$\because 2$ M.J. Aziz, "Atodel for Solute Redistribution During Rapid Solidilication," Appl Phisics. 5312). pp. 1158-68. (1982).

\section{Chilpter 8}

\& I D.B. Muharial, I. Jin, and G.R. Purds, "The Eflect of Delia Ferrate on the Pust-soliditication llomoginization of Allu! Stecls," Metalluigical lransalums 5. $59-63(1964)$

Sz K llirano, M1. Cohen, and B.L Averbach, "Diflusion of Nichel into Iron," Aits btciallurgica 9. 440-4t5 (1961).

8.: Gi. Hancoch ani G.M. Leah. "Dilfusion of Nichel in Binars Allus al Irun

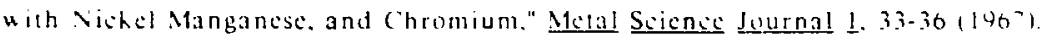

S.t P.J.Alberry and C.H. Haworth, "Interditiusion ol Cr. Mo, and W in Iron," Notal Soiense 8.407 .41211974$)$.

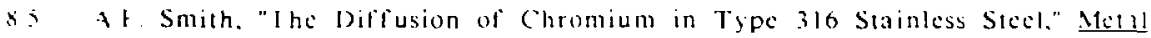
s.ic日es 2. $375-378(1975)$. 
8.6 R.A. Perkins. J.R. Padgett, and N.K. Tunali, "Traeer Dilfusion in Fe and Cr in Fe, 7 H't Pet Cr, 12 Wt Pet Ni Austenitic Alloy." Metallurgical Transactions 4. $2535-2540(1973)$.

8.7 R.A. Perkins. "Tracer Diflusion in $\mathrm{Ni}$ in Fe-17 Wt Pet $\mathrm{Cr}-12$ Wi Pet Ni," Metallurgical Transactions 4(A), 1665-1669 (1973).

8.8 A.F. Smith and R. Hales, "The Dilfusion of Chromium in a Duplex Alloy Stecl." Meral Science. +18.423 (1976).

8.9 J. Singh. G.R. Pardy, and G.C. Wentherly, "Microstrucural and Micromechanical Aspects of the Solid-state Decomposition of Delta Ferrite in Austenitic Stainless Stccls," Mctallurgical Transactions 16(A), 1363-1369 (1985).

8.10 M. Hillert. "Thermodynamies of the Massive Transformation." Mctallurgical Transactions 15(A), 411-419 (1984).

8.11 M.R. Pichta, W.A.T. Clark, and Aaronson, "The Nucleation Kinetics, Crystallography and Mechanisms of the Massive Transformation," Metallurgical Transactions $15(\mathrm{~A}), 427.435 .(1984)$.

8.12 J.H. Perepezho. "Growth Kinctics and Mechanism of the Massive Transloramtion," Mctallurgical Transactions 15(A), 427-447, (1984).

8.13 J.W. Christian. The Theory of Transformation in Metals and Alloys, Pari 1. Pergamman Press, (1975).

8.14 C.A. Dubc, H.l. Aaronson, and R.F. Mehl, Rev Met. 52, 201 (1958).

8.15 Decomposition of Austenite by Diffusiona! Proeesses, edited by V.W. Zackay, and H.I. Aaronson, AIME, 387-548, (1962).

8.10 W. Johnson and R.F. Mchl,"Reaction Kinetics in Processes of Nucleation and Growth." Trans AlME 135 416, (1939).

8.17 M. Avrami, J. Chem. Phys. 7, 103, (1939)

8.18 R. D. Townsend and J. S. Kirkaldy, "Hidmanstatten Ferritc Formation In Fi-C Alloys," Iransactions ASM. (61). pp. 605-619 (1968).

8.19 see relerenec 7.6

8.20 C. Zener, Tralisactions AIME, (167), p 550, (1946).

\section{Appendices}

B.I SURFER, Golden Soltware, Golden, Co.

C.1 B. Sundman, B. Jansen, and J. Anderson. "The Thermo-Cale Databank Systen," Calphad 9(2), 153-190(1985). 
C.2 B. Sundman and J. Agren, "A Regular Solution Model for Phases with Several Components and Sublatrices Suitable for Computer Applications," I Phys. Chem. Solids 42, 297.30i (1981).

D.I Y. Chuang and Y. A. Chang. "A Thermodynamic Analysis and Calcul: :un of the Fe-Ni-Cr Phare Diagram," Mct. Trans. A, 18A(6), p. 733. (1987).

G.1 Christensen, N.. Davies, V.. and Gicrmendsen, K." The Distribution of tcmpcrature in are welding," British Welding Journal 12 (?):54-75, (1965).

G.2 Rosenthal, D.," The theory of moving source of heat and its application to metal tratment." [ransactions ASME 43 (11):849-866, (1946). 


\section{APPENDIX A}

\section{Derivation or The Cooling Rate Equation}

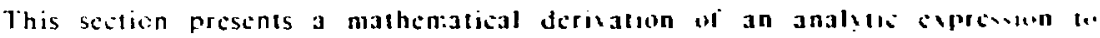
represent the cooling rate. The formulation of the problem is diseused in sition

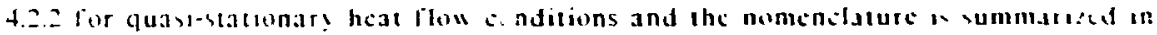
labic 4.2.

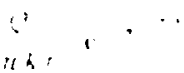

$1+i \quad i \quad i$

First Derisative of ca 4.3 urt

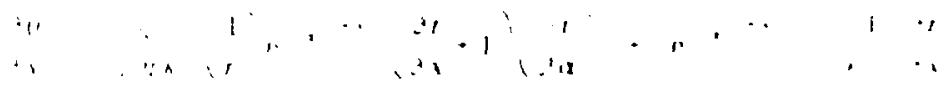

where.

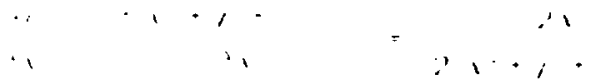

therelure.

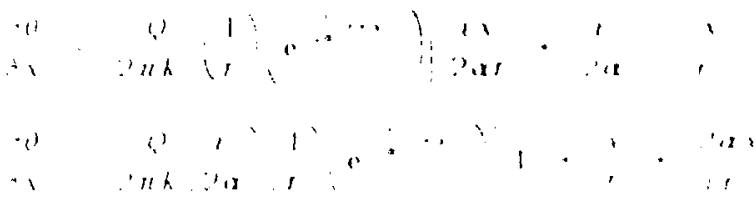

\section{Cooling Rate Equation}

$$
\left(1, \begin{array}{lll}
01 & 0 \\
1 & .1
\end{array} \quad+1 ; 1\right.
$$

substilutien of equation $A 1$.

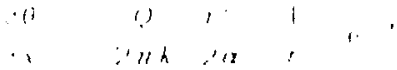


since.

$$
\begin{aligned}
& \theta=\frac{(1)}{\therefore H A}, \ldots \cdots \\
& \therefore \theta=01 \frac{1}{20}+1+\frac{1}{1}+\frac{31}{11}
\end{aligned}
$$

\section{Derivation of The Location of The Maximun Weld Pool Width}

This scetion derives an expression for the distance behind the sourse. in. on the lop surtace of the plate $z=0$ ). "here the weld pool achicies its mavinum "idth

$I_{w}$ depends on the radius at this point. $r_{w}$, whith must be detcrmined bs a trial and error method using equation $\mathbf{A . 5}$.

$$
\begin{aligned}
& \left.H=\frac{Q}{(2 \pi k)}\right)_{0} \therefore \cdots
\end{aligned}
$$

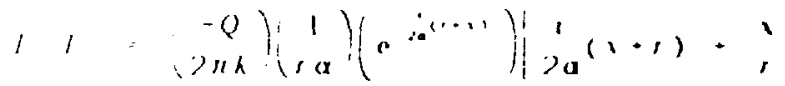

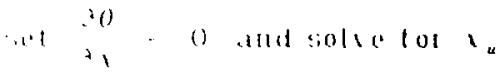

$$
\begin{aligned}
& \therefore(1+1)+1=0 \\
& \left(\frac{1}{2}+\frac{1}{1}+\frac{-11}{2 x}\right. \\
& \left.\begin{array}{c}
11+\nu a \\
\nu a r
\end{array}\right)=-21 \\
& v_{1}=\left(\begin{array}{c}
-11 ; \\
1{ }_{n}+2 a
\end{array}\right)
\end{aligned}
$$

substitution into cquation 4.3 gives.

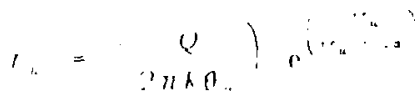




\section{APPENDIX B}

\section{Temperature Gradient and Cooling Rate Calculations}

This appendix summarizes the progranis which must be run in order wa wilate the cooling rate in welds. The output of two computer runs are also shoun in lables B.1 and B.2. These results shou: (1) the temperature gradient in the solid. $1 \mathrm{~s} .121$ the cosine between the unit normal to the weld pool and the trasel speed dircition. in $n$. and (3) the cooling rate in the solid. . for each of the boundars nodat houns in the solidilying half of the weld pool.

Fisc prograns must be run to calculate the cooling rate. The sufiuare is written on DEC RTll and requires a 3-D mesh of the base plate. The progran will then calculate the temperature at each nodal point in the plate for quazl steady-state heat flow eonditiuns using the boundary conditions discussed in Chapter 4 . From the temperature distribution. a temperature gradient is calculated at cach point on the liquid-solid interlace and the cooling rate is calculated a: each nodal point by the vector product of the temperature gradient and the interface selocits.

The physical property data is assumed to be indepoendent of temperature and should be input in the followillg units: $T(K), k(N) m-k)$. C(J kg-K), (th $\left.\mathrm{m}^{3}\right)$. (m) s). The dincensions on the 3-D grid should be in inches and the travel speed should be input in the units of (inch s). The output from tixe program gives the temperature gradient $\left({ }^{\circ} \mathrm{C} / \mathrm{inch}\right)$ and the cooling rate $\left({ }^{\circ} \mathrm{C} / \mathrm{s}\right)$.

The data presented in Tables B.I and B.2 were used to creatc 'topographical' and orthographic plots. The topographical maps show lines of constant cooting rate and temperature gradient on the $x=0$ cross sectionai plane of the melt These plots are shown in rigures $4 \mathrm{f}$ and 4.7 and represent the behatior on the mell isotherm. Ihe orthographic projections represent this same data in threc dimensional form and are shown in ligures B.I through B.4. The topographical maps and the orthigraphiprojections were both caleulated with the 'Surfer' soltwarc paihage [H.1] using a $100 \times 100$ grid ereated by the Kriging method. 


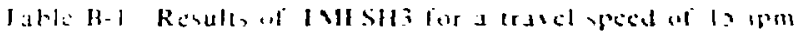

\begin{tabular}{|c|c|c|c|c|c|}
\hline \multicolumn{3}{|c|}{$\begin{array}{l}\text { (inind } \\
\text { cinch) }\end{array}$} & \multicolumn{2}{|r|}{1.} & \multirow[t]{2}{*}{$\therefore n$} \\
\hline$-\lambda$ & $i$ & 7 & 113 & I In:h) & \\
\hline 0.0000 & 1300100 & $004^{-} 0$ & $000011+001$ & $-11: 151+1+3$ & $(1+1+1,1)+14)$ \\
\hline 0.0000 & 0.0148 & $0.11+45$ & $0.00011+001$ & $-112151+615$ & $(1114,2+1,6)$ \\
\hline $0.0 \geq 13$ & $0(1000$ & $0.042^{-}$ & $-1)=211+00$ & $-0:=-1+0,5$ & $113 \times 110.121$ \\
\hline $0.0=04$ & 00130 & 0.0408 & $-0.2211+04$ & $-0: i n \mid+05$ & $(1: 51 \cdot 11)$ \\
\hline 0.0000 & 011200 & 0.0 .991 & $0.000 \mathrm{t}+110$ & $-0=30 t+65$ & $(11)(10)+(11)$ \\
\hline 0.0184 & $0,12+3$ & 00304 & $-0.2111+04$ & $-0.2511+015$ & $0::-1+00$ \\
\hline 0.0000 & 110332 & 00.32 & $0.0001+00$ & $-0.255 i+11$. & $000001+000$ \\
\hline 0.0161 & 0.0315 & 00.315 & $-0.1921+04$ & - to $20 \leq 1+00$ & $11=4 .+1+04$ \\
\hline 0.0000 & $\left(1,14^{-0} 0\right.$ & 0.0000 & $0.000 \mathrm{E}+00$ & $-0 \leq 191+05$ & $110001+110$ \\
\hline 0.0000 & $00+45$ & $0.01+8$ & $0.000 \mathrm{E}+00$ & $-0.2071+05$ & $000(11+00$ \\
\hline 0.0213 & $11142-$ & 0.0000 & $-0.2225+04$ & $-0 \geq 281+05$ & $03901-101$ \\
\hline 0.0204 & $0.11+08$ & 0.0136 & $-0.221 E+04$ & $-0.230 L+05$ & $03741+110$ \\
\hline 0.0000 & 110391 & 0.0260 & $0.000 \mathrm{r}+00$ & $-0.230 \mathrm{E}+05$ & $0000 t+00$ \\
\hline 0.0184 & 00.304 & $0.02+3$ & $-0.215 E+04$ & $-0.250 t+05$ & $0.3371+0$ \\
\hline 0.0348 & 110000 & $0.034 i$ & $-0.430 F+04$ & $-0 \geq 6.31+0 j$ & $0.6531+00$ \\
\hline 0.0339 & 0.0110 & 0.033. & $-0.420 \mathrm{E}+04$ & $-02051+05$ & $06.34+00$ \\
\hline 0.0315 & 0.1205 & 0.0307 & $-0.388 \mathrm{E}+04$ & $-0.26 \mathrm{dl}+05$ & $0.5801+00$ \\
\hline 0.0284 & 0.0 .75 & 0.0275 & $-0.3+9 E+04$ & $-0.265 t+05$ & $052 \div 1 \rightarrow 00$ \\
\hline $0.03+8$ & 00343 & 0.0000 & $-0.4241:+04$ & $-0.2591+05$ & $00531+00$ \\
\hline 0.0 .339 & 0.0 .332 & 0.0110 & $-0.413 \mathrm{E}+04$ & $-02001+05$ & $06.341+00$ \\
\hline 0.0315 & 00307 & 0.0205 & $-0.39 .3 \mathrm{~F}+0 \mathrm{~s}$ & $-02681+05$ & $05861+00$ \\
\hline $0.0+10$ & 0.0000 & 0.0278 & $-0.532 \mathrm{E}+04$ & $-0:-21+05$ & $0.811+110$ \\
\hline 0.0402 & 00091 & 0.0273 & $-0.518 \mathrm{t}+0 \mathrm{t}$ & $-0.2701+05$ & $(1-6.51+1) 61$ \\
\hline 6.0 .382 & 00172 & 0.0258 & $-0.483 \mathrm{E}+04$ & $-0 \geq 6 ? I+05$ & $0^{-3}: 31+10$ \\
\hline 0.0354 & 0.0238 & 0.0238 & $-0.4371+04$ & $-026 \geq 1+05$ & $00001+001$ \\
\hline $0.0 \pm 10$ & $0.0 \geq 78$ & 0.0000 & $-0.516 \mathrm{E}+04$ & $-0.2611+05$ & $0-811+00$ \\
\hline $0.040=$ & 0.023 & 0.0091 & $-0.502 \mathrm{~F}+04$ & $-0202 I+05$ & $0)^{-7}(5,51+00$ \\
\hline $0.038=$ & $0.0 \div 58$ & 0.0172 & $-0.4811+04$ & $-0.2(0,1)+05$ & $0)^{-2}=31+110$ \\
\hline 0.0510 & 0.0000 & 0.0000 & $-0.6099 \mathrm{E}+04$ & $-0.280 i+05$ & $01001+01$ \\
\hline 0.0494 & 00000 & 0.0113 & $-0.65+\mathrm{F}+04$ & $-11=-11+015$ & $090.51+0111$ \\
\hline 0.0494 & 0.011 .3 & 00000 & $-0.6541+04$ & $-0120-1+05$ & $(1+2051+16)$ \\
\hline 0.0481 & 0.0110 & 0.0110 & $-0.0241+04$ & $-\left(1=20^{-}-1+015\right.$ & $(1) \div-11+00$ \\
\hline 0.045 & 00000 & 0.0208 & $-0.5881+04$ & $-f 1, \cdot 1+05$ & i) $8811+(1)(1$ \\
\hline $0.04+6$ & 0.0101 & 0.020 .3 & $-058 i 1+04$ & $-11 \geq 2: 1+05$ & $0 S 581.010$ \\
\hline 0.045 & 0.0208 & 0.0000 & $-0.5731+04$ & $-1)=0011+015$ & 08511.00 \\
\hline 0.0446 & 0.0203 & 0.0101 & $-057(1)+104$ & $-026,1,1+105$ & $08581+001$ \\
\hline
\end{tabular}




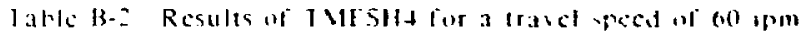

\begin{tabular}{|c|c|c|c|c|c|}
\hline \multicolumn{3}{|c|}{$\begin{array}{l}\text { Cincred } \\
\text { innen) }\end{array}$} & \multirow{2}{*}{$\frac{1 .}{1 \times(c)}$} & \multirow{2}{*}{$\frac{I s}{\ln (n+h)}$} & \multirow[t]{2}{*}{$\therefore n$} \\
\hline$\cdot 1$ & $\vdots$ & $\gamma$ & & & \\
\hline 0.0000 & 0.0000 & $0.1=\$ 0$ & $0.000 F+00$ & $-0620 r+1) 5$ & $0.0001+00$ \\
\hline 10000 & $0100^{-}=$ & $0.0=18$ & $0.000 \mathbf{E}+00$ & $-050^{-} \mathrm{E}+05$ & $110005+00$ \\
\hline $00=-2$ & 0.1000 & $0.0=04$ & $-0.104 \mathrm{E}+05$ & $-0.54 i 5+05$ & $0.19=1+00$ \\
\hline 0.0268 & 0.0005 & 0.0195 & $-0.100 \mathrm{I}+05$ & $-0.5281+05$ & $0.1881+.30$ \\
\hline 0.0000 & $0(1)=-$ & 0.0191 & $0.000 \mathrm{E}+00$ & $-0.535 E+05$ & (1) $000 \mathrm{E}+00$ \\
\hline 110256 & 0.0115 & $001^{-2}$ & $-0.090 \mathrm{E}+05$ & $-0.50+E+05$ & $01-9 \mathrm{E}+00$ \\
\hline 010000 & $0.016=$ & $0.016=$ & $0.000 \mathrm{E}+00$ & $-0.508 \mathrm{E}+05$ & $0.000 \mathrm{E}+00$ \\
\hline 011242 & $0101+8$ & 0.0148 & $-0.080 \mathrm{E}+00$ & $-0.485 \mathrm{E}+05$ & $0.16^{-} \mathrm{F}+00$ \\
\hline 0.0000 & $00=30$ & 0.0000 & $0.000 \mathrm{E}+00$ & $-0.6: 2 t:+0 j$ & $00001+00$ \\
\hline 0.0000 & $00=18$ & 00072 & $0.000 E+00$ & $-0.568 \mathrm{E}+05$ & $0.000 E+00$ \\
\hline $0.02=2$ & 0.020 .4 & 00000 & $-0.104 \mathrm{E}+05$ & $-0.5+5 E+05$ & $0.192 \mathrm{E}+00$ \\
\hline 0.0208 & 0.0195 & 0.0065 & $-0.100 E+05$ & $-0.5311 \mathrm{~F}+05$ & $0.188 E+00$ \\
\hline 0.0000 & 0.0191 & 0.0127 & $0.000 \mathrm{E}+00$ & $-0.5=3 E+05$ & $0.000 E+00$ \\
\hline 0.0256 & $0.01^{-2}=$ & 0.0115 & $-0.091 E+05$ & $-0.51 .3 \mathrm{E}+05$ & $0.179 \mathrm{E}+00$ \\
\hline $0.04^{-3}$ & 00000 & 0.0141 & $-0.241 \mathrm{E}+05$ & $-0.546 \mathrm{~F}+05$ & $0.442 F+00$ \\
\hline $0046^{-}$ & 0.0045 & 0.0136 & $-0.230 \mathrm{E}+05$ & $-0.536 \mathrm{E}+05$ & $0.4301+00$ \\
\hline 0.0451 & 00084 & 0.0126 & $-0.201 E+05$ & $-0.502 \mathbf{E}+05$ & $0.401 \mathrm{~F}+00$ \\
\hline $0.04=9$ & 0.0113 & 0.0113 & $-0.174 \mathrm{E}+05$ & $-0.4 \div 5 \mathrm{~F}+05$ & $03661+00$ \\
\hline $104-3$ & 0.0141 & 0.0000 & $-0.243 E+05$ & $-0.5361+05$ & $0.4421+00$ \\
\hline $0.046^{-}$ & 0.0136 & 0.0045 & $-0.230 E+05$ & $-0.5251+05$ & $0+30 \mathrm{~F}+00$ \\
\hline 00451 & 0.0126 & 0.0084 & $-0.202 E+05$ & $-0.506 \mathrm{~F}+05$ & $0+015+00$ \\
\hline 0.0550 & 0.0000 & 0.0091 & $-0.342 E+05$ & $-0.516 \mathrm{~F}+05$ & $06621+00$ \\
\hline 0.0546 & 0.0030 & 0.0090 & $-0.327 E+05$ & $-0.505 r+05$ & $00451+00$ \\
\hline 0.05 .34 & $0.005 i$ & 0.0086 & $-0.289 E+05$ & $-0.480 E+05$ & $0.602 F+00$ \\
\hline 0.0518 & 0.0081 & 0.0081 & $-0.292 \mathrm{E}+05$ & $-0.449 \mathrm{E}+05$ & $0.5+91+00$ \\
\hline 0.0550 & 0.0091 & 0.0000 & $-0.32+E+05$ & $-0.481 \mathrm{E}+05$ & $0662 \mathrm{~L}+00$ \\
\hline 0.0546 & 0.0090 & 0.0030 & $-0.322 E+05$ & $-0.476 \mathrm{E}+05$ & $0.6451+00$ \\
\hline 0.0534 & 0.0086 & 0.0057 & $-0.280 \mathrm{E}+05$ & $-0.468 E+05$ & $06025+00$ \\
\hline 0.0600 & 0.0000 & 0.0000 & $-0.060 \mathrm{E}+06$ & $-0.609 E+05$ & $0.100 \mathrm{t}+01$ \\
\hline 0.0592 & 0.0000 & 0.0035 & $-0.060 \mathrm{~F}+06$ & $-0.5951+05$ & $092^{7} 1+160$ \\
\hline 0.0592 & 0.0035 & 0.0000 & $-0.053 \mathrm{~F}+05$ & $-0.5721+05$ & $09 \geq-1+130$ \\
\hline 0.0586 & 0.0034 & 0.0034 & $-0.491 E+05$ & $-05651+05$ & $08.01+110$ \\
\hline 0.0574 & 0.0000 & 0.0066 & $-0.434 E+05$ & $-0.5581+05$ & $0.2-1+100$ \\
\hline 0.0569 & 0.0032 & 0.0065 & $-0+11 \geq t+05$ & $-0.5+61+05$ & $01-551+010$ \\
\hline 0.6574 & 0.0066 & 0.0000 & $-0 .+12 t+05$ & -1) $524 t+05$ & $0-8-1+0(1)$ \\
\hline 0.0569 & 0.0065 & 0.0032 & $-0.3401+115$ & $-05241+05$ & $0-531+010$ \\
\hline
\end{tabular}




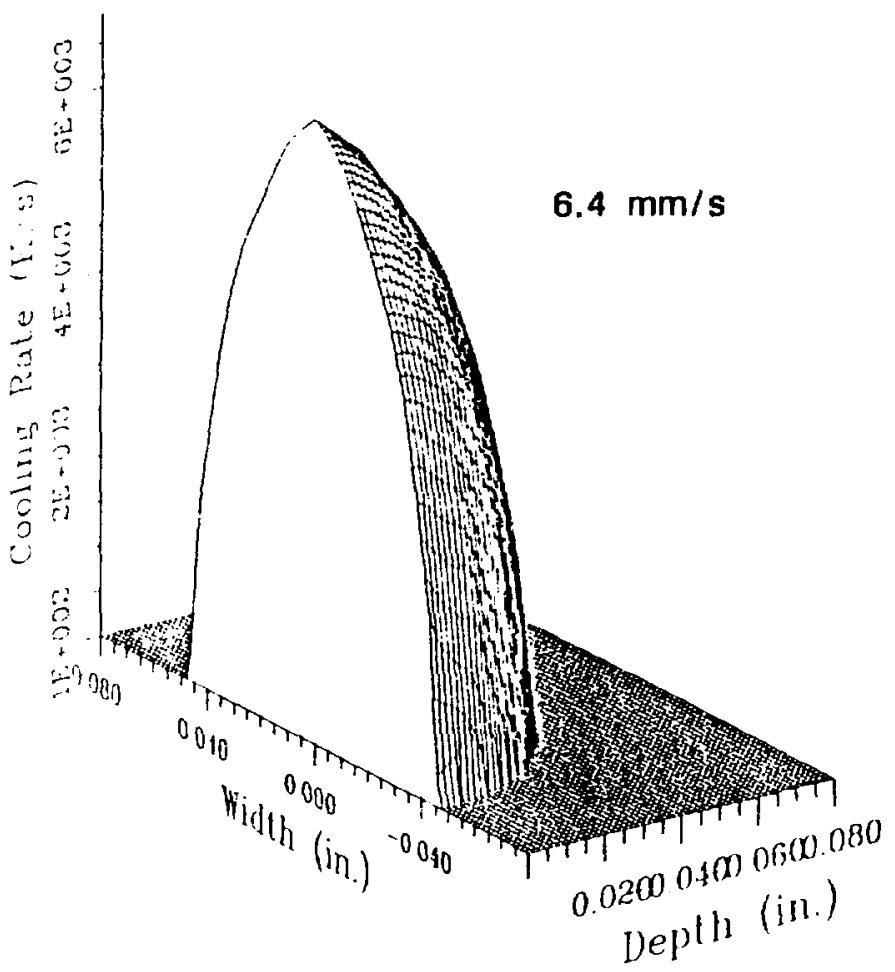

Figure B.l Results of the FEM program showing the distribution of cooling rates at the $\mathrm{L} . / \mathrm{S}$ interface of a surface melt moring at $6.4 \mathrm{~mm}, \mathrm{~s}$ in 304 stainless stecl. 


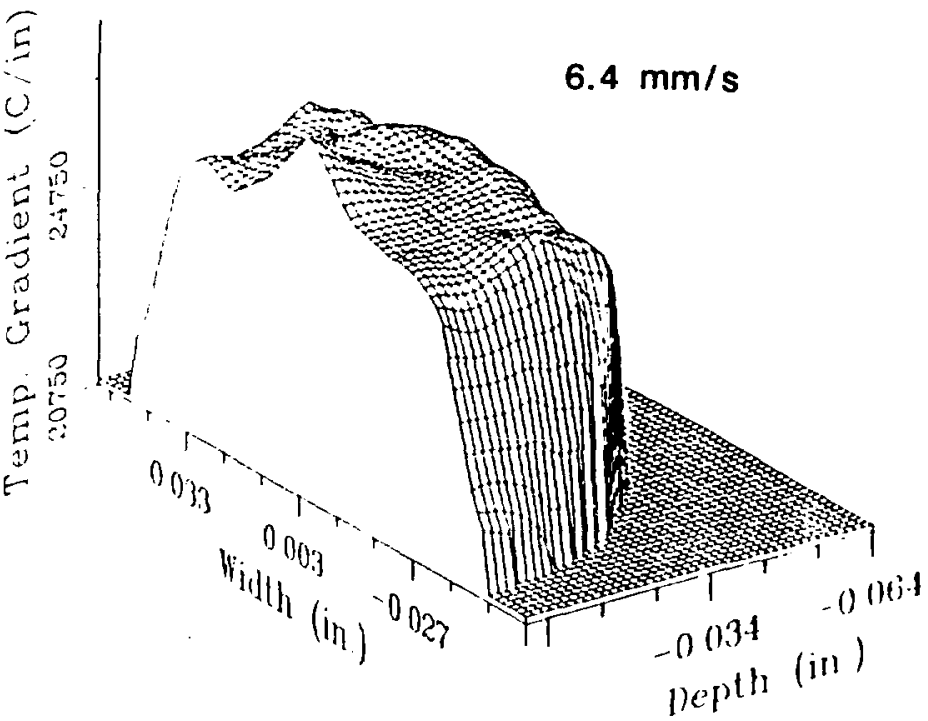

Figurc B.2 Results of the FEM program showing the distritution of tempcrature gradients at the $l$. $S$ interface of a surface melt moving at $6.4 \mathrm{~mm} / \mathrm{s}$ in 304 stainless stecl. 


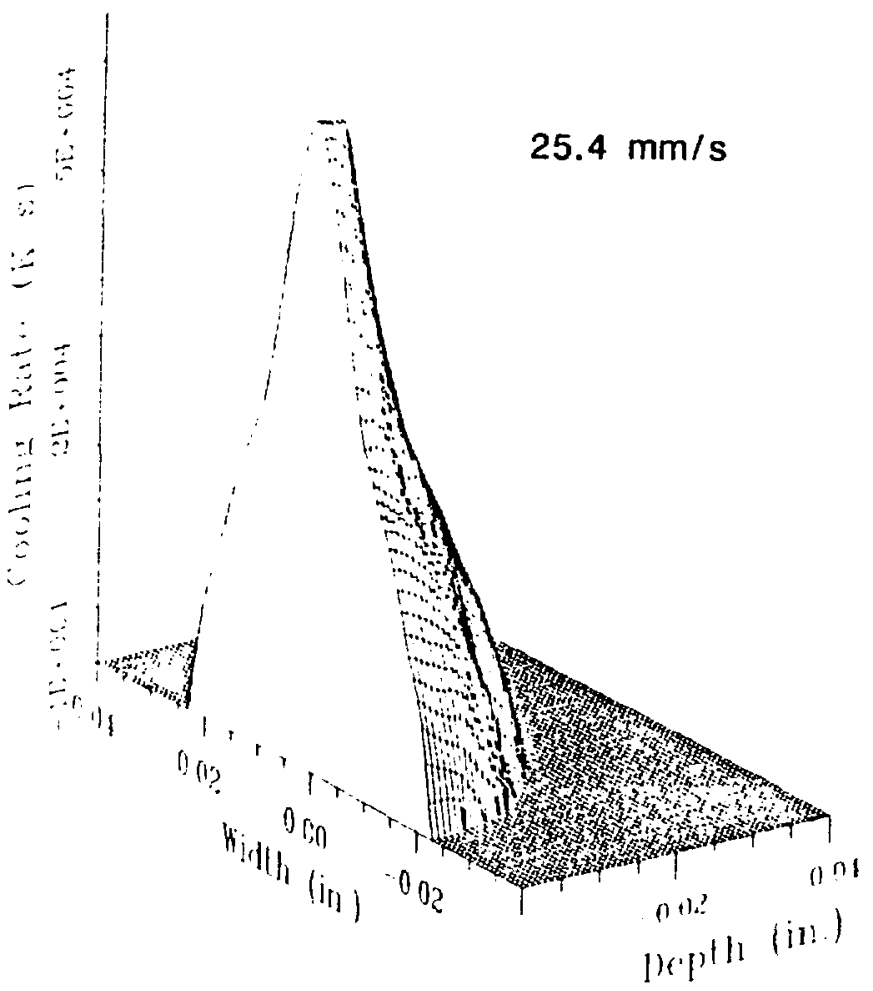

Figure B.A Results of the FEA program showing the distrituturn of temperature gradicnts at the $1 S$ interface of a surlace melt moving at $25.4 \mathrm{~mm} s$ in 304 stainless stcel 


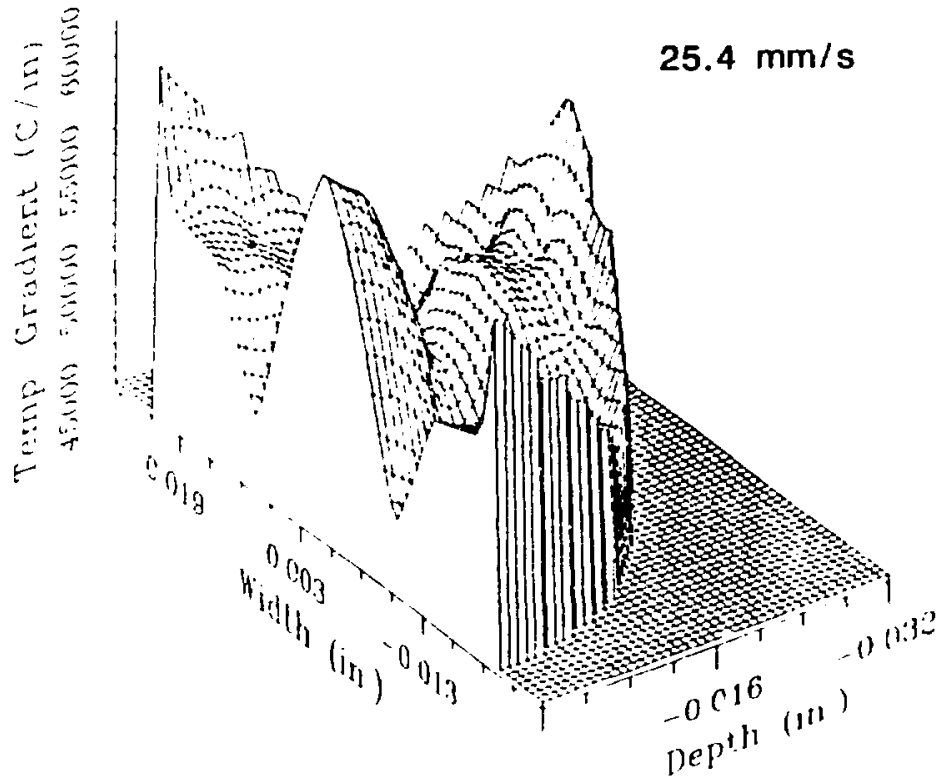

Figure B.3 Results of the FEM program showing the distritution of cooling rates at the $1 . S$ interlace of a surface melt mosiag at $254 \mathrm{~mm}$ s in 304 stainless stect. 


\section{PROGRAMIS}

\section{(1) REARR}

This program rearranges the 9-track tape data which contains the i-D mesh of the base plate. However, before running this program. take out the weld pool data and leave onl! the data for the base platc. The input data format for $n$ nidal points is:

$\begin{array}{ll}\text { line } I & \text { total nodal points } \\ \text { line }=\text { to } n & \text { node } * \quad x \quad \text { total elements } \\ \text { line } n+1 & \text { clement } \# \text { node } \# \text { node } \# \text { node } * \text { node } \\ \text { line } n+2 \text { to end } & \end{array}$

The arrarged output data are stored in FEM3D.DAT

\section{(2) OPTNLM}

This program reduces the bandwidth to save computalional time The inpat data file must be FEM3D.DAT output data file is BWRED.DAT (invisible)

\section{(3) BOL'ND}

This program locates the interfacial nodal numbers. Since the weld pool is the combination of two ellipsoids, the complex weld pool shape (optinn \#2) is recommended to locate the interfacial boundary point numbers. Input data files are BWRED.D.AT (invisible) and FEM3D.DAT. The output data files are NODE.DAT, ELEINT.DATA. UNKNOWN.DAT, INPUT.DAT, (all are invisible) and BNODE.DAT

Note: In the floppy disk, there is another file called BOL'NDO.FOR. This program locates the boundary interfacial node \# when the weld pool is at the 'corner' of the base plate.

(4) FEM 3 D

This program calcualtes the temperature profile in the base plate. MAKE SLRE THAT YOU CHANGE THE DIMENSIONS IN THE COMMON BLOCKS EVERY TIME YOU CHANGE TO A MESH and then recompile this program. The command to compile is: FORT FEM3D. LINK FEM3D, RUN FEM3D. 


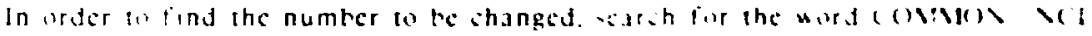
is alua!s I VP is the total node number and $\backslash B N$ is the banduidth lli bo rorget NBW. open the lile BWREDDAT and $\times B W$ is at the foltom of the liles Input jata

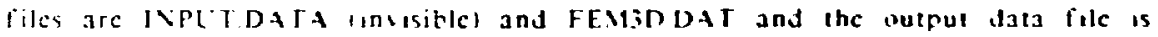
TEMP DAT IInISitel.

\section{(5) TEMTGRD}

This program salculates the temperature gradicnt in the base plate and frum the temperature gradient it calubles the cocting rate Open BNODE DA tesase it includes all the data points at the interface, and the final result of cooling rate can be found in the COOLRT.DAT filc. Input dats files are TEMPDAT :invisibles. FEMBD.DAT and or BVODERAT. The output data file is COOIRT DAT 


\section{REARK}

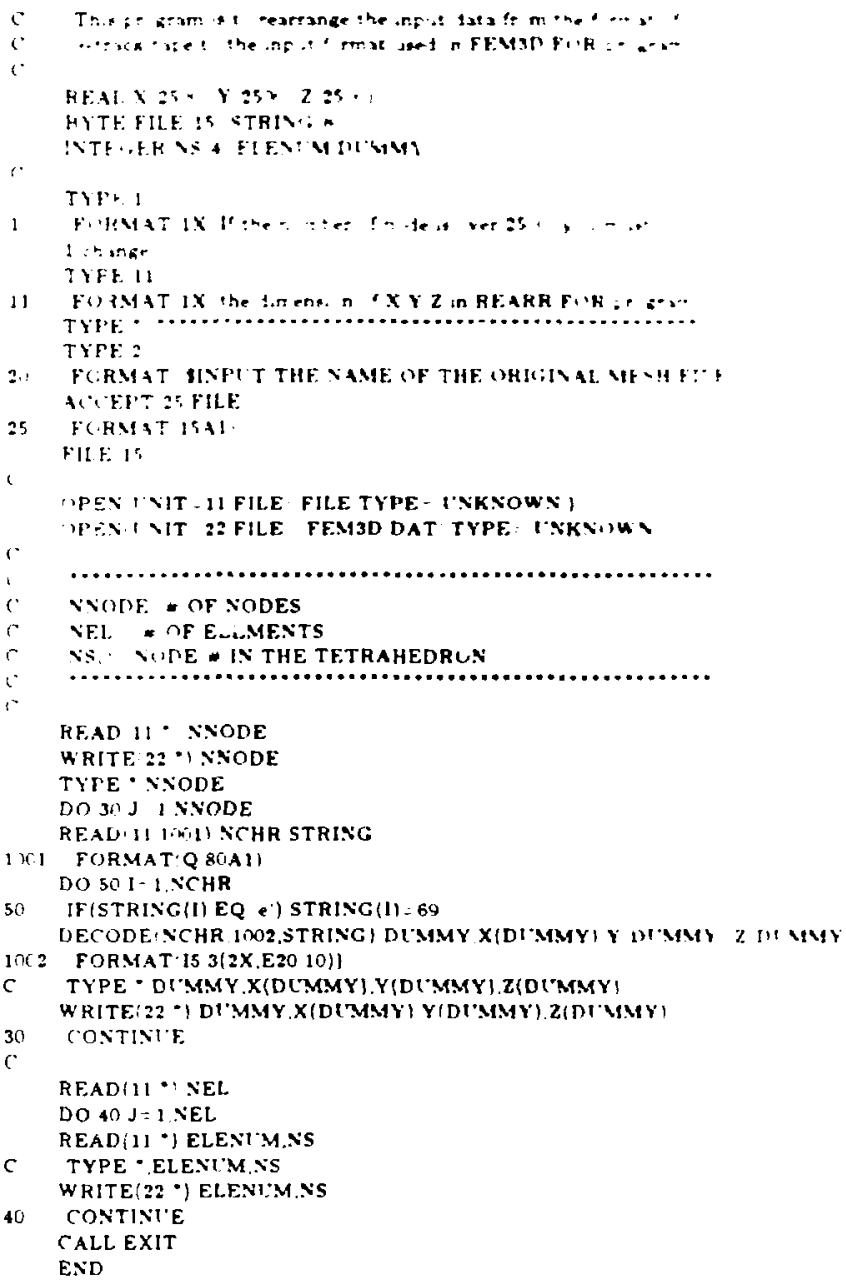




\section{OPTNUM1}

VIRTLAL NEWJT(20) ' JUINT ? " 4)

VIRTL'AL JNT (2000)

VIRTUAL JMEM(200(1)

BYTE FILE(15)

VIRTCAL MEMJT(9GO)

INTEGER JT(38000)

$c$

DATA MAXCON 48, , XNONE:

C

For more detall, see Intertist. nat Juurnal for Numencal Methode

in Engineering. Vol 6, 345-35: $(1,73)$ by $\mathbf{R} \mathbf{J}$ Collins

For example

If I have 18 triangles with the is . te cunfigurated hike

$\begin{array}{llll}1 & 15 & 2 & 4\end{array}$

$\begin{array}{llll}14 & 16 & 3 & 5\end{array}$

$6 \begin{array}{lll}6 & 8 & 9\end{array}$

$\begin{array}{llll}10 & 11 & 12 \quad 13\end{array}$

NJTS TOTAL NODE \# J"

LMENTS TOTAL ELEMENT \#, (b) (SINCE 1 HAVE 18 TRIANGLES)

NHW ORIGINAL BANDWILTH

NNODE \# OF NODE IN ONE ELEMENT (3 FOR LINEAR TRIANGLE)

MAXCON MAXIMCM CONNECTING POINT + FOR THE INTERIOR POINT

e $g$ in triangular element MAXCON $=6$

JT SIZE = LMENTS NNODE: The firat row to the last

of the node \# which is imiluded in the element 1. the

bast row is the list if the minte which is ineluded in

the lagt element (s.t) it in this example)

e $116 \quad 15$

11416

$\begin{array}{lll}15 & 3 & 2\end{array}$

15163

and $\mathrm{BO}$ on

$8 \quad 1213$

MEMJT SIZE = MAXCON*NJTS

The first column is the list if the node \# which is related to nuite \# I the last column is the list of the node \#hich is teided to the last node \#

e $8 \quad 14 \ldots \ldots \ldots \ldots \ldots \ldots$

1614

15

0

01

JMEN SIZE $=1 \cdot$ NJTS

The 1st entry is 3 since minde 1 has 3 nodes related to it

The last eniry is 6 sitice nide 16 has 6 nodes related to it

eg $\quad(3,4,6,2, \because \because \because \because \because \because \because$ (i)

JNTI NODE \#

JJT NODE \#

IDIFF MODIFIED BW"

MAX MODIFIED BW

NEWJT SIZE = 1\%NTS E. ? $341725(6 . . .6$ wid 123456789 new

ald mide $3=$ new node \# 1

ㄱa node $0=$ new nude \# 2

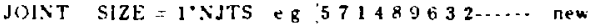

$$
123456789 \text { old }
$$

new node $\neq 1=$ mid nude $=3$

new nude $\# 2$ : id node $\# 9$

JNT SIZE I*NJTS 


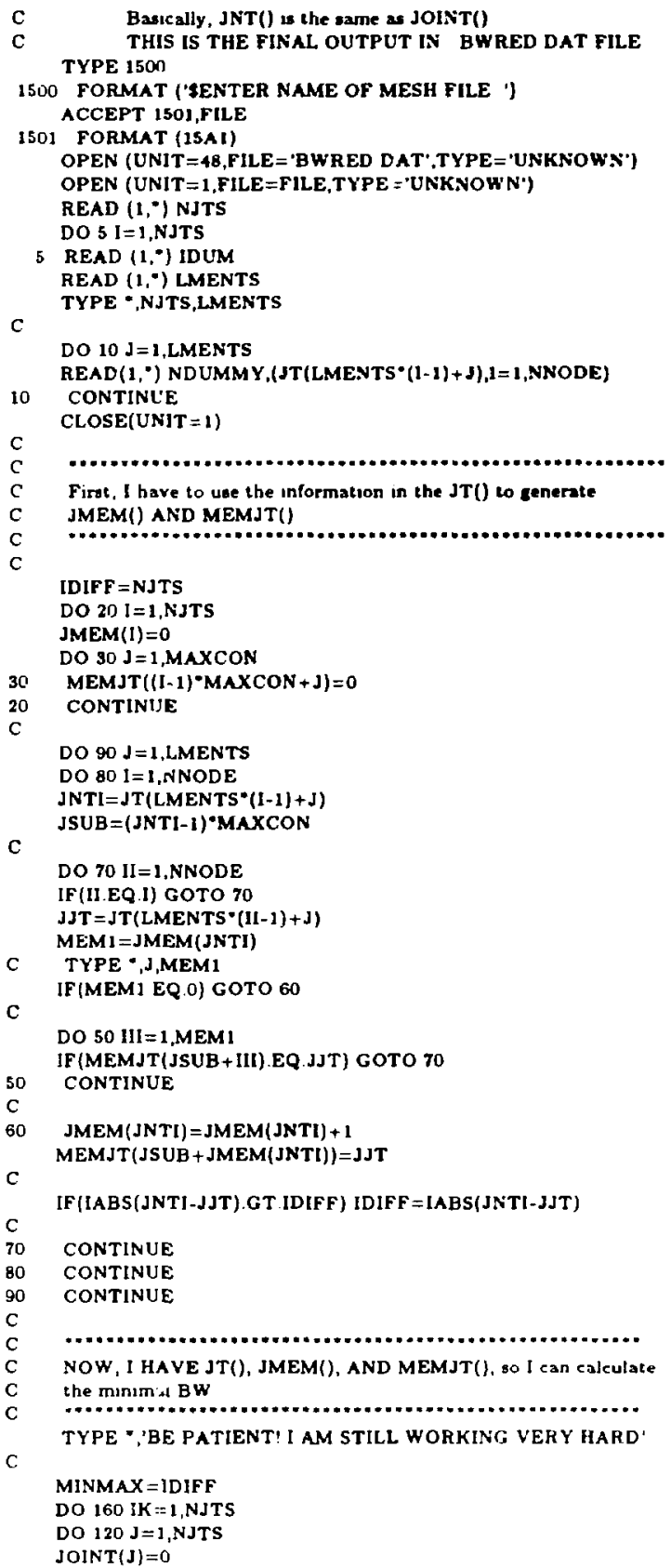




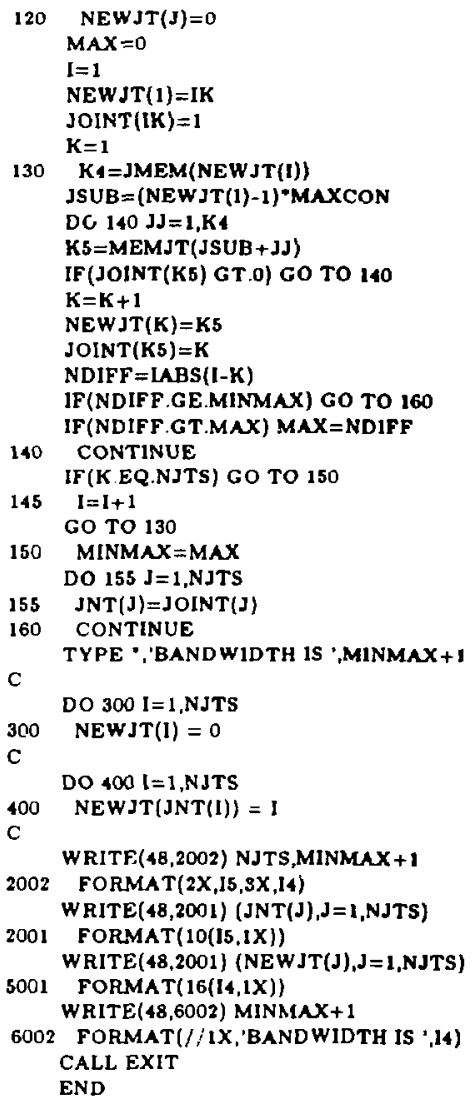

\section{BOUND}

C This program is to find the boundary nodal number.

C However, the output node number for the boundary unterface nodea

C are the NEW rode number from BWRED.DAT tile

c.

INTEGER NS(4),NS1(4),NS2 (4),NUM(60),TEST,IBF(6)

INTEGER N(2000),NEWNOD(2000),LTETRA(400)

REAL BF(6),MP(400)

COMMON NBOUN(1500), NBOUN1(1500)

C BYTE FILE(15)

\footnotetext{
TYPE 100

100 FORMAT('\$ENTER NAME OF THE MESH FILE ') ACCEPT 110,FILE

110 FORMAT(15A.1)

TYPE GU
}

90 FORMAT('\$MELTING POINT OF THIS MATERIAL ? (deg Ki ") 


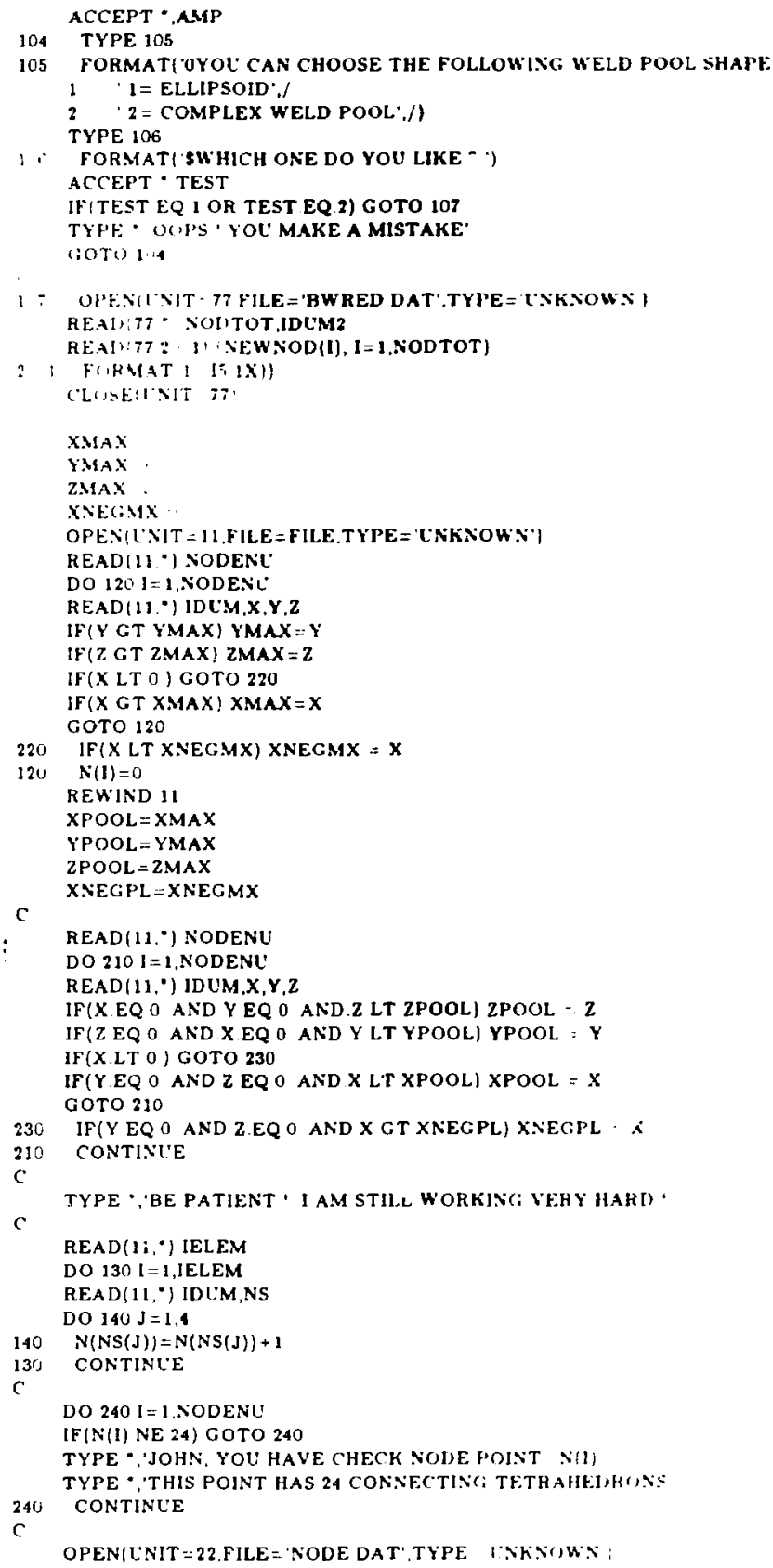




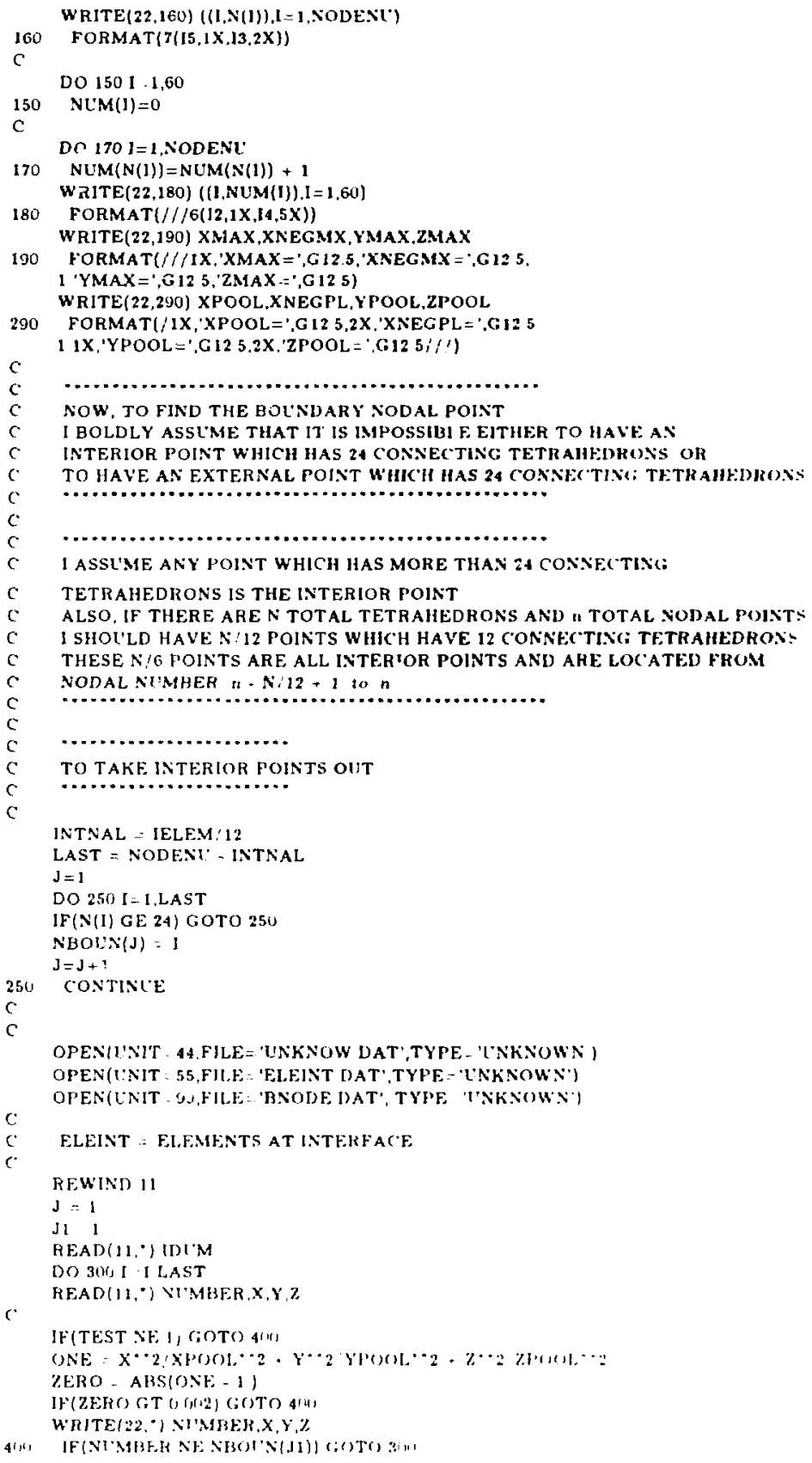




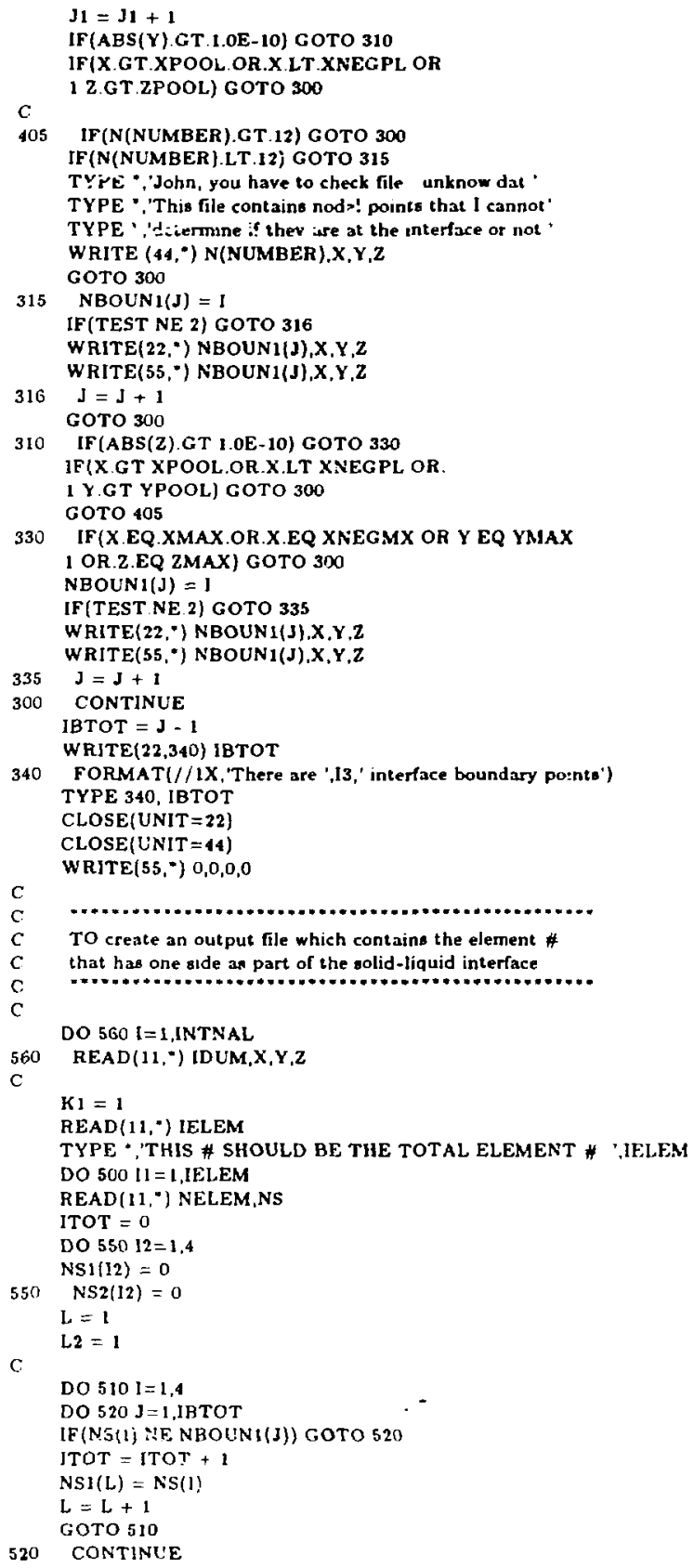




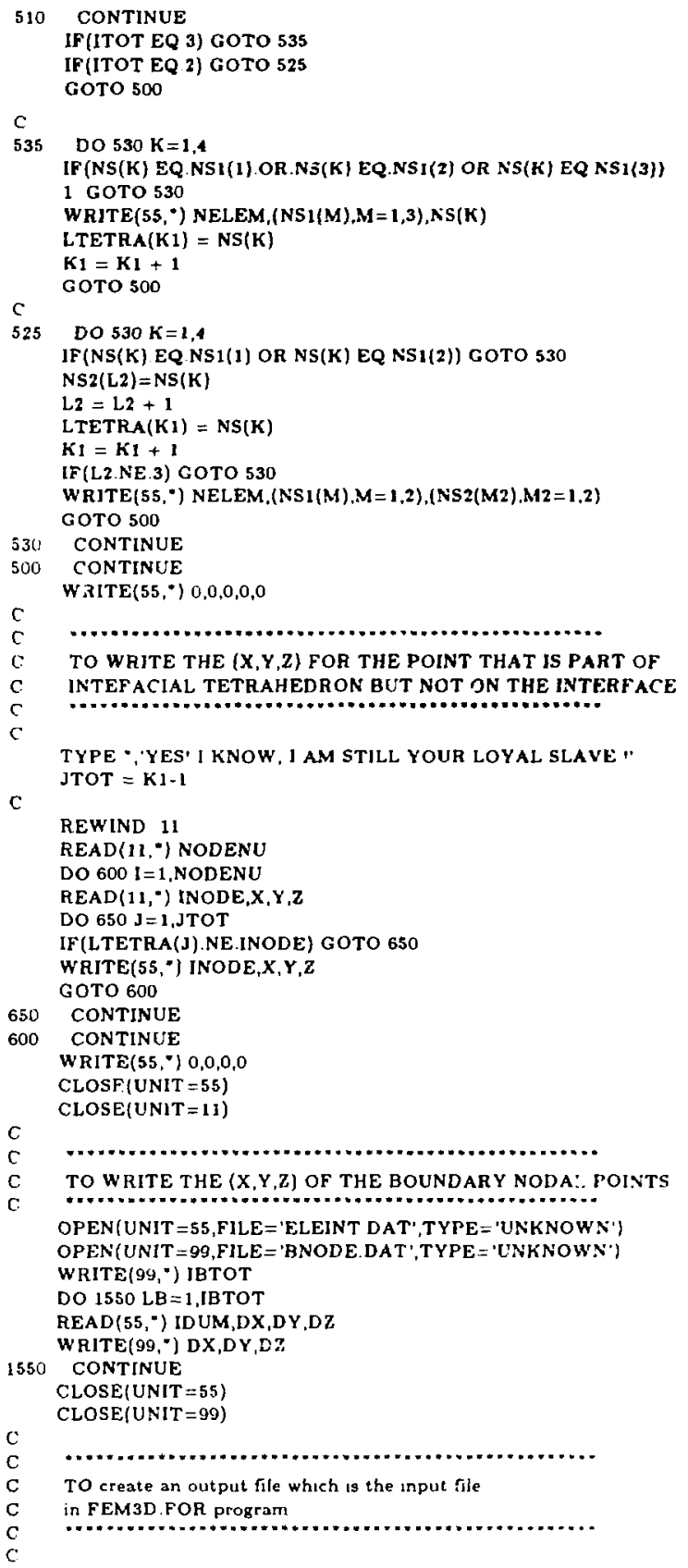




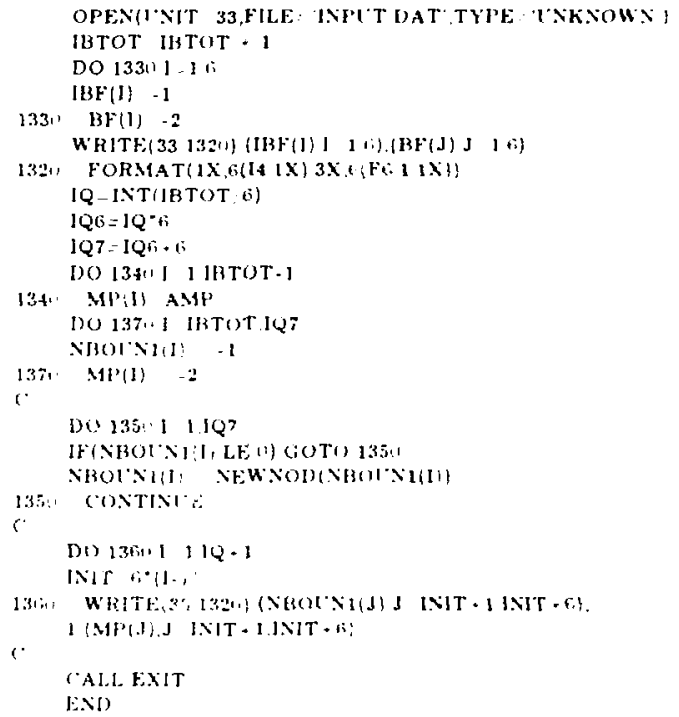

\section{FE(113I)}

(.

(

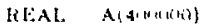

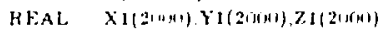

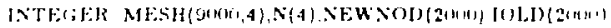

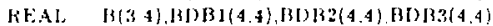

KEAL ESM(4.4),EF(4),X(4).Y(4).Z(4)

ISTFIFH NSAt)

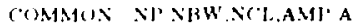

BYTE FILE(I:)

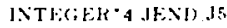

43.13nidaty romintions are

(1) constant temperalure at the hquad-sidid anterface

fist at the free surface except at the

This ta is Cartesian conrdinate

TIIS PHOGHAM IS TO CALCILATE THE TEMPERATIRE PKOFLI, OE THF.

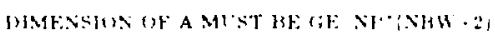

IYATA $X$ XI. I

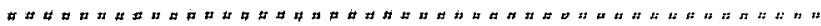

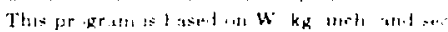

a the 


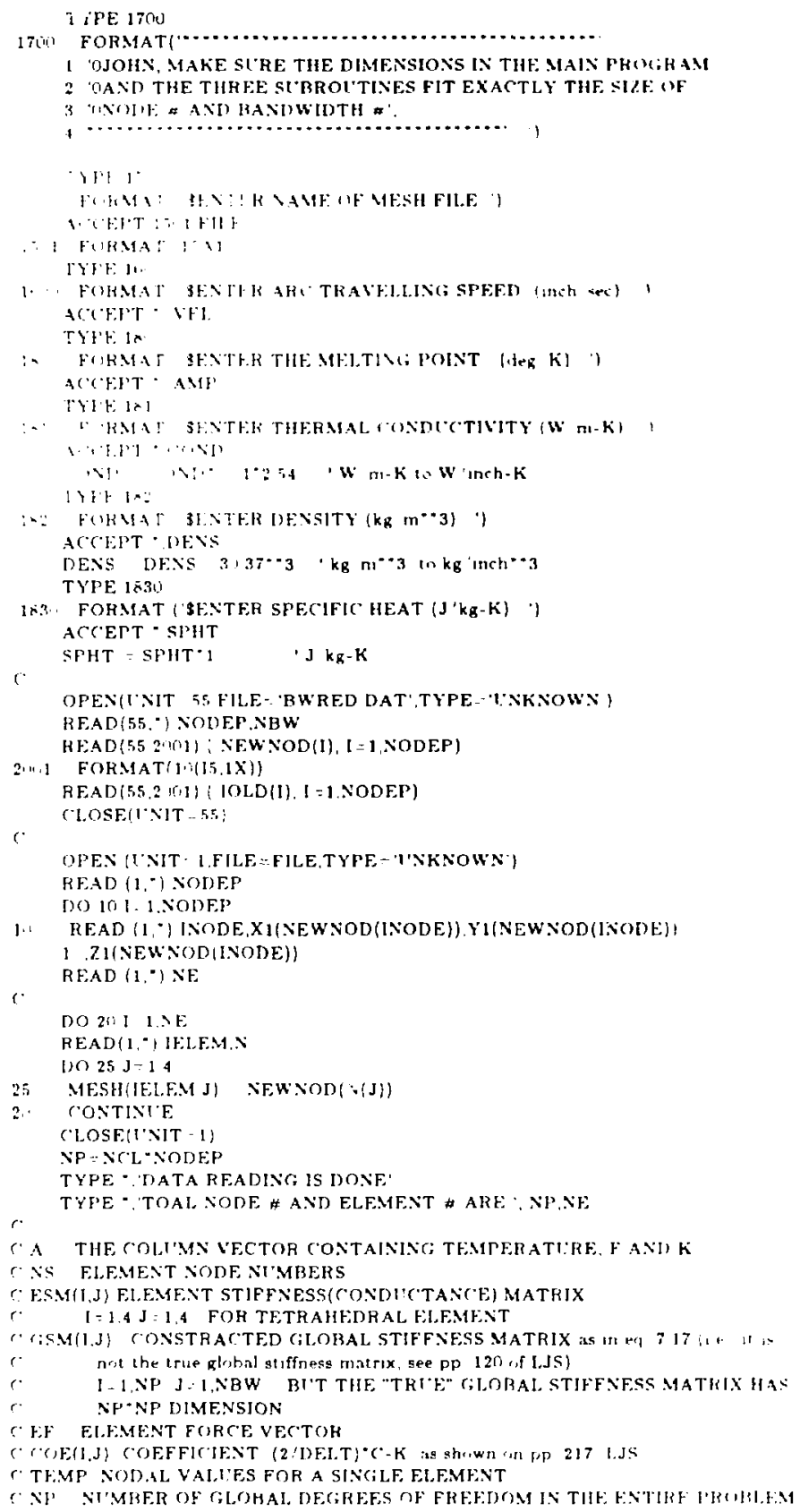


C NE TOTAL NUMBER OF ELEMENTS

C NBW BANDWIDTH OF THE SYSTEM OF EQATIONS

C NEL NUMBER OF AN INDIVIDUAL ELEMENT

C NCL NUMBER OF LOADING CASES USUALLY $=1$

C $X(1), Y(1)$-...- COORDINATES OF THE ELEMENT NODES(COCNTER CLOCK $W$ ISE

C B\&C COEFFICIENTS THAT OCCUR DURING THE EVALCATION OF THE ELENENT MATRIX

C VOL6 SIX TIMES THE TETRAHEDRAL VOLUME

C AR2 TWO TLMES THE ELEMENT AREA

C JGF A POINTER INDICATING THE LAST STORAGE LOCATION FOR TEMPERATLEE IN A

C JGSM A POINTER INDICATING THE LAST STORAGE LOCATION FOR F IN A

$C$ JEND A POINTER INDICATING THE LAST STORAGE LOCATION FOR $K$ IN A

C COND THERMAL UCTIVITY (cal/cm-sec-deg.C)

C SPHT SPECIFIC HEAT ( $\mathrm{cal} / \mathrm{gm}-\mathrm{deg} \mathrm{C}$ )

C DENS DENSITY (gm/ $/ \mathrm{cm}^{* \cdot 3}$ )

C. ISIDE WHEN ISIDE( $)=1$, IT MEANS THIS IS THE "FREE" SLRFACE

C WHEN ISIDE()=0, IT MEANS THIS IS NOT THE "FREE" SU'RFACE

$\mathrm{C} H$ HEAT TKANSFER COEFFICIENT $\left(W / \mathrm{m}^{*} \cdot \mathbf{2}^{*} \mathrm{deg} \mathrm{C}\right)$

C NEWNOD() NEW NODE NUMBER ARRAY

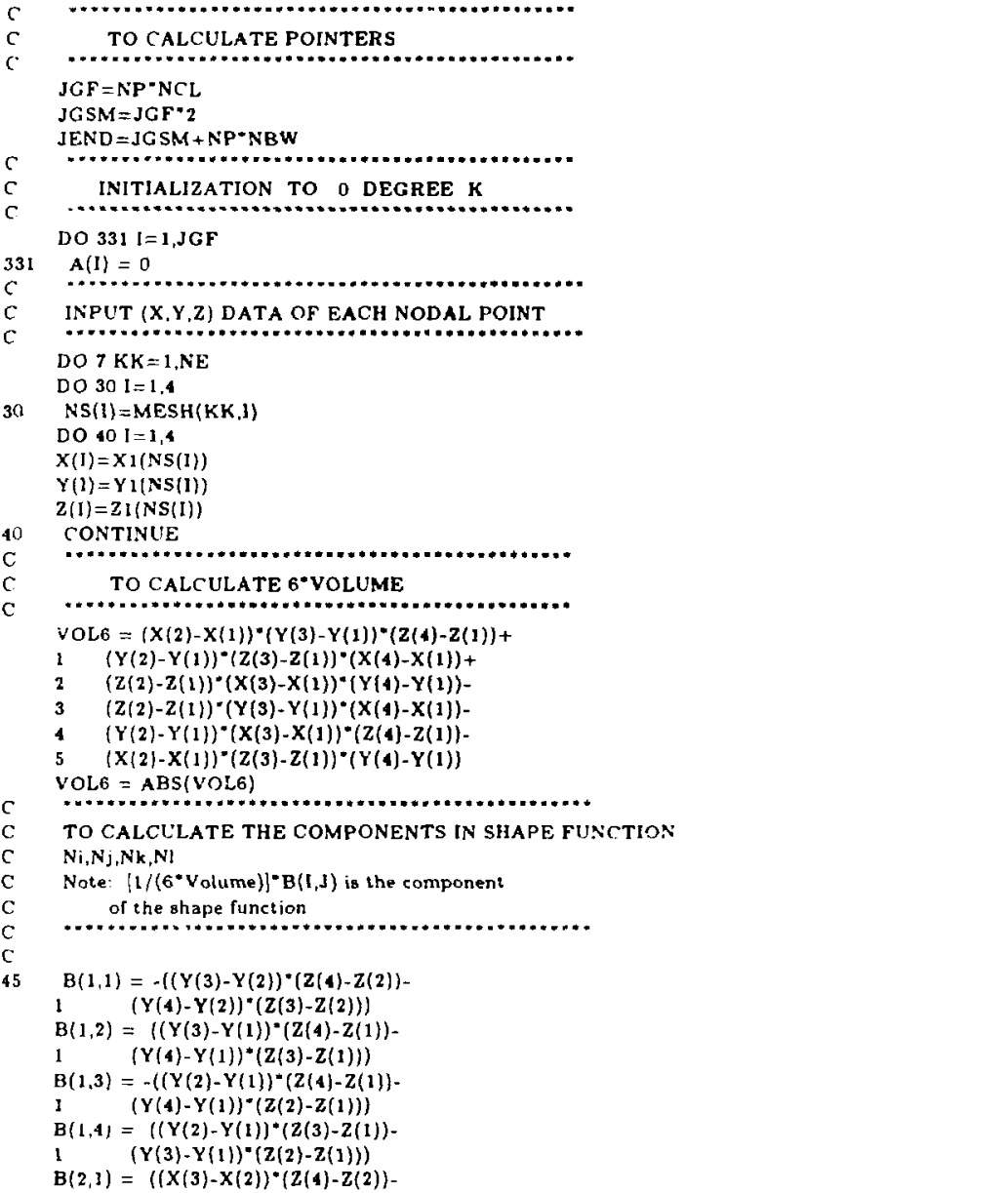


$\left.1 \quad(X(1)-X(2))^{-}(Z(3)-Z(2))\right)$

$B(2,2)=-\left((X(3)-X(1))^{*}(Z(4)-Z(1))-\right.$

$1 \quad(X(4)-X(1)) *(Z(3)-Z(1)))$

$B(2,3)=((X(2)-X(1)) \cdot(Z(4)-Z(1))-$

$\left.1 \quad(X(1)-X(1))^{*}(Z(2)-Z(1))\right)$

$B(2,4)=-((X(2)-X(1 ;)-(Z(3)-Z(1))-$

$1 \quad(X(3)-X(1))-(Z(2)-Z(1)))$

$B(3,1)=-\left((X(3)-X(2))^{-}(Y(4)-Y(2))-\right.$

$\left.1 \quad\{X(4)-X(2)\}^{*}(Y(3)-Y(2))\right\}$

$B(32)=(\{X(3)-X(1)) *(Y(4)-Y(1))-$

$\left.1(X(1)-X(1))^{*}(Y(3)-Y(1))\right)$

$B(3,3)=-\left((X(2)-X(1))^{*}(Y(4)-Y(1))-\right.$

l $\left.\quad(X(4)+X(1))^{*}(Y(2)-Y(1))\right\}$

$B(3,4)=((X(2)-X(1)) *(Y(3)-Y(1))-$

$\left.1 \quad(X(3)-X(1))^{*}(Y(2)-Y(1))\right)$

C

$\mathrm{C}$

C

$\mathrm{C}$

$\mathrm{C}$

CONST2 $=$ VEL $*$ DENS SPHT $/ 24$.

DO $35 \mathrm{I}=1,1$

DO $35 \mathrm{~J}=1,4$

$\operatorname{ESM}(\mathrm{I}, \mathrm{J})=\operatorname{ESM}(\mathbf{I}, \mathrm{J})+\operatorname{CONST} 2 * \mathbf{B}(1, \mathrm{~J})$ !-ve $\mathrm{X}$ direction

CONTINUE

INITIALZATION OF THE FORCE MATRIX

DO $940 \mathrm{I}=1,4$

$940 \quad E F(I)=0$

C

C

C

TO CALCULATE THE VOLUME INTEGRAL CF $\{B\}^{-}\{D\}^{*}\{B\}$

This integral (actually, summation) is expressed by

DO $920 \mathrm{I}=1,4$

$920 \mathrm{~J}=1,4$

$\operatorname{BDB} 2(1, J)=B(2,1)^{-B}(2, d)$

$B 3(1, J)=B(3,1)^{*} B(3, J)$

The volume integral of $(B\}^{*}\{D\} *\{B\}$ is the summation

B $1(I, J), B D B 2(I, J)$, and $B D B 3(1, J)$ and then

CONST $1=$ COND $/$ YOLG

$30 \mathrm{I}=1,4$

$\operatorname{ESM}(I, J)=\operatorname{CONST} 1 *(\operatorname{BDB} 1(1, J)+\operatorname{BDB} 2(1, J)+$

$1 \quad \operatorname{BDB} 3(\mathbf{I}, \mathbf{J})\}$

TO Consider the additional term vel" $\mathrm{Cp}$ "density "temp gradient The arc is travelling in the -ve $X$ direction.

$$
E F(I)=0 \text {. }
$$

ASSUME that convective and radiative heat logs can be neglected 


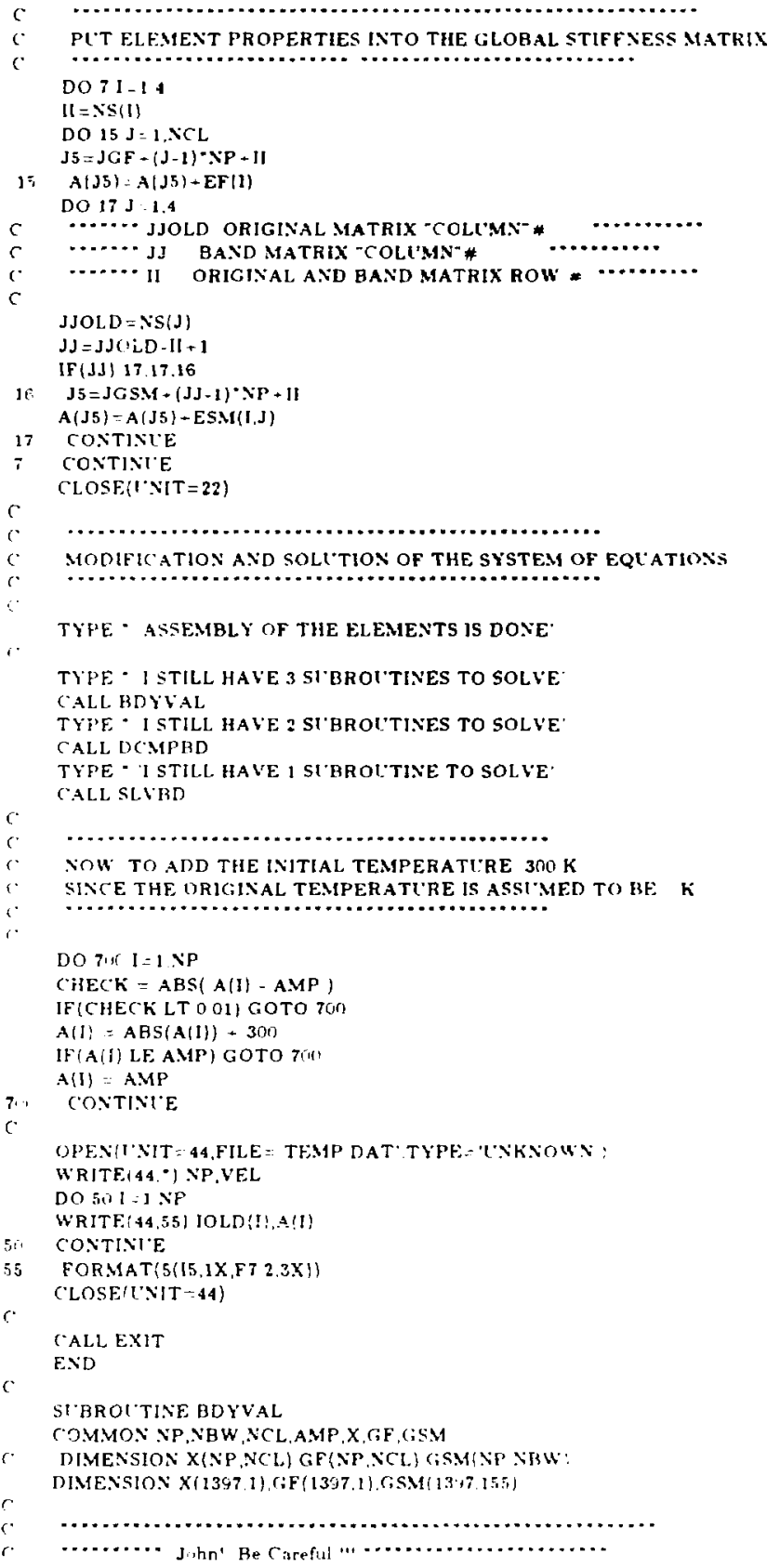


THE DIMENSION OF X,GF AND GSM MIST BE - EXACTLY THE NITMEY OF X(NP NCL),GF(NP.NCL) AND GSMINP NBW)

THIS SIBROITINE IS TO READ KNOWN VALIES IN F AVD PH ANI MWUIES h A ON PP 110 OF L J SEGERLIXN TU MAKE IT READY TW WE SU VED

DIMEXSION IB(6) BV(6)

INPIT OF THE NODAL FORCE VALI'CES

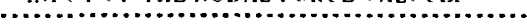

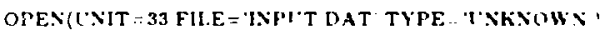

DO $216 \mathrm{JM}-1 \mathrm{NCL}$

INK -0

2. 2 READi33,, IH BV

BECAI'SE THE DIMENSION OF IR ANI BV ARE G THE DATA IN TORSIZ DAT

SHOLLD RE I.IKE THIS SIX INTEGERS SIX REAL IHLIES

ENTII.SAY $1123-1,-1,-1,-1-2,-1-1-1-1-1$

-... - MEANS NO MORE DATA - 2 MEANS THE STARTING OF NO DATA FOR BY

.... NOTE EYEN NO DATA FOR IB OR BV. YOV HAYE TOPIT -VE - TO SHOW NU DATA

IB NODE \# ON BOCNDARY BV BOI'NDARY \ALIES. IT MAY BE KNOWN NUDAL FOHCE:

VALIFS(LPPER PART) OR KNOWN SODAL VALIESISAY. TEMP.POTENTIAL STRFSS

BLT BE CAREFLL.THE FIRST SET DATA LN TORSI2 DAT REFEAS TO KNONX NOIAL. FORCES. THE SECOND SET REFERS TO KNOWX NODAL VALIES AND IF THE ఎ UF KNOW NOUAL FORCE SET IS INTEGRAL TIMES OF G.THEX BETWEEN KNOW NODAL FORCE AND KNOWN NODAL VALI'ES DATA SET THERE MT'ST RF ANOTHFR DATA - I IS RETWFEN TO INDICATE THE END OF KNOWX NURAL. FORIE DAT S SET

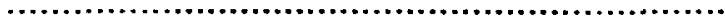

ID: 0

DO $204 \mathrm{~L}-1$ i

IFIIB(L)LE, ! GO TO 205

ID - ID $\rightarrow$ ]

$I=I B(L)$

$2+14 G F(1 . J M)-B V(L)+G F(1, J M)$

GOTO 200

$2 \div \quad$ INK $=1$

IFIID EQ O) GO TO $\$ 16$

2 it IF(INK EQ 1$)$ GO TO 216

(:O TO 212

$c$

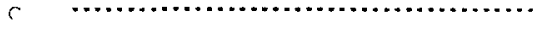

C INPLT OF THE PRESCRIBED NODAL VALIES

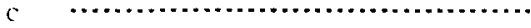

$c$

21\% CONTINIE

$1 \times K=0$

2U READI33, - IB.BY

$\Omega^{*}$

DO 310 IC $=1,6$

IF(BVIIC) EQ AMP) GOTO $31^{\circ}$

$\mathrm{BV}\{\mathrm{IC}\}=\mathrm{AMP}$

3li CONTINE

c

ID $-6 !$

DO $221 \mathrm{~L}=1,6$

IF IIB(L) LE O) 60 TO 215

ID $-1 \mathrm{In}+1$

$\mathrm{I}=\mathrm{IB}(\mathrm{L})$

AC - RV (L) 


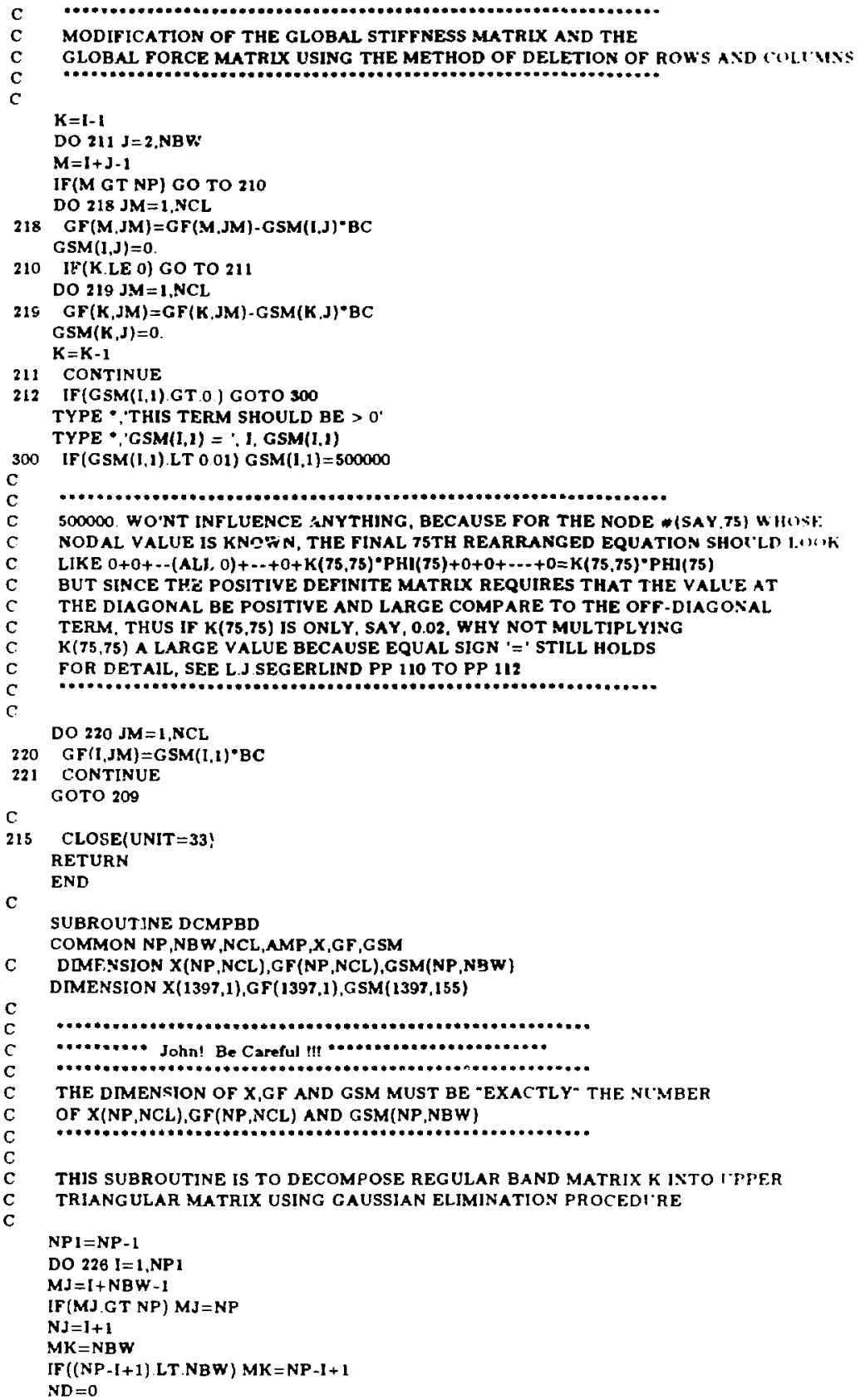


DO $225 \mathrm{~J}=\mathbf{N J}, \mathbf{M J}$

$\mathrm{MK}=\mathrm{MK}-\mathbf{1}$

$N D=N D+1$

$N L=N D+1$

DO $225 \mathrm{~K}=1, \mathrm{MK}$

$\mathrm{NK}=\mathrm{ND}+\mathrm{K}$

225 GSM $(J, K)=G S M(J, K)-G S M(1, N L) \cdot G S M(I, N K) / G S M(1,1)$
226 CONTINUE.

RETURN

C

END

SUBP JUTINE SLVED

COMMON NP,NBW,NCL.AMP,X.GF,GSM

C

DIMENSION X(NP,NCL),GF(NP.NCL),GSM(NP,NBW)

DIMENSION $X(1397,1), G F(1397,1), G S M(1397,155)$

$$
\text { C }
$$

C

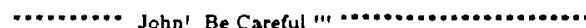

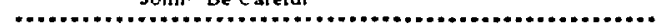

THE DIMENSION OF X,GF AND GSM MUST BE -EXACTLY THE NUMBER OF $X(N P, N C L), G F(N P, N C L)$ AND GSM(NP,NBW)

C

$\mathrm{C}$

THIS SLBROLTINE IS TO DECOMPOSE F THEN SOLVES FOR TEMPERATURE USING THE METHOD OF BACKWARD SLBSTITLTION

$N P 1=N P-1$

DO $265 \mathrm{KK}=1, \mathrm{NCL}$

$\mathrm{JM}=\mathbf{K} \mathbf{K}$

C

$\mathrm{C}$

c

c

C

DO $2501=1 . N P 1$

$M J=I+N B W-1$

[F (MJ.GT NP) MJ $=\mathbf{N P}$

$\mathrm{NJ}=\mathrm{I}+\mathrm{l}$

$\mathrm{L}=\mathbf{1}$

DO $250 \mathrm{~J}=\mathrm{NJ} . \mathrm{MJ}$

$\mathrm{L}=\mathrm{L}+1$

$250 G F(J, K K)=G F(J, K K)-G S M(I, L) * G F(I, K K) / G S M(I, 1)$

C

C

C

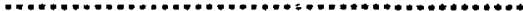

BACKWARD SUBSTITUTION FOR DETERMINATION OF X()

(..................................................

$X(N P, K K)=G F(N P, K K) / G S M(N P, 1)$

DO $252 \mathrm{~K}=1, \mathrm{NP} 1$

$\mathrm{I}=\mathrm{NP}-\mathrm{K}$

$\mathrm{MJ}=\mathbf{N B W}$

IF $((1+N B W-1) G T N P] M J=N P-I+1$

SUM $=0$.

DO $251 \mathrm{~J}=\mathbf{2}, \mathrm{MJ}$

$\mathbf{N}=\mathbf{I}+\mathrm{J}+\mathbf{1}$

SUM $=$ SUM + GSM $(I, J) \cdot X(N, K K)$

265

$X(I, K K)=(G F(I, K K)-S(U M) / G S M(I, 1)$

CONTINUE

RETURN

E.'i) 


\section{TEMGRD}

6. This pregram is so calcutate the temperature gradient

REAl. X:3i-Y $(300), Z(3,2), X F(150), Y F(150), Z F(150)$

REAL T 3MO: SI:ML(4)O)

REAL NORM(3),X3(3) Y $3(3), 23(3)$

REAL XNODE(4), YXODE(4).ZXODE(4), TV(4)

REAL XINT:2IYINT(2) ZINT(2).TINT(2)

BYTE FILEi15)

INTEGER NS(AM,4).NEL(4OM) YODE(300),OLTNIM(40)

INTEGER NTET(4).TEST

C COMMON SLOPE XO,ZO,YO.YZ,DEPTMX,AO,BO,AZ,BZ,YORM

COMMON PLAX X3,Y3,Z3,A,B,C,D

COMAMON INTCP : AI,B,C,D,XO,YO,ZO,NORM,XI,YI,ZI

COMMON FLLIP'XO,YO.Z'AX.CZ,BY,NORM.ITEST

COMMON SI MORD 'XO,YOZONODE,X.Y,Z,NS,JTOT.IETOT SIML UTVM

COMMON ORD SIML.IETOTI OITTLM

COMAON LIM! X3 Y3 23 XI YIZITEST

COMMIOS ISTIL XXODE YNODE ZNODEXINT,YINT,ZINT TV

1 TINT TEMG;

c

EQTIVAIFATF STMLI STMLI

$i$

DATA IHOI:SI) 300

DATA IFLTOT $4 \%$

5

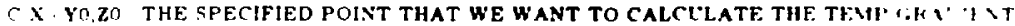

C IDEPTM MAXIMI'M DEPTH OF THE WFLD POOL ( inch)

$\because 2$ Y IS A LITTLE BIT LARGER THAN YO (In the depth direction)

OA $\quad$ HAI.F SHORT AXIS LENGTH OF THE ELLIPS AT Y Y YO

C B. HALF LON; AXIS LENGTH OF THE ELLIPS AT $Y=Y O$

$\because \times 3$ Y3.23, $B$ C D $\{\times 3, Y 3.23\}$ THESE THREE POINTS CAN MAKE A PI.ANF.

(* WHICH CAN BE EXPRESSED AS AX + BY + CZ + D - 1

C $X 1$ Y $1.21|X I, Y I, Z I|$ IS THE INTERCEPT POINT BY THE LINE DETERMIXYD HY

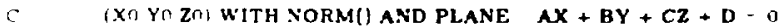

C AX BY, $C Z$ HALF AXIS LENGTH IX X,Y,Z DIRECTION RESPECTIVELY

( ITEST IF ITEST = 1, THEN INPLT DATA HAS SOMETHING WRONG

("ITNIM() The first 10 tetrahedron NCMBER, which have the smslleat

(c) summation of the line segment lengthe from $(x 0, y 0, \pm 0)$

C I ONLY TAKF, THE FIRST 8 DATA

$C$ IFTOT TOTAL BOLNDARY INTERFACIAL ELEMENTS WHICH HAVE TWO OR

C. THREE NODES AT THE INTERFACE

( JTOT \# of the : ines that are insude the tetrahedron which has 2

c. of 3 nodes at the solid-liquid interiace

C X!'Y!!Z! (X,Y,Z) ARE THE VERTEX OF THE TETRAHEDRON WHICH HAS $2 O H$

(C) 3 NIDEES AT THE SOLID-LIQIID INTERFACE.

TYPE 1

1. FORMAT! $X$ are travelling direction, trasling sense in + ve'

1 ' $Y$ depth direction, downward is + ve',/

$c^{\prime}$

TYPE 12

I2 FORMAT('John remember that all the interested points:'

1 'shciutd be VERY CLOSE TO the interface', ')

$\therefore$

15 TYPE 2:1

26 FORMATIOYOC CAN HAVE THE FOLLOWING CHOICES

$1 \cdot 1=$ TEMP GRADIENT AT SINGLE POINT: $/$

$2 \cdot 2$ = TFMP GRADIENT AT MANY POINTS',

TYPE 30

3: FORMATI W WICH ONE DO YOI LIKE - ')

ACCEPT *IPOINT

IF(IPOINT EQ 1 OR IPOINT EQ 2) GOTO 40

TYPE - OOPS " ¿OL MAKE A MISTAKE " 
GOTO 15

TYPE Bं

GL FORMAT( SENTEH NAME OF THE (X.Y.Z) F ILE I ACCEPT 7IFILE.

74 FORAATI15AI

OPENICNIT 1$]$ FILE- FLLE TYHE LNKNOWN)

READ(11.") NP

DO $901=1 . N \%$

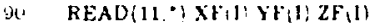

CLOSE:IITIT 11

FILE $\{15\}$. .

GOTO 80

5 TYYE - $(X$ Y $Z$ PUINT AT THE INTERFACE: -

ACCEPT - XI Y Z

DIPE T!"!

7. 14 FORMAT: WCH CAN HAVE THE FOLIOWINL CHOICES

1 I ELLIPSUII WELLP POOL .

2 2 (N) I\} IFX WELD POWI ।

TYPE 71!

71) FORMAT:S WHICH ONE DO YOU LIKE ' ")

ACCEPT - ISHAPE.

IF(ISHAYE EQ : OH ISHAEE EU 2) GOTO T2O

TYPE , OOPS' YU MAKE A MISTAKE"

GOTO \&U

721: IF(1SHAFE EQ:I LOTO 735)

TYPE "HALF AXIS LENGTHS IN X.Y.Z DIRECTION " (InCh)

13 data are requred

ACCEPT - AX BY $(22$

GOTO 741

73 TYPE 75!

75. FOHMAT('SESTEH THE NAME OF THE GEOMETRY DATA FLLE ') ACCEPT - FILE:

TYPE - John if you choose ths complex weld pool, then'

TYPE * the Yil. the point interested, $(X 0, Y 0, Z 0)$, will'

TYPE ' 'have to be EXACTLY' the same an the Y coordinate'

TYPE - if one of the ponte contaned in this data file '

OPES(LNIT = 44.FILE - FILE.TYPE = 'CNKNOWN')

74. OFEN(CNIT 2: FILE: 'ELEINT DAT'.TYPE : '('NKNOWN')

DO $1001-1,113(1) \mathrm{NI}$

READ $(2,,+)$ NOI)E $(1) \times(1), Y(I), Z(J)$

JF(NODE\{I) FQ (I) GOTO 130

HA CONTINLF

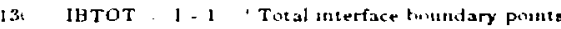
DO IIO I IFLTOT

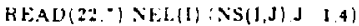

IF(NEL(I) EQ 1$)$ CIOTO 120)

11. (") NTNTE:

12. IE.TOT $1-1$ - T.tal interfacsal elements

DO 1411 - [BTOT - 1 [BOLND

READ $\left\{2^{-}\right) \mathrm{S}\left(\mathrm{I}^{\prime}\right) \mathrm{L}(\mathrm{I}) \mathrm{X}(\mathrm{I}), Y(1), Z(I)$

[F(NOI)E(1) EQ (1) GOTO 1511

14. CONTINIF

15. JTOT $1-1$ ' Tietal points relited tin the interfacial elements

(LOSEIINIT 22$)$

6

OPEN(TNIT 33,FILE 'TEMP DAT TYTE TNKSOWN'

RFAD(33, ' NODENI, VEL

DO $160 \mathrm{I}-1, \mathrm{NODERT}$

HFADI33." INOIDEDEGHEE

DO $170 \mathrm{~J}: 1 . \mathrm{J}]^{\circ} \mathrm{OT}$

IF(NODE(J) NEINOIN:) GOTO $17 \%$

T(J) - DEGHEE

(is) TO bri 


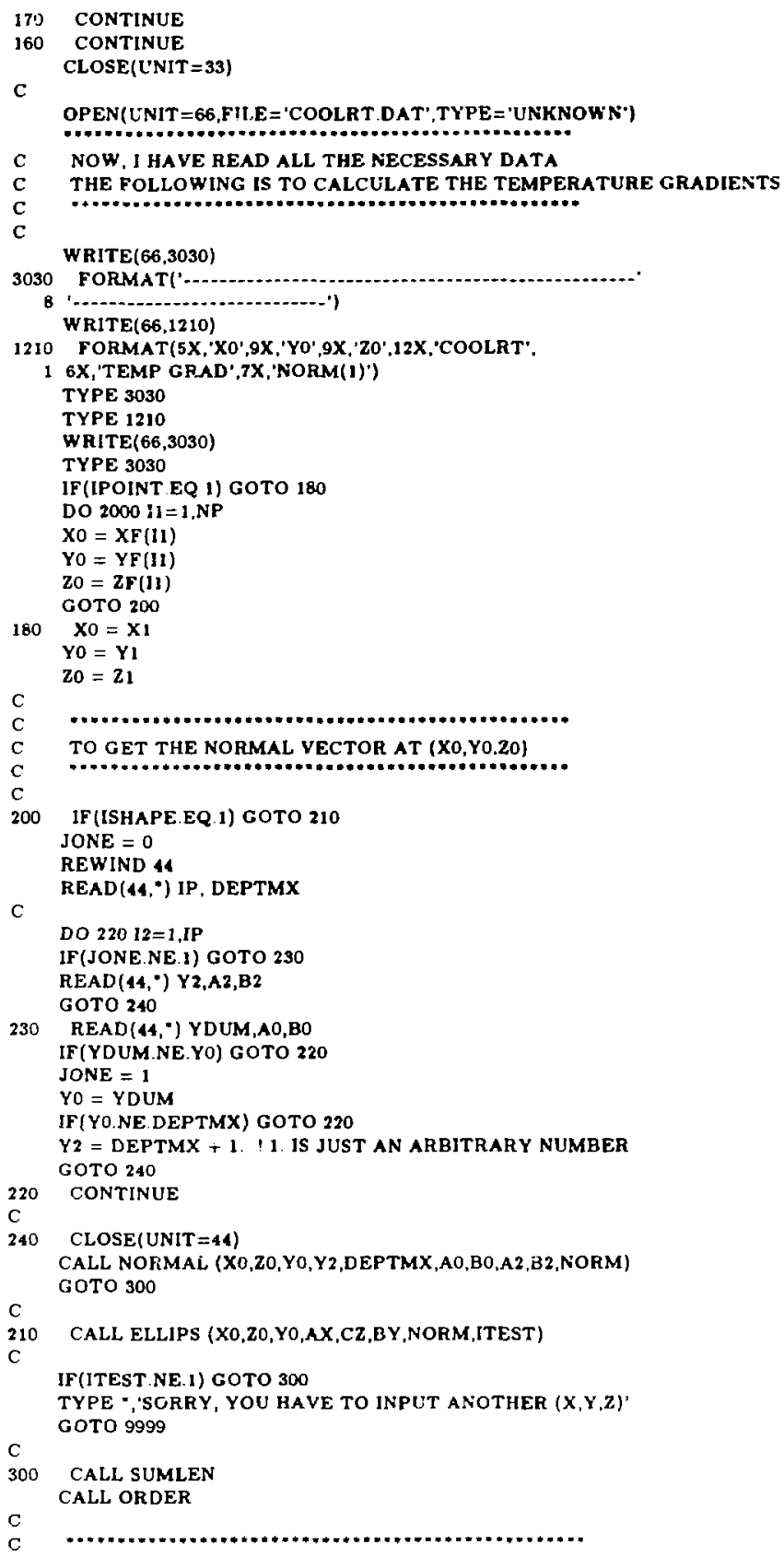




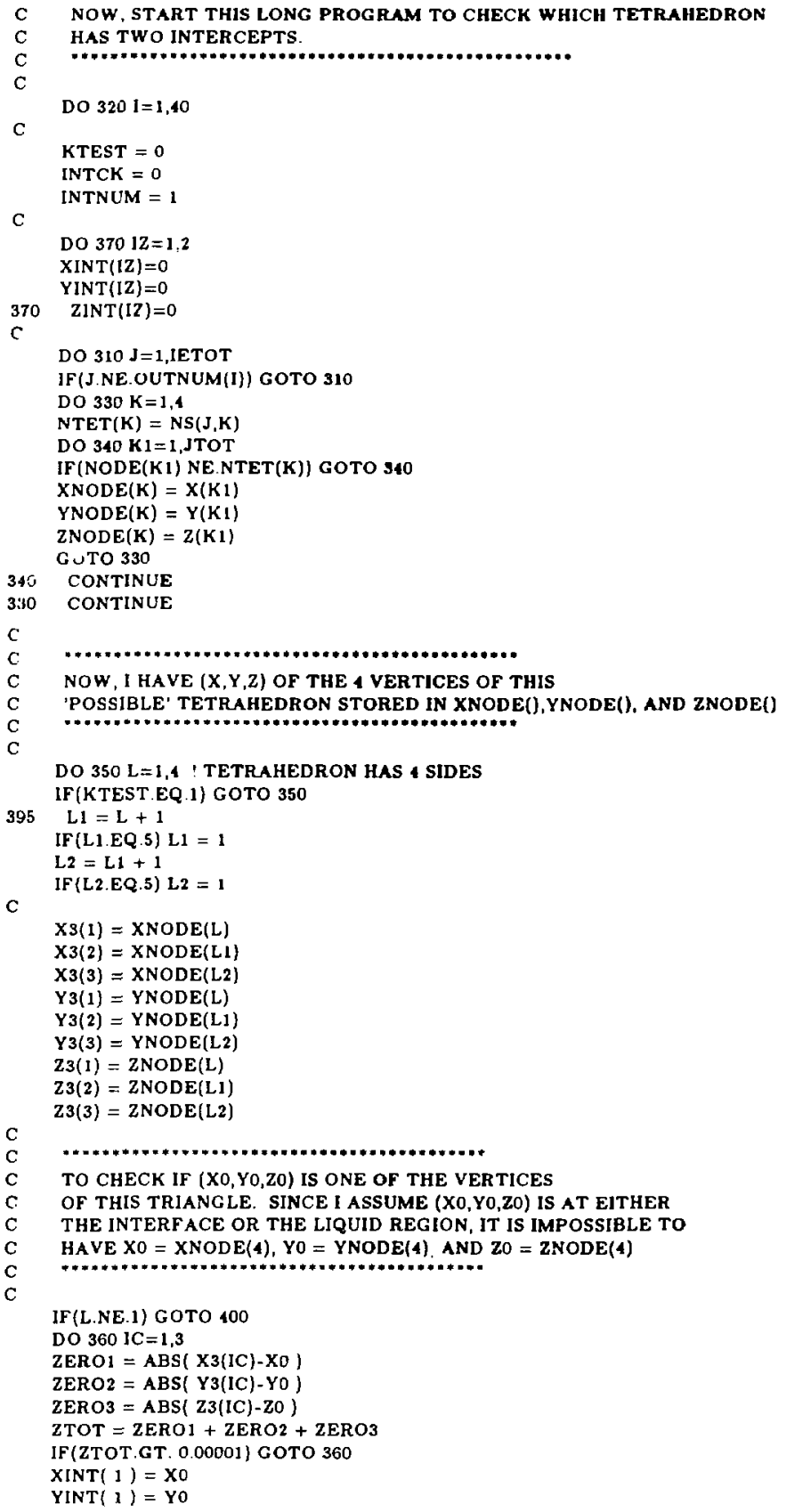




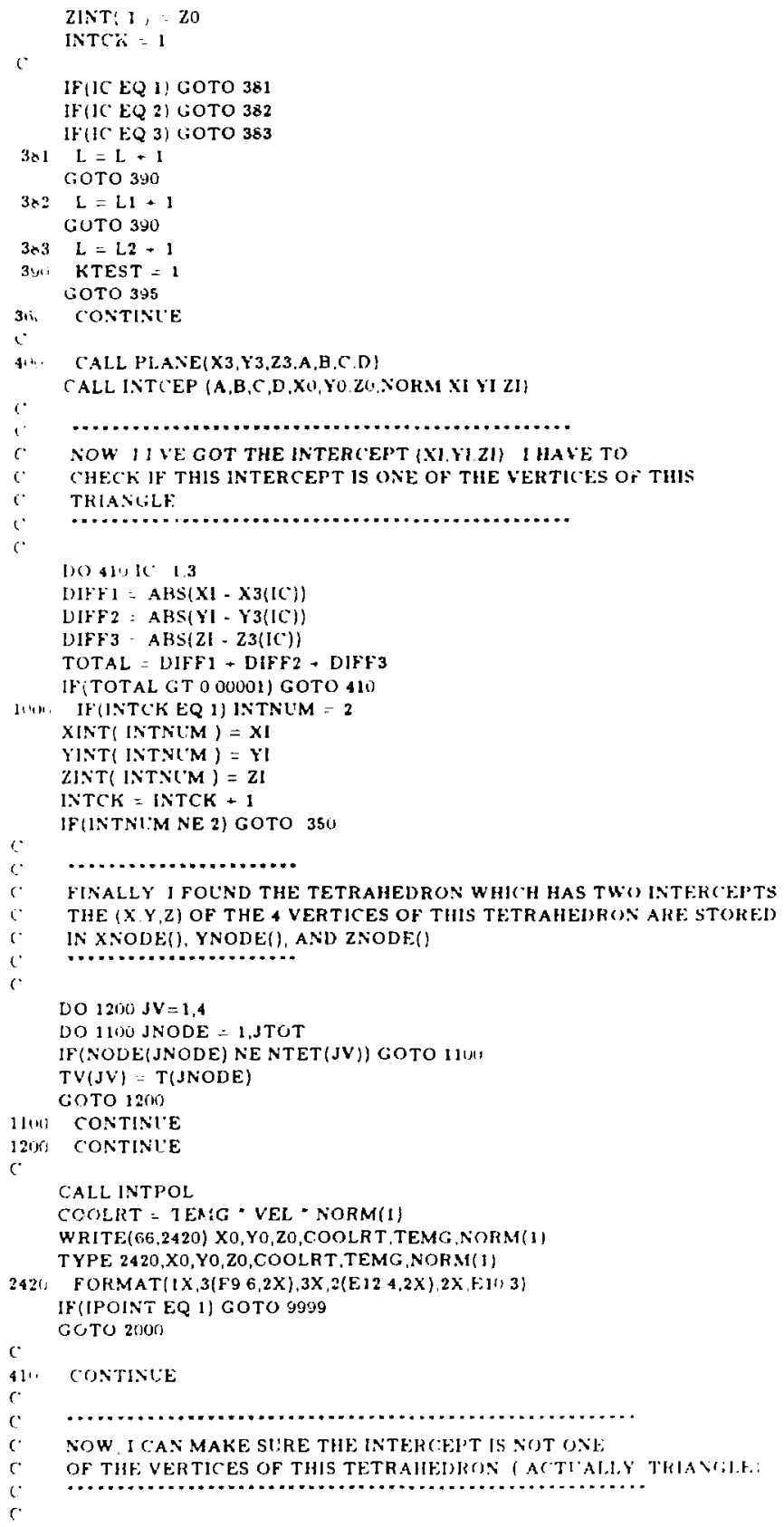


CALL LIMIT

IF [TEST EQ 1) GOTO 35U

$c^{2}$

$\sigma^{\prime}$

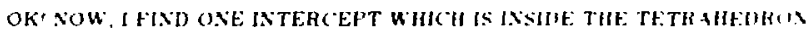

(c)

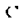

GOTO 1114

C

35. CONTINIF

IF(INTCK EQ 2) TYIE ?IMPOSSIBLE TO RE :

GOTO 32.

31.1 CONTIN!F:

TYPE - IMPOSSIBLE NOT TO FIND TETRAHTDRON

GoTo gen:

3:1 CONTINTE:

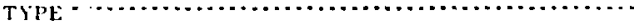

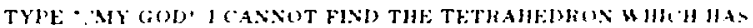

TYPE " TUO) INTER(FIPTS HFL" HEL" HE:L"

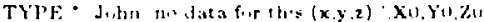

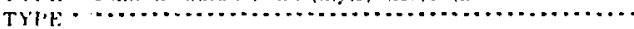

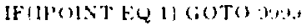

(

21,4 CONTINE

c

A., (ALL, FXIT

END

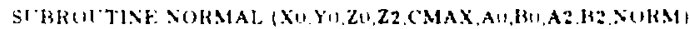

This pregram is to ealculate the normal at any peint oll is

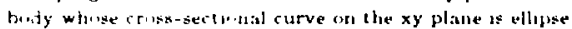
with half lerigth of the ling axis. a, and of the start axis, t.

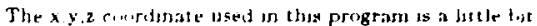
comfusing Originally. thus program is based (nll the cuntrituste with downwart $2(+$ ve 2 ) as the axis to represent the deptit of

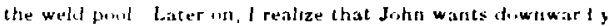
(T) $y$ ) as the axis to represent the depth of the wollt port

Therefore. 1 put the "equivalence" $X($ new $)=X(0,1)$.

$Y($ new) - Z(n.) $), \quad Z$ (new) - Y(nild)

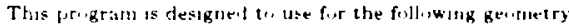
Long ixis of ellips is in the $X$ ilirection

Sharl ixis of ellits is mil the (new) $Z$ directl il

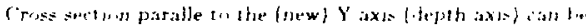
any kurd if shape

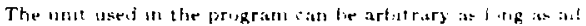
the dista unte are contelstent

The datil mout are

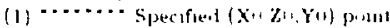

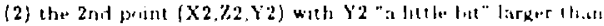

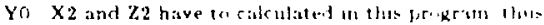

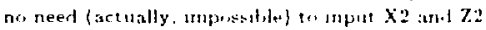

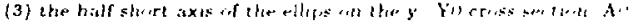

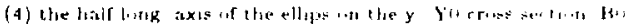

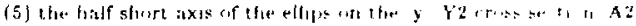

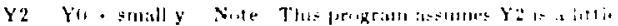

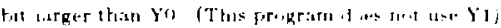

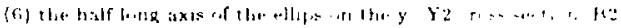




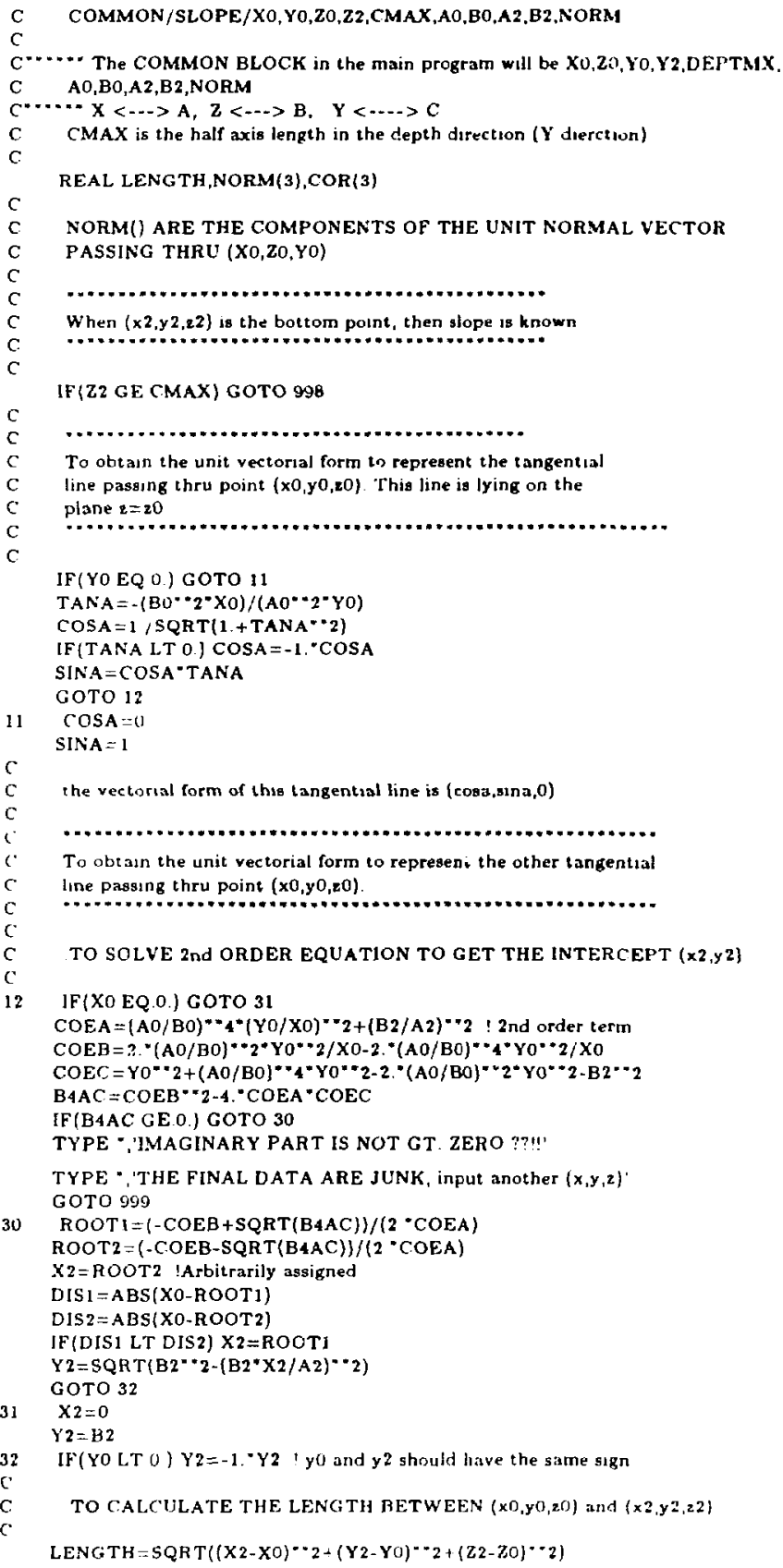




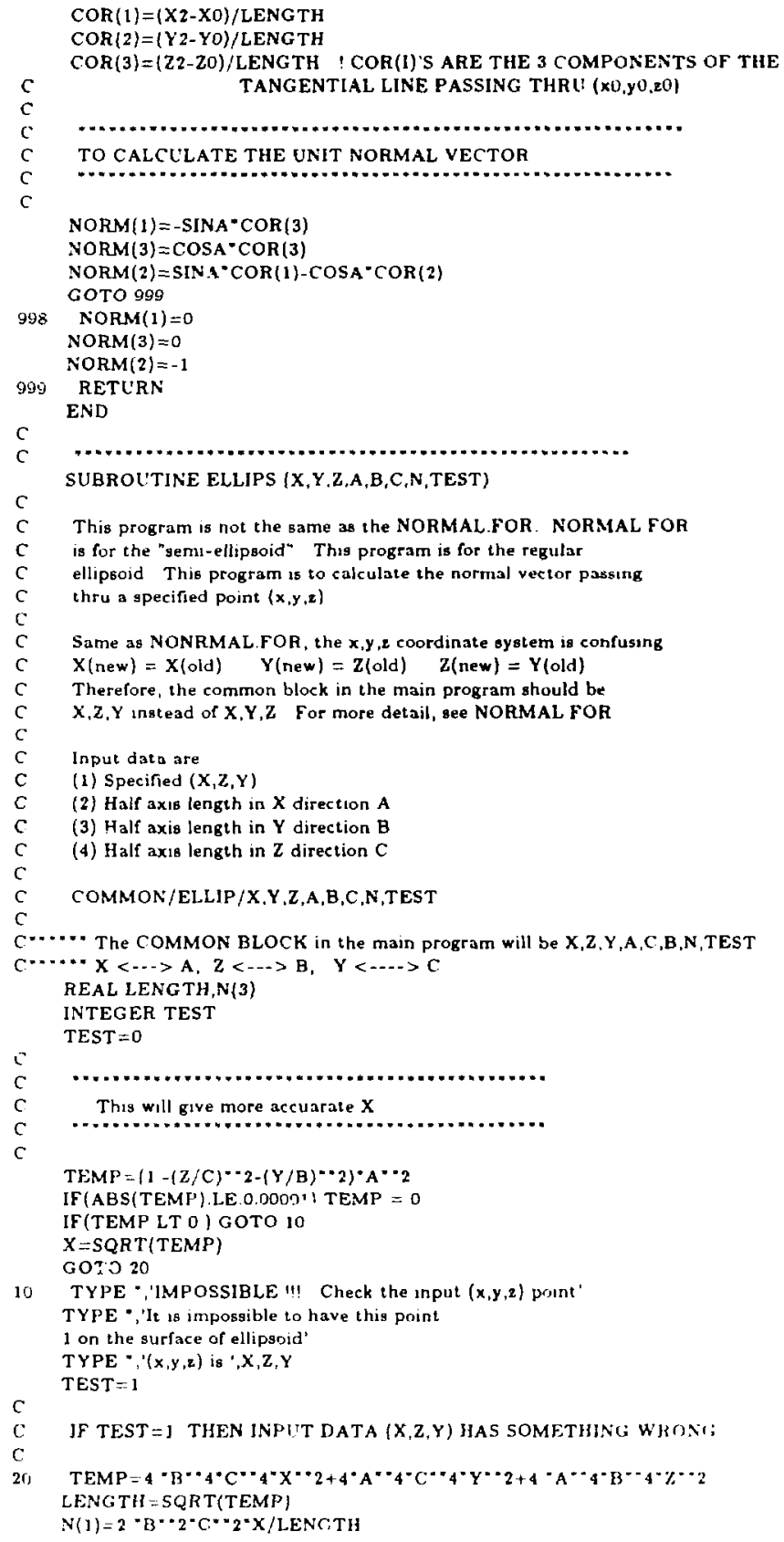


$\therefore(3)-2 \cdot A * z \cdot \cdots \cdot * \cdot$, LENGTH

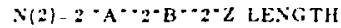

y.

RETIRN

ENI

$\mathrm{C}$

SLBROTTISE SIMH,EN

(

This program is to ealculate the simmotion of the fulur l.the segmerits form $\{x 0 . y(1,211\}$ pont te the three four of the

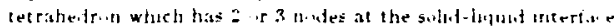

\section{INPT IATA AKE}

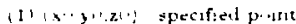

(2) (x) z of the vertex of the letrabe fron which his 2 r i

n...t.e th the interface

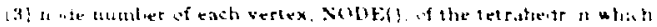

has 2 r 3 nodes at the motertive

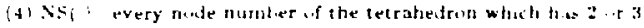
nings it the interfice

(5) JTOT tital of the nusles m the tetrahedrons whith hate $\geq$ i 3 mondes at the imterface

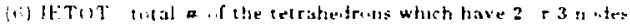
at itie intertisce

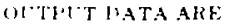

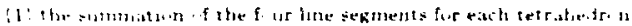

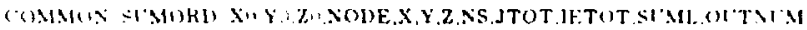

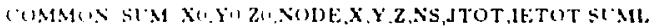

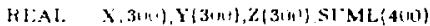

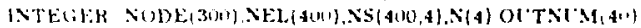

c.

1)(1) 11 1.12To1

Sis M, II)

(i) $20 \mathrm{~J} 14$

(id) $\mathrm{NS}(1 \mathrm{~J})$

J) $31+1 \cdot 1 \mathrm{JTOT}$

IFINODE:!I NE: $\mathrm{N}\{\mathrm{J}\}$ (IOT) in

$x<x(1)$

ir $r(1)$

(2) $2(1)$

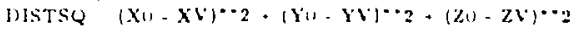

UIST SQRT(DISTSQ)

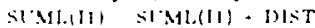

(i)

3. (I) TTINIF:

TYPE - MMONSIHLF:

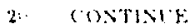

I) (ONTINTE

KFII RN

(x)

(

SIRKOTINE ORIVK

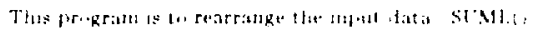

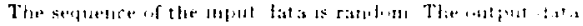

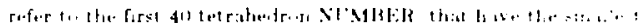

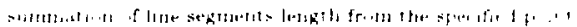

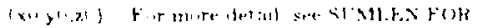

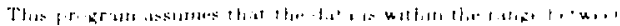

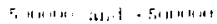


C INPNCM NUMEER OF INPIT DATA

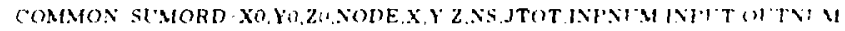

(

(

C

COMMON ORI INPNIMANTTOTSTM

REAL X(3t)

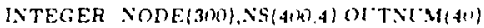

INTEGEH N(4)i)

r.

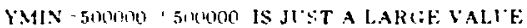

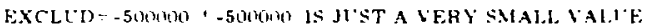

DO610 J-1.INPNEM

DO GOO I I,INPNIM

IF(INPITII) LE EXCLID) GOTO (WA)

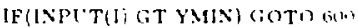

YMIX INFIT

MIN; I

$\therefore$ CONTENIE

$\mathrm{N}(\mathrm{J})-\mathrm{M}[\mathrm{N}]$

EXCL1.D YMIX

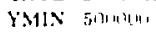

$\therefore$ CONTINIE

Nis 1

notionl l ININT)

IFII G; 41:60070 090

तx $\mathrm{Nil}$

(1)

NIT NINA 1

i. CONTINIE

d. RETIHN

H.Nil

,

(c)

ST

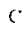

$(c$

This pr igram is to input 3 punts which are not on the sime line, then til calculate the criefficients if the

gerieral equat, on fir the plane in the space

The final equatmon for the platre is ax - by $+c z+d-0$

(OMMON PLAN X,Y.Z,A,B,C.D

RFAL X(3) Y (3),Z(3)

$c$

$A 1-(Y(2)-Y(1)) \cdot(Z(3)-Z(1))$

BI - $(2,2)-Z(1) \cdot(X(3)-X(1))$

(1) $(X, 2)-X(1))=(Y(3)-Y(1))$

A2 $\quad(Y(3)-Y(1)\} \cdot(Z(2)-Z(1))$

H2 $\{Z(3)-Z(1\}) \cdot(X(2)-X(1)\}$

$(\cdot 2 \quad(X) 3)-X(1))^{*}(Y(2)-Y(1))$

A : A1-A2

B $B 1-B 2$

$c \cdot r 1-(25$

D) $-X(1) \cdot A 1-Y(1) \cdot B 1-Z(1) \cdot(1) \cdot$

$1 X(1)-A 2+Y(1)-B 2+Z(1)-C_{2}$

RETI'RN

E.ND

(

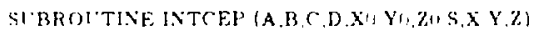

$r$

Thug pringari is tei calculate the intercept $\{x \mid$ y $\mid$ z. 1$\}$

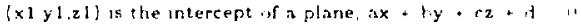

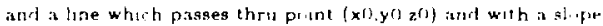
sl 82.53 91.52,53 are the 3 crimponents of the unt grwintit vertior 
C

C COMMON/INTCP/A,B,C,D,XO,YO,ZO,S,X,Y,Z

REAL S\{3),LENGTH

$c$

c

C

c

DENOM $=A^{*} S(1)+B^{-S}(2)+C^{*} S(3)$

IF(ABS(DENOM) GE.0 DO00001) GOTO 100

$c$

C

$\mathrm{X}=0$

$Y=0$

$z=0$

GOTO 909

(1) LEXGTH $=-\left(A^{-} \mathrm{XO}^{-}+\mathrm{B}^{-} \mathrm{YO}^{\circ}+\mathrm{C}^{-} \mathrm{ZO}+\mathrm{D}\right)$ ! DENOM

C

$\mathrm{X}=\mathrm{X} 0+\mathrm{S}(1) \cdot$ LENGTH

$Y=Y O+S(2) \cdot$ LENGTH

$\mathrm{Z}=\mathrm{ZO}+\mathrm{S}(3) \cdot$ LENGTH

C

99 GETL'RN

END

$c$

SLBROLTINE LIMIT

$c$

$\mathrm{C}$

C

C

c

c

c.

C

C

C

$c$

COMMON/LIMI/X,Y,Z,XI,YI,ZI,TEST

REAL X(3),Y(3),Z(3),DIST\{3),INNPRO\{3\},COS(3),THETA(3)

REAL SUM(3)

INTEGER TEST

C

C

TEST $=1$

DO $10 \mathrm{~J}=1,3$

$\operatorname{DiST}(\mathrm{J})=\operatorname{SQRT}\left((\mathrm{X}(\mathrm{J})-\mathrm{XI})^{*}{ }^{*} 2+(\mathrm{Y}(\mathrm{J})-\mathrm{YI}) \boldsymbol{*}^{*} 2+\right.$

$\left.\left.1 \quad(\mathrm{Z}(\mathrm{J})-\mathrm{ZI})^{\cdots}\right)^{*}\right)$

C

DO $20 \mathrm{~J}=1,3$

$\mathrm{L}=3 ; 1$

$\operatorname{IF}(\mathrm{L} E \mathrm{EQ}) \mathrm{L}=1$

INNPRO(J) $=(X(J)-X 1) \cdot(X(L)-X 1)+$

$1 \quad(\mathrm{Y}(\mathrm{J})-\mathrm{YI}) *(\mathrm{Y}(\mathrm{L})-\mathrm{YI})+$

$2 \quad(\mathrm{Z}(\mathrm{J})-\mathrm{ZI}) \cdot(\mathrm{Z}(\mathrm{L})-\mathrm{ZI})$

$\operatorname{COS}(\mathrm{J})=\operatorname{INNPRO}(\mathrm{J}) /(\operatorname{DIST}(\mathrm{J}) \cdot \operatorname{DIST}(\mathrm{L}))$

CONTINUE

$\cos (1)$ IS COSINE(THETA), THIS THETA IS THE ANGLE BETWEEN

LINE I AND LINE 2.

$\operatorname{COS}(2)$........ BET WEEN LINE 2 AND LINE 3

$\operatorname{COS}\{3\}$......... BETWEEN LINE 3 AND LINE 1

LINE ] $(X I, Y I, Z I)$ TO $\left(X_{1}, Y_{1}, Z 1\right)$

LINE 2 . (XI,YI,ZI) TO $\left(X_{2}, Y_{2}, Z 2\right)$

LINE $3 \quad(X I, Y I, Z I)$ TO $(X 3, Y 3, Z 3)$ 


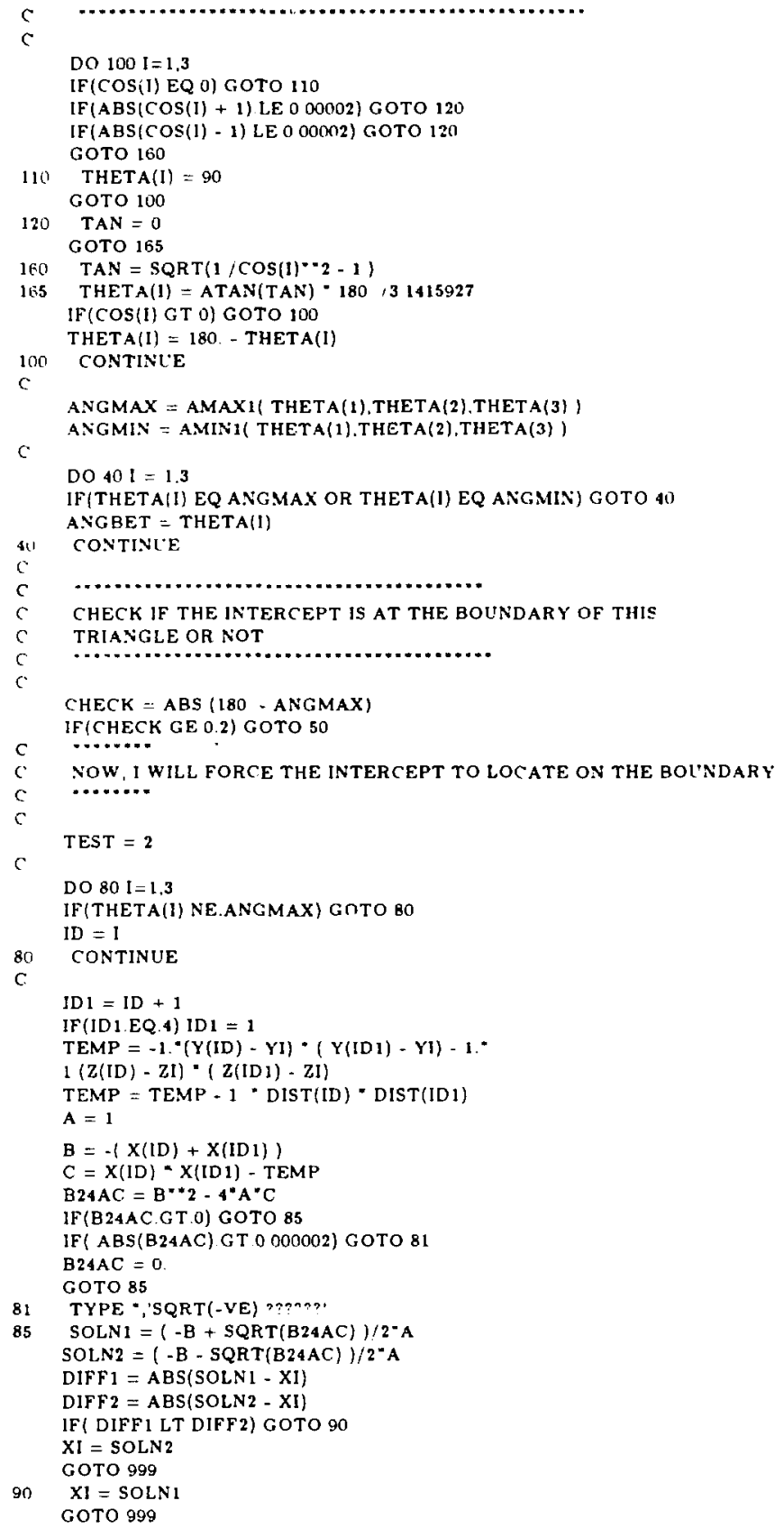


5. $[(x), 113$

J $1 \cdot 1$

(FiJ EQQ I) I

i. STM,II TIETA I. THHTA

$\imath^{\circ}$

ITOT i

(ii) $31.1 \quad 13$

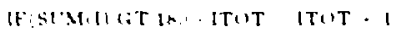

i rutivit:

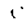

IF ITUT E:Q 1! TEST ?

… HFTIR

(i)

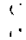

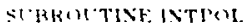

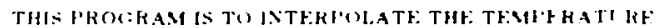

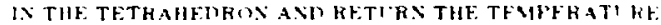

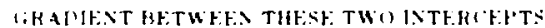

INAMUS INTHE X Y $Z$ XI Y I T T TI TEMI:

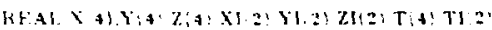

RFA], \&34) 3 (4 $\mathrm{Ni}+2$ !

TU('ALCIIATE G-VOLITSE

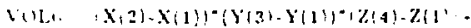

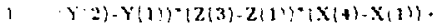

$=\quad z, 2\}-2(1) ! \cdot(x(3)-x(1)) \cdot(1)(1)-x(1)\}-$

$3 \quad(3,2)-Z(1))=(Y(3)-3(1)) \cdot x(+)-x(1))-$

$4 \quad y(2)-Y(1))^{*}(X(3)+X(1))^{*}(Z(4)-Z(1))$.

; $\quad x: 2)-x(1)) \cdot(Z(3)-Z(1) \cdot(Y)(4)-Y(1))$

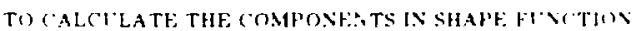
$\mathrm{Ni}, \mathrm{Nin}, \mathrm{Ni}$

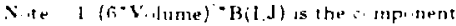
if the shape function

(1)

R.11 $-((1,3)-Y(2)) \cdot(Z(4)-312 !$

$1 \quad\{Y\{4)-Y: Z !\}=\{Z\{3\}-Z\{2\}:\}$

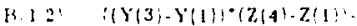

$1 \quad(Y(4)+3) 1) \cdot(Z ; 3)-Z(1)+\}$

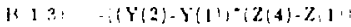

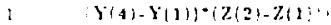

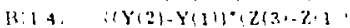

$1 \quad Y(3)-Y(1)-\{Z(2)-Z(1), 1$

$H=11 \quad\{(x(3)-X(2)+12(4)-Z 2:$

$1 \quad(x+1)-x(2)\}(2)(3)-212 i, 1$

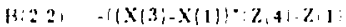

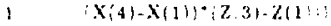

$\{123: \quad\{x(2)+x(1) ; 2 ; 4\} 21:-$

$1 \quad(x)(4)-x(1) 1-1212)-2(1):$

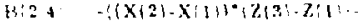

$1 \quad: x(3)-x(1) ! 2(2)-211$

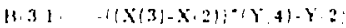

$1 \quad\{x(+1-x i 2)+(y) \cdot 3) \cdot 2 !$

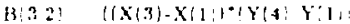

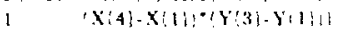

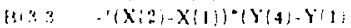

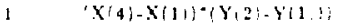




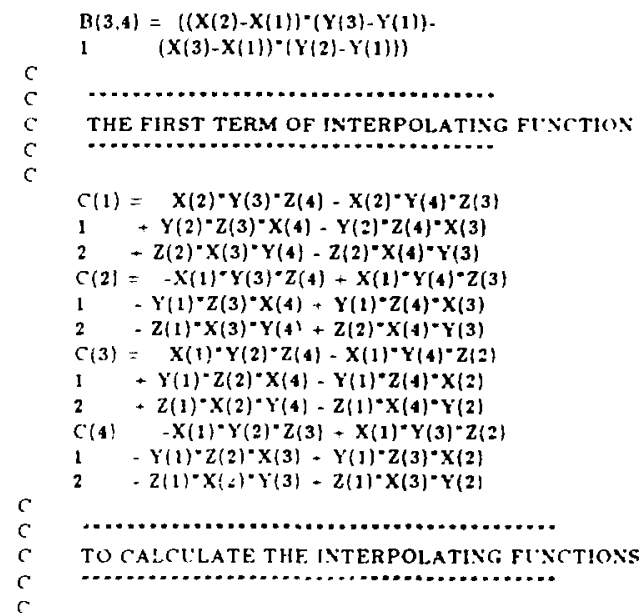

Do fn $\mathrm{J}:=12$

N(1.J) \& vol, $1 \cdot([1)$

$1+B\left(1,1 I^{*} X(J)+B(2,1)^{*} Y^{\prime}(J)\right.$

$2 \quad+\mathrm{H}(3 \mathrm{3}) * \mathrm{ZI}(\mathrm{J}))$

$\mathrm{N(2.J)}(1 \cdot V 01,(3) \cdot \mathrm{C}(2)$

$1 \quad-B(1.2)^{*} \mathrm{XI}(\mathrm{J})+\mathrm{B}(2.2)^{\bullet} \mathrm{Y}(\mathrm{J})$

$2 \quad+B(3,2)^{*} z[(J))$

$N(3.3)$ (1 VOLG) $(\mathrm{Cl})$

$1+B(1.3)^{*} \mathrm{XI}(\mathrm{J})+\mathrm{B}(2.3)^{*} \mathrm{Y} I(\mathrm{~J})$

$2+8(3,3)^{-} \mathrm{Zl(J))}$

$N(4 . J)=(1$ VOLG $)(C(4)$

$1+B(1.4)^{*} \times(J)+B(2,4) \cdot Y(J)$

$\left.2+\pi(34)^{*} Z I(J)\right)$

10 CONTINIE

C

$T H(1)=T(1) \cdot N(1)+T(2) \cdot N(2,1)$

$1-T(3) \cdot N(31)-T(4) \cdot N(4,1)$

$T 1\{2\}=T \cdot 1) \cdot N(1.2\}+T(2) \cdot N(2.2)$

$1-T(3) \cdot N(3,2)=T(4) \cdot N(4,2)$

6

DISTSQ : $\quad(X I(2)-X 1,1): \cdots 2+(Y 1(2)-Y 1(1)\}^{\cdots 2}$

$1 \quad+(Z 1 ! 2,-21(1) \cdots 2$

DIST SQRT'DISTSQ।

IFIDIST GT, ,UMtWI, GOTO 20

TYPE - THE DISTANCE BETWEEN TWO INTERCEITS IS "

TYPE - (XY Z) OF INTER(EPT 1 XIil) YIIII.Z1 1'

TYPE - (XYZ) OF INTERCEPT 2 XI 2 ! $\because 1(2) Z l_{1} 2$ :

TEMIC : $($ T1 2) TII): HIST

RETI'HN

ENi) 


\section{APPENDIX C}

\section{Thermodynamically Calculated Isothermal Sections}

Isothermal sections through the Fe-Ni-Cr ternary system were thermodsnamisally calculated between $1873 \mathrm{~K}$ and $1023 \mathrm{~K}$. The results of these calculations an be used to represent the liquidus surface, solidus surface, and the austenite + ferrite two-phase solvus surfaces for predicting interfacial cquilibrium during solidification and solid state transformation of stainless stecl alloys. Sigma phasc. which acturs at temperatures below $1223 \mathrm{~K}$. was not included as part of this insestigation.

Tie-lines were generated in all of the two-phase regions to predict segregation during solidification and partitioning during the ferrite-to-austenite transformation. The thermodynamic calculations correlate well with the existing experimental data for hinary and ternary insariant points. phase-ficld locations, and tic-! ines in the two-phase riclds. In addition. the metastable phasc cquilibrium betucen ferrite and liquid and betwecn austenitc and liquid was eals:lated to lou temperatures by suspending the alternatc solid phase. The metastable phase cquilibrium calculations are useful when conjecturing the possibilitics of phase selection during rapid cooling rate conditions.

The calculations were performed by the "Thermo-Calc" software package produced b) the Royal Institute of Technology in Stockholm [C.1]. These calculations are based on a subregular lattice solution model [C.2] and the Kaufiman databasc. which are integral portions of the softurace. The program calculates $x-3$ data pairs that correspond to the compositional end points of the ternary tic-lines. The rhase boundaries were sinstructued by sunnecting the end points and then eser? third ile line was plotted in each of the two-phase itelds.

The location w the line of two-told suturation. ferrte sollus and austents: silus

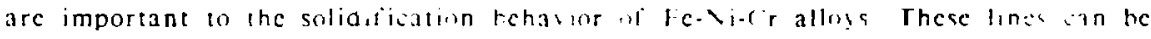

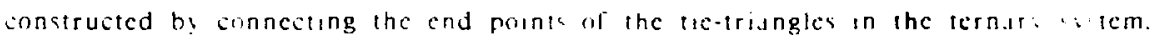

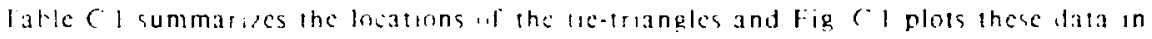
h: I $\mathrm{c}-V_{1} \cdot \mathrm{l} ! \mathrm{d}, \mathrm{ag} ! \mathrm{am}$ 
Table $($ I. Tic-Triangle losations from the calculated isothermal diagrams

\begin{tabular}{|c|c|c|c|c|c|c|}
\hline Temperature & Ferrite & & Austeni & & I ryutel & \\
\hline $1^{\circ} \mathrm{Cl}$ & $(4) \mathrm{Ni}$ & $k_{n} \mathrm{Cr}$ & $\mathrm{Ni}$ & $x_{1} \mathrm{Cr}$ & $\cdot V_{1}$ & $" \because r$ \\
\hline 1500 & 3.1 & $\geq 9$ & 4.2 & 2.7 & 50 & $i=$ \\
\hline 1480 & 3.6 & 8.7 & 5.6 & 7.7 & 64 & 911 \\
\hline $14^{-5}$ & 3.8 & 10.1 & 6.1 & 8.8 & 68 & 104 \\
\hline 1450 & 4.7 & 17.4 & 8.7 & 14.3 & 91 & $1^{-1}$ \\
\hline 1440 & 5.1 & 20.5 & 10.0 & 16.4 & $10=$ & 196 \\
\hline $143^{\circ}$ & 5.3 & 21.5 & 10.3 & 17.1 & 105 & 204 \\
\hline 1431 & 5.5 & 23.5 & $1 \mathrm{i} .2$ & 18.3 & $11=$ & $=19$ \\
\hline 1425 & 5.8 & 25.5 & 12.0 & 19.6 & 11.0 & $\therefore 35$ \\
\hline 1419 & 6.1 & 27.5 & 12.9 & 20.8 & $1=6$ & 250 \\
\hline 1413 & 6.4 & 29.7 & 13.9 & 22.1 & 134 & 26.5 \\
\hline 1407 & 6.7 & 31.9 & 14.8 & 23.4 & 14.2 & 280 \\
\hline 1401 & 7.1 & 34.5 & 16.0 & 24.8 & 151 & 29.8 \\
\hline 1375 & 8.8 & 44.7 & 21.0 & 30.1 & 190 & 36.1 \\
\hline 1350 & 11.2 & 55.9 & 27.3 & 35.5 & 23.9 & 42.5 \\
\hline $1: 25$ & $\begin{array}{l}16.0 \\
41.2\end{array}$ & $\begin{array}{l}66.5 \\
58.7\end{array}$ & $\begin{array}{l}35.5 \\
44.0\end{array}$ & $\begin{array}{l}41.6 \\
55.0\end{array}$ & $\begin{array}{l}30.5 \\
48.6\end{array}$ & $\begin{array}{l}493 \\
513\end{array}$ \\
\hline
\end{tabular}




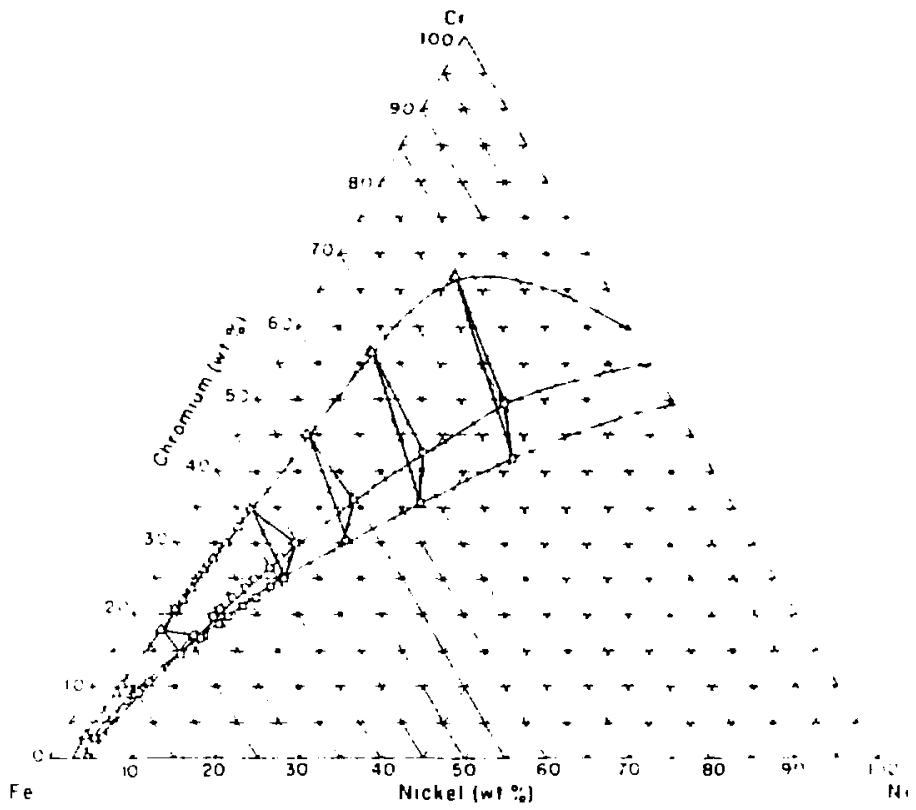

Figure (.l Insation of the ferrite solvus. austenite solsus and hine of

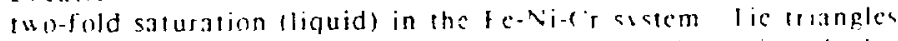
are indicated and were deternuned trom thermots namis calculaind 
FERRITE-AUSTENITE-LIQUID EQUILIBRICMI
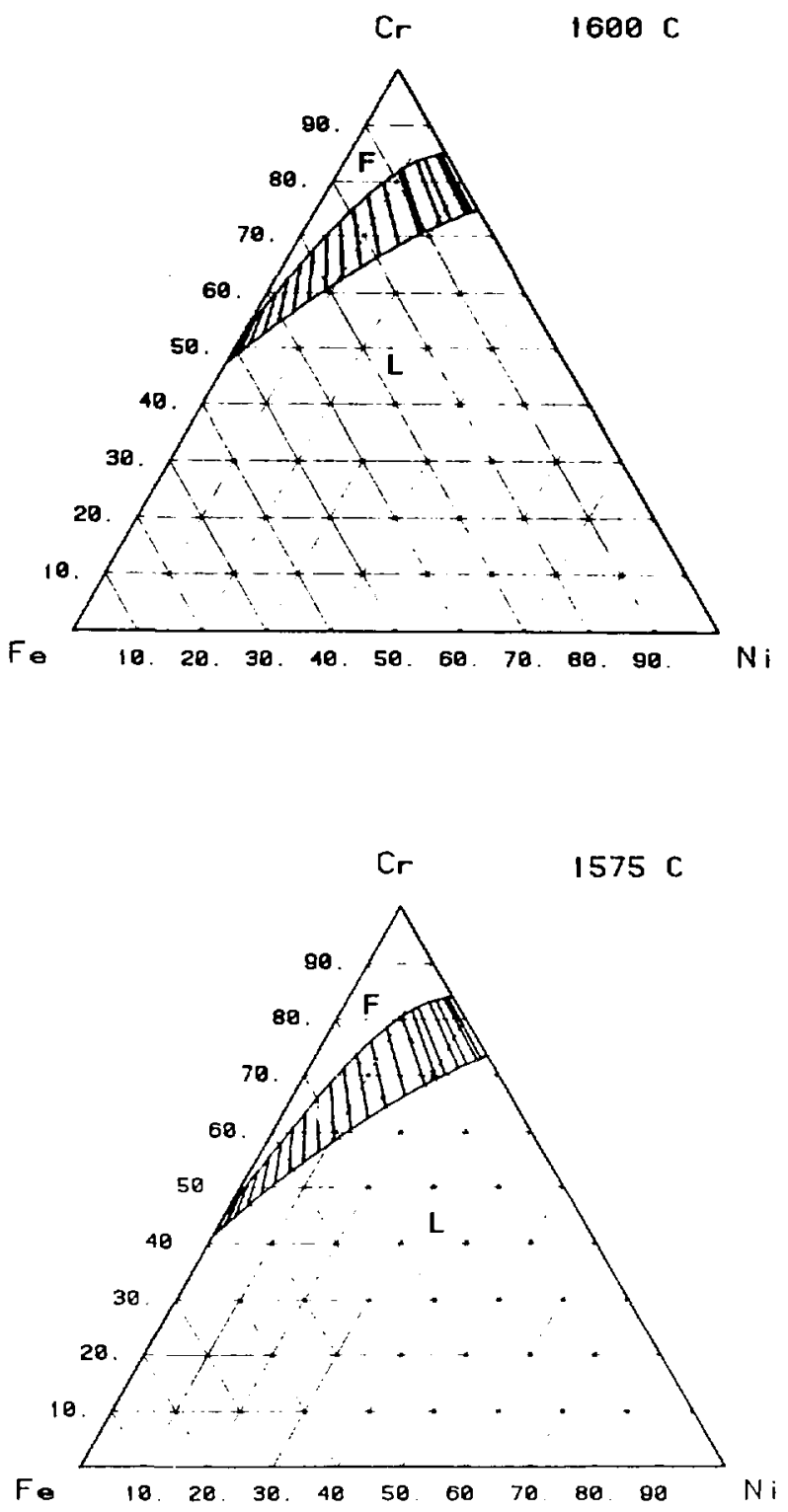

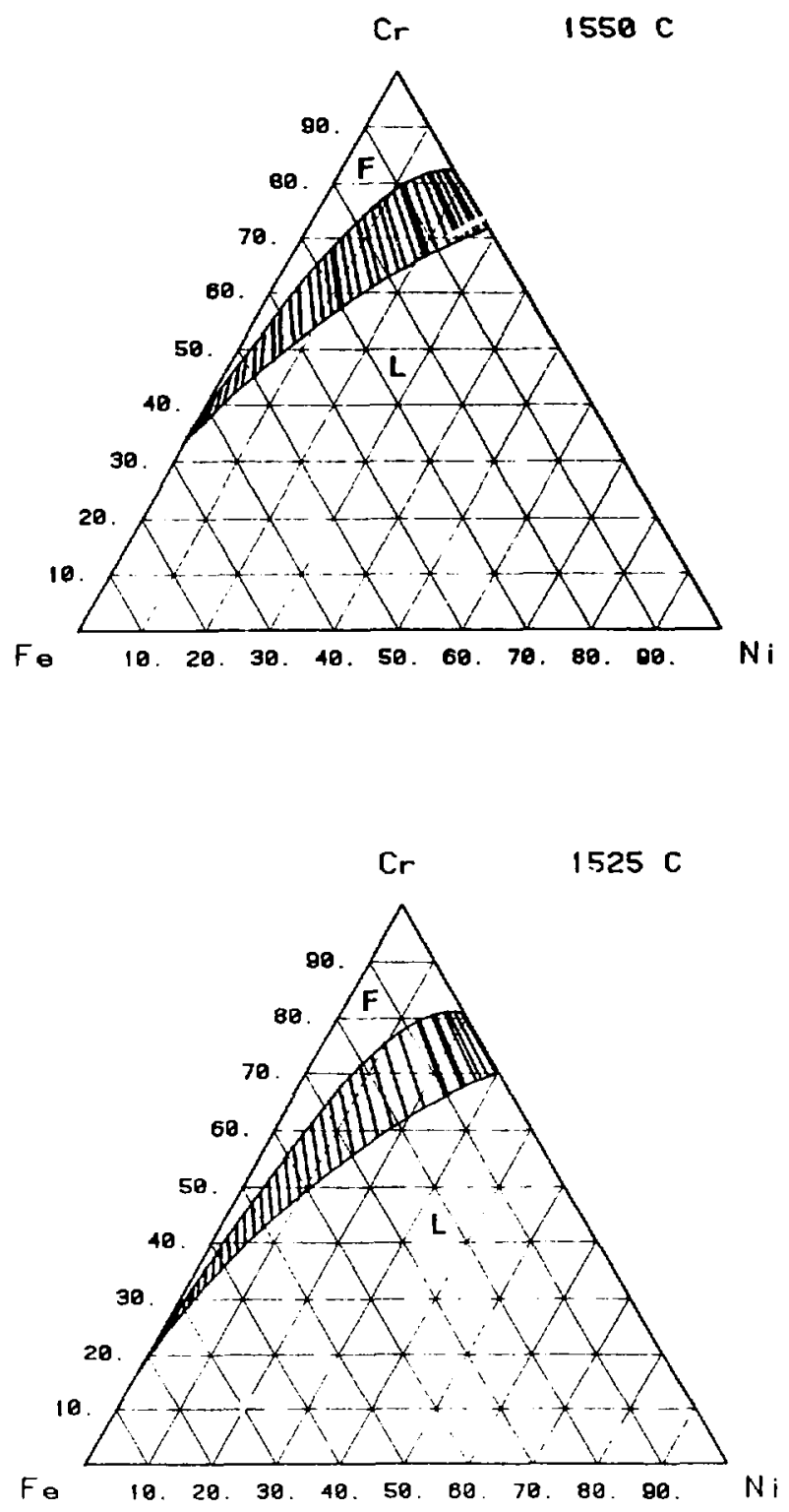

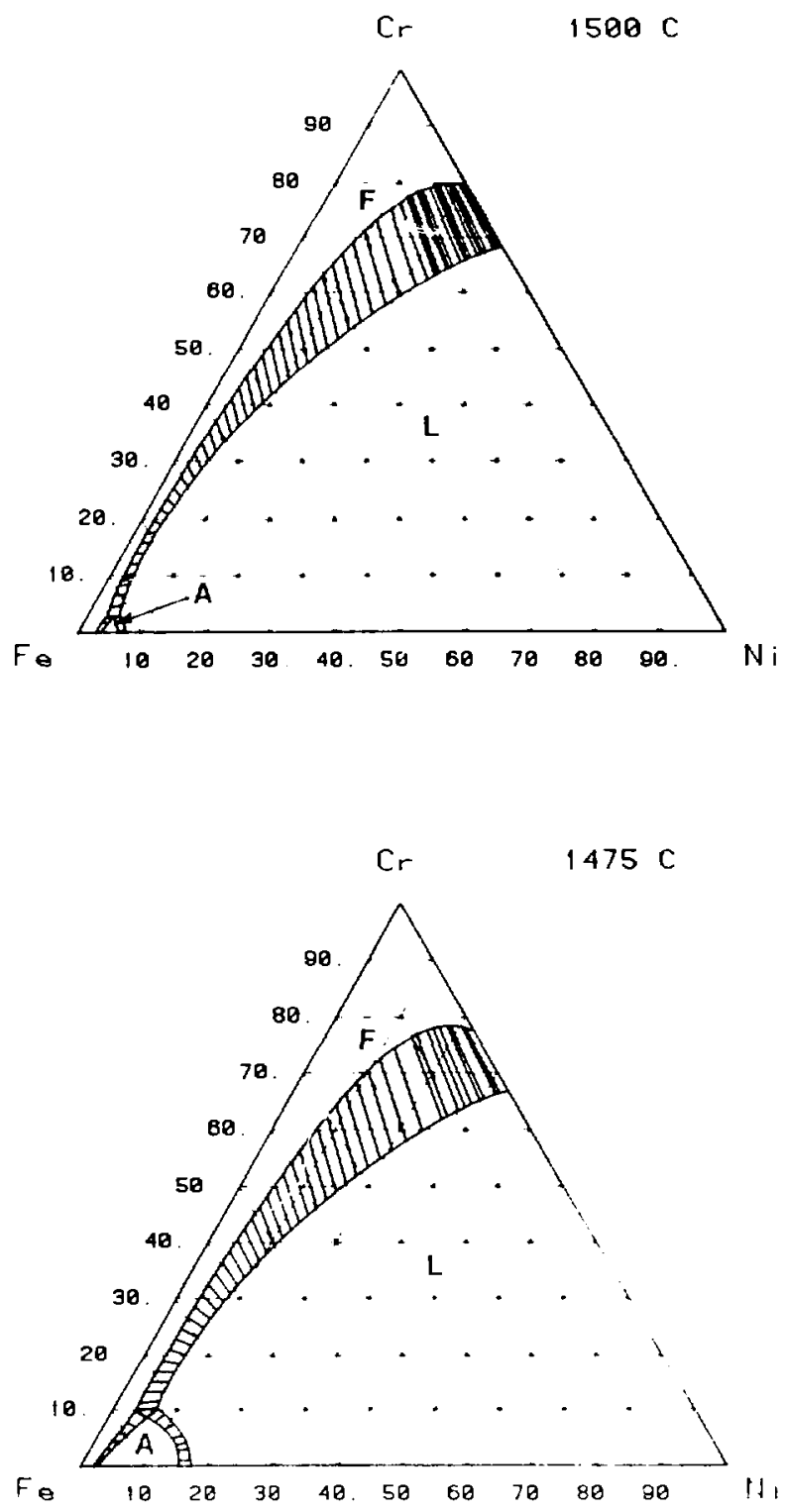

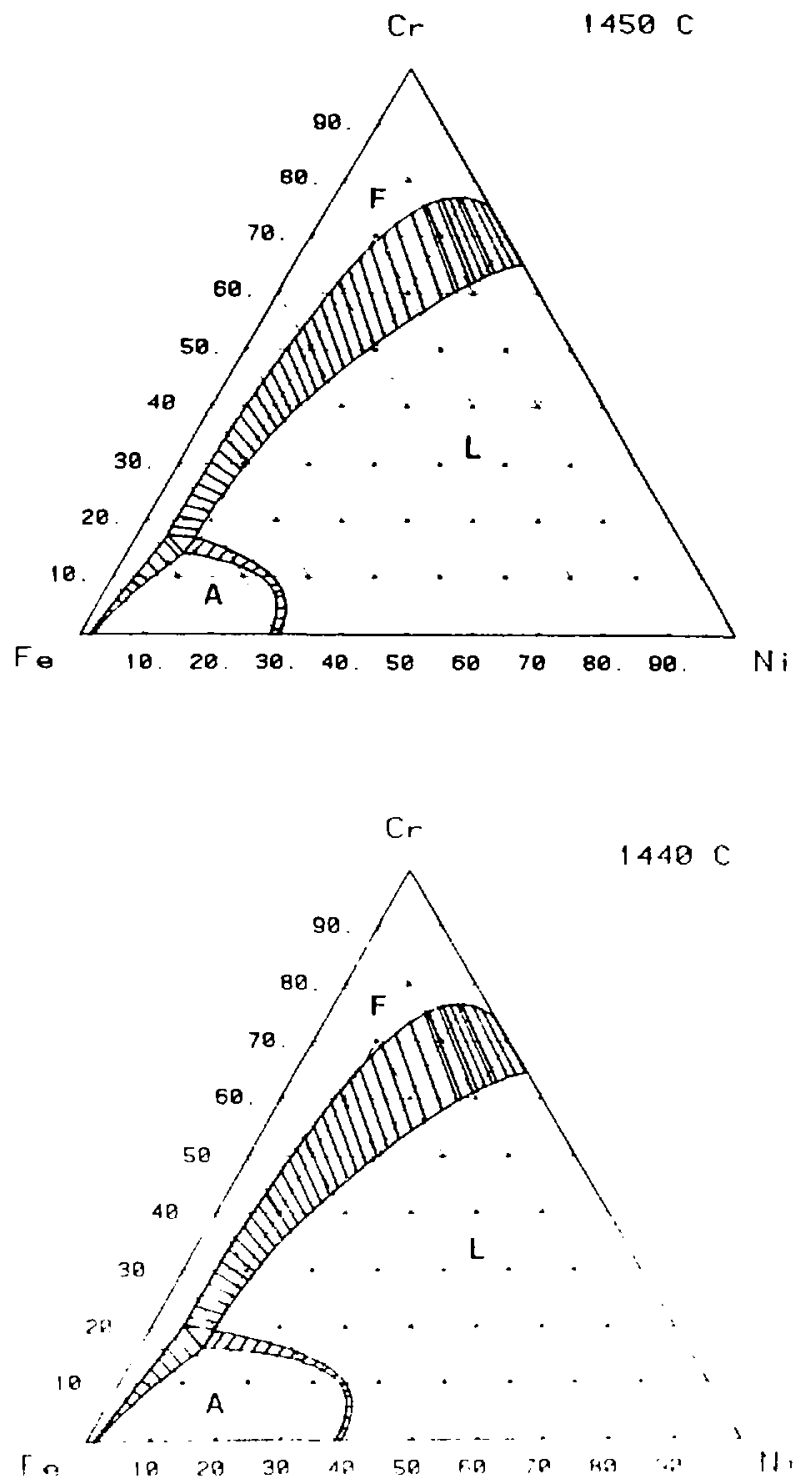

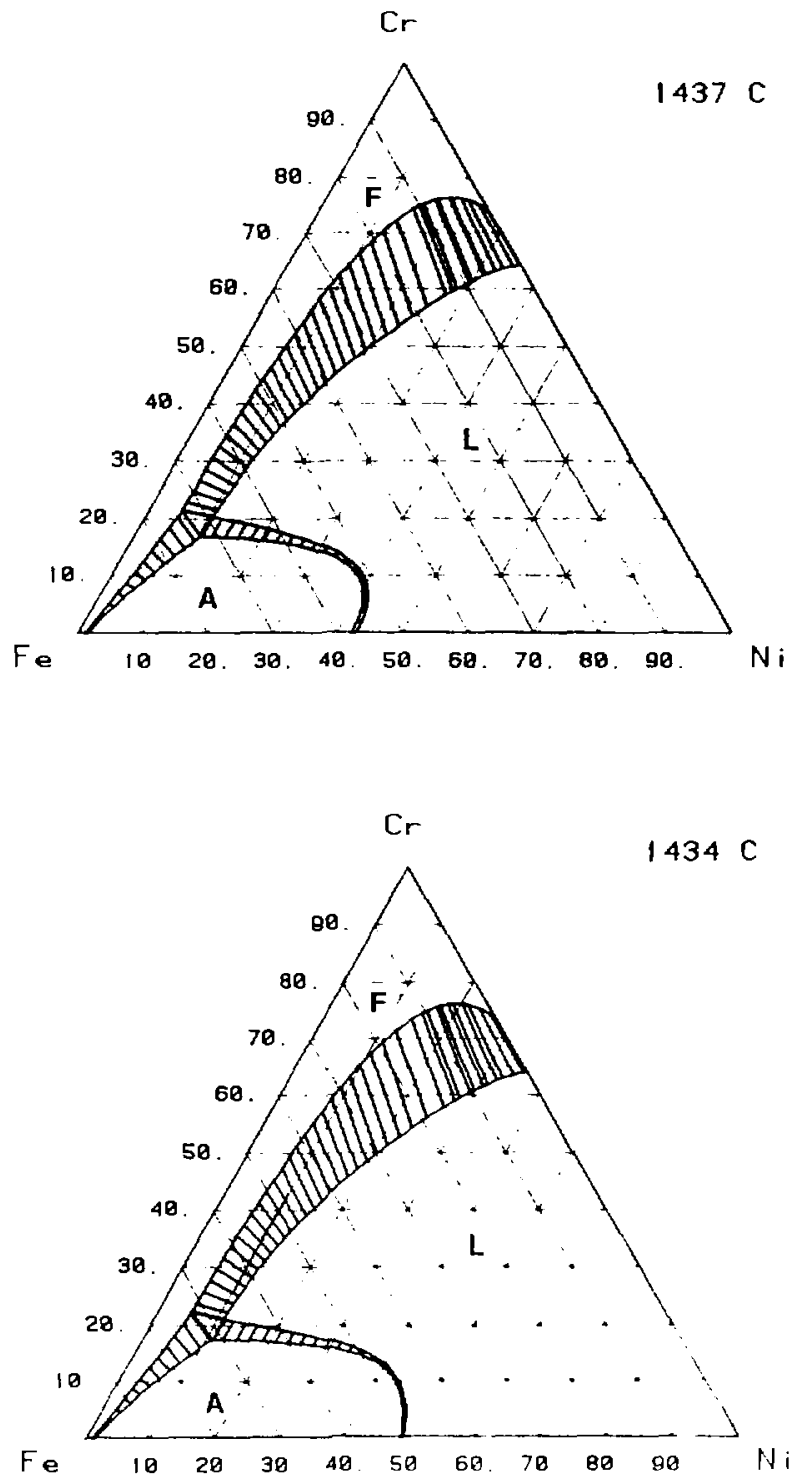

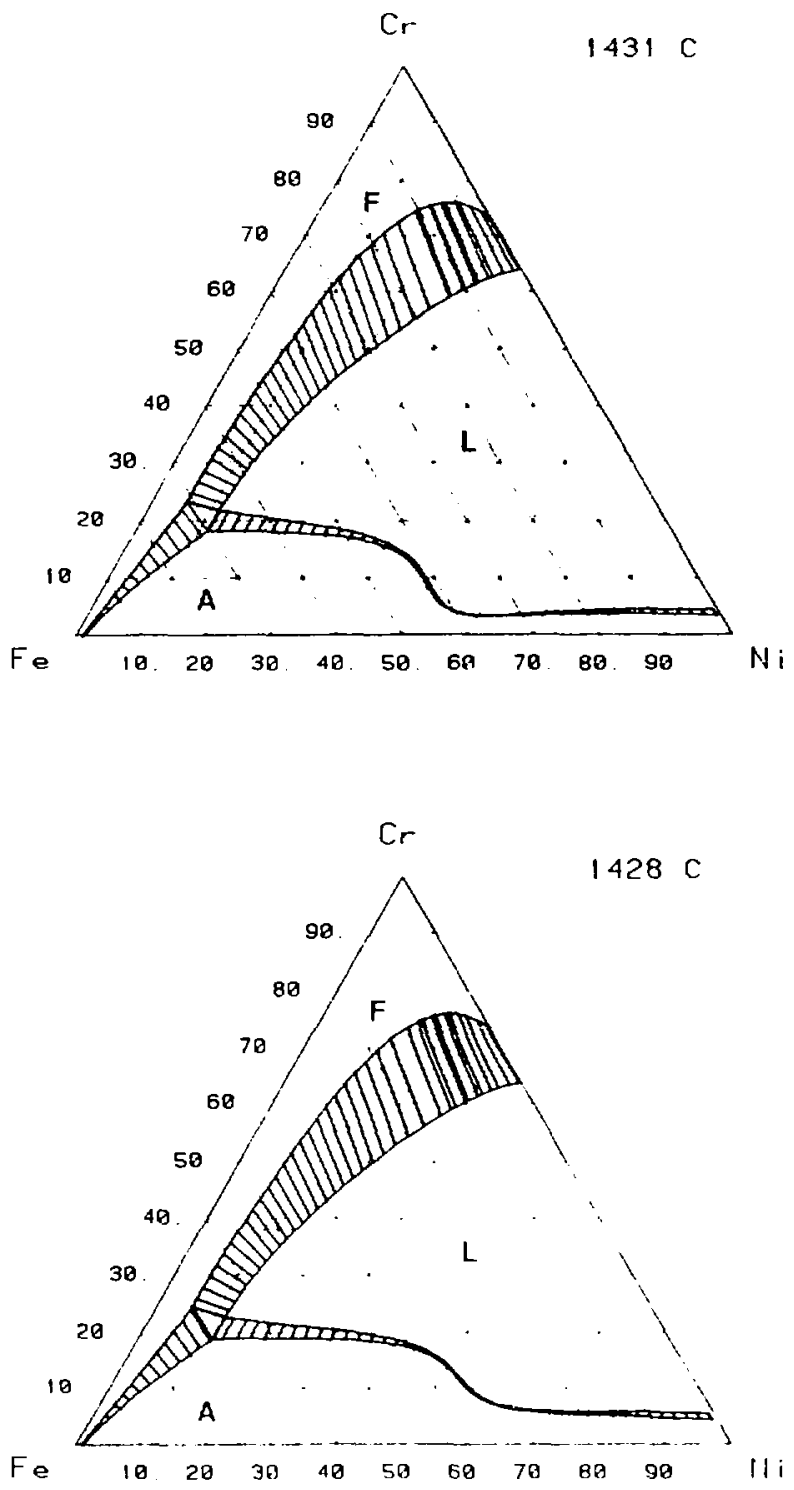

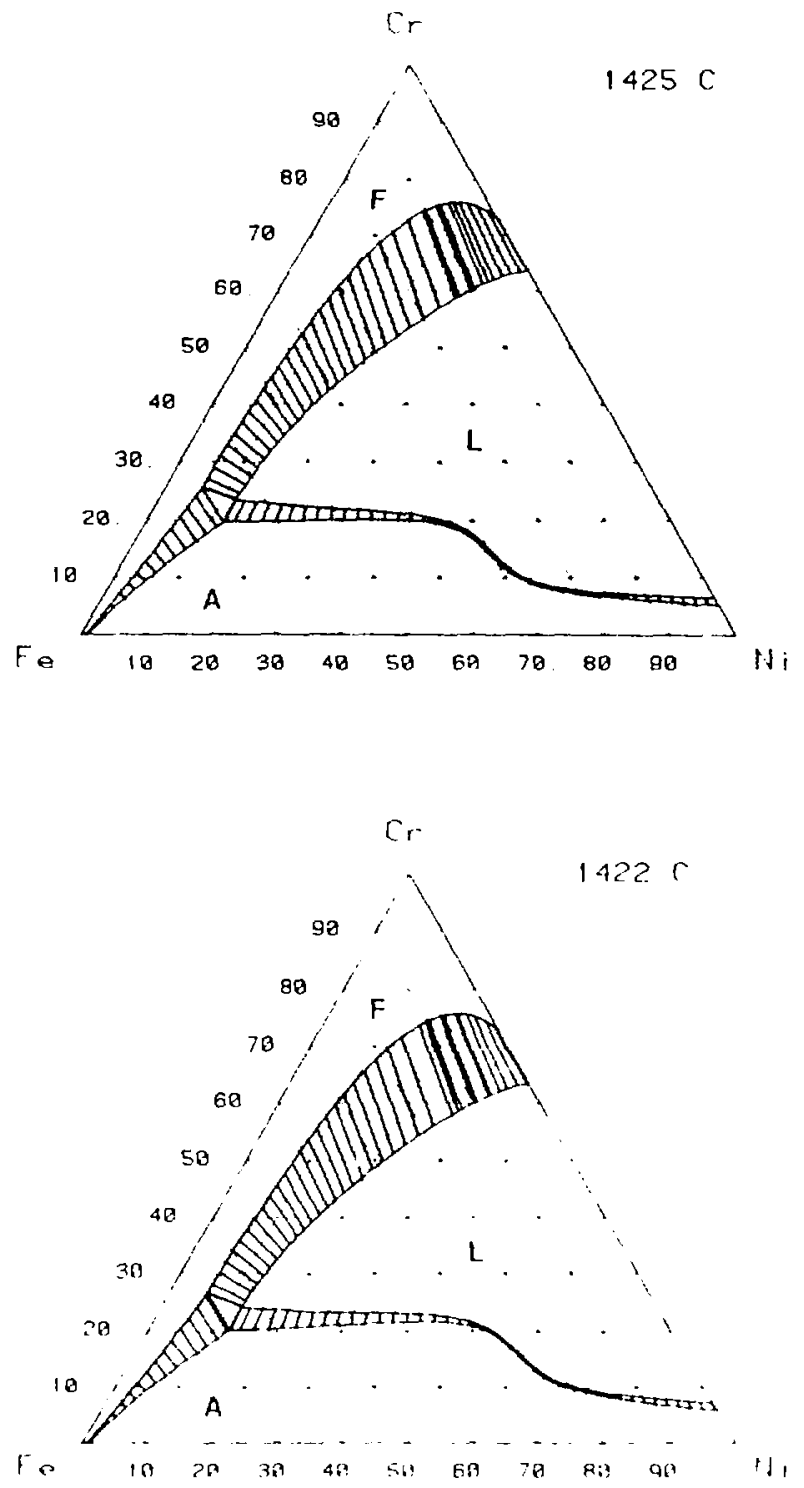

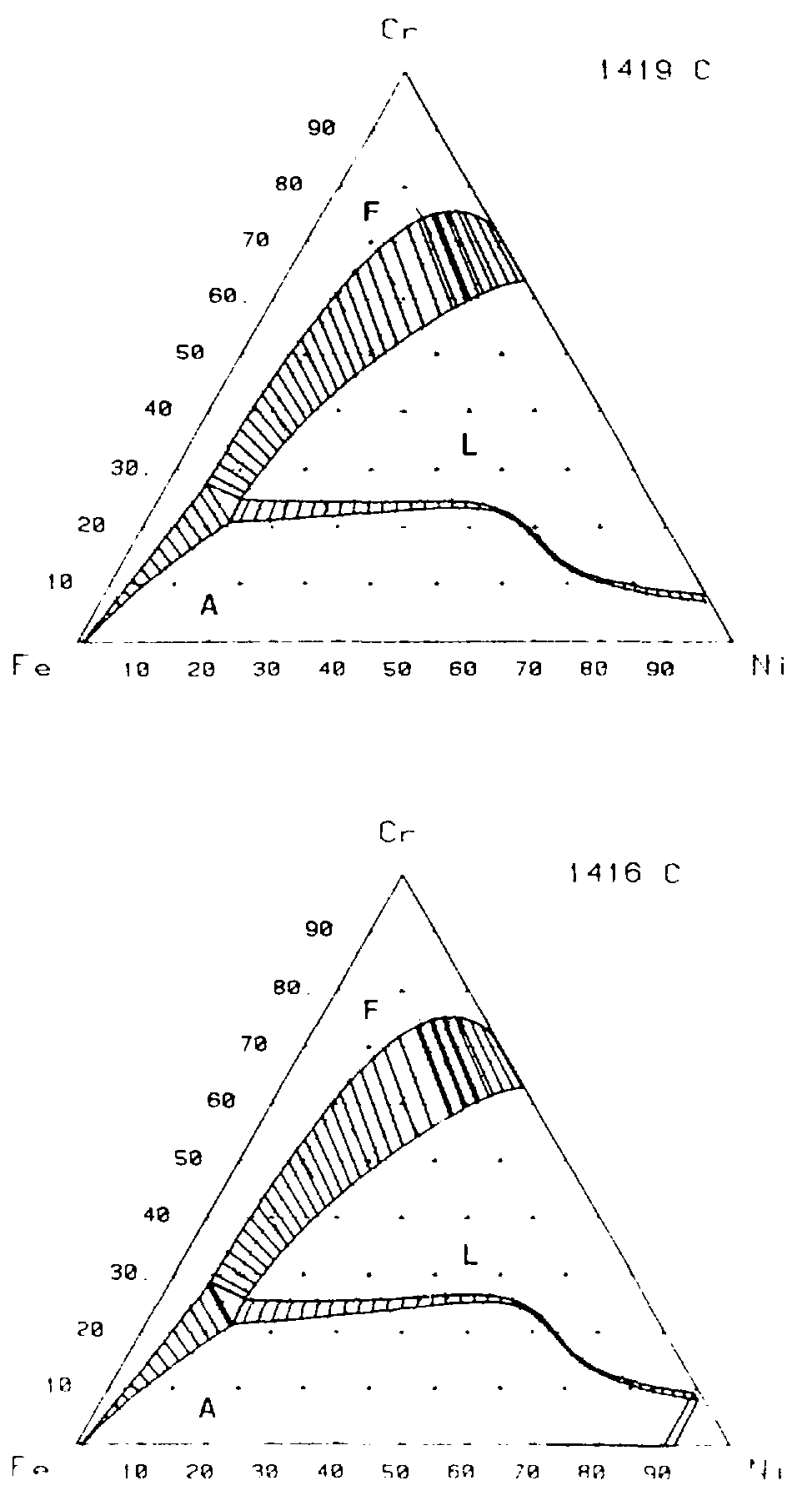

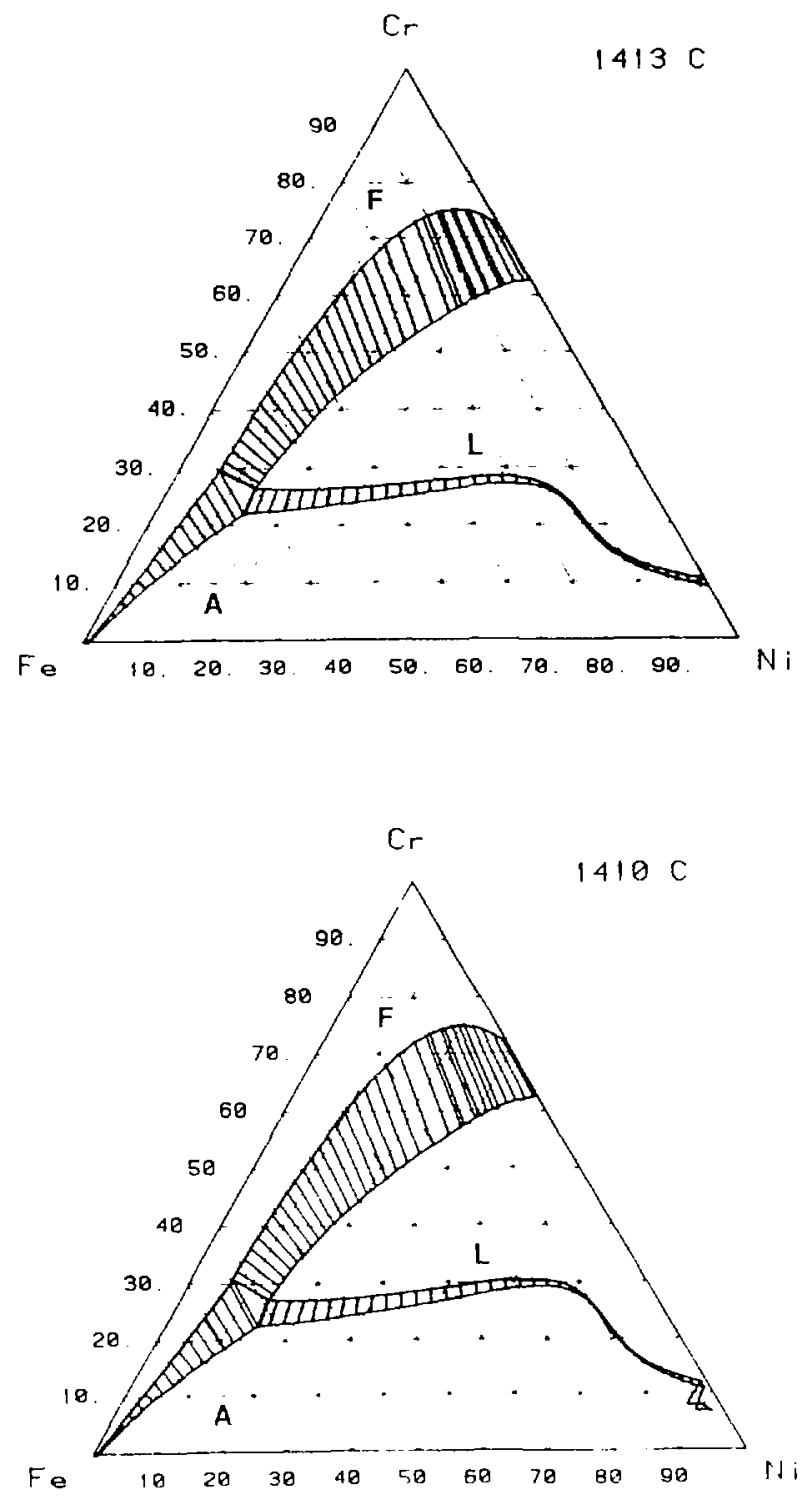

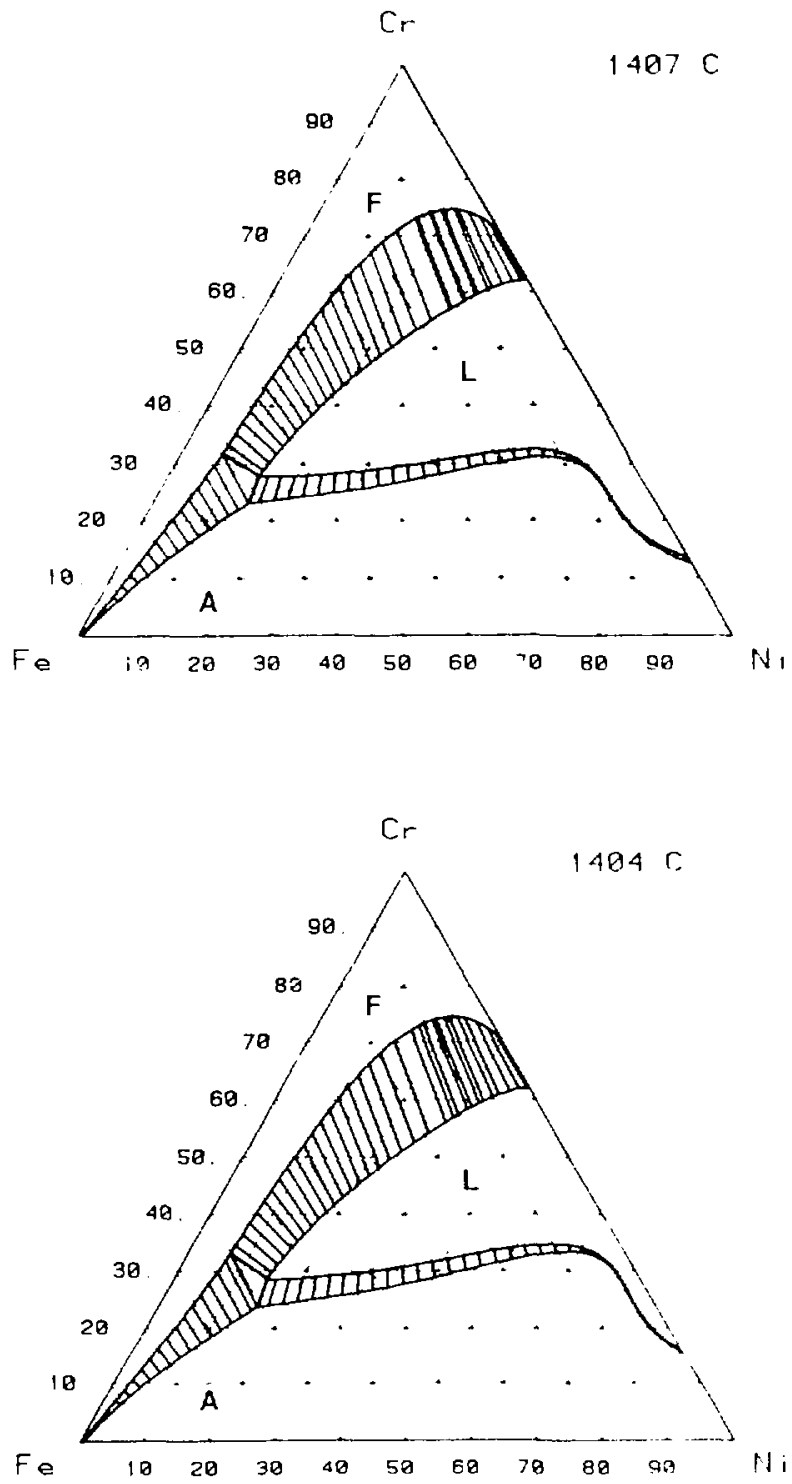

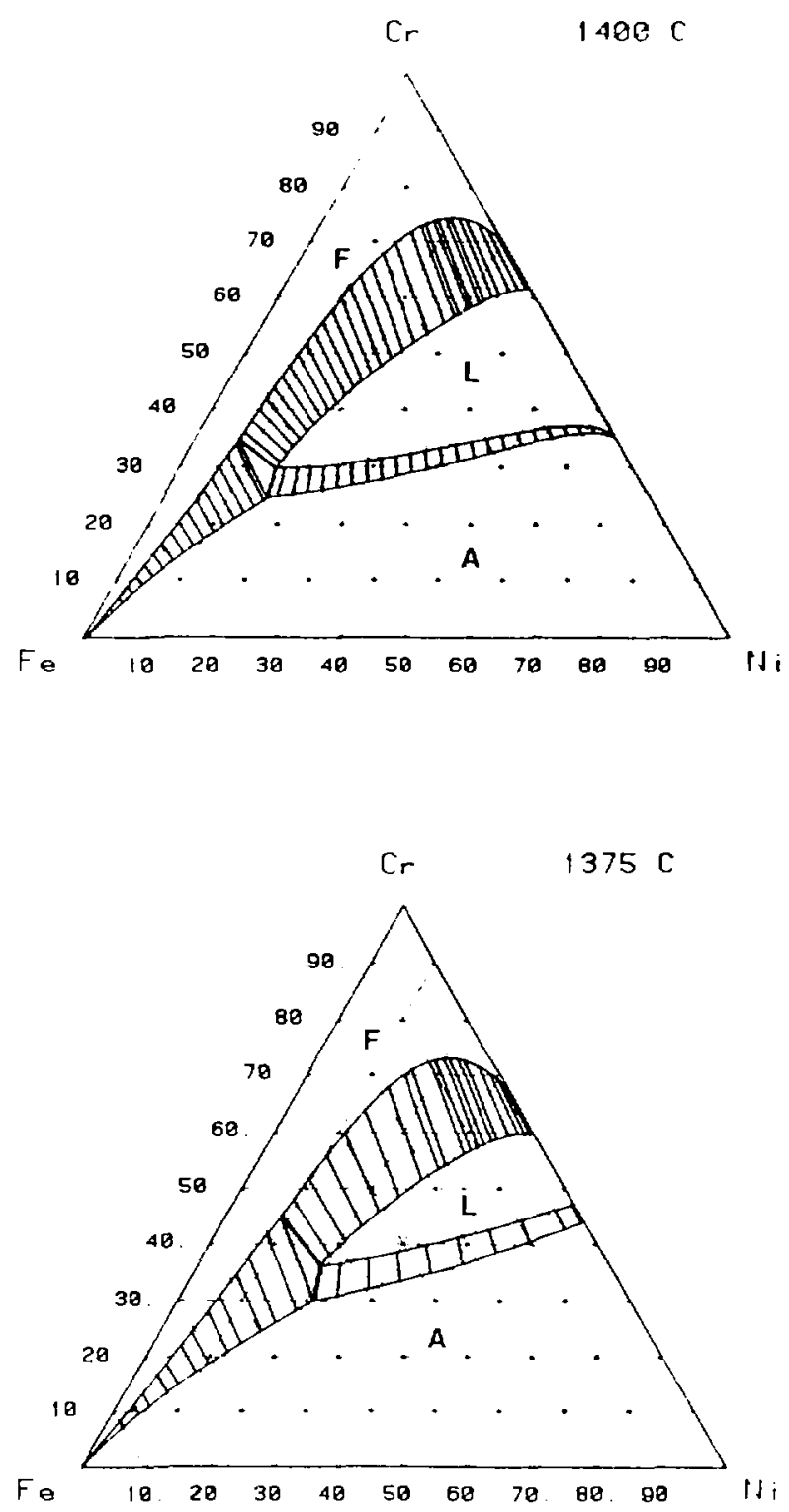

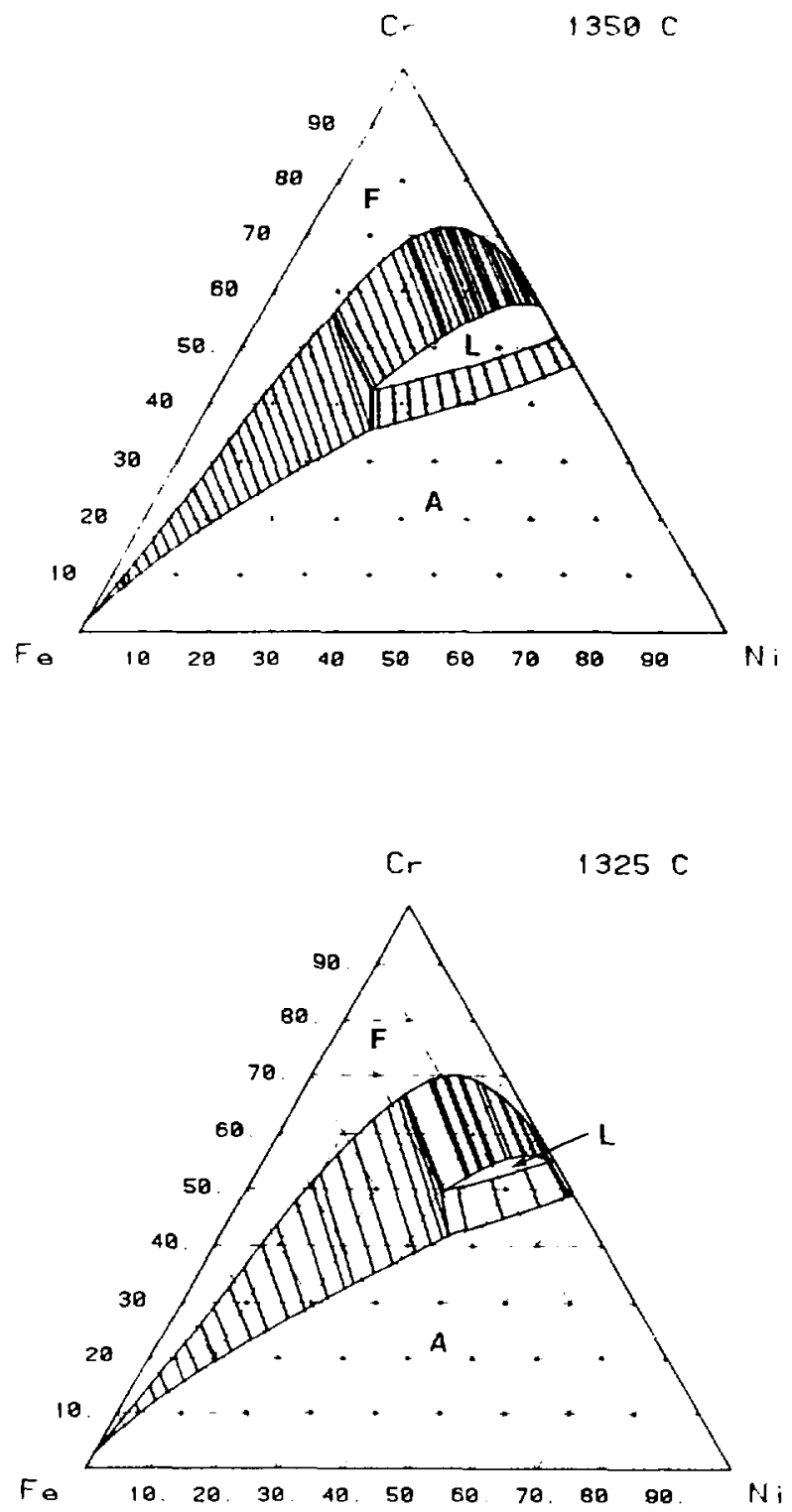

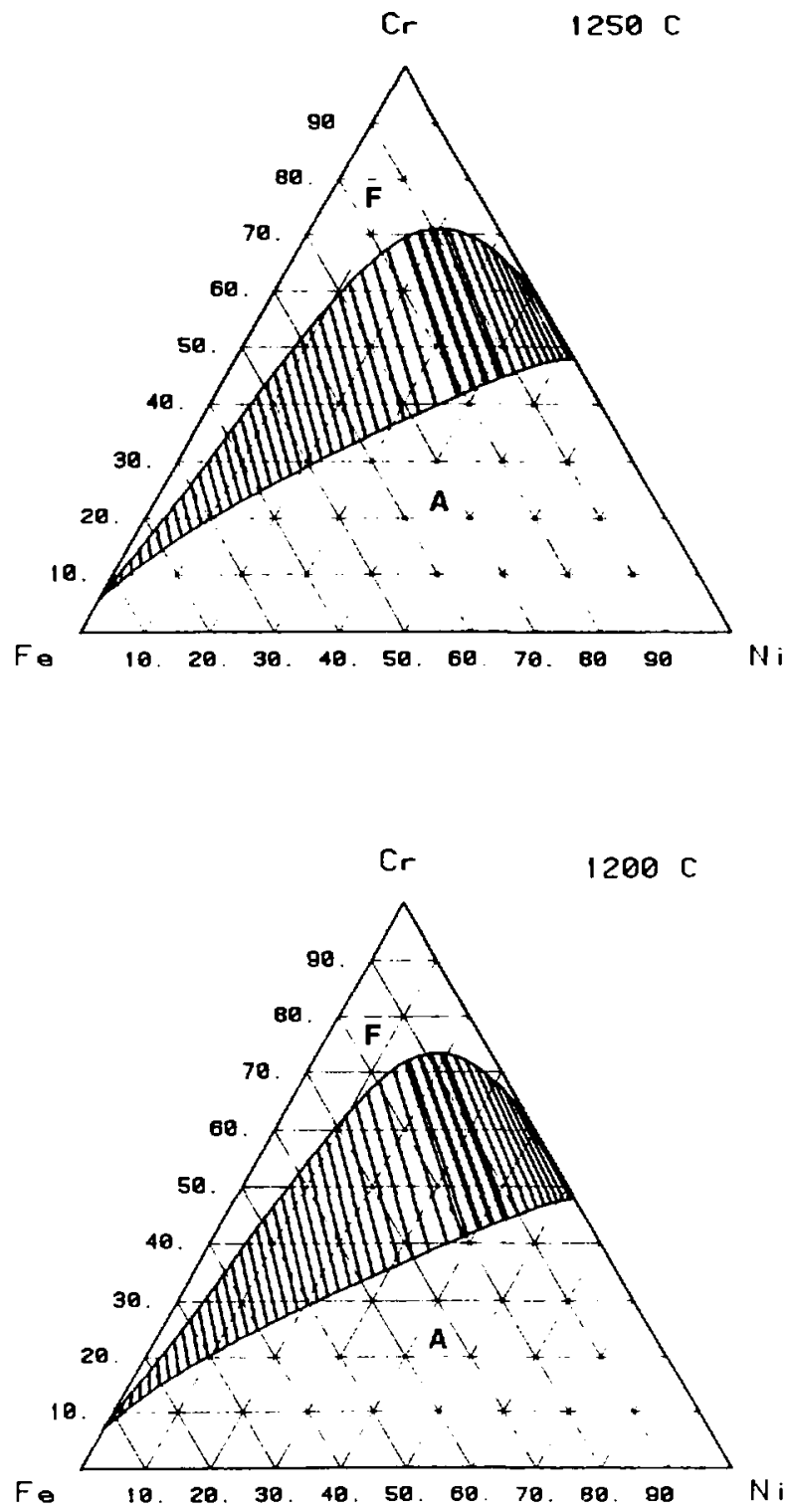

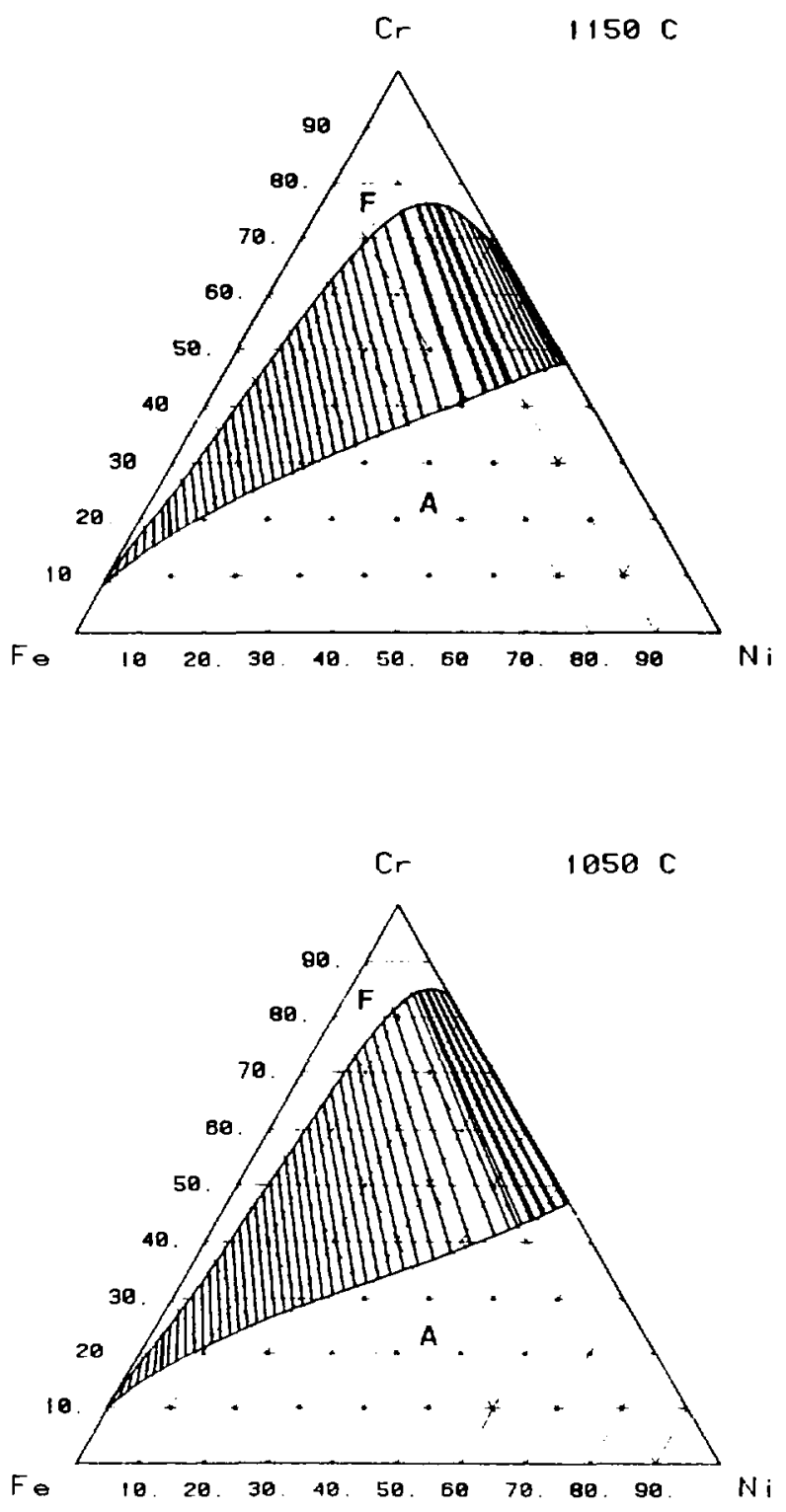

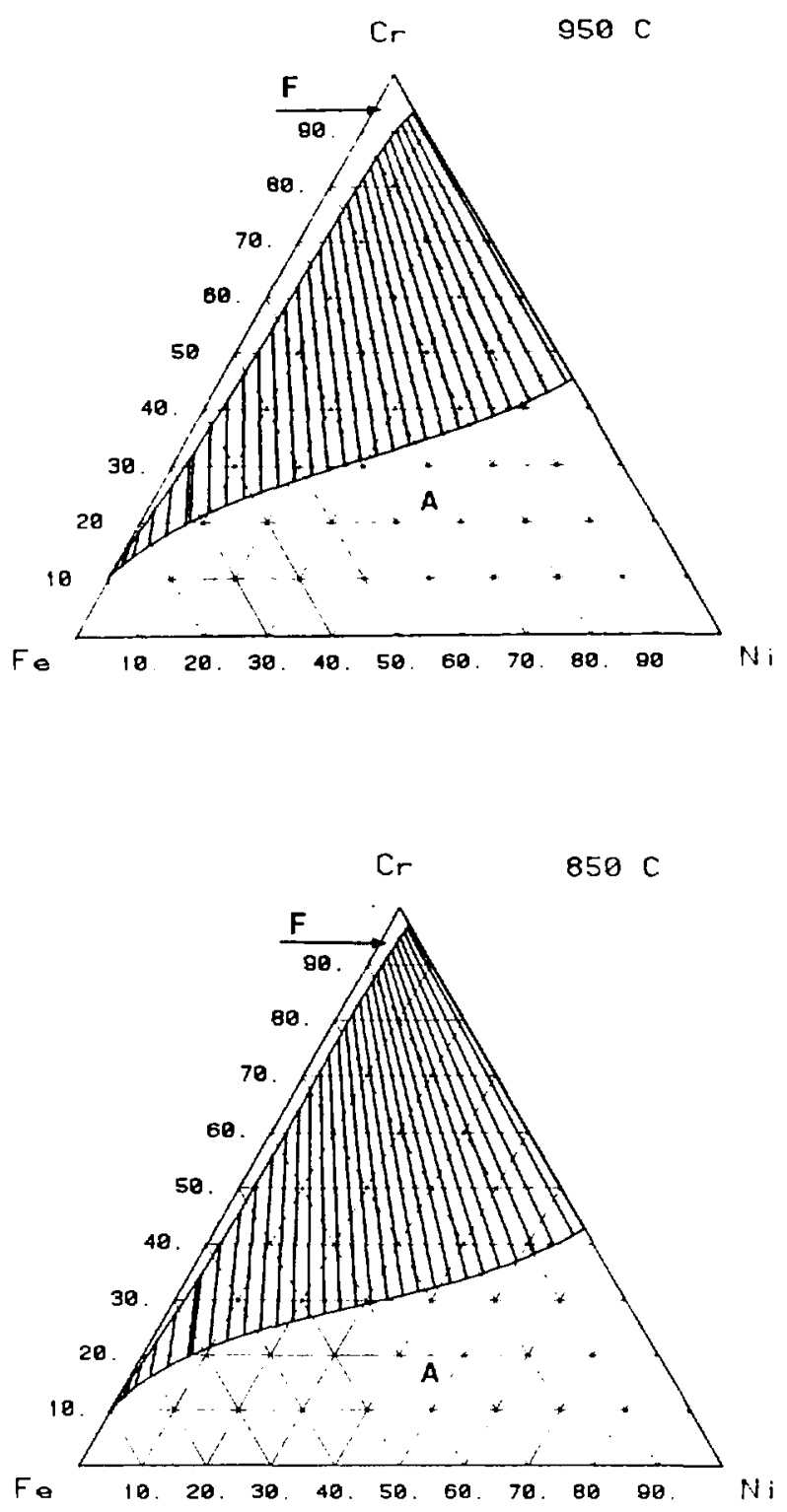
FERRIIF-IIQUID MEIASI +BIE FQIIIHHRII
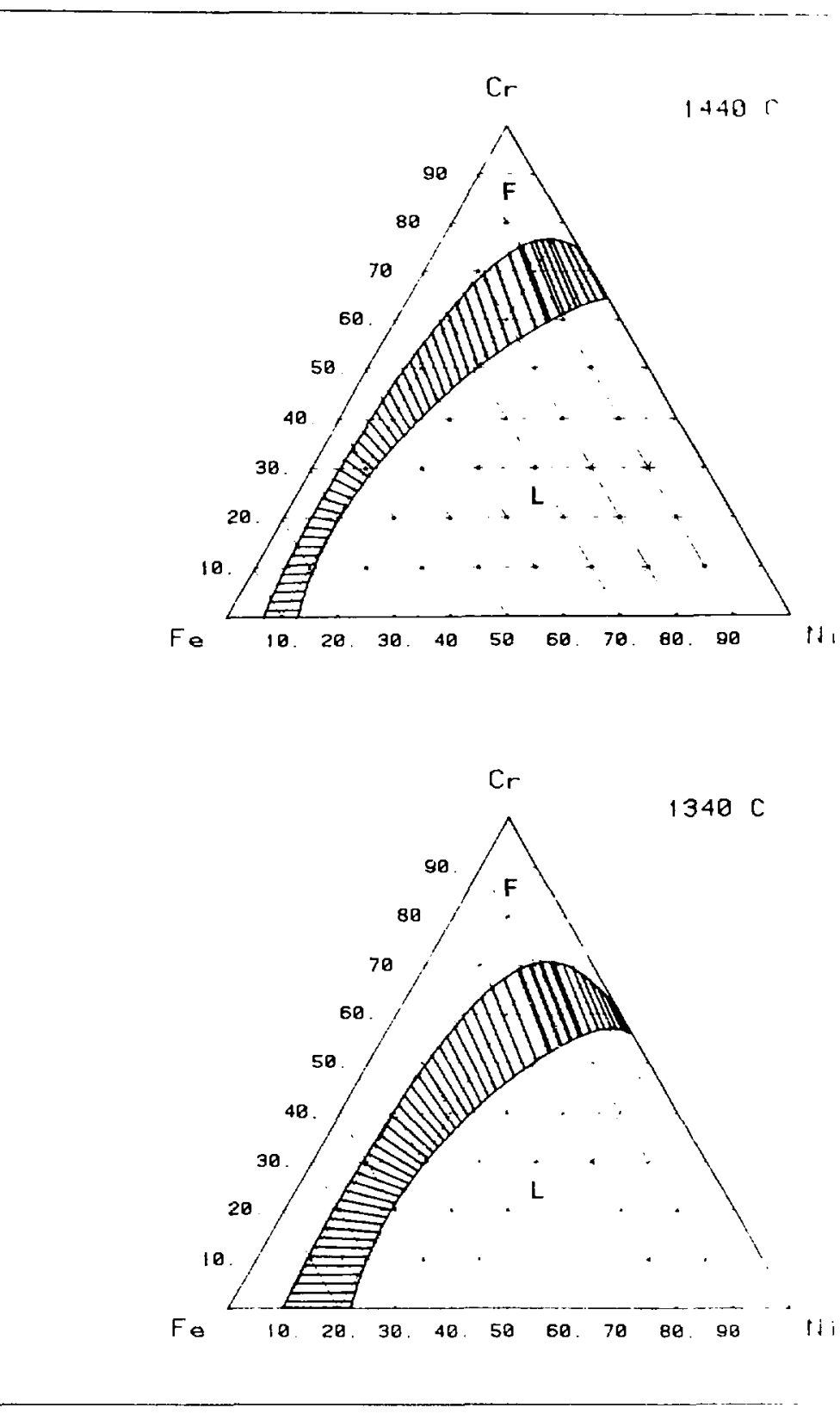

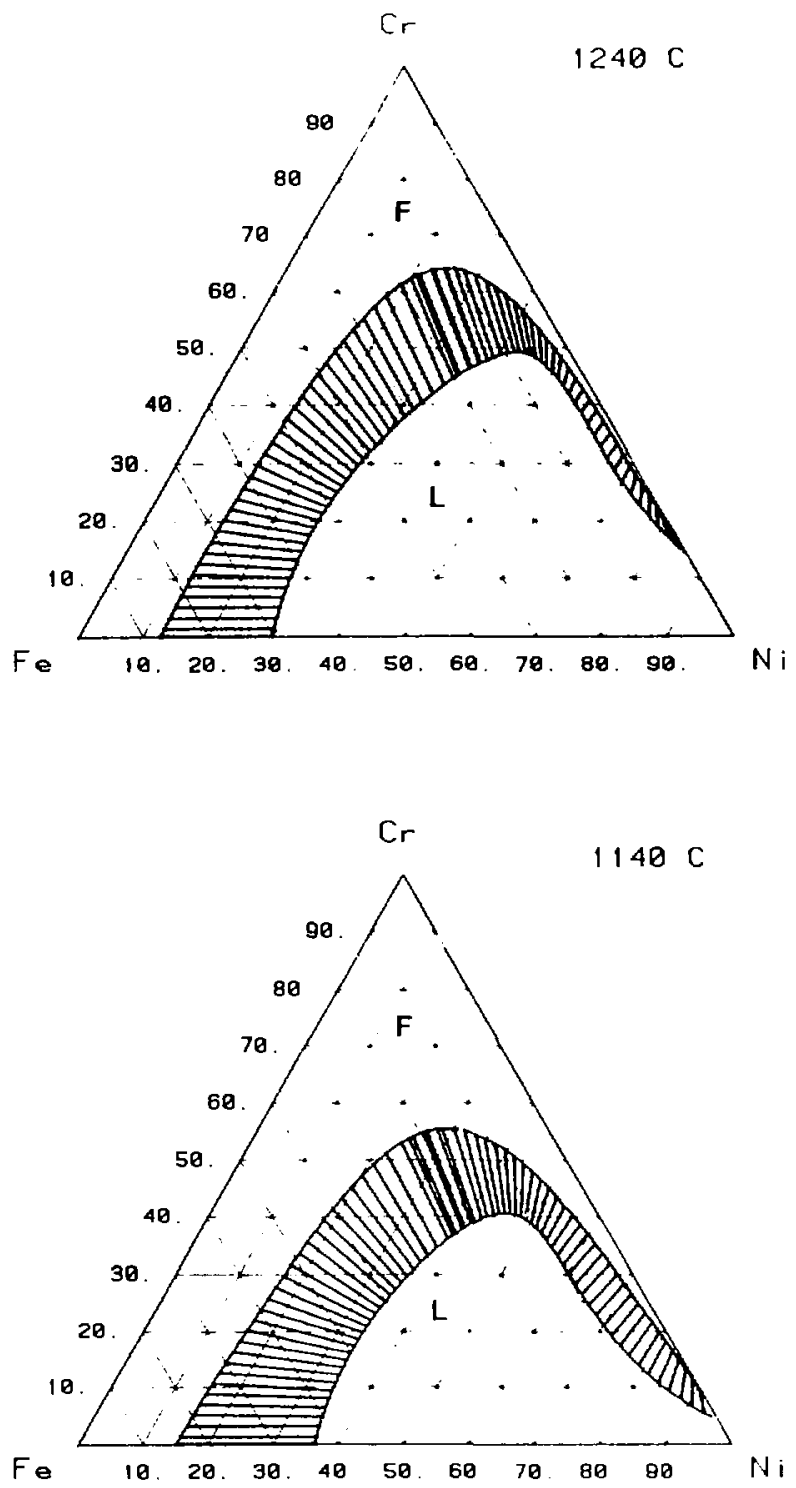

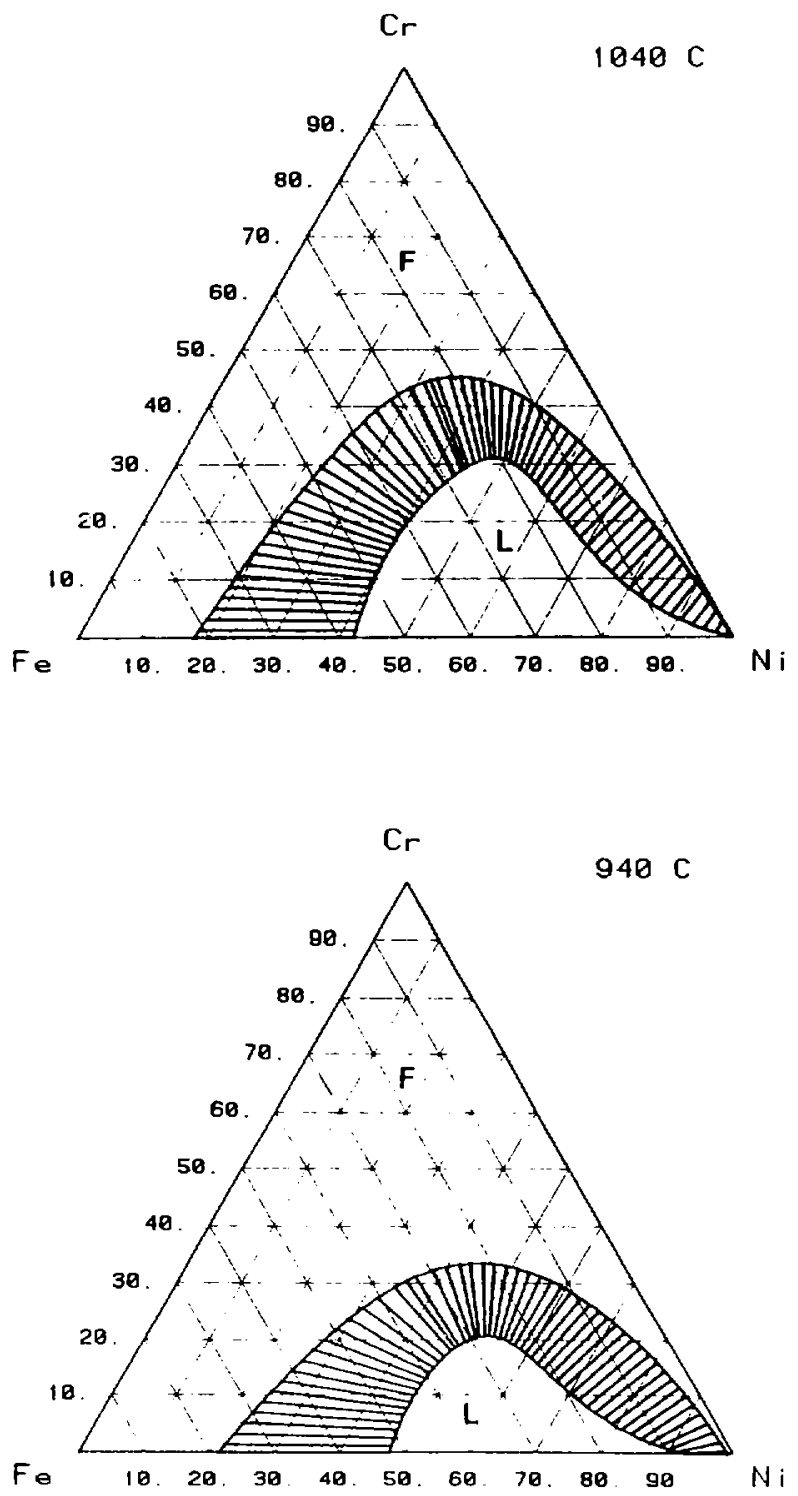

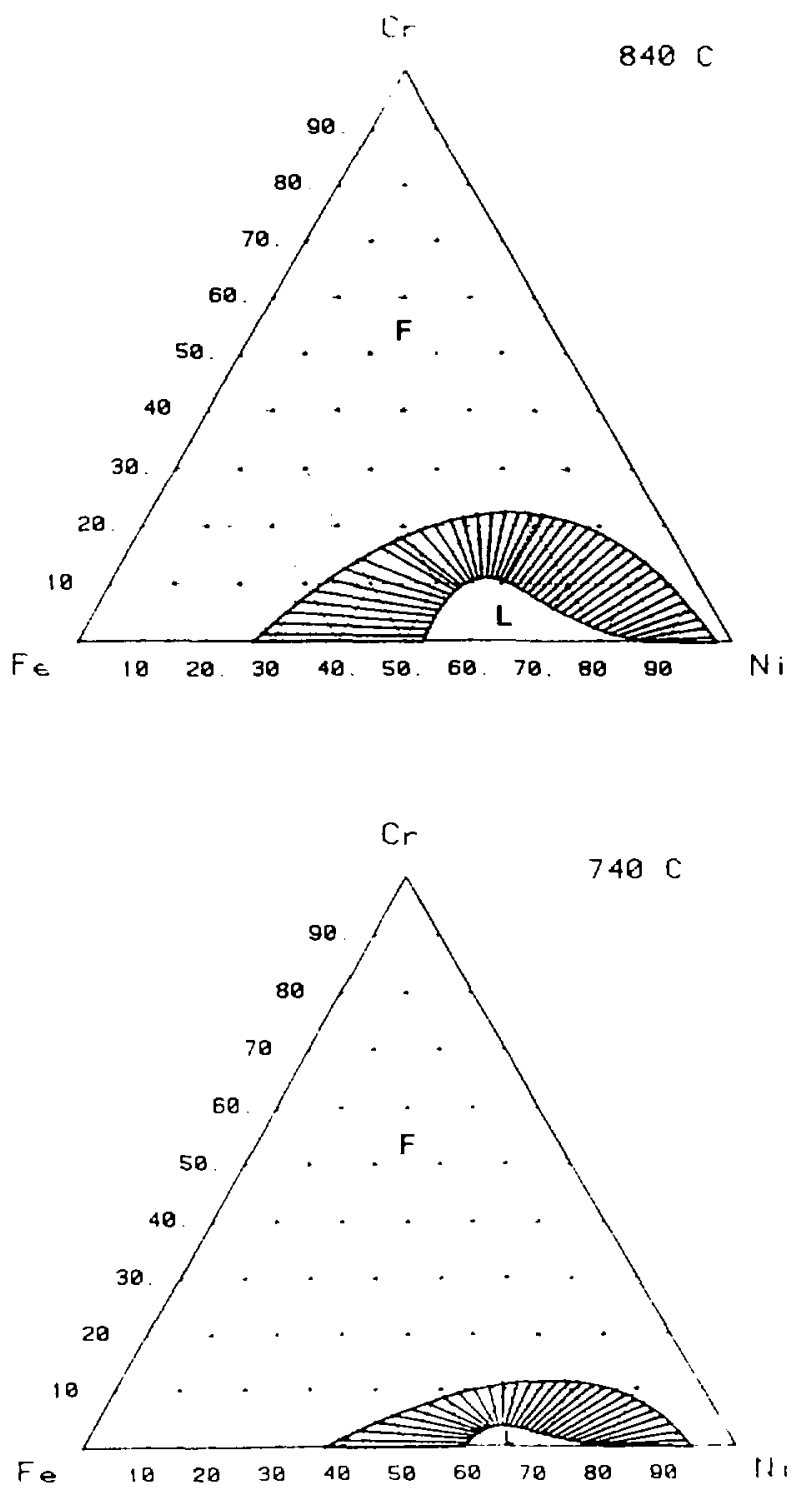


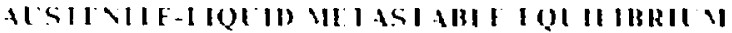
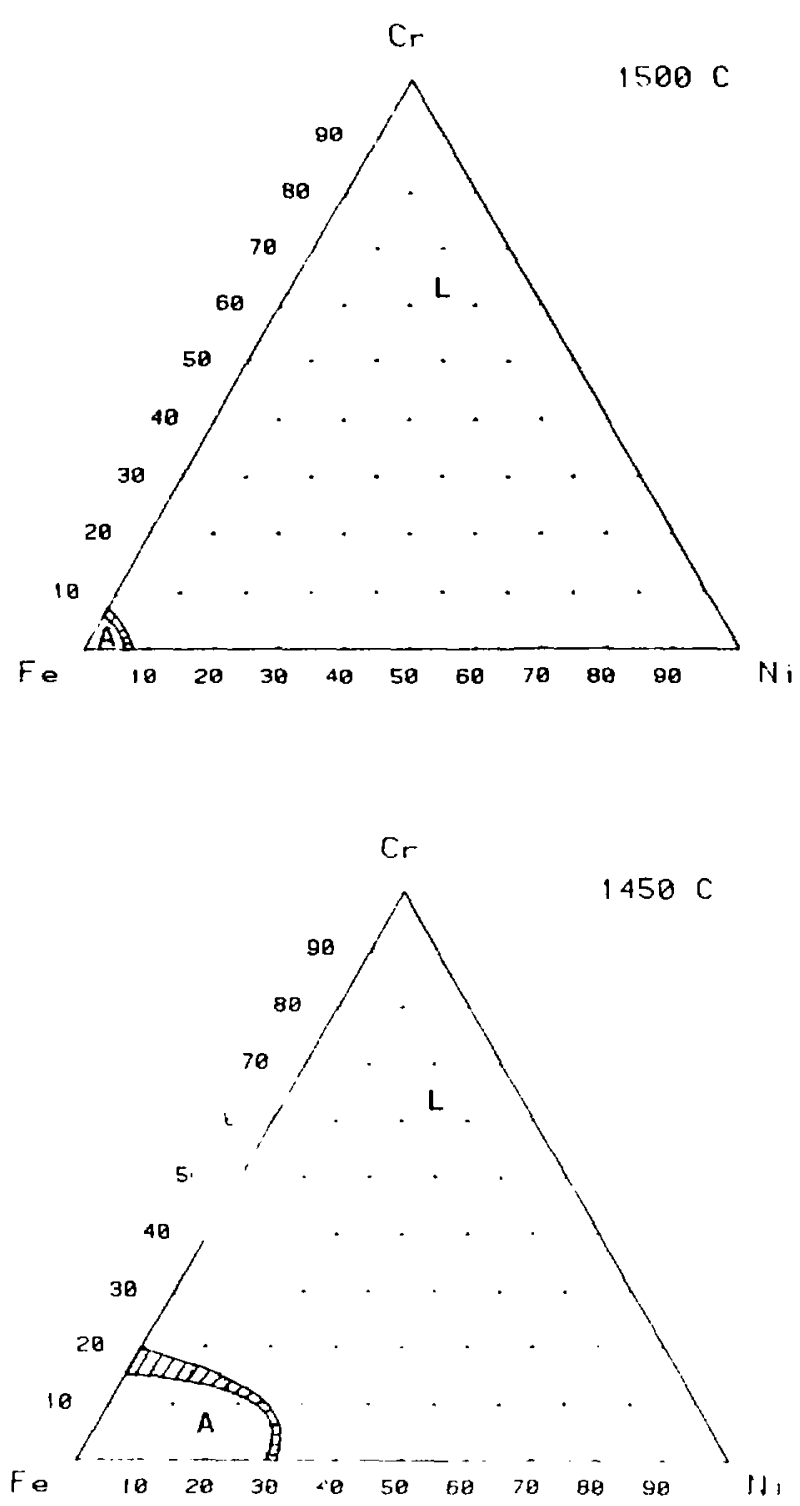

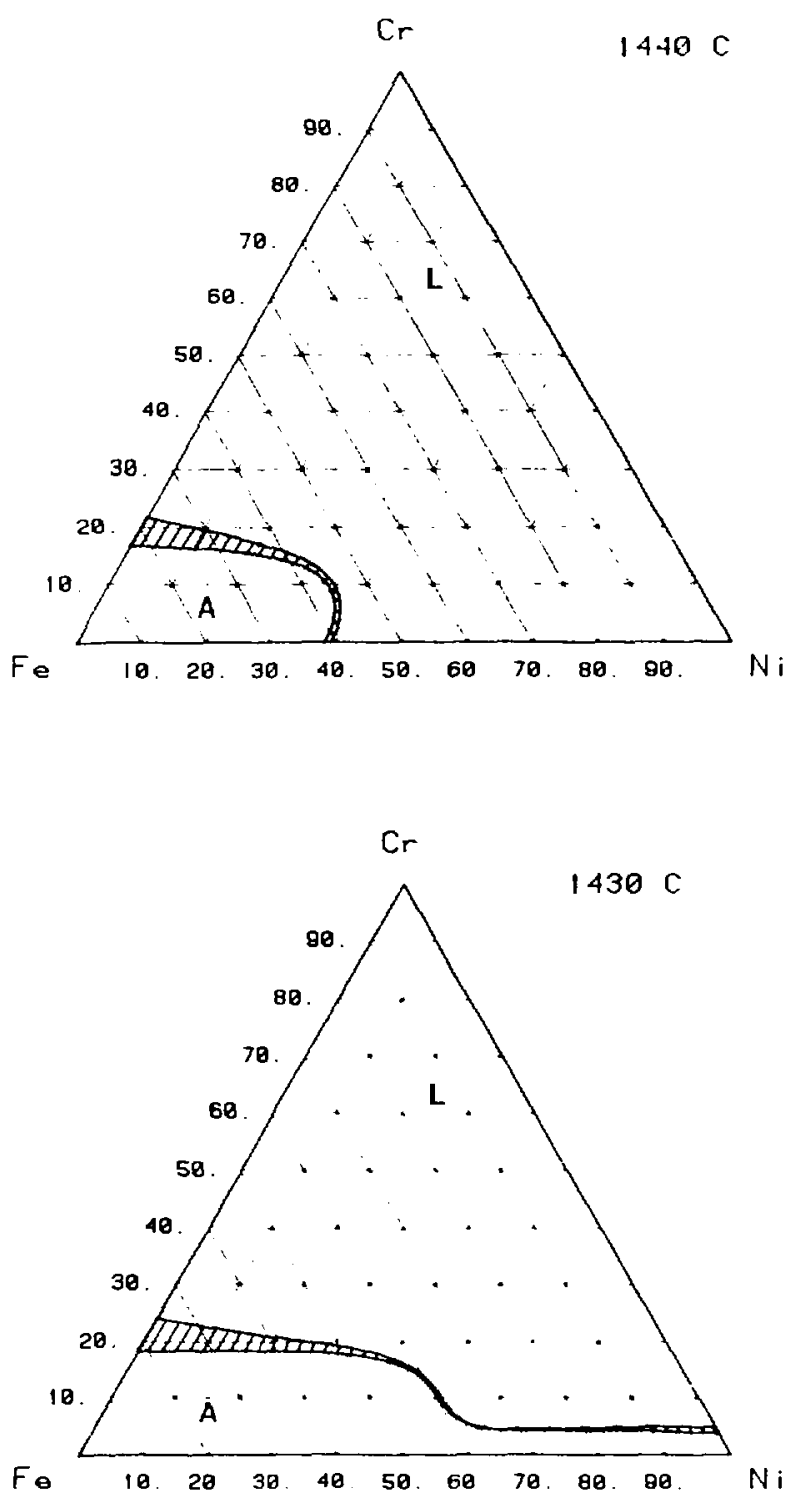

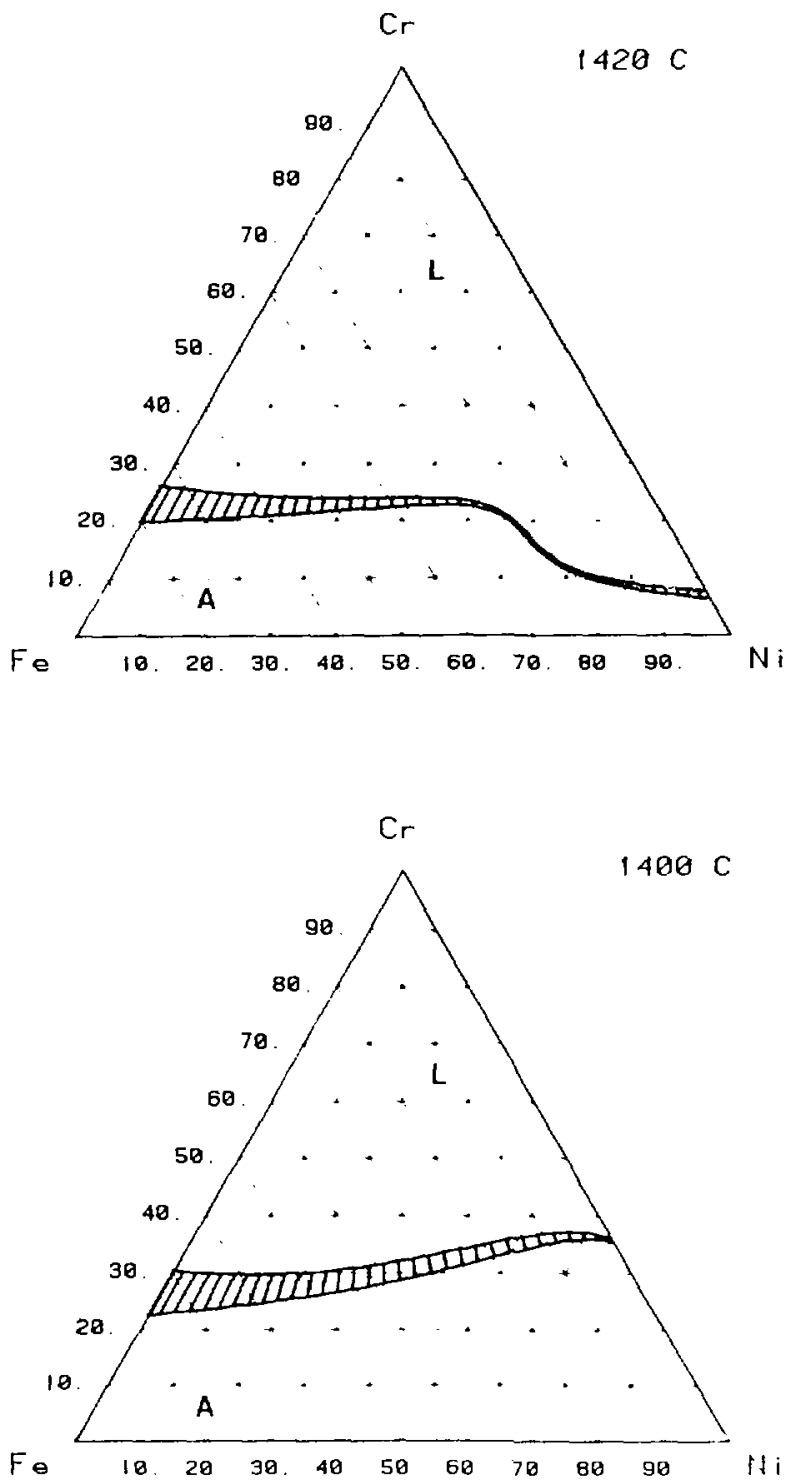

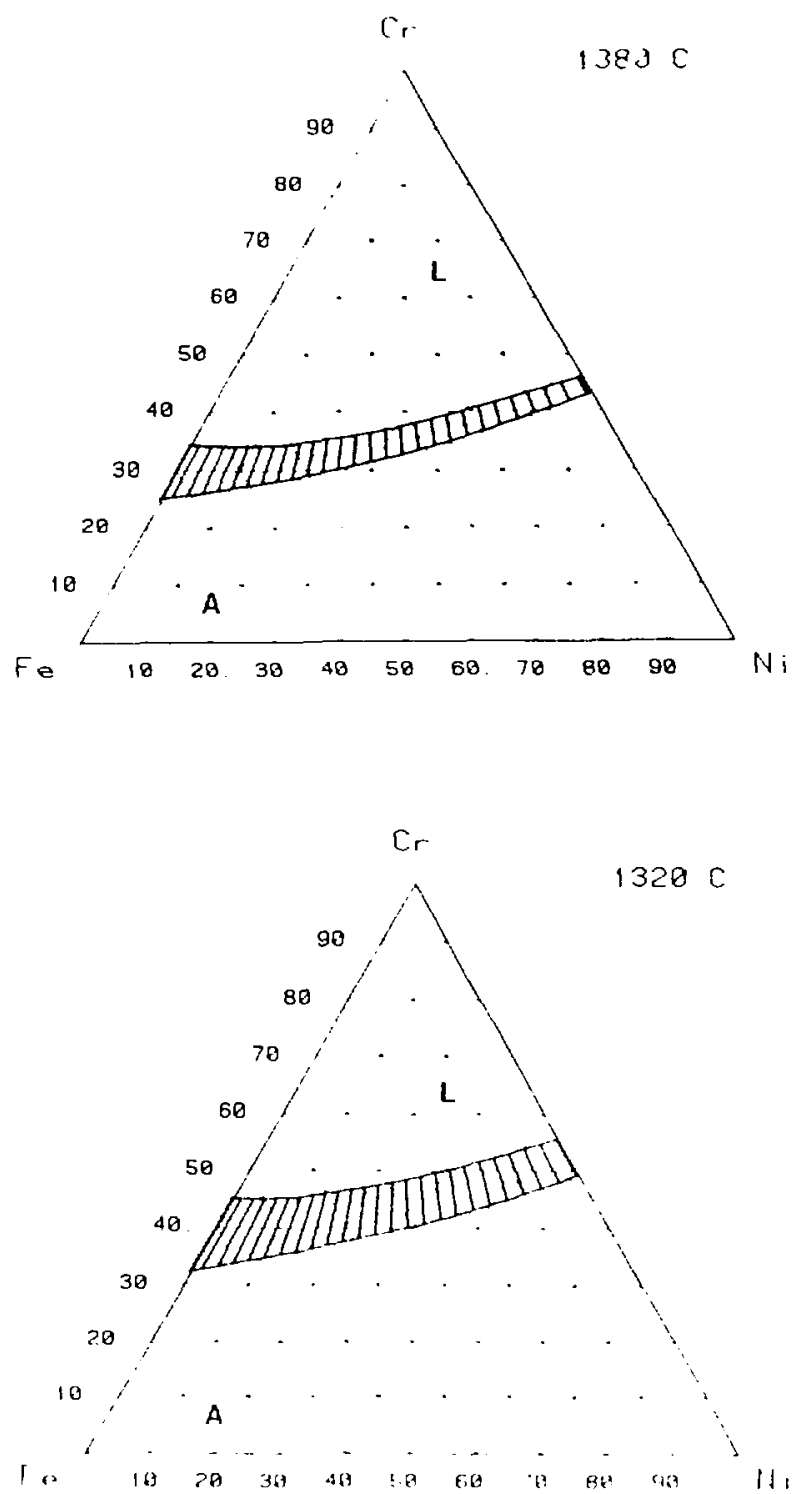

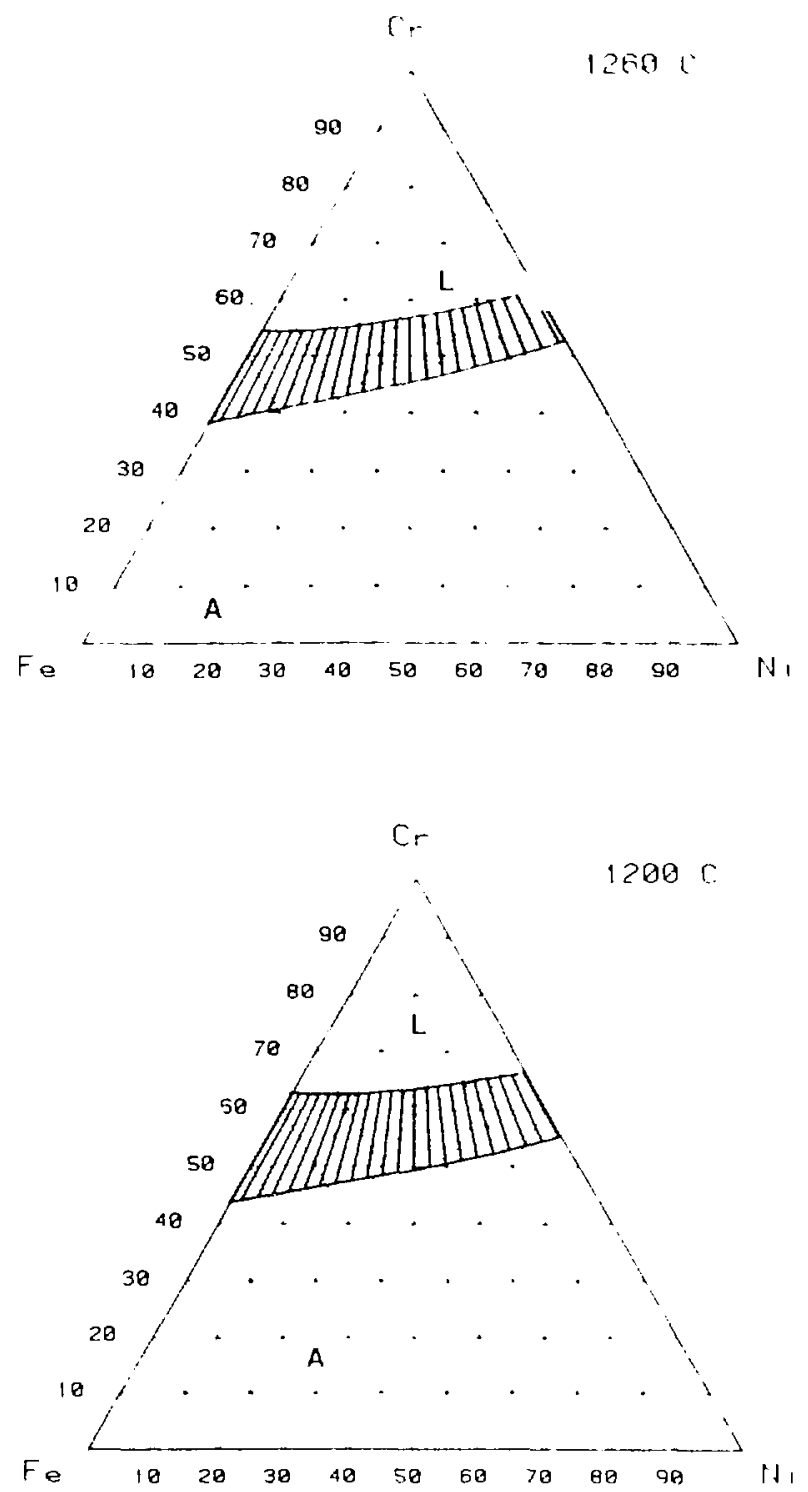

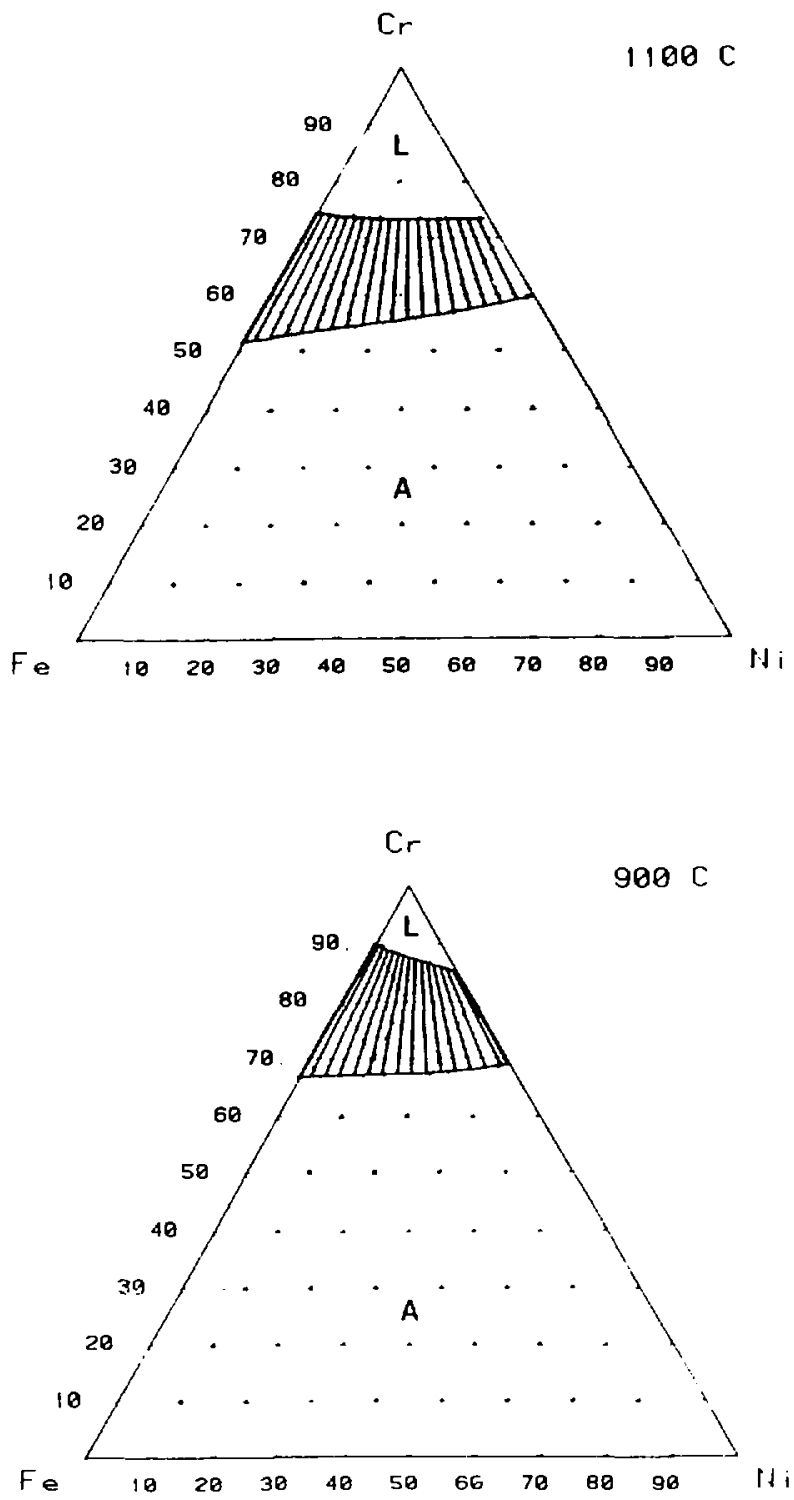


\section{APPENDIX D}

\section{Finite Difference Model for Diffusional Growth}

The lerrite to austenitc transiormation oscurs b! $a$ diffusion controlled mechanism for the majorits of conditions observed in this insestigatuon. This appendis set up the mathematical approach necessary to solse the governing diflusion citations in the Fe-Ni-Cr ternary system. The information provided in this appendiv is sufficicnt to declop a finite difference model of the iransformation which san be used 10 predict the rate and the cxtent of the ferritc to austenite transformation as a function of cooling ratc.

This phasc transiormation model applics to a tuo-phasc, ternary conponent system. The problem is complex because of the presence of three diffusing species, therelure. scime assumptions are made in order to simplif! the problem. Firstly, the sum of the lluses of the threc species will be assumed to be zero. This assumption is represented rs equation D.A and implies that Kirkendall-type vacancies are not created. Sccondly. the composition gradients in the transformed austenite will be assuned to be negligibly small. The dliving forec for the transformation under these conditions is serictly the composition differenec between ferrite and austenite at the interlace and no back diffusion from the transformed austenitc occurs. Third, diffusion will be assumed to occur for simple geometrics. Planar diffusion along the $x$-orthagonal axis is assumed for Widmanstatten austenite platelets while radial dilfusion in sylinderical coordinants is assumed for the transformation of ferrite dendrites.

The finitc difference method is separated into four sections:

I Input the arbitrary initial composition profilc.

Il Adjust the compositions at cach non-interface grid point using the boundary conditions at the interface and the diffusion cquation.

III Adjust the compositions at the interface using thermodynamic information. 
I) Acount for the mosing boundars, proced to the nest time increment and rencat steps II. III. Il as man! times asnecessar!

\section{Input Inirial Composilion Profile}

In a threc-iomponent sistem. the composition of two components must be specilied at each grid point. The two components to be specificd will be ( $r$ and Vi

sinec these hate the largest compositional differences petueen the austenite and forrite phases. Figure D.l illustrates a possible grid in which a full ferritic specimen is translorming to austenite. A unilorm ferrite composition is assumed and the composition af austenite at the interiace san be determined by the cquilibirum tic-line at the transformation temperature.

Although a uniform ferrite composition is depicted in Fig. D.l an! arbitrar! composition profile in the ferrite could be used without adding complexity to the somputalional meihod.

\section{I1. Idjusting the Composition of the Non-Interfacial Girid Points}

Grid point zero is located at the center of the specimen and at the first time step its composition corresponds to that of the austenite boundary condition. Grid point I is in the ferrite phase at the first time step and thus has a diflerent composition than grid point zero. This difference in composition provides a drising forec for diffusion and the flux between these points can be calculated using ficks first law of diffusion:

$$
h= \pm \cdot n \cdot\left(\begin{array}{l}
d r \\
d
\end{array}\right)
$$

where $k$ relers to $\mathrm{Cr}$ or $\mathrm{Ni}$. I relers to $\mathrm{Cr}$. Ni. and Fe. The subseript $\mathrm{i}$ refers to the lerrite or austenite phase, houever, since the flux in the austenitc phase is assumed to be small. only diffusion in the ferrite is considered. Other nomenctature used in this chapter is summarized in Table D.I. The flux of the third component (fe) can be determined lrom the flux balance: 
Ihe shange in composituon of grid punt l tue w the flux atine ... in.

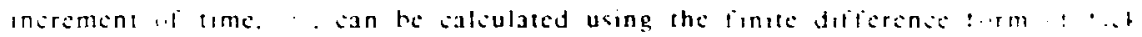
scosnd !au

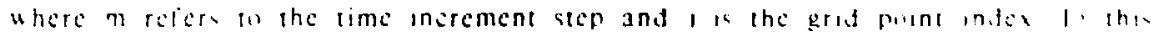

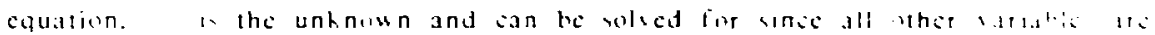

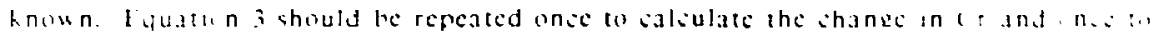

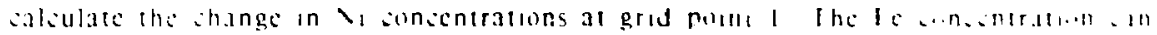
He alculatcith the masi balanec

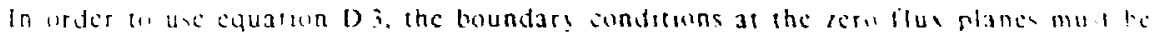

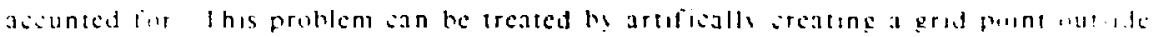
the ample and elong us composition cquat to the suriace concentratun

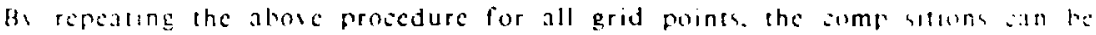

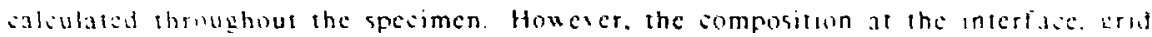

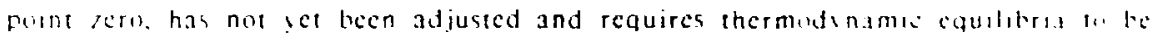
satulica in atfllon lo the hinctic considerations.

\section{Adjusting the Compositions at the Ferrite Austenite Interface}

As difusion necurs. the austenite phase gre:s and the austente ferrile interian adanses ints the ferrite. The celocity of the interlace motion is related to the flus of the dititusing elements

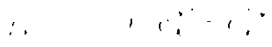

Thus. four set of hinctic equations need to he solved simulancuusls in urder t."

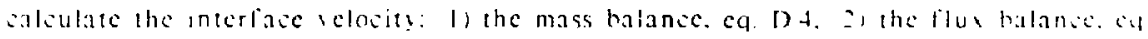

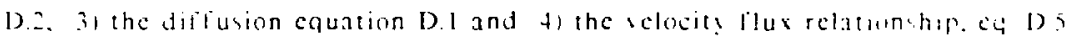

Starting with the dillusion equations in the ferrite phase

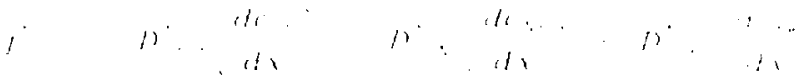




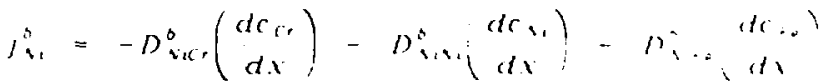

$$
\begin{aligned}
& \hat{J}_{F_{0}}=-J_{V}-j_{c}^{0} \quad \text { (flus balance) }
\end{aligned}
$$

and substituting the differential form of the mass balance.

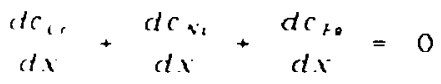

the flux of $\mathrm{Cr}$ and $\mathrm{Ni}$ can be equated to their concentration gradients

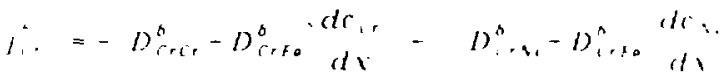

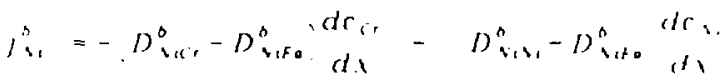

Equation's D.6 and the following velocity-flux relationships :

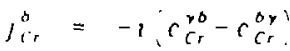

$$
\begin{aligned}
& \rho_{v_{i}}=-1 r_{s i}^{\gamma_{1}}-c_{s i}^{\delta}
\end{aligned}
$$

can be solved simultaneously for the interface velocity:

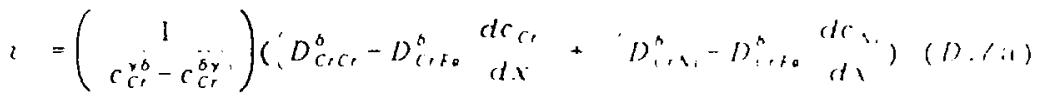

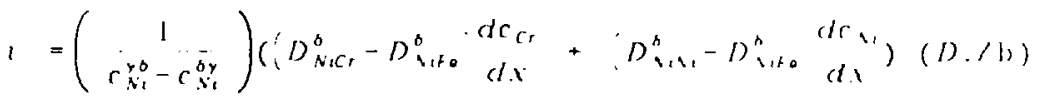

Equations D.7a and D.7b each represent the interiace velocity and the phasc transformation problem appears to be overspecificd. That is, a given tie linc fixes $\therefore-\because:$ and $r:-1:$ which specifies all variables on the right hand side of both equations. Therefore, there appears to be two independent means of calculating the velocity.

However, in the ternary system, tic-line movement involves one degree of freedom and can be used to "adjust" $e^{\prime \prime}-c^{\prime}$ : and $r:-r$ so that both equation D.7a and D.7b can be satisfied with a common velocity. Movement of the tic-line must satisfy thermodynamic cquilibrium at the interface:

$$
C_{k}^{*}=C_{k}^{*}
$$


where the partial molar Gibbs energy for component $k$..- is a function al temperature and composition. Expanding equation D.8 into its standard Gibbe energ: and aetisit? somponents gives:

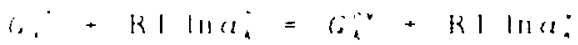

where $k$ relers to $\mathrm{Ni}, \mathrm{Cr}$ and Fe.

Equations D.73. D.7b and D.9 must be solved simultancously to ohtain the interiace composition and vclosit!. Thereforc. a means of detcrmining . $\therefore . .$. and . as a function of tempcraturc and and .. must be cstablished. Thermudinamic data lor $\mathrm{F} e \mathrm{Ni}$, and $\mathrm{Cr}$ are reported as a function of temperature by Chuang and Chang [D.1]. From these data. the standard free energy and activity coefficicnts can lic caliulated.

An alternative scheme for detcrmining the tic-line location could be used to incorporate the previously determined tie-lines in the Fe-Ni-Cr system. These tic-lines are summarized in Appendix $C$ and could be used as a substitute for equation D.9. This approash is less flexible in the sensc that only those tempcratures where the isothermal scetions werc calculated are available and the tic-lincs at other temperatures would have to be interpolated from the cxisting data.

\section{V. Accounting for the Moving Boundary}

The composition at all the grid points and at the interface has been adjusted to satis? involves a moving boundary. additional adjustments must be made to the grid in order to kecp the same number of grid points in the ferrite phase. Therefore. a grid transformation must be accomplished in which the spacing betwecn points is transformed. Since each grid point moves, the composition at each point must also be readjusted. These manipulations are common to moving-boundary problems and details are not necessary here.

The time increment should be increased onc step, $t^{\prime}=t+1$, and the program should be repeated from step 11 using the new interface composition as a boundary condition and the new composition profile. 


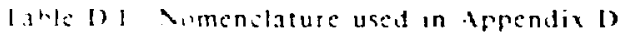

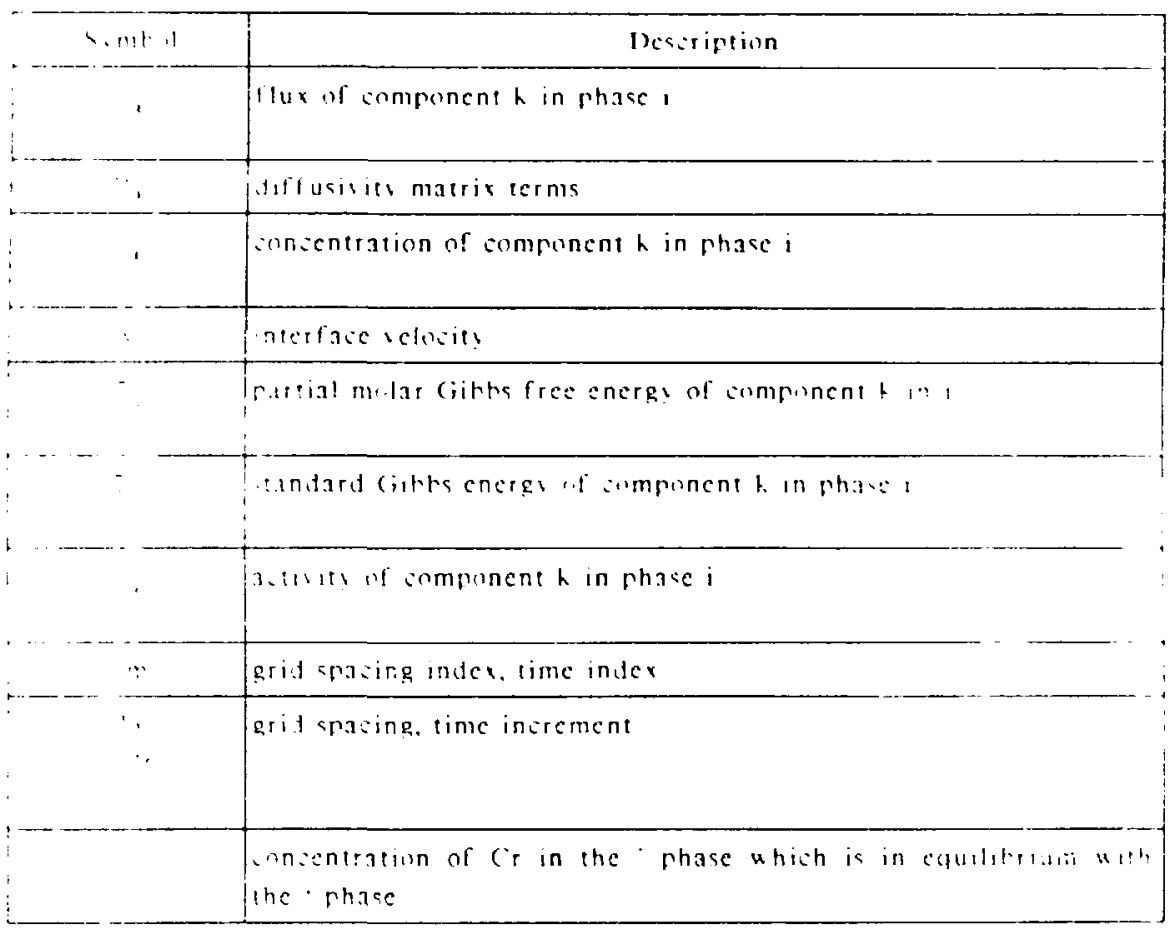

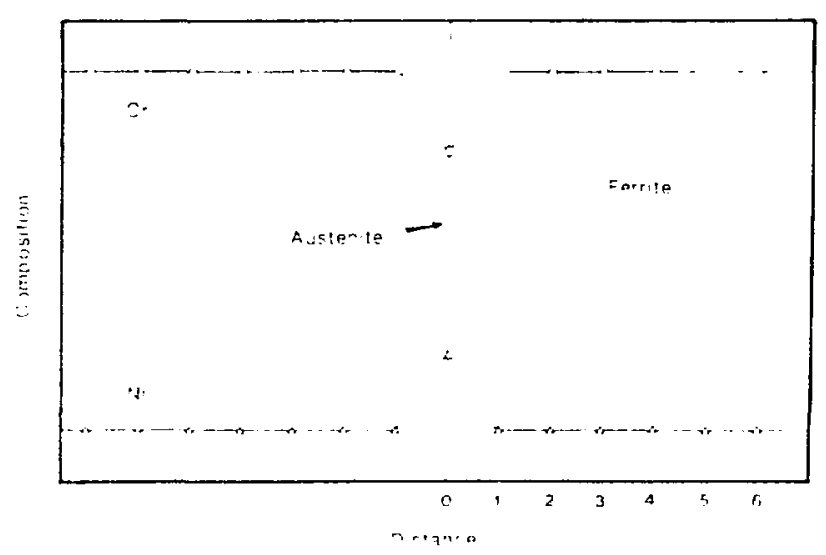

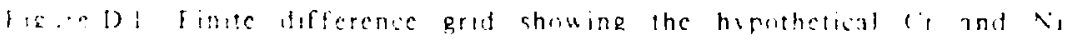

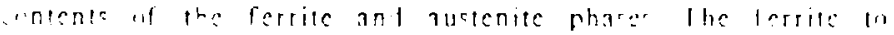

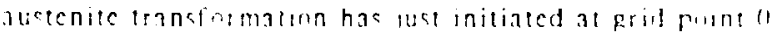




\section{APPENDIX E}

\section{Dendrite Tip Calculations}

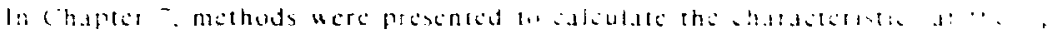

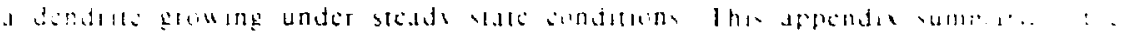

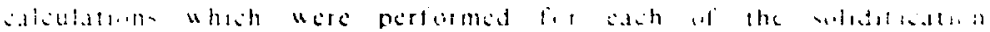

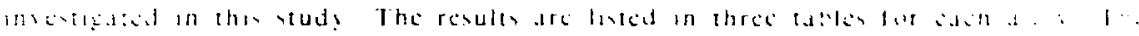

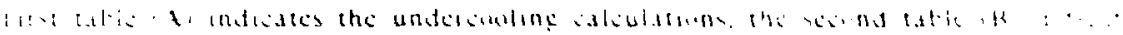

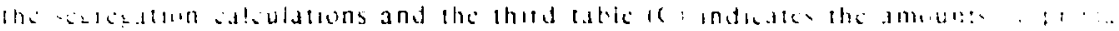

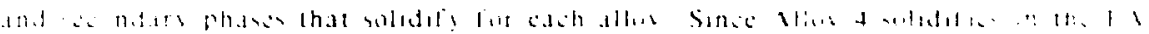

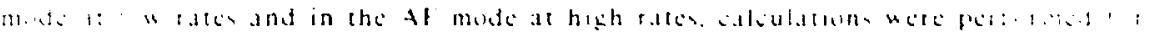

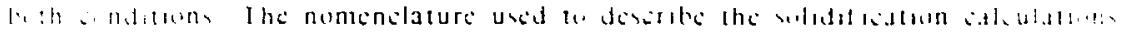
-

Deserapton of the iatiables

\begin{tabular}{|c|c|}
\hline & undcisuling causcd bs lip radiu \\
\hline$\cdot$ & underoobling saused bs soluial clicis \\
\hline$\cdot$ & lutal undercooling \\
\hline$\cdots$ & 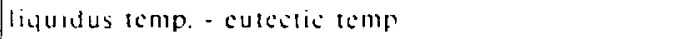 \\
\hline$\therefore$ & Actual undercooling belou the culc:ta lsmpetslute \\
\hline$i_{1}$ & 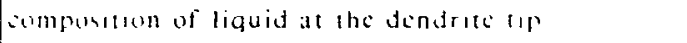 \\
\hline 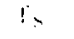 & 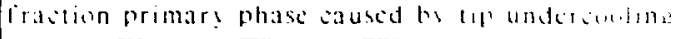 \\
\hline it. & trastion cutcitic liquid \\
\hline .1 .1 & isuicnile. lersate \\
\hline P... I & 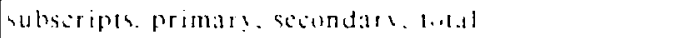 \\
\hline
\end{tabular}


D.IA: Alloy I C'ndercooling Ealiulations

\begin{tabular}{|c|c|c|c|c|c|}
\hline Melt & $\begin{array}{l}1 \% \\
(k)\end{array}$ & $\begin{array}{l}11 \\
(k)\end{array}$ & $\begin{array}{l}1 /: \| \\
(k)\end{array}$ & $\begin{array}{l}1 i \\
(k)\end{array}$ & $\begin{array}{l}11 \\
(k)\end{array}$ \\
\hline Cast & 0.46 & 7.25 & 7.71 & 46 & - \\
\hline E-B I & 1.30 & 12.1 & 13.4 & 46 & - \\
\hline$E-B=$ & 1.35 & 12.4 & 13.7 & 40 & - \\
\hline F-B 3 & 2.24 & 15.3 & 17.5 & 40 & - \\
\hline$E-B+$ & 3.96 & 18.7 & 22.6 & 40 & - \\
\hline E-B 5 & 5.65 & 20.7 & 26.4 & 40 & - \\
\hline$E-B 6$ & 7.11 & 22.2 & 29.3 & 40 & . \\
\hline
\end{tabular}

Table D.IB: Alloy I Segregation calculations

\begin{tabular}{|c|c|c|c|c|c|c|}
\hline Ileit & $C_{L}^{*}$ & $f_{B}$ & $f_{E}$ & $A_{P}$ & $A_{S}$ & $F_{B}$ \\
\hline Cast & 23.30 & 0.279 & 0.17 & 0.82 & 0.12 & 0.05 \\
\hline E-B 1 & 24.17 & 0.448 & 0.15 & 0.85 & 0.12 & 0.05 \\
\hline E-B 2 & 24.23 & 0.460 & 0.15 & 0.85 & 0.12 & 0.05 \\
\hline E-B 3 & 24.74 & 0.553 & 0.14 & 0.86 & 0.13 & 0.04 \\
\hline E-B 4 & 25.34 & 0.659 & 0.12 & 0.88 & 0.13 & 0.04 \\
\hline E-B 5 & 25.71 & 0.721 & 0.10 & 0.90 & 0.14 & 0.03 \\
\hline E-B 6 & 25.93 & 0.761 & 0.09 & 0.91 & $0 ! 4$ & 0.03 \\
\hline
\end{tabular}

Table Dl.C: Alloy 1 \% Primary and secondary phases

\begin{tabular}{|c|c|c|c|c|c|c|}
\hline $\begin{array}{c}\text { Solidification } \\
\text { Condition }\end{array}$ & $F_{P}$ & $F_{S}$ & $F_{T}$ & $A_{P}$ & $A_{S}$ & $A_{T}$ \\
\hline Equilibrium & 0 & 0 & 0 & 100 & 0 & 0 \\
\hline Scheil & 0 & 5.80 & 5.80 & 82.0 & 12.2 & 94.2 \\
\hline Cast & 0 & 5.27 & 5.27 & 8.3 & 11.7 & 94.7 \\
\hline E-B 1 & 0 & 4.65 & 4.65 & 85 & 12.3 & 95.3 \\
\hline E-B 2 & 0 & 4.60 & 4.60 & 85 & 12.5 & 95.4 \\
\hline E-B 3 & 0 & 4.30 & 4.30 & 80 & 12.8 & 95.7 \\
\hline E-B 4 & 0 & 3.70 & 3.70 & 88 & 13.2 & 96.3 \\
\hline E-B 5 & 0 & 3.10 & 3.10 & 90 & 13.9 & 96.9 \\
\hline E-B 6 & 0 & 2.79 & 2.79 & 91 & 142 & 97.2 \\
\hline
\end{tabular}


Table D.2A: Alloy I Lndersooling calculations

\begin{tabular}{|c|c|c|c|c|c|}
\hline Mcli & $\begin{array}{l}1 \% \\
(\mathrm{~K})\end{array}$ & $\begin{array}{l}1 \% \\
(\mathrm{~K})\end{array}$ & $\begin{array}{l}1 K_{1 s t} \\
(\mathbf{K})\end{array}$ & $\begin{array}{l}\mid r_{t} \\
(\mathrm{~K})\end{array}$ & $\begin{array}{l}11 \% \\
(\mathrm{~K})\end{array}$ \\
\hline Cast & 0.47 & 7.63 & 8.10 & 19.7 & - \\
\hline E-B 1 & 1.32 & 12.8 & 14.1 & 19.7 & $=$ \\
\hline$E-B=$ & 1.39 & 13.1 & 14.5 & 19.7 & - \\
\hline$E-B 3$ & 2.30 & 16.2 & 18.5 & 19.7 & - \\
\hline$E-B+$ & 4.11 & 19.9 & 24.0 & 19.7 & 0.2 \\
\hline E-B 5 & 5.84 & 22.1 & 27.9 & 19.7 & 2.4 \\
\hline$E-B O$ & 7.60 & 23.8 & 31.4 & 19.7 & 4.1 \\
\hline
\end{tabular}

Table D.2B: Alloy I Segregation calculations

\begin{tabular}{|c|c|c|c|c|c|c|}
\hline Micil & $C_{L}$ & $f_{0}$ & $f_{E}$ & $A_{P}$ & $A_{S}$ & $F_{0}$ \\
\hline Casi & 25.06 & 0.27 & 0.30 & 0.70 & 0.21 & .093 \\
\hline E-B I & 25.94 & 0.44 & 0.27 & 0.73 & 0.19 & .084 \\
\hline E-8 I & 26.05 & 0.45 & 0.27 & 0.73 & 0.19 & .083 \\
\hline E-B 3 & 26.60 & 0.54 & 0.25 & 0.75 & 0.17 & .078 \\
\hline E-B 4 & 27.26 & 0.65 & 0.23 & 0.77 & 0.16 & .071 \\
\hline E-B 5 & 27.65 & 0.71 & 0.18 & 0.82 & 0.12 & .056 \\
\hline E-B 6 & 27.95 & 0.76 & 0.15 & 0.85 & 0.10 & .047 \\
\hline
\end{tabular}

Table D2.C: Alloy I *o Primary and sccondary phases

\begin{tabular}{|c|c|c|c|c|c|c|}
\hline $\begin{array}{c}\text { Solidification } \\
\text { Condition }\end{array}$ & $F_{P}$ & $F_{S}$ & $F_{T}$ & $A_{P}$ & $A_{S}$ & $A_{T}$ \\
\hline Equilibrium & 0 & 18 & 18 & - & - & 82 \\
\hline Sohcil & 0 & 14.4 & 14.4 & 55.0 & 30.6 & 85.6 \\
\hline Cast & 0 & 9.30 & 9.30 & 70.0 & 20.7 & 90.7 \\
\hline E-B I & 0 & 8.37 & 8.37 & 73.0 & 18.6 & 91.6 \\
\hline E-B & 0 & 8.30 & 8.30 & 73.1 & 18.7 & 91.7 \\
\hline E-B & 0 & 7.75 & 7.75 & 75.0 & 173 & 92.3 \\
\hline E-B & 0 & 7.13 & 7.13 & 77.0 & 15.9 & 92.9 \\
\hline E.-B5 & 0 & 5.58 & 5.58 & 82.0 & 12.4 & 94.4 \\
\hline$E-B 6$ & 0 & 4.05 & 4.05 & 85.0 & 10.4 & 953 \\
\hline
\end{tabular}




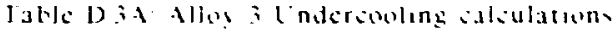

\begin{tabular}{|c|c|c|c|c|c|}
\hline sklt & $\begin{array}{c}!: \\
(h)\end{array}$ & $\begin{array}{l}1: \\
|\mathrm{h}|\end{array}$ & $\begin{array}{l}1: \\
\text { (h) }\end{array}$ & $\begin{array}{l}i \\
(h)\end{array}$ & $\begin{array}{l}\because \vdots \\
|h|\end{array}$ \\
\hline ixs & $0.4^{-}$ & -82 & 8.29 & 45 & 3.3 \\
\hline $1-B \quad 1$ & 1.35 & $1: 2$ & 14.5 & 4.2 & s. \\
\hline $1 \cdot B=$ & $1.4=$ & 13.5 & 15.0 & 45 & 9.0 \\
\hline $1-83$ & 2.54 & $10^{-7}$ & $! 9.0$ & 45 & $12: 2$ \\
\hline $1 \cdot B 4$ & 4.18 & 20.5 & $24^{2}$ & +5 & 10.0 \\
\hline $1-135$ & 5.93 & 228 & $28 .^{\circ}$ & 4.5 & 183 \\
\hline 1.86 & -80 & 24.6 & 32.4 & 45 & 201 \\
\hline
\end{tabular}

Table D iB: Allo! 3 Segregation calculations

\begin{tabular}{|c|c|c|c|c|c|c|}
\hline valt & $C_{L}$ & $j \mathrm{~s}_{\mathrm{s}}$ & $i_{\mathrm{E}}$ & $A_{p}$ & is & $1 s$ \\
\hline ( $15 \mathrm{st}$ & 20.00 & 0.27 & 0.48 & 0.52 & 0.33 & 0.85 \\
\hline$A-B \quad I$ & 20.96 & 0.43 & 0.36 & 0.04 & 0.25 & 0.89 \\
\hline $1-B=$ & 27.03 & 0.44 & 0.36 & 0.04 & 0.25 & 0.89 \\
\hline $1 \cdot B 3$ & 27.59 & 0.54 & 0.29 & $00^{-1} 1$ & 0.20 & 0.91 \\
\hline 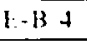 & 28.27 & 0.64 & 0.22 & 0.78 & 0.15 & 0.93 \\
\hline $\mathrm{V}-\mathrm{B} 5$ & 28.67 & 0.70 & 0.18 & 0.82 & 0.12 & 094 \\
\hline $5-136$ & 29.99 & 0.76 & 0.17 & 0.83 & 0.12 & 0.94 \\
\hline
\end{tabular}

Table D3.c: Allo! i "" Primar! and secondars phases

\begin{tabular}{|c|c|c|c|c|c|c|}
\hline $\begin{array}{l}\text { Suldedifisacion } \\
\text { Conditun }\end{array}$ & $F_{P}$ & ls & $F_{T}$ & $t_{p}$ & $A_{s}$ & $A_{T}$ \\
\hline rquilibrium & 0 & in & 32 & - & - & 68 \\
\hline Schcil & 0 & 23.6 & 23.6 & 26.0 & 50.3 & $70 .:$ \\
\hline Cast & 0 & $1+.9$ & 149 & 520 & 331 & 851 \\
\hline$E-B I$ & 0 & 11.6 & 116 & $6+0$ & $2+8$ & 88.8 \\
\hline $1-B=$ & 0 & 11.6 & 11.6 & 040 & 24.8 & 88.8 \\
\hline I- B 3 & 0 & 9.00 & 9.00 & 71.0 & 20.0 & 91.0 \\
\hline $1.13+$ & 0 & 0.82 & 0.82 & -80 & 15.1 & 93.2 \\
\hline $1-135$ & 0 & 5.58 & 5.58 & 820 & 12.4 & 94.4 \\
\hline 1.136 & 0 & 5.30 & 5.30 & 8.0 & $11^{-}$ & 94.7 \\
\hline
\end{tabular}




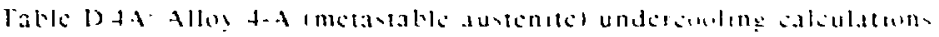

\begin{tabular}{|c|c|c|c|c|c|}
\hline biclt & $\begin{array}{l}1 \\
\text { | } \mathrm{h}_{1}\end{array}$ & $\begin{array}{l}1 ! \\
(\mathbf{h})\end{array}$ & $\begin{array}{l}1: \\
|k|\end{array}$ & $\begin{array}{l}\ddots \\
\text { (k) }\end{array}$ & $\begin{array}{l}! \\
|k|\end{array}$ \\
\hline C.3st & $0+8^{-}$ & 8.04 & 852 & -3.8 & 11.8 \\
\hline $1 \cdot B 1$ & $1 i^{-}$ & 13.5 & 14.9 & -3.8 & $1-3$ \\
\hline $1-B=$ & 1.44 & 13.9 & 153 & -38 & $1 \cdots$ \\
\hline $1 \cdot B i$ & 2.38 & $1-.0$ & $19 j$ & $\therefore s$ & $=1.4$ \\
\hline $\mathrm{H}-\mathrm{BH}$ & 4.25 & 211 & 253 & -38 & $2+4$ \\
\hline I-B 5 & 003 & 234 & 244 & $-3 x$ & $\because=$ \\
\hline $1-B O$ & 80 & 25.0 & 330 & $-5 x$ & 28.8 \\
\hline
\end{tabular}

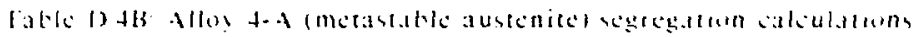

\begin{tabular}{|c|c|c|c|c|c|c|}
\hline visit & $\left(\cdots_{L}\right.$ & $\therefore{ }^{\prime}$ & $i_{\mathrm{L}}$ & $x_{1}$ & ts & 1 \\
\hline $\cos t$ & $=084$ & . & - & - & - & . \\
\hline$|-B|$ & $=-82$ & - & . & - & - & - \\
\hline$A-B=$ & 27.88 & 0.51 & 0.49 & 0.51 & 0.33 & 0.10 \\
\hline $1-B 3$ & 28.46 & 0.61 & 0.49 & $0 \$ 1$ & 0.33 & $0.1=$ \\
\hline $1: B+$ & $29.1^{\circ}$ & $0.7=$ & 0.28 & 10 & $(1.19)$ & 0.114 \\
\hline $1-B 5$ & $=9.50$ & 0.78 & 0.22 & $11^{-s}$ & 0.15 & $(1.1)^{-}$ \\
\hline $1-B O$ & 29.8 & 0.81 & 0.19 & 0.81 & $0.1 ;$ & 0.116 \\
\hline
\end{tabular}

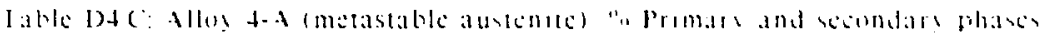

\begin{tabular}{|c|c|c|c|c|c|c|}
\hline $\begin{array}{l}\text { Solldiliciouson } \\
\text { Condition }\end{array}$ & $1 ?$ & $1 s$ & $\mathrm{rT}$ & $a_{1}$ & 45 & $r_{1}$ \\
\hline I yuilibriom & - & - & - & - & - & - \\
\hline Sithcil & . & - & - & - & - & - \\
\hline Casi & - & - & - & - & - & - \\
\hline $1-B \mid$ & - & - & - & - & - & - \\
\hline$A \cdot B=$ & 0 & 100 & 100 & 511 & $3: 0$ & 8.111 \\
\hline $\mathrm{I}-\mathrm{B} 3$ & 0 & 120 & 120 & 610 & $=-11$ & 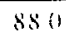 \\
\hline E. $-13+$ & 0 & 40 & 111 & $\because 11$ & 190 & (2) \\
\hline 1.135 & 0 & -1 & -11 & -81 & $1: 11$ & $12: 11$ \\
\hline $1-130$ & 0 & 011 & 10 & 810 & $1 ; 11$ & 1401 \\
\hline
\end{tabular}


Table D.4D: Allos 4-F l'ndercooling saleulations

\begin{tabular}{|c|c|c|c|c|c|}
\hline Melt & $\begin{array}{l}11 \\
(\mathrm{k})\end{array}$ & $\begin{array}{c}W \\
(\mathrm{k})\end{array}$ & $\begin{array}{l}1 / \ldots \\
(\mathrm{k})\end{array}$ & $\begin{array}{l}1 \% \\
|K|\end{array}$ & $\begin{array}{l}11 \\
(k)\end{array}$ \\
\hline Cast & 0.35 & 6.80 & 7.15 & 0.7 & 0.1 \\
\hline E-B I & 1.05 & 12.3 & 13.4 & 0.7 & 11.6 \\
\hline E-B 2 & 1.10 & 12.9 & 14.0 & 0.7 & 12.2 \\
\hline$E-B 3$ & 1.75 & 15.9 & 17.7 & 0.7 & 15.2 \\
\hline $\mathrm{E}-\mathrm{B}+$ & 3.20 & 20.5 & 23.7 & 0.7 & 19.8 \\
\hline E-B 5 & 5.00 & 23.2 & 28.3 & 0.7 & 22.5 \\
\hline E-B 6 & 6.1 & 25.5 & 31.6 & 0.7 & 24.8 \\
\hline
\end{tabular}

Table D.4E: Allo! 4-F Segregation calculations

\begin{tabular}{|c|c|c|c|c|c|c|}
\hline Mclt & $C_{L}^{*}$ & $f_{s}$ & $f_{E}$ & $F_{p}$ & $F_{S}$ & $A_{s}$ \\
\hline Cast & 16.6 & 0.22 & 0.71 & 0.29 & 0.51 & 0.49 \\
\hline $\mathrm{E}-\mathrm{B} \quad \mathrm{l}$ & 17.3 & 0.37 & 0.52 & 0.48 & 0.64 & 0.36 \\
\hline E-B : & 17.3 & 0.38 & 0.52 & 0.48 & 0.0 & 0.36 \\
\hline E.B 3 & 17.8 & 0.47 & 0.44 & 0.56 & 0.70 & 0.30 \\
\hline $\mathrm{E}-\mathrm{B} 4$ & 18.4 & 0.58 & 0.33 & 0.67 & 0.77 & 0.23 \\
\hline E-B 5 & 18.8 & 0.65 & 0.28 & 0.72 & 0.81 & 0.19 \\
\hline$E-B 6$ & 19.0 & 0.70 & 0.23 & 0.77 & 0.84 & 0.16 \\
\hline
\end{tabular}

Table D4.F: Alloy 4-F " Primary and secondary phases

\begin{tabular}{|c|c|c|c|c|c|c|}
\hline $\begin{array}{l}\text { Solidilication } \\
\text { condition }\end{array}$ & $F_{P}$ & $F_{s}$ & $F_{T}$ & $A_{p}$ & $A_{5}$ & $A_{T}$ \\
\hline Equilibrium & - & - & 48 & () & 52 & $5=$ \\
\hline Schcil & 8 & 29.4 & 37.4 & 0 & 620 & 62.6 \\
\hline Cası & 29.0 & 22.0 & 51.0 & 0 & 49.0 & 49.0 \\
\hline E-B I & 48.0 & 16.1 & 64.1 & 0 & 35.9 & 35.9 \\
\hline$E-B=$ & 48.0 & $1+.1$ & 04.1 & 0 & 359 & 35.9 \\
\hline E. $-\mathrm{B} 3$ & 56.0 & 13.6 & 690 & 0 & 30.3 & 30.3 \\
\hline $\mathrm{E}-\mathrm{B} 4$ & $6: 0$ & 10.2 & $\because .2$ & 0 & $\therefore-$ & 22. \\
\hline E-B 5 & 720 & $8^{-}$ & 80.7 & 0 & $10:$ & 19.3 \\
\hline 1.136 & $\because 7.0$ & $\therefore 1$ & $8+1$ & 0 & $15 \%$ & 15.9 \\
\hline
\end{tabular}


Table D.5A: Allo: 5 Lndersooling saleulations

\begin{tabular}{|c|c|c|c|c|c|}
\hline Melt & $\begin{array}{l}1 \% \\
(k)\end{array}$ & $\begin{array}{l}11 \\
(k)\end{array}$ & $\begin{array}{l}\mid r: \\
(k)\end{array}$ & $\begin{array}{l}1 / \\
(\mathbf{k})\end{array}$ & $\begin{array}{l}1 i \\
(\mathrm{k})\end{array}$ \\
\hline Cast & 0.36 & 6.84 & .2 .1 & 10.4 & - \\
\hline E-B I & 1.00 & $11 .^{-}$ & 12.7 & 10.4 & 1.3 \\
\hline$E-B=$ & 1.06 & 12.0 & 13.1 & 10.4 & 1.0 \\
\hline $\mathrm{E}-\mathrm{B} 3$ & 1.75 & 15.2 & 16.9 & 10.4 & 4.8 \\
\hline$E-B+$ & 3.14 & 19.3 & 22.4 & 10.4 & 8.9 \\
\hline E-B 5 & 4.4 & 21.8 & 26.3 & 10.4 & 11.4 \\
\hline F.B 6 & 0.00 & 23.0 & 29.0 & 10.4 & 12.6 \\
\hline
\end{tabular}

Table D.5B: Alloy 5 Segregation Ealiulations

\begin{tabular}{|c|c|c|c|c|c|c|}
\hline Melt & $C^{*}$ : & $10 \mathrm{~s}$ & $i_{\mathrm{E}}$ & $F_{P}$ & $A_{S}$ & $F_{s}$ \\
\hline Cast & 15.32 & 0.23 & 0.62 & 0.38 & 42.7 & 42.7 \\
\hline$\Gamma-B \quad 1$ & 15.98 & 0.38 & 055 & 0.45 & 38.0 & 38.0 \\
\hline$E-B=$ & 10.03 & 0.39 & 0.55 & 0.45 & 38.0 & 38.0 \\
\hline$E-B i$ & 16.46 & 0.48 & 0.46 & 0.54 & 31.7 & 31.7 \\
\hline$E-B+$ & 17.00 & 0.59 & 0.34 & 0.66 & 23.4 & 23.4 \\
\hline$E-B 5$ & 17.35 & 0.65 & 0.29 & 0.71 & -0.0 & $=0.0$ \\
\hline $\mathrm{E}-\mathrm{B} 6$ & 17.50 & 0.68 & 0.25 & 0.75 & 17.3 & 17.3 \\
\hline
\end{tabular}

Table D5.C: Alloy 5 "m Primary and secondars phases

\begin{tabular}{|c|c|c|c|c|c|c|}
\hline $\begin{array}{c}\text { Solidification } \\
\text { Condition }\end{array}$ & $\mathrm{FP}_{\mathrm{P}}$ & $\mathrm{F} s$ & $\mathbf{r} \mathrm{T}$ & $A_{p}$ & $A_{S}$ & $A_{T}$ \\
\hline Equilibrium & - & - & 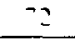 & 0 & 28 & 28 \\
\hline Scheil & 33.0 & 21.4 & 54.4 & 0 & 45.6 & 45.6 \\
\hline Cast & 38.0 & 19.2 & 5.2 & 0 & +2.7 & 42.7 \\
\hline$E-B \quad$ & +5.0 & 1.0 & 62.1 & 0 & 38.0 & 38.0 \\
\hline$E-B=$ & +5.0 & 170 & $0: 0$ & 0 & 38.0 & 38.0 \\
\hline$E-B 3$ & 54.0 & 14.2 & 68.2 & 0 & $31 \%$ & $31 . ?$ \\
\hline $\mathrm{E}-\mathrm{BS}$ & 66.0 & 105 & .05 & 0 & 23.1 & 2.3 .4 \\
\hline E. - S 5 & 71.0 & 900 & 80.0 & 0 & 2010 & 20.0 \\
\hline $5-136$ & 75.0 & .80 & $8: 3$ & 0 & $17 i$ & 17.3 \\
\hline
\end{tabular}


Table Dot: Allos o linderouling saliuldiun,

\begin{tabular}{|c|c|c|c|c|c|}
\hline Vicli & $\begin{array}{l}1 / \\
\langle\mathbf{k}\rangle\end{array}$ & $\begin{array}{l}\mid 1 \\
(\mathrm{~K})\end{array}$ & $\begin{array}{l}!: \\
(k)\end{array}$ & $\begin{array}{l}\because \\
(\mathbf{k})\end{array}$ & (k) \\
\hline Casi & 0.35 & 6.47 & $0.8=$ & $1-0$ & - \\
\hline$E-B \quad I$ & 0.98 & 11.2 & 12.2 & $1-.0$ & - \\
\hline$L-B=$ & 1.03 & 11.5 & 125 & $1-.0$ & $\cdot$ \\
\hline$E-13 ;$ & 1.0 & 14.58 & 10.2 & 10 & $\cdot$ \\
\hline$[-B]$ & 3.05 & 13.4 & 21.5 & $i^{-0}$ & 14 \\
\hline $\mathrm{E}: \mathrm{B} 5$ & 4.34 & 20.8 & 25.2 & $1-0$ & Is \\
\hline$E-1 B$ & 5.90 & 22.8 & 28.7 & $1-0$ & 58 \\
\hline
\end{tabular}

Table D.6B: Allos 6 Segregation saliulations

\begin{tabular}{|c|c|c|c|c|c|c|}
\hline lall & $C^{*} \mathrm{~L}$ & $1 \% \mathrm{~s}$ & $i_{\mathbf{E}}$ & $F_{P}$ & ts & $1:$ \\
\hline Cant & 14.46 & 0.228 & 0.48 & 0.52 & 0.33 & 0.15 \\
\hline$\Gamma-B \quad I$ & 15.12 & 0.38 & 0.46 & 0.55 & $0 \div$ & 0.14 \\
\hline $\mathrm{I}:-\mathrm{B}=$ & 15.17 & 0.39 & 0.40 & 0.55 & $0.3=$ & 0.14 \\
\hline $\mathrm{E}-\mathrm{B} ;$ & 15.57 & 0.48 & 0.46 & 0.57 & 0.20 & 0.13 \\
\hline$E-B+$ & 16.10 & 0.60 & 0.36 & 0.64 & 0.25 & 0.11 \\
\hline E-B 5 & 16.42 & 0.66 & 0.29 & $0 . ? 1$ & 0.20 & 0.09 \\
\hline$I-B 6$ & 16.70 & 0.71 & 0.23 & 0.77 & 0.16 & 0.07 \\
\hline
\end{tabular}

Table DOC: Allug 6 "I Primary and secondars phases

\begin{tabular}{|c|c|c|c|c|c|c|}
\hline $\begin{array}{c}\text { Sollidrication } \\
\text { cindition }\end{array}$ & $F_{P}$ & $F s$ & $\mathrm{FT}$ & $A_{1}$ & 15 & $A_{T}$ \\
\hline isucubrium & - & - & 88 & 0 & 12 & 12 \\
\hline Sincil & +7.0 & 17.0 & $6+0$ & 0 & 30 & .30 \\
\hline Casi & 520 & 14.8 & 60.8 & 0 & 331 & 331 \\
\hline $\mathrm{E}-\mathrm{B} \quad 1$ & $5+.0$ & 14.3 & 68.3 & 0 & 31.7 & 31. \\
\hline$E-B 2$ & 54.0 & 14.3 & 68.3 & 0 & $31-$ & 31. \\
\hline$E-B 3$ & 37.0 & 13.3 & 70.3 & i) & 29.6 & 29.6 \\
\hline$E-B+$ & $6+.0$ & 11.2 & 951 & 0 & $=4.8$ & -24.8 \\
\hline 5.115 & 71.0 & 9.00 & 80.0 & 0 & 20.0 & 20.0 \\
\hline $1 \cdot-B 6$ & 77.0 & 7.13 & 84.1 & 0 & 15.9 & 15.9 \\
\hline
\end{tabular}




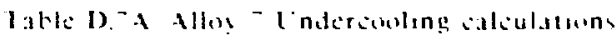

\begin{tabular}{|c|c|c|c|c|c|}
\hline$|1 c| t$ & $\begin{array}{l}1 ! \\
(\boldsymbol{k})\end{array}$ & $\begin{array}{l}\text { II } \\
\text { (k) }\end{array}$ & $\begin{array}{l}i i \\
(\boldsymbol{k})\end{array}$ & $\begin{array}{l}1 ! \\
\text { (k) }\end{array}$ & $\begin{array}{l}1 ! \\
\text { ik: }\end{array}$ \\
\hline$c a s t$ & 0.33 & 0.21 & 6.55 & $=4.4$ & . \\
\hline 1.81 & 0.95 & $10^{-}$ & 11. & 24.4 & - \\
\hline $1-B=$ & 1.00 & 11.0 & 12.0 & $=4.4$ & - \\
\hline $1-B i$ & 1.66 & 13.9 & 15.5 & 24.4 & - \\
\hline $\mathrm{E} \cdot \mathrm{BH}$ & 298 & 17.5 & 20.5 & 24.4 & - \\
\hline $1-115$ & 4.22 & 19.8 & 24.0 & 24.4 & - \\
\hline $1-110$ & $5-1$ & 21.9 & 27.6 & 244 & $3:$ \\
\hline
\end{tabular}

Ialle D. B: Alloy Segregation calculatuns

\begin{tabular}{|c|c|c|c|c|c|c|}
\hline Ifll & $\left({ }^{\prime} \mathrm{L}\right.$ & I"s & $i_{F}$ & $r_{s}$ & $1 s$ & I. \\
\hline$(3: 1) t$ & 13.64 & 0.23 & 0.37 & 0.6 .3 & $0 \geq 6$ & 0.12 \\
\hline$|-B|$ & 14.25 & 0.39 & 0.36 & 0.64 & 0.25 & 0.11 \\
\hline $\mathrm{H} \cdot \mathrm{B}=$ & $1+30$ & 0.40 & 0.56 & 0.65 & 0.24 & 0.11 \\
\hline $\mathrm{F}-\mathrm{B} 3$ & 14.68 & 0.49 & 0.33 & 0.67 & 0.2 .3 & 0.10 \\
\hline $\mathrm{I}-\mathrm{BH}+$ & 1517 & 0.60 & 0.29 & 071 & 0.20 & 0.09 \\
\hline $1-135$ & 15.48 & 0.67 & 0.25 & 0.75 & 0.17 & 0.08 \\
\hline I. $-\mathrm{H}$ o & $15 ? 0$ & 0.71 & 0.21 & 0.79 & 0.15 & $0.0 ?$ \\
\hline
\end{tabular}

Table DT.C: Alloy 7 ". Primar! and sceondar! phases

\begin{tabular}{|c|c|c|c|c|c|c|}
\hline $\begin{array}{l}\text { Soliditication } \\
\text { condition }\end{array}$ & $F_{P}$ & $F_{s}$ & $F_{T}$ & $A p$ & $\lambda_{s}$ & $\therefore \mathrm{T}$ \\
\hline Equilihrium & 100 & 0 & 100 & 0 & 11 & 0 \\
\hline Scheil & 60.0 & 13 & 73.0 & 0 & $2-$ & 27 \\
\hline Cast & 63.0 & 11.5 & 7.4 & 0 & 25.5 & 25.5 \\
\hline$F-B \mid$ & 64.0 & 11.2 & 75.1 & 0 & 24.8 & 24.8 \\
\hline$\Gamma \cdot B=$ & 65.0 & 10.9 & 75.9 & 0 & 24.1 & 24.1 \\
\hline $\mathrm{F}-\mathrm{B} 3$ & 67.0 & 10.2 & 77.2 & 0 & 21.7 & 22.7 \\
\hline $\mathrm{F}-\mathrm{B} 4$ & 71.0 & 9.00 & 80.0 & 0 & 20.0 & 20.0 \\
\hline $\mathrm{E}-85$ & 75.0 & 7.8 & 82.7 & 0 & 17.2 & 17.2 \\
\hline E. 186 & 79.6 & 6.5 & 85.5 & 0 & $1+.5$ & 14.5 \\
\hline
\end{tabular}




\section{APPENDIX F}

\section{The Composition Of Delta Ferrite}

The compostion of delta ferritc is an important parametcr which ean be used to calculate the staurization magnctization of ferritc. In Chaptcr 3. methods werc presented that allowed the iron content of ferrite to be determincd as a function of temperature, based on the thermodynamically calculated isothermal sections. This method required the composition of ferrite and austenite to be determined as a function of tempcrature and these results arc presented below.

From the thermodynamically calculated isothermal scctions. the compositional cnd points of the tic lines in the ferrite + sustenite field were determined at iron contents in the ferrite phase between 80 and 50 w.t.\%. Thesc calculations werc made at five temperatures from just below the solidus $\left(14000^{\circ}\right)$ to $950 \circ \mathrm{C}$. Thesc results are summarized in Table F.l, along with the calculations of the $\mathrm{Cr} N \mathrm{Ni}$ ratio in the austenite and ferrite phases and the ratio of $F e$ in the ferrite to Fe in the austenite.

Figure F.l and F.2 present the $\% \mathrm{Cr}$ and $\% \mathrm{Ni}$ in the ferrite. As the temperature decreases the amount of chromium in the ferrite increases while the amount of nickel in ihe ferrite decrisascs. Although the average composition changes only a $f c u$ perent over this temperature range, the $\mathrm{Cr}$.Ni ratio varies considerably because of the countervariant segregation characteristsics of $\mathrm{Cr}$ and $\mathrm{Ni}$. Figure F. 3 shows the increase in $\mathrm{Cr} / \mathrm{Ni}$ ratio of the ferrite with dcceasing temperature. At high tcmpcratures, the $\mathrm{Cr} / \mathrm{Ni}$ ratio is aboit four to onc and docs not vary considerably with Fe content in the ferrite. At $950^{\circ} \mathrm{C}$, the $\mathrm{Cr} / \mathrm{Ni}$ ratio is about 14 for the 70,60 and $50 \% \mathrm{Fc}$ alloys and is about 21 for the $80 \% \mathrm{Fc}$ allo $\mathrm{s}$.

Figure F.4 and F.5 present the $\% \mathrm{Cr}$ and $\% \mathrm{Ni}$ in the austenite phase. These data were taken from the asutenite tie-line end points which are in equilibrium with ferrite of $80,70,60$ and $50^{5 / \%}$ iron contents. The trend of $\mathrm{Cr}$ and $\mathrm{Ni}$ constents in the austenite with temperature is the reverse of that in ferrite with decreasing temperature, the $\% \mathrm{Cr}$ in austenite tends to increase or remain constant while the \% $\mathrm{Ni}$ in austenite decreases. The $\mathrm{Cr} / \mathrm{Ni}$ ratio of austenitc is presented in Fig. F.6 and shows much less of variation with tecupcrature than the $\mathrm{Cr} / \mathrm{Ni}$ ratio of ferritc. In 
austenite. the $\mathrm{Cr} \mathrm{Ni}$ ratio varies from a minimum of 1 (1 to 43 as the temperature decreases from 1400 to $950 \%$ C.

The le content of the ferrite is tie most important parameter for predieting t:e saturization magnetization of ferrite. Figure $F .7$ shous the intuende af temperature on the ratio of the Fe content of ferritc to the Fe content of austenite. Mt Ionc this ratio is close to 1.0 which means that only a small amount of Fe partitions betueen austenite and ferrite. At $950^{\mathrm{N}}$. This ratio varies hetween 0.82 and 0.96 depending on the amount of $F e$ in the ferrite. Chapter 3 utilizes this relationship :o place limits on the maximum anount of fe that can be present in ferrite. hased on the nominal alloy composition.

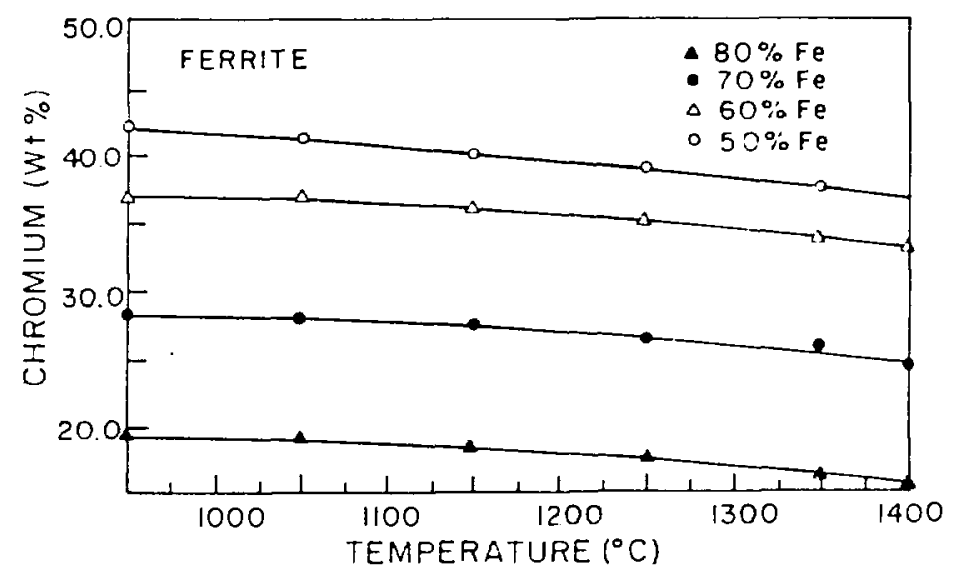

Figure fil Thermodumamic calculations of the chromium enment in lertite as a function of temperature and iron content of the ferrite. 


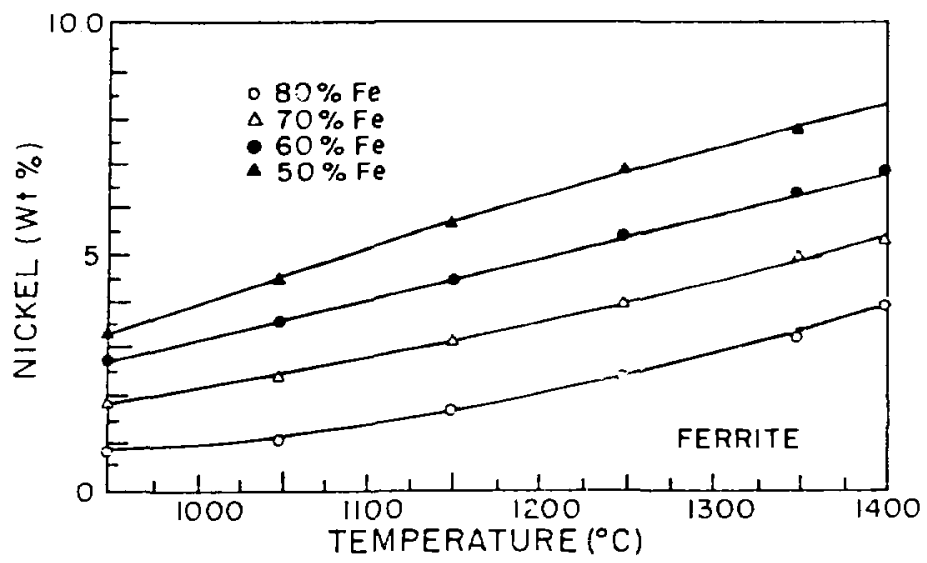

Figure F.2 Thermod!namic calculations of the niskel content in ferrite as a function of temperature and iron content of the ferritc

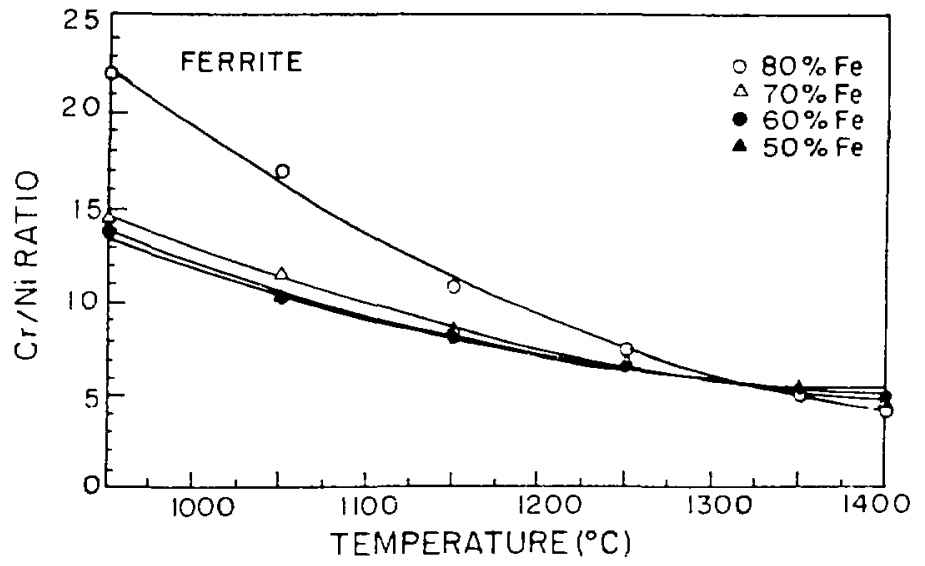

Figure F.3 Thermodynamic calculations of the $\mathrm{Cr}$ 'Ni ratio of ferrite as a function of temperature and iron content of the ferrite. 


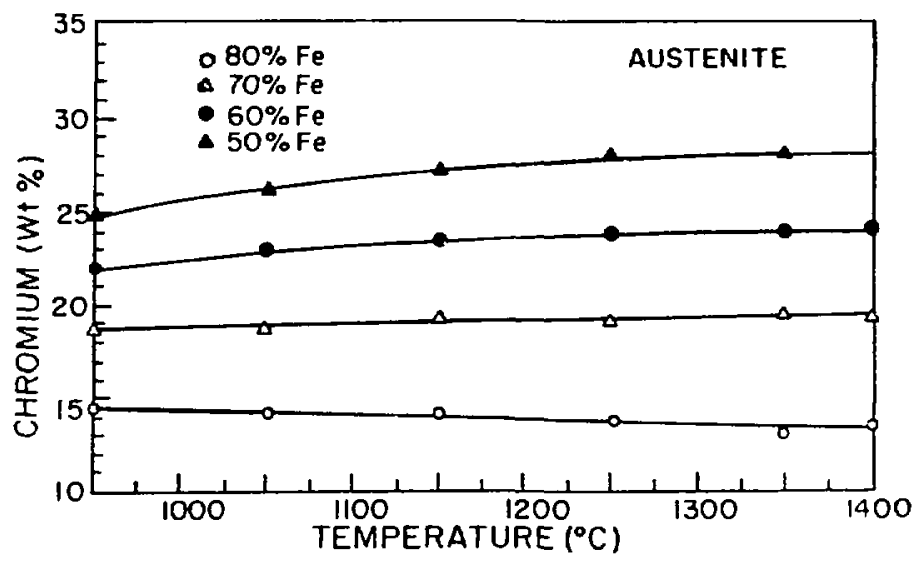

Figure F.4 Thermodynamic calculations of the chromium content in austenite as a function of temperature and iron content of the ferrite.

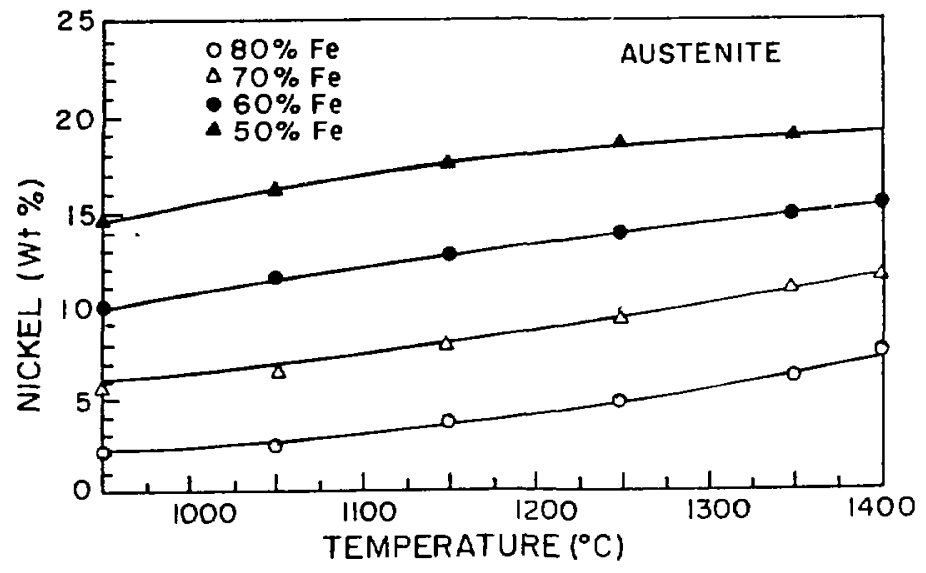

Figure F.5 Thermodynamic calculations of the nickel content in austenite as a function of temperature and iron content of the ferrite. 


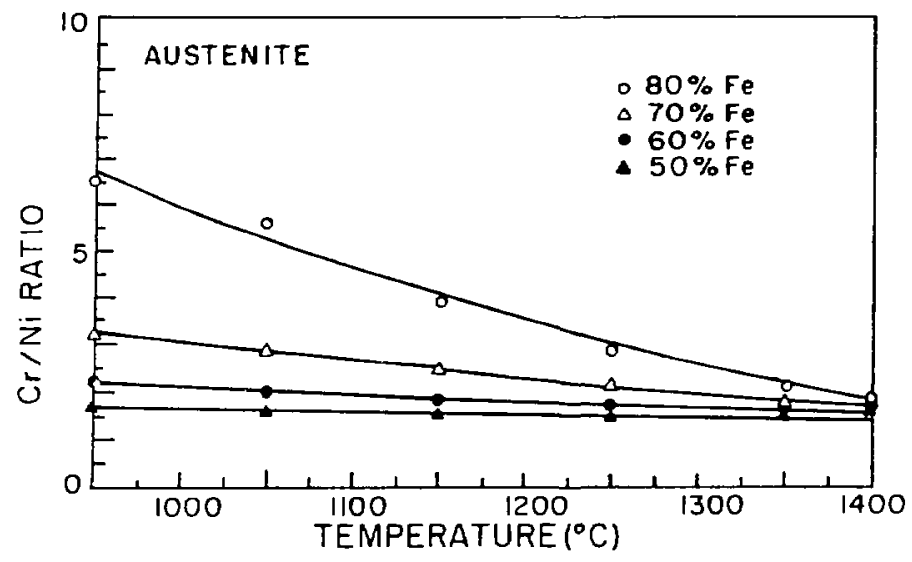

Figute F.6 Thermodynamic calculations of the $\mathrm{Cr}$ 'Ni ratio in austenite as a function of temperature and iron content of the ferrite.

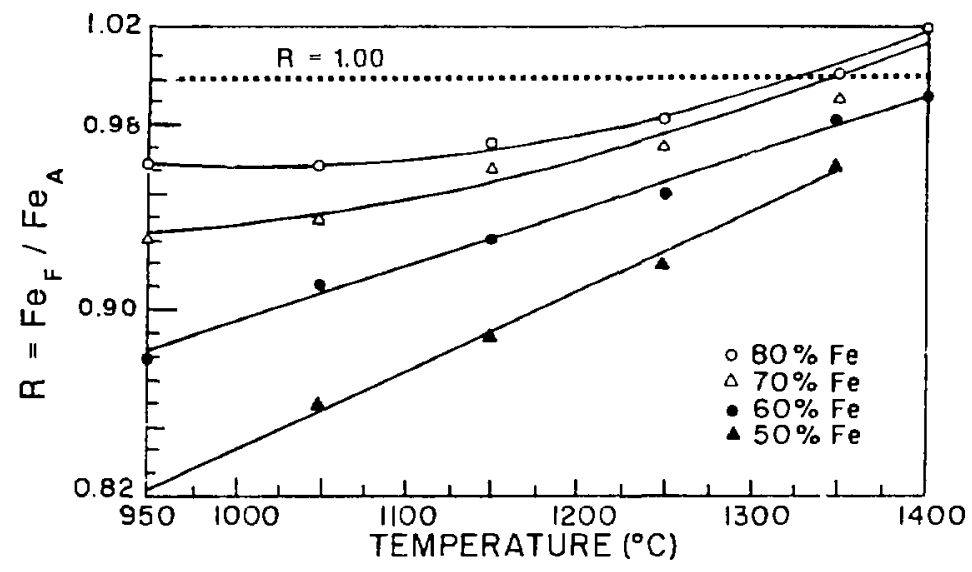

Figure F.7 Thermodynamic calculations of the ratio between the Fe content of ferrite and the $\mathrm{Fe}$ content of austenite as a function of temperature and iron content of the ferrite. 


\section{APPENDIX G}

\section{The Geometry of Electron Beam Surface Melts}

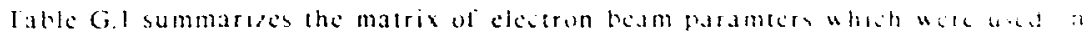

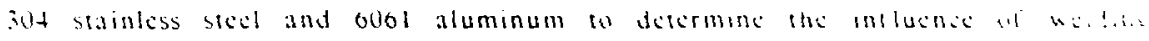

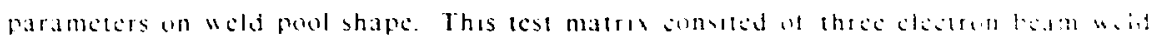

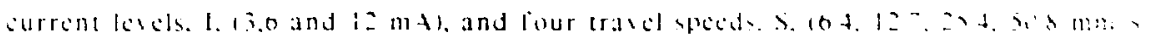

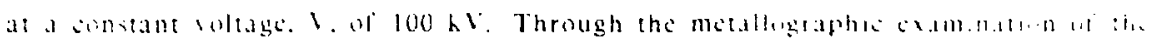

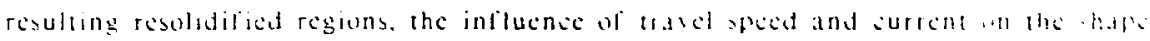

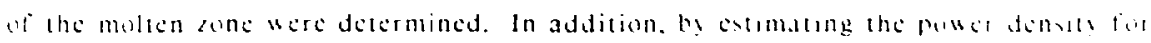

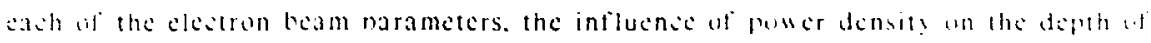

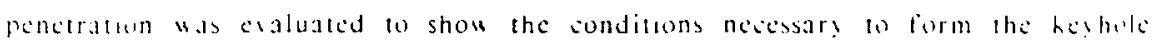

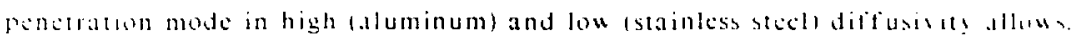

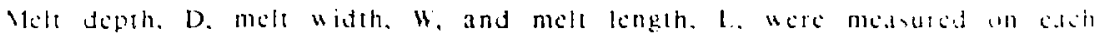

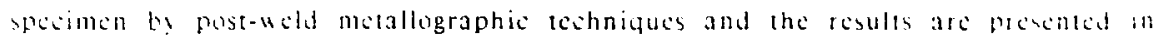
lable ci.2. Since the thermal properties of stankes stect and alumum an

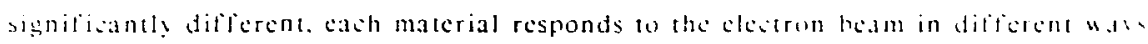
lo acount for the diterence in physical propertics. the depth. width. and lenght il eath melt was plotled versus the operating parameter. n. in ther domemumbuten DD. DW and DI respectively. This allows the intuence of a large range af cleath

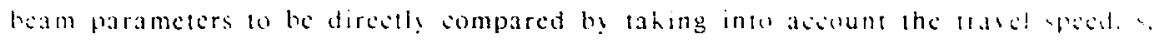

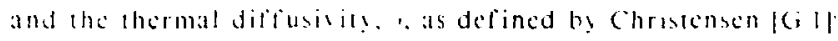

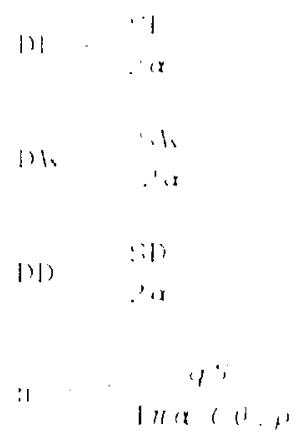


Wherc $q=$ Watts. " = density $\left(\mathrm{g} \mathrm{m} \mathrm{m}^{3}\right)$. C = heat sapacit! ( $\mathrm{g}$ "C $)$ and $"=$ melting icmperaturc. ( ${ }^{\circ} \mathrm{C}$. Thesc calculations arc summarized in Table G.3 for cach of the solidilication conditions.

Figure G.1 shows the influence of E-B parameters on melt pool lengih. Log DL is plotted versus $\log n$ and indicates that $\log$ DL increases lincarly $\mathbf{w}$ ith $\log n$ but is independent of travel specd or current at a given operating parameter. Pcnetration in aluminum and stainless stcel both show the same trend with the operatung parameter and compare fasorably with Christensen's data for GTAW welds.

Figure G.2 shows the influence of E-B parameters on the melt pool depth. Log DD is plotted versus $\log \mathbf{n}$ and the : csults are compared with Christensen's prediction for are welds. At low current levels, the data are close to Christensen's prediction but the data deviates as the current leve! is increased. This deviation is causcd by an increase in penetration as the electron beam current is increased. At low current lesels the clection beam behaves morc like a GTA weld which is similar to a point heat source from which Rosenthal [G.2] and Christensen derived their results. At high eurrent levels, the electron beam 'keyholes' into the metal and behaves like a line heat source thus giving more penctration than Christensen would predict.

Figure G.3 shows the influence of E-B parameters on the nelt pool width. Log DH is plotted versus $\log \pi$ and the results are compared to Christensen's reduced width for GTA welds. This plot indicates that the melt width deviates to lower values that the Christensen prediction as the current level is increased. This result follows directly from the previous results. Since DL is independent of beam current and DD increases with increasing current, DW will decrease with increasing current for a constant operating parameter.

The deviation of the EB welds from Christensen's GTA welds is a result of the higher power densities that can be achicved by electron beam welding. These power densitics were calculated by estimating the radius of the minimum EBW spot. $r^{*}$. for cach melt condition, based on the width of the highest specd melt. The results were plotted against the weld aspect ratio (weld depth/weld width) shown in Figurc G.4. The ; $\mathrm{mA}$ welds agree with Rosenthal's predicted values. However, as the power density is increased, the aspect ratio increases as the electron beam begins to 'keyhole' into the base metal and the clectron bcam welds deviate from Christenscn's 
predictions. The amount of keyholing is also related to the travel speed, and at a constant power density level the weld aspect ratio decreases as the travel speed increases.

Table Gl: Heat input

\begin{tabular}{|c|c|c|c|c|c|c|}
\hline \multirow{2}{*}{ Weld } & \multicolumn{3}{|c|}{ SST } & \multicolumn{3}{|c|}{$\mathrm{Al}$} \\
\hline & $\begin{array}{c}\text { Spced } \\
(\mathrm{mm}, \mathrm{s})\end{array}$ & $\begin{array}{c}\text { Current } \\
\text { (mA) }\end{array}$ & $\begin{array}{c}\text { Heat } \\
(\mathrm{J} / \mathrm{mm})\end{array}$ & $\begin{array}{c}\text { Spced } \\
(\mathrm{mm} / \mathrm{s})\end{array}$ & $\begin{array}{c}\text { Curaent } \\
(\mathrm{mA})\end{array}$ & $\begin{array}{l}\text { Heat } \\
(J, m n)\end{array}$ \\
\hline 1 & \multirow{3}{*}{6.4} & 3.5 & 47 & \multirow{3}{*}{6.4} & 3.0 & 55 \\
\hline$=$ & & 7.0 & 94 & & 6.0 & 110 \\
\hline 3 & & 14.0 & 189 & & 12.0 & 220 \\
\hline 4 & \multirow{3}{*}{12.7} & 3.5 & 24 & \multirow{3}{*}{12.7} & 3.0 & 28 \\
\hline 5 & & 7.0 & 47 & & 6.0 & 55 \\
\hline 6 & & 14.0 & 94 & & 12.0 & 110 \\
\hline 7 & \multirow{3}{*}{25.4} & 3.5 & 12 & \multirow{3}{*}{25.4} & 3.0 & 14 \\
\hline 8 & & 7.0 & 24 & & 6.0 & 28 \\
\hline 9 & & 14.0 & 47 & & & 55 \\
\hline 10 & \multirow{3}{*}{$\therefore$} & 3.5 & 6 & \multirow{3}{*}{50.8} &. & 6.9 \\
\hline 11 & & 7.0 & 12 & & 6.0 & 14 \\
\hline 12 & & 14.0 & 24 & & 12.0 & 28 \\
\hline
\end{tabular}


Table Gi: Hold pool dimenswe

\begin{tabular}{|c|c|c|c|c|c|c|}
\hline \multirow{2}{*}{ Wcld } & \multicolumn{3}{|c|}{ SSI } & \multicolumn{3}{|c|}{+1} \\
\hline & $\begin{array}{l}\text { Dopth } \\
(\mathrm{mm})\end{array}$ & $\begin{array}{l}\text { Width } \\
|\mathrm{mm}|\end{array}$ & $\begin{array}{c}\text { Icnglh } \\
(\mathrm{min})\end{array}$ & $\begin{array}{l}\text { Depth } \\
\text { (mn) }\end{array}$ & $\begin{array}{l}\text { Width } \\
\text { (mm) }\end{array}$ & $\begin{array}{l}\text { length } \\
(\mathrm{nm})\end{array}$ \\
\hline 1 & 1.16 & 2.60 & 1.30 & 080 & $10^{-6}$ & 0.91 \\
\hline$=$ & 3.68 & 4.00 & $=80$ & $=.90$ & $\therefore 00$ & 1.10 \\
\hline$:$ & 8.10 & 3.40 & 0.00 & 10.0 & $\therefore 60$ & $=111$ \\
\hline 4 & 0.51 & 1.00 & 1.30 & 0.02 & 1.00 & 118 \\
\hline 5 & 1.50 & 1.20 & 3.20 & $=-8$ & 280 & 1.81 \\
\hline 6 & 5.20 & 2.28 & +.60 & 804 & iso & $\$ 50$ \\
\hline - & 0.01 & 1.08 & 1.50 & 0.01 & 1.58 & 0.81 \\
\hline 8 & 168 & 1 to & 3.10 & $: 25$ & 2.34 & $\therefore: 2$ \\
\hline$y$ & $\therefore 60$ & 1.80 & 5.30 & 0.45 & 2.54 & 3.7 \\
\hline 10 & 0.46 & 0.90 & 1.60 & 049 & 1.16 & 0.70 \\
\hline 11 & 0.45 & 1.10 & $\therefore 40$ & 180 & 1.70 & 1.93 \\
\hline $1:$ & 2.05 & 1.40 & 5.50 & +60 & 220 & 2.80 \\
\hline
\end{tabular}

Iable (3.3 Phosal propeaticen

\begin{tabular}{|c|c|c|c|}
\hline Propern! & units & SSI & $A !$ \\
\hline iI & $1 m^{2}$ bl & $4.5 \times 10-0$ & $8.1 \times 10^{-5}$ \\
\hline .1 & $\left(g m^{3}\right)$ & 79,104 & $\checkmark$ \\
\hline$c$ & $(J g)$ & $0 j$ & 1.05 \\
\hline $1_{m} 1_{n}$ & $(\cdot \mathrm{C})$ & $14: 5$ & 6.35 \\
\hline
\end{tabular}




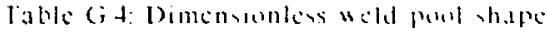

\begin{tabular}{|c|c|c|c|c|c|c|c|c|}
\hline \multirow[b]{2}{*}{ Helat } & \multicolumn{4}{|c|}{ SS1 } & \multicolumn{4}{|c|}{41} \\
\hline & $n$ & $\begin{array}{l}\because 11 \\
\therefore 1\end{array}$ & $\begin{array}{l}\because 1, \\
\therefore x\end{array}$ & $\begin{array}{l}\therefore i \\
\therefore 1\end{array}$ & $\mathrm{n}$ & $\begin{array}{l}\because 1 \\
\therefore x\end{array}$ & $\begin{array}{l}\cdots \\
\therefore 1\end{array}$ & $\begin{array}{l}\cdot: \\
\therefore 1\end{array}$ \\
\hline 1 & 1.50 & 0.84 & 1.84 & 0.92 & 0015 & $1102^{2}$ & 1100.8 & 11110 \\
\hline$=$ & $31:$ & 2.60 & 2.81 & $1.9^{7}$ & $0,0=4$ & 0.115 & 0.120 & $0.0^{\circ} 5$ \\
\hline$i$ & 0.25 & 5.0 & $\therefore 40$ & 4.23 & 0.0000 & 0.433 & (1).14: & () 185 \\
\hline 4 & $\therefore 12$ & $0 .-1$ & 1.40 & 1.83 & 0.020 & $0(1+4)$ & $0.1 \leqslant 0$ & $0(1)^{-}$ \\
\hline 5 & 6.25 & .10 & 168 & 4.10 & 0.0600 & 0.214 & $0: \geq 0$ & 11150 \\
\hline 6 & 12.5 & 2.30 & 3.15 & 0.48 & 0120 & $01080)$ & 0.250 & $0,2=0$ \\
\hline- & 0.25 & 1.0 & 3.02 & 4.3 & 0.01001 & $0(100)$ & 01.248 & $0.1=$ \\
\hline 8 & 125 & 4.09 & 4.08 & 8. -4 & 0120 & 0.354 & 0.30 .8 & 0.350 \\
\hline i) & $\because 3$ & 10.1 & 5.02 & 14.2 & $0 \Sigma+11$ & 102 & (1. $4(1)$ & ( $.5 \mathrm{~S}(\mathrm{~B})$ \\
\hline 161 & 12.5 & 257 & 5.36 & 8.00 & 0120 & 0.154 & 0400 & $012: 4$ \\
\hline 11 & 25 & 531 & 6.48 & 102 & $11.2+11$ & $1156^{-}$ & 055 & 10010 \\
\hline 12 & 51 & 11. & 8.0 & 310 & $0+811$ & 142 & (1) (1)? & 1111 \\
\hline
\end{tabular}

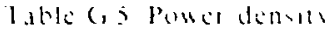

\begin{tabular}{|c|c|c|c|c|c|c|}
\hline \multirow[b]{2}{*}{ Wold } & \multicolumn{3}{|c|}{$5 S 1$} & \multicolumn{3}{|c|}{11} \\
\hline & $\begin{array}{c}\mid 1 \\
|k| 1 \mid\end{array}$ & $\underset{r}{r^{*}}$ & 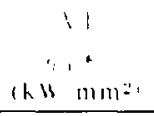 & $\begin{array}{l}\| 1 \\
|k| 1 \mid\end{array}$ & $\begin{array}{c}r^{*} \\
1 \mathrm{~m} m 1111\end{array}$ & $\begin{array}{c}1 ! \\
1+11 \mathrm{~mm}=\end{array}$ \\
\hline 1 & 1135 & $0=4$ & $1^{-0}$ & $61: 11$ & (1) $:-$ & $0 \leqslant 1$ \\
\hline$=$ & $11-0$ & 0.20 & $=311$ & 111111 & 1145 & $119^{\circ}$ \\
\hline$i$ & $1+13$ & (1) its & $\therefore 43$ & $1: 11$ & 110 & $14=$ \\
\hline 4 & 113 & $11: 4$ & $1-0$ & 11 & $11:-$ & 1181 \\
\hline : & 110 & $11=4$ & $\therefore: 10$ & $(1 \mid 1)$, & $1+8$ & 1140 \\
\hline 6 & $1+0$ & 0 is & 245 & 1211 & 011 & $14:$ \\
\hline- & $(1 ; i)$ & 0.24 & $1-11$ & 030 & $11:$ & (1) 81 \\
\hline 8 & $(1-1)$ & $0=0$ & $\therefore 310$ & $(1)(n)$ & $11+5$ & $114^{\circ}$ \\
\hline 4 & 1411 & 030 & $=95$ & $1: 0$ & $(1.20$ & $14:$ \\
\hline 10 & 11 is & 11.24 & $1^{-1}$ & $11 \mathrm{i} 11$ & $11 ;$ & $0 \times 1$ \\
\hline 11 & $0-11$ & 0.24 & $=311$ & $110(1)$ & $11+1$ & 0115 \\
\hline 12 & 140 & (1) it) & 245 & 1.21 & 1120 & 14 \\
\hline
\end{tabular}




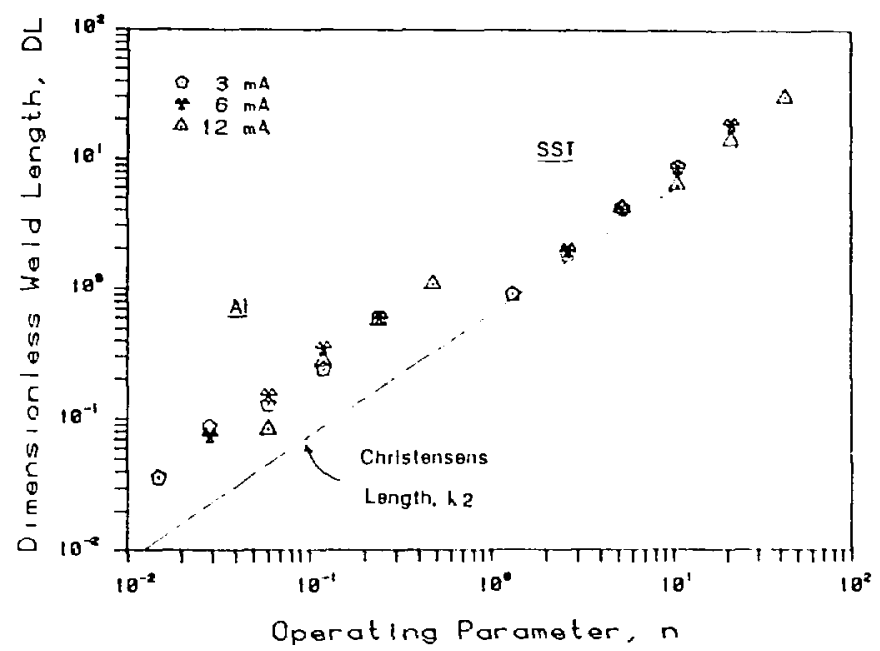

Figure (i) Dimensiontess nitel pool length for clectron beam surtace molts in stainless steel and aluminum. plotted lersus the operating parameter. Resules for 3. 6, and $12 \mathrm{~mA}$ beam currents at $100 \mathrm{hl}$ and various travel speeds are presented.

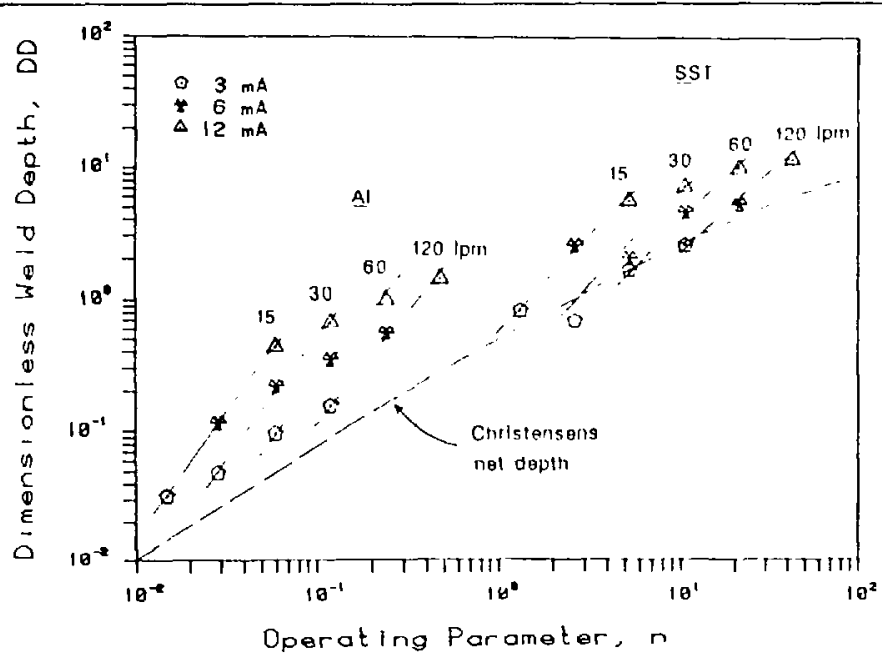

Figure 6.2 Dimensionless mele pool depth for clectron beam surface melts in stainless steel and aluminum, plotted versus the operating parameter. Results for 3, 6, and $12 \mathrm{~mA}$ beam currents at $100 \mathrm{kv}$ and various travel speeds are presented. 


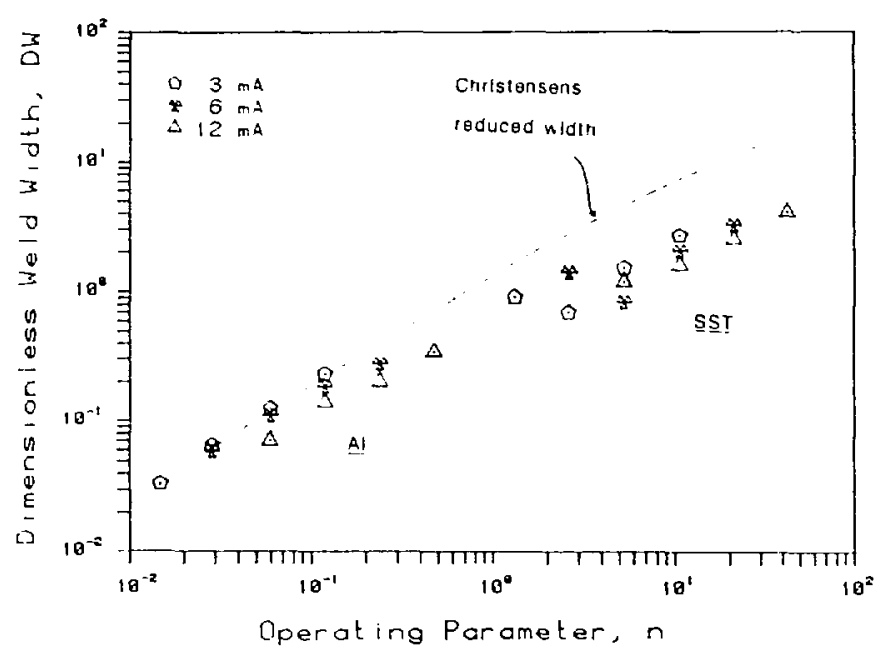

Figure G3 Dimensionless melt rool width for elcetron ham suriace melts in stainless stecl and aluminum. ploted versus tha operating parameter. Results for 3. 6, and la mA boam currents at $100 \mathrm{kl}$ and barious travel speeds are presented

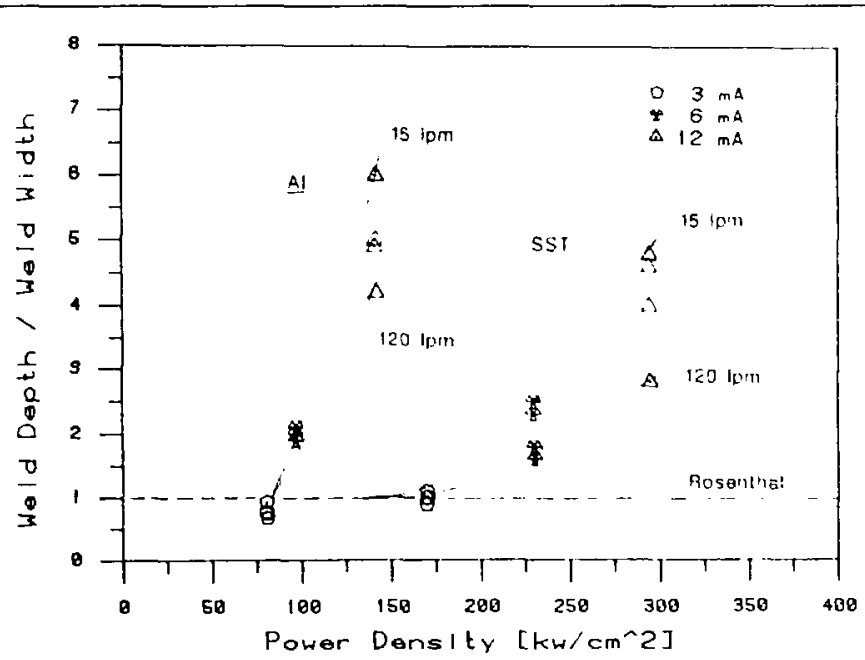

Figure 6.4 Melt depth to half-width ratio ploted lcreus the appeximate pouer density in clecton beam melts. Data are plutled for stainless stcel and aluminum a! 15, 30, 60, 3nd 120 ipm travel specds. The increased aspect ratio of the mells at high fowcr densities is associated with the formation of a heybule 


\section{APPENDIX H}

\section{Computer Programs}

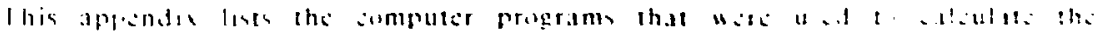

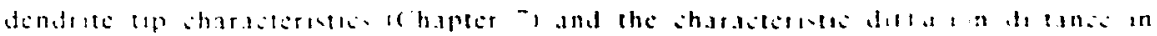

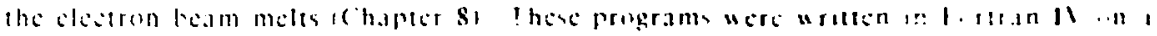
DI: PIII

\section{Denclrite Tip Radius}

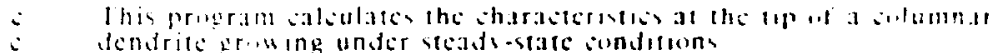

ic $\quad 11=8.5-3: 28-401$

$20 \quad a=18 \operatorname{sis} 411099^{-}$

in $\quad x i=86.3400189$

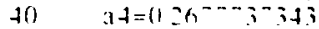

in $\quad 11=9.5-33223454$

(1) $\quad 1=25632056149$

- $0 \quad h i=21.09065 \div 083$

sก $\quad h 4=3.9584960228$

$\therefore 0=-0.5-2=1506$

100) $\quad 81=009090193$

$110 \quad: 2=-(1.2+49) 1055$

izo $23=055160,8$

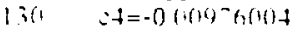

$141 . \quad 25=0.001011^{-} 85^{-}$

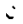

iso pi=i.14150205

isl sign $=1$

$\therefore$

inar tspe* HHos No.

$i^{\rightarrow 0}$ arent *ial

175 type*. Composition / wt. $)^{\circ}$

$1-6$ acest $* 20$

$180 \quad$ Ine * Liquidus slupe ih

185 acept *nom

190 tunc*? Partition cueli:

192 aecent *.pk

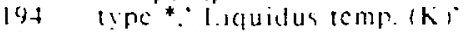

196 aiser *.11

200 trne* Solute diffusis its $1 \mathrm{~m}^{2}=45$

$210 \quad$ aecepl *.DI

215 lipe* : Interfacial cnergs if $\mathrm{m}^{*}$ 


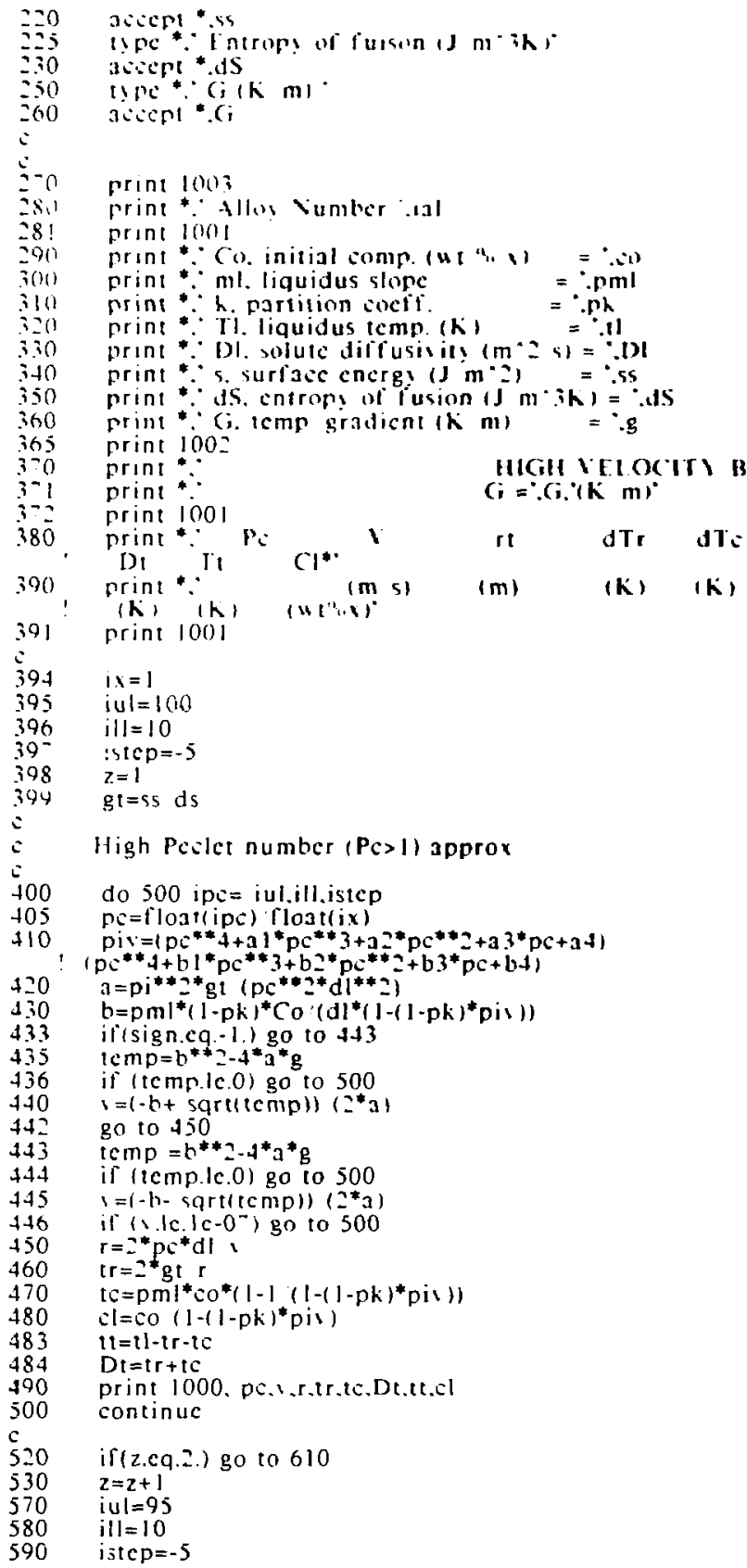

High Pcelet number (Pe> 1 ) approx 


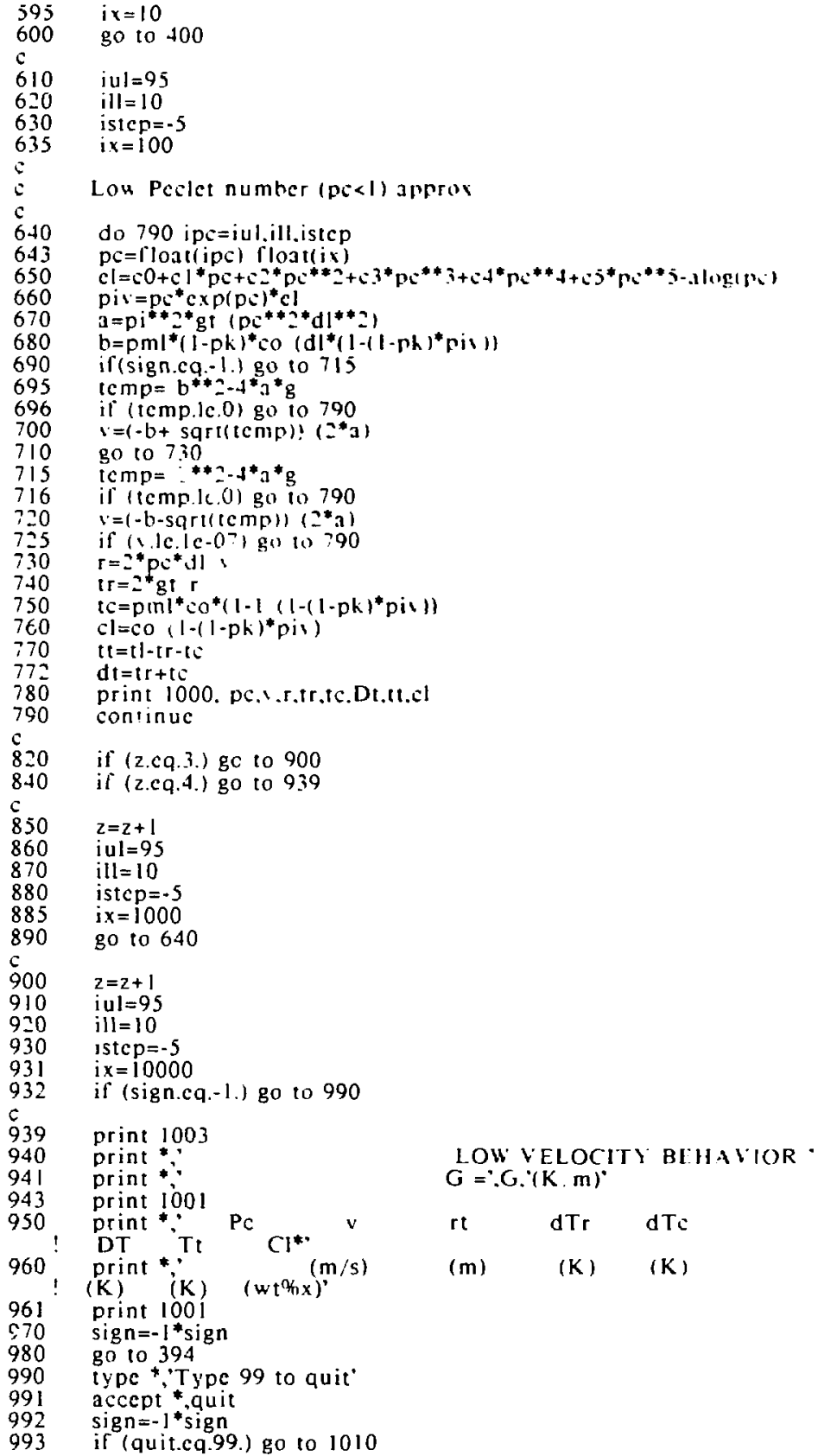

LOW FELOCITY BEHAVIOR $\mathrm{G}=\cdot G \cdot(\mathrm{K}, \mathrm{m})^{*}$$$
\text { re dTr dTo }
$$

(m) (K) (K) 


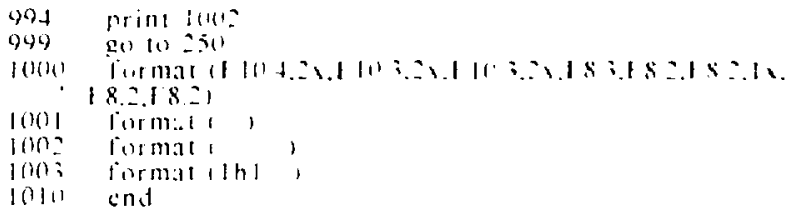

\section{Characteristic Diffusion Distance}

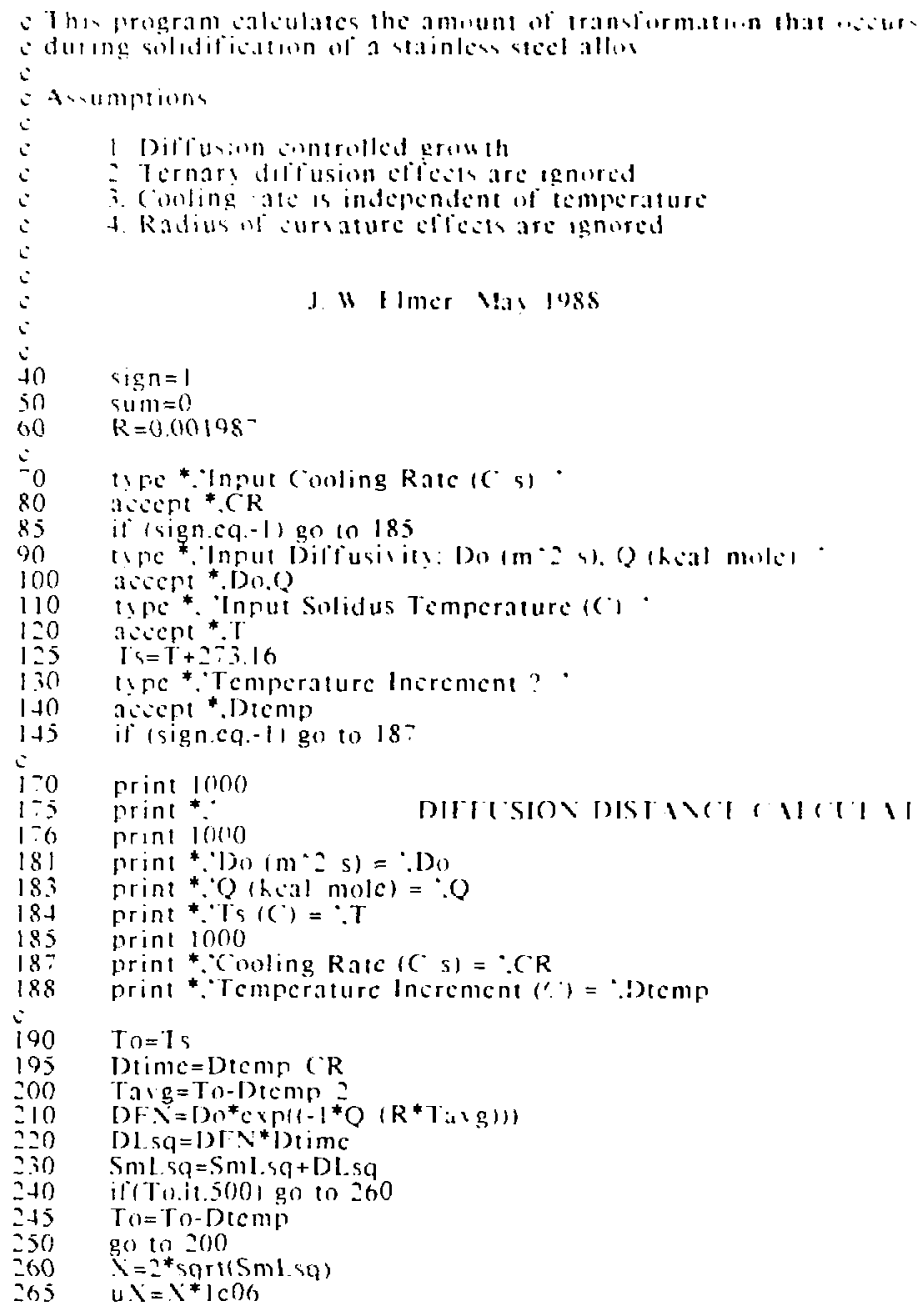


c

275 (ype *, The Diffusion Distance (um) = :ul

print * The Diffusion Distanec (um) $=$ "u.

print 1000

Type *Try a new Cooling Rate $(1=\text { es. } 0=N a)^{\circ}$

305 sign $=-1$

$310 \quad \mathrm{SmLsq}=0$

$303 \quad X=0$

$310 \quad u x=0$

3 IS TO=TI

c

320 if (ans.eq.0) go to 1010

330 go to 70

c

1000 format ()

1010 end 


\section{Biographical Sketch}

The author was boin in Homestead. Florida on December 9. 1957. He altended elementary school in the South-W'cst United States, living in Arizona and Nevada. before moving to Colorado in 1968. After graduating from Golden High Sihool in 1975. he entered the Colorado School of Mincs. in Golden Colorado. where he graduated as a Metallurgical Engineer in 1979. During that ture he worked in a cast iron foundry in the Denser area which impressed upon him a desire for higher education.

In September of 19-9. the author began graduate sihool at the Colorado Sihoul of Mines and completed 3 Masters degrec in Metallurgical Fngincering in 1981 . During this time he worhed as a Metallurgast in the Trature and Deformation Duvision at the Xiationa: Burcau of Standards in Boulder Colorado, where he performed researsh on the litw-temperature mechanical propertics of alloys

In January of 1982 he joined the staff at Laurence Livermore National Laboratory, in Libermore California. In the Materials Science Division, he performed short-term researth and desclopment projects concerning the metallurgieal quality of precision manulactured compcrints. This work dealt with advanced Joining techniques and lead to his interest in the microstructures which develop during the electron ream welding of stainless steel alloys.

In Septenter 1984. The author was admitted to the Doctoral program in the Materials Science and Enginecring department at MIT under the guidance of Professor $T W$. Eagar. His future plans are to continue rescarch at Lawrente livermore Vational laboratory, with emphasis on the effects that rapid solidification has on the microstructure of metals and alloys.

The author is a member of the American Socicts for Metals, the american Welding Socict!. Tou beta Pi. Sigma $\mathrm{X}$, and Alpha Sigma Mu. He is a registered Professional I.ngineer in Colorado and a registered Metallurgical Engineer in California. 